

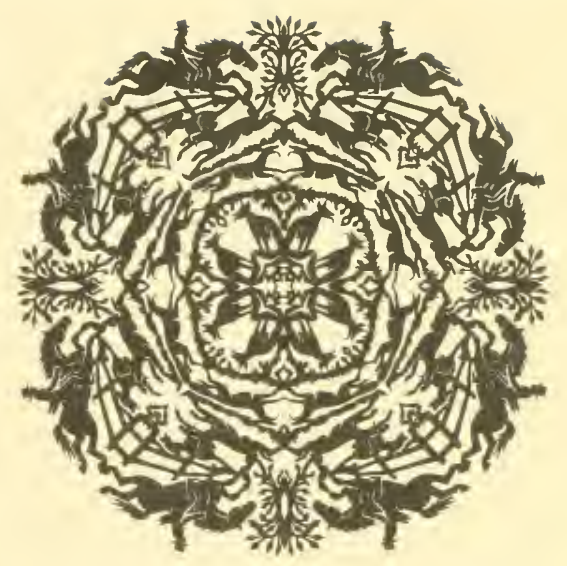

JOHN A.SEAVERNS 
TUFTS UNIVERSITY LIBRARIES

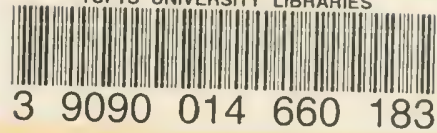

Webster Family Library of Veterinary Miedicine Cummings School of lieterinary Medicine at Tufts University 200 Westboro Road North Grafion, MA $015 \% 6$ 



\section{CAMBRIDGE BIOLOGICAL SERIES.}

Gexeral Editoll :-Arthur E. Shipley, M.A., F.R.S. FELLOW AND TUTOR OF CHRIST'S COLLEGE, CAMBRIDGE.

THE ORIGIN AND INFLUENCE

OF THE

\section{THOROUGHBRED HORSE}




\title{
THE ORIGIN OF METALLIC CURRENCY AND WEIGH'T STANDARDS.
}

\author{
New Edition in preparation.
}

"Die epochemachende Untersuchungen von William Ridgeway. "The Origin of Metallic Currency and Weight Standards." -Deutsches Rundschau, June 5, 1897.

"It is the induction which is the real strength of the present work. The collection of sure facts is so large, and the facts themselves hang so well together, that we cannot help accepting what they point to-at least until we see whether an adversary can make an equally good collection on the other side. But we do not expect to find this done."-Economir Journal, vol. II, p. 704.

"One of the most important and brilliantly original works on any archaeological subject which has appeared for many years past." Suturday Review.

"A book of profound erudition, and of the first value to everyone interested in the early history of civilization."-Scotsman.

\section{THE EARLY AGE OF GREECE, Vol. I}

\section{(Vol. If in the press).}

"No more lucid piece of argument has been produced for many years. Mr Ridgeway takes no step which is not sure. He trusts neither to prejudice nor to speculation. He admits nothing save facts, and being an eminent anthropologist he does not reason as though Greece were a province set in a vacuum far apart from the civilization of the world." Spectator.

"With the main arguments we are fully in accord. The finds both in Greece and elsewhere, on which it is largely based, appear so far as we can test the matter to be accurately stated, and no material evidence seems to have been ignored. In this part we can hardly believe that his position will be serionsly questioned.... We think the legends are most likely to be the battle-ground with his opponents. But they have never been critically examined before in the light of archaeological discoveries, nor has anyone so successfully illustrated them by the way in which historical beroes, like Alexander or Charlemagne, are treated in saga and song; and when so examined their consistency with themselves and with the finds is indeed remarkable. It is no small confirmation of their value that by following them Mr Ridgeway has been enabled to explain better than any of his predecessors the origin of the Homeric poems."Athenaeum.

"Der vorliegende erste Band des auf zwei Bände berechneten Werkes verdient wegen des Inhaltes und wegen der Art der Stoffbehandlung aufmerksame Beachtung.......An dieser Stelle muss das Hervorgehobene genügen und wird wenirstens das eine gezeight haben, dass der vorliegende Band der interessanten Schift, auch schon wegen des reichen Materials in archäologischer nnd prähistorischer Beziehtug, ein sorgfältiges und eingehendes Studium verdient."-Neue Philologische Rundschau, 1902, pp. 132-5.

"Jetzt beginnt er in einem grossen Werke, dessen erster Band vorliegt, die Frage nach Griechenlands Jugendzeit in peinlich sorgfältiger und ausführlicher Weise zu behandeln, und das Buch dünkt uns so interessant, dass wir in einer kmrzen Uebersicht seinen Gedankengang hier wiedergeben wollen."-Allgemeine Zcitung, 1901, p. 260. 


\title{
THE ORIGIN AND INFLUENCE
}

\author{
$\mathrm{OF}$ THE
}

\section{THOROUGHBRED HORSE}

BY

IVILLIAM RIDGEWAY, M.A., F.B.A., Hon. D.LITT., DISNEY PROFESSOR OF ARCHAEOLOGY IN THE UNIVERSITY OF CAMBRIDGE, FELLOW OF GONVILLE AND CAIUS COLLEGE, CAMBRIDGE, SOMETIME PROFESSOR OF GREEK IN QUEEN'S COLLEGE, CORK, HON. MEMBER OF THE ARCHAEOLOGICAL SOCIETY OF ATHENS.

"A most absolute and excellent horse."

SHAKESPEARE.

WITH NUMEROUS ILLUSTRATIONS

\section{Cambridge}

at the University Press

I 905 
CAMBRIDGE UNIVERSITY PRESS WAREHOUSE, C. F. Clay, Manager.

flonion: FETTER LANE, E.C.

שโaggow: 50, WELLINGTON STREET.

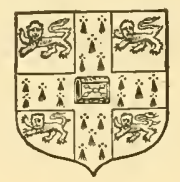

ALSO

\#ondon: H. K. LEWIS, 136, GOWER STREET, W.C.

ILripzig: F. A. BROCKHAUS.

PRow Gork: THE MACMILLAN COMPANY.

bombay ano Calcutta: MACMILLAN AND CO., LTD.

[All Rights reserved.] 


\section{JAMES COSSAR EWART, M.D., F.R.S.,}

REGIUS PROFESSOR OF NATURAL HISTORY IN THE UNIVERSITY OF EDINBURGH. 



\section{PREFACE.}

THE present work is an attempt to solve one of the chief 1 problems in the history of the horse, the most important (the ox not excepted) of all the animals domesticated by man. The nature of the inquiry rendered it necessary to treat not only of all the chief breeds of domestic horses known in historical times, but also to take a survey of all the other living Equidae, as well as of the ancestors of the genus. The question of coloration naturally holds a prominent place in the investigation, and I have tried to trace historically the origin of the various colours found in domestic horses. At the same time I have endearoured to indicate, though it must be confessed rather cursorily, the influence exercised on the history of the chief nations of the ancient, medieval, and modern world by the possession of horses, and especially by the acquisition of what I venture to term the Libyan horse. I have also tried to point out the lessons of supreme importance to the breeder which can be learner from the contemplation of the injury wronght to breeds of great value by the ill-judged and nuscientific introduction of alien blood, a practice in no small degree due to a lack of historical knowledge, and to a general behief that all our domestic races of horses, like those of tame pigeons, have been obtained solely by artificial breeding from a single wild species.

I must add a few words respecting the method of writing zoological names and the transliteration of foreign words. In zoological terminology I have, of course, conformed to the rule 
of the editor of the Cambridge Series in which this work appears, but my classical friends will understand my qualms when I have to describe, for instance, Burchell's zebra as Equus burchelli instead of using the usual Latin form, Equus Burchelli. I have used the form 'Prejvalsky's Horse' as the nearest English equivalent for Equus przewalskyi since the letter-combination Prze has no phonetic significance for the English reader. In Arabic words consistency was impossible, for although I myself use only the vowels $a, i$ and $u$ in transliteration, e.g., Muhammad instead of Mahomet or Mahomed, in extracts from other writers I had, of course, to preserve faithfully the forms which each employed according to his fancy.

It only remains for me to express my gratitude to the many kind friends who have aided me in various ways: Dr James Cossar Ewart, F.R.S., Regius Professor of Natural History in the University of Edinburgh, has given me much of his time and has read through all my proofs, and twice through those of the first two chapters; whilst Mr R. I. Pocock, F.Z.S., the Superintendent of the Zoological Society's Garden, Regent's Park, has given me valuable aid by reading the proofs of the chapter on the Living Equidae. Mr A. E. Shipley, F.R.S., Fellow of Christ's College, and University Lecturer in Invertebrate Zoology, and editor of the Cambridge Biological Series, has also read the proofs and has aided me with various suggestions. Had it not been for their criticism and advice the shortcomings of this book, of which no one can be more sensible than the writer, would have been still more numerous; but for the many that remain I alone am responsible. To Dr W. L. H. Duckworth, Fellow of Jesus College, University Lecturer in Physical Anthropology, I am indebted for various important references, and above all for having called my attention to a hitherto unpublished head and neck of a quagga in the Elgin Museum, which I figure and describe (pp. 438-9); Mr A. W. Howitt, Hon. D.Sc., the well-known Australian ethnologist, of Metung, Victoria, has supplied me with the valuable account of the feral horses of Eastern Victoria, which I have embodied; Dr R. S. Conway, Professor of Latin in Manchester University, and late Fellow of Gonville and Caius College, 
made for me in Florence the very careful measurements of the chariot from Thebes; whilst Sir Ernest Clarke, M.A., St John's College, Secretary to the Royal Agrieultural Society, has supplied me with several valuable notes which I have embodied, and has also aided me in obtaining the use of blocks and photographs. Dr M. R. James, the Provost of King's College, Cambridge, and Director of the Fitzwilliam Museum, pointed ont to me the drawings of Stradanus, reproduced in this work. I had the advantage of talking over many points in my book with the late Captain Maurice H. Hayes, the well-known author of The Points of the Horse, etc. Mr G. P. Bidder, M.A., Trinity College, long resident at Naples, and through him $\mathrm{Mr}$ E. Neville Rolfe, II.A., H.B.M. Consul for sonthern Italy, have given me much valuable information respecting the horses of Naples and sonthern Italy. I am also indebted for very important references or for help in various other ways to the following: Mr A. A. Bevan, M.A., Lord Almoner's Professor of Arabic and Fellow of Trinity College; Mr H. M. Chadwick, M.A., Fellow of Clare College; Mr J. G. Frazer, M.A., F.B.A., Hon. D.C.L., Hon. LL.D., Hon. D.Litt., Fellow of Trinity College; Dr C. S. Myers, Gonville and Caius College; Rev. Canon Greenwell, F.R.S., D.C.L.; Rev. T. T. Gray, M.A., Senior Fellow of Trinity College, Dublin; Mr J. Bass Mullinger, M.A., Librarian of St John's College; Mr R. C. Bosanquet, M.A., Trinity College, Director of the British School at Athens; Mr George Coffey, M.A., Keeper of the Museum of the Royal Irish Academy; Mr A. W. Mair, M.A., Professor of Greek in the University of Edinburgh, and Fellow of Gonville and Caius College; Mr Carl Hagenbeck, of Hamburg (for photographs); Mr C. W. Hawes, M.A., 'Trinity College (for the use of photographs); Dr J. Venn, F.R.S., President of Gonville and Caius College; Mr J. A. Venn, B.A., Trinity College (for photographs); Dr M. M. Hartog, Professor of Natural History in Queen's College, Cork; Mr Cecil Bendall, M.A., Professor of Sanskrit in the University of Cambridge, late Fellow of Gonville and Caius College: $\mathrm{Mr}$ Harold Littledale, M.A., Trinity College, Dublin, Professor of 
English Literature in University College, Cardiff; Mr Clement Gutch, M.A., Lecturer of St John's College; Mr E. H. Minns, M.A., Fellow and Librarian of Pembroke College; Dr A. C. Haddon, F.R.S., Fellow of Christ's College, University Lecturer in Ethnology, and late Professor of Zoology in the Royal College of Science, Dublin; Mr F. W. Green, M.A., Jesus College; Dr. Scharff, the Head of the Department of Natural History in the National Museum of Ireland, and Director of the Zoological Gardens, Dublin; Dr Cecil H. Smith, Keeper of the Greek and Roman Antiquities, British Nuseum; Mr A. H. Smith, M.A., Trinity College, the Assistant-Keeper of the same Department; Dr Budge, Christ's College, Keeper of the Department of Egyptian and Assyrian Antiquities, British Museum; Dr Oscar Montelius, Director of the National Museum of Sweden; Dr Brunchorst, Director of the Bergen Muselım; the Rev. J. Roscoe, C.MI.S., Uganda, and Mrs Roscoe; Mr P. IV. Sclater, F.R.S., late Superintendent of the Zoological Garden, Regent's Park; Mr H. Platnauer, Curator of the York Museum; Mr Gordon Taylor, Curator of the Elgin Museum; Don Angel Cabrera, Madrid; Mr W. W. Skeat, M.A., Christ's College; Mr J. Stanley Gardiner, M.A., Fellow and Dean of Gonville and Caius College; Mr E. C. Quiggin, M.A., Fellow and Lecturer of Gonville and Caius College; Mr R. C. Punnett, M.A., Fellow of Gonville and Cains College; Mr Alfred Newton, M.A., F.R.S., Professor of Zoology in the University of Cambridge, and Fellow of Hagdalene College; $\mathrm{Mr}$ William Bateson, M.A., F.R.S., Fellow and Lecturer of St John's College, Deputy for the Professor of Zoology; Mr J. Graham Kerr, M.A., Professor of Natural History in the University of Glasgow, late Fellow of Christ's College; Mr. T. McKenny Hughes, M.A., F.R.S., Professor of Geology in the University of Cambridge, and Fellow of Clare College; Dr Walter G. Headlam, Fellow and Lecturer of King's College; Rev. T. J. Pulvertaft, M.A.; Mr' F. A. H. Marshall, M.A., Christ's College; Mr Theodore M. Davies (through Ir Percy E. Newberry); my brother-in-law, Mr Arthur Warren Samuels, LL.D., K.C.; my niece, Miss K. F. Samuels (for photographs); Lt.-Col. Herbert Irwin, 
Warwickshire Regiment; Mr G. E. Low, Foster Place, Dublin (for photographs); Mr Alfied J. Sunith, Rendlesham, Suffolk; Mr W. B. Redfern; and Prof. H. F. Osborn, Hon. D.Se., Columbia University, U.S.A. For the loan of blocks I have to thank the Department of Agrieulture in Ireland (through Mr 'T. P. Gill), the Council of the Royal Irish Academy, the Commeil of the Cambridge Philosophical Society, and the Council of the Cambricge Antiquarian Society; and for permission to copy illustrations or to obtain electrotypes I am indebted to the Trustees of the British Museum, the Council of the Royal Zoological Society, the Council of the Royal Agricultural Society, the Council of the Shire Horse Society, the Council of the Hellenic Society, Messrs A. J. Holman and Co., and Messis Longman and Co.

\section{WILLIAM RIDGEWAY.}

Fen Ditton, Cambride,

Lammas Day, 1905. 



\section{CON'TENTS.}

CHAPTER I.

Introduction: The Ancestors of the Equidae $\quad . \quad$ PAGE

CHAPTER II.

The Existing Equidae . . . . . . . 12

CHAPTER III.

The Horses of Prehistoric and Historic Times . . 82

CHAPTER IV.

The Origin of the Libyan Hor'se . . . . 4 425

CHAPTER V. (SUPplementary.)

The Development of Equitation . . . . . 478

ADDENDA . . . . . . . . . . 506

IxDEX . . . . . . . . . 513 


\section{LIST OF ILLUSTRATIONS.}

FlG.

PAGE

1. Hind-leg of Arab of coarse type, with eallosity like that of Prejvalsky's Horse . . . . . . . . . 13

2. Chestnut on right fore-leg of a Prejvalsky Horse . . . . . 14

3. Hock Chestnut (right) of a Prejvalsky Horse . . . . 14

4. Hock Chestnut (right) of Iceland Pony of Cart-horse type . . 14

5. Ergot (Fetlock Wart) on left fore-leg of a Common Donkey . . 15

6. Ergot (Fetlock Wart) on hind-leg of a Common Donkey . . 15

7. Ergot on right fore-leg of a Chapman Zebra . . . . . 15

8. Ergot on left fore-leg of a Connemara Pony . . . . . 15

9. Ergot on right fore-leg of an Arab . . . . . . 15

10. Ergot on lind-leg of an Arab. . . . . . . . 15

11. Typical Yellow-dun 'Celtic' Pony: North Iceland . . . 17

12. Hind-leg (left) of 'Celtic' Pony showing no hock callosity . . 19

13. Typical 'Celtic' Pony: North of Iceland . . . . . 20

14. Flat-nosed variety of 'Celtic' Pony : Hebrides . . . . 21

15. Black Hebridean Pony without hock callosities . . . . 22

16. A Faroe Filly . . . . . . . . . . 23

17. Faroe Pony . . . . . . . . . . 25

18. Prejvalsky's Horse . . . . . . . . . . 27

19. Young Prejvalsky Horses and their Mongolian foster-mothers . 29

20. The Kiang . . . . . . . . . . 44

21. The Kiang . . . . . . . . . . . 45

22. The Onager . . . . . . . . . . 47

23. Assyrians lassoing a Wild Ass . . . . . . . 49

24. The Nubian Wild Ass . . . . . . . . . 50

25. The Nubian Wild Ass . . . . . . . . . . . 51

26. The Somali Wilh Ass . . . . . . . . . 52

27. The Somali Wild Ass . . . . . . . . . 53

28. The Somali Zebra . . . . . . . . . . 59

29. The Mountain Zebra . . . . . . . . . 62

30. Head of Grant's Zebra . . . . . . . . . 63

31. Skin of an unborn Foal of Grant's Zebra: Uganda . . . 64

32. Skin of a young Grant's Zebra . . . . . . . 65

33. Skin of a full-grown Grant's Zebra: Uganda . . . . . 67

34. Burchell's Zebra (Grant's variety) . . . . . . . 68

35. Burchell's Zebra (Grant's variety) from Kilima Ndjaro . . . 69

36. 'Matopo,' Prof. Ewart's Chapman Zebra . . . . . . 70

37. Typical Burchell's Zebra . . . . . . . . . 71

38. The typical Quagga . . . . . . . . . . 73

39. Lord Morton's Quagga . . . . . . . . $\quad$. 77 
FIG.

PACE

40. The Daniell Quagia. . . . . . . . . . 7!

41. A Prehistoric Horse . . . . . . . . . . . $4 \frac{1}{4}$

12. Head of Prehistoric Horse: Gourdan . . . . . . 85

43. Miniature Axe : Hallstatt . . . . . . . . 91

44. Remains of a Cliariot found at Driflield, lorkshire . . . yf;

45. Bronze Bits: Ireland . . . . . . . . . ys

46. Thracian Coin showing Ox-eart . . . . . . . 106

47. Grave-stone: Mycenae . . . . . . . . . 107

48. Norse Pony from the Isle of Iiollo. . . . . . . . 119

49. Norwegian Ponies near Mundal Glacier . . . . . . 120

50. The last of the old Lofoden I'onies . . . . . . 121

51. An old Icelandic Horse-fight . . . . . . . . 123

52. Ancient Seythians taming Horses . . . . . . . 131

53. A Buriat Horseman . . . . . . . . . . . 135

54. A Group of IBuriats rearly for the Race . . . . . . 137

55. Buriat Women setting forth to Hill Shrine on a Feast-day . . 139

56. The Tangmm of Tibet . . . . . . . . . 155

57. Black Arabian of the Imam of Museat . . . . . . 173

5.. A bay Arabian. . . . . . . . . . . . 181

59. The Horse of Anatolia . . . . . . . . . 189

60. The Turk. . . . . . . . . . . . 191

61. Impression from the Signet of Darius Hystaspes . . . . 193

62. Tiglath Pileser III in his Chariot . . . . . . . 195

63. Head of a Horse from the Chariot of Assur-bani-pal . . . 196;

64. Assyrian Lion-hunt . . . . . . . . . . . 197

6.5. Coin of Aemilius Scaurus . . . . . . . . . $20^{2}$

66. Coin of Anlus Plotins . . . . . . . . . 203

(i7. 'Hittite' Bas-relief showing Lion-hunt . . . . . . 215

68. Seti I in Battle . . . . . . . . . . 217

69. Chariot found in a tomb at Thebes . . . . . . 205

70. The Barbary Horse . . . . . . . . . . 241

71. The Moorish Horse . . . . . . . . . . 242

72. A Libyan Woman on Horsebaek . . . . . . . 243

73. The Dongola Horse. . . . . . . . . . 2 . 24)

74. Carthaginian Coins . . . . . . . . . . . 2.j5

75. The Jennet of Spain . . . . . . . . . 259

76. The Sardinian Horse . . . . . . . . . . 275

77. Archaie Hetope showing a Quadriga: Selinus . . . . 277

78. Fragment of seulpture from Tarentum . . . . . . . 279

79. Fresco showing a Samnite Warrior: Paestum . . . . 281

80. The Neapolitan Courser . . . . . . . . . 285

81. Vase from Enkomi, Cyprus . . . . . . . . . . 288

82. Vase fragment from Enkomi, Cyprus . . . . . . . 2x!

83. Greek Horsemen from the Parthenon . . . . . . 297

84. Head of the Horse of Selene: Parthenon . . . . . . . 299

85. Coin of Potidaea . . . . . . . . . . . . . 301

86. Coin of Philip II of Macedon showing a Jockey on a Race-horse . 302

87. Coin of Philip II of Macedon showing a Horse-soldier _ . 303

85. Head of one of the Horses of the Quadriga from the Mausolemm . 305

89. Roman Denarius . . . . . . . . . . 30s

90. The Lombard Horse . . . . . . . . . . 315

91. The Hungarian Horse . . . . . . . . . . . . . . . 319

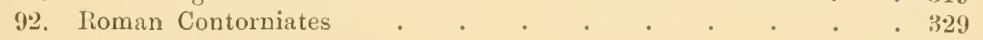

93. The German Horse. . . . . . . . . . . . 331; 
FIG.

94. The Flanders Horse

95. The Horse of Cleves

96. The Horse of Juliers

97. The Friesland Horse

98. The Danish Horse .

99. The East Prussian Horse

100. Sleipnir, Odin's Horse

101. The English Horse .

102. King William III on a Great Horse

103. Shire Stallion, 'Stroxton Tom' .

104. Typical Suffolk Punch, 'Saturn'

105. Flying Childers

106. The Godolphin Barb

107. The Iorkshire Coach-horse

108. A Hackney Mare

109. Plinth of the Cross at Kells, Co. Meath

110. Irish Horseman : Book of Kells

111. Sword of La Tène type in its sheath: Connantre, Marne

112. Iron Sword, La Tène type, in Bronze Scabbard: Hallstatt.

113. Bronze Shield: Bingen

114. Bronze Fibula: Marne

115. Alderwood Shield: Irelan

116. Bronze Fibula: Ireland

117. Bronze Fibula: Ireland .

118. Bronze Shield: Co. Limerick

119. The O'Donovan Shield: Skibbereen

120. Yellow-dun Connemara Pony .

121. A rich Yellow-dun Connemara Mare and Foal

122. Light-grey Conneniara Pony

123. New Forest Ponies

124. Light-grey Connemara Filly

125. Connemara Pony : Clifden district

126. Connemara Gelding of larger type

127. Connemara Pony nsed as a hunter

128. Irish Draught Stallion

129. Irish Thoronghbred Stallion

130. Irish Hunter Gelding

131-3. The Eigin Quagga

131. The Muscovy Drake 'Hans' and his hybrid off'spring by a white Aylesbnry duck

135. Chapman's variety of Burchell's Zebra

136. A Zebra-pony Hybrid

137. Coin of Messana showing Mnle-car

138. Ancient Irish Rein-ring with 'late Celtic' ornament . . . 493

139. Ancient Irish Rein-ring . . . . . . . . . . 495

140. Medieval Persian Stirrup . . . . . . . . . . 499

141. Prick-spurs . . . . . . . . . . . . . 500

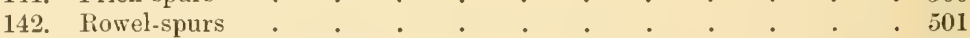

143. Old Euglish Horse-shoes . . . . . . . . . . 503 


\title{
CHAPTER I.
}

INTRODLCTION: THE ANCESTORS OF THE EQUIDAE.

\begin{abstract}
Multaque tum interiisse animantum sacela necessest nec potuisse propagando proeudere prolem. nam quaecunque vides vesei vitalibus auris, aut dolus, aut virtus, aut denique mobilitas est ex ineunte aevo genus id tutata leservans.
\end{abstract}

LUCRETIU'S V. 855-9.

NExT to the history of the various branches of the human race there is no more interesting and important subject for man's study than the origin and development of the breeds of domestic horses, the noblest of all the creatures that man has subdued to his will, and the acquisition of which has been, as will be shown presently, one of the chief factors in the rise and supremacy of the great nations of the ancient, medieval, and modern world. It lias long been a matter of dispute among naturalists whether all our domestic horses have had a multiple or a single origin. Colonel Hamilton Smith ${ }^{1}$ held that they are descended from five primitive and differently coloured stirpesthe bay (represented by the turpan), the white, the black, the dun with a striped back (represented by the horses of the Ukraine), and finally the piebald stock of Tibet. M. Sanson ${ }^{2}$ went further and divided the Equides caballines of our actual epoch into eight species (espèces) which have severally their

1 "The Horse," Naturalist's Library, Vol. xir. pp. 160 sqq.

2 M. Sanson first published his subdivisions in his "Nouvelle Détermination des Espèces Chevalines du genre Equus" (6 Dee. 1869), Comptes-Re'udus, 1xix. pp. 1204-7; then in Migrations des Animaux Domestiques, p. 9, and in his Truité de Zootechnie (ed. 2), Vol. n1. pp. 9-105.

R. II. 
own osteological types. The district where each is principally found is denoted by its Latin praenomen:-(1) Equus caballus asiaticus, (2) E. c. africunus, (3) E. c. germanicus, (4) E.c. frisius, (5) E. c. belgicus, (6) E. c. britannicus, (7) E. c. hibernicus, (8) E. c. sequanius.

Sanson divided all the horses hitherto known as 'Oriental' or 'Arab' between his two first species-Asiaticus and Africanus, as he conceived that they had two separate places of origin denoted by the names which he assigned to them. The Asiuticus he conceived to have originated and been domesticated in central Asia, whilst from the existence of a peculiar breed of black horses, commonly with white feet, known as Dongolawi, from the fact that they are found round Dongola in Nubia, he was led to maintain that this breed had "originated in northeast Africa, probably in Nubia." He declares that there are distinct osteological differences between Asiaticus and Africamus, holding that the former has a flat forehead, and a straight chaffron, which gives its head a rectangular profile, that it has prominent orbits projecting beyond the plane of the forehead, a long head, a large chest, a round barrel, a large rounded croup, and a tail borne far from the body, whilst Africanus has a forehead rounded like the segment of a globe, and the lower part of the chaffron slightly convex, features which give its head a bousque or moutonné look; the orbits are not salient, the ears are longer and are less divided apart at the base, the body not so capacious, the chest not so large, the sides less curved, the croup more like that of a mule, the tail carried near the body, the thighs always slender, and the legs longer than in Asiaticus, and it differs from the latter in the number of its lumbar vertebrae, and by the absence of hock callosities².

Sanson derives ultimately his remaining six classes from his asiaticus; several of them are known by other names, germanicus as Danish, his firisius as Flemish, whilst his britumicus comprises the Norfolk or Black Horse, the Suffolk Punch, and in France the Boulomais and Cauchois (Caux), his hibcrnicus includes all the ponies of the United Kingdom and

' Op. cit. (ed. 4), Vol. ni. p. 52: "Les membres postérieurs sont dépourvus de châtaignes." 
the Breton in France, whilst finally his sequanius is identical with the Percheron so lighly esteemed in France.

II. Piètrement ${ }^{1}$ adopted Sanson's principle of an eightfold subdivision, but carefully restricted the term species to Equus caballus, describing the eight classes as races. But not believing that the argument based on geographical distribution was of itself sufficient he rejected Sanson's ufricunus, and on the gromds that Sanson admitted that his usiuticus originated in central Asia, he assumes that it was primarily domesticated by the Aryans, and accordingly terms it aryanus to distinguish it from what he holds to be the other Oriental race (wrongly regarded as African by Sanson). As Piètrement considers that the latter was domesticated in central Asia by the Mongolian or Tartar-Finnish peoples, and that it was brought thence by the Hyksos into Egypt, he gives it the name of mongolicus. The aryomus and the mongolicus of Piètrement thus correspond respectively to the asiaticus and the afiricams of Sanson. It will however be observed that Piètrement's nomenclature is based on several unproved assumptions; first, that the original home of the Aryaus was in central Asia, secondly, that the Dongola horse was brought into Africa from Asia some two thousand years before Christ, thirdly, that it was the Hyksos who brought it there, and fourthly, that the Hyksos were Mongols. We shall presently see grave reasons for doubting the validity of the grounds on which M. Piètrement has based his terminology.

Darwin? rejected not only Hamilton Smith's five stirpes, but also Sanson's E. c. afiricanus on the ground that the latter involved the assumption "that osteological characters are subject to very little variation, which is certainly a mistake," and he was thus inclined to follow those naturalists who "from the fertility of the most distinct breeds when crossed, look at all the breeds as having descended from a single species," and he held" "that it is not probable that each larger breed, which in the course of time has supplanted a previous and smaller

1 Les Chevaux préhistoriques et historiques, pp. $13 \mathrm{sqq}$.

2 Variation of Animals and Plants under Domestication, Vol. I. pp. 53-4 (ed. 2).

3 Ibid. Vol. I1. p. 423. 
breed, was the descendant of a distinct and larger species: it is far more probable that the domestic races of our various animals were gradually improved in different parts of the great European-Asiatic continent, and thence spread to other countries." He thus left Africa out of account as a possible source for a race of horses. It will be observed that those who hold a single origin for all domestic horses base their belief on "the fertility of the most distinct breeds when crossed." Yet this cannot be regarded as a true criterion, for animals which are admittedly distiuct species, such as the dog, the wolf, and the jackal among carnivores, and the common ox, the zebu (Bos gaurus), and the yak (Bos grunniens) among herbivores, freely interbreed and produce fertile offspring. But though Darwin leaned to the belief that all our horses come from a single stock, he carefully pointed out that, "as several species and varieties of the horse existed during the later Tertiary period, and as Rutimeyer found differences in the size and form of the skull in the earliest known domesticated horses, we ought not to feel sure that all our breeds are descended from a single species.". He elsewhere ${ }^{2}$ points out that "as the savages of North and South America easily reclaimed the feral horses, so there is no improbability in savages in various quarters of the world having domesticated more than one native species or natural race."

Since Darwin wrote it has been generally held that all our domestic horses have had but a single source, whether they be the fine horses of slender build and great speed, of which the Arab is the type, or the heavy cart-horses, whose origin is commonly found in the coarse, thickset horses of Europe and upper Asia, of which the unimproved Mongolian pony is the representative, or hunters, roadsters, carriage-horses and trappers, which are as everyone knows, the result of a judicious blending of the two first-mentioned classes. Thus M. Sanson ${ }^{3}$ now holds that all our domestic breeds had a single origin, and divides recent horses into two groups--long-headed and short-headed-

1 I'ariation of Amimals and Plants under Domestication, Vol. I. p. 53.

2 Ibid. Vol. I. p. 54.

3 Traité de Zootechnie (ed. 4, 1901), pp. 2, 3. 
each of which consists of several races, while Capt. M. H. Hayes ${ }^{1}$ maintains that "no breed of horses possesses any distinctive characteristic which serves to distinguish it from other breeds." But on Dec. 2nd, 1902, Prof. J. Cossar Ewart, F.R.S., read before the Royal Society of Edinburgh a paper in which he pointed out the existence in the Western Islands of a varicty of horse hitherto unnoticed. A week earlier the present writer had laid before the Cambridge Philosophical Society a summary of the evidence which led him to conclude that the hitherto generally received notion that the Arab horse was the ultimate source of our thoroughbred and half-bred horses had no historical foundation, that the Arabs had only got their fine breed of horses firom North Africa at a period later than the Christian era, and that on the other hand there was the clearest evidence of the existence in Libya of a fine breed of horses for a thousand years before the Arabs ever bred a horse, and finally it was maintained that from this North African stock all the best horses of the world have sprung, and that it is a variety entirely distinct from the clumsy, thickset, slow horses of Europe and Asia.

The object of the following pages is to set out at length the evidence for the conclusion just stated, and to trace the important part played by this Libyan horse and its descendants in the history of the world.

It was only at a comparatively late epoch in the history of mammals that the ancestors of the horse made their first appearance, for it is not until the Tertiary period that hoofed animals begin to occur. It is among two extinct families of the Perissodactyles-the Lophiodontidae and the Palaeotheriidaethat we meet what appear to be the earliest ancestral forms of the horses and the tapirs of to-day, though it cannot be affirmed that an unbroken line of descent from any forms yet known can be made ont for the existing Equidae. Yet we can at least point to a series of forms, the salient osteological features of which have led to a belief in the relationship of our horses to these primeval Perissodactyles ${ }^{2}$. We may start with certain

1 Points of the Horse (3rd ed., 1904), p. 42.2.

2 Beddard, Mammalia (1902), pp. 247-8; Flower and Lydekker, Mammals (1891), p. 380 . 
forms in the Eocene of both Europe and America. In the Phenacodus of the American Lower Eocene the feet still retain the primal five digits, whilst in the Eocene of both Europe and America occur the diminutive Hyracotherium, which had its fore-limbs four-toed, but its hind three-toed (as is the case with the tapir, which is in many respects the most ancient of existing forms referable to the Perissodactyle order), and also Eohippus belonging to the same sub-family, but which is slightly more primitive, as its hind feet have a vestige of the first digit. Pachynolophus (or Orohippus), found in both Europe and America, shows molars somewhat more advanced towards the equine type. From this last form the Anchitherium found in the Upper lliocene is not far removed in structure; but, though it is a little nearer to the horse in several respects, it is not now considered to be in the direct line of descent, as it is considerably larger than some succeeding forms. Since both Hyracotherium and Pachynolophus occur in both the Old and New Worlds, from them may have sprung the true horses of both hemispheres. But from this point there is now a bifurcation, for Mesohippus, the next step towards Equus, is as yet only known in America, as is also the case with its successors Miohippus, Desmatippus, and Protohippus. The last-named (found in the Lower Pliocene), and which was about the size of a modern donkey, had three toes on each foot. As Mesolippus has not been discovered in the Old World we are left only with Anchitherium (already described) and Hipparion (which had come from America) in that area. The latter was very widely distributed, occurring not only in North America, but also in Asia, Europe and Africa. Its remains have been recently found in considerable ummbers at Pikermi near Athens (a fine specimen from which place is now in the National Museum of Natural History), in the isle of Samos, and in Egypt. In the typical North American and European forms there were three digits, but in the Indian Hipparion antelopinum the lateral digits seem to have disappeared.

We have already given reasons for not placing Anchitherium in the direct line of ancestry of the horse, and zoologists now hold that Hipparion must likewise be excluded. It became extinct probably owing to excessive specialization. 
Three years ago the American Musenm set on foot under the direction of Prof. Henry Fairfield Osborn a special exploration into the fossil history of the horse. "The object was to connect all the links between the Lower Eocene five-toed, and Lower Pleistocene one-toed horses and to ascertain the relations of the latter to the horses, asses, and zebras of Eurasia and Africa. The first great result obtained is the proof of the multiple nature of horse evolution during the American Oligocene and Miocene. Instead of a single series as formerly supposed there are five, one leading to Neohipparion the most specialized antelope-like horse which has ever been found, a second of intermediate form probably leading through Protohippus to Equus as Leidy and Marsh supposed, a third leading to the Upper lliocene Hypohippus, a persistently primitive probably forest or swamp-living horse with short crown teeth adapted to browsing rather than grazing, and three spreading toes; this horse has recently been found in China also. A fourth and fifth line of Oligocene-Miocene horses became early extinct. This polyphyletic or multiple law," says Prof. Osborn", "is quite in harmony with the multiple origin of the historic and recent races of horses as recently established by Ridgeway and Ewart. The Pliocene horse of America still requires further exploration before we can positively affirm either that all the links to Equus are complete, or that America is indubitably the source of this genus. The Lower Pleistocene of America exhibits a great variety of races ranging in size from horses far more diminutive than the smallest Shetland to those exceeding the very largest modern draught breeds. Yet all these races became extinct, not surviving into the human period, as was the case in South America. The relation of these North American races to those of South America and of Asia and Africa is again a subject requiring further investigation in which it is necessary to exercise the most extreme accuracy."

In the recent Equidae each foot consists of a single complex digit, but digits II. and IV. are complete in the embryo and also survive though degraded in the adult, and there is a callosity

1 "Evolution of the Horse," a paper read before the British Association (Section D), Tuesday, Aug. 23, 1904 (Nature, 22 Sep. 1904, 1. 520). 
(termed castor or chestmut) on the inmer side of the fore-leg above the carpus; the tail is furnished with long hair, either at the end or throughout its whole length. The lateral digits sometimes survive to a considerable extent, as was apparently the case with Julius Caesar's favourite charger ${ }^{1}$.

Fossil remains of horses are found abundantly in deposits of the most recent geological age in almost every part of America, from Escholtz Bay to Patagonia. According to Sir C. Lyell ${ }^{2}$ remains of no less than twelve species referred to seven genera have been discovered in the Pliocene and Pleistocene formations of that country. Recent investigations show that North America in pre-glacial times possessed at least nine perfectly distinct wild species of Equidae. These varied much in size; thus Equus complicutus of the Southern and middle Western States and $E$. occidentalis of California were as large as small carthorses, E. tou of Mexico was extremely small, whilst others, such as E. fraternis of the South-eastern States, were intermediate. "Some of the American pre-glacial Equidae were characterised by very large heads and short, strong limbs, some by small heads and slender limbs; and though the majority conformed to the true horse type, two or three were constructed on the lines of asses and zebras." domesticated, existed in any part of America at the time of the Spanish conquest, which is all the more astonishing having regard to the very favourable conditions of soil and climate as demonstrated by the thousands of horses now ranging the Pampas of South America, all descended from seven stallions and five mares introduced by the Spaniards ${ }^{4}$, whilst the mustangs of Texas, sprung from a like small beginning, prove that North America was no less suited to be the nurse of horses.

Dr Munro ${ }^{5}$ has ingeniously suggested that a satisfactory

1 Pliny, N. H. virr. 42. 64.

2 Principles of Geology, Vol, I1. p. 340 (11th ed.).

3 J. C. Ewart, "The Multiple Origin of Horses and Ponies," Transactions of Highland Society, 1904, p. 2.

4 Azara, Natural History of the Quadrupeds of Paraguay and the River La Plata (Eng. trans.), pp. 4-5.

5 " On the Prelistoric Horses of Europe and their supposed domestication in Palaeolithic Times," Archaeological Journal, Vol. Lix. pp. 112-3. 
explanation of the course which led to the extinction of the American horses will be found in the fact that after coming to the end of their evolutionary tether in the attainment of speed-the sole means by which they could escape from their enemies-they fell an easy prey to one or more of these animals, who meanwhile had succeeded in improving their methods of warfare in the struggle of life.

But it is obvious that if the great carnivorae had exterminated the horses, and thereby brought about their own destruction, they would certainly have eaten up the bisons and tapirs before they themselves had perished of hunger, for it camnot be supposed that these animals escaped because they were fleeter of foot than the Equidae.

It may well be that the destruction of these American horses was due not to the continual ravages of mighty carnivores, but to the insidious inroads of far meaner foes, for we must not forget that there are no feral horses in Paraguay, because an Hippoboscu or an Oestrus attacks the umbilical region of young foals, and produces nlcers, which invariably cause death unless human aid is interposed?

I do not for a moment suggest that the extinction of all

2 Col. Hamilton Smith, "The Horse," Naturalisl's Library, Vol. xir. p. 248, Edinburgh, 1841. Though Azara does not mention this in his Spanish version (from which the English trans. was made), yet (English trans., p. 66) spealing of the wild cattle of Paraguay he says that "from August to January, which is the calving time, the cows are driven in Paraguay twice a week to the rodeo, in order to free them from a certain worm which infests them, more especially the calves, at the umbilicus, and to such an extent that, without this assistance, they would inevitably perish. The same malady occurs in Corrientes and the Pueblos of the Missions: but in Monte Video and Buenos Ayres it is so little known that it demands no particular attention; nor are the herds during the above-mentioned months collected so frequently as usual, for the pregnant cows might be injured thereby, and many of the young calves would be lost." My friend Prof. Graham Kerr writes as follows: "The fly appears to be the ordinary blow-fly, which lays its eggs in the drying-up end of the severed umbilical cord and on the blood round it. The larvae hatch out in a few hours and cause ulceration and the death of the calf. Estancieros regularly round up the cattle every few days, and dress the calves affected with medicated glycerine. I have not personally seen the maggots on calves, but I have seen them on adult cows." Darwin cites Azara for the statement about the horses, but he used Azara's French edition, and probably Col. Smith did the sause, as we sliall see later on. 
the Equidae on the American continent was due solely to the insect scourge of modern Paraguay. But as it is clear that though lions abounded in South Africa and preyed largely on zebras, they never threatened extermination to the horse family in Africa, whilst on the other hand the tsetse-fly and horse sickness are as deadly to Equus caballus in certain areas of that region as is the insect pest of Paraguay, it seems far more probable that the extinction of the horses of North and South America was due to the inroads of mean and obscure forms of life rather than to the onslanghts of the great flesh-eating monsters of the young world's prime.

It is generally admitted that the ancestors of the living Equidae passed from America into the Old World, for before the Ice Age it was perfectly possible for American horses to cross into Asia by land bridges in the vicinity of Behring's Straits; thence they extended into Europe, and finally reached Africa either from Asia or by the land bridges which then linked Europe to North Africa. "One of the earlier immigrants, Equus stenonis, has left its remains in Pliocene deposits of Britain, France, Switzerland, Italy, and the north of Africa. While $E$. stenonis was extending its range into Europe and Africa, two others, $E$. sivalensis and $E$. namadicus, were finding their way into India, and yet other species were doubtless settling in Eastern Europe and Central Asia ${ }^{1}$." Thus, as Africa now contains several species of zebras, so Europe at the Pleistocene period was inhabited by several species of horses. Some palaeontologists believe that the Indian species $E$. sivalensis and $E$.namadicus became extinct, and that $E$. stenonis gave rise through one variety ( $E$. robustus) to the modern domestic breeds, and by another (E. ligeris) to the Burchell group of zebras. Hipparion and certain prehistoric South American species were characterised by a fossa or depression in front of the orbit for a facial gland (probably similar to the scent gland in the stag), found also in E. stenonis ${ }^{2}$ and its later ally E. quaggoides and in E. sivalensis (cf. p. 150).

In some modern horses, which have so-called Eastern blood

1 J. C. Ewart, op. cit. p. 3.

${ }^{2}$ R. W. Lydekker, Proc. Zool. Soc. (1904), Vol. I. p. 427. 
in their veins (for instance the race-horse Bend Or) there seems to be a restige of the pre-orbital depression'. Again, Equus sivalensis was usually characterised by large first pre-molar (wolf) teeth in the upper jaw, whilst large functional first premolars are found in some horses of South-eastern Asia (e.g. in Javir and Sulu ponies) and in some zebras, as for instance Grévy's zebra and in a zebra of the Burchell type found near Lake Baringo. It is hence held by some that lineal, lut somewhat modified descendants of $E$. sivulensis of the Indian Pliocene period still survive, and that $E$. sivalensis was a lineal descendant of Hipparion. But it will be presently found that the horses of Java and Sulu have no pretensions to be regarded as aboriginal.

Osseous remains show that horses were widely distributed over Europe in the Pleistocene period, but it has not yet been determined how many species of horses inhabited Europe during and immediately after the Glacial period, nor yet from which of the pre-glacial species prehistoric horses were descended. Bones and teeth from deposits in the south of England seem to indicate that during the Pleistocene period several species of horses ranged over Western Europe. The Pleistocene beds of Essex yield bones and teeth of a large-headed, heavily-built horse, which probably sometimes measured over fourteen hands high. From the 'Elephant bed' at Brighton, portions of a slenderlimbed horse have been obtained: and Kent's Cave, near Torquay, has yielded numerous fragments of two varieties or species, which differed somewhat from the Brighton and Essex species. One of these in its build approached the Essex horse, the other the slender-limbed species of the Brighton 'Elephant bed.' Although the latter has hitherto been described as very small, according to Prof. Ewart, if we are to judge from the bones in the British Museum, "it may very well have reached a height of $12 \cdot 2$ or 13 hands."

If there were two or more species in the south of England, which then formed part of the Continent, "it is probable that yet other species inhabited South and Middle Europe and the North of Africa?".

1 R. W. Lydekker, loc, cit.

2 J. C. Ewart, op. cit. p. 4. 


\section{CHAPTER II.}

\section{THE EXISTING EQUIDAE.}

Hark ! I hear horses. Macbeth, III. 8.

THE early ancestors of the horse which first crossed from the western hemisphere into Asia have had a much more successful career than their American cousins, for in spite of various great flesh-eating animals which once preyed upon their ancestors in Asia and Europe, and still continue to do so down to our own day in Africa, the genus Equus at this present moment (without including the probably extinct quagga) comprises at least some fifteen species or subspecies:-(1) Equus caballus (the horse); (2) E. caballus celticus (the Celtic pony discovered recently by Prof. Ewart); (3) E. przewalskii (Prejvalsky's horse); (4) E. kiang (the kiang); (5) E. onager (Indo-Persian wild ass); (6) E. hemippus (Syrian wild ass); (7) E. asinus (the African wild ass); (8) E. somalicus (the Somali wild ass); (9) E. grevyi (Grévy's Imperial or Somali zebra); (10) E. zebra (Mountain zebra); (11) E. crawshayi; (12) E. foai; (13) E. granti (Grant's zebra); (14) E. chapmani (Chapman's zebra); (15) E. burchelli (Burchell's zebra); (16) E. quagga (the quagga).

\section{HORSES.}

We have seen that in the true Equiclae each foot consists of a single complex digit, but with vestiges of the second and fourth digits, and there is a callosity on the inner side of the fore-leg above the carpus. Besides this there is in the common horse ( $E$. caballus) also a callosity on the back and lower surface of each fetlock joint in the centre of the tuft of hair which covers that part, and a callosity on each hind-leg a 
little below the true hock joint and immediately over the cuneiform bone (Figs. 1-t). 'The callosities noar the knee and hock are termed chestmuts or custors, and those under the fetlock ergots. The chestnuts on the fore-legs of all Equidae are more or less oval in form, those of ordinary domestic horses being usually about 2 inches long. 'The hind chestnuts (which Liquus caballus almost alone of the family possesses) are somewhat similar in shape to the fore ones, though a little smaller and narrower (Fig. 1).

The ergots in all members of the genus are more or less round (Figs. 5-10), and in ordinary domestic horses are less than a quarter of the size of the chestnuts. As Prof. Ewart has shown, the front chestnuts correspond to the wrist pads, the ergots to the micldle portion of the trilobed sole pad in the dog and cat. Other zoologists ${ }^{1}$ hold that the chestnuts are the remains of scent glands, similar to those found in some species of deer and other animals.

According to M. Sanson the absence of the hind chestnuts is of frequent occurrence among the horses and ponies of North Africa, although they are almost invariably present

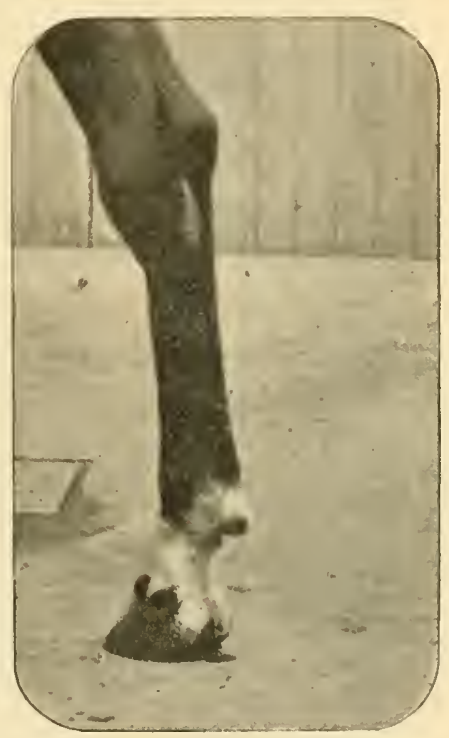

Fig. 1. Hind leg of Arab of coarse type, with callosity like that of Prejvalsky's horse. in ordinary breeds: in very rare instances there are no chestnuts on the fore-legs of domestic horses. Though ergots are generally present, Captain Hayes has "noticed their frequent

1 Sir IV. H. Flower, The Horse, p. 170 (but he held that the ergot on the hinder aspect of the horse's pastern appear's to represent one of the pads, which are still functional in the foot of the tapir). Mr R. W. Lydekker, F.R.S. (Proc. Zool. Soc., 1903, pp. 199-203) has attempted not "so much to show what the equine callosities represent," but rather "from palaeontological consiterations the improbability of their being vestigial foot-pads." 
absence in pure-bred Arab horses and in thoroughbreds." "The nearer a horse approaches the heavy draught type, the thicker is the growth of the callosities on his legs ${ }^{1}$."

We shall presently find (p. 19) that in the typical 'Celtic' pony the hock callosities are wanting, as is not unfrequently the case in North African horses, the front chestnuts are small, whilst

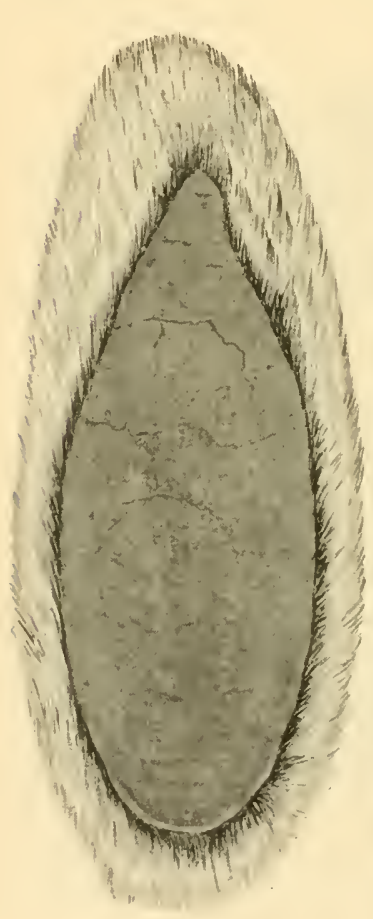

Fig. 2. Chestuut on right fore-leg of a Prejvalsky horse (natural size).

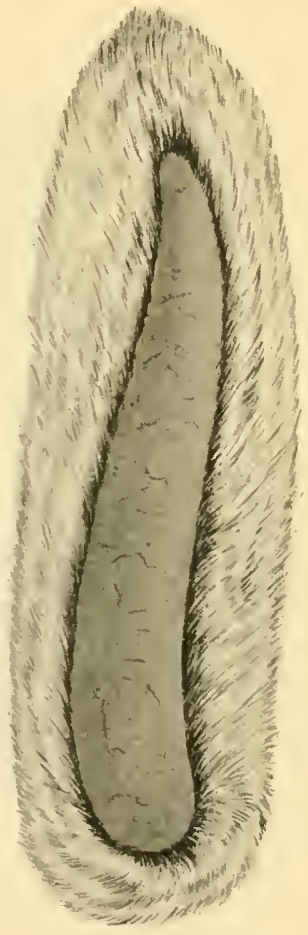

Fig, 3. Hock Chestnut (right) of a Prejvalsky horse (natural size).

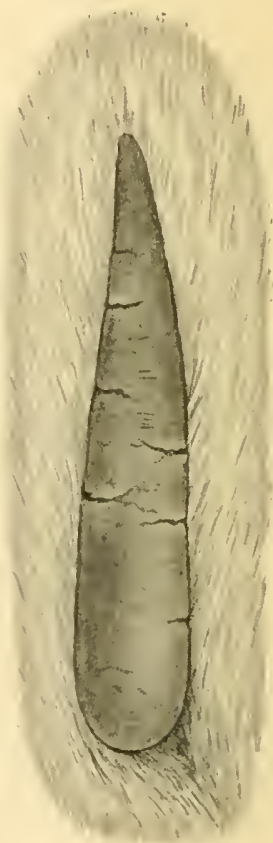

Fig.4. Hock Chestnut (right) of Iceland pony of cart-horse type ( $n a$ tural size).

the ergots have entirely vanished, as in the pure-bred Arabs and thoroughbreds noticed by Capt. Hayes.

Through the kindness of Prof. Ewart, I am enabled to figure (full-size), from drawings inade from his own animals, examples of chestnuts and ergots in various Equidae (Figs. 1-10).

1 Hayes, Points of the Irorse (ed. 3), p. 319. 


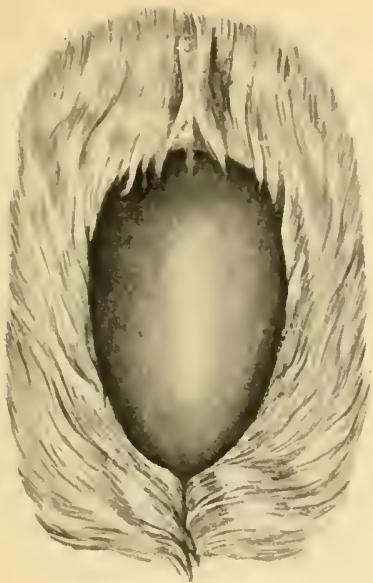

FIG.5. Ergot (fetlock wart) on left foreleg of common donkey (natural size).

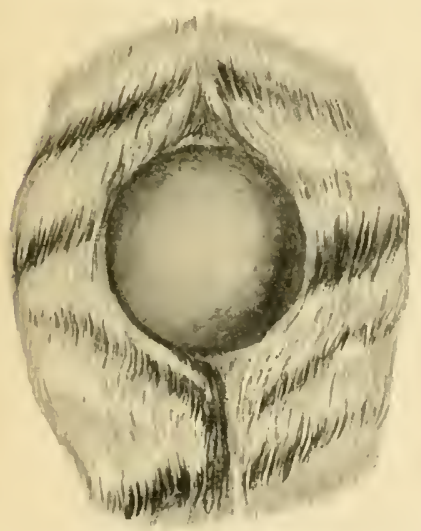

FIg. 7. Ergot (fetlock wart) on right fore-leg of a Chapman zebra (uatural size).

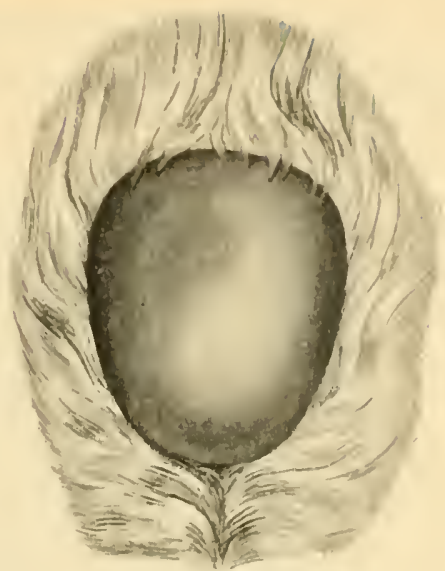

FIo, 6. Ergot (fetlock wart) on hind-leg of common donkey (natural size).

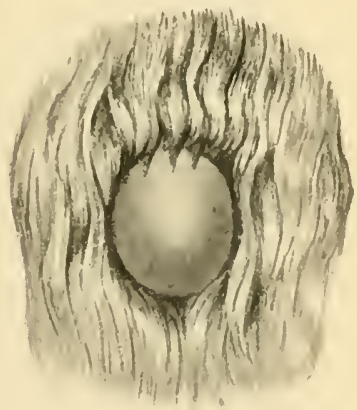

Fia. 8. Ergot (fetlock wart) on left fore-leg of a Connemara pony (natural size).

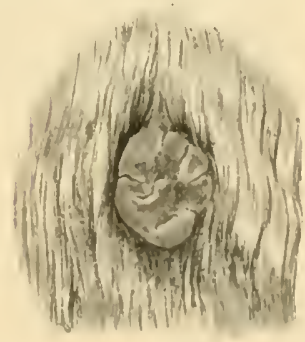

FIG. 9. Ergot (fetlock wart) on right fore-leg of an Arab (natural size).

Fig. 10. Ergot (fetlock wart) on hind. leg of an Arab (natural size). 
(1) Equus caballus has hitherto been distinguished from the rest of the family by the tail being covered with long hairs from its base to its end, and by having chestnuts on the inner sides of its hind-legs, as well as on its fore-legs. But recent investigations have rendered this statement no longer accurate, as will be made clear when we come to speak of Ewart's Celtic pony, and Prejvalsky's horse. The Equus cuballus has a forelock, a longer mane, and shorter ears than its relatives the asses and zebras, whilst in proportion to its size its limbs are longer, its head smaller, and its hoofs broader. A further distinction between the horse and the other Equidae, first pointed out by Tegetmeier and Sutherland', is the length of the period of gestation, which in the horses is eleven months, whilst in the asses and zebras it exceeds twelve months.

It is a matter of dispute whether the true Equus caballus survived in a wild state in Europe down into the historical period, for although Pliny ${ }^{2}$ declares that the north of Europe produces troops of wild horses, just as Asia and Africa produce wild asses, and Strabo $^{3}$ states that wild horses were found in the Alps, and also enumerates them among the wild animals of Spain, it has been maintained that these were not indigenous, but merely the descendants of domesticated horses which had run wild. There are abundant records of the existence of wild horses in upper Europe in not only the early but late Middle Ages ${ }^{4}$ Thus St Boniface was rebuked by Pope Gregory III. (A.D. 732) for permitting his German converts to eat the flesh of wild horses as well as of tame, and wild horses were apparently eaten by the monks of St Gallen about A.D. 1000. In i Westphalian document of 1316, the fishing, game, and wild horses of a certain forest are assigned to one Herman, and there seem to have been wild horses in the Vusges in Merovingian times and even at the end of the 16th century. There were wild horses in Pomerania in the 12th century and there were at the same period wild horses in Silesia, from which Duke

1 Horses, Asses, Zebras, Mules, and Mule Breeding, p. 2.

2 N. H. virr. 16. 3 207, 163.

${ }^{4}$ Hehn, Cultivated Plants and Domestic Animals, pp. 37-8. 
Sobeslaus carried away herds of wild mares not a few in A.D. 1132, whilst there is good proof that the woods of Prussia contained wild horses down to the time of the Reformation.

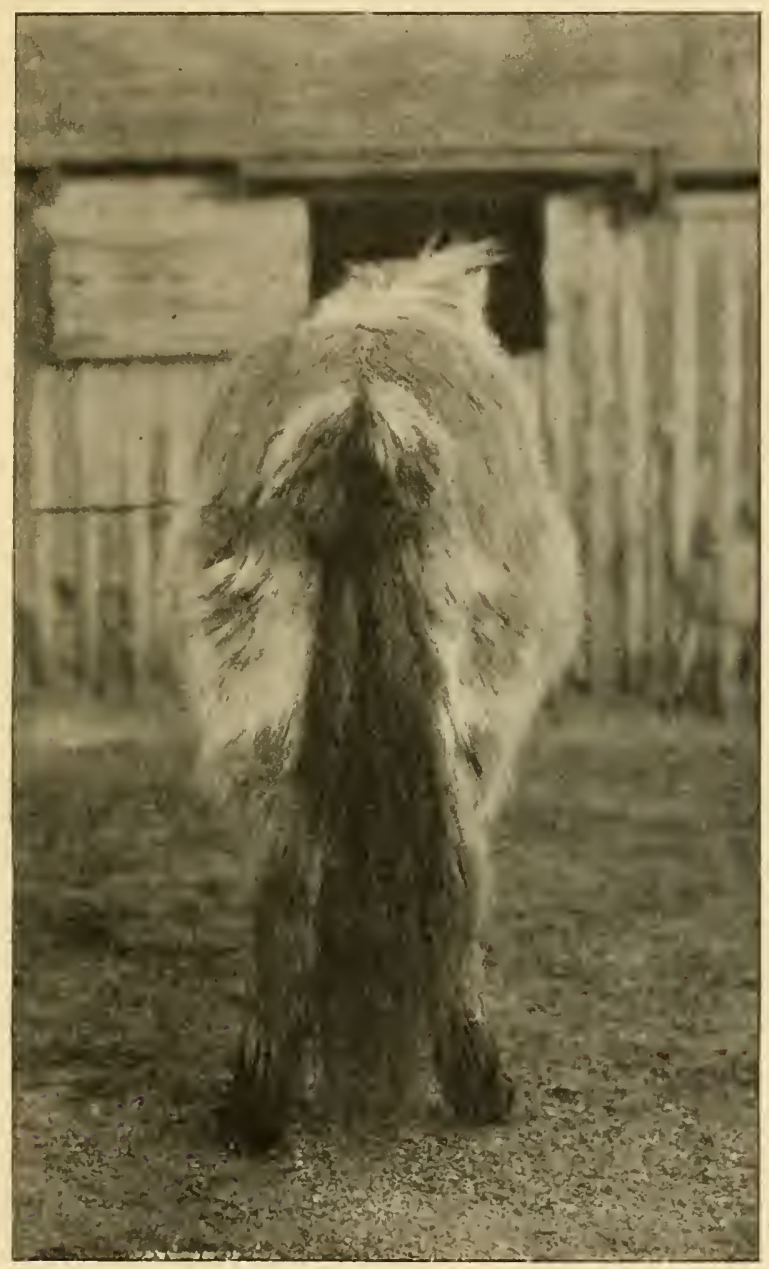

FIG. 11. Typical yellow-dun 'Celtic' pony; North Iceland.

The Teutonic Knights hunted wild horses and other game chiefly for their skins, and Duke Albert in 1543 sent an order to the commander at Lyck birlding him to take measures for

R. I. 
the preservation of the wild horses, whilst far into the 17th century the horse was hunted in Poland and Lithuania. It is almost certain that many of these horses were merely feral, but it is quite possible that some of the troops contained a genuine wild element, though greatly modified by being crossed with escaped domestic animals. But, as it will soon be seen that one, if not two genuine wild varieties have survived in eastern Europe and eastern Asia down to our own times, it is probable that troops of genuine wild horses may have lingered in parts of Europe down to a comparatively recent date (cf. p. 348).

Naturalists not unreasonably view with suspicion the supposed primitive wildness of the tarpan and Prejvalsky's horse, inasmuch as the baguals of South America, the mustangs of North America, the brumbies of Australia, the kumrahs of Nigeria, and the muzins of Tartary are admittedly feral, whilst it is not unlikely that the same holds true of the wild horses of Northern Tibet.

(2) E. caballus celticus. Prof. Ewart ${ }^{1}$, in the paper already mentioned, called attention to the existence of a distinct variety of horse, to which he has provisionally given the name of Equus caballus celticus. It is a true pony, and not a dwarf horse; it has a small head, with prominent eyes, small ears, a heavy mane, slender limbs, small joints, and well formed small hoofs. It has similar characteristics to those Arabs which have no ergots, and at the most only minute hock callosities, but with the essential difference that instead of having long hair up to near the root of the tail, the hair on the upper part of the tail forms a fringe or taillock (Fig. 11). It has been found in Comnemara and the north of Ireland, in Barra and other islands of the Outer Hebrides, and seems to have been common at one time in the island of Tiree, where ponies are now extinct, whilst the same characteristics are observed in many of the ponies imported into this country from Iceland and the Faroe Isles, a fact of considerable importance when we come to discuss the history of the horses of the North at a

1 Times, Tuesday, 2 Dec., 1902, p. 10; for a fuller abstract see Nature, Vol. Lxvir. (1903), p. 239; "The Multiple Origin of Horses and Ponies" (Trans. of Highland Society, 1904), pp. 19 sqq. 
later stage in this work ${ }^{1}$. Prof. Ewart thinks that there is some evidence of its occurrence in the New Forest, and he holds that it is "conceivable that the Celtic pony in its present form never cxisted in the East, but that it is a modified descendant of a small horse, which left the ancestral home in Central Asia and reached Europe long before the arrival of neolithic man." He pointed out that the drawings in the Dordogne caves suggest the existence of a small horse that might very well correspond to the Celtic pony, and further, that in Pleistocene deposits bones had been found of two kinds of horses, one a horse with small head, slender limbs, and small teeth, which again suggested the Celtic pony. In the Celtic pony not only are the hock callosities wanting (Fig. 12), but the front chestnuts are small, and, still more remarkable, the fetlock callosities (ergots) have entirely vanished: in asses and zebras the ergots are always present, and in some cases still play the part of pads. The Celtic pony is hence not only more specialized-further removed from the primitive type -in its mane and tail, but also

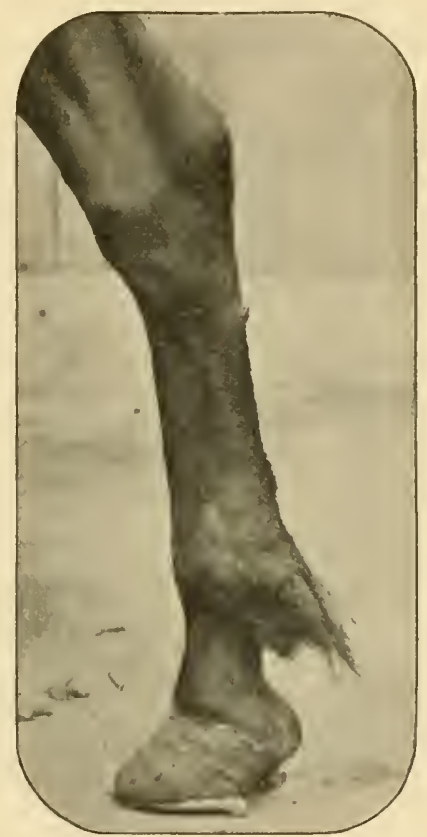

FIG. 12. Hind-leg (left) of 'Celtic' pony showing no hock callosity. in having got rid of the fetlock pads (ergots) and the hock (heel) callosities. Capt. Hayes has frequently noticed the same absence of ergots in North African and Arab horses.

"Except in size I have been unable to discover any difference between the skeleton and teeth of the Celtic pony and the small horse of the 'Elephant bed' of the Brighton Pleistocene.

1 Mr F. H. A. Marshall, B.A., Christ's College, Cambridge, has recently noticed a Welsh pony without hock callosities (Nature, 13 Aug. 1904). 
In the northern part of Iceland, where the few pure specimens of the Celtic pony survive, only a height of twelve hands (48 inches) is reached-under more favourable conditions the height would probably be 50 to 52 inches, the size of some of the 'Elephant bed' horses and the smaller variety of the desertbred Arab to which the small slender-limbed occidental pony closely approximates." The Celtic pony learns rapidly what the trainer wishes, and responds with alacrity. "In a few days its education is complete?."

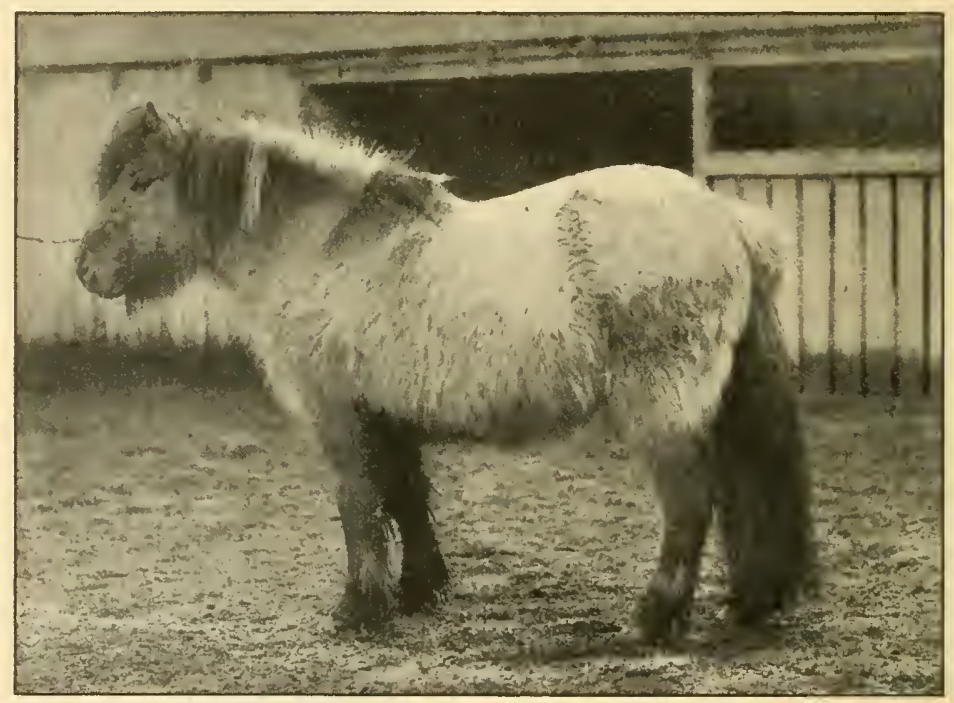

FIg. 13. 'Typical 'Celtic' pony: North Iceland.

Ewart regards the pony selected as a type (Fig. 13) as an almost pure representative of a once widely-rlistributed species. The pony in question proved sterile with stallions belonging to five different breeds, as well as with a Burchell's zebra and a kiang; but she at once bred when mated with a yellow-dun Connemara-Welsh pony, which closely approximates to the Celtic type, and she has this year been successfully mated with a Hebridean black Celtic pony (Fig. 15).

1 J. C. Ewart, op. cit. p. 25. 
In a recent paper, based partly on their own observations in Iceland and the Faroe Islands, $\mathrm{Mr}$ F. H. A. Marshall and Mr N. Amnandale ${ }^{1}$ support Prof. Ewart's doctrine and give some useful details as regards the form, size, and colour of the ponies in those two regions, as well as some interesting historical details, to which we shall refer at a later page (p. 416). Though

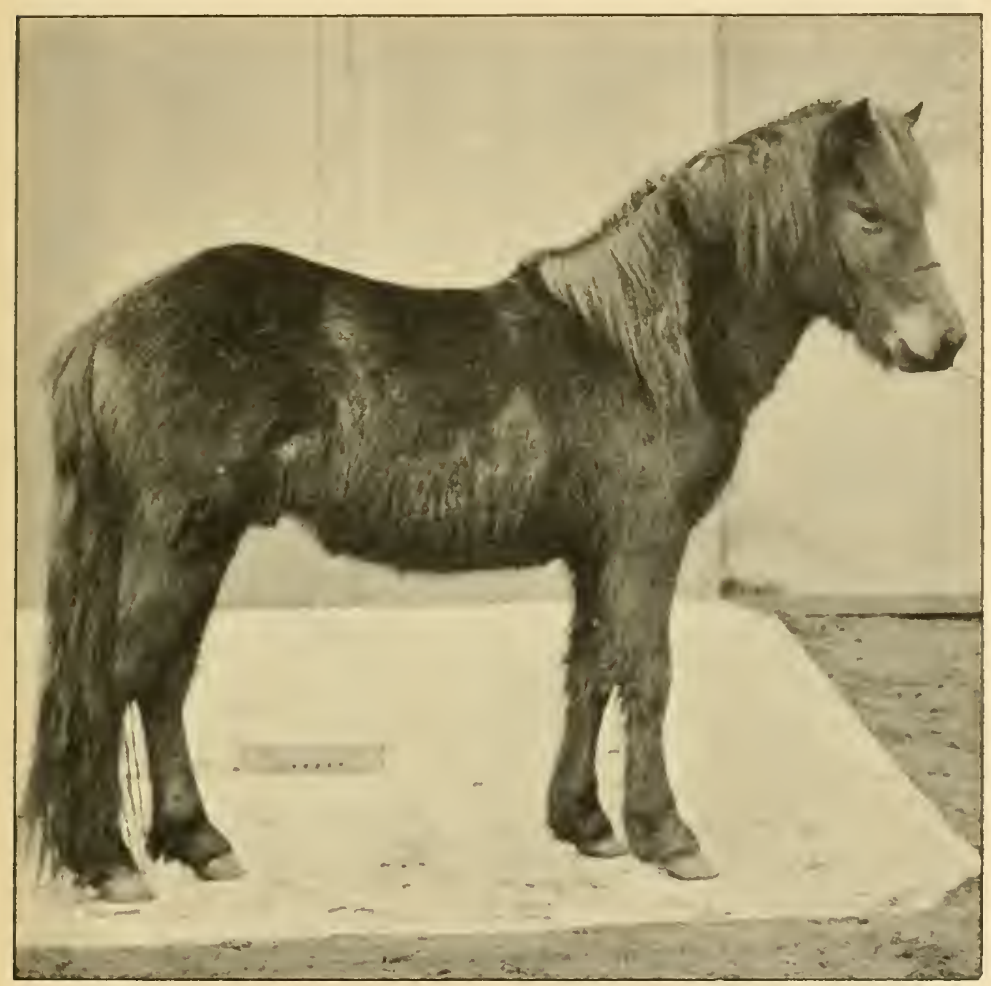

Fig. 14. Flat-nosed variety of 'Celtic' pony: Hebrides.

in recent times some efforts have been made to improve the Iceland ponies by the introduction of Norwegian stallions, it is probable that the majority used for stud purposes are still of

1 "The Horse in Iceland and the Faroes," Proc. Camb. Phil. Soc., Vol. xu. (1903), pp. 300-1. 
pure Icelandic blood". "In the case of the Faroes the Norwegian stallions have only been introduced, apparently, within the last ten or twelve years, and in spite of this admixture, of which it does not appear that Prof. Ewart was aware, the general characters of the majority of the Faroe and

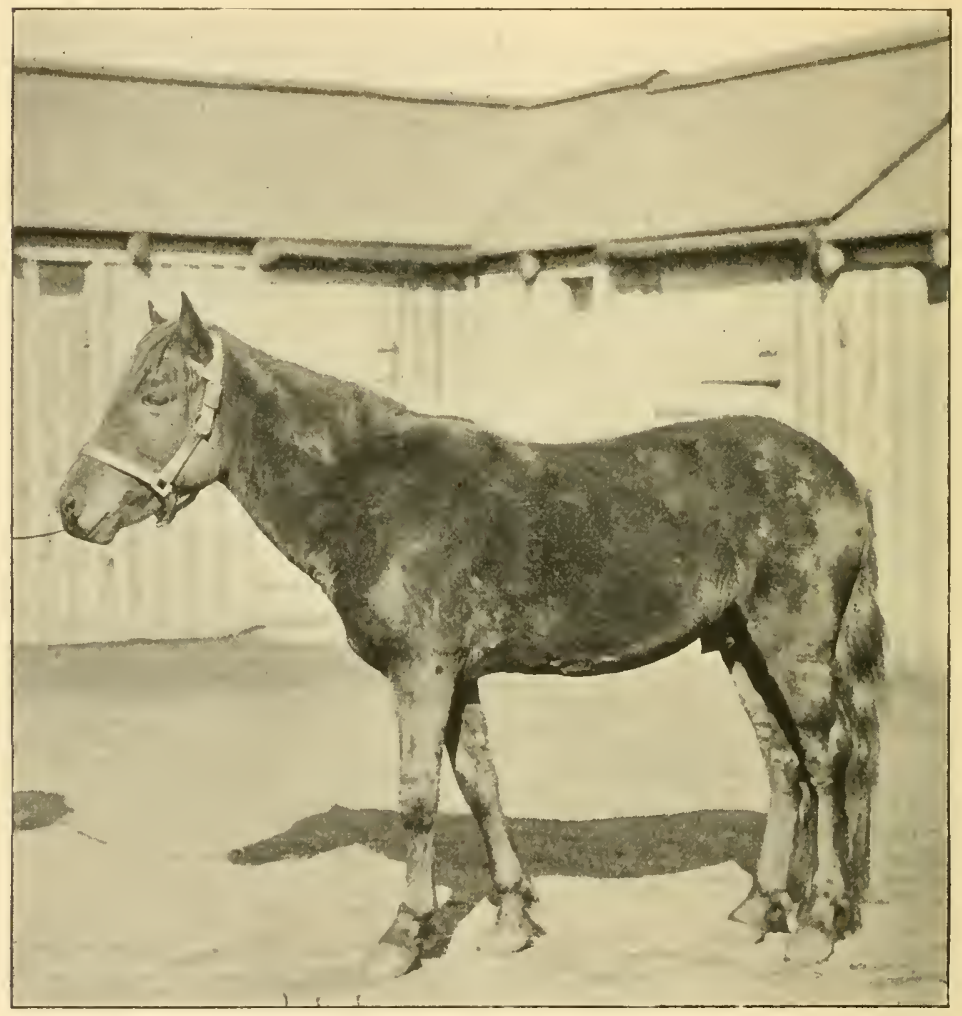

FIG. 15. Black Hebridean pony without hock callosities.

Icelandic ponies are those of the 'Celtic type' (Fig. 13). This was made evident by an examination of a number of Faroe ponies

1 "The Horse in Iceland and the Faroes," Proc. Camb. Phil. Soc., Vol. xir. (1903), pp. 298-9. Prof. Ewart doubts "if Norwegian ponies have recently been introduced into Iceland." 
in Thorshavn this summer (1903), for out of eleven individuals only one had large hock callosities, and this animal, though of small size, differed from the others in being exceptionally clumsy in build, with a large head, strongly suggestive of a eart-horse. The remaining ten ponies either had the hock callosities much reduced in size, or, as in the case of two individuals, had no hock callosities. The height of these ponies

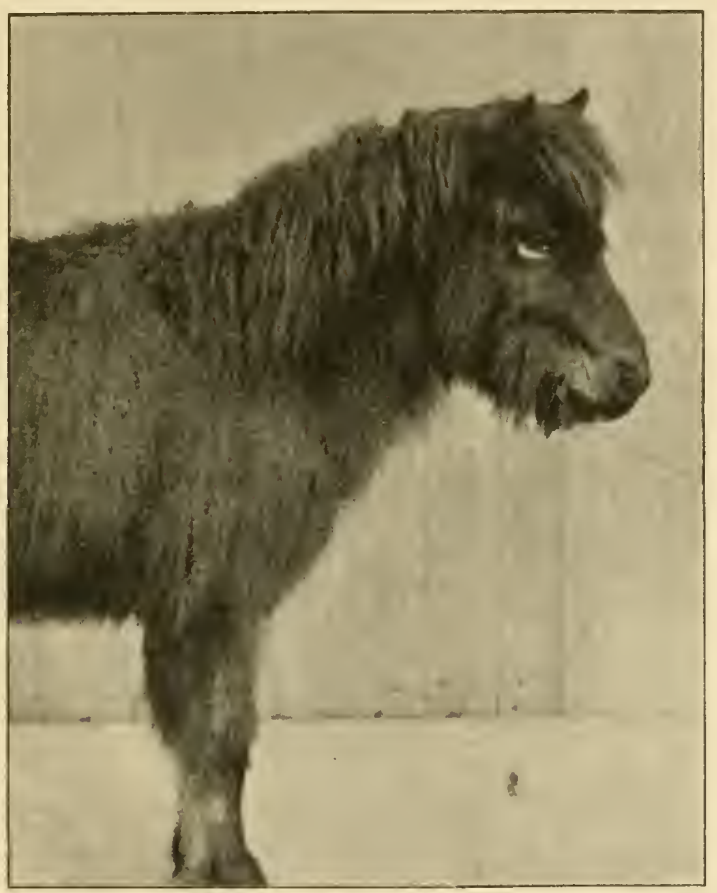

F1G. 16. A Faroe filly ${ }^{1}$.

varied from about eleven to thirteen hands. A number of Icelandic ponies, averaging about thirteen hands high, were seen on board ship on their way from Reykjavik to Denmark, and of these six were examined and found to have no hock callosities; while another, which had been imported into the Faroes, had the same peculiarity."

I From a photograph kindly given me by Prof. Ewart. 
"About a dozen Faroe ponies have very recently been imported into this country, and of these fully one-third have no hock callosities, while the others have them very small. All these ponies were characterised by having short hairs in the upper part of the tail. Of two Icelandic ponies, also recently arrived in Scotland, the hock callosities are absent in one and reduced in the other, while the tail characters are similar to those of the Faroe ponies." The authors give an illustration, here reproduced (Fig. 17), of a Faroe pony of a better type, which was stated by a native to "closely resemble the animals which existed in the Faroes before the recent introduction of Norwegian blood." In this animal the 'Celtic' characters strongly predominate, the shorter hairs in the upper part of the tail being especially noteworthy, as this character is occasionally absent in the Norwegian cross-breeds?

"So far," write Messrs Marshall and Annandale", "as we have been able to discover, the chief, if not the only difference between the Icelandic and Faroe breeds, while they remained pure, was that of colour, for while the former was, and still is, typically either light dun, with a dark line down the centre of the back and often with dark transverse stripes on the legs; the Faroe ponies, according to Landt, a most trustworthy observer, were, at the beginning of last century, generally red, and occasionally black, the skewbalds sometimes seen among them at the present day being possibly descended from Icelandic ancestors." Mr Daniel Brunn ${ }^{3}$, in a very valuable little work on the ponies of Iceland, the Faroes and Greenland, gives numerous illustrations showing the various types and colours of these animals, and according to his statemeuts the Icelandic ponies can hardly now be described as "typically light dun, since there are many skewbalds, chestnuts and bays." These 'Celtic' ponies of Iceland and the Faroes are, as we shall see below, very different in form from the now extinct ponies of the

1 "The Horse in Iceland," loc. cit. p. 301. Messrs Marshall and Annandale, and the Council of the Cambridge Philosophical Society, have most kindly allowed me to use their block. a loc. cit.

${ }^{3}$ Hesten $i$ Nordboernes Tjeneste paa Lsland, Faerфerne og Gronland, Saertryk af "Didsskrift for Landøkonomi" (Kjobenhavn, 1902). 


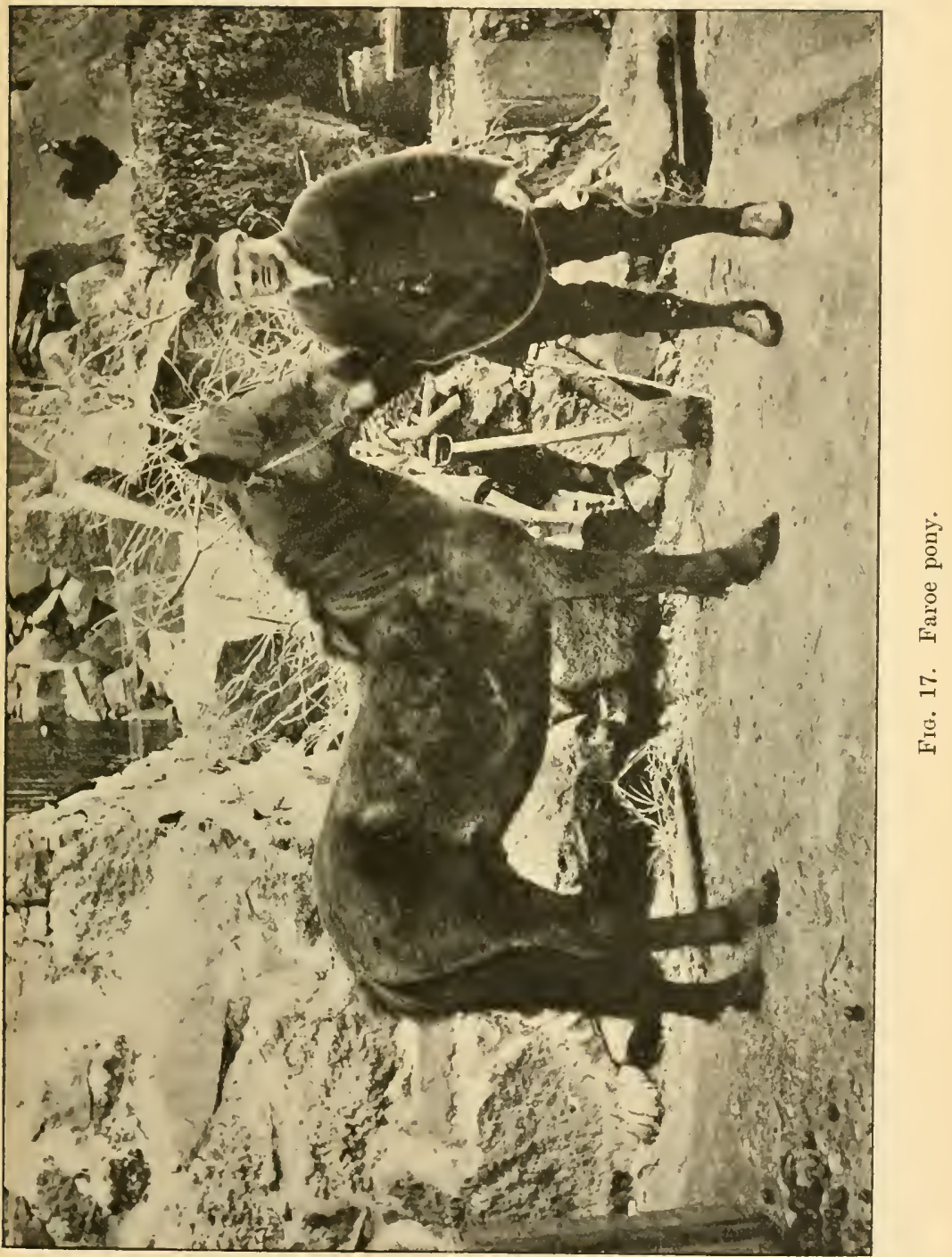


Lofoden Isles (p. 121, Fig. 50), and from those of the isle of Rodo off the coast of Norway (p. 119, Fig. 48).

(3) Prejvalsky's Horse (E. przewalskii Poliakoff) is so called from the fact that a skin was presented to that traveller by the chief magistrate of Zaizan; the latter had obtained it from Kirghis who hunt wild camels in the deserts of Central Asia. It was first described by Poliakoff in 1881. It has callosities on its hind-legs and its hoofs are like those of Equus caballus ${ }^{1}$, but it differs from the latter in having a short, erect mane, no forelock, and by the tail, on which the long hairs only begin at the lower third of the dock instead of at the root. The ears are of a moderate size, and Poliakoff maintained that it was a distinct species. Ten years later the brothers Grijimailo found many of these animals in the desert of Dzungaria, and shot three stallions and one mare.

Recently the energy of Mr Carl Hagenbeck of Hamburg (commissioned by the Duke of Bedford), has enabled naturalists to study living specimens for themselves. His agents, who employed nearly 2,000 Kirghis for the purpose, captured thirtytwo foals (17 stallions, 15 fillies), which were fostered by common Mongolian mares (cf. Fig. 19). Mr Hagenbeck's account of these young auimals, accompanied by an illustration, the first taken from a living specimen, was published by Mr Tegetmeier². "The young wild horses were obtained from three districts, and, according to their descent, certain variations in colour are to be distinguished. The districts where they were caught are south of the Mongolian town Kobdo, long. 93 E. (Greenwich). To the west the territory is a large plain, of which the great Altai mountains are the eastern frontiers. The northern and southern frontiers are formed by two rivers, both of which flow from the Altai, the Kui-kuius in the north, the Urungu in the south. The plain is bouncled 200 miles from Kobdo by the Tusgul Sea, into which both rivers discharge. The foals in this territory are of the following colours: directly after their birth, the head, the ears, the neck, the

1 The hoofs are long as in 'Arabs,' not broad as in cart-horses.

2 Field, 31 Ang. 1901, p. 391. Mr Hagenbeck also supplied a map showing the localities mentioned. 
shoulders, the collar, the back, and the croup are light red, passing into whitish colour. The nose, the throat, the chest, the belly, and the legs are of whitish colour. The white colour' blends with the upper colour on the middle of the body. 'The mane consists of light red-brown hair, the eel-back is marked pink-coloured; it ends in the tuft of the tail, the curled hairs of which are light red-brown, white, and black. The upper short-haired portion of the tail shows a whitish colour. 'The

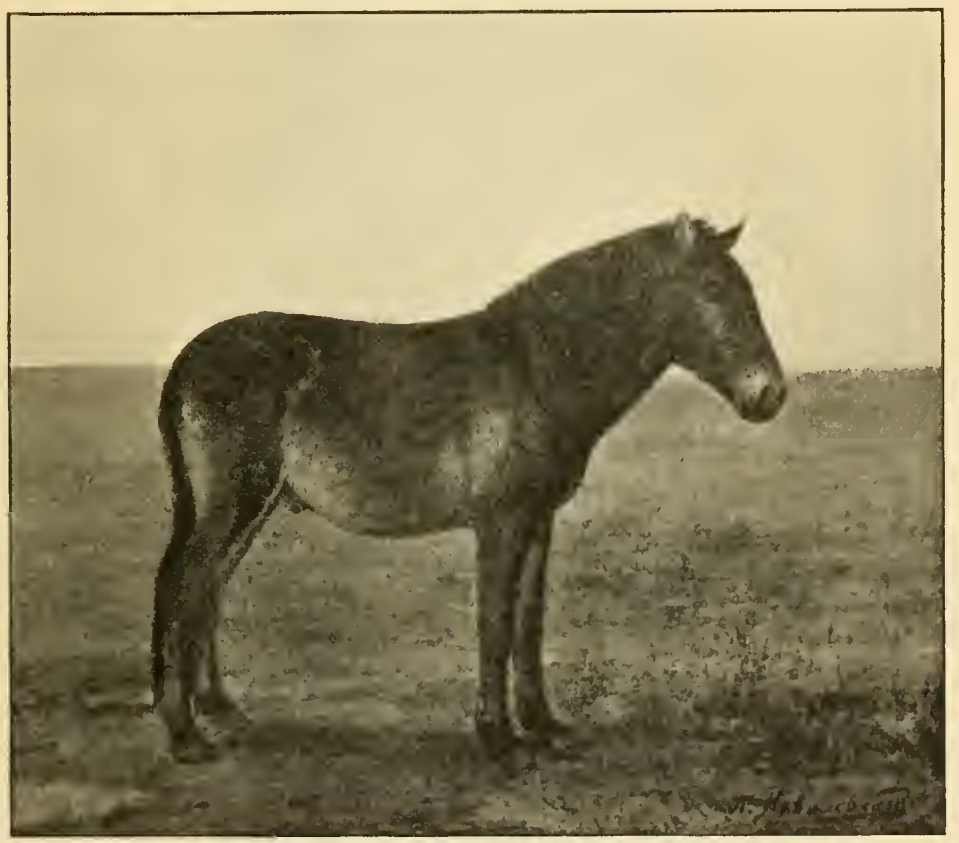

FIg, 18. Prejvalsky's horse.

lower jaw beard consists of reddish hair, which is about six inches long. The coat is smooth, except the croup, which bears curled hair. There are slightly-marked cross stripes on the withers. The eye has a whitish iris.

"The second and middle territory is situated about 200 miles south from Kobdo. The Altai mountains surromend this plain. The foals caught here bear light ashy-brown hair on the upper part of the body, marked similar to the former foals. The nose 
is white as well as the under side, just the same as the foals from the west, only the ontside of the legs is slightly tinted, and the fetlocks are black. The mane and the spine are a deep brownish colour and the beard also. They also bave the cross stripes, and stripes are to be seen in parallel lines at the shoulders. The skin is smooth, except the light curled mane. The eye has a darkish iris.

"The third variety of the horses come from the territory of the Zagan-norr Lake only, a small plateau on the southern branch of the Altai mountains, about 100 miles in a south-east direction from Kobdo. The coat of these foals has a pale, full yellowish-brown colour, only interrupted by the white belly hair, and the distinct black bands at the outside of the legs from the black hair of the fetlocks to above the hocks. The nose is whitish. The mane and the curled hair of the tail are black. The spine is an intense red-brown colour. They have also cross stripes and shoulder stripes of a blackish colour. The lower jaw beard is of a reddish colour. All these foals bear a more or less curled coat, which is also to be seen on the legs. The eye is blackish."

At the close of 1901 several of the animals secured by Mr Hagenbeck reached this country, and specimens are now in the Zoological Gardens, and in the possession of the Duke of Bedford, the Hon. Walter Rothschild and Professor J. C. Ewart'.

Since then Mr Hagenbeck has imported a second batch of young Prejvalsky horses, some of which with their Mongolian foster-mothers are here reproduced (Fig. 19) from a photograph kindly sent me by him.

Thus the habitat of this animal, as at present known, is a tolerably confined region, being a quadrangular area bounded on the north by lat. $48^{\circ}$, on the south by lat. $46^{\circ}$, on the west by long. $84^{\circ}$, and on the east by long. $90-1^{\circ}$.

Mr Hagenbeck informs me that wild horses of another variety are said to exist 600 miles south of Kobdo, that is, somewhere in the great Gobi desert.

1 Tegetmeier, Field, 11 Jan. 1902, p. 68 (with illustration of those in the collection of the Duke of Bedford); 8 Mar. 1903, p. 362 (notice of specimens in Regent's Park, and in Mr Walter Rothschild's collection). 


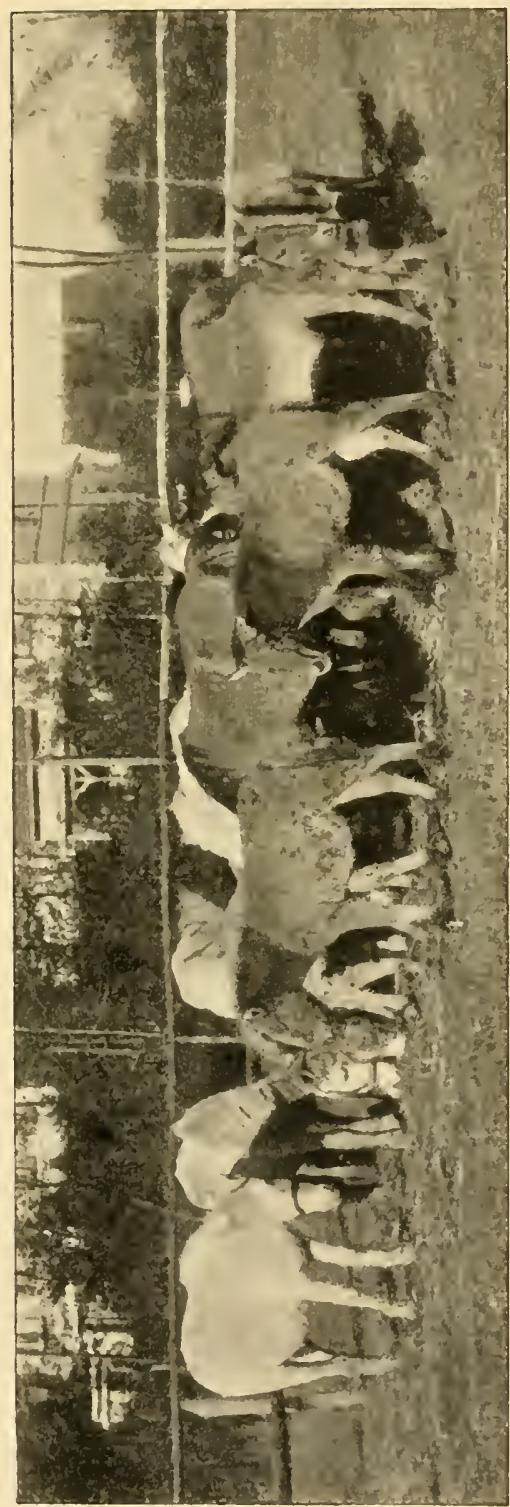

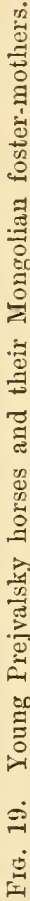


At the time when Poliakoff's paper appeared zoologists had settled down to a firm belief that no true wild horses existed, or indeed had existed for a very long time, since Sanson and Piètrement had coucluded that all primitive wild horses had disappeared in prehistoric times. True it was that Pallas həd declared that he had seen wild horses with suberect manes in Tartary, and Moorcroft and the brothers Gerrard, when they penetrated into Independent Tartary and within the borders of China, met with numerous herds of wild horses, scouring along the table-lands some 16,000 feet above the sea, but it had become a matter of faith with many naturalists that all the wild horses of Asia were sprung from the common Russian country horses turned loose for want of fodder during the siege of Azov in 1697. But in both the eighteenth and nineteenth centuries there were not wanting those who neither believed that all the known wild horses were genuine nor yet committed themselves to the belief that none but feral horses still survived. Thus Pallas, who had himself travelled in Asiatic Russia, was inclined to the same belief as his predecessor Forster, who was disposed to think that all the wild horses in Asia from the Ukraine to Chinese Tartary were descended from strayed domestic animals; Pallas ${ }^{1}$ himself thought that all the wild horses from the Volga to the Ural were the progeny of domestic animals, and that all those from the Jaik, Don, and Bokhara were of the Kalmuck and Kirghis breed, remarking that they are mostly fulvous, rufous and Isabella, whilst he noticed that those on the Volga were usually brown, dark-brown, and silver grey, some having white legs and other signs of intermixture. Linnaeus ${ }^{2}$ held that, though the wild horses of the Don were sprung from the horses that had escaped at the siege of Azov, true wild horses survived in Bessarabia and Tartary, whilst Col. Hamilton Smith came to similar conclusions from the information which he himself obtained from Russian officers of experience whom he met in Paris at the time of its occupation by the Allies in 1814. His statements are so important in reference to Prejvalsky's

1 Travels in Russia and Northern Asia, Vol. I. pp. 376-8 (French trans.); Vol. vir. pp. 89-92 ; Pl. I. (in atlas) shows a tarpan of the feral kind.

2 Systema Naturae, p. 432 (Kerr's trans.). 
discovery, or rediscovery, as it may prove to be, that I shall give them in his own words": "Whatever may be the lucubrations of naturalists in their cabinets it does not appear that the Tahtar or even the Cossack nations have any doubt upon the subject, for they assert that they can distinguish a feral breed from the wild by many tokens; and naming the former Takija and Muzin, denominate the real wild horse Turpan and Tarpani. We have had some opportunity of making personal inquiries on wild horses among a considerable number of Cossacks of different parts of Russia, and among Bashkirs, Kirghis, and Kalmucks, and with a sufficient recollection of the statements of Pallas, and Buffon's information obtained from M. Sanchez, to direct the questions to most of the points at issue. From the answers of Russian officers of this irregular cavalry, who spoke French or German, we drew the general conclusion of their decided belief in a true wild and untameable species of horse ${ }^{2}$, and in herds that were of mixed origin. Those most acquainted with the nomad life, and in particular an orderly Cossack attached to a Tahtar chief as Russian interpreter, furnished us with the substance of the following notice.-The Tarpani form herds of several hundred, subdivided into smaller troops, each headed by a stallion; they are not found unmixed, excepting towards the borders of China; they prefer wide, open, elevated steppes, and always proceed in lines or files, usually with the head to windward, moving slowly forward while grazing - the stallions leading and occasionally going round their own troops; young stallions are often at some distance, and single, because they are expelled by the older until they can form a troop of young mares of their own; their heads are seldom observed to be down for any length of time: they utter now and then a kind of snort, with a low neigh, somewhat like a horse expecting its oats, but yet distinguishable by the voice from any domestic species, excepting the woolly Kalmuck breed. These animals are found in the greatest purity on the lake Karakoum, south of the lake of Aral, and the Syrdaria, near Kusnel, and on the banks

1 "The Horse" (Naturalist's Library, Vol. xir.), pp. 160-5.

2 Cf. Pallas, Tracels (French trans.), Vol. v. p. 378. 
of the river Tom, in the territory of the Kalkas, the Mongolian deserts, and the solitudes of the Gobi: within the Russian frontier there are, however, some adulterated herds in the vicinity of the fixed settlements, distiuguishable by the variety of their colours and the selection of residence less remote from human habitation. Tarpans are not larger than ordinary mules, their colour invariably tan, Isabella, or mouse, being all shades of the same livery, and only varying in depth by the growth or decrease of a whitish surcoat, longer than the hair, increasing from midsummer and shedding in May; during the cold season it is long, heavy, and soft, lying so close as to feel like a bear's fur, and then is entirely grizzled; in summer much falls away, leaving only a certain quantity on the back and loins; the head is small, the forehead greatly arched, the ears far back, either long or short, the eyes small and malignant, the chin and muzzle beset with bristles, the neck rather thin, crested with a thick, rugged mane, which like the tail is black, as also the pasterns, which are long; the hoofs are narrow, high, and rather pointed; the tail, descending only to the hocks, is furnished with coarse and rather curly or wavy hairs close up to the crupper; the croup is as high as the withers; the voice of the Tarpan is loud, and shriller than that of the domestic horse; and their action, standing, and general appearance, resemble somewhat that of vicious mules.

"The feral horses, we were told, form likewise in herds, but have no regular order of proceeding; they take to flight more indiscriminately, and were simply called Muzin. They may be known by their disorderly mode of feeding, their desire to entice domestic mares to join them, by their colours being browner, sometimes having white legs, and being often silvery grey; their heads are larger and their necks shorter; but their winter coat is nearly as heavy as that of the wild, and there is always a certain number of expelled Tarpan stallions among them; but they are more in search of cover and watery places, the wild herds being less in want of drink and more unwilling to encounter water, being even said not to be able to swim ; while the Muzin will cross considerable rivers." 
I have given this long extract because the account which it contains of the habitat, the colour, the appearance and habits of the true wild Tarpan, and the respects in which it differed from the feral or intermixed herds has a most important bearing on our present discussion.

It is to be carefully noted that the Kirghis and Cossacks from whom Hamilton Smith obtained his information respecting the true wild Tarpan, maintained that the pure wild horses were only to be found in that very region where Prejvalsky obtained the skin of one killed by the Kirghis camel-hunters, where the brothers Grijimailo shot their specimens, and where the Kirghis have captured the numerous foals imported by Mr Hagenbeck. It is further to be remarked that the young wild horses obtained by $\mathrm{Mr}$ Hagenbeck differ in colour according to the three different localities from whence they were procured, and that the foals from the western district have their heads, necks, ears, shoulders, back and croup a light red, passing into whitish colour, the nose, the chest, the belly and the legs being of a whitish colour, whilst the mane is light redbrown, the eel-back is pink, ending in the tuft of the tail, the curled hairs of which are light red-brown, white and black, whilst the upper short-haired portion of the tail shows a whitish colour. 'The foals further east have light ashy-brown hair on the upper part of the body, the nose and under side are white, just the same as the foals from the west, only the outside of the legs being slightly tinted, whilst the fetlocks are black. The mane and spine are a deep brownish colour, and the beard also. The western foals have a whitish iris, the more eastern have a darkish iris. The foals from the most easterly district (Zagan-norr Lake) have a coat of a full yellowish-brown colour, only interrupted by the white belly hair and the distinct black bands at the outside of the legs from the black hair of the fetlocks to above the hock. The nose is white, the mane and the curled hair of the tail are black, and the spine is an intense red-brown colour, the lower jaw beard is of a reddish colour. All these foals bear a more or less curled coat, which is also to be seen on the legs; the eye is blackish. Let us now compare these descriptions with

R. H. 
that given by Smith of the true wild Tarpans which nearly a century ago were declared "not to be found unmixed except towards the borders of China," and which were then found in their greatest purity on the lake Karakoum, south of the Sea of Aral and the Syrdaria near Kusneh and in the Gobi desert, whilst those within the Russian frontiers of that time were adulterated and distinguished by the variety of their colour from the pure herds further east. The true Tarpans "are not larger than ordinary mules, their colour invariably tan, Isabella, or mouse, being all shades of the same livery." Now this would describe very well Mr Hagenbeck's foals from the two most easterly districts, but does not agree with the red heads, necks, backs, and croups of those from the western area. Again, the true Tarpan had a small head, the forehead greatly arched (which we shall soon see to be a characteristic of at least some of the Prejvalsky horses), "the neck crested with a thick, rugged mane, which like the tail is black, as also the pasterns." Now this description does not at all agree with the Prejvalsky foals from the west, for the mane is a light redbrown, and the curled hairs of the tail are light red-brown, white and black, whilst the legs are white, but it tallies quite well with the foals from the second district, which are light ashy-brown coloured instead of red on the head and back, have black fetlocks and the outside of the legs slightly tinted, and have the mane and spine of a deep brownish colour, and the beard also, thus coming much closer to the description of the pure 'Tarpan, with its black fetlocks and legs; while the foals from the eastern district, i.e., closest to China, which have a coat of a full yellowish-brown colour, and have not only black fetlocks, but also distinct black bands on the outside of the legs to above the hock, exactly correspond with the picture given us of the unadulterated Tarpan.

From these considerations it would appear that (1) Prejvalsky's horse is nothing more than the Tarpan of the older writers; (2) that if pure Tarpans still survive they are those of the Zagan-norr Lake, and (3) that the divergence in colour of these animals which characterizes those found in the middle district, and in a still greater degree those of the most westerly 
area (especially in the white colour of their legs), is to be ascribed to their being mixed with feral horses rather than to any variation due to environment or any other natural cause.

Sanson and Pietrement viewed with suspicion Prejvalsky's discovery, and Piètrement placed the animal under the same subspecies of Equus with Equus caballus. In this country Dr. Sclater took the same view as Poliakoff, whilst Sir W. Flower thought that it might be an accidental hybrid between a Kiang and a Mongolian or some other kind of horse. Flower's caution was quite justifiable at a time when only a single skin was known, although it seems not very likely that such accidental unions as he postulated would occur between different species of Equidae in a state of nature, in view of the well-known objection of the herds of half-wild horses in the Caucasus to intermix in any way. Yet, though many specimens both living and dead, which have since come to hand, render it very improbable that Prejvalsky's horse is a mule, the theory has retained its hold upon some naturalists down to the present time, who, however, have made no attempt to test the theory by experiment.

It is to the indefatigable energy and enthusiasm of Professor Cossar Ewart, who has done more than any living man to advance our knowledge of the Equidae, that we owe the experiments which seem likely to settle the question finally. It is best to let him speak for himself": "With the help of Lord Arthur Cecil I succeeded early in 1902 in securing a male wild Asiatic ass ${ }^{2}$ and a couple of Mongolian pony maresone a yellow dun, the other a chestnut. 'Jacob,' the wild ass, was mated with the dun Mongol mare, with a brownishyellow Exmoor pony, and with a bay Shetland-Welsh pony. The chestnut Mongol pony was put to a light grey Connemara stallion. Of the four mares referred to three have already (June) foaled, namely the Exmoor and the two Mongolian ponies. The Exmoor having foaled first, her hybrid may be first considered. It may be mentioned that the Exmoor pony

1 "The Wild Horse" (Equus przewulskii Poliakoff), Proc. Royal Soc. of Edinburgh, 1903, pp. 460-8.

2 This animal, now in the Zoological Garden, Regent's Park, is an onager indicus (=hemionus indicus, cf. p. 43). 
had in 1900 and again in 1901 a zebra hybrid, the sire being the Burchell zebra 'Matopo' (Fig. 36) used in my telegony experiments. In the case of her Kiang hybrid the period of gestation was 335 days (one day short of what is regarded as the normal time), but she carried her 1900 zebra hybrid 357 days, three weeks beyond the normal time. The Exmoor zebra hybrids are as nearly as possible intermediate between a zebra and a pony; the Kiang hybrid, on the other hand, might almost pass for a pure-bred wild ass. In Mendelian terms the Exmoor pony proved recessive, the wild ass dominant. In zebra hybrids the ground colour has invariably been darker than in the zebra parent; but the Kiang hybrid is decidedly lighter in colour than her wild sire, while in make she strongly suggests an Onager-the wild ass so often associated with the Runn of Cutch. Alike in make and colour the Kiang hybrid differs from a young Prejvalsky foal." This comparison Professor Ewart was enabled to make by means of his hybrid foal with the skin of a very young Prejvalsky foal (for which he was indebted to Mr Carl Hagenbeck).

"I have never seen a new-born wild horse; but if one may judge from the conformation of the hocks, from the coarse legs, big joints, and large head of the yearlings-to their close resemblance to dwarf cart-horse foals - it may be assumed they are neither characterized by unusual agility nor fleetness. The Kiang hybrid, on the other hand, looks as if built for speed, and almost from the moment of its birth has by its energy and vivacity been a source of considerable anxiety to its by no means placid Exmoor dam. When four days old it walked over twenty miles; on the fifth day instead of resting it was unusually active, as if anxious to make up for the enforced idleness of the previous evening. In the hybrid the joints are small, and the legs long and slender, and covered with short, close-lying hair. In the wild horse the joints are large, and the 'bone' is round as in heavy horses.

"As to its colour it may especially be mentioned that the hybrid has more white around the eyes than the wild horse, but is of a darker tint along the back and sides and over the hind-quarters. 'Too much importance, however', should not be 
attached to differences in colour; for though the two hybrid foals, which have already arrived, closely agree in their coloration, subsequent foals may differ considerably, and it is well known that young wild horses from the western portion of the Great Altai mountains differ in tint from those found further east.

"Of more importance than the coat-colour is the nature of the hair. A Prejvalsky foal has a woolly coat not unlike that of an Iceland foal. In the hybrid, the hair is short and fine and only slightly wavy over the hind-quarters. It thus differs but little from a thoroughbred or Arab foal.

"The mane and the tail of the hybrid are exactly what one would expect in a mule; the dorsal band, $7.5 \mathrm{~mm}$. wide over the croup in the sire, has in the hybrid a nearly uniform width of $12 \mathrm{~mm}$. from its origin at the withers until it loses itself halfway down the tail. The tail, which differs but little from that of a pony foal, is of a lighter colour than the short, upright mane, while the dorsal band is of a reddish-brown hue. In the wild horse the dorsal band is sometimes very narrow (under $5 \mathrm{~mm}$.) and indistinct. In the Kiang sire there are pale, but quite distinct stripes above and below the hocks, and small faint spots over the hind-quarters-vestiges apparently of ancestral markings: but in the hybrid there are neither indications of stripes across the hocks or withers, nor spots on the quarters. In having no indications of bars on the legs, or faint stripes across the shoulders, the hybrid differs from Prejvalsky colts; it also differs in having a longer flank feather and in the facial whorl being well below the level of the eyes. As in the Kiang and some of the wild horses, the under surface of the body and the inner aspect of the limbs are nearly white.

"In the hybrid the front chestnuts (wrist callosities) are smooth and just above the level of the skin; but instead of being ronghly pear-shaped, as in the Kiang, they are somewhat shield-shaped, as in the Onager. In the wild horse the front chestnuts are elongated. In the Exmoor dam the hind chestnuts (hock callosities) are $27 \mathrm{~mm}$. in length and $10 \mathrm{~mm}$. wide. In the sire there is a minute callosity inside the right hock. In the hybrid the hind ehestnuts are completely absent. In 
the absence of hock callosities the hybrid differs from the wild horse, in which they are relatively longer than Clydesdales, Shires, and other heavy breeds of horses. In the hybrid, as in the sire and dam, there are smooth, rounded fetlock callosities (ergots) on both fore and hind limbs.

"In the wild horses the hoof is highly specialized, the 'heels' being bent inwards (contracted) to take a vice-like grip of the frog. In the hybrid the hoof closely resembles that of the pony dam ; it is shorter than in the Kiang, and less contracted at the 'heels' than in the wild horse. The Kiang hybrid further differs from a young wild horse in the lips and muzzle, the nostrils and ears, and in the form of the head and hindquarters. The wild horse has a coarse, heavy head, with the lower lip (as is often the case in large-headed horses and in Arabs with large hock callosities) projecting beyoud the upper. The nostrils in their outline resemble those of the domestic horse, while the long, pointed ears generally project obliquely outwards, as in many heavy horses and in the Melbourue strain of thoroughbreds. Further, in the wild horse the forehead is convex from above downwards, as well from side to side, hence Prejvalsky's horse is sometimes said to be ram-headed. In the hybrid the muzzle is fine as in Arabs, the lower lip is decidedly shorter than the prominent upper lip, the nostrils are narrow as in the Kiang: and even at birth the forehead was less rounded than is commonly the case in ordinary foals. The ears of the hybrid, though relatively shorter and narrower than in the Kiang, have, as in the Kiang, incurved dark-tinted tips, and they are usually carried erect or slightly inclined towards the middle line. In the wild horse the croup is nearly straight and the tail is set on high up as in many desert Arabs. In the hybrid the croup slopes as in the Kiang and in many ponies, with the result that the root of the tail is on a decidedly lower level than the highest part of the hind-quarters. Further, in the young wild horses I have seen the heels (points of the hocks) almost touch each other, as in many Clydesdales, and the hocks are distinctly bent. In the hybrid the hocks are as straight as in well-bred foals, and the heels are kept well apart in walking. Another 
difference of considerable importance is, that while the wild horse neighs, the hybrid makes a peculiar barking sound remotely suggestive of the rasping call of the Kiang.

"The dun Mongol pony's hybrid arrived five weeks before its time, and, though perfect in every way, was short-lived. Only in one respect did this hybrid differ from the one already described. In the Exmoor hybrid the hock callosities are entirely absent; in the Mongol hybrid the right hock callosity is completely wanting, but the left one is represented by a small, slightly hardened patch of skin, sparsely covered with short white hair. In zebra hybrids out of cross-bred mares the hock callosities are usually fairly large, while in hybrids out of well-bred pony mares the hock callosities are invariably absent. The Exmoor ${ }^{1}$ pony, though not as pure as the Hebridean and other ponies without callosities, has undoubtedly a strong dash of true pony blood; the Mongol pony is as certainly saturated with what, for want of a better term, may be called cart-horse blood."

Prof. Ewart thus sums up the results of his experiment: "From what has been said, it follows that a Kiang-Mongol pony hybrid differs from Prejvalsky's horse (1) in having the merest restiges of hock callosities; (2) in not neighing like a horse; (3) in having finer limbs and joints and less specialized hoofs; (4) in the form of the head, in the lips, muzzle, and ears; (5) in the dorsal band; and (6) in the absence even at birth of any suggestion of shoulder stripes and of bars on the legs."

After this experiment it does not seem likely that zoologists will continue to hold that Prejvalsky horses are the offspring of Kiangs and feral Mongolian ponies?.

But as some naturalists had maintained that Prejvalsky horses in nowise differed essentially from an ordinary horse and held that the colts brought from Central Asia were the progeny of escaped feral Mongol ponies, and as others again asserted that they failed to discover any difference between the

1 The Exmoor ponies are said to have derived some good blood from a famous stallion Katerfelto.

2 As these pages are passing through the press the Prejvalsky horses belonging to the Duke of Bedforl have themselves triumphantly refuted the charge of their being merely mules by having this year (1904) produced offspring. 
young wild horses in the London Zoological Gardens and Iceland ponies of a like age, Prof. Ewart again resorted to the experimental method.

To test the first of these assertions he mated his chestnut Mongol pony with a young Connemara stallion; to test the second he purchased an Iceland mare in foal to an Iceland stallion. "The chestnut Mongol mare produced a foal the image of herself. The foal, it is hardly necessary to say, decidedly differs from the Prejvalsky colts recently imported from Central Asia by Mr Hagenbeck, and it decidedly differs from the wild ass hybrids described above. The Iceland foal, notwithstanding the upright mane and the woolly coat, for a time of a nearly uniform white colour, conld never be mistaken for a wild horse, and the older it gets the difference will become accentuated."

"If the Prejvalsky horse is neither a wild ass-pony mule nor a feral Mongolian pony, and if moreover it is fertile (and its fertility can hardly be questioned), I fail to see how we can escape from the conclusion that it is as deserving as, say, the Kiang to be regarded as a distinct species."

It will be obvious that in view of the facts that the Prejvalsky horses from the two western districts agree in the colour of their legs with the adulterated herds of Tarpans described by Hamilton Smith, while they differ essentially in colour from that of the true Tarpan, and that on the other hand the Prejvalsky horses from the easternmost district correspond accurately to the description of the genuine Tarpan, it would be unwise to maintain that all the Prejvalsky horses imported by $\mathrm{Mr}$ Hagenbeck are genuine wild animals unmixed with feral blood, though in view of the evidence which I have set forth one is justified in holding that the Prejvalsky horses from the Zagan-norr Lake are possibly perfectly genuine, and if not absolutely pure from all admixture, at least so little tainted that they practically give us a true picture of the primitive wild stock. Indeed, if they are impregnated with the blood of feral horses, their resemblance to the ass in the absence of the forelock, the upright mane,

I op. cit., pp. 467-8. 
and the character of the tail render it all the more certain that there was a primitive variety of horse which had these characteristics so strongly marked that they cannot be easily blurred by crossing with horses of the ordinary domestic type.

Quite recently Dr Salensky ${ }^{1}$ has urged strongly that Equus przewalskii is a true variety of Equus. He gives the characteristics of the Prejvalsky horse as the considerable size of the head, the want of a forelock, the upright mane, the back and shoulder stripes, the characteristic form of the tail, which in some particulars resembles that of the loulan, the size of the ears, which are smaller than in the ass or koulan, and the coloration of the rump, the lower parts of the body, and the striping on the legs, and he holds that the examination of the skull and skeleton leads us, as do the external marks, to the conclusion that Prejvalsky's horse represents a special type, which forms a peculiar race of the sub-species of Equus standing next to Equus caballus. In comparing Equus przewalskii to other horses he considers that the Tarpan comes first in importance, a view obviously correct in face of the considerations which have been urged above. He starts by citing Gmelin's notice of the Tarpan, the earliest in modern times at least (in his Reise durch Russland). That traveller had the opportunity of secing them at Bobrowsk (gov. Woronesh), and he describes them as mouse-coloured "with short and crisp mane" (mit kurzer und kraushaariger Mälne) and says that their legs were black from the knee to the hoof, the head disproportionately thick. The ears sometimes long as in the ass, and hanging, the tail always shorter than in domestic horses, being sometimes well furnished, sometimes sparsely. But Salensky relies chiefly on the official description of a Tarpan captured in 1866 in the Zagradoff steppe on the property of Prince Kotschubei (gov. Cherson) and which was still in the Zoological Gardens at Moscow in 1884. This animal had a forelock but had no callosities on its hind-legs. It was a dark mouse-colour, the legs from hocks and knees down to the pasterns being very black, whilst it had a mane

1 Equus przewalshii (Comptes-Rendus of Imperial Russian Academy, 1902), from which my illustration of Prejvalsky's horse (Fig. 18) is taken. 
$48 \mathrm{~cm}$. long hanging down on the left side of the neck. Unfortunately no minute study was made of its tail, but, as far as can be seen from a photograph, the tail resembled that of Prejvalsky's horse. There are in existence two Tarpan skeletons, one at St Petersburg, the other at Moscow. On the ground of the skull measurements Czerski came to the conclusion that the Tarpan has all the marks of the group of Oriental horses, being connected on the one side with the Arabian, on the other with the Scottish race to which the ponies belong. The skull comes very near to Equus przewalskii, although it does not agree with any fully developed skulls of this kind. The number of lumbar vertebrae agree in both Tarpan and Prejvalsky horse, as both have five, but this does not amount to much, as the same occurs in other horses, whilst there are asses with six such vertebrae. The most genuine resemblance between the Tarpan and the Prejvalsky horse is the black colour of the legs below the knees, a feature very persistent (says Salensky) in the Prejvalsky horse ${ }^{1}$, and which separates it from hybrid asses, in which the legs are always half or wholly white. But Salensky points out that there are some essential differences between the Tarpan and Prejvalsky horse; these are the presence of a forelock in the Tarpan, a longer mane falling down at the side, and a tail more like that of a horse. "All these marks indicate that the Tarpan is a type more specialized towards the horse side than is Equus przewalsliii. Too much stress cannot be laid on the absence of the hock callosities in the only known Tarpan, for such a feature is well known among true horses. The Prejvalsky horse represents a more universal form between the horses and the asses, and this leads to the assumption that more than any other kind of the genus Equus it comes nearest to the common stem-form of horses, asses, and half-asses."

When the reader bears in mind the evidence obtained by Colonel Hamilton Smith in 1814-that there were no pure tarpans within the Russian frontiers-he will at once see that the tarpans described by Gmelin as having sometimes long, sometimes short ears, and that the Hoscow tarpan with its long hanging mane (in which it differed from the tarpans observed by

1 But this is disproved by the facts cited on pp. 27 and 32. 
Gmelin and Pallas), with its forelock and its horse-like tail, were not genume wild tarpans, but belonged to the mixed herds of eastern Russia. We must therefore reject Salensky's view that the Moscow tarpan represents a variety of Equus distinct from Prejvalsky's horse, by being more specialized towards the side of the horse. The hypothesis that it was a cross between the true tarpan and a feral horse will likewise account for Czerski's conclusions that it approaches the Arab on the one side and the British ponies on the other, for, as has been already pointed out, Arab horses sometimes lack the hock callosities. We shall presently find that mouse-colour-the hue of the Moscow tarpan-when found in horses is an indication that crossing has taken place. Later on in this investigation it will be shown that mouse-colour and dark mouse-colour in horses are a sure indication of an intermixture of breeds.

We may therefore conclude that whilst the tarpan of eastern Asia and the Prejvalsky horse with black legs from Zagan-norr Lake are identical, we must hold that the tarpans of eastern Europe and western Asia have probably been largely crossed with escaped domestic animals for at least two centuries, and probably much longer.

To the three kinds of horses which have been just set forth above I shall venture to add a fourth-Equus caballus libycus.

\section{ASSES.}

Side by side with Prejvalsky horses the brothers Grijimailo found two varieties of wild asses in the desert of Dzungaria. The wild asses of Asia fall into a group distinct from those of Africa; the older zoologists divided then into $E$. kiang, $E$. onager, and $E$. hemippus, which were regarded by some as distinct species, but by others as merely races of the same species, the Equus hemionus of Pallas. The best modern authorities now make at least five subdivisions ${ }^{1},-E$. hemionus, E. hemionus liang Moorcroft, E. onager, E. onager indicus, and $E$. onager hemippus, whilst of course there may be other races as yet unidentified. All have a dorsal band, but no shoulder

${ }^{1}$ Dr W. T. Blanford, F.R.S. (Indian Mammalia, p. 470, 1891) holds that all are simply local races of the same species (F. hemionns). 
stripe, while their ears are a little shorter than those of the Abyssinian ass.

(4) The Dzeggetai (E. hemionus). Mr Lydekker has described a wild ass ${ }^{1}$ obtained in Kobdo north-west of the Gobi Desert, now in the possession of the Duke of Bedford. In its make and action "as well as in the general type of coloration, this wild ass agrees essentially with the wild ass of Ladak and Tibet. Both in the winter and summer coats it lacks, however,

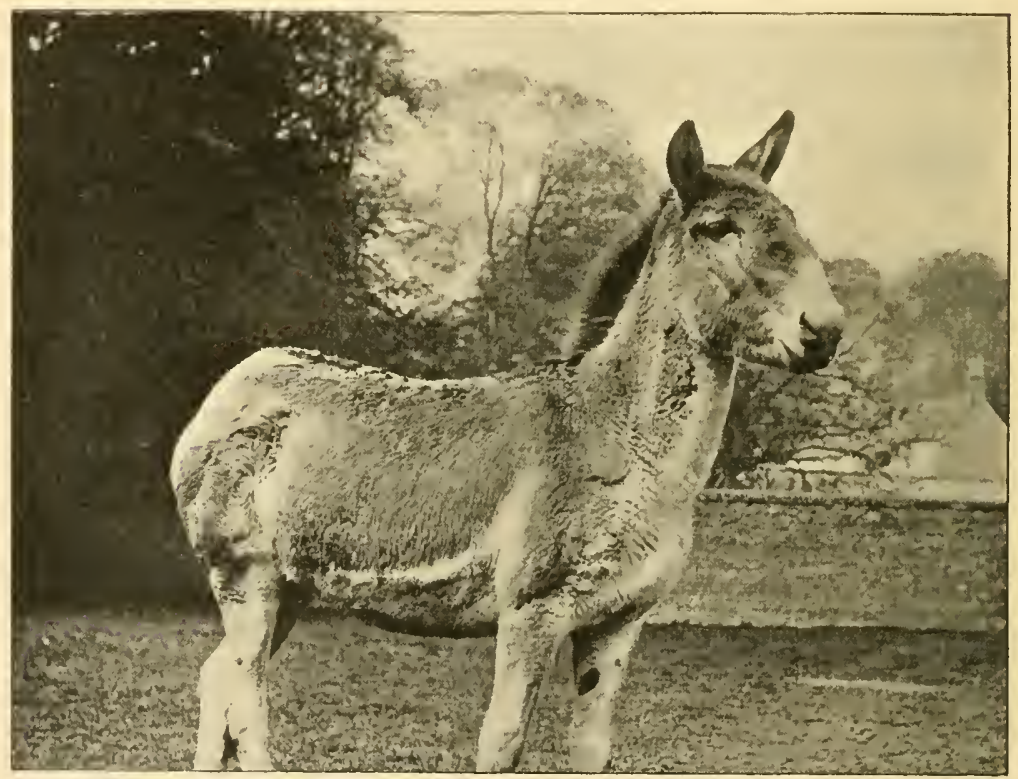

FIG. 20. The Kiang².

the distinctly rufous-chestnut tint so characteristic of the latter, while it is further characterized by the much less marked contrast between the light and dark areas of the cuat." The light areas on the muzzle, buttocks, legs, and under parts being 'Isabella' -coloured ${ }^{3}$ instead of pure white, and thus much less sharply differentiated from the fawn of the rest of the body.

I P. Z. S., 1904, p. 431 (with Plate); ef. Pallas (vIr. 92) for Mongol dshigguetéi.

${ }^{2}$ From a photograph by the Duchess of Bedford.

3 i.e. the colour of the soiled linen of Isabella of Castile. 
"The general colour is pale sandy fawn, with the tips of the ears, mane, and dorsal stripe (which is continued down the tail), brown, and there seems to be but little difference in this respect between the summer and winter coats. The dorsal stripe is narrow as in the kiang, and is thus distinct from that of the ghor-kar and onager, which is broader and bordered with white." Mr Lydekker regards this animal "as the true Equus hemionus of Pallits, which cane from IIongolia, and is known

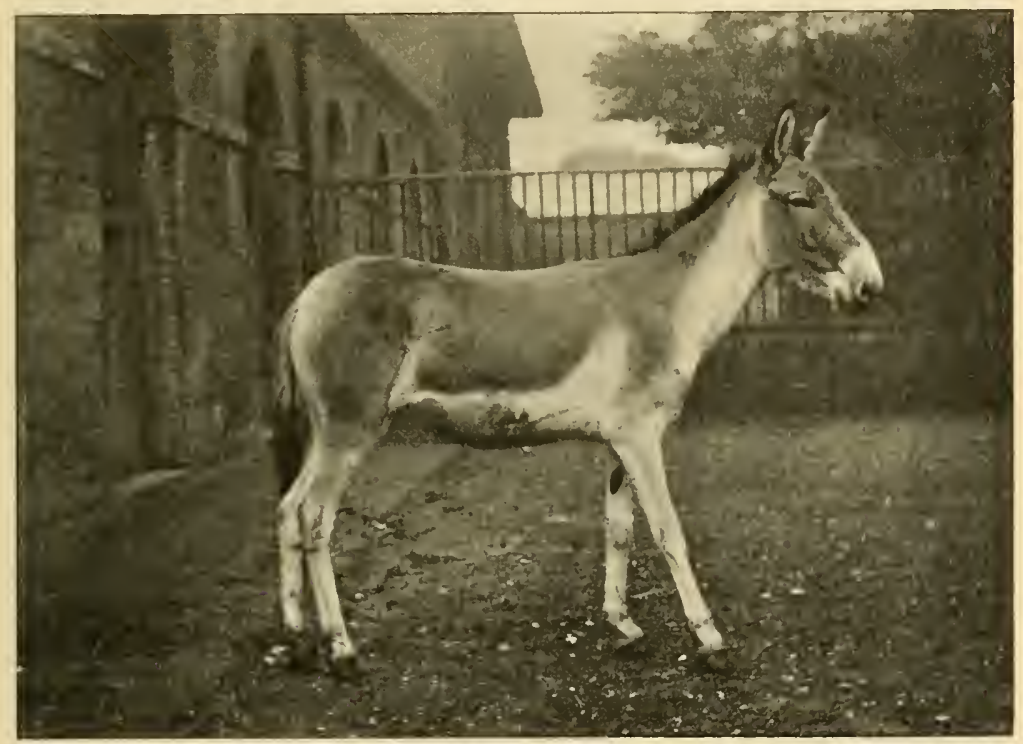

FI'. 21. The Kiang ${ }^{1}$.

to the natives as chigetai (dzeggetai). It is certainly entitled to be regarded as subspecifically distinct from the kiang of Tibet and Ladak, and the latter should be known as Equus hemionus kiang (Moorcroft)."

(5) The Kiang (E. hemionus liang) lives in the upper Indus valley, Tibet, and Mongolia, seldom at a lower altitude than 10,000 feet. It (Figs. 20, 21) differs from the onager

1 This illustration is from a photograph (copyright) of a kiang formerly in the Zoological Garden, Regent's Park, by Mr L. Medland, F.Z.S., well known for his photographs of living animals. 
in being larger, exceeding 13 hands, and by the narrowness of its dorsal stripe compared with that of the latter animal. Its hind-quarters are much more developed in length and strength. In colour it is rufous-bay, whilst its voice is said to differ from the strident bray of the onager.

$(6,7,8)$ The Onager (E. onager), the Onager Indicus, and the Hemippus ( $E$. onager hemippus) differ so slightly in habit ${ }^{1}$ that they may be described together. These animals are found on all the great plains of Asia, Chinese Tartary, Tibet, the Panjab, Afghanistan, Western India, Baluchistan, Persia, and Syria. It is called koulan by the Kirghis, ghuran or ghur by the Baiuchis, ghor-khur in Hindi, ghour or kherdecht in Persian, in all of which a common element may be recognized. Zoologists now discriminate between $E$. onager indicus (which is found in North-western India and Baluchistan), $E$. onager (found in Persia and Turkestan), and E. onager hemippus (found in Syria), whilst it seems probable that the onager of Turkestan ${ }^{2}$ differs in some respects from that of Persia. The onager indicus is not so dark in colour as the kiang, whilst the typical onager (Fig. 22) "is very white, and in fact might be described as a white animal with a yellowish blotch on the side, another on the neck, and some yellow on the head ${ }^{3}$."

They are usually found in herds of from four to forty, and in spring the mares and foals sometimes congregate in still larger numbers. The ears (Fig. 22) are large, the hair of the tail is short at the base, but grows gradually longer towards the end, which is of a black colour, whilst the mane is erect. The dorsal stripe is dark brown, sometimes with a white edging, and varying in breadth, but normally broader than that of the kiang. Some specimens show a cross stripe on the shoulder, and sometimes the legs show faint rufous bars. It varies in height from 11 to 12 hands. It has been supposed to outstrip in speed the fleetest horses, a notion

1 Blandford, Indian Mammalia, p. 470.

2 According to Pallas (vir. 92), the koulan of Upper Asia is brownish-yellow with brown dorsal stripe and two bars on legs.

${ }^{3}$ I am indebted for this accurate information to Mr R. I. Pocock, F.Z.S., Superintendent of the Zoological Garden, Regent's Park. 
apparently as unfounded as the belief that it is incapable of being domesticated. 'The groundlessness of the former has been demonstrated by the capture of these animals in Cutch by sportsmen mounted on Arabs, Walers (horses from New South Wales), and country breds ${ }^{1}$, whilst the latter is shown to be erroneous by the fact that some of the Indians in the army of Xerxes drove chariots drawn by 'wild asses?'

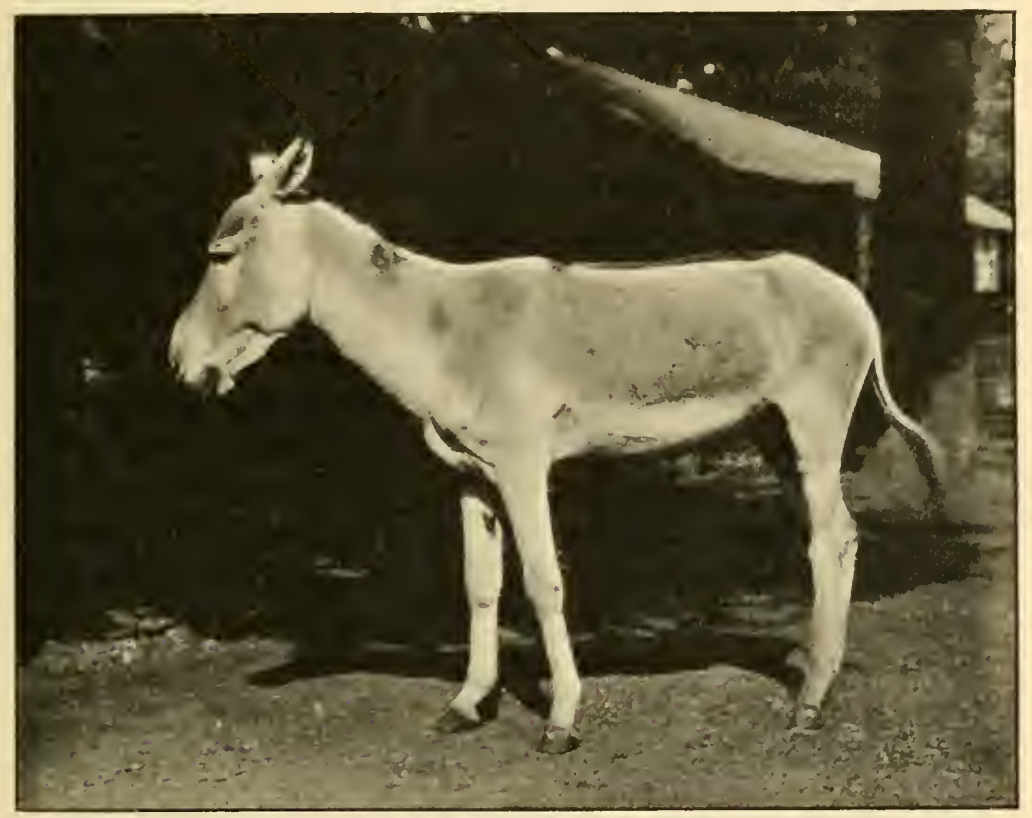

FIG. 22. 'The Onager ${ }^{3}$.

From this it is clear that the peoples of western Hindustan, who did not possess horses, had made the wild ass obedient to the yoke.

In Carmania (included in modern Persia), a region bounded by the Indian Ocean and Persian Gulf on the south, and by

1 Tegetmeier, Horses, Asses, etc., pp. 23-5.

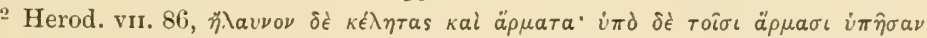

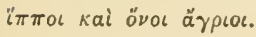

3 The illustration is from a photograph (copyright) from the specimen in the Zoological Garden, Regent's Park, by Mr WV. P. Dando, F.Z.S., ofticial photographer to the Zoological Society. 
Persia on the west, down to the time of Strabo ${ }^{1}$, "asses on account of the scarcity of horses" were "generally made use of in war. They sacrifice an ass to Ares, who is the only god worshipped by them, for they are a warlike people." The Carmanians closely resembled the Persians and Medes in their customs.

That the onager was regularly captured and domesticated in Assyria in ancient times is clearly established by one (Fig. 23) of the bas-reliefs discovered by Sir A. H. Layard at Kouyunjik (Nineveh). The relief, which is one of a series of slabs recording scenes in the life and hunting expeditions of Assur-Bani-Pal (B.c. 668-626), represents two of the king's attendants lassoing a wild ass. The other asses are seen running away 2 .

In ancient times they were well known in Syria, as is clear from the frequent allusions to the wild ass in the Old Testament. Aristotle ${ }^{3}$ speaks of "those animals called mules (hemionoi) in Syria which are so termed because of their similarity to mules (i.e. domestic mules), though they are not really of the same kind, for they breed freely," and elsewhere he states that "in Syria there are animals termed mules (hemionoi), which, though they are quite a different species from the domestic mules and resemble the wild asses (oi äypı oै $\left.\nu \iota^{4}\right)$, get their name from a certain resemblance to tame mules. Like the wild asses and the domestic mules they surpass in fleetness. These mules breed freely, as is proved by the fact that some were brought into Phrygia in the time of Pharnaces, the father of Pharnabazus, and still continue there. There are now but three, but formerly there were nine." Apparently there were two kinds of wild asses in Syria, differing but slightly from each other, the one known as the 'wild mule' (hemionos), the other as the 'wild ass' (onos), the former being probably darker in colour than the latter. Thus one corresponded to the variety termed hemippus or onager indicuts, the other to the typical onager.

1726 .

2 C. Keller (Abstimm. alt. Haustiere) takes them for Prejvalsky horses, but cf. Horses on Figs. 62-4.
3 Hist. Animals, I. 6.
4 Hist. Animals, vr. 36. 


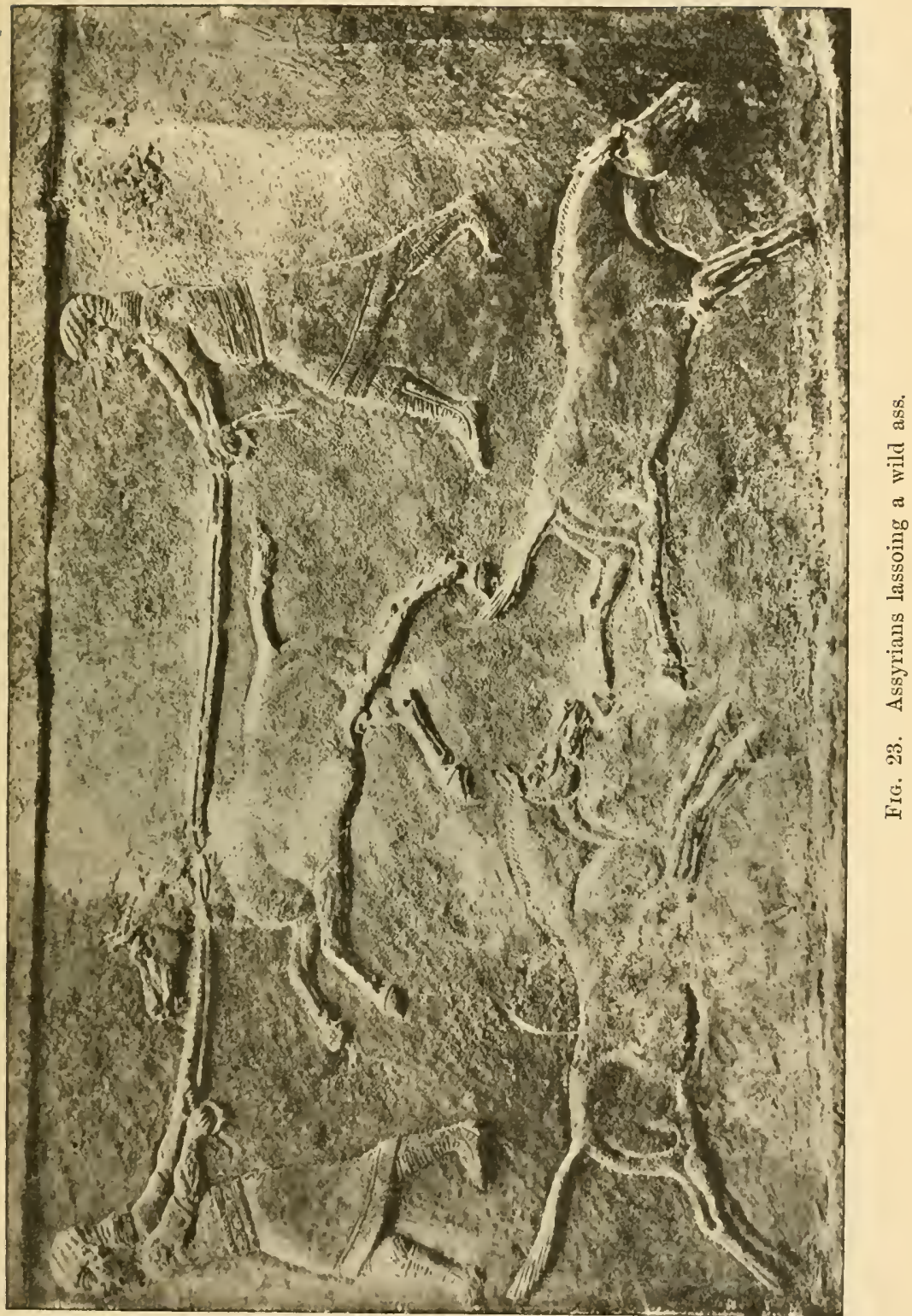

R. H. 
According to the Book of Wonderful Stories ${ }^{1}$ attributed to Aristotle, one of the wild asses led the herd, and whenever any of the younger stallions attempted to serve a mare, the master stallion became furious, pursued the colt until he caught him, then stooping down behind him he emasculated him with his teeth. A like belief is still current in India respecting the wild asses of Cutch.

In early days the wild ass was well known in Paphlagonia, for Homer ${ }^{2}$, when speaking of the Eneti who came from thence

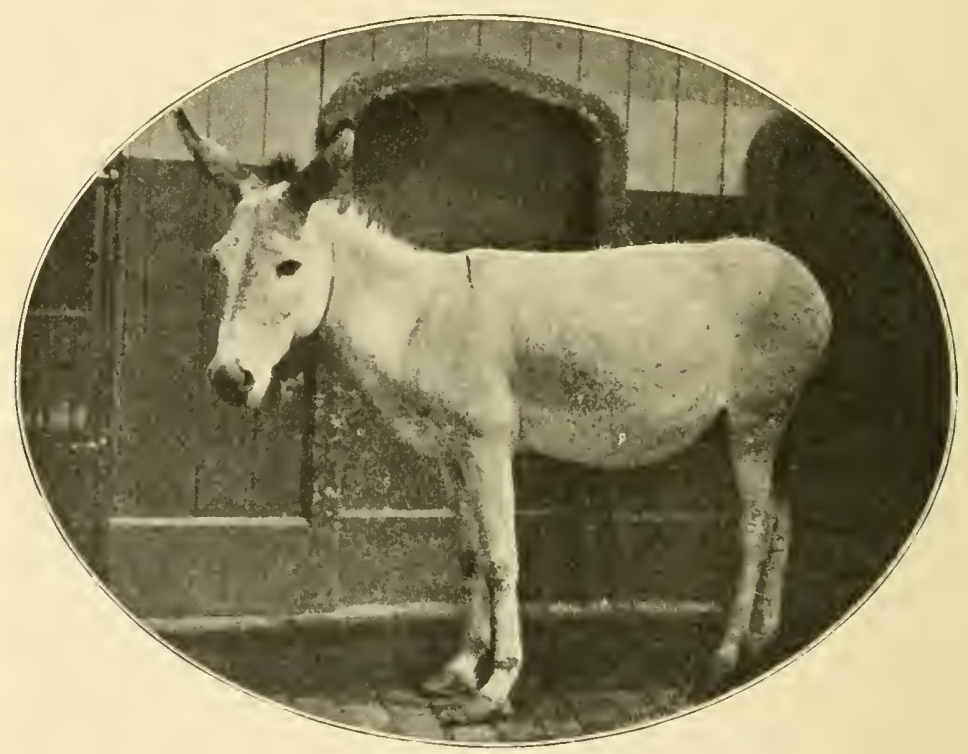

FIg. 24. The Nubian Wild Ass ${ }^{3}$.

to aid Priam and the Trojans, describes their land as "the home of wild mules." There can be little doubt that the wild mule

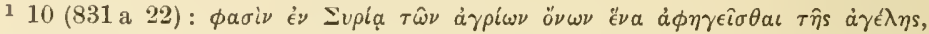

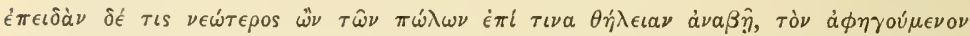

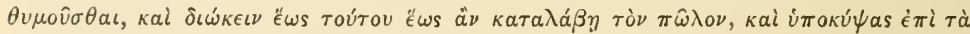

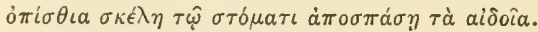

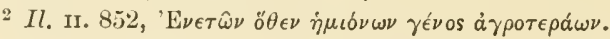

3 The illustration is from a photograph of the specimen in the Zoological Gardens, Dublin, taken by Mr G. E. Low and given to me by my friend Dr Scharff, the Director of the Gardens. 
of Paphlagonia was some form of Equus hemionus, probably the same variety as that called 'mule' (hemionus) in Aristotle's time.

The wild ass of Mesopotamia seems not to be as fleet as a first-rate Arab. Sir A. H. Layard ${ }^{1}$ in describing a mare of matchless beauty which belonged to Sofuk, a powerful Shammar sheikh, called by her master, Shammeriyah (as if the property of the tribe), says that she was the offspring of a celebrated mare named Kubleh "whose renown extended from the sources of the Khabour to the end of the Arabian promontory, and the day of whose death is an epoch from which the Arabs of

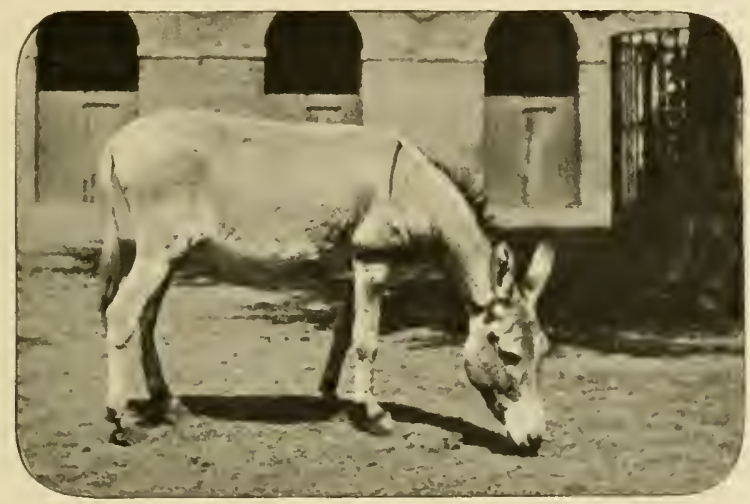

FIg. 25. The Nubian Wild Ass ${ }^{2}$.

Mesopotamia date events concerning their tribe." MohammedEmin, sheikh of the Jebours, assured Layard that "he had seen Sofuk ride down the wild ass of the Sinjar on her back."

From a passage to be cited later on (p. 125) it is clear that the wild ass (onager) existed all across southern Russia in the fifth century B.c., for it was hunted both by the Sarmatian tribes who lived on the east side of the Don (Tanais) and by the Scythians who occupied the region to the west of that river. It is even possible that the wild ass dwelt in the Danube valley almost down to the beginning of the historical

1 Nineveh and its Remains (ed. 1867), p. 74.

2 This illustration is from a photograph (copyright) by Mr L. Medland, F.Z.S. 
period. It seems certain that neither Sarmatian nor Scythian ever domesticated the wild ass, a circumstance probably due to the fact that they had a more docile and serviceable animal in the wild horses of the same region.

On the other hand there is strong evidence that the Arabs had domesticated some kind of E. hemionus from a very early time, for we shall find later on that the Arab tribes possessed

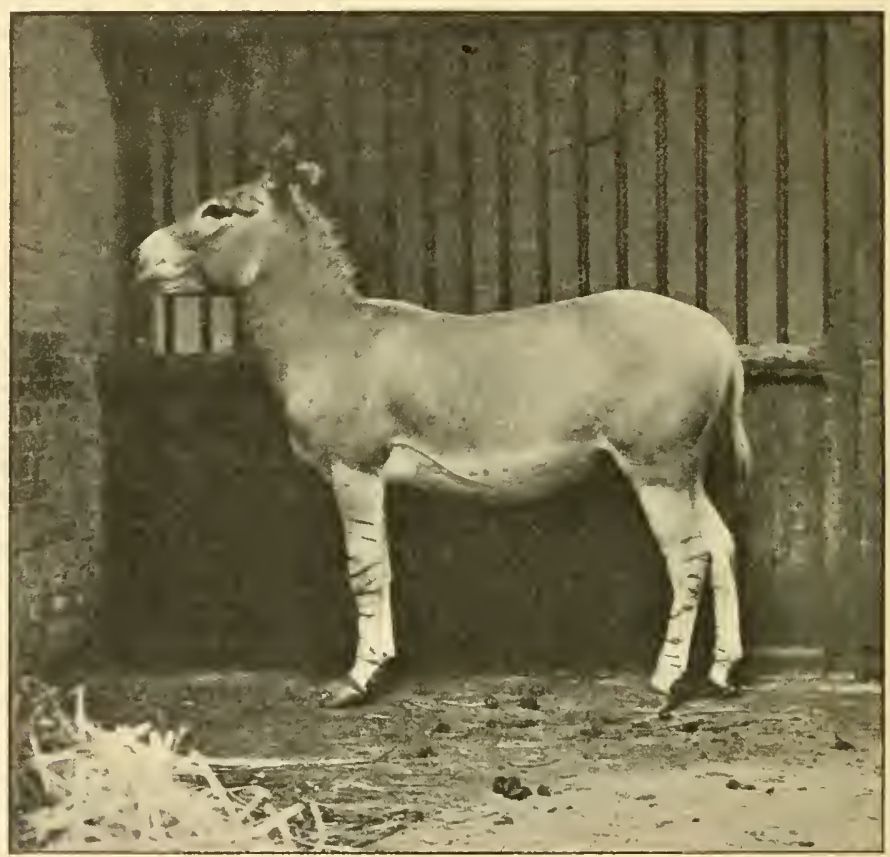

Fig. 26. The Somali Wild Ass?

asses from the dawn of history, and $\mathrm{Strabo}^{2}$ when describing the littoral of the Red Sea after Eratosthenes and Artemi-

1 This illustration and the following are from photographs (copyright) of the specimen in the Zoological Gardens taken for me by $\mathrm{Mr}$ W. P. Dando, F.Z.S., official photographer to the Zoological Society. This animal had not hitherto been photographed standing up.

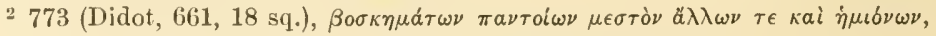

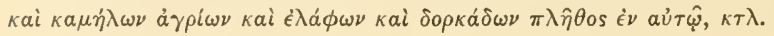


dorus, speaks of a region south of Nabataen well wooded and well watered, abounding with all kinds of cattle, wild asses (hemionoi), wild camels, deer, and gazelles; lions, leopards and wolves were also common. As there were thus both wild asses and wild camels in Arabia down to the Christian era, there can be little doubt that the domestic asses and camels of the Arab tribes were derived from the wild species of that region.

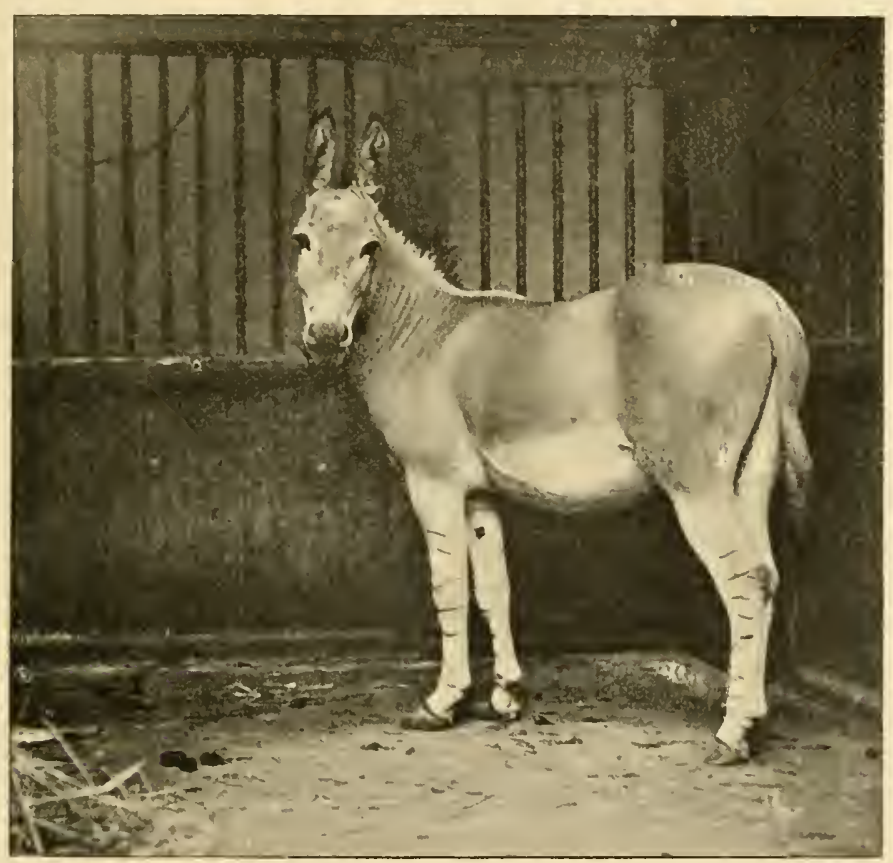

Fig, 27. The Somali Wild Ass.

Mr Lydekker ${ }^{1}$ has pointed out that " if the chigetai and the kiang are regarded as races of one species, there would seem considerable reason for considering the onager and the ghorkhar as sub-species of a second; for the two latter certainly differ from the two former much more than do the members of the two groups from one another. In their tendency to a 1 "The wild ass of Mongolia," Proc. Zool. Soc. 1904, p. 431. 
greyer colour, smaller hoofs, and possibly in a greater length of ear, the two southern forms present an approximation to the true wild asses of Africa, which is quite what we might expect from their geographical distribution. In colour, and perhaps also in length of ear, as well as in their cry, the chigetai and the kiang are more horse-like."

(9) The African Wild Ass (E. asinus, Linn., taeniopus, Henglin), which is held to be the source of our domestic ass, still survives in Abyssinia, Nubia, and other parts of North-east Africa lying east of the Nile. The term taeniopus has been applied to it from the fact that in some of the species the lower limbs show dark markings (Fig. 26). Generally speaking it resembles the domestic ass in colour and markings. It differs from the Asiatic species by being of a grey colour instead of rufous-brown or yellow, by having a very distinct shoulder stripe reaching from the withers to the top of the fore-leg, but varying in extent in different specimens (Figs. 24, 25), by having longer ears, and by much more frequently having dark marks upon its lower limbs.

(10) The Somali Wild Ass ${ }^{1}$ (E. somaliensis, Noack) differs from the ordinary wild ass by being more grey in colour, by the entire absence of the cross stripe over the shoulders, in the very slight indications of the dorsal line, and especially by the numerous black markings on both fore and hind legs, by smaller ears and by a longer mane (Figs. 26, 27). One shot by Mr Lort Phillips near Berberah stood fully 14 hands high". But it is questionable whether the Somali ass is to be regarded as more than a local variation, for one shot about fifty miles from Berberah by Mr Inverarity ${ }^{3}$ differed from the type specimen "in having slight shoulder-stripes, as well as a dorsal stripe. The general colour of the skin was also not of so grey a tint. All the four feet were banded as in the earlier specimens."

1 Sclater, Proc. Zool. Soc. 1884, p. 542, Pl. L.; Tegetmeier and Sutherland, Horses, etc. p. 19.

2 It must be remembered that measurements made after death may be misleading.

3 Proc. Zool. Soc. 1892, p. 195. 


\section{ZEBRAS.}

We now pass to the zebras, which although placed by some zoologists in a separate genus (Hippotigris) cannot be so completely divided from the other Equidae.

The zebras are all found in Africa, and it will be observed that whilst the most northerly of them overlap the true asses, in Somaliland and Abyssinia, yet for the most part they inhabit the vast regions extending from the countries just named down to the Cape and along the west to Angolaland. Similarly in Asia the true asses, though overlapping Prejvalsky's horse in Mongolia, are found largely south-west of the central mountain chain, in which region it will be made probable that the true Equus caballus never existed in a wild state.

Although the zebra only became known to the modern world after the Portuguese had established their factories on the coast of Congo and Angola, it seems certain that this animal was known to the Romans, for it can hardly be doubted that the Hippotigris ${ }^{1}$ slaughtered in the amphitheatre at Rome in the reign of Caracalla (A.D. 212-217), in company with an elephant, a rhinoceros and a tiger, was one of the striped African asses. Prof. Ewart " nay be right in suggesting that

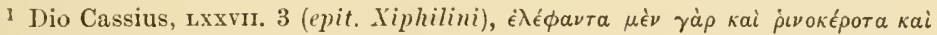

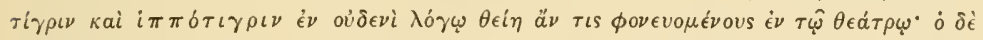

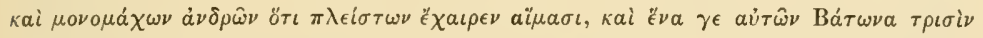

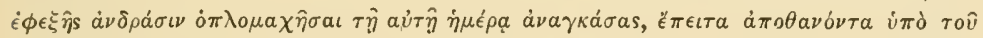

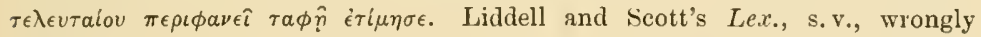
explains $i \pi \pi \delta \tau \iota \gamma p \iota s$ as a large kind of tiger on the analogy of such forms as $i \pi \pi \sigma \sigma \epsilon^{\prime} \lambda \iota \nu 0 \nu$, etc., in which the prefix gives the sense of hugeness (cf. horse-leech, the use of $\beta o v$ - in $\beta o v$ in $\mu$ os, and that of hasti, 'elephant,' in Sanskrit). The true analogues of $i \pi \pi b \tau \iota \gamma \rho$ s are such compounds as $i \pi \pi 0 \kappa \epsilon^{\prime} \nu \tau a v p o s$ (which does not mean a huge Centaur, but a creature, half-horse, half-centaur, thus distinguishing the later Centaurs of semi-equine shape from the early Centaurs, who were

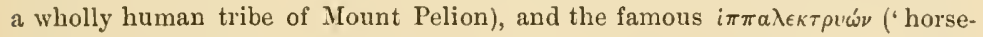
cock') of Aeschylus, which certainly was not a huge cock, but a creature

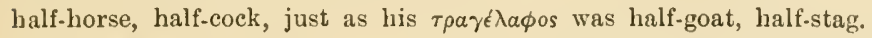

2 Penycuik Experiments, p. 10. This is rendered all the nore probable by the fact that in Roman times not only did the elephants of Abyssinia and Somaliland furnish much ivory, but Strabo describes a rhinoceros from the latter region, which he himself saw either at Alexandria or Rome. 
this animal was not, as has been supposed ${ }^{I}$, the Common or Mountain Zebra (Equus zebra) of South Africa, but rather one of the species still to be found in Somaliland and Shoa.

But it is possible that the Romans may have obtained the zebra from a region much less remote than either Abyssinia or Somaliland, for though in modern times no wild asses or zebras are known in that part of North Africa which lies between the Nile and the Atlantic and to the north of Atlas, there is good evidence that this has not always been the case. Herodotus" includes amongst the wild animals of Libya 'asses without horns' in contradistinction to 'asses with horns ${ }^{3}$.' The horned asses were probably some species of antelope, whilst in the 'hornless' kind we may recognize without hesitation some wild species of Equidae. This is rendered fairly certain by the fact that there is excellent evidence for the existence of zebras west of the Nile in medieval times.

A statement of El Masudi, the famous Arab historian and greographer (flourished about 950 A.D.), cited in a cosmography ${ }^{4}$ compiled by Muhammad ben Ahmed ben Ayas, a Circassian (who probably lived at the beginning of the sixteenth century), renders it clear that zebras were found west of the Nile. The passage runs as follows :

"The external oasis comprises an ancient town built by a Coptic king named Boudssya, one of the children of the people of Qoft. El Masondy informs us that this oasis lies between Egypt and the Said in the territory of Assouan: it is the first province of Nubia. This comntry is independent and isolated. It belongs to no other. It affords dry dates and dry grapes. It nourishes small wild asses (zebras) striped black and white in extraordinary manner. They are never mounted and if transported without the country, they only live a short time."

As there are no oases on the east side of the Nile, it would seem almost certain that the district here indicated as in the territory of Assouan and in the first province of Nubia is the

1 Flower and Lydekker, Mammals, p. 385.

2 Iv. 193.

3 IV. 191.

${ }^{4}$ Notices et Extraits des Manuscrits de la Bibliothèque Impériale et autres Bibliothèques, Tome vin. pp. 5, 19 (Paris, 1810). 
Great Oasis. Though Nubia extends on both sides of the Nile in modern times, Strabo and other aneient geographers expressly make it part of Libya, the name given to the region west of the Nile, just as Ethiopia was applied to the region on the castern side.

This passage strongly corroborates the evidence of Herodotus that in the fifth century B.c. there were wild asses in the region lying west of the Nile.

As we have just seen, the African wild ass when found in Somaliland shows zebra-like markings on its legs, and as this ass is found on the east side of the Nile in modern Nubia it may be that it had managed to get across the barrier of the Nile. On the other hand, the Arabs must have been familiar with the various kinds of Abyssinian ass, and therefore the mere occurrence of stripes on the legs of the wild animals of the oasis would not have called for special remark. It is more likely therefore that the wild asses of the oasis were a distinct species striped black on white like the Somaliland zebra, but of a smaller size, or else some variety of the Chapman-Burchell group of zebras, to which we shall presently come as we keep advancing southwards.

It is therefore quite possible that the Hippotigris exhibited at Rome in the time of Caracalla may have been brought from the Great Oasis or some other part of what was called Libya by the ancients-the vast region lying between the Nile and the Atlantic.

Up to recently three types of zebras were generally recognized. From the minute study of the ever-growing material made by Mr R. I. Pocock ${ }^{2}$ and Prof. Ewart ${ }^{3}$ we are led to conclude "that though there are three distinct types of zebras, it cannot be maintained any longer that all three types can be readily distinguished from each other by their marking." These three classes are (1) the Grévy, (2) the Burchell, and (3) the Mountain or ' Common' Zebra.

(11) The Grévy Zebra or Somali Zebra (Equus grevyi), found in the mountains of Somaliland and in Shoa, first became

1 776. 2 Aml. Mag. Nat. Hist., ser. 6, Vol. xx. (1897), pp. 33-52.

3 Penycuik Experiments (1899), p. x. 
known ${ }^{1}$ to modern Europe by a living specimen sent to M. Grévy, then President of the French Republic, in 1882 by King Menelik of Abyssinia. It was first shot in Somaliland by Capt. Swayne and Col. A. Paget in 1893. Swayne saw about 200 in all: they were in small droves of about half-a-dozen on low plateau covered with thorn bush and glades of 'durr' grass. There were none in the open grass plains of Haud; Durhi (about 300 miles from Berberah) being their northern linit.

This splendid animal (Fig. 28 ${ }^{3}$ ) stands about 15 hands high. The comparison of skins obtained later by $\mathrm{Mr}$ Tegetmeier (through Mr Carl Hagenbeck) and others, and various living specimens since brought to Europe (including three in the Regent's Park), shows that there is a considerable variation in the marking of this species. Thus in the specimen from Shoa sent by King Menelik there is a broad white space between the dorsal band and the narrow transverse stripes at each side of the croup, while in the specimen from Somaliland these narrow stripes almost reach the dorsal band, as in the 'gridiron' marking, characteristic (vide infra, p. 62) of the Mountain Zebra (Equus zebr(t) of South Africa. The ground colour is white or brown, very finely decorated all over with numerous delicate and intensely black or brown stripes, forming a pattern quite different from those of other known speciest. The stripes on the forehead fall into a number of round arches, a feature which helps to distinguish this species from the Burchell group ${ }^{5}$. The muzzle sometimes is 'mealy' coloured, while the nostril patches are of a bright tan colour; the ears are long, but in being very wide they differ from the ears of both asses and horses.

${ }^{1}$ But Job Ludolphus, Historia Aethiopica, 1681, summarized what had been written by the Jesuits concerning the Abyssinian zebra, and in his Commentarius (1691) he added more. Hamilton Smith (p. 321) knew Ludolphus' statement, cited by $\mathrm{Mr}$ E. Bidwell (Field, 1899), whilst the extracts are given at length by Mr H. Scherren (Field, 4 March, 1905).

2 Proc. Zool. Soc. 1894, p. 320 (Swayne); ibid. 1893, p. 473 (Paget).

${ }^{3}$ Fig. 28 is from a photograph kindly given me by Mr Carl Hagenbeck.

${ }^{4}$ Flower and Lydekker, op. cit., p. 387; Tegetmeier, op. cit., pp. 43-5; R. I. Pocock, Amn. Mag. Nat. Hist. Vol.xx. (1897), pp. 48 sqq. The Somali race (berberensis, Pocock) of E. grevyi has ground colour pale brown or ochre with chocolate stripes. Both races were known to Ludolphus (op. cit.), and a specimen with brown stripes had reached Constantinople.

5 Ewart, Penycuik Experiments, p. 76. 
Although in other respects it stands closer to the ass than to the horse, in having the hoofs rounded in front it resembles the horse, but in having long heels and a large frog it agrees with the African asses, whilst the chestnuts are small'. It thus differs essentially from the following group.

The Burchell Zebra (Equus burchelli). As we advance

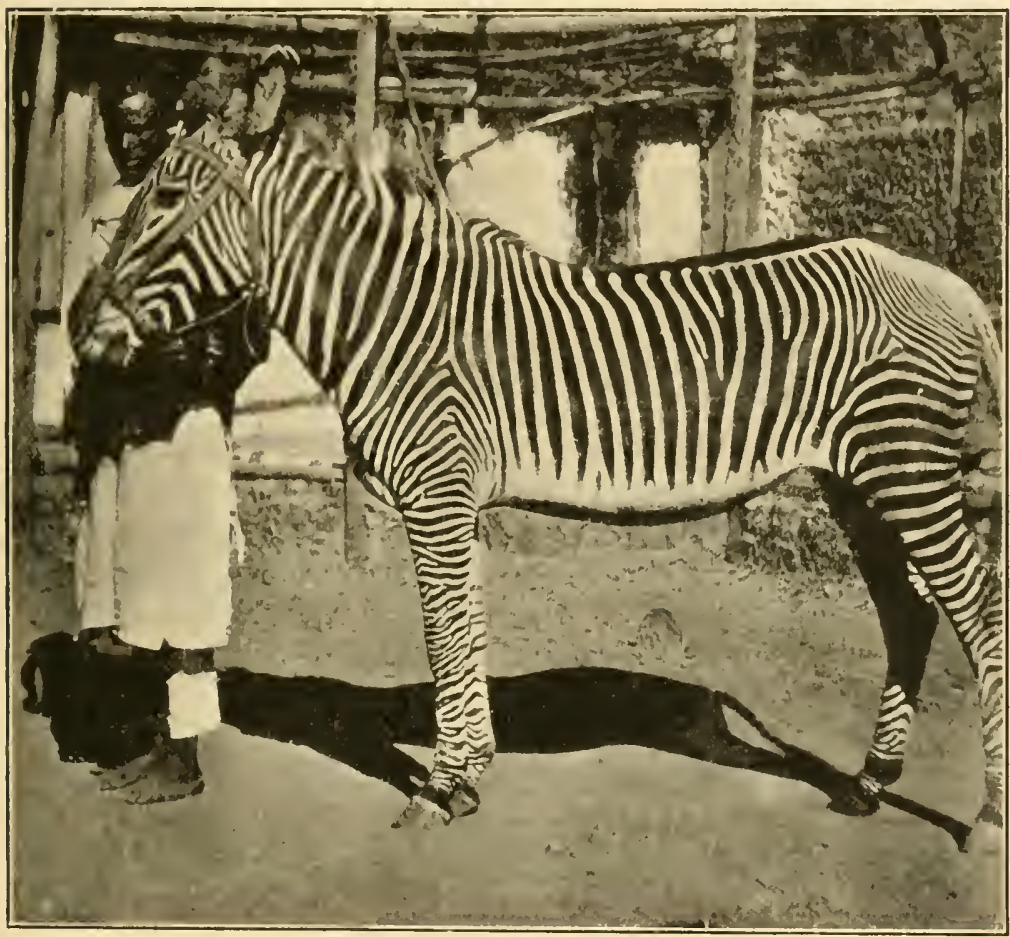

Frg. 28. The Somali Zebra.

sonthwards this zebra or group of zebras is first met with in Equatorial Africa. It is named after the traveller Burchell, who was the first in modern times at least to call attention to it, having met it near the Orange River in southern Bechuanaland. Yet from Pigafetta's ${ }^{2}$ description of the first zebra known

1 Pocock, loc. cit.; Hayes, Points of the Horse, p. 667, fig. 628 (for sole of foot).

2 A Report of the Kinglome of Congo a Region of Africa, Drawn out of the writings and discourses of Odoardo Lopez a Portingall, by Philippo Pigafetta, Translated out of Italian by Abraham Hartwell (London, 1597), p. 73. The original was published at Rome by Bartolomeo Grafli, 1591. A Dutch trans- 
to modern Europe, that found by the Portuguese after they had established themselves on the coast of Congo and Angola, that animal seems to have been one of the varieties of $E$. burchelli, and not the Mountain Zebra (E. zebra).

"There breedeth likewise in this Countrey another Creature, which they call a Zebra, commonly founde also in certaine Provinces of Barbary and Africa: which although it be altogether made like a great Mule, yet is not a Mule indeed, for it beareth young ones. It hath a most singular skinne, and peculiar from all other creatures. For from the ridge of the chine downe towards the bellie, it is straked with rowes of three colours, blacke, white, and browne Bay, about the breadth of three fingers a peece ${ }^{1}$, and so meet againe together in a circle, every rowe, with his owne colour. So that the necke, and the head; and the Mane (which is not great) and the eares, and all the legges are so interchaunged with these colours, and in such manner and order, as without all faile, if the first strake beginne with white, then followeth the second with blacke, and in the thirde place the Bay: and so another course beginning in white endeth still in Bay. And this rule is generally and infallibly observed over all the body. The tayle is like the tayle of a Mule, of a Morell colour, but yet it is well colourerl, and hath a glistring glosse. The feet like the feet of a Mule, and so are the hooffes. But touching the rest of her carriage and qualities, she is very lusty and pleasaunt as a horse: and specially in going, and in running she is so light and so swift that it is admirable. In so much as in Portingale and in Castile also, it is commonly used (as it were for a proverbe) As swift as a Zebra, when they will signifie an exceeding quickeness. These creatures are all wilde, they breede every

lation by Martin Everart was issued at Amsterdam, 1596. The brothers De Bry issued a German translation at Frankfurt in 1597, and a Latin version in 1598. This Latin version is only an abbreviation. The latest English version is that of Margaret Hutchinson (London, 1881) with a bibliography.

1 Hartwell's version seems correct, and the Latin version coincides with it: tribus enim diversis coloribus, nigro, albo, et spadiceo, qui per lineas tres digitos latas, corpus a dorso versus ventrem hemicyeli in modum ambiunt, per totum corpus distinctum est. On the other hand Miss Hutchinson translates "These large stripes are three fingers' length from each other, and meet in a circle, every row with its own colour." 
yeare, and are there in such aboundanee that they are innumerable. If they were made tame, they woulde serve to rume and to drawe for the warres, and for inany other good uses, as well as the best horses that are."

In the same chapter we learn that Lopez (from whose writings Pigafetta compiled his own work) had a tame zebra, which was eventually killed by a leopard. The breadth of the stripes, the fact that they were of three colours, and finally the docility of the animal-characteristics of the Burchell rather than of the Mountain Zebra (E. zebra), as will be immediately shown-render it probable that the animal deseribed by Lopez belonged to the former rather than to the latter species.

It is doubtful whether Burchell's zebra can be subdivided into species or sub-species, though Dr Natschie ${ }^{1}$ makes four species-E. antiquorum, E. burchelli, E. chapmuni and $E$. boëhmi ; and E. burchelli granti ${ }^{2}$ and E. burchelli selousi have been made into sub-species by some, though there is no evidence that they are more than local races. It is best therefore for the present to treat these and Crawshay's and Chapman's zebras as simply local races, some of which are now found in colour at least to link this type certainly to the Mountain Zebra and even in some respects to the Somali species. The Burchell group is distinguished from the last-named species by having fewer and much broader stripes, which are disposed in a pattern quite distinct on both body and head, the markings on the forehead taking the form of pointed instead of rounded arches $^{3}$ (Fig. 36) except in Crawshay's zebra, where they are round.

Prof. Ewart has shown that there is "now no link wanting in the chain (if the striping alone is considered) that has at one end the common mountain zebra (Fig. 29), with a 'gridiron' over the hind-quarters, and legs barred to the hoofs,

1 Zool. Garten, xxxv. Hefte 2 and 3; Proc. Zool. Soc. 1895, p. 690 (where Mr Sclater holds that Matschie's species are only "four different climatic forms").

2 Hamilton Smith, The Horse, p. 321. The name zebra is the Portuguese adaptation of a native name. According to Ludolplus it is the negro form of the Abyssinian zeuru of Lobo and the Galla zeora or zecora.

${ }^{3}$ Ewart, Penycuik Experiments, p. 76. 
and the true Burchell zebra, with perfectly white legs and scarcely a vestige of transverse stripes across either croup or loins" (Fig. 37), whilst "from the true Burchell zebra it is but a step to the better marked specimens of the now lost, if not extinct, quagga" (Fig. 38): let us therefore pass on for the moment to the Mountain Zebra, and then return to the Burchell group.

(12) The Mountain or Common Zebra (Equus zebra) was formerly extremely common in the mountainous parts of Cape Colony and Natal, but it has now become nearly extinct

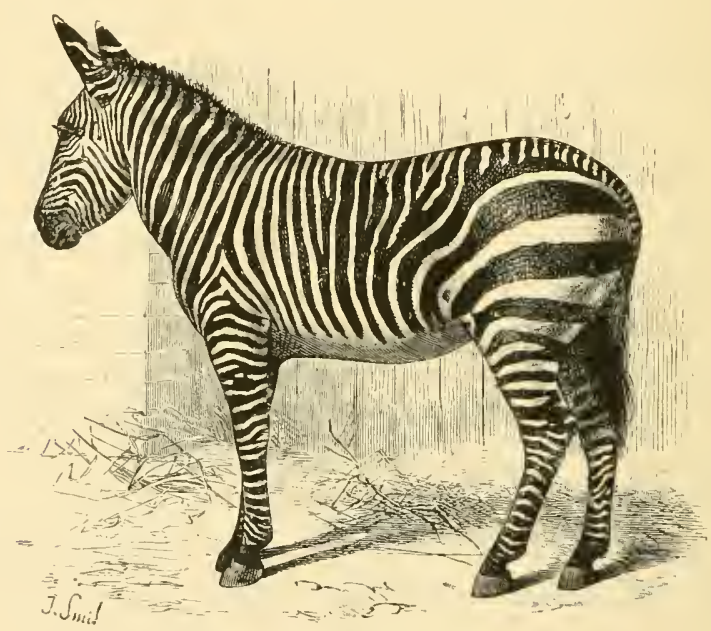

FIG. 29. Mountain Zebra.

in that area, though up to the beginning of the late war there was a fine herd near Cradock' ${ }^{1}$. It was commonly called the 'wild pard' by the Dutch of Cape Colony. A local race of this species is still to be found in $\operatorname{Angola}^{2}$ (E. zebra penricei, Thomas), whilst another race or sub-species (E. z. hartmanni,

1 From private information which I have received since the conclusion of the war, I learn that the Cradock zebras, or at least some of them, still survive.

${ }^{2} \mathrm{Mr}$ Pocock holds that E. zebra penricei and E. z. hartmami are very dis. tinct from the typical $E$. zebra, the ground colour being brownish and the black stripes only about as wide as the light spaces, whilst E. z. penricei and E. $z$. hartmanni are probably distinguishable from each other. 
Matschie) still survives in considerable numbers in German West Africa. The Mountain Zebra more nearly resembles the ass than Burchell's zebra, for its hoofs are narrow, it has a more tufted tail, a shorter mane, a thicker neck and longer ears ( $7 \frac{1}{2}$ inches); it has large and very broad chestnuts on the forelegs; it is not so large as Burchell's zebra, as it stands only about 12 hauds high. Its general ground colour ${ }^{1}$ is white, but the stripes are black and broader than the intervening spaces

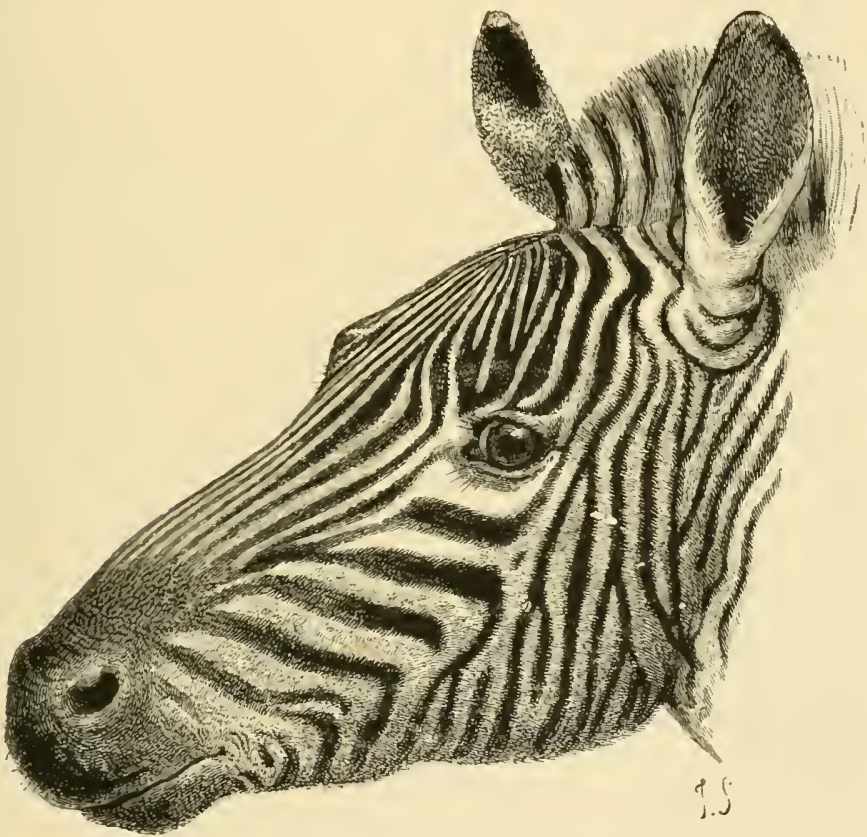

FIr. 30. Head of Grant's Zebra.

(being not so close as in the Somali zebra but closer than in Burchell's). The body stripes are all nearly perpendicular, whilst the legs are covered with horizontal bands down to the hoofs (Fig. 29). This zebra has a very narrow dorsal band, the hair of which is reversed from the croup forwards, a peculiarity only found in this species?. But the most distinctive feature in its marking is the 'gridiron'-a number of

1 Except in the Angola and German S. W. Africa races (cf. p. 62).

2 This fact was first pointed out by Mr R. I. Pocock, Ann. Mag. Nat. Hist. Vol. xx. (1897), p. 306. 
transverse stripes running across the top of its loins, croup and base of tail. Owing to the body stripes not being continned round the belly the under parts are commonly white. Many specimens show a rudimentary or vestigial dewlap, and some would regard such as a distinct variety. This animal seems never to have inhabited plains like its congeners, keeping always to mountain districts. Ward's Zebra ${ }^{1}$, found near Naevashi and the Uganda railway, in its long ears, narrow hoofs

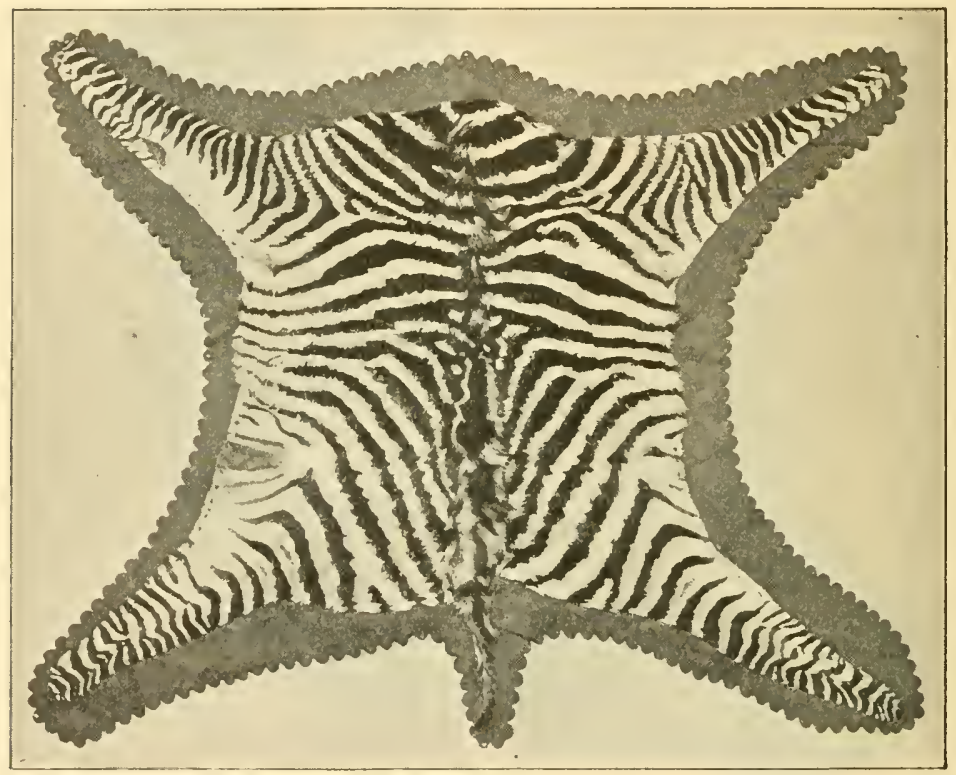

FIG. 31. Skin of an unborn foal of Grant's Zebra; Uganda².

and 'gridiron' comes close to E. zebra, whilst E. foai (north bank of the Zambesi) which in some respects approaches E. zebra and E. grevyi, comes nearest to Crawshay's race of $E$. burchelli.

(13) The Burchell Group. Let us now return to this group, which is found from the lakes of Equatorial Africa down

1 Lately described by Prof. Ewart (see Addenda).

2 The illustration is from a skin belonging to my friend Mrs J. Roscoe, Cambridge.

3 See Addenda. 
to the Transvaal and Orange River, south of which it seems never to have ranged.

(14) Chapman's Zebra (Equus burchelli chapmani), first described by Mr. Layard in 1865, is found throughout all the

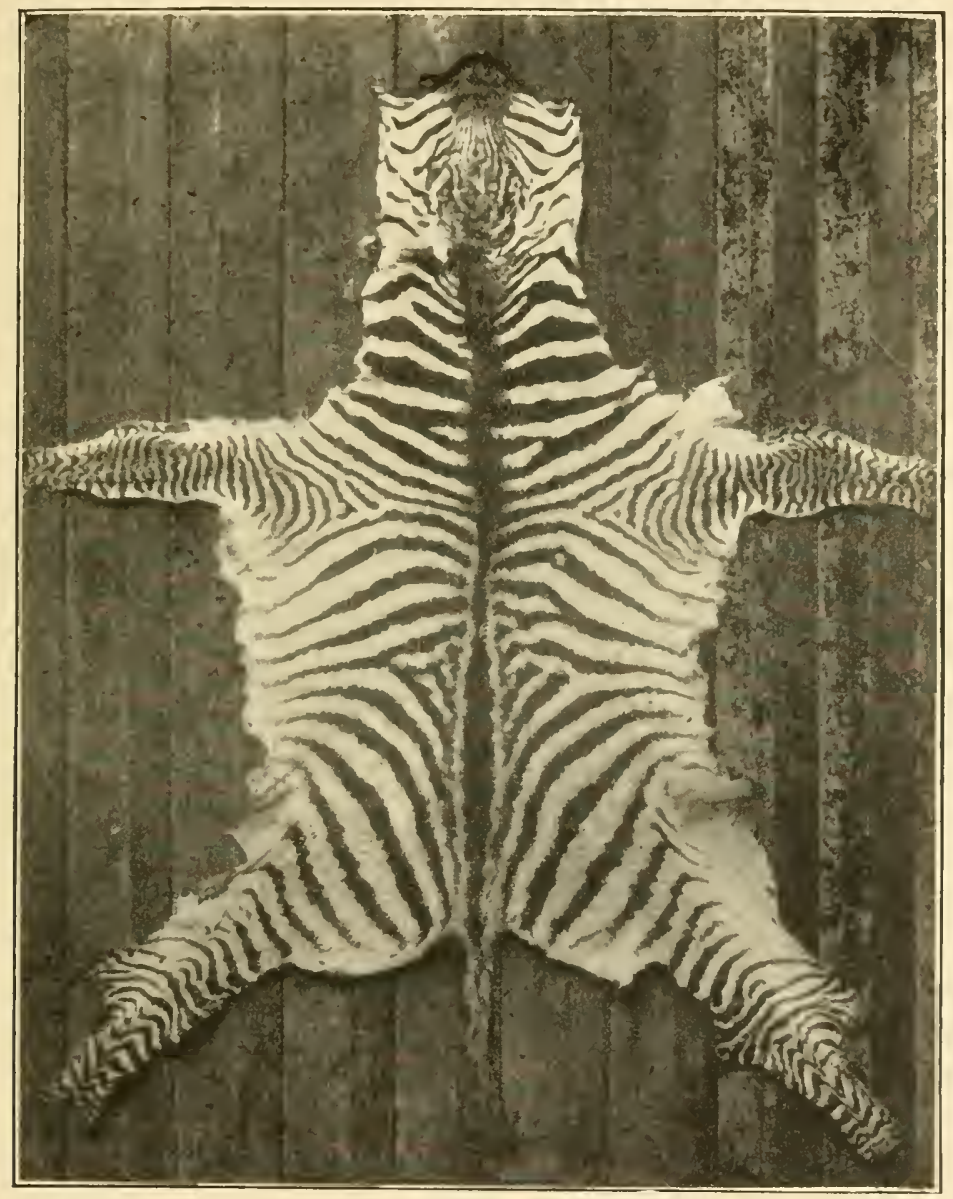

Frg. 32. Skin of young Grant's Zebra?.

vast area extending from Masailand (between the Victoria Nyanza and the east coast) down to the locality where it was

1 The illustration is from a block kindly lent me by Prof. Ewart. R. II. 
first met by Chapman, in South Africa, about 200 miles inland from Walwich Bayl between the Botletle and the Zambesi. This variety is only distinguished from Burchell's zebra by having its legs striped instead of plain (Fig. 36). But Mr T. E. Buckley ${ }^{2}$ writing of Chapman's zebra says that "out of five of these animals shot in one herd there were individuals showing variation of colour and marking from the yellow and chocolate stripes to the pure black and white, the stripes in some cases ceasing above the hock and in others being continued distinctly down to the hoof. The true Burchell zebra (Equus burchelli typicus) was first discovered by Burchell near the Orange River in southern Bechuanaland. It is still to be met with along the northern and eastern borders of the Transvaal, in Kama's country, and up to lately it still survived in great numbers in the neighbourhood of the Pungwe River. Its general colouring is pale yellowish-brown, the stripes being dark brown, or nearly black. There is always a longitudinal stripe along the under side, and the dorsal stripe is defined by a white line over the haunches, and there are not any stripes proceeding from it at right angles as in Crawshay's zebras (infra); whilst in all the Somali Zebras stripes proceed at right angles from the withers to the root of the tail, in all Burchell zebras there are three or more transverse stripes proceeding from the dorsal band behind the withers; nor has it the cross stripes on the croup which are so marked a feature of the Mountain Zebra (Fig. 29), but it has intermediate or 'shadow' stripes on the neck, trunk, and hind-quarters. The stripes on its forehead form a series of arches which are pointed instead of being rounded as in the Somali species. It differs from the Mountain Zebra (p. 63) by its greater height (ranging from 13 to $13 \cdot 2$ hands), by the greater length and thickness of its mane, by its bushy and more horse-like tail, and by the smaller size

1 Proc. Zool. Soc. 1865, pp. 417 sqq. (letter from Layard and "Notes on a new variety of Quagga observed on the elevated flats between the Botletle and Zambesi rivers during the late journey of J. Chapman and P. Baines" with a block showing the Chapman variety). Mr Selous met it in Matabeleland (P. Z. S. 1883, p. 32), but the Matabele zebra is regarded as a distinct subspecies (E. selousi) by Mr R. I. Pocock (Ann. Mag. Nat. Hist. 1897, p. 306). Tegetmeier, Horses, Asses, Zebras, pp. 51-2.

2 Proc. Zool. Soc. 1876, p. 282 ("Distribution of South African Mammals"). 
of its ears ( $6 \frac{1}{2}$ instear of $7 \frac{1}{2} \mathrm{in}$.), and by the much smaller size of the callosities on its forelegs.

'The distinct markings on the legs of Chapman's variety (Fig. 36) are entirely absent in the typical Burchell zebra. This animal is called daww by the Boers, who also frequently

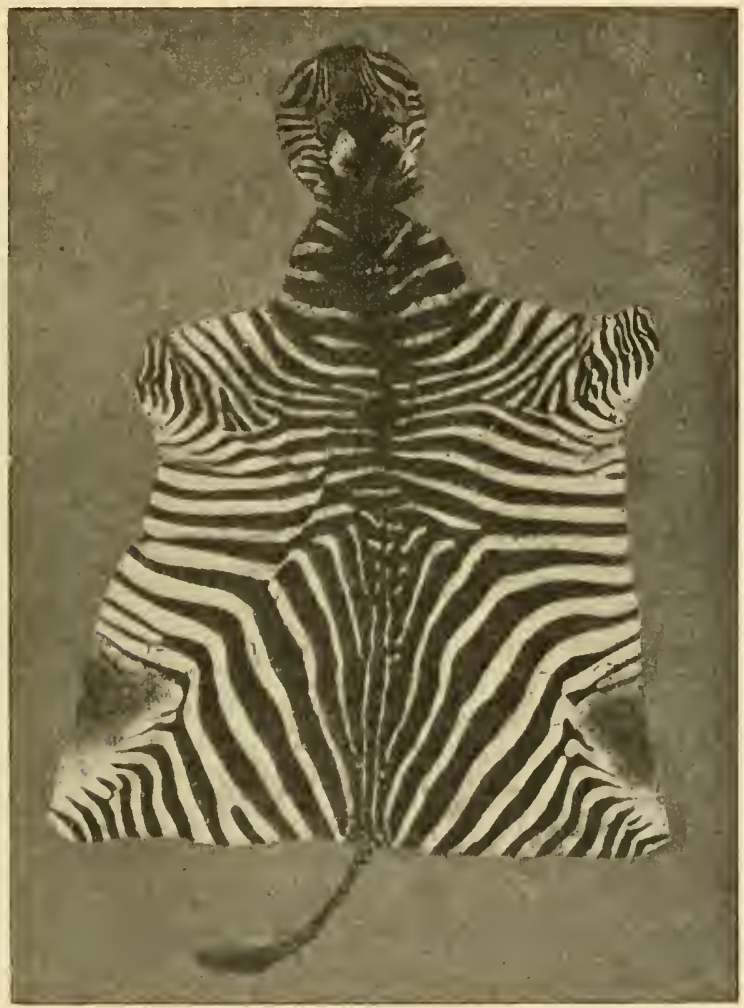

Fig. 33. Skin of a full-grown Grant's Zebra; Uganda ${ }^{1}$.

call it quagga. The typical Burchell zebra was also termed the Bonte Quagga by Comwallis Harris², and $\mathrm{Mr}$ Lydekker ${ }^{3}$

1 The illustration is from a skin in my own possession, the gift of my friend the Rev. J. Roscoe, well known for his ethnological studies in Uganda.

2 Portraits of the Game and Wild Animals of South Africa, Part I. (London, 1840). Harris used the term Burchell's Zebra both in the text and on the plate (p. 48) of his Wild Sports of Southern Africa (London, 1841).

3 Proc. Zool. Soc. 1904, p. 428 n. 
prefers the latter name. Mr Pocock ${ }^{1}$ regards the Burchell zebra or Bonte Quagga and Equus quagga as the same species, but to this point we shall presently revert.

(15) Crawshay's ${ }^{2}$ Zebra (Equus burchelli var. crawshayi), a variety found in the highlands of Nyassaland, west of Lake Nyassa, is held by Prof. Ewart ${ }^{3}$ to bridge over the supposed gap between the Burchell and the Mountain Zebra, and also

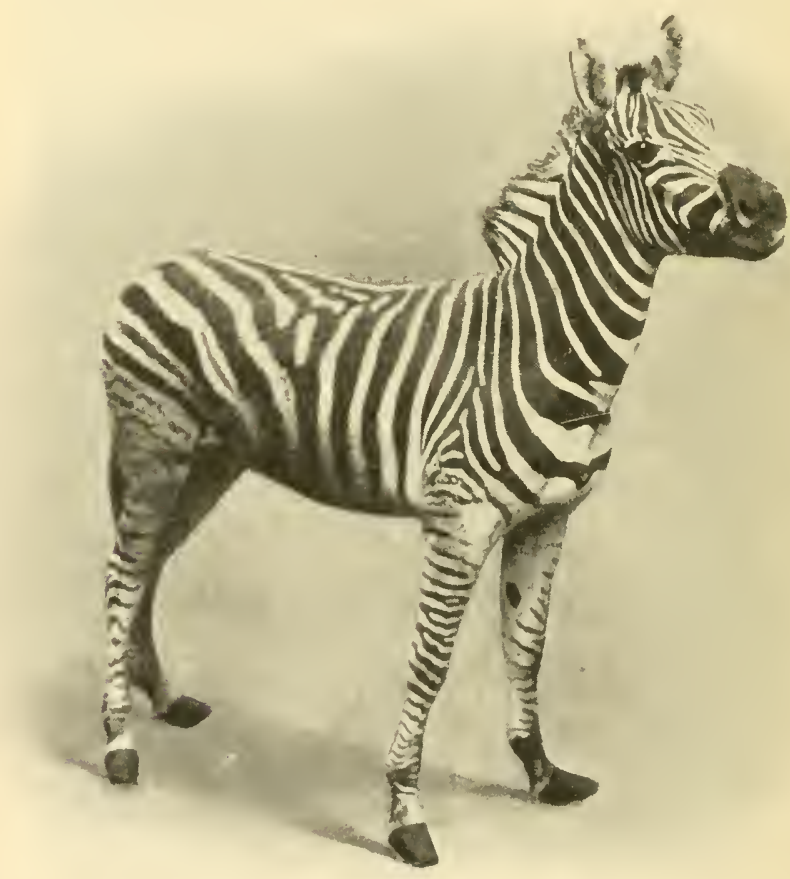

FIG. 34. Burchell's Zebra (Grant's Variety).

shows in its colouring at least one point of contact with the Somali species. It is about 13.2 hands high, and in the general disposition of its stripes closely resembles Chapman's

1 Ann. Mag. Nat. Hist. ser. 7, Vol. x. (1902), p. 306 ; ibid. 1 Nov. 1904.

2 R. Crawshay, Proc. of Zoolog. Soc., 1895, p. 688. Mr Crawshay procured his specimen in the Henga country three days S.W. of Deep Bay, Lake Nyassa.

3 Penycuik Experiments, p. 10. 
zebra, but the dark stripes upon the haunches are about the same breadth as, or are slightly wider than, the intervening light spaces, and it shows no intermediate 'sharlow' stripes whatever; the spot above the nostrils is bright tan colour; the stripes of the body are almost pure black (in this respect resembling both the Grévy and Mountain Zebras), whilst the ground colour varies from nearly pure white (as in the Grévy species) to nearly pale fawn, and there are several indistinct

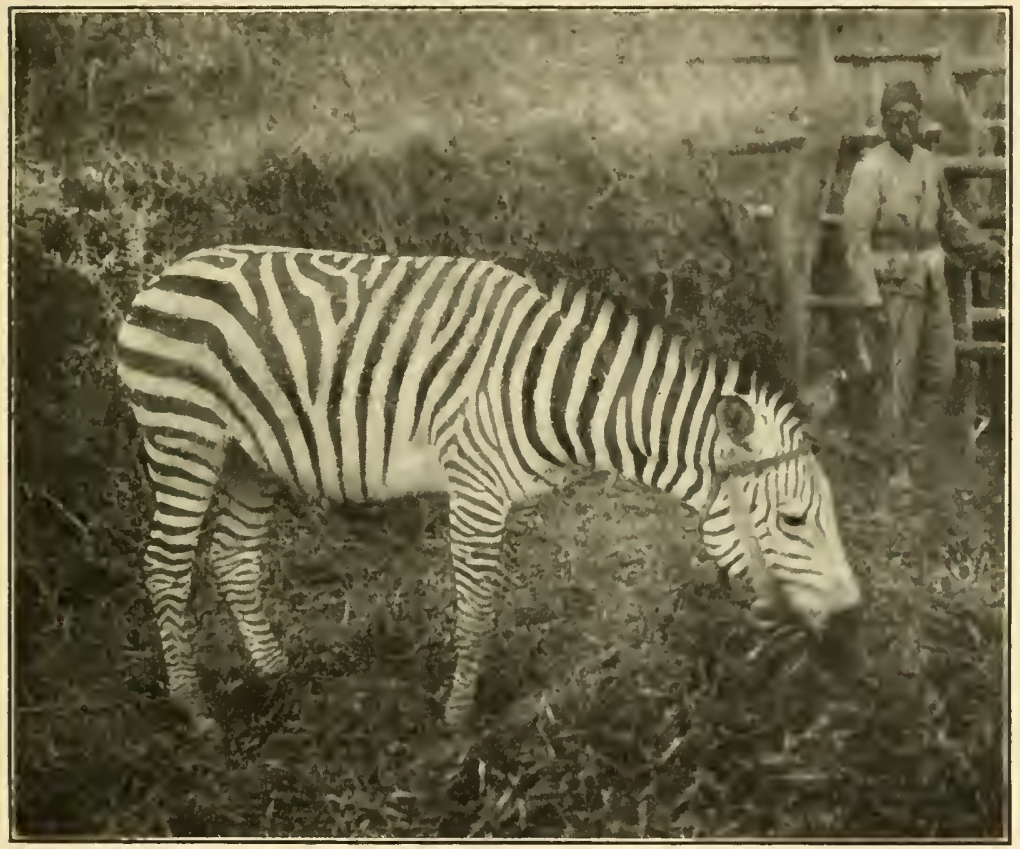

Fia. 35. Burchell's Zebra (Grant's Variety), from Kilima Ndjarol.

stripes across the croup suggestive of the 'gricliron' of the Mountain Zebra, the root of the tail having spots rather than stripes, and there are long black hairs at the tip of the tail, "and the stripes on the forehead are often arched, as in the Somali Zebra?"

1 From a photograph kindly sent me by Mr Carl Hagenbeck.

2 Hayes, op. cit., pp. 664-5 (who cites De Winton). 
(16) Grant's Zebra' (Equus burchelli var. granti) is a variety (Figs. 30-5) of the Burchell Zebra, closely resembling Chapman's, from which it only differs (1) by the dark bands on the legs being more sharply defined, (2) by the white spaces on neck and cheeks being broader, (3) by its having no 'shadow' stripes. It is found in British East Africa and German East Africa.

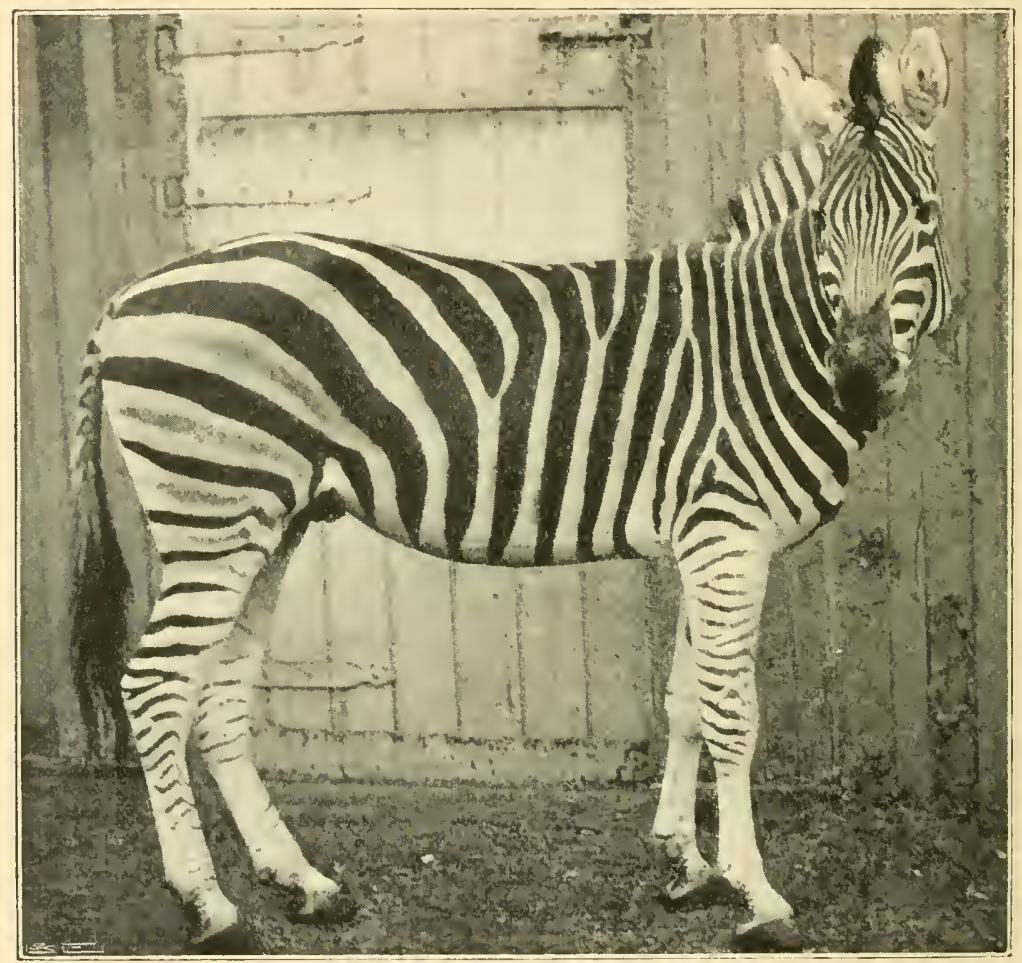

Fig. 36. 'Matopo,' 1'rof. Ewart's Chapman Zebra.

(17) The Quagga or Quacha (Equus quagga), so-called from its neigh, is now probably as extinct as the Moa and the Dodo, although it is not very long since living specimens were in European collections. Down to the middle of the last century

1 Proc. Zool. Soc. 1883 ("Notes on the zebra met with by the Speke and Grant Expedition in Eastern Africa," by Col. J. A. Grant, F.R.S.), F. 175, with woodcut of head, p. 176. My illustration (Fig. 30) is from an electrotype of the block just mentioned, which the Council of the Zoological Saciety has kindly permitted me to have made. 
it roamed in immense herds over the plains of Cape Colony, the Orange River Colony, and part of Griqualand West, but it appears never to have been found north of the Vaal River. It closely resembled Burchell's zebra, being more like the horse than the ass, though like some North-African horses and Celtic ponies it had no chestnuts on the hind legs. It approached the horse in colour and character of the tail more

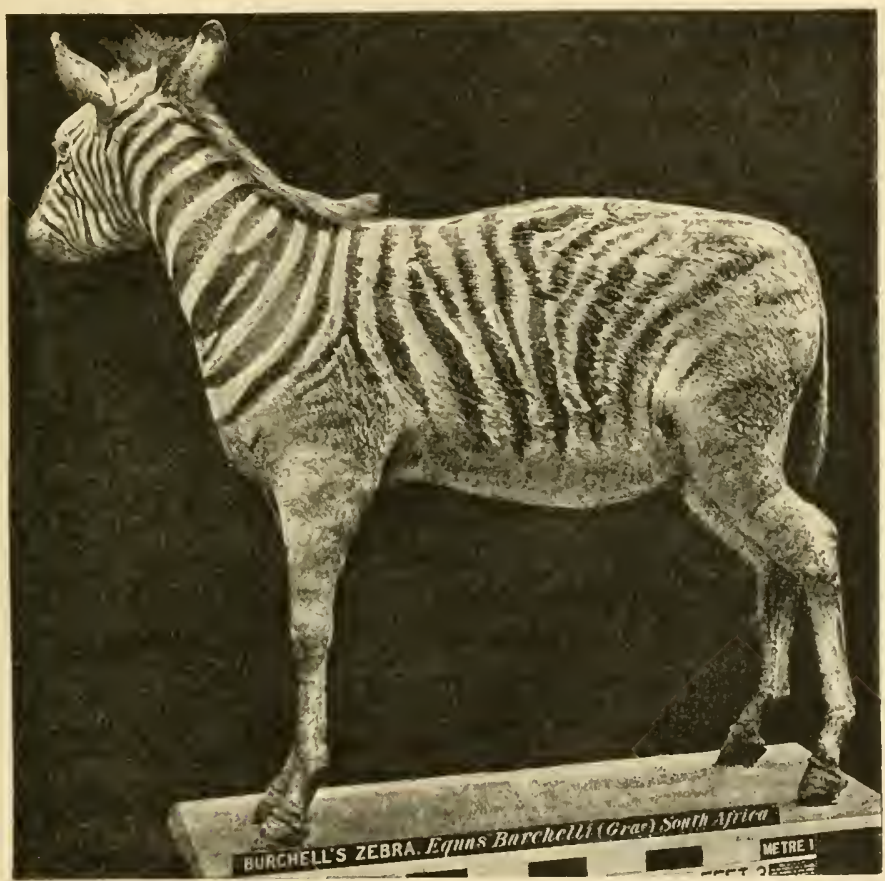

F1G. 37. Typical Burchell Zebra.

than any other of the striped Equidae. The ground colour of the upper parts of the body was light reddish-brown or bay, the under surface of the body, the legs and the tail were nearly white. 'The head, neck, and front of the body were marked with dark brown stripes, which are commonly said to fade away gradually behind the shoulders, the hinder part of the body, save for a broad dorsal stripe, and the legs being free from marks ${ }^{1}$, but according to Dr Noack$^{2}$ the transverse

1 Tegetmeier, op. cit. pp. 62-3.

2 "Das Quagga," in Kool. Garten, 1893, p. 289. 
stripes reached back as far as the buttocks; they were however completely absent from the legs.

The first description of the quagga is that given by G. Edwards" in 1758: "For size and shape it is much like the last described (i.e. the Mountain Zebra). To speak of its general colour (exclusive of its stripes, which are all black), the head, neck, upper part of the body, and thighs, are of a brightbay colour: its belly, legs, and the end of the tail are white: on the joints of the legs it has such corns as we see in horses: the hoofs are blackish: the head is striped a little different from the last described (Mountain Zebra): the mane is black and white: the ears are of a bay colour: it is a little white in the forehead: it hath several broad stripes round the neck, which become narrow on its under side: it hath a black list along the ridge of the back, and part of the tail, and another along the middle of the belly; the stripes on the body proceed from the list on the back, and some of them end in forks on the sides of the belly, others in single points, and these have some longish spots between them. The hinder part of the body is spotted in a more confused, irregular manner. The two sides of this, as well as the last described, were marked very uniformly. The noise it made was much different from that of an ass, resembling more the confused barking of a mastiff $\operatorname{dog}^{2}$."

1 Gleanings of Natural History (London, 1758), p. 29, Pl. 223. (Cited by Mr Pocock, Ann. Mag. Nat. Hist., 1 Nov., 1904.) My illustration is a reduced facsimile of the plate from the drawing made by G. Edwards himself "from the living animal belonging to his Royal Highness the Prince of Wales," in 1751. The legend under the plate is Zebra femina, sive Asina sylvestris Africana, the animal being considered the female of the Mountain Zebra, figured on Plate 27 of the same work and labelled Zebra mas, sive Asinus sylvestris Africanus, the latter being drawn from a stuffed skin. It was believed that the quagga was the female of the Mountain Zebra. Edwards states that he "never saw a skin brought over agreeing with this, which makes it a much greater curiosity than the male. I suppose the skins of the female are not counted so beautiful as those of the male, for which reason they are not brought to us. The female hath not till now been figured or described."

2 On the other band, Thomas Pringle, the well-known poet of South Africa, in his poem "Afar in the Desert," describes it thns:

"Afar in the desert I love to ride,

With the silent bush boy alone by my side; 
Here is the description of a quagga as given by Sir W. Cornwallis Harris, who had abundant opportunities of studying (1836-37) the quagga, the Burchell Zebra, and the Mountain Zebra in their native haunts. "The true zebra is exclusively confined to mountainous regions, from which it rarely, if ever, descends: but the extensive plains of Southern Africa abound with two distinct species of the same genus, the quagga, and

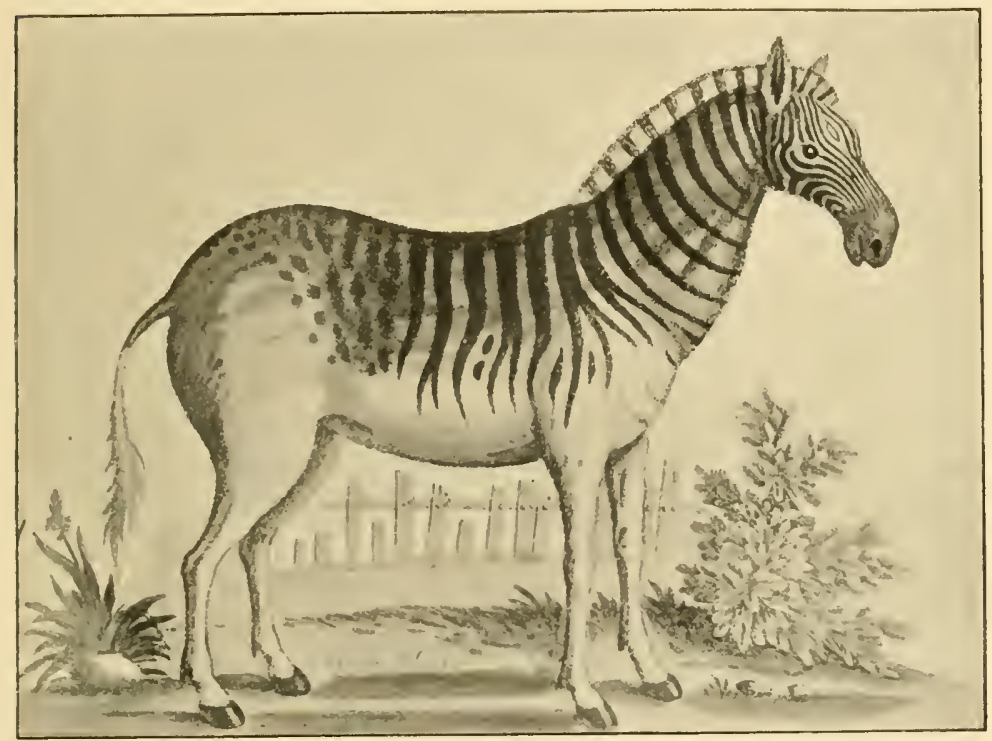

FIG. 38. The typical Quagga.

O'er the brown Karroo, where the bleating cry Of the springbok's fawn sounds plaintively, And the timorous quagga's shrill whistling neigh Is heard by the fountain at twilight grey, Where the zebra wantonly tosses his mane, With wild hoofs scouring the desolate plain."

Pringle adds in a note "The cry of the quagga (pronounced quagha, or quacha) is very different from either that of the horse or ass, and I have endeavoured to express its pecnliar character in the above line." (Pringle's lines and note are cited by Mr Tegetmeier, Horses, Asses, Zebras, p. 62.) It is quite possible that the discrepancy between the descriptions of Edwards and Pringle may be due to Pringle's using quagga in the common Boer fashion to deseribe the Burchell Zebra. 
the striped quagga, or Burchell's Zebra. These differ little from each other in point of shape or size, both having the tail and ears of the horse, whilst the zebra has those of the ass. Of a pale red colour, the quagga is faintly striped only on the head and neck, but Burchell's Zebra is adorned over every part of the body with broad black bands, which beautifully contrast with the plain yellow-brown. The gnoo and the common quagga, delighting in the same situations, not unfrequently herd together, but I have seldom seen Burchell's Zebra unaccompanied by groups of the brindled gnoo,- - an animal differing materially from its brother of the same genus, from which, though scarcely less ungainly, it is readily distinguishable at a great distance by its black mane and tail, more elevated withers and chumsier action'."

Much controversy rages round the quagga, and is likely to continue, since the scantiness of the available data and the hopelessness of obtaining much more precludes the possibility of certainty in conclusions. $\mathrm{Mr}$ Pocock has pointed out that the current descriptions of the quagga are made up by blending together animals of different types, and $\mathrm{Mr}$ Pocock and Mr Lydekker have suggested that the quaggas figured by Edwards 2 (Fig. 38), by Harris', and Hamilton Smith ${ }^{4}$, may be sub-specifically distinct from the one photographed by York and the specimens preserved in various museums; and Mr Lydekker has proposed names for two new sub-species-E. quagga greyi (the British Nusemm, Amsterdam, Tring, and Edinburgh specimen), and E. quagga lorenzi (the Viemna specimen). Mr Pocock thinks that Lord Morton's famous quagga stallion known only from a drawing (Fig. 39) belonged probably to the Quagga greyi sub-species ${ }^{5}$. Mr Lydekker is now very doubtful whether the division into races is justifiable, although it is possible that the Vienna specimen may be distinct, and "despite certain differences in regard to the width and backward extension of the

1 The W'ild Sports of Southern Africa (London, 1841), p. 48.

2 Gleanings of Natural History (London, 1758), p. 29, Pl. 223.

${ }^{3}$ Sir W. Cornwallis Harris, The Game Amimals of South Africa (1840), P1. II,

${ }^{4}$ Horses (Pl. xxiv).

5 The Elgin quagga's head, here first published (pp. 436-8, Figs. 131-3), seems to come closest to this category. 
stripes, and also the relative proportions of the white and fawn areas," he is "disposed to regard the quagga, as figured by Edwards, Harris, and Smith, as representing the same type of animal." He believes that the difference between the stuffed quaggas and the figures taken from living animals or fresh slins is entirely due to fading or inaceurate drawing. $\mathrm{Mr}$ Pocock ${ }^{1}$ not only adheres to the subdivision given above, but adds a third sub-speeies-E. quagga danielli (Fig. 40)-which, although "known only from figures and descriptions, is the best marked of the four, and the one that is perhaps the most interesting in the matter of coloration to students of the equine family." The head, neek, and upper part of the shoulders and of the hind-quarters were chestnut, the head being normally striped, the muzzle being black, the neck having sepia-brown stripes much narrower than the intervening areas, tapering and wavy inferiorly aud sometimes bifurcating, but falling short of the middle line of the throat. The mane was white with narrow stripes, about thirteen in number, from behind the ear. There were a few stripes on the withers like those on the neck, and not reaching half-way down on the shoulder. Behind the withers there were also a few similar short stripes, but the posterior half of the body and the hindquarters were neither striped nor spotted. Between the principal stripes on the neck and withers there were here and there a few narrow detached stripes; the lower half of the shoulder, of the body, and of the hind-quarters as well as the legs were white with a narrow dark rim above the hoof and a dark tuft at the back of the fetlock. The white tail was equine in charaeter, the long hairs extending to the root. In its markings the Vienna quagga comes nearest of all existing specimens or representations to the Burchell Zebra.

Mr Pocock has argued with considerable force that the Burchell Zebras and the quaggas of Cape Colony are only sub-

1 Ann. IIag. Nat. Hist., 1 Nov., 1904 (with plate), reduced facsimile of the drawing from life in Samuel Daniell's Africun Scenery (1801-8), No. 15. (The types are said to be drawn from life.) My figure is a still more reduced facsimile from the same drawing. I have been enabled to give this figure and that of the typical quagga (Fig. 38) by the kindness of Mr Pocock. 
specifically distinct, and he includes all the varieties of the Burchell group as well as the true quaggas under the species Equus quagga. On the other hand, Mr Lydekker supports the older view that the Burchell Zebra and the quagga are specifically distinct, on the grounds that (1) the pattern on the forehead of the quagga forms a shorter and more regular diamond than in the Bonte Quagga, and that in the former the centre of the diamond is a pale stripe with four or five dark stripes on either side of it, whereas in all Bonte Quaggas or Burchell's Zebras the diamond is made up of from five to nine stripes, the middle line being black with from two to four stripes on each side: and (2) that quaggas may be distinguished from Burchell's Zebras (Grant's, Crawshay's, Chapman's, and the typical Burchell's), by the presence on the skull in front of the orbit of a depression claimed to be the remains of a pit which in the case of more archaic forms lodged a facial gland.

Mr Pocock replies by showing that Mr Lydekker's first proposition "is not in all cases true either of the 'quaggas' or the 'Burchell's Zebras'," and against Mr Lydekker's second objection he urges that the depression noted in two quagga skulls "belongs to the category of characters likely to appear sporadically as atavisms," and he maintains that "such characters are of doubtful value as a basis for the formation of natural groups"; he points out that $\mathrm{Mr}$ Lydekker has not cited a single skull of a true Burchell Zebra, and shows that "although the skulls of the female Grant's Zebras [in the British Museum] have practically no trace of the depression, it is very perceptible both to eye and touch in the skull of the stallion." These questions therefore still remain sub judice, but it is manifest that whether the Burchell's Zebras and the quaggas of Cape Colony were specifically or sub-specifically distinct, the relationship between them was extremely close.

The testimony of most competent observers is unanimous in stating that the quagga was the best adapted for domestication of the striped Equidae, as is proved by the fact that the colonists not unfrequently kept tame quaggas to run with their herds of horses, since the watchfulness of the former was a 
powerful means of protecting its civilized congeners from the attacks of lions. Its extinction therefore is all the more deplorable, and indeed no words ean fitly characterize the stupidity of the Dutch and English colonists, who, though dependent for locomotion on horses and oxen, and frequently living in areas rendered deadly to domestic horses and cattle by the ravages of the tsetse-fly and horse-sickness, the latter of which wrought such terrible havoe amongst the horses of the British army in the recent campaigns against the Boers, and

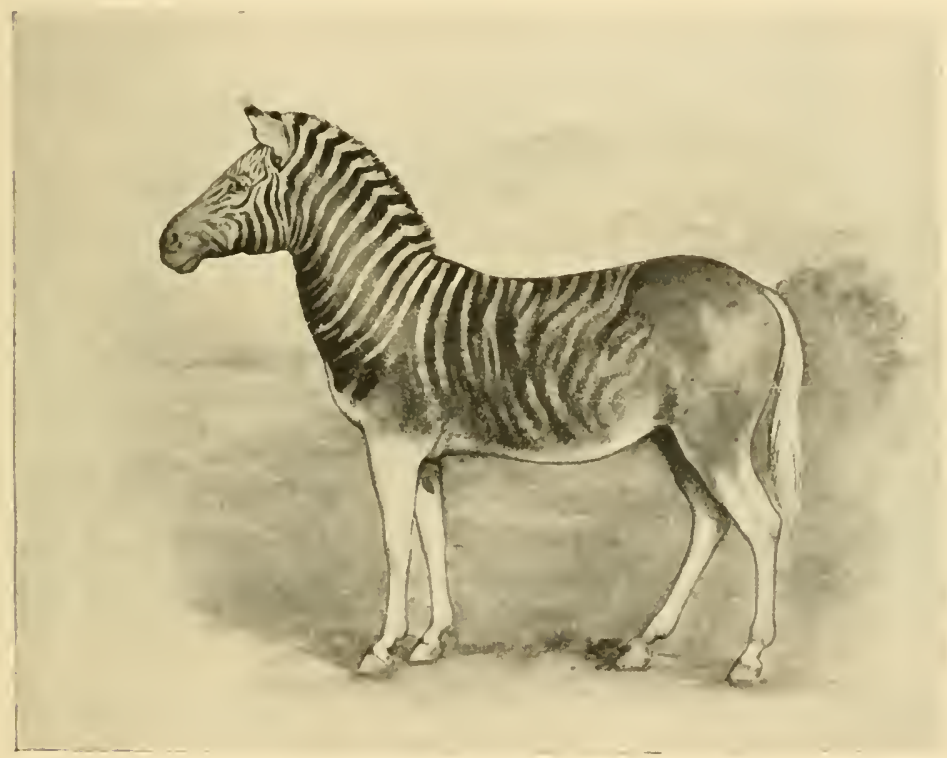

FIG. 39. Lord Morton's Quagga'.

though they had in the quagga, to all intents and purposes, a native horse, immune from the attacks of the pests so deadly to European horses, and able to thrive on the unkindly herbage of the veldt, thought only of its extermination; and though the settlers had in Burchell's Zebra at their doors an animal, which,

1 The illustration is from the block which Prof. Ewart had made from Agasse's drawing (Penycuik Exper., p. 65), and which he has most kindly lent to me. 
if not quite so docile as the quagga, nevertheless enjoyed a similar immunity from the native horse-pests, it was not until 1892 that any effort was made to domesticate this fine animal. At the Agricultural Show held in Pretoria in April of that year the distinguished Irishman, Capt. M. H. Hayes, "broke in a zebra, which belonged to $\mathrm{Mr}$. Ziervogel, quiet to ride after about half-an-hour's handling without having to throw him down, tie him head to tail, or to resort to any of the other heroic methods of the horse-tamer." Capt. Hayes having thus shown the ease with which the Burchell Zebra could be utilized, the Boers seem to have at once caught at the idea. Mr Harod Stephens, writing from Pretoria in the following December, stated that the coaching firm of Messrs Zeedesberg had some two months previously [October] purchased eight halfgrown zebras from a hunter named Groblaar, who "caught them in a wild state between four and five months ago [i.e. in July or August] by riding after and lassoing them." "During the last month they have been in training for harness, with the result that four of them are perfectly quiet and well-trained, and the remaining four partially trained." "They pull very well and are very willing, and never jib—a vice which is very prevalent in the horses of this country ${ }^{1}$."

The Germans in East Africa, learning wisdom from the folly of the Boers and English in South Africa, are now utilizing the Grant Zebras in Kilima Ndjaro ${ }^{2}$, and I learn from Prof. Ewart that the same wise policy is being carried out in British East Africa, where in addition zebra hybrids are bred.

The survey of the Equidae shows that the tendency to stripes is least in the northern latitudes where the genus first made its appearance in Asia, that this tendency gradually increases as we advance southwards, that it reaches its maximum in the tropical and sub-tropical regions of Africa, and that it shows a tendency to disappear in Chapman's Zebra (Fig. 36) of the Transvaal and Orange River Colony, and to a still greater

1 Tegetmeier, Horses, Asses, Zebras, p. 56.

2 The Field, 1901. I learn from Mr C. W. Hobley, Sub-commissioner in Brit. E. Africa, that the domesticated zebras both there and in German E. Africa at first suffered greatly from the ravages of an obscure form of life, but a remedy has now been found, and their utilization is proceeding successfully. 
degree in the quagga (whose geographical range seems always to have been south of the Vaal River), the stripes on the hind-quarters breaking up into spots (Fig. 38), which in turn disappear (Fig. 39), whilst by the diffusion of colour from the stripes the upper parts become a bay colour, the stripes only surviving from the head to the midlde of the back (Fig. 40). To this question I shall return (p. 437) when I shall describe and figure a new specimen of the quagga (Figs. 131-3).

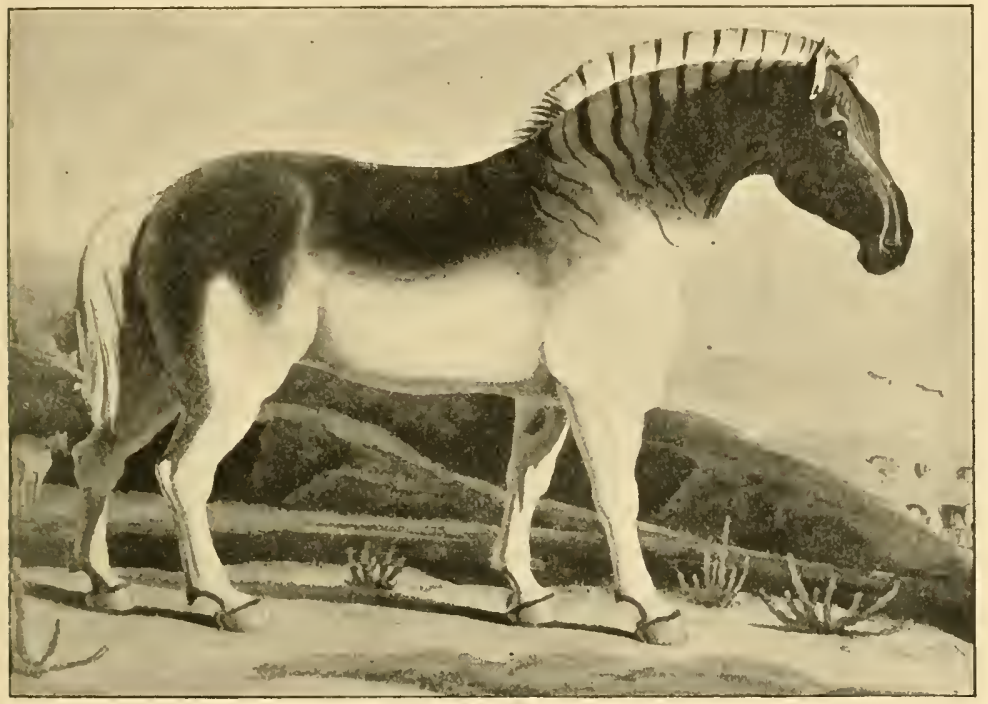

Fig. 40. The Daniell Quagga.

Now it will be admitted that the Equidae, as a whole or in part, are either gradually divesting themselves of stripes or gradually putting them on, unless it be contended that a separate act of creation has taken place in the case of each species or variety. If as a whole they are in process of getting rid of the marking of a many-striped ancestor, it is clear that the Equidae of Asia and Europe have succeeded in doing this to a far greater degree than their brethren in A frica, to which continent the zebras are confined. On the other hand, if the Equidae, either as a whole or only certain species, are gradually assuming stripes (a less likely hypothesis), it is plain that those 
of Africa have far outstripped their congeners of the northern latitudes. From these considerations it follows that the presence of manifold stripes all over the borly in any member of the genus Equus is a strong indication that it has been long domiciled in Africa, where its progenitors for protective or other purposes either retained and modified the gaudy coat of a common ancestor of all the Equidae, or else put on stripings differing in different species and varieties according to the nature of their environment. That in either alternative such modifications have taken place as I assume, on African soil, is rendered highly probable by Prof. Ewart's careful study of the markings of the zebras, from which he has been led to conclude that the Somali Zebra represents the oldest type, "that the plan of marking in the common zebra might be easily derived by a modification of the stripes in the Somali Zebra, and that by further modifications in the same direction the various patterns presented by the stripes in the Crawshayi, Chapmani, and Burchelli types of zebras might also be obtained. I do not wish it to be inferred that the Burchell Zebras have been derived from the common zebras, but simply that the ancestors of the Burchell Zebras once upon a time more or less resembled in their markings the common zebra of to-day, and that their still more remote ancestors probably resembled in their markings the Somali Zebra?." But it by no means follows that the peculiar markings of the Somali Zebra represent the original livery of the common ancestors of horses, asses and zebras, for we are not more justified in making such an assumption than zoologists five-and-thirty years ago before the discovery of the Somali Zebra would have been warranted in assuming that as the markings of Burchell's Zebra and the quagga could be derived from those of the Mountain Zebra, the latter therefore represented in its striping the livery of the common ancestor of all the Equidae. Nloreover, the Grévy Zebra from Shoa differs in the transverse stripes of the croup, and in its coloration (p. 59), from that from Somaliland. In other words, since it is highly probable that much modification has taken place in the stripings of the

1 Penycuik Experiments, p. 90. 
Equidae on African soil, it must not be assmmed that the disposition of stripes in the Gréry Zebra is original, and not as in the ease of the other species the result of modification due to environment.

Again, we have seen (p. 12) that the presence or absence of hock callosities has been taken as one of the chief means of differentiating Equus caballus from the asses and zebras, and though zoologists are at variauce regarding the primal use of these excrescences, they are agreed in holding them to be survivals from a remote ancestor. It is therefore to be carefully noted, that whilst the hock callosities are present in Prejvalsky's horse, and are especially of large size in domestic horses of heavy breed, they are not unfrequently absent in North African horses (and always absent in pure, and frequently in half-bred 'Celtic' ponies of the British Isles, the Faroes, and Iceland), they are completely wanting in all the asses and zebras, or in other words, in the wild Equidae of Africa (although the wild ass of central Asia occasionally shows a vestige, p. 37 ).

Finally, the true Prejvalsky horse and true tarpan have their fetlocks and lower portion of the leg always black, whereas the asses and zebras have their legs either white or covered with dark and white stripes. It therefore follows that any one of the Equidae which shows stripings all over its body and face, white and black bands on the lower parts of the legs, and does not possess hock callosities has a very strong prima fucie claim to be considered African in origin. 


\section{CHAP'TER III.}

\section{THE HORSES OF PREHISTORIC AND HISTORIC TIMES.}

They buried the dark chief-they freed Beside the grave his battle steed; And swift an arrow cleaved its way To his stern heart! One piercing neigh Arose,-and on the dead man's plain The rider grasps his steed again.

LONGFELLW, The Minnisink.

LET us now return to Equus caballus. There is evidence that in the later Palaeolithic time two varieties at least existed in western Europe. Owen held that the ossiferous caves and post-Pliocene deposits of Europe indicate two species, of which one (Equus caballus) was as large as a middle-sized horse of the present day, whilst the other (E. plicidens) was about the size of a large donkey, but differing from the first-mentioned as well as from the modern horse in the more complex foliation of the enamel on its molar teeth, and he held that the fossil horse had a larger head than the domesticated race. On the other hand, Cuvier and others maintained that no difference can be detected between the fossil horses of the Quaternary times and Equus caballus save such as can be explained by the difference in size of the animals compared. We have seen that the Pleistocene beds of Essex yield bones and teeth of a large-headed, heavilybuilt horse, which probably sometimes measured fully 14 hands, whilst from the 'Elephant bed' at Brighton portions of a slender-limbed horse have been obtained. It is not improbable that at the same period horses of a diminutive size inhabited 
Ireland, for not long since a lower jaw was found ${ }^{1}$ in the marl below the peat near Athlone, co. Galway, which is but twelve and a quarter inches long and four inches at the widest part, and must therefore have belonged to an extremely small race. But as the jaw may have only sunk from the peat into the upper portion of the marl, it is not impossible that the bone may belong to a more recent period.

During the Quatemary period wild horses were abundant in Europe and formed an important part of the food supply of Palaeolithic man and various wild mimals such as the hyaena. Their remains have been found in the Kirkdale Cave, Yorkshire, and Kent's Careru, near Torquay, which in addition to many bones of horses, hyaenas, and other animals contains mueh evidence of human habitation. These carly men have left us at least one picture of the horse, which they hunted and ate. In one of the caves of the Creswell Crags, on the borders of Derbyshire and Nottingham, was found a small fragment of rib with its polished surface ornamented with the incised figure of a horse ${ }^{2}$; the head with its eyes, mouth, and nostrils, is admirably drawn, and a series of fine oblique lines, stopping at the bend of the back, are supposed to prove that the animal was hog-maned, but these lines may have simply been the primitive artist's way of indicating the mane, whether hogged or Howing.

Prof. Boyd Dawkins has shown in his tables of the Pleistocene animals living to the north of the Alps and the Pyrenees that the remains of the horse were found in thirty-one out of the forty stations tabulated; and Dr IImro has pointed out that the horse was one of the most common animals among the eave-fauna of Belgium, both during the mammoth and reindeer periods. From this it is clear that the horse must have been very common in Belgium. No less common was the horse in France. The station of Solutré, near Ilâcon (Siône-et-Loire), partially exeavated by MM. Ferry, Arcelin, Ducrost, Lortet, and others, has revealed a great abundance of implements of flint

I I am indebted to my friend Dr Scharff, of the National Museum, Dublin, for this information.

2 Boyd Dawkins, Early Man in Britain, p. 184, Fig. 53. 
and reindeer horn, and quantities of broken bones, chiefly those of the horse and the reindeer, which had plainly been used as food.

On the sonth side of the settlement piled-up bones of horses formed a sort of protecting wall. The estimate of the number of animals represented by these relics varies from two thousand to one hundred thousand, but it is very difficult to make a just calculation, for the bones were so broken in extracting the marrow, that it was with difficulty a complete skeleton could be constructed for the museum at Lyons.

According to M. Toussaint the horse of Solutré was of low stature, the average height being from $1.36 \mathrm{~m}$. ( 13.2 hands) to $1.38 \mathrm{~m}$. (13:3 hands). The lower jaws were highly developed,

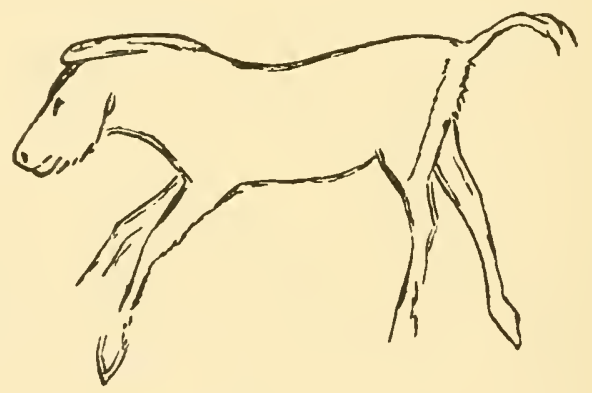

FIG. 41. A Prehistoric Horse.

and the teeth were so large that they might readily be taken as belonging to animals of a much greater size. The large size of the head ${ }^{1}$ in proportion to the rest of the body harmonizes remarkably with the engraved figures of horses found in some of the Dordogne caves. "The bones of the limbs were strong, with large articulations, prominent muscular attachments, and broad hoofs." It is noteworthy that in the leg the metacarpal and metatarsal vestigial bones were not united to the main bone, as is usually the case with modern

${ }^{1}$ It is worth noting that the head and teeth in one of the varieties of Prejvalsky's horse are relatively very large (J. C. E.).

2 Iunro, Arch. Jour. Vol. LIx. pp. 114 sqq. 
horses, a fact which supplies an intermediate link between the latter and the Hipparion.

The investigations of MM. Lartet and Christy in the cares of the Vezère (Dordogne) have revealed bones of the Equus caballus in great abundance, for in the list of animals whose bones were found in greatest numbers in the caves of $\mathrm{La}$ Madelaine, Langerie, and Les Eyzies, Equus cuballus heads the list, followed by Sus scrofu, Cervus tarandus, C. elaphus, C. cupreolus, the Irish elk, and various others'. Of seven boneyielding caves of Vezère all save one supplied remains of the

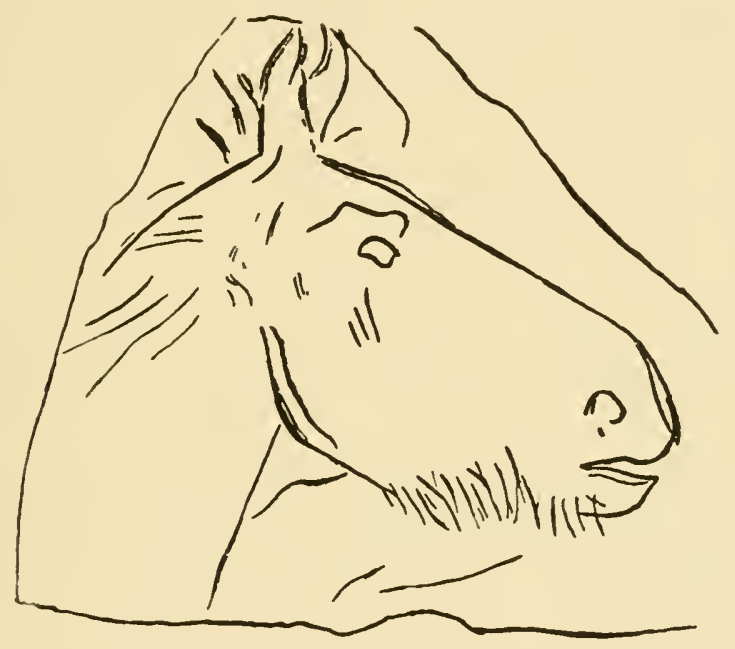

FIG. 42. Head of Prehistoric Horse: Gourdan.

horse $^{2}$. At the famous rock-shelter of Cro-Magnon the bones of the horse were more numerous than those of any other animal, and M. Lartet ${ }^{3}$ rightly inferred that it must have formed the chief food of its primitive inhabitants. It is clear then that during the Reindeer period the horse was found in considerable numbers in sonth-western France.

${ }^{1}$ Lartet and Christy, Reliquiae Aquitunicae, p. 172; ef. Munro, op. cit., p. 116.

" Lartet and Christy, op. cit., p. 181.

3 Lartet, op. cit., p. 94. 
But the Dordogne caves have furnished us with another class of evidence of the highest importance in the shape of a large series of representations of animals engraved on fragments of bone, ivory, or stone, or occasionally carved out of bone or reindeer horn ${ }^{\mathrm{I}}$. It is needless to observe that the animals pourtrayed are those with which the artists were themselves familiar. Similar drawings and carvings have since been discovered in a number of other caves in France and Switzerland, "the whole now culminating in a collection of over 300 specimens illustrating the social life of the period, more especially animals and hunting scenes, the former being pourtrayed with singular fidelity and artistic skill"." In the series of portraits the horse figures prominently, especially on the storied reindeer horns and bones from La Madelaine, "all of which unmistakably represent big-headed (cf. Figs. 41-2) animals, with the exception of one or two which show a small head, sharp muzzle, and long ears ${ }^{3}$."

Mr Conrad Merk discovered in the Kesslerloch cave near Schaffhausen a piece of reindeer horn engraved with the outline of a horse, apparently small-headed: "the woll-formed headrather long, with small ears-the upright mane, the graceful, well-formed body, the elegant and light-formed feet, and especially the remarkably thin tail, reaching nearly to the ground, represent without doubt a young, well-bred animal." "This Kesslerloch horse," remarks Dr Munro, "must have been a very different animal from the clumsy, rough pony, with its shaggy tail and big ugly-looking head, figured on bones and horns from La Madelaine."

These indications of the possible existence of at least two kinds of horses during the Reindeer period have lately gained further support by the discovery of engravings of a large size and of coloured paintings of various animals, on the walls of some newly explored caves in southern France, especially those of Combarelles and Font-de-Gaune, Commune of Tayac, Dordogne, and not far from the well-known station of Les Eyzies.

1 Reliquiae Aquitanicae, p. 16, B. Pl. II. ; Munro, op. cit., p. 117.

2 Munro, loc. cit., Pl, I, Fig. 1.

3 Rel. Aquit., B. Pll. II, vI-viI, Ix-x, $\mathrm{xIx}-\mathrm{xx}, \mathrm{xxIV}$, and $\mathrm{xxx}-\mathrm{xxxI}$. 
As carly as 1875 slight traces of this style of decoration had come to light in the cave of Altamira, near Santander, in N.E. Spain. Later on better examples were revealed in the caves of Chabot (Gard), La Monthe (Dordogne), and Pair-non-Pair (Gironde), in all of which figures of equine animals occurred along with those of other animals regarded as characteristic of the Palaeolithic period.

The cave of La Mouthe, explored with signal success by M. E. Rivière, extends for about 260 metres, and on the walls of its inner recess are drawings clearly representing the bison, reindecr, goat, mammoth, and two Equidae. These horses were cut on a panel $128 \mathrm{~m}$. from the entrance. One represents an animal with a small head, slender neck, and well-formed forequarters, "but the posterior part is heavy and altogether out of proportion," while the other had a stout neck, a long head directed almost vertically and a hairy chin. "Whatever may have been the defects of the artists, the originals of these two drawings must have been very different animals." Yet one cannot help wondering whether it may not be that it is the fore-part and not the hind-quarters of the first animal which is out of proportion.

The cave had been occupied by man both in the Palaeolithic and Neolithic periods, the two strata being separated by a layer of stalagmite of varying thickness. The Neolithic débris contained bones of horse, stag, a small-sized ox and other animals.

But two caves surpassing in importance those hitherto explored were discovered by MM. Capitan and Breuil in 1901, at Combarelles and Font-de-Gaune. It is noteworthy that whilst the former is adorned with engravings cut more or less deeply by Palaeolithic man, the other is decorated with paintings in ochre and black, or sometimes only in one colour, forming real silhonettes of the animals thus depicted. The painted figures at Font-de-Gaune number 77 , comprising fortynine aurochs, eleven indeterminate animals, four reindeer, one stag, two mammoths, three antelopes, two horses, three geometrical and two scalariform signs.

The cave at Combarelles extends for $234 \mathrm{~m}$. The engravings begin about $118 \mathrm{~m}$. from the entrance, and are continued on 
both sides with only slight intervals for $100 \mathrm{~m}$. Many of the designs are covered with a film of stalagmite. Sometimes the incised lines are emphasised by thin bands of black paint. The figures represent animals in various attitudes in a style and manner of execution resembling those of La Madelaine and other later Palaeolithic settlements. 109 animals have been distinctly made out, whilst 19 have not been identified, and a human face is marked as doubtful. There are 23 whole drawings, and many heads of Equidae. In spite of their evident difficulty in identifying a considerable number of the figures, the explorers hold that these are accurate documents of great palaeontological value. They consider that there are at least two species of horses distinguishable among the forty figures already deciphered.

"On peut nettement distinguer au moins deux espèces très différentes. Les uns sont de gros chevaux, à crinière ordinairement droite, à queue très fournie, à grosse tête et nez busqué avec lèvres très fortes. D'autres sont beaucoup plus élancés, plus fins; la tête est petite, la crinière, également droite et courte, arrive jusqu'à sur la tête qui est notablement plus petite, le nez paraît bien plus droit, que chez les précédents, enfin la queue est implantée tantôt plus bas, tantôt au contraire plus haut, comme celle des bovides; elle est glabre, souvent terminée par un touffe de poils."

If we can rely on the faithfulness of the artists, we have here evidence for the existence in Europe in Palaeolithic times of a small, light-built horse, as well as a stout-built animal with a bushy tail and a large head. But, as the artists of Combarelles delineated both the breeds alike with a short, erect mane, and as the historical evidence shows that the large-headed horses of the later period which may be held to represent the large-heacled animals of Solutré, had very thick, long manes, we must hesitate before accepting as "precise documents for palaeontology" the cave engravings. It is probable that the Combarelles artists simply represented horses' manes in a conventional fashion by a number of straight lines.

Moreover, it must be borne carefully in mind, that, whilst there is abundant evidence for the large-headed animal in the 
remains of Solutré and elsewhere, we have few osseous data for the existence of the supposed small-headed type.

Not only have the recent discoveries in caves of the late Palaeolithic period led to the suggestion that at least two distinct species of Equidae were known to their occupantsa thing in itself not at all improbable-but to the further theory that man had already subdued the horse to his will. The evidence furnished by the bone-caves of Belgium and Britain led to the conclusion that man hunted the horse like any other animal for purposes of food. The general scarcity of vertebrae of the horse in cave deposits seems to indicate that the hunter took away the more detachable portions to his home, but left the carcase on the field, a method followed in the case of all big game'. Both man and the hyaena alike broke the bones of the horse which formed their prey, but their methods differed; the former smashed them with hammerstones, the latter erushed them in his teeth. Further, in the bones broken by men the spongy and cartilaginous portions were not removed, "thus presenting a marked contrast to those gnawed by hyaenas or by the dogs of the 'kitchen-midden' people of Denmark." M. Dupont ${ }^{2}$ inferred from the frequency with which certain caudal vertebrae of the horse were met with in the caves of Belgium that the hunters were in the habit of entting off and bringing home the tails of their horses as trophies, like the brush of the fox in modern days. Later on we shall see some reason for conjecturing that these tails may have been prized as ornaments.

The masses of bones of the horse and the reindeer found at Solutré ${ }^{3}$, already mentioned, led us to infer that the horse was habitually hunted and eaten for food. But M. Toussaint maintained that the horse-bones were those of domestic animals, basing his opinion on the fact that the bones showed few old or young animals, being usually those of horses from five to seven years old. But M. Piètrement t retorted the argument, show-

1 Yrunro, op. cit., pp. 123-4.

2 Dupont, Les Temps Préhistoriques en Belgique, p. 173 (cited by Munro).

${ }^{3}$ Piètrement, Les Cheraux dans les Tempss Préhistoriques et Ilistoriques, pp. 86-96.

+ up. cit., p. 96. 
ing that the fact relied on by MI. Toussaint was a cogent proof that the bones were those of wild animals, because in a troop of wild horses it is always the most vigorous adults which occupy the post of danger in the rear, and are therefore more liable to be killed. He argued that if these animals were simply kept to be slaughtered it was not necessary to keep them for seven years, for they would have been full grown and better fitted when three or four years old: "Les chevaux de Solutré ne pouvaient être que des chevaux sauvages, ou bien des animaux utilisés comme moteurs pendant quelques années avant d'être sacrifiés pour l'alimentation; on ne peut hésiter à ądmettre que c'étaient des chevaux sauvages qui ont été chassés, tués et mangés par l'homme quaternaire de la localité."

MM. Capitan and Brenil have given a fresh start to the domestication theory from certain characters and markings observed by them on some of the engravings of horses in the cave of Combarelles. Let them speak for themselves ${ }^{1}$ :

"Plusieurs des équidés figurés présentent des caractères de domestication très nets. Le grand équidé reproduit (Fig. 4), porte sur le dos, comme on le voit facilement, une large couverture avec ornaments en forme de dents. Un autre porte également une couverture très nettement représentée. Il en est autour du museau desquels il semble qu'il existe une corde; enfin un des trois petits chevaux du groupe ci-dessus (Fig. 5) indiqué porte-ainsi qu'on peut le voir sur la figure, qui reproduit la tête de cet animal au tiers de grandeur naturelle (Fig. 3) - un chevêtre indiqué avec une précision telle qu'il n'y a pas d'erreur possible. Enfin deux animaux portent sur le milieu du corps des signes nettement tracés; sur le flanc.d'un cheval il existe un signe en losange, et un antre animal, qui semble avoir des cornes, porte sur le flanc trois signes qui ont un aspect alphabétiforme (Fig. 5).

"Il est impossible de ne pas rapprocher cette particularité des figurations grecques archaïques de chevaux portant un nom gravé sur les fesses.

"Il parait bien vraisemblable qu'il s'agit sur nos bêtes de

1 Revue de l'École a'Anthropologie, 1902, p. 39 ; Munro, op. cit., pp. 126-7. 
marques de propriété ou de marques de tribus comme les Wasms en usage chez tous les nomades de Sud algérien."

Dr Munro has shown a wise hesitancy in accepting this conclusion. He rightly points out that if the horse had been employed for riding, "we would undoubtedly ere now have had a representation of the fact, either anong the varied assortment of objects in the Palaeolithic art gallery, or among the scenes of animal life so fortuitously brought to light in the caves of Combarelles, La Mouthe, and others." He would explain the supposed bridle and covering on the back of the horse by the hypothesis that the hunter after trapping the wild horse brought him home, being able to cow him completely in a short time, and that the supposed horse-cover "may be nothing more than the skin coat of the hunter thrown over the back of the animal when led home by means of a haiter made of thongs or withies, to be there slaughtered."

But it must be pointed out, that even if the markings on the animals are not accidental, they may very well be purely conventional, such as those to be found on numerous objects in the early Iron age of central Europe and in the geometrical period of Greece. We have many representations of horses, dogs, and cows ${ }^{1}$, decorated with circles (Fig. 4:3), and other designs, which the artist had never seen on any animal. So Dutch potters commonly decorated their Delft cows and horses by scattering little flowers all over

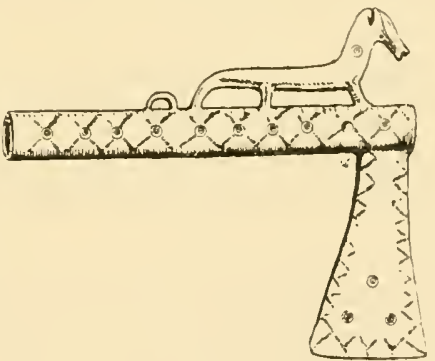

Fıg. 43. Miniature Axe; Hallstatt. them. As M. S. Reinach holds", the cave pictures may be due to the desire of the primeval hunters to employ magic in capturing their prey.

It is by no means clear that man had tamed the steed in Neolithic times, and from the evidence derived from the British barrows it would appear that there is no anthentic case of such

1 So on a late Mycenean vase from Enkomi in Cyprus a cow is pourtrayed, the body of which is covered with conventional patterns, which plainly were never seen in nature.

2 L'Anthropologie, 1903, pp. 257-66. 
remains being found in any long barrows. "The bones of the horse," says Prof. Rolleston", "are both durable and conspicuous, and it is difficult to think that if the Neolithic man had used the animal either for purposes of food or for those of carriage, as his predecessors and successors did, we should not have come upon abundant and unambiguous evidence of such nse."

Lord Avebury has shown that of the 28 cases given by Mr Bateman in which the bones and teeth of horses occurred, "nine were in tumuli which had been previously opened, and in one case 110 body was found. Of the remaining 18 five were tumuli containing iron, and seven were accompanied with bronze. In one more case, that of the 'Liffs,' it is doubtful whether the barrow had not been disturbed. Of the remaining six tumuli, two contained beautiful drinking vessels of a very well-marked type, certainly in use during the Bronze age, if not peculiar to it; and in both these instances, as well as in a third, the interment was accompanied by burnt human bones, suggestive of dreadful rites." Out of 297 interments only 63 contained metal, or about 21 per cent., while out of the 18 barrows with horses' remains, twelve, or about 66 per cent., certainly belonged to the age of metals.

Later on I shall offer an argument to show that the use of the horse by man in the British Isles cannot be placed before the end of the Bronze or the beginning of the Iron age. This would be completely in accord with the view commonly held that the primeval horses of Britain whose bones are found in the caves became extinct, and that the horse was reintroduced from the Continent at no long time before the dawn of history.

Passing to the Continent we find that there is but scant evidence of the horse in Neolithic times in the Swiss Lakedwellings, for though Rutimeyer ${ }^{2}$ held that the horse had been domesticated by the Swiss Lake-dwellers in the Neolithic period, he himself contrasts the extreme paucity of the remains of that animal in the oldest settlements such as Wangen, Moosseedorf, Robenhausen, and Wauwyl, as compared with their abundance in the Bronze age stations. It is generally

1 Greenwell, British Barrous, p. 736.

- Die Fanna der Pfahlbauten in der Schweiz (1861), p. 122. 
held that the domestic horse was employed by the Lakedwellers from the Bronze age, and beyond doubt bronze bits, bronze trappings, and even a bronze wheel and other chariotfittings have been discovered. Thus a bronze bit completely preserved was found at Moeringen, and a perfect specimen of another made of two tines of stag-horn with a transverse mouth-piece of bone was found at Corcelettes, while many fragments of both kinds, especially side-pieces made of horn, have been obtained from various sites ${ }^{1}$. But eren Mfocringen and Auvernier, where these bits make their appearance, belong to the latest Bronze period, and remains undoubtedly of the Iron age, such as a La Tène sword, have been found at least at the former. It must be carefully borne in mind that long after iron had come into use for cutting weapons, bronze, horn, bone and stone continued to be used, bronze being especially adapted for horse-bits and horse-trappings and for fittings for chariots. The Swiss horse was small, as is proved by the bits made of bronze and stag-horn, which have been found at Moeringen and Auvernier. These bits are only three-and-a-half inches wide.

Various Swiss sites have yielded great numbers of antiquities of the later Iron age (commonly called the La Tène period, from the fact that this peculiar class of antiquities first became known at the Pile-settlement of La Tène on Lake Neuchatel). The weapons and ornaments are similar to those found on the battle-fields where Caesar overthrew the Helvetians. From the osseous remains of horses found on sites of the La T'ene period it is clear that the horses of the Helvetians were of slender build. According to Dr Marek ${ }^{2}$ the La Tène horse agrees in its fundamental characters, size excepted, with the Oriental races of horses, whose typical representative is the 'Arab.' This Helveto-Gallic horse, as he terms it, was 135$141 \mathrm{~cm} .(13 \cdot 2-14$ hands) at the withers, and it thus occupies an intermediate position between Arabs and ponies. But it is important to bear in mind that the finest type of Arab is

1 Munro, Lake-duellings of Europe, pp. 28, 524, etc. Fig. 191 shows various horse-bits.

2 J. Marek, "Das helretisch-gallische Pferd" (Abhandl. Schweiz. palacontol. Gesellschaft, Vol. xxv. 1898); Scharff, R. I. A. Proc. Vol, xxv. Sec. C. 
rarely over 13.2 hands. On a later page (321) these La Tène horses will be identified with a breed well known in northwestern Italy and south-western France in the first century B.C., whose descendants still survive in Provence, and it will be shown that this race is Libyan in origin.

The Sigynnae, who were the only tribe of all those to the north of the Danube whose name is known to Herodotus ${ }^{1}$, "had horses with shaggy hair, five fingers long, all over their bodies, and which were small and flat-nosed, and incapable of carrying men, but which when yoked under a chariot were very swift, in consequence of which the natives drove in chariots." This description of the appearance of the little horses of the Sigynnae of central Europe agrees very well with the skeletons found near Mâcon. The simous shape of the head tallies well with the ugly-shaped skull and powerful jaws of the bone deposits.

We can hardly believe that we have here horses such as those whose bits have been found in the later Lakedwellings of Switzerland. The depth of their hair forcibly recalls the description of the winter coats of the tarpan, of Prejvalsky's horse, and the Iceland ponies already cited, though it has to be borue in mind that the last-named ponies have often very small heads.

Unluckily Herodotus does not give us any information respecting the colour of these little horses, but we shall presently adduce evidence which will render it probable that they were dun-coloured.

The reason assigned by Herodotus for the practice of the Sigynnae clearly explains why most early peoples yoked the horse to a car long before they ever habitually practised riding?

It was apparently the same reason which induced the Britons of Caesar's time to continue the use of chariots, although by that date they had been given up for war by the

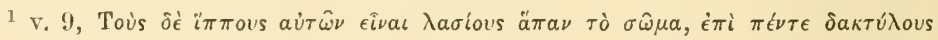

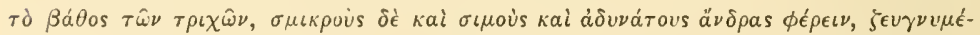

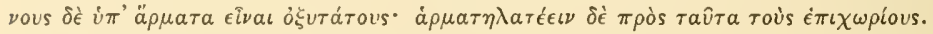

2 W. Ridgeway, "Why was the Horse driven before he was ridden?" Academy, Jan. 3rd, 1890 , p. 14. 
Celts and other inhabitants of Gaul, whose chief strength lay in their horsemen (equites). It will presently be shown that this change in the methor of using the horse on the Continent was due not solely to the development in size of the indigenous animal, but to the fact that by the middle of the second century B.C. the Gauls had procured from southern Europe horses of a size far superior to their own and better adapted for riding.

Dio Cassius, when speaking of the Caledonians and Maeatae, two chief tribes of northern Britain, says that they "went to war on chariots, as their horses were small and fleet?". Since the country which these tribes inhabited would bave been much more easily traversed by men on horseback than by wheeled vehicles, it is clear that they used chariots because their ponies, which, in part at least, may be represented by the 'Celtic' ponies of to-day, were too small to carry a full-grown man for any considerable time or distance.

The statement of Dio Cassius concerning the practice of the tribes of northern Britain is completely confirmed by the discovery of the remains of a considerable number of chariots in Torkshire barrows.

In one (Fig. 44) of the sixteen tumuli known as Danes' Graves, situated in the parish of Driffield, Mr J. R. Mortimer² and Canon Greenwell, in 1897, discovered the remains of two adult bodies (Fig. 44), the iron tires of two wheels and other pieces of iron belonging to a chariot, two iron snaffle-bits, and several rings and ornaments of bronze belonging to the horsetrappings, though not a single bone of a horse was found. The wheels had apparently been taken from the axle. The tires measure respectively $2 \mathrm{ft} .6 \frac{3}{4}$ in. and $2 \mathrm{ft}$. $5 \frac{1}{4}$ in. in diameter, both being $1 \frac{3}{5}$ in. broad and $\frac{3}{10}$ in. in thickness. The iron hoops for the naves likewise survived, being 5 in. in diameter (inside), $\frac{5}{8}$ in. wide, and nearly a quarter of an inch thick ${ }^{3}$.

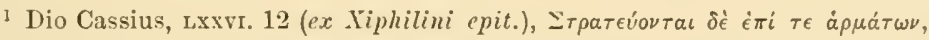

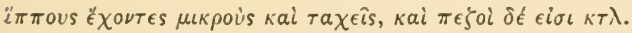

2 Ant. Report of the Yorkshire Philosophical Soc. for 1897, pp. 3-4.

3 Ibid., p. 10. The Yorkshire Philosophical Society hare most kindly lent me the block for Fig. 44 . 
D.
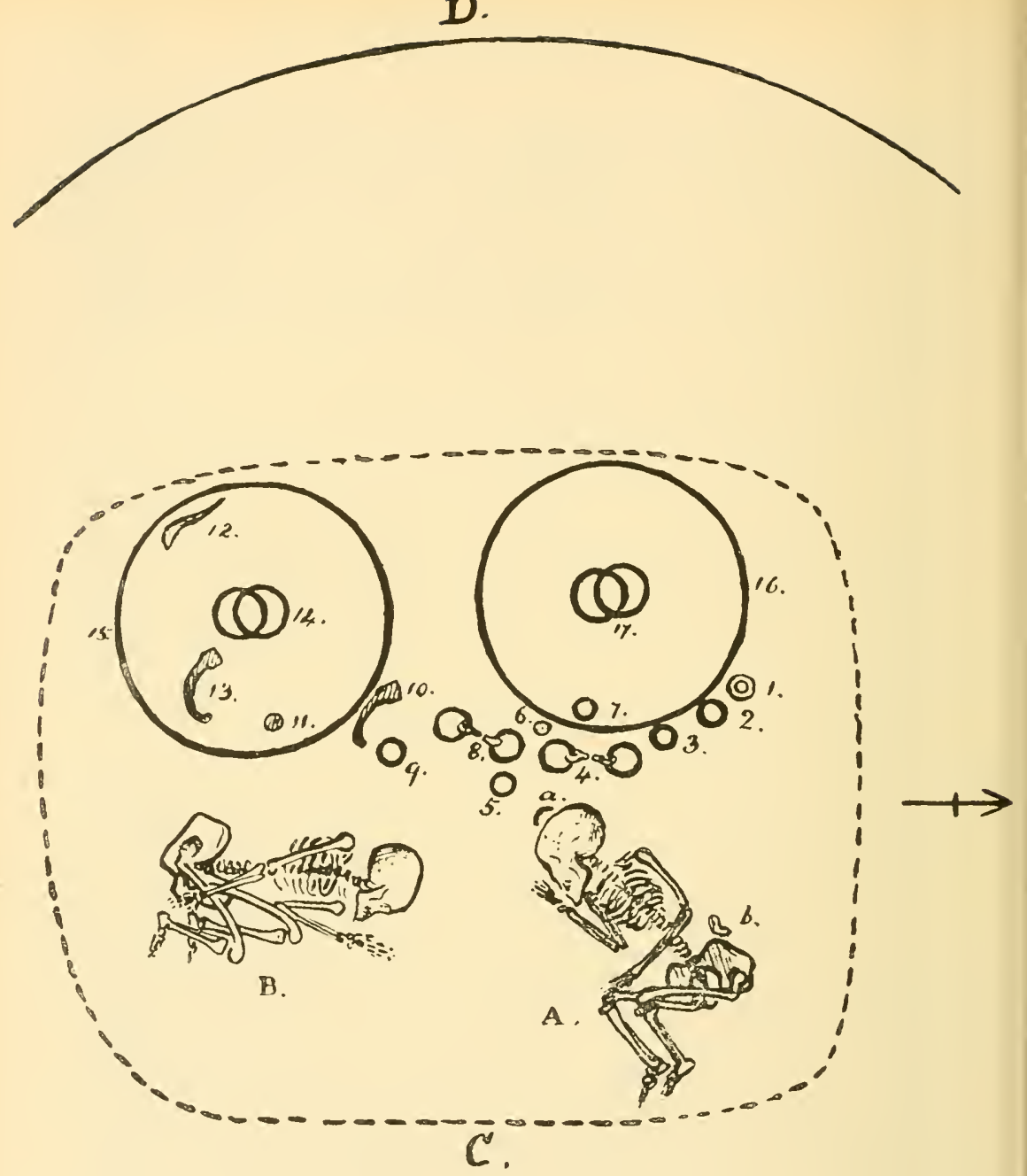

\section{D.}

FIG. 44. Remains of a Chariot found at Driftield, Yorkshire. 
In a group of over 200 small barrows elosely resembling the Danes' Graves, which once existed at Arras near Market Weighton, the remains of three chariots were found ${ }^{1}$.

The fragments of another chariot discovered in one of the barrows at llessleskew, were presented to the Museum of the Yorkshire Philosophical Soeiety (which possesses also the relies from Arras and Danes' Graves), by the Rev. E. W. Stillingfleet in $1865^{2}$.

The evidenee derived from the finds at Silchester and along the Roman wall confirms the statement of Dio Cassius respecting the small size of the British horse. There can therefore be little doubt that the cause which led the Sigynnae to drive in chariots had induced Britons to follow the same custom, even in a country beset with forests and morasses, and where it is obvious that riding on horseback, as in medieval times, would have been much more convenient than driving in chariots, had horses of sufficient size been available.

The Belgic tribes of Britain at the time of Caesar's invasion used both horsemen and chariots, for on learning of Caesar's ${ }^{3}$ intended landing, "they sent forward cavalry and eharioteers, which formed their chief arm in warfare." Caesar describes elsewhere the value of the war-chariots, and their method of handling them. "At the first onset they drove the cars in all directions, hurled their javelins, and by the din and clatter of horses and wheels commonly threw the ranks of the enemy into disorder, and making their way amongst the squadrons of the enemy's eavalry they leaped down from their chariots and fought on foot. The eharioteers then little by little withdrew out of the fight and placed their chariots in such a way that if they were hard pressed by the enemy they could readily retreat to their own side. Thus in battle they afforded the mobility of eavalry, and the steadiness of infantry.

1 Oliver, History of Beverley, p. 4 (footnote), cited by Mr Nortimer, loc. cit.

2 For information about all these finds I am indebted to my friend Canon Greenwell, and aiso to Mr Platnauer, the curator of the Musenm of the Yorkshire Philosophical Soc., York, who (through my friend and former pupil, Mr C. Gutch) most kindly supplied me with photographs of the Arras and Hessleskew remains. An elaborate monograph by Canon Greenwell on all the chariot-burials found in England will appear very shortly in Archaeologia.

${ }^{3}$ B. G. IV. 24.

R. II. 
Daily practice enabled them to pull up their horses when in full speed on a slope or steep declivity, to check or to turn them in a narrow space, to run out on the pole and stand on the yoke, and to get nimbly back again into the chariot.".

This statement, confirmed by other ancient writers ${ }^{2}$, puts it beyond donbt that it was not lack of intrepidity or agility that induced the Britons to drive their horses instead of mounting on their backs, and also shows that their cars were not scythed.

The evidence just offered for the diminutive size of the Irish horse combined with the fact that in the oldest Irish epics the horse is not ridden, for Cuchulainn and Queen Medhbh are always represented as fighting in chariots, renders it highly
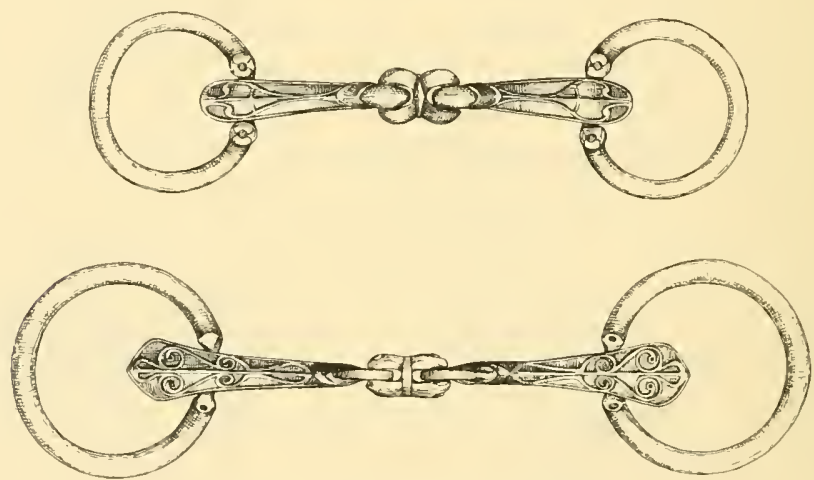

Fig. 45. Bronze Bits: Ireland ${ }^{3}$.

probable that here also the use of the chariot in a country singularly difficult for vehicles was due at least in part to the smallness of the steeds.

It is not unlikely, that as the domesticated horse was introduced into Britain, so also was he brought into Ireland at no very remote date, for all the bits and trappings hitherto known belong to the Iron age in that country, where as I have elsewhere argued iron found its way at a comparatively late

1 B. G. Iv. 33.

2 Juvenal, Iv. 126.

3 The larger and more richly decorated bit is one of a pair found along with a pair of the well-known spur-shaped objects, on the hard turf bottom of a bog at Atymon, co. Mayo, in 1891. 
epoch. The bronze bits here shown (Fig. 45), each being one of pairs in the IIuseum of the Royal Irish Academy, belong beyond doubt to the late Celtic period, as is demonstrated by the beautiful ormament on one of the bits and its fellow, as well as on the pair of mysterious pieces of trapping, found at the same time, one of which is figmred on a later page.

It has been urged that it was easier to learn to drive than to ride. But is this true? Under modern conditions it may be so, when a person's first essay in driving is made on some old and steady animal tightly embraced in harness and shafts. But when primitive man first subdued the little wild horse, was it easier for him to learn to drive two of these animals, when simply attached by means of a yoke and pole, with free play for their heels, their first instinct being to kick to pieces the rattling, creaking wheels and axle, which formed the primitive car, or to learn to sit firmly on his back ${ }^{1}$ ? The South American Indians found no difficulty in acquiring the latter art when they obtained the hor'se from the Spaniards.

As the Britons were famous for their intrepidity in running out and standing on the chariot pole, and as we shall presently see, Odysseus and Diomedes had no hesitation in getting on the backs of Thracian steeds, it is clear that it was not from fear that either Achean or Briton drove habitually in a chariot instead of riding on horseback.

But though mounted men formed the chief weapon of the Gauls in their death-struggle against the Romans, it is clear from both literary and monumental evidence that at no long time previously had the chariot been in universal use among all the Celts of Ganl and north Italy. Thus Diodorus makes it plain that down to a late date they, like the Homeric Acheans, had regularly gone to war in two-horse chariots, containing each a warrior and a charioteer: the former first hurled spears called saumia at the foe, and then dismounted to finish the combat at close quarters with the sword, the latter being donbtless of that type known as La T'ène (Fig. 111). The opening of many tumuli in Champagne has brought to light

1 W. Ridgeway, Acalemy, 1890, p. 91.

2 v. 29.

7-2 
the remains of Gaulish chieftains, who were interred, seated on their chariots, the horses and trappings being buried along with them. These interments, as is proved by the swords and fibulae of the La Tène ${ }^{1}$ type, cannot be earlier than 400 B.c. and are probably to be set at least a century or two later ${ }^{2}$.

This evidence is completely corroborated by that of Livy ${ }^{3}$, who narrates that in the great battle fought at Sentinum in Etruria (292 B.c.), in the third Samnite War, when the Romans under Fabius Maximus and Decius Mus overthrew the combined Samnites and Gauls, the latter had a thousand chariots (esseda) and cars (carri), the charge of which completely routed the Roman cavalry, and would have decided the battle in favour of the allies, had not Decius Mus, following the example of his father at the battle of Vesuvius in the Latin War, dedicated himself and the enemy's host to the infernal gods, and by this act of devotion gave fresh courage to his legionaries to make a stand which led to ultimate victory.

It is therefore clear that when the Gauls entered Italy at the end of the fifth or the beginning of the fourth century B.C., they like the Sigynnae on the north side of the Danube were drivers of chariots and not yet riders of horses.

How then did it come to pass that though the Gauls of north Italy are still using chariots in 292 B.c., yet by Caesar's day the peoples of Gaul had universally discarded the warchariot and were employing cavalry alone? Fortunately sufficient evidence has survived from antiquity to enable us to trace the way in which this important change was effected. I am now going to show that the Gauls of north Italy had taken to horseback by the latter part of the third century B.c., and probably much earlier, that the Transalpine Gauls had fully adopted the same practice by the middle of the second century B.c., whilst even the Belgic tribes of the Continent had

1 Ridgeway, Eurly Age of Greece, Vol. I. p. 410.

2 Morel, La Champagne Souterraine, p. 23, Pll. r. x. etc.

3 x. 28-30, "Essedis carrisque superstans armatus hostis ingenti sonitu equorum rotarumque advenit, et insolitos eius tumultus Romanorum conterruit equos." 
discarded the chariot by Caesar's time, though their kinsfolk who had crossed into south-eastern Britain still retained it in use side by side with cavalry.

Later on it will be shown that the Celts of Noricum and the Danube had begun to ride on horseback in the early Iron age, though retaining the use of the chariot, and that by the beginning of the third century B.c. the Celtic tribes of this region had developed a highly organised cavalry system. Furthermore, it will be shown that this change from charioteering to riding went pari passu with the importation of superior horses from the Mediterranean area into the Upper Balkan and into the countries beyond the Alps.

When Hannibal arrived in north Italy (B.c. 218) he first cane into contact with the Romans in the cavalry engagement on the Ticinus (Ticino). Here his Numidian horsemen, who rode without either bridle or saddle, and his Spanish cavalry who used bridles, at once proved their superiority not only to the Gallic horsemen, whom Scipio ${ }^{1}$ had placed with his javelinthrowers in his front line, but also to the cavalry of the Romans and the best of their Italian allies which were superior to that of his Gallic auxiliaries.

In the year 170 B.c. envoys arrived in Rome from Cineibulus, a king of the Gauls. One of the king's brothers addressed the Senate and complained that C. Cassius, one of the consuls of the previous year, had ravaged the lands of the Alpine peoples, who were in alliance with Rome, and had carried thousands of persons into slavery. At the same time envoys came also from the Carni, the Istri, and Iapodes with similar complaints. As Cassius was absent in command of an ar'my in Macedonia, the Senate could not take any immediate action, but wishing to appease the anger of the injured tribes they not only sent commissioners to examine on the spot into the charges brought against Cassius, but also loaded the Gaulish envoys with presents, especially the two brothers of Cincibulus. It was decreed that they should be given two torques marle out of five pounds of gold, five vases made ont of 20 pounds of

1 Livy, xxı. 46, "Scipio iaculatores et Gallos equites in fronte locat ; Romanos sociorumque quod roboris fuit, in subsidiis." 
silver, two caparisoned horses (equi phalerati) with their grooms, cavalry armature, and cloaks, and gifts of apparel for the members of their retinue, bond as well as free. These were the voluntary gifts of the Senate. But at their own request each of the two brothers was granted the right of buying ten horses, and permission to export them out of Italy ${ }^{1}$.

Twenty stallions brought back by the Gallic chieftains to their home beyond the Alps would in a very few years produce a great effect on the quality of the little indigenous horses, even if no fresh blood was imported. But Caesar himself, in a passage shortly to be fully cited, points out that the Gauls were always importing foreign horses and paying very long prices for them. But as Caesar contrasts the excellence of the Gallic horses with those of the German, it follows that the horses imported by the Gauls must have been brought from the countries lying south of the Alps and Pyrenees.

It is very significant that on the series of silver Gaulish coins, the earliest of which may be dated from about 150 B.c., and which from the first commonly display native types and not imitations of Greek or Roman issues, a horseman is one of the most favourite types, whilst practically the chariot nowhere appears, although it forms the regular type on the reverse of the gold coins imitated from the gold stater of Philip II. of Macedon, which bore on one side the head of Apollo, on the other a two-horse chariot ${ }^{2}$.

It would appear that by Caesar's time the Belgic tribes, who occupier all the region bounded by the Marne, the Seine and the Rhine, had given up the use of chariots, although their brethren who had crossed into south-eastern Britain continued to employ them in warfare, for Caesar does not refer to the use of war-chariots by the former in any of his campaigns against them. Probably by his time they had obtained horses of a kind fully suited for cavalry, and had therefore given up the use of the chariot in war; their relations in Britain, though able to put a considerable number of mounterl men into the field,

1 Livy, xum1. 5, "Illa petentibus data, ut denorum equorum eis commercium esset, educendique ex Italia potestas fieret."

2 Ridgeway, Origin of Metallic Currency, p. 90. 
still retained the war-chariot, whilst with the original tribes of the interior, who had nowe but very small horses, the chariot apparently still reigned supreme.

The monuments of northern Italy demonstrate likewise that though the horse was in use in Italy from the beginning of the Iron age, as is proved by the discovery of brouze horsebits associated with remains of that period both at Este and Bologna, the chariot was still employed by the Umbrians, though the art of riding on horseback was becoming known. At Sesto Calende, near the point where the Ticino issues from the southern extremity of Lake Maggiore, was found a tomb of the Iron age. It contained a helmet made of plates of bronze rivetted together, two bronze greaves, a very short sword, a lance-head, arrow-heads, two horse-bits, two iron circles (the tires of the chariot-wheels), two large hollow objects, and other pieces of iron belonging to the chariot. The horse-bits are bronze mounted in iron. There was also a bronze bucket ornamented with horsemen, footmen, stags, birds, and dotted circles, and dotted lines. This bucket is one of a class well known in the region lying on both sides of the head of the Adratic, and may be assigned to the sixth or seventh century B.c.; from its evidence we may infer that the peoples of those regions had learned to ride the horse at a period much earlier than the tribes beyond the Alps, a conchusion in complete harmony with the evidence of Herodotus respecting the Sigynnae. To the question of the development of riding in Italy we shall presently return.

The evidenee here stated makes it elear that the Umbrian tribes who had passed down into Italy in the Bronze age and had subdued or driven back into the mountains the aboriginal Ligurians, employed the horse and the chariot from the early Iron age onwards, and that when the Celts, the close kinsmen of the Umbrians, crossed the Alps at a later date, they too came as a chariot-driving and not as a horse-riding folk. We have seen, that though by Caesar's time the Gauls were wellsupplied with cavalry, and the war-chariot was virtually extinct. yet they never abandoned its use until they had obtained a superior breed of horses from the southern side of the Alps. 
The Veneti, who lived at the head of the Adriatic, and who have left their name in Venice, had a peculiarly good breed of horses at an early date, or to speak more accurately one family among them owned this valuable possession. These horses were branded with a representation of a wolf. "They were remarkable," says Strabo ${ }^{1}$, "more for speed than for beauty." According to the story the breed had its origin thus: A man notorious for the readiness with which he became surety for other's happened to fall in with some hunters who had a wolf in their nets. They asked him in jest if he would go bail for the wolf on condition that he would become responsible for all the damage the beast had done. He agreed, and the wolf being set free at once went and drove a herd of unbranded horses to the steading of his benefactor; he accepted the gift and branded them with a representation of a wolf. His descendants kept both breed and brand, and in order to retain the pure strain in their own hands made it a rule never to part with a mare. The statement that these horses were more remarkable for speed than for beauty would of itself suggest that they were only an improved breed of the little horses of central Europe. This is actually confirmed by ancieut testimony, for Aelian ${ }^{2}$ when describing under the name of Lycospades the horses called Lycophori by Strabo, speaks of them as in appearance thickset and short, and also with flat noses.

Dionysius, the despot of Syracuse (B.C. 405-367), got some of the Venetian breed for his stud, in consequence of which Venetian colts became known in Greece and the breed long enjoyed a high repute ${ }^{3}$. But by Strabo's time it had died out and the Veneti had given up altogether the breeding of horses ${ }^{4}$. There was a shrine in their land said to be dedicated to Diomedes, in which white horses were sacrificed to the hero ${ }^{5}$.

White horses, such as those bred by the Veneti, were held in great esteem in Sicily, and it is highly probable that the famous four-horse chariot drawn by white horses in which Dionysius regularly rode was horsed by the imported Venetian

1215.

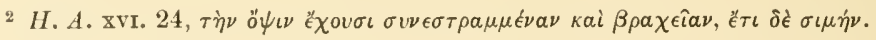

3 Strabo, 215.

4 Id. 211.

5 Id. 215. 
steeds and their progeny. This practice, which was not followed by either Hiero or his son Gelon, was revived by the foolish Hieronymus, who clad in purple and wearing a diadem used to drive forth from the palace in a quadriga drawu by white horses, like a second Dionysius ${ }^{1}$. White horses were apparently in favour with the Sicilian aristocrats at the close of the fifth century B.c. According to Diodorus Siculus ${ }^{2}$, Exaenetus of Agrigentum, on returning home after his victory with his chariot at the Olympic games in 412 B.C., was brought into the town escorted by 300 bigae drawn by white horses.

The statement that white horses were sacrificed by the Illyrian Veneti in a shrine called after Diomedes by the Greeks has every stamp of truth, for we know that it was a general practice amongst the Illyrians to sacrifice horses to a deity identified with Cronus by the Greeks. Moreover, we shall presently see that white horses were held in special esteem by the tribes of Germany, and we shall find that the sacrifice of horses was a characteristic of the religion of the Teutonic and Scandinavian peoples. The value set on white horses by the Sicilian Greeks and by various other peoples both ancient and modern was due not to any superiority in speed or other qualities, but rather to the sanctity attached to animals of a white colour, as for instance to white elephants in Further India, and to white asses in Persia.

At the dawn of history all the peoples of the Balkan peninsula like those of the Italian seem to have kept horses, but they all appear to have used the chariot and never mounted the steed. The Upper Balkan was occupied almost wholly by the closely related Illyrian and Thracian tribes on whom the fair-haired people known as Celts to the Greek writers of the classical period, were constantly pressing down. These Celts were distinguished from the indigenous tribes, not only by their xanthochrous complexion, but by the fact that whilst all the Illyrian and Thracian tribes tattooed, the Celts never followed this custom. The Thracians tattooed themselves with figures of animals such as deer, which were probably their 
tribal badges, or even totems. The wolf-brand used to mark the horses of the Veneti was probably the badge or perhaps totem of the clan which owned them.

Though the Thracians were using oxen for draught (Fig. 46) in the sixth century B.C., and though

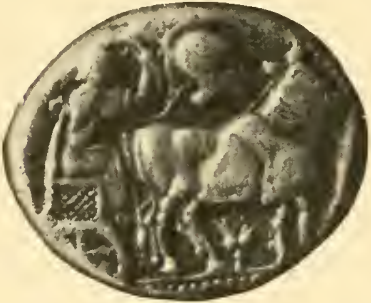

FIG. 46. Thracian coin showing Ox-cart. by that time the riding of horses must have been very familiar to them from their Greek neighbours on the south and the Scythians on the east, yet it seems certain that two-horse chariots continued to be used by certain peoples in Thrace down to late times. On the hills which surround the valley of the Kritchma, the last affluent of the Maritza (ancient Hebrus) before the latter reaches Philippopolis, there are many large tumuli, which have been partially explored during the last fifty years ${ }^{1}$. In a pit close to the most remarkable of these, called Doukhova Moghila ("The Barrow of the Spirit"), in 1851 the brothers Shkorpil found the remains of a chariot and a pair of horses. Ten years later a peasant found the remains of another chariot and pair of horses close to the same spot. MM. Gueroff and Berti commenced working at this spot, and at a point nearer to the tumulus they found a body in an upright position, the skull broken, and with an arrow-head still sticking in one of the ribs. Horses and chariots had been placed in trenches rumning east and west and liad then been covered with earth. They found various objects in iron, bronze ornaments for the bridles, iron bits with bronze attachment, and bronze statuettes for ornamenting the body of the car, consisting of horses, bears sitting up, a Poseidon, and two plaques bearing in low-relief horses' heads incrusted with silver. In 1877-8 the Russians quartered at Philippopolis excavated at the same spot and were said to have found a chariot as well as a silver disc, a silver cup, and a three-legged table. In 1888 sixteen pits were opened and according to MM. Shkorpil each grave

1 Georges Seure, "Voyage en Thrace," Bull. de Correspondance Hellénique, Vol. xxv. (1901), pp. 156 sqq., Figs. 11-23. 
contained the bones of two or four horses of a small breed (Equus caballus minor, Linn.), but it does not appear that more than four or eight chariots were discovered. In 1898 M. Dobrusky found near the old workings the fittings of iron and bronze belonging to a chariot and various human skeletons. In 1899

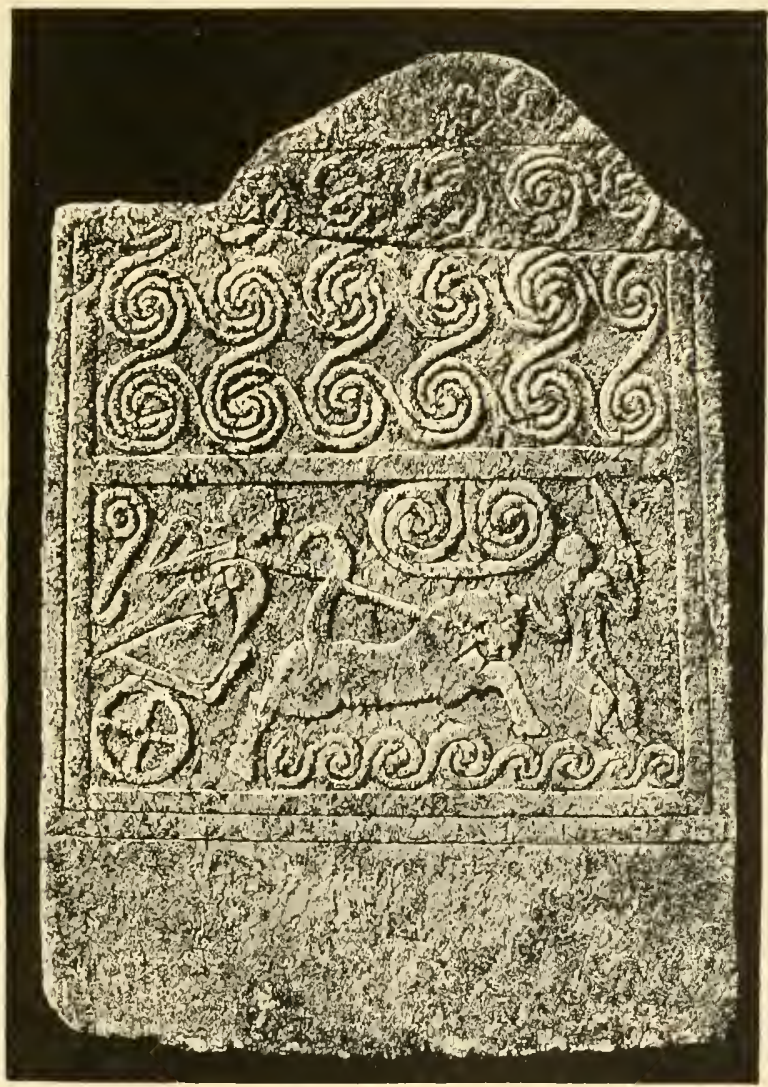

Fig. 47. Grave-stone, Mycenae.

-1900 M. Seure made further explorations and discovered a chariot, which he has described with admirable minuteness, and the remains of horses of a small size. M. Seure would refer this interment to the fourth century A.D., and would assign it to a settlement of Scythians in Thrace, on the ground that the 
Thracians did not bury slaves and horses with their chiefs, whilst the Scythians did both. But there is nothing in the ancient statements ${ }^{1}$ respecting the Thracian funeral customs to hinder us from believing that the Thracians might occasionally so honour a great chief inasmuch as concubines were regularly put to death and all kinds of victims were offered. On the other hand, as the Scythians did not use chariots in the time of Herodotus, it is most unlikely that they would have resumed their use in the centuries after Christ, when all other peoples had taken to horseback.

The monuments of the Bronze age of Greece, commonly termed the Mycenean period, furnish the earliest evidence of the use of chariots and horses in that country. These monuments are the relics of the Pelasgians, who were the indigenous people of Greece, and also the close congeners of the Illyrians and Thracians; and the grave-stones of the acropolis of Mycenae, on three of which are sculptured in low relief a man driving a two-horse chariot with four-spoked wheels (Fig. 47), may be placed in the fourteenth century B.c.

The Homeric poems fumish us with very copious evidence from at least 1000 B.c. respecting the method of employing horses, their breeding, their management, and their colours, not only for Greece itself, but also for Thrace and Asia Minor. We shall first examine the evidence for Thrace.

That the Thracians used chariots in war is shown by the episode of the slaying of Rhesus the Thracian king and twelve of his best men. Dolon, the Trojan spy, when captured by Odysseus and Diomede, said that if they desire "to steal into the throng of the Trojans, lo, there be those Thracians, new-comers, at the furthest point apart from the rest, and among them their king Rhesus, son of Eïoneus. His be the fairest horses that ever I beheld, and the greatest, whiter than snow, and for speed like the winds. And his chariot is fashioned well with gold and silver, and golden is his armour that he brought with him, marvellous, a wonder to behold 2."

1 Herod. v. 4 ; Pomponius Mela, 1I. 2, 18; Solinus, x. 28.

2 Il. x. 433 sqq. (Lang, Leaf, Myers). 
"Then the twain went forth through the arms, and the black blood, and quickly they came to the company of Thracian men. Now they were slumbering, foredone with toil, but their goodly weapons lay by them on the ground, all orderly, in three rows, and by each mau his pair of steeds. And Rhesus slept in the midst, and beside him his swift horses were bound with thongs to the topmost rim of the chariot?" "Then Diomede fell to slaying the sleeping Thracians", "but whomsoever he drew near and smote with the sword, him did Odysseus of the many counsels seize by the foot from behind and drag him out of the way, with this design in his heart, that the fair-maned horses might lightly issue forth, and not tremble in spirit, when they trod over the dead; for they were not yet used to dead men." Then when Diomede is slaying Rhesus himself, "meanwhile the hardy Odysseus loosed the whole-hoofed horses, and bound them together with thongs, and drave them ont of the press, smiting them with his bow, since he had not taken thought to lift the shining whip with his hands from the well-dight chariot. Diomede pondered, whether he should take the chariot where lay the fair-dight armour, and drag it out by the pole, or lift it upon high, and so bear it forth," but yielding to the monition of Athena he "swiftly sprang upon the steeds, and Odysseus smote them with his bow, and they sped to the swift ships of the Acheans." When they had come thither Nestor was the first to hear them, and when they had leaped down to earth the old man asked them whether they had won the horses by stealing into the press of Trojans, or had some god given them to them. "Wondrous like," said he, "are they to the rays of the sun. But never yet saw I such horses, nor deemed of such ${ }^{3}$."

Plainly then the white horses of the Veneti to which we have just referred were no new feature in the countries south of the Danube, but it is clear from the words put in the mouths of both Nestor and the Trojan Dolon that white horses were unknown both in Greece and on the Asiatic side of the Aegean.
${ }^{1}$ Il. x. $469 \mathrm{sqq}$.
2 $I l . x .480 \mathrm{sqq}$.
${ }^{3}$ Il. x. $543 \mathrm{stl} 4$. 
This inference is fully borne out by the evidence touching the colour of horses supplied by the poems themselves.

The Iliad and the Odyssey, which present us with immortal pictures of the fair-haired Acheans, who in the early Iron age became the masters of the Pelasgians of upper Greece and the Peloponnesus, represent those heroes as breeders and drivers of horses. The warrior goes to battle in a two-horse chariot with his charioteer beside him, as was the practice of the Celts of Gaul down to the century before Christ. We have also clear evidence respecting the type and colour of their horses.

The evidence of the Iliad amply suffices to show that the horses bred and used by the Acheans were almost uniformly dun-coloured, for the epithet xanthos, commonly applied to them, was used by the Greeks to describe the colour of gold and golden-coloured hair. In two passages at least this epithet is applied generically to Achean horses. Achilles when he rejects in scorn the gifts proffered by Agamemnon, exclaims, "Kine and goodly flocks are to be had for the lifting, and tripods and yellow-dun (xunthos) horses can be bought; but to bring back man's life neither harrying nor earning availeth when once it hath passed the barrier of his lips"." Again, Nestor relates how once he headed a foray into the land of the Eleans-the land in which Pelops and the Acheans had especially established themselves - " and a prey exceeding abundant did we drive together out of the plain, fifty herds of kine, and as many flocks of sheep, and as many droves of swine, and as many wide flocks of goats, and yellow-dun (xanthos) horses a hundred and fifty, all mares, and many with their foals at their feet ${ }^{2} . "$

The horses of Achilles which had been given to his father Peleus by Poseidon himself were named Xanthos (Dun) and Batios (Dapple), "swift horses that flew as swift as the winds, the horses that the harpy Podarge bare to the West Wind, as she grazed on the meadow by the stream of Oceanus." Here we have the earliest reference to the belief so common in classical times that the fleetest horse came from the West
1 Il. 1x. 407 sqq.
2 Il. xi. $680 \mathrm{sqq}$.
${ }^{3}$ Il. xvI. 149 sqq. 
and that in that region the mares became impregnated by the west wind, an aetiological myth to explain the swiftness of steeds, who rivalled in speed the strong west wind from the Atlantic. As balios is regularly applied to cleer and to the lynx ${ }^{2}$, there can be no doubt that when it is used of horses it means dappled, and accordingly Achilles' steed was a dappled-dun. These famous steeds had very heavy manes. After the slaying of Patroclus they kept "apart from the battle weeping, since first they were aware that their charioteer was fallen in the dust beneath the hands of man-slaying Hector. They stood unmoved abasing their heads unto the earth. Hot tears flowed from their eyes to the ground as they mourned in sorrow for their charioteer, and their rich manes were soiled as they drooped from beneath the yoke-cushion on both sides beneath the yoke ${ }^{2}$."

Again, when at the funeral games of Patroclus Achilles lays down prizes for the chariot-race, he says that if in some other's honour the Acheans were holling games he himself would compete: "but verily I will abide, I and my whole-hoofed horses, so glorious a charioteer have they lost, and one so kind, who on their manes full often poured smooth oil, when he had washed them in clear water. For him they stand and mourn, and their manes are trailing on the ground, and there stand they with sorrow at their hearts ${ }^{3}$."

In the horses of Achilles, with their long, heavy manes, one dun-coloured, the other dappled-dun, we can recognize the same breed of horses as those used by the Sigynnae of central Europe in the fifth century B.c., and this identification will gain further confirmation from colour and other arguments as our investigation proceeds. As the poet seems carefully to note any peculiarity of colouring in horses, such as those of Rhesus already described, and those of Aeneas to be discussed later on,

1 Eur. Hec. 90, Alc. 579.

2 Il. xvir. 437 sqq. :

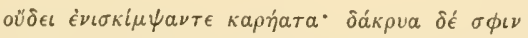

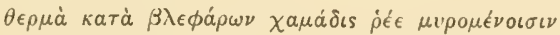

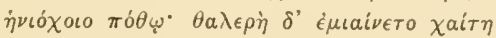

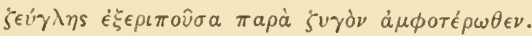

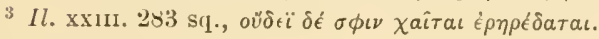


it is natural to suppose that the horses used by the different heroes in the chariot-race were of the ordinary dun colour, unless it is otherwise stated.

The evidence of Homer renders it certain that horses were bred all over Greece in the early Iron age. We have just seen that the Eleans kept mares in large numbers, and we are told that the horses of Nestor, driven by Antilochus in the chariot-race, were bred by the old chief himself at Pylus ${ }^{1}$, whilst it is probable that horses were bred in 'horse-pasturing' Argolis. Thus Aethe ${ }^{2}$ (Blazer), Agamemnon's mare, which Menelaus drove in the chariot-race along with his own horse Podargus ${ }^{3}$ (Swift-foot), had been given to the former by his vassal, Echepolus of Sicyon, as a fee in lieu of following his lord to Troy.

Not only were horses largely bred in Homeric Greece, but the ass played a familiar part in the life of the people, as is clear from a famous simile in the Iliad: "And as when an ass passing along by a cornfield, hath overmastered the boys that be with him, a lazy ass, round whose ribs full many a cudgel hath been broken, and he maketh his way into the deep corn and croppeth it, while the boys smite him with cudgels, and feeble is their force, though with might and main they drive him forth when he hath had his fill of fodder, even so did the great-hearted Trojans and their allies, called from many lands, smite great Ajax, son of Telamon, with darts on the centre of his shield and ever followed after him."."

No doubt the ass was of the Nubian species, which had been domesticated at a very early period, and, as we shall see, had been commonly used from very remote times in Egypt, from whence it probably had made its way into Greece.

As both horses and asses were thus commonly kept, it was but natural that the breeding of mules should be carried

${ }^{1}$ Il. xxi11. 303.

2 Il. XxIII. 295.

${ }^{3} \mathrm{Il}$. Xxilr. 295 (cf. Il. virr. 185, where it is the name of Hector's horse). It probably means 'swift-foot' not 'white-foot,' since it is used of the harpy Podarge (Il. xvi. 150, xix. 400).

${ }^{4}$ Il. XI. 558. 
on, although from the circumstance that two different terms are used for mules-hemionos ('half-ass') and oureus - it might naturally be inferred that these hybrids were both true mules (the offspring of a mare by a male ass), and jennets (the offspring of a she-ass and a male horse), but this apparently was not the case, since both terms are applied to the same animals ${ }^{1}$, and it seems certain that hemionos was a true mule and not a jennet, since the second prize in the chariot-race was a mare in foal with a mule (hemionos) 2 .

Inles played a leading part in agriculture and the other ordinary avocations of life, being regularly employed for drawing waggons $^{3}$, for hauling timber ${ }^{4}$ and for ploughing, and preferred for the last-named purpose to oxen ${ }^{5}$.

Leaving aside for the moment the Homeric evidence touching horses in Asia Ninor let us return to the regions lying north of the Illyrians and Thracians. We have already described the little, large-headed, shaggy horses of the people who lived on the north of the Danube in the time of Herodotus. We shall now show that down to the time of Julius Caesar's campaigns in Gaul this same small ugly breed of horses was the only one possessed by the tribes of Germany, for although in Caesar's time the Germans used horses for riding, his description shows that these native horses were of a very inferior kind. "They admit traders into their country rather because they want persons to purchase what they themselves have captured in war than through any desire to buy imported wares. Moreover, foreign horses, in which the Gauls take special delight and for which they pay large sums, the Germans do not employ, but their own native-born horses, which are bad and ugly, they train to endure the severest toil by daily exercise. In cavalry actions they frequently jump off their horses and fight on foot, and they train their horses to remain where they stand, and if need arise they betake themselves

1 Cf. $I l$. xxirr. 115 with 121, and xxIv, 702 with 716 .

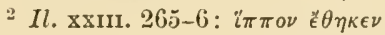

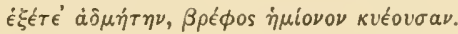

3 Il. vir. 332 , xvir. 742 , xxIv. 702 .

+ Il. xxiI. 121. 5 Il. x. 352.

R. 11 . 
back to their horses with all speed. Nothing, according to their standard, is more disgraceful or a greater mark of laziness than to use a saddle, and no matter how few in number they may be, they boldly attack any number of cavalry furnished with saddles "."

The method of fighting here described is identical with that of the peoples who used chariots, for the latter, as we have seen, regularly descended from their chariots and fought on foot, the charioteers keeping the chariot in readiness close at hand. The Germans had simplified this method of warfare by using their ponies as mere vehicles and not as war-horses; they dismounted from their horses as others did from their chariots, and leaving their horses to await them, as the others did their chariots, they fought on foot. Thus they were mounted infantry rather than true cavalry. However, by the time of Tacitus we shall find that one tribe of Germans possessed a true cavalry finely organised. It is not improbable that the Germans had once used chariots, but had abandoned the use in warfare in favour of the system of rough-riding, which they may have learned from the peoples who lay east of them, such as the Sarmatians and Scythians.

The description of these small, ugly, native German horses makes it clear that they were the old small European horse with a big head, of the same breed as those of the Sigynnae. That the horse had been domesticated and used by some of the Germans from a remote antiquity is rendered clear by various circumstances, foremost amongst which is the fact that, according to Tacitus ${ }^{2}$, divination from horses was accounted the surest mode of foretelling the future. "It is peculiar to this people to seek omens and monitions from horses. Kept at the public expense, in these same woods and groves, are white horses, pure from the taint of earthly labour; these are yoked to a sacred chariot (currus) and accompanied by the priest and the king, or chief of the tribe, who note their neighings and snortings. No species of divination is more trusted, not only by the people and by the nobility, but also by the priests, who 
regard themselves the ministers of the gods, and the horses as acquainted with their will." We shall presently find that the ancient Persians had very similar beliefs and practices concerning white horses to those held by their Germanic kinsmen.

But in the interval between Caesar and the date when Tacitus wrote his account of Germany, one German tribe had developed a cavalry organization of so high a quality as to call forth the warm admiration of the latter writer. This was the tribe called Tencteri by Tacitus, Tenchtheri by Caesar. In Caesar's day this tribe, being hard pressed by the Suevi, had made their way to where the Menapii occupied both banks of the Lower Rhine. The Menapii on the eastern side hastily removed to the western bank, taking with them all their boats. The Tencteri, thus baffled, pretended to return whence they had come, and the Menapii of the east bank recrossed the river to their homes, thinking that all was now safe. But the Tencteri suddenly returned by a long night march accomplished on horseback, slew the Menapii, seized their boats, and were thus enabled to cross the Rhine?

In the time of Tacitus the Tencteri were dwelling on the west bank of the Rhine, near the Chatti and Usipii. The historian states that the Tencteri, "besides the more usual military distinctions, particularly excel in the organization of cavalry, and the Chatti are not more famous for their footsoldiers than are the Tencteri for their horsemen. What their forefathers originated, posterity maintains. This supplies sport to the children, rivalry to their youths; even the aged keep it up. Horses are bequeathed along with the slaves, the divellinghouse, and the usual rights of inheritance; they go to the son, not to the eldest, as does the other property, but to the most warlike and courageous"." Tacitus is probably also referring to this people when he says that the bridegroom brought such gifts as oxen, a caparisoned horse, a shield, a lance, and a sword $^{3}$. Occasionally the horse was burned along with his master on the funcral pyret.

It will be noted that the Tencteri had crossed the Rhine
1 Caesar, B. G. iv. 4.
2 Germ. 32.
3 Ib. 18.
+ Ib. 27. 
and had thus got into immediate contact with the Gauls, who had already, from at least the beginning of the second century B.c. (p. 101), been importing good horses and their caparisons at great cost from beyond the Alps, and thus continually improving their native strains. It has also to be remembered that from B.c. 150 the Gauls had practically abandoned the chariot and become essentially a nation of knights, as Caesar found them in his campaigns. These circumstances render it highly probable that the reason why the Tencteri surpassed in horses the rest of the Germans was the fact that their geographical position gave them special facilities for improving their own indigenous horses with which they had reached the Rhine and surprised the Menapii in a night march, in Caesar's day, as already described.

The evidence hitherto adduced respecting the use of the horse by the Germans referred only to the tribes of western and central Germany, with whom the classical peoples first came into contact. Tacitus, however, furnishes us with some invaluable information respecting the tribes of eastern Germany, whilst for the north-east we can draw upon native sources.

We learn from the former ${ }^{1}$ that Vannius, who had become King of the Suevi by the help of Drusus, though well supplied with native infantry, had to rely for cavalry entirely on the neighbouring Sarmatian tribe of Iazyges, whose strength, as the same writer ${ }^{2}$ tells us elsewhere, consisted solely in horsemen.

From the fortunate circumstance that Pausanias ${ }^{3}$, who wrote in the second half of the second century of our era, chanced to see a Sarmatian corselet in the sanctuary of Aesculapius at Athens, the historian was led to give us a vivid picture of the Sarmatians, their mode of life, their arms, and method of warfare. "Here, among other things, is dedicated a Sarmatian corselet: anyone who looks at it will say that the barbarians are not less skilful craftsmen than the Greeks, for

1 Ann. xIr. 29-30, "ipsi propria manus pedites, eques e Sarmatis Iazygibus erat."

2 Hist. III. 5, "vim equitum, qua sola valent, offerebant."

3 I. 21. 5-7 (Frazer's trans. 
the Sarmatians neither dig nor import iron, being the most isolated of the barbarous peoples in these regions. But their ingenuity has supplied the defect. Their spears are tipped with bone instead of iron, their bows and arrows are of the comel-tree, and the barbs of the arrows are of bone. They throw ropes round the enemies whom they fall in with; then wheeling their horses round they upset their foes entangled in the ropes. They make their corselets in the following way. Every man breeds many mares, for the land is not divided up into private lots, and it produces nothing but wild forest; for the people are nomads. These mares they not only employ in war, but also sacrifice to their local gods, and, moreover, use them as food. They collect the hoofs, clean them, and split them till they resemble the scales of a dragon. Anyone who has not seen a dragon has at least seen a green fir-cone. Well, the fabric which they make out of the hoofs may not be inaptly likened to the clefts on a fir-cone. In these pieces they bore holes, and having stitched them together with the sinews of horses and oxen, they use them as corselets, which are inferior to Greek breastplates neither in elegance nor strength, for they are both sword-proof and arrow-proof. Linen corselets, on the other hand, are not so serviceable in battle, for they yield to the thrust of iron; but they are useful to huntsmen, for the teeth of leopards and lions break off short in them."

According to Grunau ${ }^{1}$ the East Prussians acquired horses and a knowledge of arrow-shooting from the Masuren, a people who lived in what is now Poland, in the district round Warsaw, and whose name still survives in the dance called 'mazurka.' The same writer also mentions a sacrifice of white horses ${ }^{2}$, and we are told that white horses are to be kept for the gods. Moreover, a sacred shield described by Grunau ${ }^{3}$ is represented as supported by two white horses. The last statement naturally reminds the reader of the white horse in the arms of Hanover. The evidence of Grunau concerning the acquisition of horses and a knowledge of arrow-shooting from the Masuren, who were almost certainly a Sarmatian tribe, taken along with

1 Tract, in. $5,1$.

2 Tract, Ix, 3, 8.

3 Tract, II. 5, 1.

4 The cream-white horses used by our king on state occasions are descended from white horses formerly kept in the royal stables at Hanover. 
that of Tacitus at a far earlier period, indicates clearly that the peoples of eastern Germany learned to ride the horse, if they did not also obtain him, from the nomad tribes of ancient Russia.

There are no early remains of the horse in Scandinavia, and he only appears in Denmark in the Bronze age, and then he is of small size. The northern mythology indeed indicates that it was only at a late epoch that the horse was either driven or ridden, since Thor, the oldest and greatest of the Northern divinities, is never represented as driving in a chariot or riding on horseback, but always as going on foot. On the other hand, the later members of the Pantheon, such as Odin (Fig. 100), are represented as riding on horseback, and to their horses we shall presently refer.

Though in the time of Tacitus ${ }^{1}$ the Swedes (Suiones) are renowned for ships and sea-craft, we hear nothing of horses or horsemen, yet if like the Tencteri they had been noted for the possession and employment of such animals the historian would probably have made some reference to it. But in the sixth century the Swedes had become famous for the excellence of their steeds, since they are likened in this respect by Jornandes $^{2}$ (circ. A.D. 550) to the Thuringians. As the Swedes at that time supplied the Roman markets with costly furs, which passed south along the ancient trade-routes through the tribes of Germany, they had not only the opportunity, but also ample means of purchasing horses from upper Europe and the south. And he adds that they were noted for the sable furs which they wore and also exported. Adhils, the Swedish king, was a great lover and breeder of horses ${ }^{3}$. In the great battle between the gods, the Vanir (Freyr and Ierdth) rode through the Eisir (Thor and Odin), but, as Freyr is a Swedish god, and as already mentioned, Thor always journeys and fights

1 Germania, 44.

2 Historia de origine Gothorum, c. 3 (p. 82, ed. 1611): "alia vero gens ibi moratur Suethans, quae velut Thuringi, equis utuntur eximiis; hi quoque sunt qui in usus Romanorum Saphirinas pelles, commercio interveniente, per alias innumeras gentes transmittunt. famosi pellium decora nigredine hi, quum inopes vivunt, ditissime vestiuntur."

3 Ynglinga Saga, ch. 33. He had the best horses of his time and owned Hrafn, once Ali's, from which sprang another Hrafu given to king Gothgestr. 
on foot, whilst Odin never rides except on his mysterious steed, eight-legged Sleipnir, it would appear not improbable that the Swedes were rider's of horses before the Norse, and that therefore they, like the Prussians, had got them from the tribes of western Russia, such as the Sarmatians, who, as I have already shown, possessed admirable cavalry from at least the beginning of the Christian era. It is therefore not

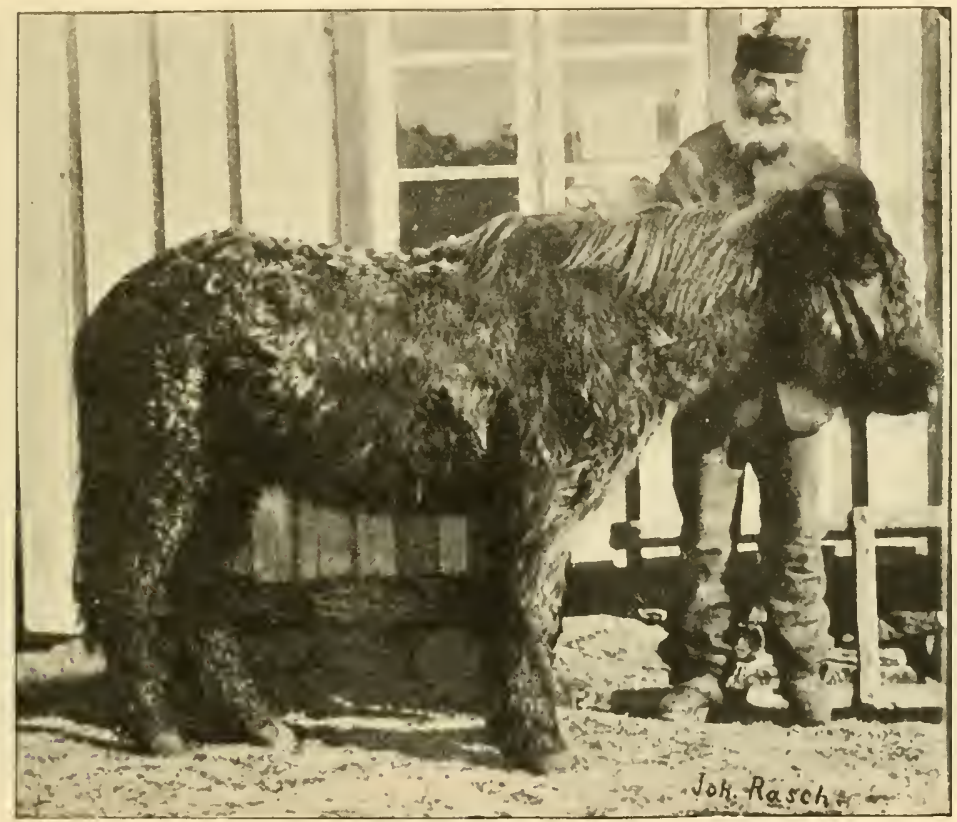

FIG. 48. Norse Pony from the Isle of Rodo.

improbable that the Norse derived their horses in great part, if not altogether, from Sweden. Otherwise they must have derived them from Germany, for we have already noticed (pp. 23-4) the sharp contrast between the 'Celtic' ponies of Iceland and the Faroes and those of a clumsier build, with large heads, and large hock callosities, which are almost certainly to be ascribed to the introduction of Norwegian blood In either case then it is probable that the original stock of horses in Norway and Sweden, whether derived from Russia or 
from central Europe, was the old heavy-built, large-headed European Asiatic type found at Solutré. In the ponies of the Isle of Rodo, which lies off the coast of Norway considerably to the south of the Lofoden group, we have probably the best living examples ${ }^{1}$ of the ancient race (Fig. 48).

The earliest information concerning the colour of the horses of Scandinavia is contained in Beowulf, supposed to have been

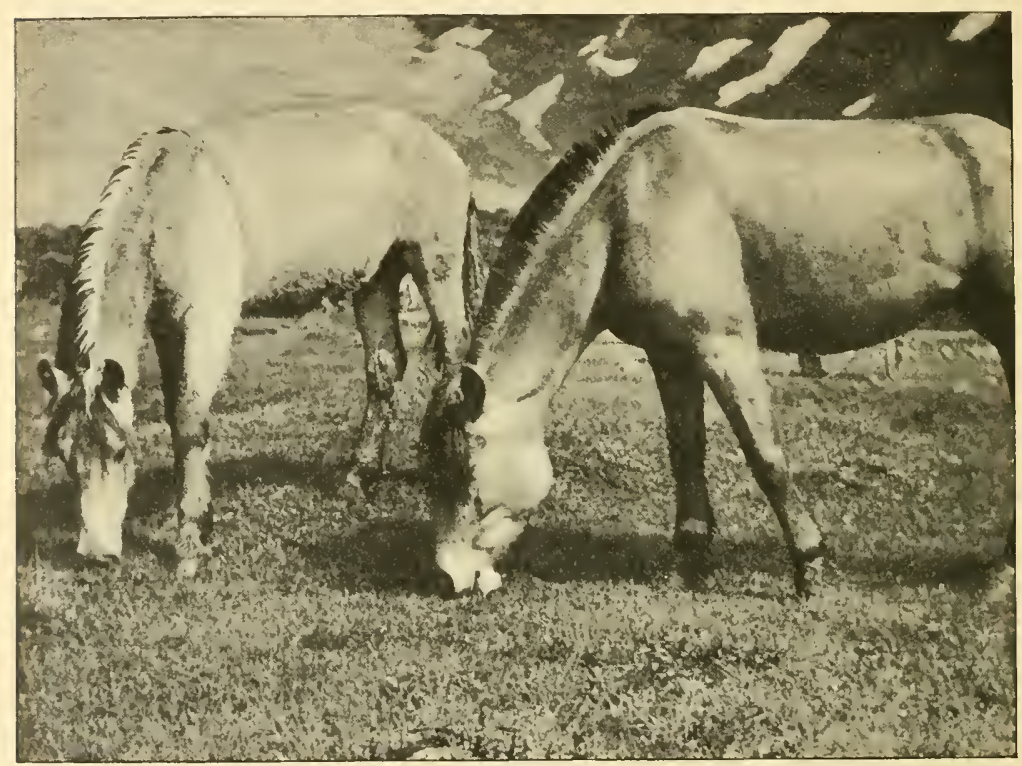

Fıg. 49. Norwegian Ponies, near Mundal Glacier.

composed in the eighth century. In it we read of fallow (i.e. dun-coloured) ${ }^{2}$, of 'apple-fallow' (i.e. dapple-dun) ${ }^{3}$, and white horses 4 . From the dun horses described in Beowulf are probably descended the Norwegian ponies of modern times, which are

I I am indebted (through my friend Dr Venn, F.R.S.) to Dr Brunchorst, Director of the Bergen Museum, for the loan of the photographs from which this and the Lofoden pony are taken.

2 1. 856, fealwe mearas ; for colour meant by fealwe, cf. 917 (fealwe straete), 951 (fealone flod).

3 1. 1266, oeppel-fealuwe mearas.

4 1. 856, mearum ridan on blancum. 
usually dun-coloured (Fig. $49^{1}$ ), those from remote distriets, such as the pony from Rodo (Fig. 48), being probably the most typical representatives of those of earlier times, for it is certain that the ordinary Norwegian ponies of to-day have been much improved by superior blood from the south. The white horses of Beowulf were in some respects probably well represented down to our own times by the white ponies of the

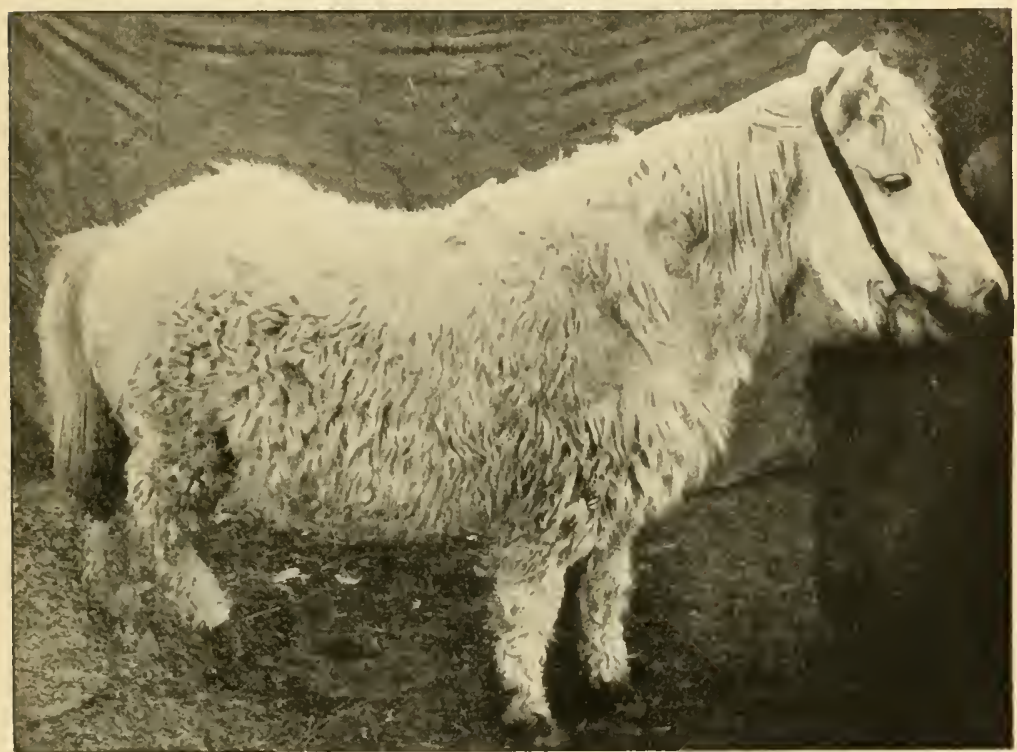

Fig. 50. The last of the old Lofoden ponies (in its summer coat).

Lofoden Isles, which became extinet in 1897. I figure here (Fig. 50) the last of these in its summer coat from a photograph taken before it was shot in order to be preserved in the Bergen Museum.

Gylfinnung gives the names of the gods' horses, which were eleven in number: Heimdal's horse was Gulltoppr ('Goldtopped,' i.e. golden-maned?), whilst Odin's famous eight-legged steed (Fig. 100) Sleipnir (the offspring of Loki when he turned

1 From a photograph taken in 1904 by my friend Mr J. A. Venn, Trinity College, Cambridge. 
himself into a mare, and a smith's magic-working stallion) was gratt at bit, "grey in aspect or complexion." As the cult of Odin had made its way up northwards from central Europe, and never formed the popular religion of Norway, the fact that Odin is represented as riding on a grey horse, whilst the older Thor always fares on foot, makes it likely that horses of a certain kind had made their way into the North from central Europe. It is also to be remarked that whilst Sleipnir is grey, Heimdal's horse is evidently a chestnut or yellow-dun.

We shall presently see that the grey colour of Sleipnir is a valuable indication of the importation of Libyan blood into Upper Europe.

From the horses' names given in the appendix to Sijmon's Edda we can learn something of the colours of the horses of a later date. Ali's horse was named Hrafn ('Raven'), Actie's steed was called Grar ('Grey'), whilst other horses are named Soti ('Sooty'), Goelfaxi ('Golden-haired,' i.e. dun), Silfrentopr' ('Silver-topped,' i.e. silver-maned ?).

In addition to the dun, grey, and white horses of the earlier period, we now find black horses making their appearance.

The Icelandic sagas furnish some useful evidence concerning the horses used by the early Norse settlers in Iceland, who were especially addicted to the pastime of horse-fighting (an amusement practised in modern Siam), and who, until their conversion to Christianity by the simple but effective methods of Thangbrand, the militant missionary sent by King Olaf of Norway in 997, regularly ate horse-flesh on certain occasions.

In the saga of Burnt $\mathrm{Njal}$, the scene of which is laid in the tenth century, there are constant allusions to horses and riding, but no description is given of these animals, unless they are of an exceptional kind. "Starkad had a good horse of chestnut hue, and it was thought that no horse was his match in fight"; Gunnar of Lithend had a brown ${ }^{1}$, and on the great fight between these two stallions and its sequel the development of the tragedy depends. "Now men ride to the horse-fight, and a very great crowd was gathered together. 


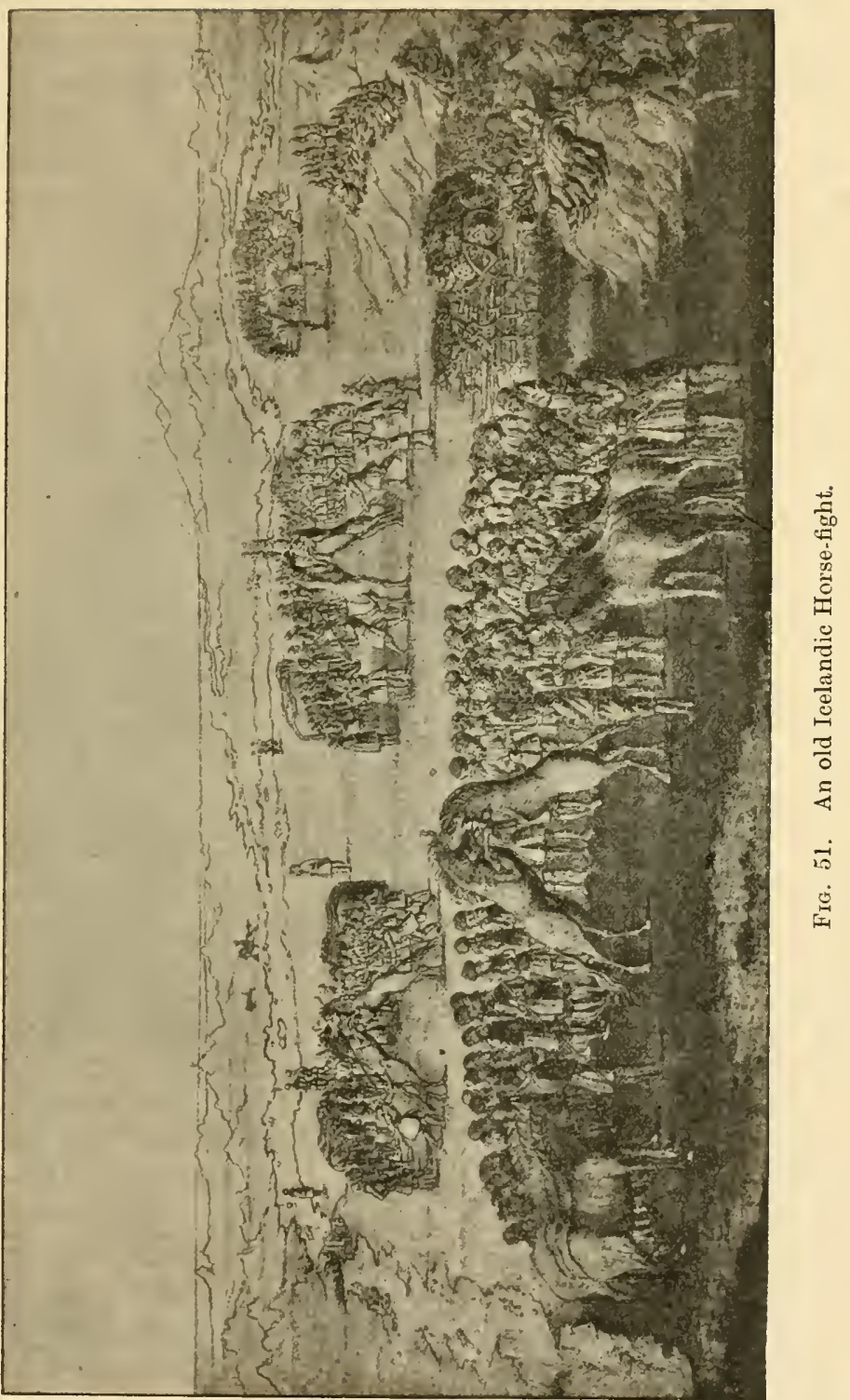


Gunnar and his friends were there, and Starkad and his sons, ' and they said to Gunnar that now they would lead the horses together.' Gunnar said that was well. Skarphedinn said, 'Wilt thou that I drive thy horse, kinsman Gunnar?' 'I will not have that,' says Gunnar. 'It would not be amiss, though,' says Skarphedinn; 'we are hot-headed on both sides.' 'Ye would say or do little,' says Gunnar, 'on both sides before a quarrel would spring up; but with me it will take longer, though it will be all the same in the end.' After that the horses were led together; Gunnar busked him to drive his horse, but Skarphedinn led him out. Gunnar was in a red kirtle, and had about his loins a broad belt, and a riding-rod in his hand (see Fig. 51). Then the horses ran at one another, and bit each other long (cf. Fig. 51), so that there was no need for anyone to touch them, and that was the greatest sport. Then Thorgeir and Kol made up their minds that they would push their horse forward just as the horses rushed together, and see if Gunnar would fall before him. Now the horses ran at one another again, and both Thorgeir and Kol ran alongside their horse's flank. Gunnar pushed his horse against them, and what happened in a trice was this, that Thorgeir and his brother fall down flat on their backs, and their horse atop of them." After this the horse-fight, as Gunnar had foreseen, turned into a man-fight. In the course of the struggle Thorgeir knocked out one of the eyes of Gunnar's brown horse, in consequence of which Gunnar has him killed. I here reproduce (after Brunn ${ }^{1}$ ) a picture of a medieval horse-fight still preserved in the library at Reykjavik.

Again, "Otkell had two horses, dun-coloured, with a black stripe down the back. They were the best steeds to ride in all the country round"." From this it is clear that though the Norwegian dun-coloured pony with a black dorsal stripe was already known it was regarded as a very exceptional animal both in colour and quality.

It is therefore clear that the light dun pony with a dark line down the centre of the back, which has long been a 
typical Icelandic breed (p. 24), was not the usual type of animal in use in Iceland and Scandinavia in the tenth century. The fact that dun-coloured ponies with black dorsal stripes were regarded as exceptional by the Norsemen of that period will be of considerable importance in a later stage of this inquiry.

We have already seen that the Sarmatians, who by the time of Christ were dwelling on the east of the Teutonic peoples, were well furnished with horses. But the evidence of other writers makes it clear that for many centuries before that epoch the Sarmatians and Scythians principally subsisted on the flesh and milk of these animals, which they likewise employed in war and the chase. Strabo ${ }^{1}$ has left us some valuable evidence respecting the horses and horsebreeding of these two peoples: "All the Scythian and Sarmatian tribes have the peculiar custom of gelding their horses to make them docile. For their horses, though small, are very spirited and difficult to manage. They hunt stags and wild boars in the marshes, and wild asses (onagri) and roes on the plains."

The method employed by the Scythians and Sarmatians for rendering their horses more manageable is that followed regularly in modern times by the Kalmuck Tartars, with their domestic horses ${ }^{2}$, and by both the Querenda Indians and the Gauchos of the Pampas when they capture the buguals or feral horses for domestication ${ }^{3}$.

It is difficult to say to what race of onager or hemionus belonged the wild asses hunted by the Sarmatians and Scythians, a doubt which also arose when we spoke of 'wild mules' in Cappadocia.

We have seen reasons for believing that there were once not merely feral, but genuine wild tarpans in the steppes of the Caspian. This is curiously confirmed by the statement of Herodotus" that "around a great lake from which issued the river Hypanis (the modern Bug) there grazed wild white horses"; a fact of considerable importance, whether the animals

1312.

2 Hamilton Smith, The Horse, p. 273.

3 Felix Azara, The Natural IFistory of the Quadrupeds of Paraguay and the River La Plata, p. 7 (trans. by W. Perceval Hunter).

4 IV. 52. 
referred to were simply tarpans (or Prejvalsky horses) in their winter coats (p. 32), or whether they were really white, a less likely alternative.

The Sarmatians, termed Sauromatae by Herodotus, in the time of that writer ${ }^{1}$ lived in the region on the east side of the Tanais (the modern Don), which formed the boundary between them and the nomad Scythians. Their territory stretched northward from the upper end of the Palus Maeotis (Sea of Azov), a distance of fifteen days' journey, and was "entirely bare of trees, whether wild or cultivated"." The Sauromatae differed essentially in their habits from the Scythians. Thus, whilst the Scythian women lived in their ox-waggons, and never rode on horseback or went hunting with their husbands, the Sarmatian women frequently followed the chase on horseback with their consorts, sometimes even unaccompanied, and in war-time took the field, dressed exactly like the men ${ }^{3}$. Their marriage law ordained that no girl should wed until she had killed a man in battle. "Sometimes it happens that a woman dies unmarried at an advanced age, having never been able in her whole lifetime to fulfil this condition." In Strabo's ${ }^{4}$ time a large number of the tribes of the Cancasus who traded with the emporium of Dioscurias (the modern Iskuriah) were considered Sarmatians, and it is not unlikely that the Ossetes of the Caucasus, who according to Ptolemy and their own tradition apparently once dwelt on the shore of the Black Sea, may be of Sarmatian origin.

In the fifth century B.c. the chief wealth of the nomad Scythians, who dwelt on the north sicle of the Don, and tilled not the soil, consisted chiefly of large herds of horses, on the milk and flesh of which they principally subsisted, as has been the case with all the Turko-Tartaric tribes of central Asia down to our times.

Herodotus ${ }^{5}$ remarks that the horses bore well the winter, cold as it was, but mules and asses were quite unable to bear it, "whereas in other countries mules and asses are found to cndure the cold, while horses if they stand still are frost-
1 Iv. 21.
2 IV. 116 .
3 Herod. Iv. 117.
497, 499.
5 Iv. 28. 
bitten." He also thought that the rigorous cold was the reason why the Scythian oxen had not horns. Strabo ${ }^{1}$ remarks that asses are not reared in the region of the Borysthenes becanse of the cold, and he ascribes the diminutive size of the horses to the same cause. As he has already stated that "wildasses ' roamed the steppes, he is here referring (like Herodotus) to the domestic ass, which being derived, as we saw (p. 54), from the Abyssinian ass, was naturally not constituted to endure the rigours of a Russian winter.

'The Scythians do not appear to have used their horses for draught, for it is clear from Herodotus ${ }^{2}$ and Hippocrates ${ }^{3}$ that the waggons which formed their homes, and from which they derived their name of Hamaxoeci ('Waggon-dwellers'), were regularly drawn by oxen. Similarly the Kalmucks and Nogais of modern times, though possessing great numbers of horses, employ oxen for draught purposes.

Herodotus $^{5}$ describes how the Scythians blinded their captives to use them in preparing the milk of their mares, and their method of milking the latter. "The milk thus obtained is poured into deep wooden casks, about which the blind slaves are placed, and then the milk is stirred round. That which rises to the top is drawn off, and considered the best part; the under portion is of less account." This koumiss is still prepared from mares' milk by the Kalmucks and Nogais, who keep the milk in continual movement whilst making it.

There can be no doubt that the Scythians, under the name of "the milk-drinking Mare-milkers" (Hippemolgi), were known to the Greeks in Homeric days, since in the Iliad ${ }^{6}$ they are represented as living in the same part of the world as the Thracians, who bordered on southern Russia in classical and later times, whilst Hesiod? ${ }^{7}$ as cited by Eratosthenes, applies the very name of 'Mare-milkers' as an epithet to the Scythians. The fact that the Scythians and allied tribes and their descendants down to modern times preferred and still

I 307.

2 IV. 69.

3 De dere, Aqua, ct Locis, 44, p. 353.

4 Pallas, Vol. I. p. 532, I'l. 6.

5 Ir. 2 ; Clarke's Travels, Vol. I. p. 313 ; cf. Rawlinson, ad loc.

6 XIII. 5.

7 Strabo, 300 . 
prefer mares' milk to that of the cow naturally suggests that the Turko-Tartaric peoples ${ }^{1}$ had domesticated the horse before they possessed the ox, and that they tamed the former not for locomotion, but rather as a means of subsistence. The treeless steppes of Asia probably at no time produced wild cattle which always haunt wooded regions, and accordingly when at a later date the Scythians and cognate peoples acquired domestic cattle a taste for mares' milk had already been long engrained in the race.

They used in ordinary sacrifices all kinds of animals as victims, but most commonly horses?. When a Scythian king died, his horse, as well as one of his concubines, his cook, his cupbearer, and several other chief members of his household, were buried with him, as we learn from Herodotus ${ }^{3}$, the accuracy of whose statement has been amply confirmed by the evidence of the great tumuli opened in Russia during the last half-century. After the lapse of a year further ceremonies took place at the king's grave. Fifty of the best youths from amongst his attendants, all native Scythians, were strangled, with fifty of the best horses. All the bodies were disembowelled and stuffed with chaff. The bodies of the youths were then fixed upright on those of the horses, which previously had been set up on posts in a circle round the grave, each horse being furnished with a bit and bridle. Doubtless this ghastly squadron was intended to keep watch and ward around the last resting-place of their lord. We shall presently fiud a survival of these horrid practices in full operation among the Tartars in the thirteenth century of our era.

Away to the north of the Sauromatae dwelt a tribe called

1 All these peoples have a common name (at) for the horse, just as all the Indo-European peoples have had a common term which appears, in Sanskrit acvas, Lat. equus, Irish ech, Welsh eb, Gaulish epona, Greek i $\pi \pi$ s etc.

2 Herod. Iv. 62.

${ }^{3}$ Iv. 72. In 1341 a Couman prince named Jonach died at Constantinople, and when he was buried in a tumulus near that city, eight warriors and twentysix horses were slain (Jirecek, Geschichte Bulgariens, p. 172, cited by Seure, Bul. Corresp. Hellén. xxv. p. 204). As late as 1781 at the funeral of Frederic Casimir, Commander of Lorraine, a horse was killed and buried with his master.

+ Herod. IV. 7\%. 
by Herodotus ${ }^{1}$ Iyrcae, but Turcae by Pliny and Pomponius Mela (from which some have thought that this is the earliest appearance of the Turks of later times). These people subsisted by hunting in the following way. As the country was well wooded the hunter climbed a tree and there waited for his quarry, his horse being trained to lie down and thus conceal itself, and his homd being close at hand. As soon as he espied the game he shot it with an arrow, and then mounting his horse rode the animal down with the aid of his dog.

To the east of Scythia, in Strabo's ${ }^{2}$ time, lay the Massagetae and the Sacae, both of whom the ancients regarded as of the same race as the nomad Scythians. Some of the Massagetae dwelt in the mountains, others in the marshes of the river Araxes, others on the islands in the marshes, and others again in fertile plains. Their only deity was the Sun, and to it they sacrificed a horse. They were excellent horsemen, and also fought well on foot. They used bows, swords, breastplates, and bronze battle-axes (sagareis), they wore golden belts, and turbans on their heads in battle. Their horses had bits of gold and golden breastplates. They had no silver, and iron only in small quantities, but plenty of gold and copper. They did not cultivate the soil, but subsisted on their flocks and on fish, "after the manner of the nomads and Scythians." The inhabitants of the marshes and islands, like other lakedwellers, lived on fish, and wore the skins of seals, while the mountaineers lived on wild fruits and the milk of their few sheep.

More than four centuries earlier Herodotus ${ }^{3}$, when narrating the great battle in which the Massagetae, under queen Tomyris, had defeated and slain Cyrus, says that the Massagetae dressed and lived just like the Scythians, that their forces consisted of horsemen and footmen, armed with bows and spears, and battle-axes, and that they used gold and copper for all their equipment-copper for their spears, arrow-heads, and axes, whilst they decked with gold their head ornaments, their girdles, and their corselets; that they protected their horses

$$
{ }^{3} \text { IV. } 22 . \quad 2513 . \quad 3 \text { I. } 215 .
$$

R. H. 
with copper breastplates, their bridles, bits, and trappings being adorned with gold. They did not use either iron or silver, as these metals are not found in their country, whilst copper and gold were to be had in abundance. Plainly, then, in the fifth century B.c. their culture was much the same as it was at the beginning of the Christian era, except that by that date iron was coming into use.

The famous Nicopol vase (Fig. 52) and the coins of Olbia probably offer us fairly accurate representations of the Scythian and Sarmatian horses in the fourth century B.c. Both vase ${ }^{1}$ and coins are probably the work of Greeks living in the Greek towns of Sonthern Russia, such as Olbia and Pantacapaeum (Kertch). The vase was found in $\mathbf{1 8 6 3}$ in a tumulus at Tchertomlitsk near Nicopol (government of Ekateriıoslav) with many Scythian antiquities. The frieze on the vase shows that it was made for a wealthy Scythian by an artist who had a complete knowledge of the customs of the country. The scene is laid in the steppe; in one place we see a young mare, and near her four Scythians, two old, two young and beardless; in another two horses moving quietly, whilst two others have just been lassoed by two grooms, who are bending down in the effort to restrain their captives: on the left is a groom lifting up the left fore-leg of a horse with one hand, and grasping the bit with his other; on the right is a Scythian putting hobbles on the fore-feet of a horse, which is standing quietly. It has been remarked that this last horse is the only one of those pourtrayed which resembles in type the Kirghis horses of modern times. The large heads and thick shaggy manes of the majority show them to be closely related to the little horses of the Sigynnae of central Europe. It is possible that those represented with hog manes may be another breed, but it is far more likely that the hogged manes are simply due to individual taste in the owner or the artist. In Pliny's" time it was believed that a mare was rendered less erotic by hogging her mane.

1 Antiquités de la Russie méridionale, by Prof. Kondakof, Count J. Tolstoï, and M. S. Reinach (Paris, 1891), pp. 88, 295-8 (from which my figure is copied).

2H. N. vilr. 164: "equarum libido extinguitur iuba tonsa." 
Although some of the blood of the ancient horses probably

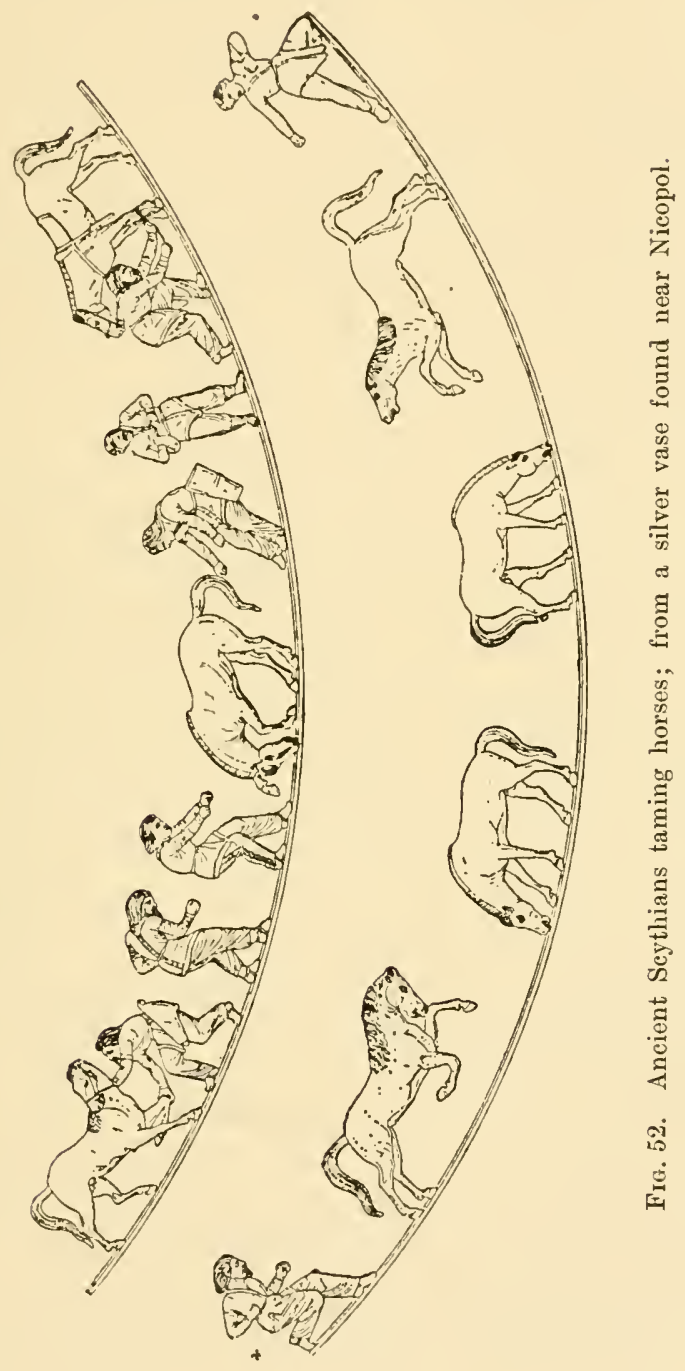

still flows in the veins of the horses of the steppes, and in the large agricultural breed, yet as all the horses of superior quality, 
whether stud or agricultural, are descended wholly, or in part, from Dutch, Danish, Mecklenburg, English, and Arab sires and mares imported at various times since 1712 , it will be best to defer our account of modern Russian breeds until after we have treated of the various stocks of medieval and modern times from which they are derived.

Just as the Cossack pony from the steppes, though completely modified now by foreign blood, is yet lineally descended from the sinall steeds of the Scythians and Sarmatians, so the oldest element in the breeds of the various Turko-Tartaric tribes, who may be taken as the modern representatives of the Massagetae, Sacae, and other cognate tribes, is probably derived from the horses of the last-named peoples.

It is very important to notice that the Massagetan horsemen not only wore corselets, but also protected their horses with copper breastplates, since this is one of the earliest notices of the use of horse-armour. At a later period, when the Sarmatians aided the Germans against Rome, they wore hauberks (p. 116), and it may prove that the use of the war-coat (bellica vestis) and eventually the use of horse-armour was ultimately derived from the peoples of Eastern Europe and Western Asia.

The Turcoman horses primarily belonged to the tribes of Turkestan-the region lying north-east of the Caspian, by some termed Southern Tartary-but they have spread thence along with their first owners into Armenia, Persia, Mesopotamia, and Asia Minor. The modern Turcomans claim the descent of their horses from Arab sires, and are continually improving the breed, as the Turcomans and Kurds are ever anxious to obtain the service of the best Arab stallions for their mares. Yet the description of this improved breed is sufficient to demonstrate that it is certainly not the source of the bloodhorse. For, although they have wonderful powers of endurance, their heads are disproportionately large, they have the barrel too small and the legs too long, and are frequently ewe-necked.

'The best Turcoman horses are found only in Merv and in the Persian province of Khorassan ${ }^{1}$. They usually stand

1 Hayes, Points of the Horse, p. 606 (ed. 3). 
about fifteen to sixteen hands high, and are generally bays or greys, but some of them are black, always with white feet and a white star in the forehead'. They are derived from Arab blood, introduced by 'Tamerlane, who distributed five thousand Arab mares among the Turcomans, whilst Nasir-ed-Din sent them five hundred mares of the same breed ${ }^{2}$. The Turcomans and Katschenstzis of Eastern Tartary had a breed called Karabulo, highly valued for its speed and bottom, which was remarkable for a white or grey mane, tail, and feet, while the rest of the body was shining black. There is in Eastern Asia a prevalent opinion that black horses come from the West ${ }^{3}$.

It is most important to observe that we have here an undoubted case of black horses with white feet and a white star in the forehead as a result of crossing the indigenous horses of Upper Asia with so-called Arab blood, for we shall have frequent occasion to notice similar phenomena as our investigation proceeds. A century ago the Kalmucks of Khoten in Eastern Turkestan bred great numbers of small but hardy horses, and great droves of them were exported to the south, as far as the plains of Indiat. The good qualities of Turcoman horses were remarked by Marco Polo ${ }^{5}$ (A.D. 1274), who, speaking of 'Turcomania and the Turcomans, says that "excellent horses known as Turquans are reared in their country and also very valuable mules."

The evidence here adduced, so far from indicating that any element in the thoroughbred was derived from the indigenous horses of Russia or Southern Tartary, demonstrates that the peoples of Russia, and the various Turko-Tartaric tribes have been constantly endeavouring to improve their native strain by the admixture of so-called Arab blood.

When we advance further east the Turcoman is replaced by his kinsman the Mongolian pony, which belongs primarily to the highlands lying between the Hinalayas and Siberia, for as Captain Hayes ${ }^{6}$ points out, "there is no distinctive difference

1 Hamilton Smith, op. cit. p. 239.

${ }^{2}$ Hayes, loc. cit.; Hamilton Smith, loc. cit.

${ }^{3}$ Hamilton Smith, op. cit. p. $273 .+$ Hamilton Smith, op. cit. p. 273.

5 Vol. I. p. 45 (Yule's trans.).

${ }^{6}$ Points of the Horse, p. 599 (ed. 3). 
between the ponies of Bhootan, Nepal, Spiti, Yarkand, and Mongolia."

These ponies have been much less affected by extraneous blood than the Turcoman. "They are strong and sure-footed, but very slow," and stand about $12 \cdot 1-13 \cdot 2$ hands high, and Captain Hayes ${ }^{1}$ gives them as the type of the coarse thickset horse of Asia and Europe, and he maintains" that "as the ancestors of all living horses were inhabitants of Siberia after their emigration from North America, and as Siberia is closely connected with Mongolia, it is reasonable to infer that the present Mongolian pony, which has always lived under more or less natural conditions, is nearer the original type of horse than any other domesticated horse." Marco Polo noticed the good qualities of these horses, for when writing of the Tartars, he states that "their horses will subsist entirely on the grass of the plain, so that there is no need to carry store of barley, or straw, or oats; and they are very docile to their riders. These in case of need will abide on horseback the livelong night, armed in all points, while the horse will be continuously grazing.".

In treating of the city of Chandu (now but a heap of ruins, but whose name still survives in that of the river Shangtu), founded by Kublai, he says": "You must know that the Kaan keeps an immense stud of white horses and mares; in fact, more than 10,000 of them, and all pure white without a speck. The milk of these mares is drunk by himself and his family, and by none else, except by those of one great tribe, that have also the privilege of drinking it. This privilege was granted them by Chinghas Kaan, on account of a certain victory that they helped him to win long ago. The name of the tribe is Horiad. Now when these mares are passing across the country, and anyone falls in with them, be he the greatest lord in the land, he must not presume to pass until the mares have gone by. He must either tarry where he is, or go a half-day's

1 Points of the Horse, p. 269 (ed. 2).

2 Op. cit. pp. 600, 601 (ed. 3).

3 Vol. I. p. 252 (Yule's translation).

4 Marco Polo, Yule's translation, Vol. I. p. 291. 
journey round if need so be, so as not to come nigh them; for they are to be treated with the greatest respect. Well, when the lord sets ont from the park on the 28th of August, as I told you, the milk of all those mares is taken and sprinkled on the ground. And this is done on the injunction of the

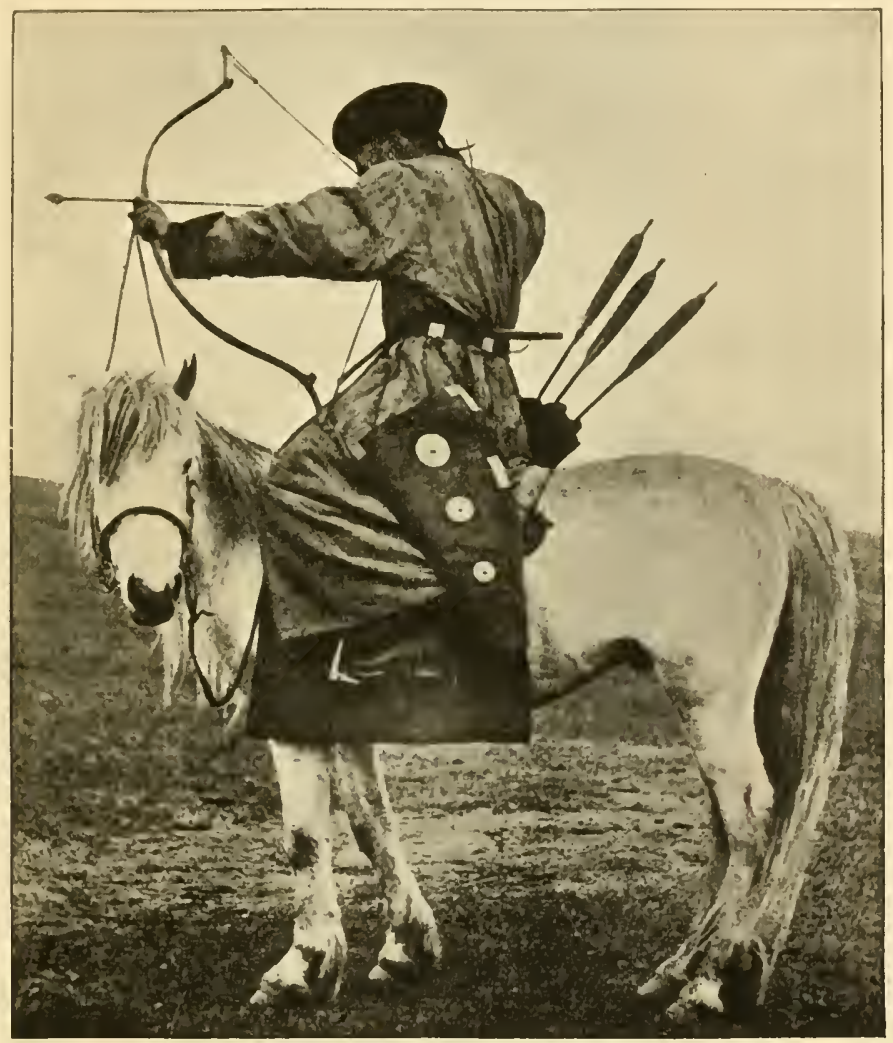

Fig. 53. A Buriat Horseman ${ }^{1}$.

Idolaters and Idol-priests, who say that it is an excellent thing to sprinkle that milk on the ground every 28th of August, so

1 This and the two following illustrations are from photographs kindly lent me by my friend Mr C. H. Hawes, M.A., Trinity College, Cambridge, well known for his In the Uttermost East (in which two of the same scenes are shown, pp. 441-9). 
that the Earth and the Air and the False Gods shall have their share of it, and the Spirits likewise that inhabit the Air and the Earth. And thus those beings will protect and bless the Kaan and his children, and his wives and his folk and his gear, and his cattle and his horses, and his corn and all that is his. After this is done the Emperor is off and away."

Speaking of the festival held by the Great Khan and all his subjects on New Year's Day (which fell in February), Polo ${ }^{1}$ says that " it is the custom that on this occasion the Kaan and all his subjects should be clothed entirely in white, so that day everybody is in white, men and women, great and small. And this is done in order that they may thrive all through the year, for they deem that white clothing is lucky. Also all the peoples from all the provinces and governments and kingdoms and countries that own allegiance to the Kaan, bring him great presents of gold and silver and pearls and gems, rich textures of divers kinds. On that day, I can assure you, that among the customary presents, there shall be offered to the Kaan from various quarters more than 100,000 white horses, beautiful animals and richly caparisoned."

Polo ${ }^{2}$ also tells us that the Tartars, who were carrying the body of a Khan to the Altai, where all the Khans were buried, put to death not only every human being they met, but also every horse, in order that they might serve the Khan in the life beyond the grave. "When the emperor dies they kill all his best horses in order that he may have the use of them in the other world." This story at once recalls the Scythian customs at the funerals of their kings (p. 128).

At the present day cattle and stock-breeding is practically the sole legitimate occupation of all Mongols, and the animal of first importance is still the pony. "He is the commonest of all possessions, the every-day means of locomotion, and the staple topic of conversation. The Mongol who walks is indeed poor, for he must be friendless as well as moneyless. A man who does not own a pony is rarely refused the use of one from a neighbour's drove. From early childhood the Mongol acquires 
the habit of scrambling on the back of the nearest pony to cover any distance over a few yards. The out-door life of both sexes

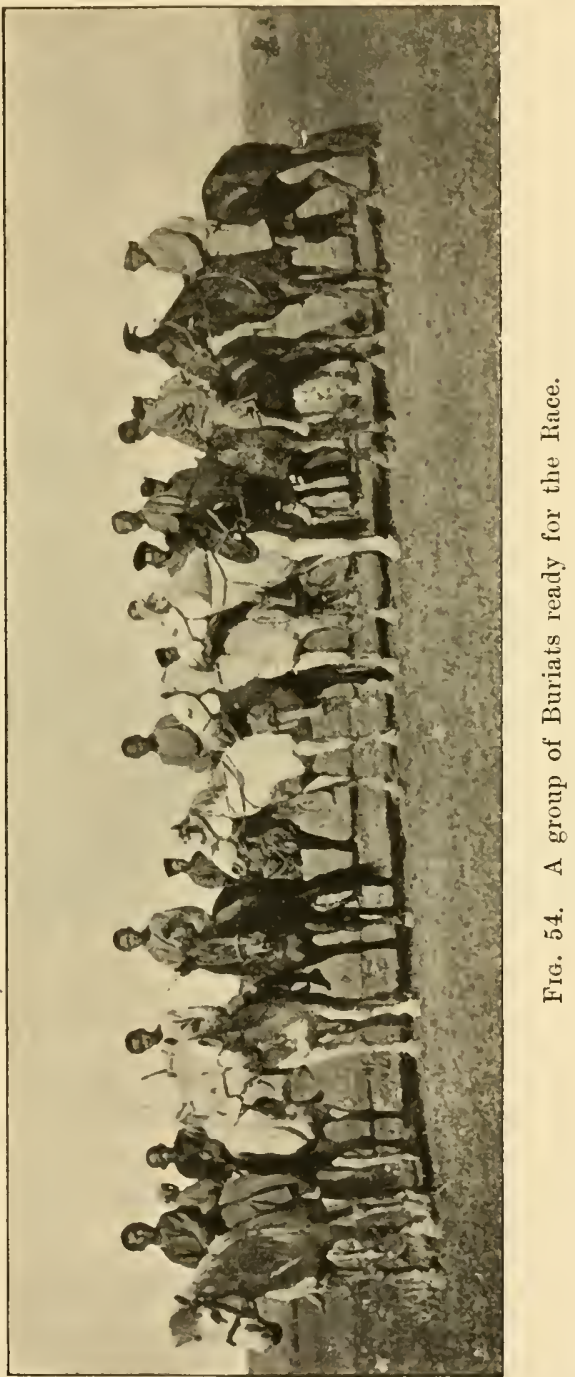

and of all ages is spent on horseback (Figs. 53, 55). A good specimen of the Mongol pony is perhaps the best of his size in the 
world for general use. The head and shoulders will be too heavy for elegance, the eyes none too full, the muzzle and crest coarse, and the manners too often objectionable, but the quarters, loins, and legs are good, the barrel deep and long, and there is no deficiency of bone1." Reared on the open steppes, with little or no human care, they are accustomed to great extremes of weather and thrive on the coarsest forage. For mounted infantry purposes in a wild country there is no more useful animal. "The size and character vary with the locality. The commonest colour is grey, chestnut follows, and then come bay and sorrel ${ }^{2}$. Stallions are selected animals, especially in North Mongolia, but the mares are not, and no special pains are taken anywhere to improve a breed. Along the China border the ponies are undersized, 12 to 13 hands, the result of the incessant demands of the China markets for all the larger beasts. As one travels northwards, and the China markets become more remote, the horse-flesh improves (12 to 14 hands), and the best, specimens of the Mongol pony are found in the valley of the Kerulon." There are said to be about five millions of ponies in Mongolia.

Racing is the national pastime of the Mongols, and from May to August pony races (Fig. 54) are the attraction at the temple festivals (Fig. 55) and fairs, and most of the wealthy owners train some of their best ponies for the local meetings. "A racing-stud of dimensions coinmensurate with rank and wealth is the proper appanage of a prince or jussak, and his 'string' usually includes some of the fastest beasts of the district. The stud of the Tsetsen Khan is the most renowned in Mongolia." "This national sport is as little affected by money indelicacies, as any that I know of. I constantly heard of matches between rival owners proud of the reputation of their stock, but seldom of serious betting on the result. There are prizes to winners, rarely of tempting value. In the Chahar country the stakes are usually an ounce or two of silver (say $2 s$. $6 d$. or $5 s$.)

${ }^{1}$ Report by Mr C. W. Campbell, H.MI. Consul at Wuchow, on a journey in Mongolia (with a map) presented to both Houses of Parliament (January 1904), p. 35.

2 In a Chinese hymu known as The Emperor's horses as many as thirteen colours are referred to, a proof that already the Mongolian pony had been crossed with a stock from the West, known to the Chinese from 2nd cent. в.c. (p. 186). 
for a race of ten miles, but now and then an opulent magnate has occasion to be generous, and offers something exceptionalcattle, sheep, or ponies, silk or clothes. The races are never under ten miles." "The Derby of Mongolia is held near Urga under the direct patronage of the Bogdo and is over a course of thirty miles of rough steppe, and the winners are presented to the Bogdo, who maintains them for the rest of their lives in honourable idleness. The jockeys are the smallest boys capable

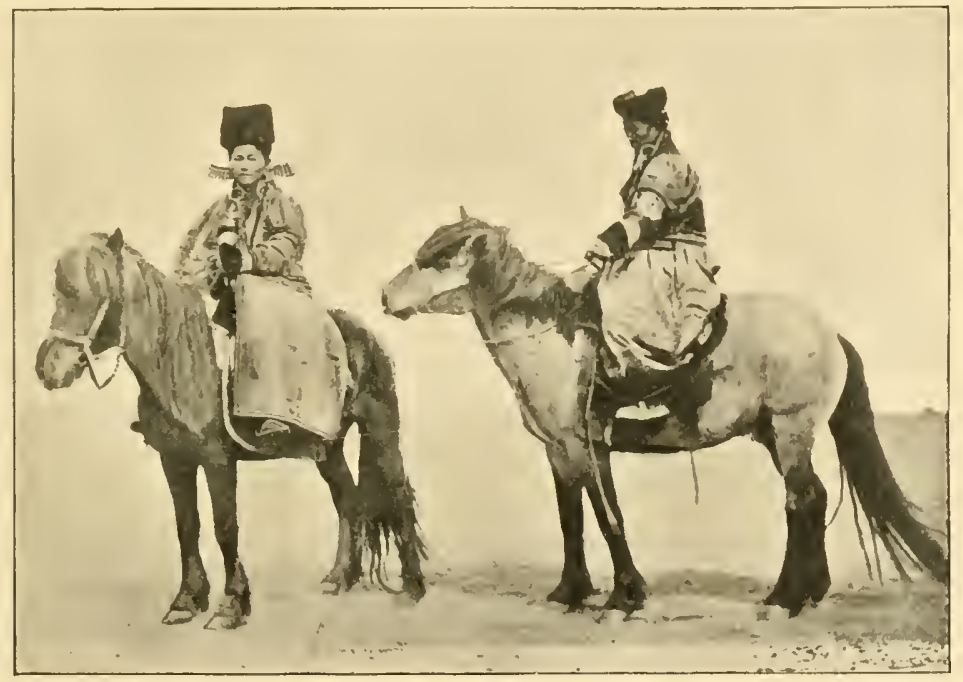

FIg. 55. Buriat Women setting forth to hill shrine on a feast-day.

of riding the distance, which the owners can secure ${ }^{1}$. A saddle or seat aid in any form is not allowed; the jockeys simply roll up their loose cotton trousers as high as they can, and clutch the pony's ribs with bare legs, and all carry long whips. The bridles, single snaffles with raw-hide reins, have each a round disc of burnished silver attached to the headband."

As already mentioned, China is the great market for Mongolian ponies. Just outside the Ta-ching Mên, "Great Frontier Gate," which affords ingress and egress through the

I C. W. Camplell, op. cit., pp. 36-38. 
Great Wall, is held the market. "Hither flock horse-dealers from as far south as Hunan, and ponies from Urga and the Kerulon. In Jume and July the horse trade is in full swing." The average price of a pony is twenty taels ${ }^{1}$.

As at the present day the Mongolian pony is the chief horse in China, so too was it in medieval, and we may therefore presume in still earlier, days. Marco Polo, speaking of the province of Carajan (the modern Yunnan), which then formed part of the dominions of the Great Khan, says that the country is one in which excellent horses are bred, and the people live by cattle and agriculture?. In another part of Carajan were "bred large and excellent horses, which are taken to India for sale, and you must know that the people dock two or three joints of the tail from their horses to prevent them flipping their riders, a thing which they consider very unseemly. They ride long like Frenchmen, and wear armour of boiled leather, and carry spears and shields and arblasts, and all their quarls are poisoned ${ }^{3}$." To this day the tribes of Honhi, in the extreme south of Yunnan, have plenty of horses, buffaloes, oxen, and sheep".

At what exact period the Chinese began to employ the horse is not certain. Horses are only twice mentioned in the Book of History (Shu Ching), but frequently in the Odes (Shih Ching). King $\mathrm{Mu}^{5}$, who visited the West about B.C. 975, travelled in a chariot drawn by eight horses. It would thus appear that in China, as elsewhere, the horse was first driven ${ }^{6}$. It is now clear that the thoroughbred horse has not come from any of the stocks which have ranged through Upper Asia and Upper Europe in historical times, and it will be just as easy to prove that it is not derived from any of the horses of Southern China, Further India, or the Malay Archipelago.

1 C. W. Campbell, op. cit., p. 8.

2 Vol. 11. p. 52.

3 Vol. rr. p. 63.

4 Vol. Ir. p. 101, Yule's note.

3 For this information I am indebted to the kinduess of my friend Prof. H. A. Giles. The Chinese profess to tell a horse's age by the teeth up to thirty-two years.

${ }_{6}^{6}$ At the funeral of Li Hung Chang a chariot and horses made of paper were burned. This probably is a survival from a time when a great man's chariot and horses would have been buried with him, just as his horses were buried with a Tartar khan and a Scythian king. 
The so-called China pony is commonly bred in and sent from Mongolia (including Manchuria) to China vica Tientsin ${ }^{1}$, and Darwin" has pointed out that to the "eastward of the Bay of Bengal over an enormous and humid area, in Ava, Pegu, Siam, the Malay Archipelago, the Loo Choo Islands, and a large part of China, no full-sized horse is found."

Passing down into Further India, we meet the Burmese or rather Shan ponies, for these useful animals are almost exclusively bred by the Shan tribes of the hills, since in the wide region extending from Rangoon to Mandalay there are $n o$ good native ponies. The Shan pony (sometimes also known as the Pegu pony) is about the same height as the Mongolian, from which he is certainly derived, though modified by other blood. $\mathrm{He}$ is a great weight carrier, and jumps well, but is slow.

Closely akin to the Shan pony are those of Manipur, but they " are smaller and smarter for their size." "These two kinds of ponies," says Captain Hayes, "appear to belong to a distinct breed, which seems to have no relationship with ponies of any other country except, possibly, those of Sumatra and Java." The reason for the probable connection between the last two and the first two breeds will shortly be made clear.

The Sumatra ponies (also called Battak or Deli ponies) are bred in the Battak range of hills in Sumatra, and are commonly exported to Singapore from the port of Deli. "They have handsome heads, set on to high-crested necks, are full of spirit, and are simply balls of muscle ${ }^{3}$." The Battak ponies have almost entirely lost their original type from frequent crossing with imported Arabs. The majority of them are brown, but many are skewbald, and their average height is about 11.3 hands, the best measuring from $12 \cdot 1$ to $12 \cdot 2$. One of the latter height, probably the fastest racing pony in Sumatra, was of a chestnut roan.

The Gayoe ponies come from the hills which stretch from the Battak mountains to the north end of Sumatra, and "are

1 Hayes, op. cit., p. 599 (ed. 3).

2 Variation of Animals and Plants, 1868, Vol. I. p. 53.

${ }^{3}$ Hayes, op. cit., pp. 632-3. 
much more sturdy in build than Battak ponies. They have heavy crests and good shoulders, similar to the latter breed, but their legs are shorter and thicker, and they are stronger behind. They are not nearly so fast nor so fiery as the Battaks." Captain Hayes" believes "that they have not been crossed nearly so much with foreign blood as the Battaks." How it comes that the Battaks have better blood than their neighbours is readily explained by the fact that some sixty years ago the sultans and princes of Achen kept high-caste Arabs and supplied the Battaks with Arab blood to improve their ponies, "the result being a blend which combines in almost perfect harmony the fire and the beauty of the Son of the Desert, with the hardiness and endurance of the Battak pony." The original colour of the unimproved Battak ponies is said to have been mouse-grey, with a black stripe down the back; skewbalds and piebalds are in the majority, although all other colours are met with except creams and greys. "Pure white ponies with red eyes (albinos) and without any marks, remain the property of the chief of the district, and cannot be obtained by purchase." But it would be rash to assume that "the original Battak pony," the type which existed before the intruduction of Arab blood sixty years ago, was free from all admixture of the latter, since it is more than probable that many centuries earlier Arab horses were imported into Sumatra and Java. And we shall find it also highly probable that the Shan and Manipur ponies owe their peculiar qualities and their resemblance to the Sumatran and Javanese ponies from their having a similar admixture of Arab blood, but in varying degree, as is the case with the Battak and Gayoe breeds.

The striped ponies of Java have been cited by Darwin as examples of primitive horses which still retain ancestral stripings. Mr Lydekker holds that because E. sivalensis of the Indian Pliocene is usually characterised by large first premolar teeth in the upper jaw, and as large functional premolars are found in some Javanese and Sulu ponies (as also in some zebras), lineal but somewhat modified descendants of $E$. sivalensis

1 Hayes, op. cit., pp. 633-6 (who also embodies notes from Mr Fitzwilliams and $\mathrm{Mr}$ Carl Maschmeyer). 
still survive; again, it has been long known that Hipparion had a deep fossa in front of the orbital bone, which is supposed to have lodged a gland. Prof. Huxley in 1870) indicated the existence of a rudimentary pre-orbital pit in the skull of Equus sivalensis, an Indian fossil species, and Dr Forsyth Major in 1880 pointed out the existence of a similar feature in Equus stenonis, the closely related species found in the Pliocene beds of the Val d'Amo and its somewhat later ally Equus quaggoides, and he also showed its existence in the Quagga (cf. p. 76); Mr Lydekker has recently direeted attention to the occurrence of what he considers "a vestige of the Hipparion's face-pit in the skull of an Indian domesticated horse in the collection of the British Museum," and to the occurrence of a similar depression in the skull of the well-known racer Bend Or, in which it is still shallower than in the Indian domesticated horse. "From the occurrence of the feature in question in these skulls, both of which probably belonged to horses of Eastern origin, and its entire absence in all the skulls of the prehistoric European horse," Mr Lydekker ${ }^{1}$ has suggested "that the blood-horse," unlike the "cold-blooded horse" of Western Europe, may possibly have been the descendant of Equus sivalensis. Mr Lydekker endeavours to meet the obvious objection that a similar rudimentary pit existed in the European $E$. stenonis by urging that "it had apparently disappeared in the Pleistocene horse of Western Europe" (cf. p. 470).

Mr Lydekker" has noted a like depression in the skull of a young ass in the British Museum, whilst Mr Pocock has pointed out a similar feature in the skull of a male Grant's zebra in the same collection ( $p .76)$; Mr Lydekker thus holds that the thoroughbred horse as well as the ponies of Java and Sulu are lineal descendants of $E$. sivalensis and Hipparion. It may be pointed out that the large functional premolars, on which he bases the relationship of the Javanese and Sulu ponies to $E$. sivalensis, are likewise found in some zebras, and that of the four species or sub-species of Equidae in which the pre-orbital depression oceurs three are undoubtedly of African 
origin, and that there is as yet no proof that either the "Indian domesticated horse" or Bend Or was of oriental lineage. In view therefore of the theories just stated, it is most important to ascertain as accurately as possible the history of the horses of the Indian Archipelago, of the Malay Peninsula, and of Hindustan.

When John Crawfurd ${ }^{1}$ wrote his admirable work on the Indian Archipelago in the beginning of the last century, in many of these islands the horse was still unknown. 'Cavalry,' he writes, "may be looked upon as a matter of pomp and luxury rather than as a useful arm of war. The great and their retainers are mounted upon horses, and in Java and Celebes they are numerous. The latter island in particular contains extensive plains, so unfrequent in the rest, where horse might be employed for the purposes of war with advantage. The horses of that island too are superior in size and strength to those of any other of the Archipelago, and the habit of following the chase on horseback makes the people bolder and more expert riders than are the rest of the tribes. The Javanese are very bad riders, and in many countries of the Archipelago the horse is nnknown altogether:" As the horse has been used for war by all peoples who have tamed him or long possessed him, this statement is sufficient to raise serious doubts respecting the antiquity of the horse even in Sumatra and Java, and we naturally seek for information from earlier sources. The spices for which the western islands of the Archipelago were the emporium had from an early period attracted thither the adventurous merchants of Arabia, who gradually began to establish themselves on the coasts and to propagate the faith of Islam. When the celebrated traveller Ibn Batuta ${ }^{2}$ of Tangiers visited Sumatra and Java in 1345 he found that, although the town of Sumatra was held by an Arab prince, the chief spice-growing parts of that island were still in the hands of the infidels. When he and the merchants that were

1 History of the Indian Archipelago by John Crawfurd, late British Resident at the court of the Sultan of Java (Edinburgh, 1820), Vol. I. pp. 229, 230.

2 Voyages d'Iln Batoutah (translated from the Arabic into French by C. Defremery and Br. Sanguinetti: Paris, 1853), Vol. Iv. pp. 230, 231. 
with him reached the roadstead of Sumatra, Bohruz, the viceadmiral, came on board and having questioned the merchants permitted them to land. 'The town of Sumatra was four miles from the port, and Bohruz wrote to the Sultan to tell of the arrival of Batuta and his fellows. "The latter ordered the Emir Daoulecah, accompanied by the noble Kadhi, Emir Sayyid of Shiraz, and Tadj Eddin of Ispahan and other lawyers to come meet me. They brought one of the Sultan's horses as well as others. I mounted on horseback and my companions did the same." Sumatra was a fine town recently fortified by a wooden stockade and wooden towers. The Sultan Almalic Azzhahir professed that form of orthodox Muhammadanism known as Shafi'y, and he surrounded himself with men learned in the Koran, and his subjects held the same tenets. As this is that one of the four orthodox forms of Islam which is now universal with minute exceptions in the Indian Archipelago and as it is also the prevalent doctrine of Arabia, particularly of the maritime portion of that country, it is clear that the traders who first introduced Islam into the Archipelago came direct from Arabia, and that too at a time when, as we shall soon see, great numbers of horses were being annually brought direct from Arabia and the Persian Gulf to southern as well as western India. From Sumatra our traveller passed to Java (termed by him Moule Djaouah), the entire population of which were infidels. He came to the court of a great sultan, whom he found sitting on the ground before his palace reviewing his troops, who were all on foot. "Nobody in the country has a horse, not even the Sultan'. The people ride elephants and fight from these animals." This Sultan and all his people were infidels, that is, they practised Hinduism. These very important passages render it certain that at this period there were no horses in Java, and hence the Javanese striped ponies cannot be regarded as a primitive stock; but as horses were found with Arabs in Sumatra, where that people

1 Voyages d'Ibn Batoutah, Vol. iv. p. 245. My friend Prof. Bevan has kindly pointed out to me that two texts give the reading "not even the Sultan," though others read "except the Sultan." But as the Sultan when reviewing his troops was not on horseback, but seated on the ground, it is most improbable that he had a horse. Transeribers and editors would naturally be inclined to assign a horse to the Sultan, even if no one else in the island had one.

1. H. 
had recently fortified a stronghold, it is reasonable to infer that the Arabs had already by 1345 brought horses from Arabia into Sumatra, and also that they were probably the first to introduce any horse into the Indian Islands. We can now readily understand why the Javanese are such poor horsemen, why the little Javanese ponies so closely resemble Arabs, and why none of the Indian Islanders, not even in Celebes, ever employed cavalry in war. Furthermore it is now clear that Arab horses had reached Sumatra some five centuries before their re-introduction some sixty years ago by the Sultan of Achen. Finally it is plain that the correspondence between the first premolars in the upper jaw of $E$. sivalensis, of the Javanese and Sulu ponies, and of the Grévy and Baringo zebras (p. 11), must find a different explanation from that hitherto offered.

It is probable that not only was the horse not indigenous in the Indian Archipelago, but that it was not introduced into those islands by the Malays, since they do not appear to have possessed the horse even on the mainland. It is very significant that there is no native Malay word for horse, kuda the ordinary term now in use being simply a Malay form of the Tamil loanword ghura ${ }^{1}$. This fact taken in connection with the complete absence of horses in all southern Burmah, whether indigenous or imported, renders it unlikely that any indigenous domesticated horse ever existed in the Malay Peninsula and the contiguous regions.

Coming to India itself, we are told by one of the greatest living authorities ${ }^{2}$ on the horse, that the native Indian horses are small, and to get speed they must constantly be crossed with Arab or English blood. The evidence of Mr Nelson for South India is especially striking, for speaking of the Madura country he says that "the horse is a miserable, weedy, and

1 I am indebted to my friend Mr W. W. Skeat, M.A., Christ's College, Cambridge, one of the best living authorities on everything Malay, for this information.

2 Hayes, op. cit., pp. 628-9. As these pages are passing through the press, I learn with sincere regret the death of Capt. Hayes, who was always ready most generously to impart his unrivalled first-hand knowledge of horses of all kinds and from all parts of the world. 
vicious pony, having but one good quality, endurance. The breed is not indigenous, but the result of constant importations, and a very limited amount of breeding." After hearing such testimony as this we need have no hesitation in accepting implicitly the statements of Marco Polo ${ }^{2}$ respecting horses in the same region. Speaking of South India he writes: "Here are no horses bred; and thus a great part of the wealth of the country is wasted in purchasing horses; I will tell you how. You must know that the merchants of Kis (Kishm), and Hormes (Ormuz), Dofar, Soer, and Aden collect great numbers of destriers and other horses, and these they bring to the territory of this king and of his four brothers, who are kings likewise, as I told you. For a horse will fetch among them 500 saggi of gold, worth more than 100 marks of silver, and vast numbers are sold there every year. Indeed this king wants to buy more than 2,000 horses every year, and so do his four brothers, who are kings likewise.

The reason why they want to buy so many horses every year is that by the end of the year there shall not be a 100 of them remaining, for they all die off. They bring these horses by sea, aboard ships."

Polo adds a very important statement: "another strange thing is that there is no possibility of breeding horses in this country, as hath often been proved by trial. For even when a great blood mare here has been covered by a great blood horse, the produce is nothing but a wretched wry-legged weed animal, not fit to ride."

A medieval Persian writer, in reference to the birth of an elephant at Teheran, declared "that never till then had a she elephant borne young in Iran, any more than a lioness in Rum, a tabby cat in China, or a mare in India."

In several other passages Polo gives full details of the trade between Arabia and southern India, which was carried on in ships built without any iron, being fastened together only by trenails and twine, made from the husk of the Indian nut",

1 The Hadura Country, Pt. Ir. p. 94.

2 Vol. Ir. pp. 325-6 (Ýule).

3 Jour. Asiatic Soc., Ser. 3, Vol. 1rr. p. 127 (cited in Yule's note to passage of Marco Polo just given).

4 Vol. r. p. 111. 
exactly like the ships of the same seas described by Procopius seven centuries earlier ${ }^{1}$. The city of Cail, on the coast of South India, was frequented by ships from the west bringing horses and other wares". Aden seems to have been the chief port in Arabia for the export of horses: "There are despatched from the port of Aden to India a very large number of Arab chargers, and palfreys, and stout nags adapted for all work, which are a source of great profit to those who export them. For horses fetch very high prices in India, there being none bred there, as I told you before; in so much that a charger will sell there for 100 marks of silver and more. On these the soldan of Aden receives heavy payments in port charges, so that it is said he is one of the richest princes in the world ${ }^{3}$."

Another very important port was Esher, which was subject to the soldan of Aden. "The people are Saracens. The place has a very good haven, wherefore many ships from India come thither with various cargoes; and they export many good chargers thence to India. All their cattle, including horses, oxen, and camels live upon small fish and nought else beside, for 'tis all they get to eat.".

Again, when speaking of Caltu (Kalhat, in Arabia) he says that "they export many good Arab horses from this to India, for as I have told you before, the number of horses exported from this and the other cities yearly to India is something astonishing." He adds here again the statement that horses were not bred in India, and also that the natives did not know how to treat them.

If the reader's scepticism is roused by the statement that the horses of Esher were fed on fish, it will be at once allayed when he remembers that at the present day in Kamtschatka the horses and cows in winter subsist entirely on dried salmon ${ }^{6}$ and that in Iceland the ponies are similarly fed on stock-fish.

1 Ridgeway, Early Age of Greece, Vol. I. p. 615.

2 Marco Polo, Vol. II. p. 357.

4 Vol. II. p. 439.

3 Vol. II. p. 434 (Yule).

o Guillemard, The Cruise of the Marehesa, p. 68 (ed. 2). 
Polo shows clearly that the chicf, if not the whole, supply of horses to southern India was derived from the Persian Gulf and Arabia Proper, a fact to be borne in mind when we come to deal with the Arab horses of the present day.

But it was not only southern India which imported horses, for western India, then as now, drew large supplies of these animals from the west. Speaking of Tana, which is the modem town of Thana, on the landward side of the island of Salsette, about twenty miles from Bombay, he says that it was "a great kingdom lying towards the west, and that the king protected corsairs, which plundered ships, and that he received as his share all horses captured on board ${ }^{1 . "}$

As in the present day Bombay draws its supply of horses principally from the Persian Gulf, so was it in earlier times, for Polo" states that "in this country of Persia there is a great supply of fine horses; and people take them to India for trade, for they are horses of great price, a single one being worth as much of their money as is equal to 200 livres Tournois; some will be more, some less, according to the quality. Here are also the finest asses in the world, one of them being worth full thirty marks of silver, for they are very large and fast, and acquire a capital amble. Dealers carry their horses to Kisi and Curmosa, two cities on the shores of the sea of India, and there they meet with merchants who take the horses on to India for sale."

Colonel Yule remarks that the horses here mentioned were probably the same class of 'Gulf Arabs' that are now carried thither, but he points out that the Turcoman horses bred in Persia are also very valuable, especially for cudurance, as we have already seen. Two hundred livres Tournois was equivalent to about $£ 193$ sterling.

But southern Persia had not been a home of horses from a very ancient period, for we have seen (p. 49) that in Carmania down to the time of Strabo, asses, on account of the scarcity of horses, were generally made use of in war, and that the Carmanians sacrificed asses to their war-god. Doubtless the maguificent Persian asses to which Polo refers were the

1 Vol. II. p. 385.

2 Vol. I. p. 84, with Yule's note. 
descendants of those on which the Carmanians once went to battle.

It is noteworthy that Marco Polo says nothing of the prices paid either for 'Turquans' or 'Tartar horses, or for those of Yunnan imported into India, though he repeatedly mentions the high prices paid for the horses from Arabia and the Persian Gulf. From this it may be justly inferred that the horses of Upper Asia, though very useful animals, were far inferior to the high-priced steeds from Aden and other western ports.

The evidence already given puts it beyond doubt that southern Hindustan has never possessed an indigenous breed of horses of any merit, the climate apparently being ill-adapted for the Equidae. The incessant mortality of imported Arab horses, and the speedy degeneration of the few native-bred horses, render it highly improbable that there is in them any primeval strain derived from E. sivalensis. If there really exists such a stock, it is strange that it does not thrive and multiply in India as do the zebras in tropical Africa.

After the evidence respecting the native country-bred horses of southern and central India, it is difficult to believe that the Arab race, from which the horse Bend Or. was sprung, has been derived from that part at least of the Indian peninsula. It is also clear that in the thirteenth century vast numbers of the best Arabs were shipped direct to southern India, and also to Bombay and the surrounding regions.

These facts will be of considerable importance when we come to deal with certain characteristics not only of the horses of Kattywar and Tibet, but also of the ponies of Java and Sumatra, with which the Arabs traded at an early date, for it has been shown that those adventurous merchants reached not only south India and Ceylon, but exercised much influence in the great islands of the Indian Archipelago.

But though southern and western Hindustan were not well adapted for the rearing of horses, and had always to depend largely on importation, it is otherwise with the northwestern and northern regions. The Aryans of the Rig-Veda were keepers and breeders of horses, which, like their brethren 
whom they left behind in their old home in Upper Europe, they did not ride, but yoked in pairs to chariots. Only once do we hear of the riding of horses in the Rig-Veda ${ }^{1}$, and then it is described in such a way as to indicate that it was exceptional. Probably the horse and chariot were only used for war, as they certainly also possessed the ox-cart, for the red streaks which herald the dawn are described as the cows that draw her waggon. Again, like their brethren in Europe, the Vedic Aryans habitually sacrificed horses to their gods".

The Vedic hymus furnish us with data respecting not only the colour of the horses, but even perhaps their anatomy. The horse normally has eighteen ribs, though occasionally, according to Youatt, nineteen are found, the additional one being always the posterior rib $^{3}$. It is a remarkable fact that the horse is said in the Rig-Veda to have only seventeen ribs", and so great an authority as V. Piètrement ${ }^{5}$ argues that this statement is trustworthy, since in early days the Hindus carefully counted the bones of animals. Yet we must not overlook the circumstance that the ancient Hindu commentators on the Veda knew that a horse has thirty-six ribs ${ }^{6}$.

We have already seen that in the leg of the horses of Solutré (p. 84) the metacarpal and metatarsal vestigial bones were not united to the main bone, as is the case with modern horses, whilst an additional bone in the hock, and certain abnormal appearances between the tibia and astragalus, are quite common in Irish horses, and not due to disease? Again,

1 v. 61-2.

${ }^{2}$ R. V. 1. 162, is a hymn for such a sacrifice.

3 Darwin, Variation of Animals and Plants (2nd ed. 1875), 1. p. 75.

${ }^{4} R$. V. 1. 162, 18: cátustrinșad vājíno devábandhor ván̄krīx ásvasya sváditih sám eti.

5 Mémoires sur les Chevaux, ì trente-quatre côtes, 1871; Les Chevaux dans les temps préhistoriques et historiques (1883), pp. $223 \mathrm{sqq}$.

${ }^{6}$ Ludwig (Rig-Veda, Bd. III. p. 186) thinks that the passage is astronomical (the 34 ribs=sun, moon and 5 planets +27 nakshatras, and he compares the Aitareya Brahmana, 11. 6, 15-a formula recited at the slaughter of other animals. Here we read of 26 ribs, which according to Ludwig means 26 half-months $=12$ months +1 intercalary month.

7 Darwin, Variation of Animals and Plants, 1. p. 52. Prof. Ewart writes to me: "in modern horses living in natural conditions, such as moor and mountain ponies, the second and fourth metacarpals and metatarsals are not as far as my experience goes united to the middle metacarpal and metatarsal." 
Darwin ${ }^{1}$ has shown that instances of horses having hornlike projections are not uncommon. Azara ${ }^{2}$ has described two cases in South America in which the projections were between three and four inches in length, whilst other examples have occurred in Spain and England. It is quite possible that the statement of Megasthenes ${ }^{3}$ that in Asia there were horses with horns may have been based on like abnormalities.

The Vedic horses are called red (arushas), dun (haritas), and ruddy (rohitas), and as all these epithets seem to be applied to the same horses ${ }^{4}$ the animals so described had probably ruddy heads and backs, shading off into dun on the lower parts of the body, as is the case with Prejvalsky's horse.

From the muster-roll of Xerxes' army (в.c. 480) we learn that though the tribes of north-west and western India still employed chariots, they had now also horsemen in considerable numbers, "some of the Indians rode on horseback, some in chariots drawn either by horses or wild asses.". The chariots drawn by asses probably came from western India, whilst those drawn by horses and the cavalry came from the nortl-west. This gets support from the fact that the same list tells us that the Bactrians, who occupied the modern Afghanistan, furnished horsemen, but not chariots ${ }^{6}$.

By the time of Alexander the people of the Panjab mainly relied upon their cavalry, although still keeping a limited number of chariots, for the army with which Porus, the Indian king, attempted to stay the conqueror's advance was composed of 4,000 cavalry, about 300 chariots, 200 elephants, and a very large force of infantry ${ }^{7}$. About 300 horsemen were slain, and all the chariots were broken in pieces ${ }^{8}$.

According to Aelian" "the Indians regard the horse and the elephant as being most valuable in war, and therefore honour them especially. The king takes particular care to

1 Op. cit., I. pp. 52-3.

2 Nat. Hist. of the Quadrupeds of Paraguay (trans. by W. Perceval Hunter), pp. 30-1. There is at present a horned thoroughbred near York, and Mr A. Day has a similar animal (Sporting Times, 4 Mar. 1905).
3 Cited by Strabo, 710.
+ R. V. I. 14, 12.
5 Herod, vir. 84.
6 Ibial.
7 Arrian, Anab. v. 15, 4.
8 Id. v. 18, 2.
9 An. xn11. 25. 
see that the keepers of his elephants and his grooms provide good provender for these animals. If they do not, he punishes them very severely." The same writer ${ }^{2}$ says that the Indian horses were very diffieult to ride save for those trained to do so from boyhood, and beeause their mouths were hard it was customary to control and guide them not with a bit but with perforated muzzles. As will presently be made clear, the untractable temper of the Indian horses at this period is sufficient of itself to show that they were Upper Asiatic and neither Arabian in origin nor themselves the souree of the Arab race.

The evidence just adduced renders it certain that India as a whole has never been able to breed horses in any numbers of good quality ${ }^{2}$, and it is equally certain that in the thirteenth century A.D., and we know not how long previously, two separate breeds of horses kept steadily streaming into Hindustan-the Mongolian from the Himalayas, and the Arab and its derivatives from Arabia and the Persian Gulf; it has also been shown that the modern ponies of Bhotan, Nepal, and Spiti may be safely considered as in the main Mongolian, whilst we shall soon find that various breeds of trans-Indus horses, which are largely used in India, and which do not stand heat as well as the 'country-breds' (mainly of Arab strain, as we have just seen), are merely Mongolian ponies modified by Arab blood. These considerations, when taken along with the description of the Vedic horses just eited, put it beyond doubt that the chariots of the Aryan conquerors of the Panjab were drawn by horses of the Mongolian, i.e. Upper Asiatic, stoek.

From the facts cited it is clear that there has been a continual blending of the Mongolian and Arab blood all across Hindustan, especially in the northern area, and accordingly

1 op. cit. xir. 9.

2 Prof. Ewart has sent me the following extract from a letter from an Indian chief in the Bombay Presidency dated May 1901: "My danghter has two Shetland pony mares: one of them foaled after her arrival, six years ago. That foal is alive and in good health. Since then both the mares have foaled regularly every year to a stallion that was imported with them, but none of the foals live more than a month." 
some at least of the distinguishing features of various breeds may be ascribed to the mixing of the two stocks, and this may be done with still greater safety when these characteristics are the same as those found in horses which without doubt are the result of crossing the two stocks. We have just seen that in Sumatra the crossing of the old breed of ponies with Arab blood has produced piebalds and skewbalds, and perhaps a black dorsal band. Tibet has long been noted for its richly marked horses (commonly called tangums from the Tangustan mountains of Bhotan), piebald, skewbald, and striped, frequently with white legs and marked with such large clouds of bay that two or three spread over the whole body, head, and neck, the head being generally included in the bay colour, and when it comes down over the shoulder and the thigh that colour deepening into black (Fig. 56): there is also a proportion of black and white in the mane and tail, and not unfrequently black edging on the ears, whilst the callosities are scarcely perceptible on the hind legs ${ }^{1}$. From the fact that Father Georgi had seen these horses apparently in a wild state on the northern declivities of the Himalayan range, and that d'Hobsonville had also seen such animals (which he describes as below 10 hands in height, and in their winter dress covered with long hair and marked symmetrically with spots), and from the fact that another account referred to wild spotted horses about Nipchow in Eastern Tartary, about the size of asses but more compact and handsome, Colonel Hamilton Smith was led " to believe that these tangums, as they are called in India, are a primeval stock from which are derived not only the great proportion of pied horses all over China, and even so far south as the Indian Archipelago," but even the steeds of the Centaurs, from which sprung the Thessalian breed in Greece, and the Borghese piebald breed of Italy. But the wild horses seen by Father Georgi, d'Hobsonville, Moorcroft, and others, were undoubtedly either feral or merely half-wild ponies turned out on the mountains, whilst we have just seen that the pied ponies of Sumatra and Java are merely a modern outcome from blending

1 Hamilton Smith, The Horse, pp. 289-92. 
Arab with native blood, itself already largely of Arabian origin. Furthermore, piebalds and skewbalds are not at all uncommon amongst Indian country-breds, which, as we have seen, are the outcome of crossing the Upper Asiatic horse with the Arab, and on such the trumpeters of the native cavalry regiments are usually mounted. As there is no question of the large

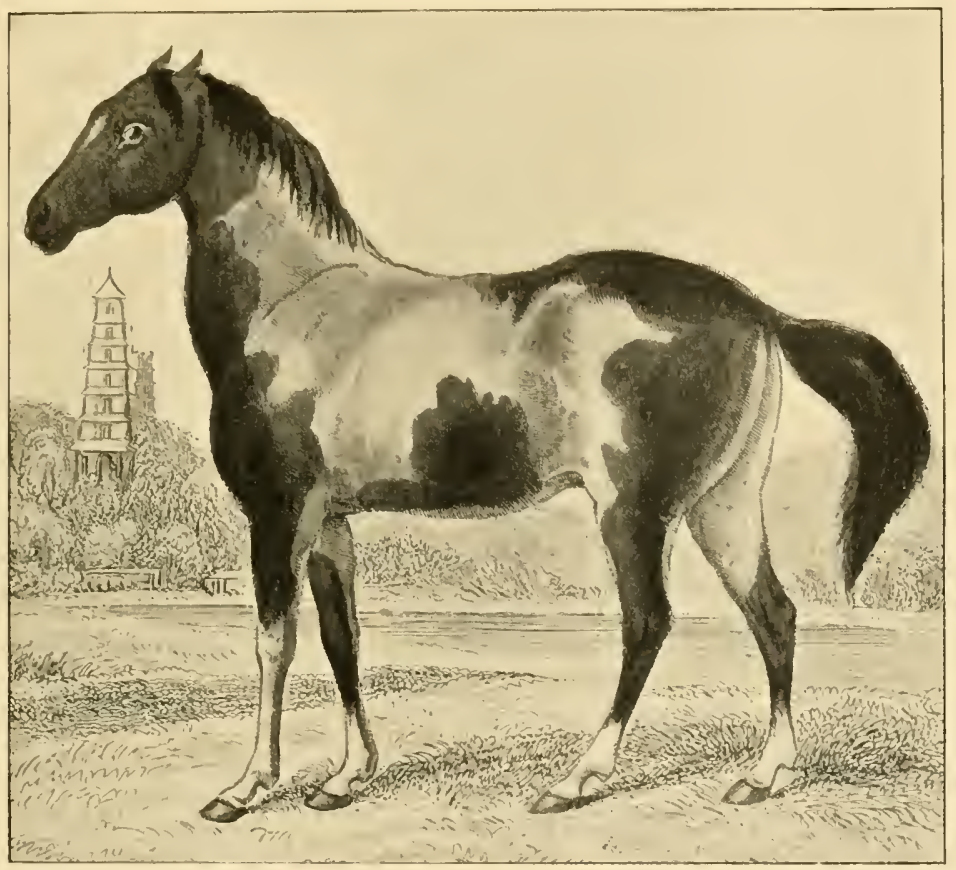

FIG. 56. Tangum of Tibet.

amount of Arabian blood in such animals, just as in the ponies of Java, we are all the more justified in ascribing the existence of piebalds amongst the tangums of Tibet to a similar blending of the Mongolian and Arabian stocks. It has also to be borne in mind that the Arab stands the heat in India far better than the horses from the north, a circumstance which renders it all the more likely that in country-bred Indian horses it is largely the Arabian element which survives in a far greater degree than the Upper Asiatic. 
According to a recent traveller ${ }^{1}$ the best Tibetan ponies are creamy fawn-coloured, i.e. yellow-dun. "Many of the fawn coloured Thibetan ponies are brindled, but none of the many I have seen were marked so fully as an exceptionally fine pony bought in Bhotan from a Thibetan merchant. It had a black stripe down the spine; the tips of the ears, nose, and tip of the tail were black, and it had broad black stripes over the shoulders, flanks and legs, and dappled spots over the haunches."

We may here point out that the black colour often seen in the coats of Tibetan ponies is also found in Turcoman horses, which are the result of crossing Mongolian ponies with Arab blood, and that the fawn-colour with stripes of the typical Tibetan pony recalls the mouse-grey with dorsal stripe, the colour of the old Battak ponies of Sumatra, which, as has been shown (p. 142), were largely Arab in origin, whilst, with reference to the bay colour and the stripes so frequently found in the Tibetan ponies, we shall presently have something to say. The very small size of the hock callosities is of the highest importance in view of the fact that the same callosities are frequently reduced in size in the case of the typical piebald and skewbald ponies of Iceland, the Faroes, and in the other ponies classed by Professor Ewart as 'Celtic' and the further circumstance that many North African horses also lack these hock callosities.

On the whole the balance of probability is in favour of the piebald colour of the tangums of Tibet being due to the crossing of the Mongolian and Arab stocks, as seems certainly the case with the piebalds of Sumatra.

Amongst the 'country-bred' horses of India, those of Kathiwar hold a prominent position. They are lightly built, the body being very long compared to its depth, but often with good shoulders, good forearms and gaskins, and with good bone below the knee, and they are capable of great endurance. The Kathiwar horses are usually of a rufous grey or khaki colour, and at one time they were not considered well bred unless they had a dorsal band and stripes across the legs. 
Sometimes in addition there were stripes on the neck, forehead and withers. "There are sometimes stripes on the grey and bay Kattywars when first foaled, but they soon fade away."

According to Major-General Tweedie 2 the "comparatively uncrossed breeds of horses, mostly dun, or slate-coloured, which still exist in several remote provinces of India, especially Kathiawar, are remarkable for their hardy constitutions, power of endurance, and indomitable tempers," and he mentions among other characteristics their tendency to stripes, and to long ears with their points much turned inward.

As Darwin adduced the striped Kathiwar horses as typical examples of the primitive dun-coloured striped animal from which all our domestic breeds have come, and as a stuffed dun Kathiwar horse with stripes is exhibited in the National Nuseum of Zoology to illustrate this doctrine, it is very important to ascertain, whether the Kathiwar horses are an indigenous uncrossed breed, or if not indigenous an uncrossed breed derived from some other region, or whether they are only a mixed breed of modern formation. If it should turn out that they are neither indigenous nor uncrossed, the argument founded on them by Darwin and sueceeding writers will lose its validity.

We have just seen that of the peoples from the frontiers of western India, who furnished contingents to Xerxes' army in 480 B.C., the Bactrians supplied horsemen, the Indians chariots drawn either by horses or by 'wild asses.' From this it follows that in some of the countries subject to the Persian king and which bordered on India, horses were scarce and accordingly asses were used instead. As we have already seen (p. 49), the people of Carmania, that is the eastern portion of the modern Persia and the western part of Baluchistan, through want of horses still continued to use asses in warfare down to the time of Christ. Now in view of the fact that the Bactrians (who occupied the modern Afghanistan) supplied cavalry and that the Vedic Indians who lived on the upper Indus had chariots and horses, and that the Indians of that region were amply

1 Darwin, Variation of Animals and Plants, Vol. I. p. 61.

2 The Arabian IIorse, p. 266. 
provided with horsemen and chariots drawn by horses at the time of Alexander's invasion, it is clear that the Indians who furnished Xerxes with chariots drawn by wild asses were either the tribes from the western side of the Indus, who dwelt in what is now Baluchistan and eastern Persia, or else from the peoples of the eastern bank of that river, who dwelt in what is now Cutch, Kathiwar and Baroda. But, though Cutch is still the stronghold of the wild ass, yet as we have seen that all the region round Bombay was supplied with horses from the Persian Gulf and Arabia in the thirteenth century A.D. and we know not how long before, it is most improbable that the horse was indigenous in Cutch or Kathiwar. On the other hand there is the clearest historical evidence that by the Christian era great numbers of the yellow-dun horses of upper Asia and Europe had been brought into all the regions lying on the east bank of the lower Indus.

We saw that the Scythians had been keepers of horses from a remote period and that these horses were probably of the same stock as the Mongolian pony of morlern times, and that the wild horses of the Caspian steppes were probably of a light dun colour. Along the ancient highway which led from the Caspian region up the Oxus valley, the Scythian tribe of Sacae forced their way into Bactria (Afghanistan) in the second century B.c., and ultimately overthrew the Greeks who had ruled that region from the time of Alexander. The Scythians then carried their arms across the Hindu Kush, and subdued all the territory previously under Greek doninion extending down the valley of the Indus to the sea. Though these Scythians had been expelled before the time of the Periplus of the Erythraean Sea, and the country was then subject to the Parthian king, the name had survived, and it is accordingly called Scythia in that treatise, as indeed it was long after in the days of Ptolemy (120 A.D.), who more distinctly terms it Indo-Scythia. This comprised the whole region adjoining the lower course of the Indus now known as Scinde, together with Cutch, Kathiwar, and Gujerat ${ }^{1}$. As it is incredible that the Scythians would have 
discarded their horses and invaded Bactria and India on foot, it follows that in the century before the Christian era many horses from the Caspian steppes had made their way into Kathiwar and the contignous regions. It is not then surprising to find light dum horses in that area. But, as we know from Marco Polo, that vast numbers of horses were imported from the Persian Gulf and Arabia to Bombay and the surrounding region, and as we have repeatedly seen that Turcomans, Mongols, Malays, and Hindus are ever eager to improve their native breeds by crossing them with Arab blood, there can be no doubt that the Kathiwar horse is a cross between the duncoloured horse of upper Asia and the Arab, and the better bred they are, the more of the latter blood there is in their veins.

As it is absolutely certain that the native horses of Kathiwar have been long saturated with the blood of Arab horses, which have been continually introduced, it is important to notice that in addition to the dun colour which we habitually associate with the Mongolian pony, we here meet both rufous, grey, and bay horses, all of which show a great tendency to dorsal and other stripes, as is the case with ponies of Sumatra also saturated with Arab blood, and likewise with the tangums of Tibet. In view of these facts it would indeed be rash to assume that "the Indian domesticated horse" with a preorbital depression was of an indigenous stock and not rather like all the comtry-bred Indian horses, of which we have any evidence, a blend of the Mongolian pony and the Arab. But as Bend Or, the racer of Arab lineage, had a similar depression, and all the evidence shows that the Arab has not been derived from Hindustan, we must look for the source of Mr Lydekker's "domesticated Indian horse" and Bend Or in some region farther west, and to this point I shall return (p. 470).

According to Captain Hayes ${ }^{1}$ the horses of Cabul, Baluchistan, and other trans-Indus horses, "which are largely used in India, and which, though stonter and shorter on the leg, are neither as smart nor as hardy in hot climates as the 'comtry-bred,' may be considered as intermediate between 
the East Indian horse and the Mongolian pony." In other words, as the 'country-bred' horses of India are almost mainly of Arab blood, the Cabuli, Baluchi, and other horses referred to, are cross-breds between the Mongolian pony and the Arab. The horses of the Waziris of Afghanistan are said to be not uncommonly decorated with stripes on the legs, but to this point we shall return later on.

Let us now briefly survey the chief breeds of western Asia, south of the great mountain chain. The common horses of Persia are, as already remarked, Turcomans mixed more or less with older breeds, which in their turn were, as we shall see, derived from the same stock as the Turcoman. But the Turcoman horses have been, and are being, modified by Arab blood, and the further west we advance the more is this the case, for in the provinces which lie close to Arabia are found pure-bred, or nearly pure-bred, Arabs.

The Turk, or Turkish horse, is sprung from the old Turcoman, identical with the Mongolian horse of upper Asia, but the stock has for many centuries been so saturated with Arab blood that it possesses the docility and the beauty of the latter, yet without its vigour and endurance, whilst from the Turcoman blood arises a teudency to Roman-nosed chaffrons and ewe neck, but the head is well set on. The Turkish horse is chiefly found in Anatolia, and only to a limited extent in Turkey in Europe.

The most typical indigenous horses in Turkey at the present day are those bred on the plains near Sivas, and which are termed Kurdistan ponies. The mares are crossed with Arab stallions, and produce the ordinary horses used in 'Turkish towns ${ }^{1}$. The ponies properly come from the province of Kurdistan in western Persia, and are therefore from the same upper Asiatic stock as the Turcoman. They are hardy little animals, usually 14 to 14.2 hauds high. They have, commonly, coarse heads, thick necks, short bodies, and good bone, especially below the knees, and are very hardy and enduring. They are usually grey or bay", but according to General Tweedie ${ }^{3}$ "sooty

${ }^{1}$ Hayes, Points of the Horse (ed. 3), p. $603 . \quad{ }^{2} I d . p .608$.

3 The Arabian Horse, p. 261. 
blacks prevail in the vulgar stock of the pastoral and agricultural Kurds round Kar-kuk and Mosul."

Advancing westwards from Persia, it is in the region of I'râk, the ancient Babylonia, on the eastern side of the Tigris, that we first meet with Arabs and Arab horses, the capitals of this district being Bagdad and Bussorah; next in the region between the Tigris and the Euphrates-the ancient Mesopotamia-we meet the great Shammar tribes; then crossing the Euphrates into the region called Shamiya by the Arabs, the Palmyrene or Syrian desert by Europeans, we reach the powerful Anazah tribes, the great hereditary enemies of the Shammar. Both these tribes have migrated into their present territories from central Arabia, probably owing to lack of food at home. There seems to be no doubt that the Anazah, who are said by Lady Anne Bluut to be to the Shammar as 7 to 3 , were the first to migrate from Najd. This great nation, composed of many of the wealthiest and most powerful tribes in the peninsula, at an early time became masters of a great part of central Arabia, acquired the rights of pasture throughout all Najd, and possessed the pahm-trees in certain districts and many of the most important wells. At the present moment the breeding of the best horses seems practically confined to the two great rival nations, but by common consent of both Bedouins and Europeans the Anazah have the best horses.

We must, before proceeding further, define what is meant by an Arabian horse, and it will then be clear that the true Arab horses form but a small proportion of those bred and used even in Arabia itself, and of those exported as 'Arabs' to India, Syria, Egypt, and Constantinople. Writers on the history of the horse have long since recognised three kinds of horses in Arabia. Youatt, for example, states that there are "three breeds or varieties of Arabian horses: the Atteschi, or inferior breed, on which the natives set little value, and which are found wild in some parts of the desert; the Kadischi, literally horses of an unknown race, answering to our halfbred horses-a mixed breed; and the Kochlani, horses whose genealogy, according to the modern exaggerated accounts, has been cultivated during two thousand years. Many written

R. II. 
and attested pedigrees extend, with true Eastern exaggeration, to the stud of Solomon"."

'Though, as we shall see, there are many inaccuracies in this statement, it will be found that its main proposition is true. Down to a quarter of a century ago all that was known at first-hand about the history of the Arabian horses was derived from the writings of Niebuhr, Burckhardt, and Palgrave, the former of whom had never visited the great horse-breeding tribes of Arabia, whilst the last-mentioned took but little interest in the horses of the region through which he travelled. Fortunately since 1876 several most competent observers, whose chief interest was centred in the horse, have travelled or lived in various parts of the wide region occupied by the Arab tribes, and have published invaluable accounts of the horse based on their own first-hand knowledge.

The late Major Upton ${ }^{2}$, who in 1876, after visiting the Sebáa, Maoli, and other tribes, published, to use the words of Mr W. Scawen Blmt, "an exceedingly good account" of Arabian horses. Next, Mr W. S. and Lady Anne Blunt ${ }^{3}$ published in 1879 an account of the Bedouin tribes of northern Arabia and the horses bred by them, and in 1881 a diary of a second journey made into central Arabia ${ }^{4}$. In the same year appeared a posthumous work by Major Upton ${ }^{5}$; whilst thirteen years later was issued the sumptuous volume of Major-General Tweedie ${ }^{6}$, who, having been for many years the British Consul-General at Bagdad, had exceptional opportunities for collecting information, and for checking and criticising the observations of his predecessors, a task which he performed vigorously whenever occasion offered.

The following description of the Arabian horses has been compiled from a careful comparison of the facts collected by the writers named, and as they are practically agreed on all main questions, though differing in their theories of the origin

1 The Horse, pp. 22-3 (ed. 4).

2 Frazer's Magazine, Sept. 1876.

3 The Belouin Tribes of the Euphrates (1879).

* d Pilgrimage to Nejal (1881).

5 Gleanings fromi the Desert of Arabia (1881).

"The Arabian Horse, his Country and People (1894). 
of the Arabian horse and in various numportant details, we may assume that all facts of vital importance relating to the various breeds and strains, form and colour, as well as the native traditions respecting their history, are now accurately ascertained.

With reference to the three classes just enumerated Upton writes ${ }^{1}$ : "That there are three such distinct breeds or classes of Arabian horses is an erroneous opinion, but there is some ground for the supposition, which is this: in Syria and some other districts, and in towns near the coast, are to be found three kinds of horses-the Arabian, not as a native, but as a horse of lnxury; the Kidish, which class has no pretension to being an improved breed, and is not of Arab blood at all. Kidish means first a gelding, and the term is applied to any common sort of horse used for travelling or baggage, from the fact that many of this kind are geldings, and some of this sort are runners or pacers, and are used by merchants and other classes of townsmen as hacks. And there is another class well described as 'sons of horses' in Syria. They are not genuine horses, i.e., Arabian horses; they may be, and often are, the produce of Arabian horses from common mares, be they Kurdish or Turcoman; they are the sons of horses, but not the sons of mares, i.e., of Arabian mares. Many of these 'sons of horses' show much blood, and I have seen less bloodlike horses passing as Arabs in India. Considerable numbers of this class are bought up in Syria by agents from Egypt and elsewhere, who give rather a better price than the 'Turkish government allows for remounts for the cavalry service; and on horses of this class the cavalry of the army corps of Syria, which is the best horsed, is generally monnted."

Upton thus recognised (1) true Arabian horses, (2) common Turkish and Kurdish horses, which are frequently geldings, and (3) half-breds, the offspring of the two first classes, and his statements are confirmed by the other writers. Mr Blunt ${ }^{2}$ amply confirms Upton's statement respecting the Kadish or common 'Turcoman and Kurdish ponies, for he points out

1 Gleanings from the Desert of Arabia (London, Kegan Paul, 1881), p. 270.

2The Bedouin Tribes of the Euphrates, Vol. II. p. 246. 
that descendants of horses, "members perhaps of other original stocks, those of the Russian steppes or of Central Asia, are found still existing in the shape of stout ponies all along the northern edge of the desert-animals disowned by the Bedouins as not being horses at all, yet serviceable for pack-work, and useful in their way. This Chaldean type, from whatever source it springs, stands in direct contrast to that of the true Arabian. It is large-headed, heavy-necked, straightshouldered, and high on the legs-a lumbering, clumsy beast, fit rather for draught, if it were large enough, than for riding." According to Major-General Tweedie", "for the simple water-wheels and antediluvian wooden ploughs of the cultivating classes when horse-power is used, and not mules or hurned cattle, it is in the form of nondescript ponies, coming, like the loads carried by them, from the four points of the compass, and called in Arabia kudush (pl. of ka-dish)." Major-General Tweedie ${ }^{2}$ likewise substantiates Upton's third class-the 'sons of horses' - for he says that "the only animals that we have ever heard called by their sire's family name in the desert have been those which the Bedouins describe as not 'horses,' but 'sons of horses'-that is, got by a first-class sire out of an inferior mare."

Accorling to Upton "among the tribes of the deserts of Arabia the Arabian is the only horse. $\mathrm{He}$ is one by himself. The tribes of the interior desert have the best horses"." " $\mathrm{Al}$ though of Arabia alone the Arabian horse may be said to belong rather to certain families or tribes in the desert of Arabia than to the country or people at large." 'The best horses are not numerous in Arabia, certainly not in proportion to the size and extent of the country. In the Hijaz (the narrow strip of country along the Red Sea), and in Yaman there are but few horses, and in Mecca itself these animals are very few in number, the merchants contenting themselves with mules and Kadishes (horses of the common kind). The few true 'Arabs' at Mecca are purchased from the neighbouring Bedouin. Similarly at Medineh (in Burckhardt's time) there
1 The drabian Horse, p. 22.
2 op. cit. p. 231.
3 Op. cit. p. 270. 
were no good horses except those of the sheikh and his followers. The Bedouin, in the Hijaz, are very poor in horses, a few sheikhs only having any, but those near Medineh have nore. Upton shows that the statement that wild horses are found in the deserts is completely fallacious ${ }^{1}$.

There is but one breed of the true Arabian-that termed Kohl, so called from lohl, antimony, because the skin not only on the face but all over the body has the blue-black tint of the human skin when dyed with that mineral, so largely used by Eastern women to enhance their charms. From lohl come the derivatives kheilan and lieheilet, the generic names for the horse and mare of this breed respectively. Mr Blunt ${ }^{2}$ gives the same derivation for the name of the breed, only he explains it as arising from "the black marks which certain Arabian horses have round their eyes"; marks which give them the appearance of being painted with kohl, after the fashion of the Arabian women, an explanation rejected by Major-General Tweedie", who refers the name to the fact that "in this breed, especially in white and grey horses, the skin is characterised by a dark blue tinge which appears through the hairy covering."

All existing true-bred 'Arabs,' i.e., horses of the Kohl breed, are descended from one or more of the strains known as Al Khamseh, The Five. But the origin of the 'Five' it is not so easy to determine. According to a common Arab statement they are the five stocks descended from five out of the seven mares owned by Muhammad, on which the Prophet and his first four successors-Abubekr, Omar, Atman, and Alifled from Necea to Hedineh on the night of the Hejira, and which were specially blessed by their master. This, however, seems to be nothing more than a late invention of townsmen, for Upton ${ }^{4}$ states that in the desert he never heard of Muhammad's mares, nor was his name ever mentioned in any way as connected with the Arabian horse.

Another story fashionable amongst the Arab horse-dealers of Bussorah and Bombay is that all pure-bred Arabs are descended from certain mares of King Solomon, who, being

1 op. cit. p. 273.

3 The Arabian Horse, p. 233.

2 The Bedouin Tribes, etc., pp. 266-7.

+ Op. cit., p. 280. 
a great lover of horses, was one day so absorbed in his stud that he forgot to say his prayers. Stung by remorse for this omission he turned loose his horses all over the country, whereupon six of the best mares were selected by six individuals, and kept for breeding purposes. Major-General Tweedie ${ }^{1}$ has shown that this is a mere modem perversion of a passage in one of Muhammad's homilies, in which the Prophet, to admonish his hearers, brought in a fragment narrating how once upon a time the great and pions King Solomon, absorbed in admiration of his mares, omitted his evening prayer, and afterwards, when his conscience pricked him, sacrificed his four-footed idols.

The other tradition, and that held by all the Bedouin tribes, is that the Five families in Al Khamseh are all descended from one particular mare, called Keheilet Ajuz, "the Mare of the Old Woman2." Tweedie writes ${ }^{3}$ that "cluring a long residence in El I'râk and on many journeys we have made constant inquiry on this subject from the Bedouin. One undeviating answer has been given on two points: first, that every noble strain in the Arabian desert goes back to the Ku-hai-la of the old woman; and further, that it does so through one or other of the lines which constitute AL KHAM-SA." The birth of the Keheilet Ajuz was on this wise. An Arab flying before his foes made a short halt, whereupon his mare gave birth to a filly foal. Forced to press on he abandoned the foal. When he once more stopped to rest his mare, to his surprise the foal soon made its appearance, having stoutly followed her mother's tracks. He placed the foal in charge of an old woman, who reared her, and hence arose her name.

Some have supposed that the names of the five different strains are merely the invention of modern horse-dealers to impose on the credulity of Englishmen in India. "It is difficult to give more than a guess," says Mr Blunt, "as to the antiquity of the names now in use. The five breeds known as the Khamsa are not possessed by the tribes of Northern Africa; and it is therefore probable, that at the

3 Op. cit., pp. 227-8.

2 Upton, op. cit., p. 280.

3 Op. cit., p. 234. 
time of the first Arabian conquest, in the seventh and eighth centuries of our era, they had not yet become distinguished from the general stock. The Emir (Abdul Kadir), however, does not donbt of their extreme antiquity, and I think it is certain that the Keheîlans must have been contemporary with Mahomet; for a breed called Koklani exists in Persia, and we may fairly suppose it to have been brought there by the early Arabian invaders. It has not, however, been kept pure in Persia." I hope presently to make it probable that at least one of the strains goes back to the days before the Prophet.

In modern times Carsten Niebuhr ${ }^{1}$ (not to be confounded with his son B. G. Niebuhr the illustrious historian) seems to be the first who refers to the various strains of the Keheilan race, denominated by him as Kochlani, and which are contrasted by him with the Kadishes, or town horses of the peninsula. "The Kochlani," he says, "are reserved for riding solely. They are said to derive their origin from King Solomon's stud. However this may be they are fit to bear the greatest fatignes....... The Kochlani are neither large nor handsome, but amazingly swift; it is not for their figure, but for their velocity and other good qualities that Arabians esteem them.

"The Kochlani are chiefly bred by the Bedouins settled between Basra, Merdin, and Syria, in which countries the nobility never choose to ride horses of any other race. The whole race is divided into several families, each of which has its proper name; that of Dsjulfa seems to be the most numerous. Some of these families have a higher reputation than others, on account of their more ancient and uncontaminated nobility. Although it is known by experience that the Kochlani are often inferior to the Kadischi, yet the mares at least of the former are always preferred in the hopes of a fine progeny. The Arabians have indeed no tables of genealogy to prove the descent of their Kochlani; yet they are sure of the legitimacy of the progeny; for a mare of this

1 “Description de l'Arabie d'après les observations et recherches faites dans le pays même par M. Niebuhr," Copenhagen (1773), Vol. I. pp. 142-4, Euglish transl. Cited by Blunt, The Bedouin Tribes of the Euphrates, Vol. II. pp. 25, 267-9. 
race is never covered unless in the presence of witnesses, who must be Arabians. This people do not indeed always stickle at perjury; but in a case of such serious importance they are careful to deal conscientiously. There is no instance of false testimony given in respect to the descent of a horse. Every Arabian is persuaded that himself and his whole family would be ruined if he should prevaricate in giving his oath in an affair of such consequence. The Arabians make no scruple of selling their Kochlani stallions like other horses; but they are unwilling to part with their mares for money. When not in a condition to support them, they dispose of them to others on the terms of having a share in the foals, or of being at liberty to recover them after a certain time.".

"These Kochlani are much like the old Arabian nobility, the dignity of whose birth is held in no estimation unless in their own country. These horses are little valued by the Turks. Their country being more fertile, better watered, and less level, swift horses are less necessary to them than to the Arabians. They prefer large horses, who have a stately appearance when sumptuously harnessed. It should seem that there are also Kochlani in Hedsjas, and in the country of Dsjof; but I doubt if they be in estimation in the domains of the Imam, where the horses of men of rank appear to me too handsome to be Kochlani. The English, however, sometimes purchase these horses at the price of 800 or 1000 crowns each. An English merchant was offered at Bengal twice the purchasemoney for one of these horses; but he sent him to England, where he hoped that he would draw four times the original price."

As Mr Blunt² well points out, Niebuhr was a Dane, and his ideal of a horse was formed on the heavy Danish and German horses (not Flanders, as Mr Blunt says) of his own time and country, the origin of which we shall trace upon a later page (p. 3:34, cf. Figs. 93, 98).

1 Niebuhr, loc. cit. Blunt, op. cit, Vol.n. pp. 267-8. Tweedie (op. cit. p. 231) says that "the Arab will sell a leg of his mare, that is a certain share in her produce, to a neighbour."

2 Op. cit. Vol. ir. p. 267. 
The five strains of the Kohl breed generally recognised by the Bedonins are: (1) the Keheilan itself, (2) Seglawi, (3) Abéyan, (4) Hamdani, (5) Hadban.

(1) The Keheilan strain (says Mr Blunt) " is the most numerous, and taken generally the most esteemed. It contains a greater proportion, I think, of bays than any other strain. They are the fastest, though not perhaps the hardiest horses, and bear a closer resemblance than the rest to English thoroughbreds, to whom indeed they are more nearly related," the Darley Arabian, "perhaps the only thoroughbred Auazah horse in our stud book, being a Kehîlan." 'The Keheîlan is not by any means the most beautiful of the strains. Its subdivisions are very numerous, the favourites being the Keheilan Ajuz, the Keheîlan Nowag, the Keheîlan Abu Argub, Abu Jenub, and the Ras-el-Fedawi.

(2) The Seglawi generally is held in high repute, and has several sub-strains, all of which are highly valued, though the Seglawi Jedran is most esteemed in the desert. "They are, however, comparatively rare, and exist only in a few families of the Anazah, the Shammar no longer possessing any of the breed. The Seglawi Jedran of Ibn Nederi is powerful and fast, but not particularly handsome."

(3) The Abéyan "is generally the handsomest breed, but is small and has less resemblance to the English thoroughbred than either of the preceding." The best sub-strain is the Abéyan Sherrak, and a mare of this breed was the most perfect that Mr Blunt saw in Arabia, but her sire was a Keheîlan Ajuz.

(4) The Hamdani "is not a common breed either among Anazah or Shammar," and only one sub-strain, the Hamdani Simri, is recognised as hadud (worthy) by the Bedouin. Most of the Hamdani seen by Mr Blunt were grey. A very handsome brown Hamdani horse shown him by the Gomoussa proved to be a Hamdani Simri. The very beautiful white mare, Sherífa, owned by Blunt, was a Haundani Simri. "She was bred in Nejd, and had belonged to Ibn Saoud. Her head is the most perfect I have seen. She stands $14 \cdot 2$, and is pure white in colour, with the Kohl patches round the eyes and 
nose very strongly and blackly marked. Her ears are long, like a hind's, and her eyes are full and soft. She was admired all over the desert. In shape, head apart, she is more like an English hunter than a race-horse."

(5) The Hadban is uncommon now amongst the Anazah, the best having formerly been possessed by the Roala. The best sub-strain is Hadban Enzekhi, and to it belonged a remarkable mare owned by Muhammad Jirro at Deyr. She stood about fourteen hands two and a half inches, and was a bay, with black points, carried her tail very high, and was full of fire. "She looked like a race-horse, though not an English one." There are two other sub-strains not so much esteemed.

The blood of any one of the five strains is freely mixed with that of another, care only being taken to secure the best sire. To attain this mares are sometimes sent long distances to the horse of another tribe. From this fact and from inquiries made amongst the Bedouins themselves, Upton ${ }^{1}$ concludes, apparently rightly, that Al Khamseh is really one select breed or family, and not five distinct breeds.

Besides the Keheîlan and its four great derivatives which form Al Khamseh, there are some sixteen other strains, and most of them with one or more strains of blood accounted equal to the Khamseh, whilst two of them-Jilfan and Maneghi - are sometimes included in the Khamseh by townsmen and horse-dealers.

(1) The Maneghi is said by some, but without authority, to be an offshoot of the Keheîlan Ajuz. These horses are plain and without distinction, have coarse heads, long ewe necks, powerful shoulders, much length, and strong but coarse hind-quarters. They have also much bone and are held in high repute for their qualities of endurance and staying power. There are two sub-strains.

(2) Jilfan, with a sub-strain, Jilfan Stam el Bulad, 'Sinews of steel,' to which breed belonged a fine bay seen by Blunt. The Jilfan is beyond doubt the Dsjulfa of Niebuhr, regarded by that writer as the most numerous amongst the Kochlani. 
Upton, when remarking on the absence of black horses amongst the Bedouin, mentions that snch horses are to be seen in Syria, and that they are usually Jelfon (Jilfan). But to this point we shall return.

(3) Saadan. The sub-strain Saadan Togan is in high repute. The handsomest and strongest mare possessed by the Blunts was of this breed. She was a chestnut, fourteen hands two inches, of perfect beauty, and immense power, but could not gallop with the Keheîlan.

(4) Dakhman. All the horses of this breed seen or heard of by the Blunts were dark bay or brown.

(5) Shueyman, with one sub-strain, Shueyman Shah. Faris Sheykh of the northern Shammar had a mare of this breed. She was coarse, but of immense strength and courage. She was dark bay, and about 14:3 hands.

(6) Toessan. The only horse of this breed seen by the Blunts was a bay, handsome, but very small.

(7) Samhan. The tallest and strougest colt seen by the Blunts with the Gomoussa tribe was of this breed.

(8) Wadnan, (9) Rishan, (10) Kebeyshan, (11) Melekhan, (12) Jereyban, (13) Jeytani, (14) Ferejan, (15) Freyfi, (16) Rabdan.

Upton's description" of the Arabian horse is "based upon personal observations of the horses of the Anazah." Their great beauty and "great general length is the striking characteristic. This gives them a great stride, a great reach; they are natural born racers." "Thronghout the whole frame of the Keheilan it is the extreme natural appearance of the horse, the absence of any one predominant or conventional point arti. ficially produced, the beautiful balance of power, and symmetry displayed in his form, the just organization of sensorial and structural functions, which cause him to be so beantiful, so perfect an animal. The head is very beautiful (Fig. 57), not only pleasing to the eye in its outline, but beautiful from its grand development of the sensorial organ, and the delicacy of such parts as are more subservient. It is not particularly small or short in its 
whole length, in proportion to the size or height of the horse, but it is large above the eyes, small and short from the eyes to the muzzle. The centre of the eye more nearly divides the length of the head into equal parts than is observable in other horses; from the top of the head to the centre of the eye will often measure as much as from the centre of the eye to just above the upper edge of the nostril. The head of the horse of the Anazah especially tapers very much from the eyes to the muzzle, and the lower jaw does so equally, or even in a greater degree to the under lip, and if these lines were prolonged they would meet or cut each other at a short distance only beyond the tip of the nose. The nostril, which is peculiarly long, not round, rums upwards towards the face, and is also set up outwards from the nose, like the month of a pouch or sack which has been tied. When it expands it opens both upwards and outwards, and in profile is seen to extend beyond the outline of the nose, and when the animal is excited the head of this description seems to be made up of forehead, eyes, and nostrils. Such a head is often supposed to denote a violent temper. It is the type, however, of the head of the Arabian horse, and is, we thought, more marked, and to be seen more frequently among the Anazah tribes than elsewhere.

"The ears are beantifully shaped, pointed, and well placed, and point upwards, in a marked and peculiar manner, which is considered a point of great beauty and a great sign of pure breeding.

"The neck is of moderate length, and is of a graceful curve or gentle arch from the poll to the withers. It is a strong, light, and muscular neck, with the splenous muscle well developed. The withers are high and run well back, are well developed, and not too narrow or thin. The back is short, the loins are powerful, the croup high, the haunch very fine, the tail well set on and the dock short. The quarters are both long and deep; the gaskins sufficiently full and museular without being heavy, ponderous, or vulgar; the thighs are well let down; the hocks are clean, large, well formed, well placerl, and near the ground. The shoulders are long and powerful, well developed,.but light at the points; the scapulars 
are long and of a good slope, and broad at the base. The arms are long, lean, and muscular, deep at the elbow, which is well developed. The knees are large, and square, and deep. The trapezium or bone at the back of the knee is very prominent. The legs are short, deep, and of fair sized bone; the tendons and ligaments large and well strung. The fetlock joint is large and bold; the pasterns are long, large, sloping, very elastic, and strong; the feet wide and open at the heels, and not very high in the desert.".

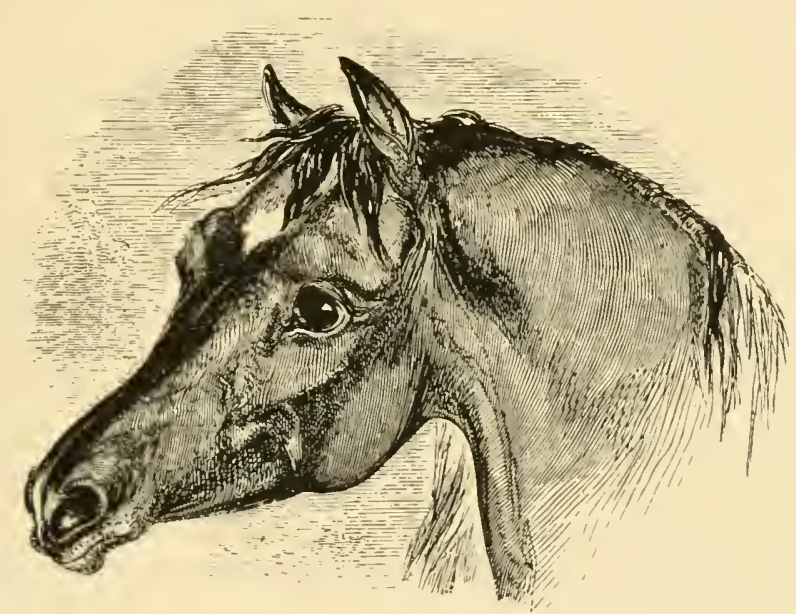

FıG. 5̃7. Black Arabian of Imam of Muscat.

In height the Anazah lıorses are usually about 14 hands 3 inches, and the height hardly varies a hand".

It is of great importance to note (1) that the Keheîlans are the swiftest, and are generally bay, and that they have constantly a white star or blaze on the face, and one or more white feet; the typical bay horses figured by Major-General 'Tweedie ${ }^{3}$ are all distinguished by such marks; $(\because)$ that the Hamdani, which are generally grey, are built more like English hunters than race-horses; (3) that the inferior strains not in Al Khamsch show the largest and strongest horses, but not the swiftest;

\footnotetext{
1 op. cit. p. 331.

2 Op. cit. p. 343.

${ }^{3}$ Op. cit. Frontispiece, pp. 182, 258.
} 
(4) that it is in these inferior strains that the colours black and brown are found.

The fact that the cross-bred horses are taller and stronger than the pure Keheîlans is of great importance, but it must not therefore be supposed that the stock with which the Keheîlan was crossed was necessarily taller than the latter, for it can be demonstrated that cross-breds are constantly taller than either of the parents. Frequently a stout mare well under 15 hands by an Arab sire of 14 hands has offspring over 16 hands high ${ }^{1}$. This fact is of great importance, for it renders it clear that size and strength are due not solely to the so-called Arab, and that it was not by this element alone that size was added to the little primeval horses of Europe, so that they became capable of carrying riders instead of being merely useful for chariots.

According to Upton about 87 per cent. of genuine Arab horses are of a dark colour; but not only are horses of grey and white colour found among Al Khamseh, but beyond all doubt great numbers of horses termed Arabs, and sold as such in Syria, Egypt, Turkish Arabia, Constantinople, and India, are grey or white. It is obvious that it will be of great importance if we can obtain from the available data any reliable results concerning the distribution of colour among all the high-bred horses of Asia. From Mr Blunt's observations it is now clear that bay is the chief colour among the Keheîlans, whilst grey is characteristic of the Hamdani, and chestnut is found in strains not reckoned in $\mathrm{Al}$ Khamseh.

Mr Blunt" writes as follows. "The head of the English thoroughbred differs from the Arab, for where there is a mixture of blood, the head almost always follows the least beautiful type of the ancestors. Thus every horse with a cross of Spanish will retain the heavy head of that breed, though he have but one-sixteenth part of it to fifteen of a better strain. The head of the Arabian is larger in proportion than that of the English thoroughbred, the chief difference being in the depth of the jowl; the latter is fine and beautifully shaped, but not

1 I am indebted to Prof. Ewart for this fact.

${ }^{2}$ Bedouin Tribes of the Euphrates, II. pp. 249-54. 
very small; the forehead large. The tail is carried high (Fig. 58) both in walking and galloping, and this point is much looked to as a sign of breeding. There is among English people a general idea that grey, especially flea-bitten grey, is the commonest Arabian colour. But this is not so among the Anazah. Bay is still more common, and white horses, though fashionable in the desert, are rare. Our white Hamdani mare Sherifa, which came from Nejel, was immensely admired amongst the Gomoussa for the sake of her colour almost as much as for her hearl. Perhaps out of a hundred mares among the Anazah one would see thirty-five bay, thirty grey, fifteen chestnut, and the rest brown or black. Roans, piebalds, duus and yellows are not found among the pure-bred Arabians, though the last two are occasionally among Barbs. The bays often have black points, and generally a white foot, or two or three white feet, and a snip or blaze down the face. The chestnuts vary from the brightest to the dullest shades, and I once saw a mottled brown. With very few exceptions all the handsomest mares we saw were bay, which is without doubt by far the best colour in Arabia, as it is in England; the chestnuts, as with us, are hottempered, even violent; black is a rare colour, and I never saw in the desert a black mare which I faucied. In choosing Arabians I should take none but bays, and, if possible, bays with black points.

"Among the Shammar we saw only two first-class mares, among the Fedaan perhaps half a dozen, and among the Roala, once the leading tribe, none. The Gomonssa alone of all the Anazah have any large number of really fine mares. I doubt if there are two hundred really first-class mares in the whole of northern Arabia. 'The Shammar have not now a single specimen of the Seglawi Jedran breed for which they were formerly famous. The Montetik in the south, once celebrated for their horses, have allowed the purity of their breed to be tampered with, for the sake of increased size, so necessiry for the Indian market, which they supply. It was found that a cross-bred animal of mixed Persian and Arabian blood would pass muster among the English in India as pure Arabian, and would command a better price for his extra height. The Persian or 
Turcoman horse stands fifteen hands two inches, or, even, I am told, sixteen hands; and these the Montefik have used to cross their mares with. The produce is known in India as the Gulf Arab, but his inferior quality is now recognised. Lastly among the Sebaa themselves, who have maintained the ancient breeds in all their integrity, various accidents have occurred to diminish the number of their mares. The deterioration is probably due also to the small number of horses kept for the mares, one horse perhaps being all that is found for two hundred mares. The Shammars have been cut off from the rest of the Arabs for a long time, and with the exception of occasional Anazah horses captured in war, they have no means of renewing their stock ${ }^{1} . "$

At the present moment all the blood stock of the Anazah tribes must be related in the closest degree of consanguinity. The horses bred from are not chosen for their size or shape, or for any quality of speed or stoutness, only for their blood. Mr Blunt saw a stallion of great reputation among the Aghedaat, for no other reason than that he was a Maneghi Hedruj of Ibn Sbyel's strain. "He was a mere pony without a single good point, but his blood was unexceptional, and he was looked upon with awe by the tribe." "It is difficult to understand how the pure Arabian race should have in fact retained as much of its good qualities as it has. In all ages and in all parts of Arabia, to say nothing of the points I have already mentioned, an unpractical system of breeding has prevailed, due in part to prejudice, and in part to peculiarities of climate and soil. The Bedouins only allow the mare a month before and a month after foaling for rest, the foals come at any time of the year. They are weaned after a month and fed on camel's milk. The best colts are sold to the townsmen of Der, Aleppo, and Mosul. The dealers will not buy hadud colts, as they cost about three times as much as the others, and it is easy to forge a pedigree. The fillies are generally kept in the tribe. The Bedouin never uses bit or bridle of any sort, but instead a halter with a fine chain passing round the nose. With this he controls the 
mare easily and effectually. He rides on a pad of cotton fastened on the mare's back by a surcingle, and uses no stirrup. The Bedouin does not know how to tell a horse's age by the teeth, and still less of any dealer's trick in the way of false markings ${ }^{1}$."

Major-General Tweedie ${ }^{2}$ has gone carefully into the question of the colours of Arab horses and the Arab terms for colour. In England, he writes, "an antiquated idea lingers that the authentic Arab must be grey. When the eminent Assyriologist, Sir H. C. Rawlinson, exhibited in 1864 a bay Arabian stated to have a pedigree of four hundred years, London actually rejected him on the score of his being a bay, and not a grey. This illusion is sanctioned by Palgrave, who says in his article in the Encyclopaedice Britannica 'that dark bay never occurs in the genuine Nejdee.' If by dark bay he meant dark brown, or quasiblack, the statement might be received subject to qualification. But every Arab prizes dark bay, as understood by horsemen. In the old rhapsodies about horses by desert riders the bay colour is set above every other. In one such passage the descriptive epithet used is $A h$-mar. Perhaps ah-mar includes chestnut. Ah-mar may mean bright bay, but unquestionably the ancient Arabic word ku-mait, which Im-ru'l Kais uses, signifies dark bay. $K u$-mait is explained as 'the dark red hue verging towards black of the fresh ripe date.' Col. Hamilton Smith describes the Arabian breed as one of great admixture, and this view is illustrated by the diversity of its colours. At the same time this diversity has its limit. Thus the dun colour is most unusual in Arabian horses. Sooty blacks prevail in the vulgar stock of the pastoral and agricultural Kurds round Kar-kuk and Mosul. There are however many different classes of black horses, and those of the Kurds can have no real relationship with those of the black Arabians, one of which was taken by Yonatt as a model. Not half a dozen Arubians of this colour have made foot-prints on the turf in India. Occasionally we hear of a noble black, which is the boast of the Ae-ni-za (Anazah), but such of the colour as come our way too

\footnotetext{
1 Op. cit., Vol. Ir. pp. 258-9.

2 The Arabian Horse, pp. 260-1.
}

R. H. 
much resemble the dismal quadrupeds which in Europe are reserved for the last scene of all. Practically the Ku-hai-lan colours are bay and chestnut, and the numerous different shades of grey and roan. Nobody can pretend to say of any one of these colours that it is more 'typical than another.' There is an Arab saying that the 'kings of horse-kind are those which are of a dark colour.' Another Eastern saying is that 'one should be slow to buy a chestnut horse, and still slower to sell one of that colour which has turned out well.'

"The Emir Fai-sal of Najd told Col. Kelly that the finest Arabian horses may be of any colour; that the prevalent colour among the first blood was various shades of grey; that as a rule the foal received its colour from its sire; that on the whole, colour went for little, height for nothing, and that blood was everything." We shall presently see why the Arabs set a value on white and grey horses quite disproportionate to their real merits. In view of this native opinion Mr Palgrave may well be forgiven for stating that grey is the colour of the horses of Najd.

General Tweedie ${ }^{1}$ gives valuable details respecting the different terms for various colours and their shades as well as their distribution among Kuhailan horses and also among Kadishes. He tells us that ah-mar and ku-mait when applied to horses are the same, and remarks that the Arabs use ah-mar to denote a European. Ash-kar denotes chestnut. In ku-mait or ah-mar the mane and tail are black; in ash-kar they are red or sorrel. Chestnut of a dark copper colour is not very common in Arabian blood horses. Adham, which includes coal-black and dark brown, which might pass for black, is rare in Al Khamseh. Aswad means black, and is synonymous with adham, but horsemen say adham, just as we do not speak of a red horse, but of a bay or a chestnut. The old poets called a dark coloured or pitch-black horse jaun, and this colour was evidently much esteemed. Passing on to the white, grey, and roan, he points out that as-fur, ' white,' not only means white with a saffron or sorrel infusion, chiefly apparent in the mane and tail, but also 
milk-white, and under this term the Bedouin include all white and light-grey horses. Ash-liab has the same connotation as as-far except that the infusion into the white is blackish, not yellowish. Am-lah means practically silver-grey, and is applied to all the vaguer shades of grey, whilst ash-a'l has much the same signification, though in Irak it is strictly used of a horse with much white on the face and in the tail. Ni-li means bluegrey (indigo), and is 'opener' and with less of black than our iron-grey; the latter is more of a kadish than a kuhailan colour. Az-rak is a lighter variety of the last named, being a blue or blue-grey colour. It is a colour much prized, and is even further from iron-grey than is the $n i-l i$. Dappling is not very common in kuhailans. Of the greys the az-rak perhaps most inclines to a light fleecy-grey. Rum-ma-ni (from rumman, the pomegranate) means nutmeg-grey, and it is the muwar-rad, or 'rose-colour' of Najd, and it like all the greys admits of different proportions of white, red, and black. The desert contains no vulgar, patchy, or mealy roans; and no flesh-coloured muzzles and pink orifices. The true nutmeg-roan or nutmeggrey runs the bay colour close for the prize of excellence in the Arabian bred. No matter how white in the course of years a rum-ma-ni turns, his strawberry spots remain. Ab-rash, fleabitten-grey, is certainly found in Kuhailan, yet it is also common in kadishes.

'The Arabs set great store by the markings, such as white stockings and the height to which they rise on the leg. They also draw presages from the whirls in the hair. Curly places or 'feathers' of certain shape in certain situations are taken for omens that he who owns or mounts the horse will rue it; and similar arrangements on other spots for assurances of prosperity. Moreover feathers on a horse's neck or body no more indicate high breeding than a twist in the beard does in man. Horses in whose coats hair thus disports itself are commoner among the Shammar than among the Ae-ni-za (Anazah). "The Arab believes implicitly in blood and holds that generosus nascitur, non fit. If he sees a colt sulking, he at once considers that he is bad from the egg, and thinks nothing about tuition. But the Najd has plenty of resolution. His admirable self-command 
habitually subdues the fire of his highly nervous temperament; but if any one would fight him, he will fight. Even the noble mare, which the Arabs compare to the high-born lady, on whom it is meet that all maidens should attend, frequently shows her aversion, when those whom she does not know approach her. The stallion picketed beside the tent is as good as a sentinel. The first sound of an intruder brings him to attention. Generally he will stamp with one fore-foot and challenge, not braying like a ka-dish, but sounding one or two short and sharp notes, to indicate that he will make no terms. On the open plain his strong character is even more exhibited. He seems to increase in size when moved from his standingplace. After a gallop every joint and sinew and useful part stands out, as if made by work and for work. There is very little of the mere 'pet' about him. When his glance is not fixed on some object near him, in which he imagines that there is danger, he is always scanning the horizon. His gentle salutations of passing mares are widely different sounds from the bagpipe-like squeals of the I'raki stallion. At the sight of a crowd he neighs out musically like one who is delighted to meet others of his species ${ }^{1 .}$

Major Upton, in the work already cited, embodies the result of wide and careful observations made on the horses not only of the Anazah tribes of the deserts of central Arabia, but also on those found in Syria, among the Bedouin tribes in the deserts lying south-west and west of the Euphrates, the coast tribes, such as the Mofitsch, who, though chiefly fishermen, yet breed horses, on the shore of the Persian Gulf, the horses of Erack (Irak), as also those of the Shammar tribes, who occupy most of the country between the Euphrates and Tigris north of Erack.

Upton states ${ }^{2}$ that bay is the most general colour of the Anazah horses, and that it is the favourite colour among the Arabs (Fig. 58). "Horses of a very rich dark bay rather than a brown colour are not uncommon. Chestnuts and greys are less numerous, and together would not equal the number of those 
of a bay colour. But those colours were all distinct, marked, and good. The Arabs like a decided or clear colour. In other tribes of Bedouin the colour among the grey horses we saw was much less decided. Grey horses were more numerous; bays are not so general a colour." Upton did not " remember to have seen any horses or mares among the Bedouin of a black colour, but in Syria and the Turkish districts we occasionally did see blacks, and generally these were said to be Jelfon ${ }^{2} . "$

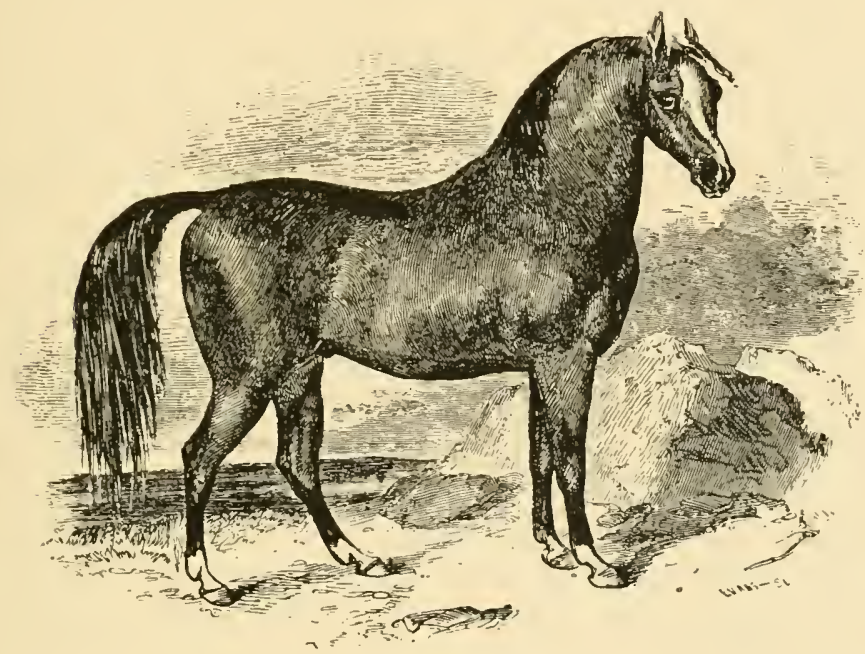

Fıg. 58. A Bay Arabian.

It is important to remind the reader that the Jelfon strain is not properly included in Al Khamseh, and that accordingly horses of a black colour are not pure-bred, but are the result of blending Al Khamseh with other blood. This is in complete harmony with the facts already stated (p. 133) that the best Turcoman horses of modern times, which are the result of crossing Turcoman mares with Arab stallions, are frequently black, with a star in the forehead, and white feet, and that sooty black horses are commonly found amongst the Kurds,

1 The Arabian Horse, p. 341.

2 op. cit. p. 339. 
who, as we saw, have for a long time been constantly crossing their Turcoman ponies with Arab stallions (p. 132).

Upton $^{1}$ noticed very frequently among colt foals, though not in fillies, "a line somewhat darker than the general colour of the animal running in continuation of the mane along the spine, and to be traced for some way even among the long hair of the tail. It is not obliterated with age; it can be traced in old horses and in those of a very dark colour."

The Bedouin tribes of the desert south-west and west of the Euphrates, who are far less migratory than the Anazah, some being almost stationary, and cultivating the soil to some extent, as a rule, have very few mares, and though there are some good mares to be found, they do not present the same appearance of high breeding and class as those of the Anazah, being "less even and more variable in appearance," occasionally ewe-necked, a feature unknown among Anazah horses. According to their own account these tribes use little or nothing but Anazah horses as sires, and Upton² had known instances where mares had been sent long distances to an Anazah horse, whose owner had taken up his temporary abode with one of these tribes. "The colours of their horses are not so decided or distinct nor are bays so decidedly frequent as among the Anazah tribes." They pass on their own colts to other tribes, to the villages on the border of the desert and into Syria and Erack (Turkish Arabia).

In Syria, where, as we have already seen, there are the common Turcomans, "the sons of horses," and full-blooded Arabs, many of the horses are called Anazah, but as it seems probable that any desert-bred horses in Syria are obtained from the nearest Bedouin, they have, therefore, Anazah blood in them, and very often are the progeny of Anazah sires ${ }^{3}$.

Turkish Arabia (the Babylonia of the ancients) is the country which supplies Arab horses both to Constantinople and to India. There are horses of nearly pure Arab blood, and there are horses of a mixed race from the blood of the Arabian introduced upon the former Babylonian, Persian, and

1 Op. cit. p. 339.

${ }^{2}$ Op. cit. pp. 380-1.

3 op. cit. p. 372. 
Median stocks, all passing under the general designation of Arabs. We shall soon make clear the origin of these last-named breeds. "In the district between Euphrates and Tigris there are many breeds of horses," which vary much in class and appearance, "and passed into India are called ligh or low caste." The Indian dealers obtain their supply from agents at Bassorah and Koweit, who get them from people who live near the coast ${ }^{2}$. Most of the horses supplied by these settled people near the coast they breed themselves. "The wandering tribes of the interior of Erack are said to have a great many Persian, Turcoman, and Barb horses and mares, and they sell these spurions mares to those people near the coast who supply the Indian dealer with horses ${ }^{3 . "}$ Upton saw on one occasion ${ }^{4}$ over thirty horses collected by the Pasha of Bagdad and with very few exceptions they were grey.

Elsewhere he observes that "in Turkish Arabia grey horses appear to be so numerous that grey might be said to be the usual colour ${ }^{5} . "$

Upton had never visited the Shammar tribes who live in the region between the Euphrates and Tigris north of Erack, but he had many opportunities of seeing horses bred by them. "They present to the eye a somewhat different appearance to those of the Anazah; they are less bloodlike, and to some extent present a heavier and more beefy appearance. The Shammar are the hereditary foes of the Anazah tribes, but possess Anazah blood in their horses from animals captured in war. The Shammar horses are not much or generally esteemed by the other Bedouin. The Arabs between Syria and the Euphrates do not appear to use Shammar horses, although to many they were close at hand; yet these tribes will always get Anazah horses as stallions if they can. Above all Anazah are prized by the Shammar, but no Anazah will have a Shammar horse." The Shammar also appear to have some strains of blood unknown to the Anazah tribes. A famous Sharnmar mare which could ontstrip every horse or mare anong

\footnotetext{
1 Op. cit. p. 361.

3 Ibid. p. 364.

${ }^{5}$ Ibid. p. 341.
}

2 Ibid. p. 362.

4 Ibid. p. 360 .

6 Ibid.p. 356. 
the Shammar was white, and of six selected Shammar horses seen by Upton in the possession of an Arab gentleman, the only good one, which proved to be a pure Anazah, was chestnut, whilst of the remaining five, which were all inferior, three were grey, and two reddish-grey ${ }^{1}$.

It seems, therefore, highly probable that a beantiful young mare belonging to a Shammar sheikh described by Layard was of Anazah blood. She was chestnut, "her limbs were in perfect symmetry, her ears erect, slender, and transparent; her nostrils high, dilated, and a deep red; her neck gracefully arched, and her mane and tail of the texture of silk2." To the same Anazah strain probably belonged the mare of matchless beauty owned by the Shammar sheikh, Sofuk, already mentioned, and named Shammariyah ${ }^{3}$, whose dam was said to be able to hunt down the wild ass with her master on her back (p. 51).

"There is some difference in external form to be observed between horses in Syria and those east of the Euphrates, even among such as are supposed to be of genuine Arab blood, but bred respectively in these two districts; and in general character, and in several minute respects, both differ from the Arabian horse, or the Keheilan of the superior tribes of the interior desert. Many horses bred in and to be found in both of the before-mentioned countries are not real Arabs at all, but most are related to, or are partly of Arabian blood; for it must be understood that the Arabian bears a similar relation to all other horses in the East, as also to the horses of northern and north-western Africa, as does the thoroughbred horse in England to the various half-breds, only in a far greater degree.".

We shall soon see that Upton, like all previous writers, completely misunderstood the relation of the horses of Arabia to those of North Africa.

The Syrian horses, i.e., horses bred in Syria and on the west side of the desert, of supposed pure Arab blood, and

1 Op. cit. p. 358.

2 Nineveh and its Remains (ed. 1867), p. 66.

3 Op. cit. p. 74.

${ }^{4}$ Op. cit. p. 375. 
the Bagdad-horses of the same pretensions bred to the east of the Euphrates-have not the perfect head and ears of the Anazah. "In neither kind are the jaws so fine, so deep, nor set so wide apart as in the desert Arabian, but the Syrian appears to have cleaner jaws than the Bagdad. Again, the Syrian has a better nostril, though inferior to that of the desert horse. The Bagdad horse frequently, and the Syrian sometimes, has the nostril too small and set too low down. The neck of the Syrian is generally lighter and more muscular than that of the Bagdad horse. The Syrian appears to have better shoulders, the croup of the Bagdad horse is often handsomer and the quarters better turned than those of the Syrian. Both kinds have good legs and feet, but the Syrian seems preferable in these respects, though inferior to the Anazah horses. The barrel of the Bagdad horse is as a rule longer than that of the Syrian, which latter is more like the desert horse in this respect. On the whole, the Syrian looks a hardier, more active, and more muscular horse; the Bagdad rather more bulky, and of a more imposing appearance. But these are only general indications, as in many instances these distinctions are not so decided or marked "." This general statement is in complete accord with the more detailed evidence of Mr Blunt and Major-General Tweedie. We may therefore feel sure that the facts relating to the colours of Keheilan horses and those of inferior strains are accurately known.

The evidence here presented makes it clear that the horses of the tribes of Central Arabia are admitted to be the best by all the other tribes; that the horses bred by the tribes who have the advantage of being able to procure Anazah stallions for their mares come next in quality; and that the best Arab horses of Syria, though inferior to the Anazah, are yet as a rule superior to those bred to the east of the Euphrates; while the horses of the Shammar tribes in Mesopotamia show still less of the pure Arab strain. The same evidence demonstrates that amongst the pure-bred Arabs bay and chestnut vastly predominate, grey being seldom, and black and brown never 
seen (and that too in spite of the fact that Arab horse-breeders from religious motives have a predilection for white or grey animals) ${ }^{1}$, and the colours being very decided and pure; that in Syria there are more grey, and far fewer bay horses, and occasionally black, that in Turkish Arabia grey practically becomes the universal colour, and sooty black is common in the Kurdish horses, whilst the Shammar horses seen by Upton were white, grey, and reddish-grey. It has also been shown that the Syrian Arab is of a coarser build than the Anazah breed, whilst the horses of Turkish Arabia are still more coarsely and clumsily built. Thus the further we advance from Arabia Proper, into which we shall find evidence of the importation of horses from North Africa in the centuries after Christ, the more do the horses differ in form and colour from the pure-bred Arab.

On the other hand we have absolute proof of the existence of Turcoman horses in great numbers in Syria, in Turkish Arabia, and Armenia. The Turcoman is sprung from the horse of Upper Asia, of which the pure Mongolian pony is the type; but the Turcoman (which represents the Nisaean horses of Armenia and Media, and the Parthian horses of a later date) has been modified by the admixture of so-called Arab blood.

Marco Polo has shown us that in his time the Tartars had vast numbers of white horses, and we know from Herodotus that white horses, either aboriginal or feral, existed in Russia in his own time; furthermore, we have seen that in Homeric and classical days white horses were known in Thrace, Illyria, and Upper Europe. From this it follows that the tendency to grey and white evinced by the so-called Arabs of Syria and Turkish Arabia, in contrast to the dark colours of the pure-bred horses of Central Arabia, is due to the fact that the Upper Asiatic horse forms the substratum of all the horses of Syria, Turkish Arabia, Armenia, and Persia.

It would appear that the black horses occasionally seen in Syria and other parts of Asia Minor are the result of an admixture of Turcoman and Arab blood, since Upton did not

1 Hayes, op. cit., p. 326 (citing a private communication from Mr W. S. Blunt). 
see any of this colour among the Anazah tribes, and also by his observation that the fine black horses which he saw were generally of the Jelfon strain, which is not one of the genuine Al Khanseh. 'This is completely corroborated by the fact that the fine black horses with a star on the forehead and white feet, which are owned by some modern Turcoman tribes, are known to be the outcome of crossing Turcoman mares with Arab sires.

Finally, Upton's testimony confirms the fact already well attested, that the tendency to stripes is especially dominant in pure-bred Arabs and Barbary horses.

It is not impossible that the chestnut colour of some Anazah horses, which we have seen to be a colour of the best horses of the Shammar, whose breeds are known to have more Upper Asiatic blood than any other class of 'Arabs,' may result from a slight admixture of a Turcoman strain.

The Arab horses used by the Turks are principally imported from Turkish Arabia, where common Turcoman and Kurdish horses have been much crossed with Arab blood. Passing، across the desert into Syria we find that the common horses there are either Turcoman, or half-breds out of Turcoman mares by Arab sires, whilst Arab horses are in general use, being either bred in the country or imported from the Bedouin of the desert, the latter being much the best.

Thus it is clear that at the present hour all over western Asia the main stock is the Turcoman, or horse of Upper Asia, which is continually being improved and modified by Arab blood. We shall presently show that from very early times the same two stocks were similarly meeting and acting on each other. It is most important to note, that as the Arabs from religious motives, like the ancient Germans and Illyrians, the medieval Tartars and modern Sumatrans, have a predilection for white and grey horses, but pay little regard to other colours, bay, which has been for ages the colour of the best Keheilan horses, is not the result of artificial breeding, and must therefore be inherent in the race.

The Arabs trace the pedigree of their horses through the dams and not through the stallions as with us, just as they 
traced their own lineage in ancient days through females instead of males. This practice is probably also due to their believing, as did the ancient Veneti (p. 104), that the dam is a more important factor than the sire in the production of a good progeny. From this arises the extreme difficulty of procuring the best Arab mares for export, for although a first-class stallion can be obtained for a heavy price in the desert, it is practically impossible to purchase a mare.

Aristotle $^{1}$ was of the same opinion as the Arabs and Veneti, for he says that "among solid-hoofed animals the males have no teats, except those species which take after the mother, as is the case with horses." Later on it will be seen from the history of the English thoroughbred stock that pure-blooded mares had to be imported before the real foundation of the English race-horse was laid.

Now let us trace back the history of the horses of Western Asia. The horses of Anatolia and Syria were well known in Europe by the 16th century, for in a series of engravings from drawings made by the artist Stradanus (died 1603) and issued under the title of Equile Iohannis Ducis Austriaci "The Stable of Don John of Austria"), a picture of 'Natolus,' here reproduced (Fig. 59), is included. As we shall see that not only were the horses and mares of Charles II. which laid the real foundation of the English racing stock procured from Smyrna, but that the famous Darley Arabian was brought from Aleppo, the importance of the horses of this region in relation to the English thoroughbreds will be fully realised.

The horses used by the Persians in the Middle Ages were strong enough to carry their own armour as well as their mail-clad riders. The size of their horses gave the Persians superiority over the Turks in the great wars of the fifteenth and sixteenth centuries, as the latter were mounted on much lighter horses, and had no defence except their shields". It would appear that the Persians used large, stout horses probably resembling the Bagdad horses of to-day, and like the latter, originally obtained by crossing the heavy-limbed Upper Asiatic 
horse with so-called Arab blood, whilst the Turks were probably for the most part mounted on common unimproved 'Tureoman ponies, although by the sixteenth century the horse known in Europe as the Turk was a fine well-bred animal developed out of the Turcoman pony by continual crossing with Arab blood. In The Stable of Don John of Austria, the 'Turcus' here reproduced (Fig. 60), is included, whilst 'Thomas Blundeville, writing in 1580 , says that the horses which he had seen "come

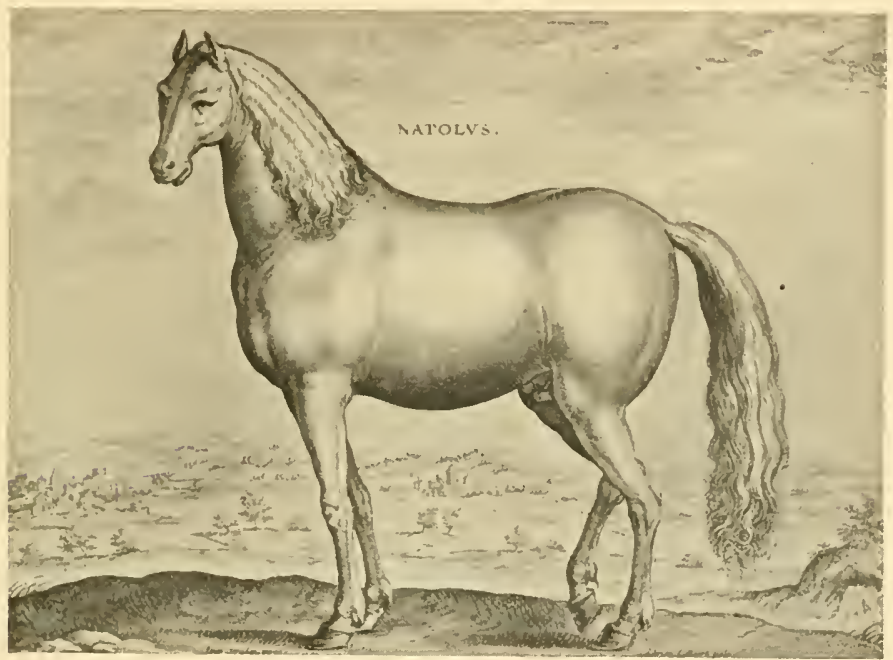

FIG. 59. The Horse of Anatolia.

from Turkey, as well into Italy as hither into England, be indifferent faire to the eie, though not verie great nor strong made, yet verie light and swift in their running and of great courage" (cf. p. 377).

When we go back to Roman times we find that the Parthians had the best horses in Asia. Strabo' says that they were not like the Greek or any other horses "in our" parts" (by which he means the comntries lying around the eastern Mediterranean) and elsewhere; he also compares them to the Celtiberian horses of Northern Spain, which were of a grey 
colour, as we shall soon see. Another author ${ }^{1}$ says that the Parthian horses were regularly of a dim colour (flavus). The statements of these two writers are by no means contradictory, as might appear at first sight. It is the best horses of the Parthians of which Strabo speaks when he likens them to the Celtiberian grey horses, whilst the other is only referring to the general colour of Parthian horses when he speaks of them as dun-coloured. But the evidence which we have just passed in review has shown that at the present day the horses in the regions included within the Parthian empire, such as the common Turcoman ponies, are regularly of a rufous or dun colour, like the horses of the Vedic Aryan, whilst the superior horses of the same countries, which are the result of crossing the Upper Asiatic blood with Arab horses, are regularly of a grey colour. It is therefore clear that in the first century B.c. the horses of Asia Minor, Armenia, and Persia were practically of the same colours as they are to-day, and it seems that the peoples of that region already possessed horses of a type similar to those obtained in modern times by crossing Upper Asiatic and Arab stocks. Whence this superior element was obtained we shall soon learn.

Now Strabo ${ }^{2}$ makes the very important statement that the Parthian horses of his day were similar to the famous Nisaean steeds, which were bred by the ancient Achaemenid Persian kings in the fifth century B.c.

The ancient Persians rode habitually on horseback, and no gentleman would ever be seen going on foot anywhere ${ }^{3}$. In camp they always hobbled their horses", and they sacrificed horses as well as bulls to their gods. According to Arrian a horse was sacrificed every month to Cyrus at his famous tomb at Pasargadae ${ }^{6}$. For sacrifice they apparently preferred white horses, which they held to be sacred, and which seem regularly to have accompanied the army on the march. So great value was set by the Persians on white horses, probably for sacrifice, that the tribute paid by the Cilicians was set at "three hundred

1 Nisa omnes equos flavos habet.

3 Xen. Cyr. Iv. 3, 28.

4 Ibid. III. 2.

6 Arrian, Anab. vi. 29 ; Strabo, 729.
2524.

5 Ibid. viII. 24. 
and sixty white horses, one for every day in the year, and five hundred talents of silver ${ }^{1}$," a fact which shows that white horses were especially plentiful in that region. On the march of Xerxes' host the following order was observed. First came a thousand picked horsemen, then a thousand chosen spearmen, after whom came ten sacred Nisaean horses, splendidly caparisoned. These horses were called Nisaean because they were reared in Media, on the wide Nisaean plain, which produced horses of large size. After these ten horses came the sacred car of Zeus, drawn by

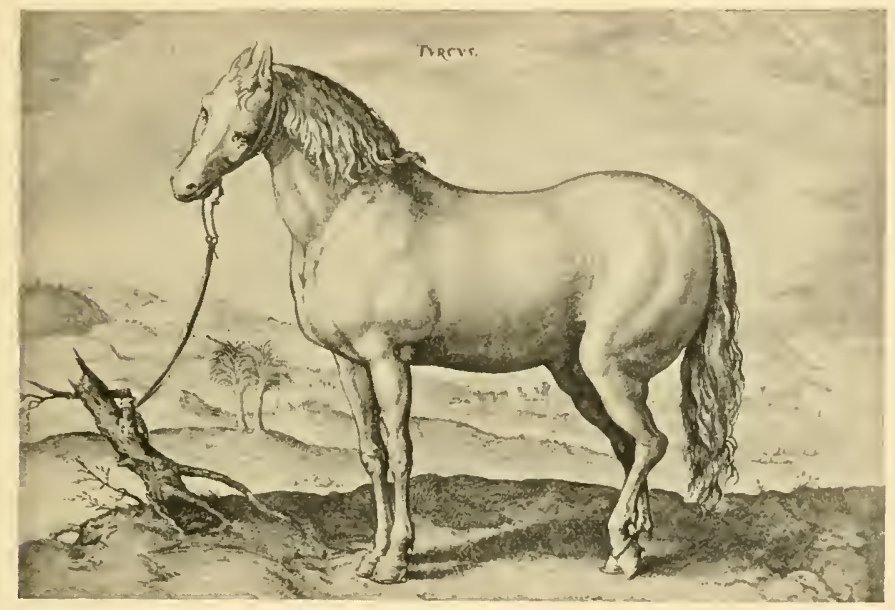

Fig. 60. The Turk.

eight white horses, followed by the charioteer on foot, and holding their bridles, for no mortal was allowed to mount the seat. After him followed Xerxes himself in a chariot drawn by Nisaean horses, with his charioteer beside himı2.

When Cyrus was about to cross the large river Gyndes, a tributary of the Tigris, we are told that one of the sacred white horses having in wantonness entered the river and tried to cross it he was swept away by the stream. Whereupon Cyrus was very wroth with the river, and threatened that he would so reduce its stream that henceforth even women might cross
1 Herod. III. 90,
2 Herod. vir. 40. 
it without wetting their knees'. Apparently Xerxes thought it desirable to propitiate the rivers which he crossed by voluntarily sacrificing white horses to them. Thus on his march through Thrace the magi sacrificed white horses into the Strymon ${ }^{2}$.

The muster-roll of the army with which Xerxes invaded Europe (480 B.C.) furnishes an invaluable account of all the horse-breeding peoples who were subject to the great king. The following were the nations which furnished cavalry: the Persians; the nomad tribes known as Sagartians, a people half-Persian, half-Pactyan, who supplied eight thousand horses. These men fought with the lasso; the Medes, the Scythians, the Indians, some on horseback, some in chariots, which were drawn either by horses or wild asses; the Bactrians and Caspians; the Libyans all riding in chariots; the Caspeirians and Paricanians ${ }^{3}$.

We have no difficulty in ascertaining which of the peoples of Asia at that period had the best horses, for Herodotus has already shown us that the Nisaean enjoyed this position, and he elsewhere ${ }^{4}$ not only states that they were larger than the Indian horses, but also implies that they were the largest then known. The signet of Darius Hystaspes, the father of Xerxes, which I here reproduce, probably gives us a representation of two typical horses of this famous breed. The signet (which is now in the British Museum) exhibits Darius seated in a chariot drawn by two horses (Fig. 61).

But there is no evidence that this was an indigenous breed, for Strabo" tells us "that the Nisaean horses, which are the largest and best and are used by the Persian kings, come, according to some from Media, according to others from Armenia." According to Strabo Armenia was especially suited for horse-rearing. That part of Armenia through which pass those who journey from Persia and Babylon to the Caspian Gates was called the Horse-feeding Mead. In the time of the Persian kings, the royal herds, which numbered as many as 50,000 mares, were pastured there. In another passage Strabo ${ }^{6}$
1 Herod. 1. 189.
2 Ibid. viI. 114.
3 Ibid. viI. 84-7.
4 Ibid. III. 106.
5524.
6529. 
declares that Armenia yielded in no respect to Media in its horse-breeding capabilities, "so that the Nisaean horses were produced here which the Persian kings used themselves. The satrap of Armenia had to send each year 20,000 colts on the feast of Mithras."

There is evidence that by 600 B.c. Armenia was noted as a horse-breeding region, for according to the prophet Ezekiel the people of Togarmah, usually supposed to be Armenia or part of it, "traded in the fairs of 'Tyre with horses and mules"." The chief horses and ponies of Armenia at the present day are known as the Karadagh breed, which is said to have been

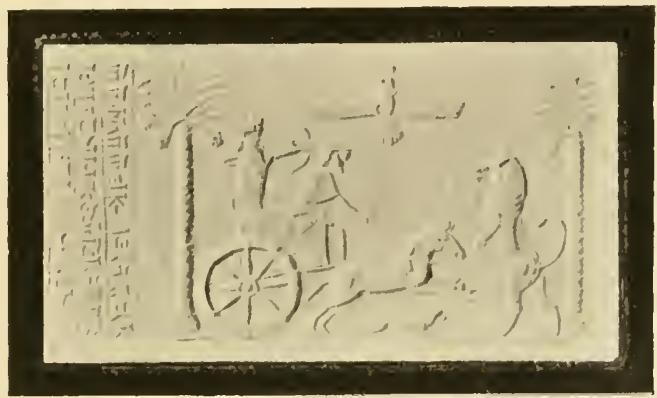

Fia. 61. Impression from the Signet of Darius Hystaspes.

developed on the southern slopes of the Caucasus, and they have been crossed with 'Arab' blood, and probably some of them at least with Russian strains, which, as already mentioned (p. 132), are all of modern origin, being derived from Arab and English thoroughbred blood. 'The Karadagh horses are from 14 to 15 hands high, and are usually bay or chestnut with black mane and tail, and they all have a black dorsal stripe about an inch broad. They are strongly built and are par excellence the harness horses of Persia, and are used as cab horses in Teheran and for all kinds of waggon-work, but are very seldom ridden².

1 Ezek. xxvii. 14 : "They of the house of Togarmah traded in thy fairs with horses and horsemen and mules." Others have supposed that Phrygia or Cappadocia is meant by Togarmah.

2 Hayes, Points of the Horse, pp. 610-1 (ed. 3).

R. H. 
Their strong build and want of speed in spite of their cross of 'Arab' blood proves that the substrate of the breed is the primitive horse of Upper Asia, and though frequent crossing may have made bay and chestnut common colours, it is likely that there is in their veins much of the blood of the ancient Nisaean horses of Armenia and Media, 'the largest' horses of the Persian empire.

As the Parthian horses, which were both grey and also commonly dun, were descended from the Nisaean breed, and resembled it in appearance, we may conclude that the Persian horses of the fifth century B.c. were dun, white, or grey. But we have just seen that dum and white especially characterised the horses of Upper Europe and Upper Asia in classical and medieval times. From this it would appear that the Nisaean horses bred in Armenia were of the Upper Asiatic, i.e. Turcoman stock, and that by 600 B.c. and probably far earlier, the latter had made its way down into Palestine, where, as we have just seen, it still forms the chief element in the ordinary horses of the country. The Median empire had been absorbed into the Persian, but as the horses bred on the Nisaean plain in Media were of the same stock as those of Armenia, and by some were said to have been brought from the latter country, we may conclude that they were also of the Upper Asiatic stock, though probably modified and improved by another strain, as we shall presently see. It is also highly probable that the horses of the other great monarchies of westeru Asia absorbed into the Persian empire were mainly of the same Asiatic stock.

Though the Lydians in the time of Croesus (560-546 в. c.) were admirably furnished with cavalry, they themselves held that the horse was not a native, but an imported animal, as is demonstrated by an incident mentioned by Herodotus ${ }^{1}$. When the Persians advanced on Sardis, the space in front of the city was filled with serpents, which were eagerly devoured by the horses. Disturbed by the portent Croesus sent to the Telmessian soothsayers, who declared that it presaged invasion and conquest by a foreign host, for (said they) "the suake is a child of the land, but the horse is an enemy and a stranger."

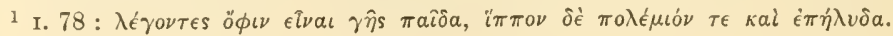


On the monuments (Figs. 62-4) of Nineveh the horse plays a prominent rôle, whether driven under chariots or ridden. The horses of the archers who are fighting with the enemy, and who have consequently both hands engaged, are represented as led by mounted warriors, who ride by their side. They wear skull-caps, probably of iron ${ }^{2}$. The bas-reliefs of Konyunjik" show "warriors urging their horses at full speed, and archers on foot turning backward to discharge their arrows at their pursuers. Beneath the horsemen are rows of chariots and led horses. In their trappings and harness the horses of

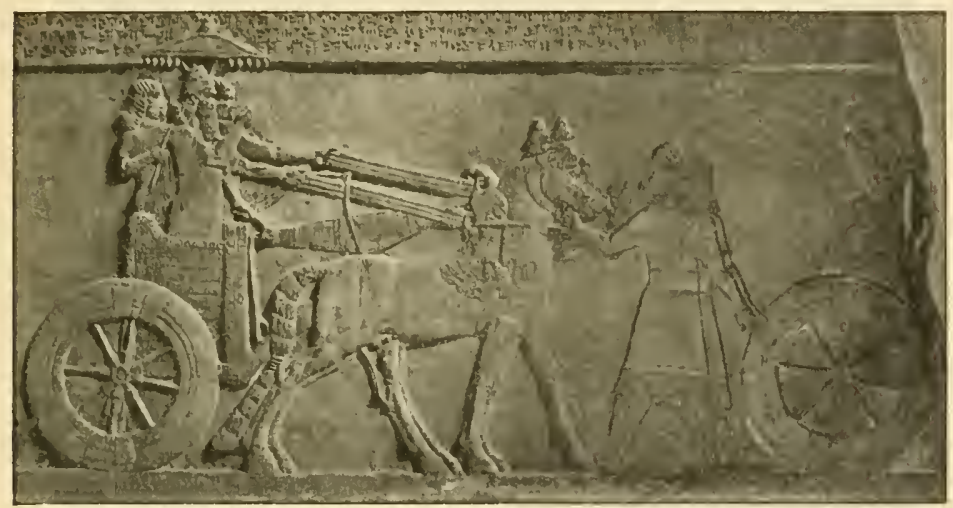

F1G. 62. Tiglath Pileser III in his chariot.

the Konyunjik bas-reliefs differ from those represented on the sculptures from Nimround. Their heads are generally surmounted by a high arched crest, and bells or tassels are hung round their necks, or, as at Khorsabad, high plumes, generally three in number, rise between their ears. The bridle consisted of a headstall, a strap divided into three parts joining the bit, the straps over the forehearl, under the cheeks, and behind the ears. Three richly embroidered straps (Fig. 63), passing round the body of the horse, keep the harness and chariot pole in their place, and were attached to a highly decorated breast-band. To the yoke was suspended an elegant ornament in the form of

${ }_{1}$ Layard, Nineveh and its Remains (ed. 1867), pp. 234-5.

2 Ibid. pp. 362-3. 
the head of an animal, and a ring which generally enclosed a winged bull. The horses' manes were allowed to fall loosely on the neck, or were plaited, and their tails were tied in the middle with a ribbon adorned with tassels"." The fact that the Assyrian horses seem always to have been controlled by bits and not merely by nose-bands will be of importance at a further stage in our investigations.

To judge from the sculptures alone, cavalry must have

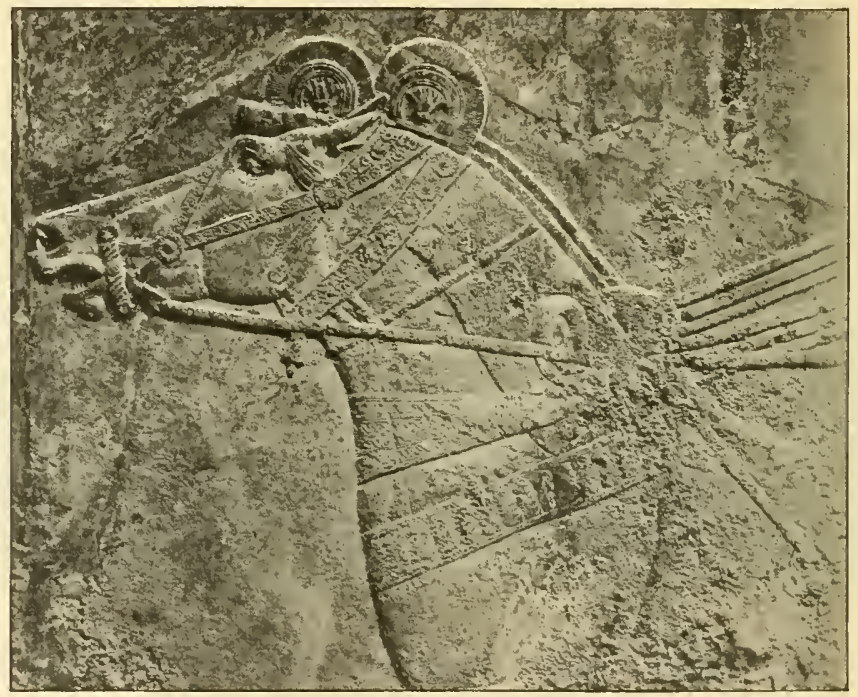

FIG. 63. Head of a Horse from the chariot of Assur-bani-pal.

formed an important part of the Assyrian armies, a conclusion fully confirmed by the Old Testament, where the Assyrian horsemen are frequently mentioned. Thus Ezekiel ${ }^{2}$ describes the Assyrians as "clothed in blue, captains and rulers, all of them desirable young men, horsemen riding upon horses." Again, Holofernes ${ }^{3}$, the general of Nabuchodonosor, is stated to have had no fewer than twelve thousand archers on horseback. On the monuments the rider is represented as seated on the

\footnotetext{
${ }^{1}$ Layard, op. cit., pp. 237-8. $\quad 2$ xxiii. $6 . \quad 3$ Judith ii. 15.
} 
back (Fig. 64) of the horse, which is only adorned with a cloth even when led behind the chariot of the king. Layard ${ }^{1}$ thought that "the horses of the Assyrian bas-reliefs were evidently drawn from the finest models, and the Assyrian sculptor has not altogether been unsuccessful in their delineation. The head is small and well shaped, the nostrils large and high, the neck arched, the body long, and the legs slender and sinewy." The prophet Habakkuk ${ }^{2}$ characterises the horses of the Chaldees as "swifter than the leopards and more fierce than evening wolves."

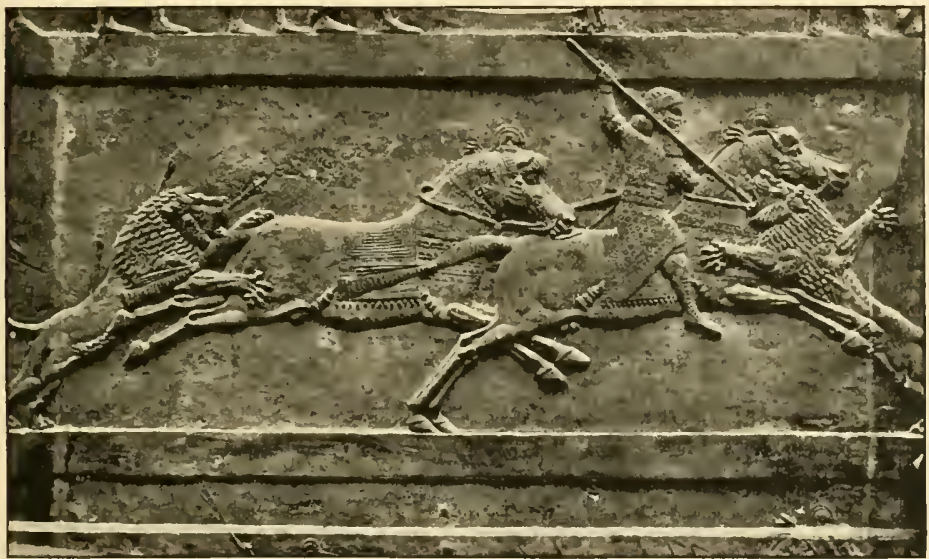

F1G. 64. Assyrian Lion-hunt.

As the connection of Assyria with Armenia was very close, it is probable that the horses which the Assyrians rode and drove, and the possession of which was a chief factor in the story of Assyrian conquest, were largely supplied by Armenia, which was sending horses as far as Tyre in the seventh century B.C., and which supplied the Persian monarehs, and later still the Parthian kings, with vast numbers of excellent horses. But as we shall see presently, it is more than probable that the best horses of Assyria had in their veins some of the blood from which both the Arabian horse and our thoroughbreds are

\footnotetext{
1 Nineveh and its Remains (ed. 1867), pp. 234-5.

2 i. 8.
} 
derived. A recent writer has endeavoured to show that the asses on an Assyrian monument (p. 49) closely resemble Prejvalsky's horse. But, as I have already pointed out that the Asiatic lorse is probably derived from Prejvalsky's horse, or rather from a common stock, we need not assume that the Assyrian steeds were actually the latter variety, but simply its derivative, now best exemplified in the Mongolian pony. In the time of Herodotus' the satrapy of Assyria was the most important province of the Persian empire, and bred horses in considerable numbers. The satrap of Assyria (exclusive of war-horses) himself owned eight hundred stallions and sixteen thousand mares, twenty mares being thus allotted to each horse. As the statements of Herodotus already cited show that the Nisaean horses were the best in Asia, the horses of Assyria were evidently not considered first-rate, and we may therefore infer that they were of the Mongolian stock, not so much improved by crossing or selection as the Nisaean steeds of Media and Armenia. As the Assyrian horses of the fifth century B.c. were probably descended from the animals pourtrayed on the Assyrian monuments of the eighth and ninth centuries P.C., the evidence touching their quality which we infer from Herodotus harmonises well with the Mongolian-like appearance of the horses on the bas-reliefs.

According to the best authorities ${ }^{2}$ on the history of Babylonia, the horse does not appear to have been known in that region much before 1500 B.C. As I have already shown that the Upper Asiatic horse forms to this day the substratum of all the various breeds of that region, we are justified in holding that the first horses known in the Euphrates Valley had come down from Upper Asia. Of course it may be at once suggested that the Nisaean horses of the Persians and their progenitors used by Mede and Assyrian were derived from Arabia, like the best horses in Turkey, Persia, and India at the present day. But to this view there is at least one fatal objection. Herodotus ${ }^{3}$, when enumerating the nations which supplied horsemen and chariots to the host of Xerxes, does not include the Arabs among them, but expressly states that they only supplied a

1 I. 192.

2 Hilprecht, Explorations in Bible Lands, p. 527.

3. vII. 86. 
camel corps, "all riding on camels not inferior in flectness to horses." On some Assyrian bas-reliefs men mounted on camels are seen flying before Assyrian horsemen, and we may without hesitation recognise the former as Arabs.

To the mind of Aeschylus ${ }^{1}$ all the south-eastern part of Asia Minor was inhabited by Indians, who, men and women alike, roamed from place to place on camels which were ridden like horses, but carried pack-saddles. It may be of course urged that Aeschylus in this passage is alluding not to the Arabs, with whose name he was acquainted, as he mentions them elsewhere, but that he is rather thinking of the Bactrians, who would not inappropriately be termed Indians. But it must be remembered that the Bactrians supplied horsemen and no camels to the army of Xerxes, and that it is only in later writers such as Pollux that they are described as fighting on camels, which were swifter than horses, more calculated to inspire terror, owing to their size and shagginess, and better adapted to rough work from not suffering from thirst ${ }^{2}$. From this it looks as if in the fifth century B.c. the Bactrians either liad not yet begun to use the camel, or at least had not as yet utilized it for war. Pollux evidently regarded the Bactrian custom as exceptional, for he says that whilst the horse and the elephant are only used for war, asses were employed as pack-animals, oxeli for draught, mules for both, whilst camels also carried baggage on packsaddles. There are two quite distinct species of camels, the Bactrian (Camelus bactrianus) with two humps, and the Arabian (C. dromedarius) with only one: though zoologists denominate the Bactrian only as Asiatic, it seems certain that both are such in origin, the former being found in Upper Asia, the latter in Arabia, where, as we shall soon see, wild camels still existed in Strabo's time, for there is no need to assume that all the wild camels then existing there were feral. At the present day there are no wild camels in Arabia; there are, however, wild Bactrian camels in Lob-nor in Eastern Mongolia (p. 26),

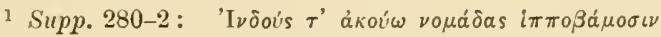

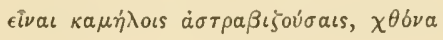

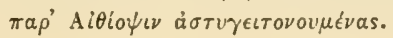

I. 140-1. 
but it has been suggested that these reputed wild camels may be descended from animals that belonged to the peoples of the dead cities of that region 1 .

It may well be that the peoples of Central Asia had not domesticated the two-humped camels till a comparatively late period, and as the camel with a single hump did not get a foothold in Africa until the time of Ptolemy Philadelphus ${ }^{2}$, we need not wonder if the employment of the other species was equally late in Central Asia. That the Bactrian camel had been domesticated by the time of Christ is made certain by Strabo", who in his description of Persia states that "the camelkeepers' dwelt on the extreme northern frontier of that region, that is in the deserts on the northerm borders, where there was scarcely any cultivable land except between certain mountain groups of the waterless upland. This is just the country where man would begin to use the camel.

It is quite possible that although the camel was indigenous in Central Asia, it may not have been domesticated by the peoples of that region until a comparatively late period. Though wild camels still survive in Eastern Asia, the Tartar

1 Beddard, Mammalia, p. 285.

2 Strabo, 815. It has long been noticed that the camel does not appear in Egyptian inscriptions or pictures before the Greek period (Erman, Aegypten, p. 493, Engl. trans.), whilst others hold that it only got into North Africa in Roman times. Yet Strabo (loc. cit.) renders it certain that Ptolemy Philadelphus opened up the route from Berenice and Myus Hormus on the Red Sea to Coptus, by which all the merchandise of India and Arabia passed to Alexandria in his own day. "Philadelpluus is said to have been the first to cut with an army this road, thongh it was then waterless, and to have established halting-places, and he did this on account of the difficult navigation of the Red Sea, especially for those who set sail from its inmost recess. Formerly the camel-merchants used to make the journey by night, directing their course by the stars, and like mariners they brought supplies of water with them. But now they have provided watering-places by digging deep wells and they have constructed cisterns to hold the rain-water, scanty though it be. The journey takes six or seven days." Yet the camel must have been known to Egyptians from a very remote epoch from their trade with Arabia. Thus the Ishmaelites who brought Joseph from Canaan into Egypt, "came from Gilead with their camels bearing spicery and balm and myrrh, going to carry it down to Egypt" (Gen. xxxvii. 25). In 1903 Prof. Flinders Petrie found at Abydos a statnette representing a camel.

3727. 
tribes do not appear ever to have employed them in early times. This difference between the Tartars and the Arabs was probably due to the fact that whilst wild camels were foun both in Upper Asia and Arabia, the horse, though indigenous in the former region, was not a native of the latter.

The reader will probably be startled by this last statement, inasmuch as it has hitherto been generally held that Arabia is the original, and not merely the adoptive, mother of the famous steeds that bear her name. But the testimony of the great geographers, Eratosthenes (flor. B.c. 300) and Strabo (flor. A.D. 1), would of itself be sufficient to put it beyond all doubt that the Arabs aid not breed, or even possess, horses until after the beginning of the Christian era.

Strabo ${ }^{1}$, who embodied and supplemented from other sources the information collected by his great predecessor, gives the following account of Arabia in general: "The iirst people next after the Syriaus and the Jews who occupy this region are husbandmen. Next to them comes a barren and sandy tract, producing a few palms, the acanthus, and the tamarisk; water is obtained from dug wells, as in Gedrosia. It is inhabited by Arab tent-dwellers, who breed camels. The extreme parts towards the south and opposite to Ethiopia are watered by summer showers, and are sown twice, like the land in India. Its rivers are exhausted in watering plains and in running into lakes. The fertility of the country is very great, and there is in particular an abundant supply of honey. With the exception of horses, mules and swine, there are numerous herds of cattle, and there are all sorts of birds except geese and domestic fowl. Four principal tribes occupy this great territory-the Minaei the parts towards the Red Sea; the Sabaeans (whose chief city is Mariaba); the Cattabaneis, whose territory extends to the Straits and the passage across the Arabian Gulf; and the Chatramotitae, the furthest of these nations towards the East. Their city is Sabata." This description of itself is sufficient to show that no horse-breeding was carried on in any part of Arabia Felix at the time of Christ. But Strabo gives more detailed accounts of the various territories of this vast region. 
In describing the littoral of the Red Sea from Eratosthenes, after making mention of the Elanitic Gulf (the Gulf of Alsaba) and Nabataea, "a country well peopled and abounding in cattle," he thus proceeds": "next comes a plain well wooded and well watered; it abounds with cattle of all kinds, and among other animals, wild asses (hemionoi), wild camels, deer and gazelles; lions also, leopards and wolves are frequently to be found." South of the harbour of Charmothas (apparently the ancient Iambo, and called by the Arabs, Iambo el Nakel, "Iambo of Palm-trees") "follows a rugged coast, and after that are some bays, and a country occupied by nomads, who live by their camels. They fight from their backs; they travel upon them, and subsist on their milk and flesh. These are known as Debae." This people occupied the modern Sockia. "The country of the Sabaeans, a very populous nation, is contiguous, and is the most fertile of all, producing myrrh, frankincense, and cinnamon."

Strabo ${ }^{2}$ states that the land of the Nabataeans was fruitful save in olive oil, that it produced sheep with white wool, and oxen of a large size, but adds emphatically that "the land does not produce horses, whose place is served by camels." The Nabataeans were the Arabs who occupied the ancient Edom, or Idumea, the region lying between Syria and South Arabia, and which was made in 105 A.D. by Trajan into the Roman province of Arabia, commonly termed Arabia Petraea from its capital, Petra. The documentary evidence is thoroughly con-

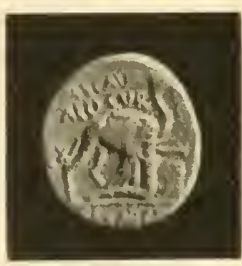

Fig. 65. Coin of Aemilius Scaurus. firmed by the nonumental, for when Aemilins Scaurus in B.C. 62 or 60 received the submission of the Nabataean king Aretas, he issued coins bearing on the reverse an Arab leading his one-humped camel (Fig. 65) and holding out an olive branch as a suppliant, accompanied by the legend Rex ARETAs ${ }^{3}$. The Arabian king himself is thus pourtrayed not as a cavalier, but as a camel-rider.

1776 . 281.

3 Mommsen, Histoire de la Monnaie romaine, Vol. 1 I. p. 489 ; Josephus, Ant. Jud. xiv. 5, 1; Bell. Jud. I. 8, 1. 
Some years later Aulus Plotius ${ }^{1}$, one of Pompey's lientenants in his campaign in Judaea (B.C. 6 6 ), placed a similar type (the camel also being one-humped) on a coin which he struck to commemorate his victory over some Jewish chieftain, as is shown by the legend Irdaevs Bacchivs (Fig. 66).

It is now plain from the statements of the profane writers that the tribes of north and south Arabia did not breed horses before the Christian era, though they had asses and camels in abundance, and the same writers make it clear that whilst there were no wild

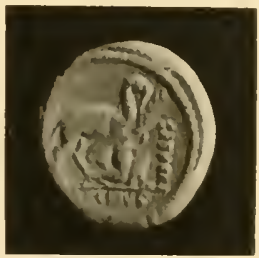

Fig. 66. Coin of Aulus Plotius. horses in Arabia, there were both wild asses and wild camels, facts which may explain the early domestication of the ass and camel and the late appearance of the horse in that region.

Nor was this condition of things of recent date in Arabia Petraea and Arabia Felix, for the evidence of the Semites themselves set forth in the Old Testament puts it beyond doubt that neither the tribes of Arabia Proper nor those of Mesopotamia possessed horses until a comparatively late period.

Thus Job, who dwelt in the land of $\mathrm{Uz}^{2}$, which is identified with Arabia Petraea, though he was "the greatest of all the men of the east," and possessed seven thousand sheep, three thousand camels, and five hundred yoke of oxen, did not own a single horse, his only equine possessions being five hundred sheasses. If so great a sheikh as Job did not possess horses, we may reasonably infer that these were as little bred or used in Arabia, when the Book of Job was composed, as they were in the days of Strabo. Nor is there any more reason for believing that the Sabaeans, who fell upon Job's oxen as they were ploughing, and his she-asses as they were feeding beside the oxen, were any better provided with horses than they were at the later date.

Of course it is clear that the author of the Book of Job was well acquainted with the war-horse, "who paweth in the

1 Mommsen, op. cit., Vol. 11. p. 495.

"Job i. 1; Jer. xxv. 20; Lam. iv. 21. 
valley and rejoiceth in his strength, who goeth on to meet the armed men, who mocketh at fear and is not affrighted, neither turneth he back from the sword, who swalloweth the ground with fierceness and rage, who smelleth the battle afar off, the thunder of the captains and the shouting." But even supposing that the writer lived in Arabia Petraea, there is no need for assuming that he knew the horse in his own land, as be would have had ample opportunities of becoming acquainted with that animal in the contiguous regions of Palestine and Babylonia.

When Terah, Abraham and Lot went forth from Ur of the Chaldees to go into the land of Canaan, and came to Haran ${ }^{2}$, although they appear to have been very wealthy, they did not possess horses. For though Abraham had gold, silver, cattle, sheep, camels, and slaves, he had not a single horse, not even after his sojourn in Egypt, where Pharaoh had given him for the sake of Sarah "sheep and oxen, and he-asses, and menservants and maidservants, and she-asses and camels.". So was it too with Abraham's kindred in Haran, for neither when Eliezer the servant of Abraham was sent with ten camels to seek a wife at Haran for Isaac, nor when later Jacob fled from his brother Esau and kept the flocks of Laban, is there any mention of the horse amongst the numerous possessions of his father-in-law nor himself, although he had much cattle, and maidservants and menservants, and camels and asses ${ }^{4}$. Again, when Jacob sent a present of all the best that he possessed to assuage the wrath of Esau, he selected "two hundred she-goats and twenty he-goats, two hundred ewes and twenty rams, thirty milch camels with their colts, forty kine, and ten bulls, twenty she-asses, and ten foals ${ }^{5}$ " but not a single horse, and on the other hand when Esan came to meet Jacob with four hundred fighting men we hear of no horse ${ }^{6}$.

The literary records are in complete harnony with the evidence obtained by modern research from the monuments of Mesopotamia. According to the latest authorities "the horse
1 Job xxxix. 19-25.
2 Gen. xi. 31 ; cf. xxiv. 35 .
3 Gen. xii. 16.
4 Ibid. xxx. 43.
5 Ibid. xxxii. 14, 15.
6 Ibid. xxxiii. 1. 
appears in Babylonia first shortly before the middle of the second millennium."

The conclusions which I have drawn from the statements of classical authors, and from the Old Testament, are confirmed by the native Arab traditions. It seems certain that in the centuries between the birth of Christ and the rise of $\mathrm{Mu}$ hammad the Arabs or at least some of the great men amongst the tribes of South Arabia had become possessed of horses. This can be demonstrated not only by many passages in the old poets of the Ignorance, but also by inscriptional evidence. Thus a great chief is termed furris (i.e. cavalier, from farts, a horse). A Sabaean inscription of uncertain date ${ }^{2}$, but in any case considerably anterior to the time of Muhammad, states that a small Arabian tribe (Hamdān) presented 'horses' to someone whose name does not appear. There can be no doubt that by the sixth century A.D. the Arabs were themselves breeding horses, for in that period there was a famous horse named Dähis about whose breeding we have very full details, as this animal was the cause of a war between two tribes ${ }^{3}$. The inscription just cited is of the lighest importance for the history of the Arabian horse. It will be remembered that one of the five strains of Al Khamseh is called Hamdan, and as there is good reason to believe that in some cases at least these various strains derive their names from families or tribes which bred them, it seems more than probable that in the record of the Hamdan tribe which possessed horses before the coming of Nuhammad we have the earliest historical reference to the Kohl breed.

That however even then horses were scarce and only possessed by very few seems indicated by the fact that warriors are described as riding on certain horses. Thus Numan, son of Amraalgais, is described as "the rider (cavalier) of Halima" (fürisu Halimata). According to the Anazah tradition

${ }_{1} \mathrm{H}$. v. Hilprecht, Explorations in Bible Lands during the Ninetecnth Century (1903), p. 527.

2 Mordtmann and Nüller, Sabäische Denkmüler (Vienna, 1883), no. 9, p. 35; cf. note on p. 41.

3 G. Jacobs, Altarabisches Beduinen-leben (2nd ed. Berlin, 1897), pp. $73 \mathrm{sq}$.

4 Nöldeke, Geschichte der Perser und Araber (translated from the Arabic of Tabarî), p. 79 . 
Rabiah, the ancestor of their race, was surnamed Al-Faras, "of the horses"," from which it would appear that the acquisition of the horse was an event which marked an epoch in the life of the tribe. Again, we are told that when Muhammad attacked the Koreish tribe he had only two horses in his army, and although he captured many thousands of camels, yet there is no mention of horses in the booty. The legend respecting the seven mares of the Prophet, so far as it has any value, confirms the other evidence, for none of them is said to have been bred by Muhammad, since three had been purchased, and four were gifts. We hear much less about his horses than his she-camels, especially Al-Kas-wa (from whose back he addressed four thousand people on a great occasion), or about his mule Dul-dul and his ass $\mathrm{U}$-fair".

It is now clear that the Arabs had no horses at the begimning of the Christian era, but that for several centuries before Muhammad, horses were possessed by some of the great men amongst them, and reasons have been given for believing that one of the strains of Al Khamseh may have originated from the Hamdan tribe, who were owners of horses before the days of the Prophet. It is therefore highly important to bear in mind that the Hamdani horses are not bay, but generally grey or white, colours which, in the case of Arabian horses, we have learned to regard as sure signs of much Upper Asiatic blood, a conclusion supported by the fact that Mr Blunt's beautiful white Hamdani mare was, head excepted, more like an English hunter than a thoroughbred.

What then is the origin of the Kohl breed? According to a common Arab tradition Ismail-ibn-Ibrahim, or Ishmael, was the first tamer of the steed. After having being turned out of his father's tents he is said to have captured a mare from a herd which he found rumning wild "like the wild ass" (mittl wahash" ${ }^{3}$ ).

The Emir Abd-el-Kader told Blunt that the children of Ishmael had a mare from this principal stock, which grew up crooked, for she had been foaled on a journey, and being unable to travel had been sewn into a khourj, or goats'-hair sack, and

1 Upton, Gleanings from the Desert of Arabia, p. 294.

2 Tweedie, op. cit., p. 230.

${ }^{3}$ Blunt, The Bedouin Tribes, etc., Vol. II. pp. 265-6. 
placed upon a camel. From her descended a special strain of blood, known as the Benat-el-Ahwaj, or "daughters of the crooked," and this was the first distinction made by the Bedouins among their horses. The Benat-el-Ahwaj, or Ahwaj, as it is more commonly called, may therefore be considered the oldest breed known. "I have never heard of it in the Arabian deserts, but the Emir assures me that it exists under that name in the Sahara, and that the breeds now recognised in Arabia are but ramifications of this original stock." Blunt ${ }^{1}$ conchudes that the Keheilans were "an early sub-breed of the Ahwaj, receiving their name from the black marks certain Arabian horses have round their eyes," marks which give them the appearance of being painted with kohl after the fashion of the Arabian women. Or indeed Keheîlan may be merely a new name for the Ahwaj, used first as an epithet, but afterwards superseding the older name in Arabia. Abcl-el-Kader told Blunt that the five mares of Solomon so often mentioned by Arab townsmen were Benat-el-Ahwaj, purchased by Solomon from the Ishmaelites, and that one of them, the most celebrated, was given by him to the Sheikh of $\mathrm{Uzd}$, in which tribe her descendants are still said to be found. She was called Zad-elMusefir, "Food for the Traveller," on account of her being fast enough to overtake the gazelle.

The fact that the Emir Abd-el-Kader believed that the original stock of the Abwaj still survives in North Africa, when taken in conjunction with the further fact that the five great strains of the Kohl breed are unknown in that region, will be found of considerable significance at a later stage in our inquiry.

Mr Bhnt ${ }^{2}$ and Major-General 'Tweedie ${ }^{3}$ are agreed in the opinion that the peninsula of Arabia, "as at present known, can never have supported wild horses," on the ground that, as water cannot be obtained from pools, but must be drawn from dug wells, and as the pastures are burnt up during part of the year, horses would inevitably perish of thirst and hunger, unless man drew water for them from deep wells and stored up fodder for

1 The Bedouin Tribes, etc., Vol. II. p. 267.

3 Op. cit., pp. 7-8.

2 Op. cit., Vol. II. p. 215. 
the season of scarcity. But it does not follow that all parts of Arabia have always been so unfitted for wild Equidae. We have seen above (p. 202) that in Strabo's time the region south of Nabataea possessed wild animals in abundance-camels, asses, gazelles $^{1}$, and some other cervine species, as well as large carnivorae, such as lions, leopards, and wolves, the two former of which depend for subsistence on a good supply of herbivores, whilst all three must have water to drink. It would thus appear that the climate has altered considerably since the Christian era, and the movements northwards in later times of the Anazah and Shammar tribes seem probably due in the main to the failure of pasturage in Najd. Mr Blunt thinks that "we may be content with accepting the usual belief that Arabia was one of the countries where the horse was originally found in his wild state, and where he was first caught and tamed," yet he urges that it was " not in the peninsula of Arabia, where water is only to be had from wells, that the original stock can have been found, but rather in Mesopotamia and the great pastoral districts bordering the Euphrates, where water is abundant and pasture perennial. Here the wild horse must have been originally captured (just as in the present day the wahash or wild ass is captured), and taken thence by man to people the peninsula?".

But this assumes that the Arabs had the horse at a very early period, a view totally disproved by history, as we have just seen; it has also been shown that the horse does not appear in Babylonian records till about 1500 B.C., and it has just been made clear that the best horses of Babylonia and Mesopotamia under both Assyrian and Persian empires were very different from the Kohl breed of modern Arabia.

On the other hand Major-General Tweedie ${ }^{3}$, whilst agreeing with Mr Blunt that "Arabia as at present known can never have supported wild horses," holds that "at an early time the

1 Lady Anne Blunt (Pilgrimage to Nejd, Vol. I, pp. 223-4) saw in the garden of the Emir Muhammad-ibn-Rashid at Haïl in Jebel Shammar in Najd, two kinds of gazelles, one variety being more brown than the other, and a couple of ibexes with immense heads.

2 Blunt, The Dedouin Tribes, Vol. 1I. pp. 245-6.

3 Op. cit., p. 74. 
Bedouin Arab must gradually have formed bis breed of horses in accordance with the sure decree boni et fortes bonis et fortibus creentur," and urges that "if special and exclusive breeding directed to a certain object explain our English race-horse, there is no need to go further for the secret of the Arab's foraymare." But this view is confronted with the fatal objection that the Bedouins, as has been fully shown by Mr Blunt ${ }^{2}$ and by Major-General 'Tweedie ${ }^{3}$ himself, are ignorant to this day of the very first principles of horse-breeding and horse-management. Furthermore, Tweedie is careful not to tell us from what primeval stock the Arabs artificially developed the Kohl breed, since he points out that the common belief "that the Semitic peoples as a whole were indebted for the horse to the Iranian upland, which comprises Persia, is only a conjecture."

But these are not the only difficulties that beset Tweedie's view (which was also that of Darwin). Let us grant for the moment that the Arab horse is simply an artificial product. As the Arabs did not begin to breed horses until some time between the first and sixth centuries of our era, no horses of the Arab type, such as either the bay Anazah horses, or the "sons of horses," can have existed in Syria and Palestine in the first seven centuries after Christ. Yet this conclusion seems directly contradicted by the actual facts, for it seems highly probable that in the first century of our era Palestine possessed various kinds of horses very like those known there and in Arabia at the present inoment, though not of so fine a quality.

In the Apocalypse when the Lamb opened one of the seals, and one of the four beasts cried "Come and see," the writer of the splendid vision "saw and beheld a white ( $\lambda \epsilon$ єкós) horse: and he that sat on him had a bow: and a crown was given unto him : and he went forth conquering and to conquer. And there went

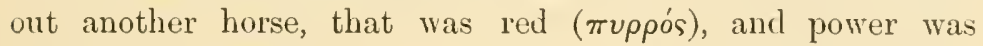
given to him that sat thereon to take peace from the earth, and that they should kill one another: and there was given unto him a great sword. And when he had opened the third seal,

1 Op. cit., p. 241.

2 The Bedouin Tribes, Vol. I. p. 258; cf. Pilgrimage to Nejd, Vol. I. p. 225.

3 Op. cit., p. 22.

4 Op. cit., p. 239.

R. H. 
I beheld, and to a black ( $\mu$ é $\lambda a s)$ horse, and he that sat on him had a pair of balances in his hand. I heard a voice in the midst of the four beasts, saying, A measure (choenix) of wheat for a penny (denarius), and see thou hurt not the oil and the wine. And when he had opened the fourth seal,...I looked, and behold a yellow ( $\chi \lambda \omega \rho o ́ s)$ horse : and his name that sat on him was Death, and Hell followed with him. And power was given unto them over the fourth part of the earth, to kill with sword, and with hunger, and with death, and with the beasts of the earth "."

As we have seen that white horses were held sacred amongst the ancient Germans, Illyrians, and Persians, by the medieval Tartars, and in modern Sumatra, and that from religious motives they are preferred by the Arabs of to-day ${ }^{2}$, although they are fully aware that bay horses are the best, it is not surprising that the white horse stands first in the estimation of the author of the Apocalypse, and that he represents the rider of that steed as given a crown and going forth to conquer. In another passage of the same book when heaven opened a white horse came forth, "and he that sat on him was called Faithful and True, and in righteousness he doth judge and make war. His eyes were as a flame of fire, and on his head were many crowns; and he had a name written that no man knew, but he himself. And he was clothed with a vesture dipped in blood, and his name is called The Word of God. And the armies which were in heaven followed him upon white horses, clothed in fine linen, white and clean ${ }^{3}$."

As the sanctity attached to white has given in all ages a higher value to horses of that colour than was really merited by their powers of speed or endurance, St John preferred the white horse to the red, that is, the bay or chestnut.

We have just seen that bay is the colour of the best Arab horses, that dun colour is characteristic of the unmixed Turcoman or Mongolian pony, and that black horses are a regular result of crossing the Arab with the Mongolian. As

1 Rev. vi. 2-8.

2 W. S. Blunt, cited by Capt. Hayes (Points of the Horse, p. 326, ed. 3).

${ }^{3}$ Rev. xix. 11 sqq. 
St John's red horse is simply bay or ehestnut, and his yellow horse a dun, that is, a common kadish, or Turcoman pony, and he also knows the black horse (now eommonly found in Jelfon, and never among pure-bred Arabs) and places it after the bay, but before the dun, we are led to conclude that in the first century of our era, before the Arabs had as yet begun to keep or breed horses, Palestine already possessed the same three kinds of horses that are there found at the present moment.

But bay horses were no new feature in Palestine at the Christian era, for the prophet Zechariah ${ }^{1}$ saw in vision in the reign of Darius (B.C. 522-484) "a man riding upon a red (muppós) horse, and he stood among the myrtle trees that were in the bottom; and behind him were there red ( $\left.\pi v \rho \rho i^{\prime}\right)$ horses,

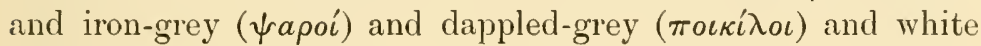

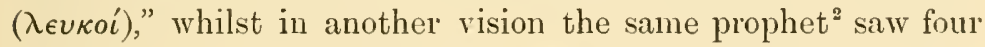
chariots come out from between two mountains: "in the first chariot were red ( $\pi v \rho \rho o i)$ horses, in the second chariot were

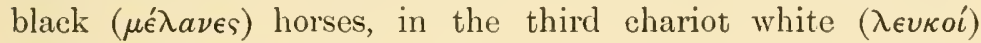

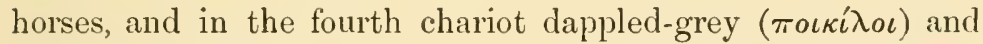

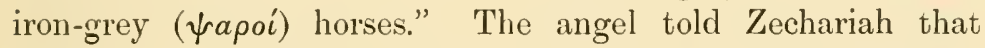
these were "the four spirits of the heavens which go forth from standing before the Lord of all the earth. The black horses which are therein go forth into the north country; and the white go forth after them; and the dappled-grey went towards the land of the south wind, and the iron-grey went forth and sought to go that they might walk to and fro through the earth." It is now elear that centuries before the Christian era not only was the bay horse known in Palestine, but the various kinds of cross-bred horses-black, iron-grey, and grey of a lighter shade, so characteristic of Asia Minor and Irak at the present hour-were already well known. It is worthy of notice that Zechariah, unlike the author of the Apocalypse, does not assign any preeminence to white horses, for he evidently regards the bay horse as the best both for riding and for driving.

Finally, Tweedie supports his view that the Arab horse is

$$
\text { 1 i. } 8 .
$$


simply the result of artificial breeding by assuming like all other writers that the English race-horse is purely the outcome of "special and exclusive breeding directed to a certain object." But it will be presently shown that "special and exclusive breeding" has been by no means the sole factor in producing that famous breed.

From the foregoing considerations it follows that the duncoloured kadishes found at the present moment amongst the Arabs of the peninsula, Syria, and Irak, were derived from upper Asia, and, as we have seen that white horses have been a feature of the northern parts of Asia and Europe from the dawn of history, there is a prima facie probability that white and grey horses of a superior quality such as the Handani family of Al Khamseh, may in part at least trace their pedigree to animals brought from Persia and upper Asia. This is rendered all the more likely from the fact that Mr Blunt's beautiful white Hamdani mare (p. 170) was in appearance, head excepted, like an English hunter, that is, like a good cross-bred horse. It may even turn out that the chestnut colour found not only in the inferior strains outside $\mathrm{Al}$ Khamseh, but also among the best horses of the Shammar, and even in some of the best Anazah strains, may be due to an intermixture of the duncoloured northern stock with some other race, for it is significant that the favourite charger of Muhammad Ibn Rashid, a chestnut mare with three white feet, was "very powerfully built, had much hair at the heel, and showed more bone than breeding," all characteristics (especially the hairy heels) suggestive of a north Asiatic strain, but to this question we shall return later on (p. 442). On the other hand, the evidence already placed before the reader shows clearly that the best Arab horses, the bay of the Anazah, so far from their having come from any part of upper Asia, are eagerly sought for by all the tribes of Syria, Irak, Mesopotamia, and the rest of western Asia to improve their own native breeds. But, as dark horses were existing in Palestine at the beginning of the Christian era, we may infer that the Arabs derived their best strain either from Palestine, or else through Palestine from some other country. In this connection the fact that Ali's famous charger Mai-mun 
was of Egyptian origin ${ }^{1}$ is of great importance, as it at least indicates that the Arabs at that date obtained their best horses from Egypt.

The myths respecting the origin of the Kohl breed point in the same direction. We have already seen that one legend derives it from five mares of King Solomon, whilst another alleges that when Ishmael was deploring the barrenness of his heritage - the Arabian desert - it was declared to him that the greatest gift to man was reserved for him, and accordingly he met and eaptured the Kohl horse in the Hijaz². But as the Hijaz is the strip of land on the Red Sea through which the full tide of commerce between Arabia and Egypt flowed in the time of Strabo (in whose day there were no horses in Arabia) and for centuries later, and as we have direct evidence for the export of horses from Egypt to Arabia, this myth itself seems to recognise Egypt as the souree of the Kohl breed.

The acquisition of horses by the Arabs in the centuries immediately preceding the birth of Muhammad was one of the most momentous events in the history of the world. In the long ages before the coming of the Prophet the Arab tribes had played no leading part in the struggles for the mastery of western Asia and Egypt, in which the Babylonian, Egyptian, Assyrian, Mede, Persian, Macedonian, and Roman, had each in his turn come forth victorious, though only to be vanquished in due course by some fresh claimant. Thongh the Arab could defy any enemy rash enough to invade the waterless, sandswept deserts, as is proved by the disastrous attempt of Aelius Gallus, the Roman general, to conquer Arabia Felix, yet so long as the Arabs fought only on foot or from the backs of camels they never were a real source of danger to neighbouting lands. All the fervour and fanaticism of the Prophet would have been of little avail, and Islam might never have affected the world as it has done, had it not been that in the period immediately before the birth of Muhammad, their leading men had obtained horses, were engaged in breeding these animals, and had become skilful horsemen. The Prophet himself clearly 
realised the immense importance of horses to his people, as is plain from variuus passages in the Koran. He declares that the Almighty created horses from a condensation of the south-west wind and he represents God as thus apostrophising that animal: "Thou shalt be for nan a source of happiness and wealth; thy back shall be a seat of honour, and thy belly of riches; every grain of barley given to thee shall purchase indulgence for the sinner!" Elsewhere he propounds the comfortable doctrine that the money which one spends on horses in the eyes of God is alms that one makes at one's own cost. "Every grain of barley given to a horse is entered by God in the Register of Good Works." Readers of history well know that it was to their cavalry that the first caliphs owed largely their astonishing conquests.

Let us now return to the horses of Persia, Media, and Assyria. It is clear from our investigations into the history of the Arab horse that the Nisaean breed-the best horses in Asia in the centuries before the Christian era-did not come from Arabia. But though the potentates of Asia could not import horses from Arabia, there was another region from which by at least 900 B.c. they habitually procured horses at a great price. In the Book of Kings we read how "Solomon had horses brought out of Egypt and linen yarn: the king's merchants received the linen yarn at a price. And a chariot came up and went out of Egypt for six hundred shekels of silver, and a horse for an hundred and fifty: and so for all the kings of the Hittites, and for the kings of Syria, did he bring them out by their means.". The Hittites are supposed to have pushed down to northern Palestine by 1400 B.c., as is inferred from letters written by the petty kings of Palestine to their Egyptian overlords, Amenophis III and Amenophis IV, preserved in the Tel-el-Amarna tablets ${ }^{2}$. According to Prof. Jensen, the Hittites were Indo-Europeans, and their script was invented by the forefathers of the modern Armenians. They may therefore have passed down from that region, from which, as we have seen, horses were being sent to Palestine in the seventh century B.C.

11 Kings x. 26-28.

2 Hilprecht, Explorations in Bible Lands, p. 620. 


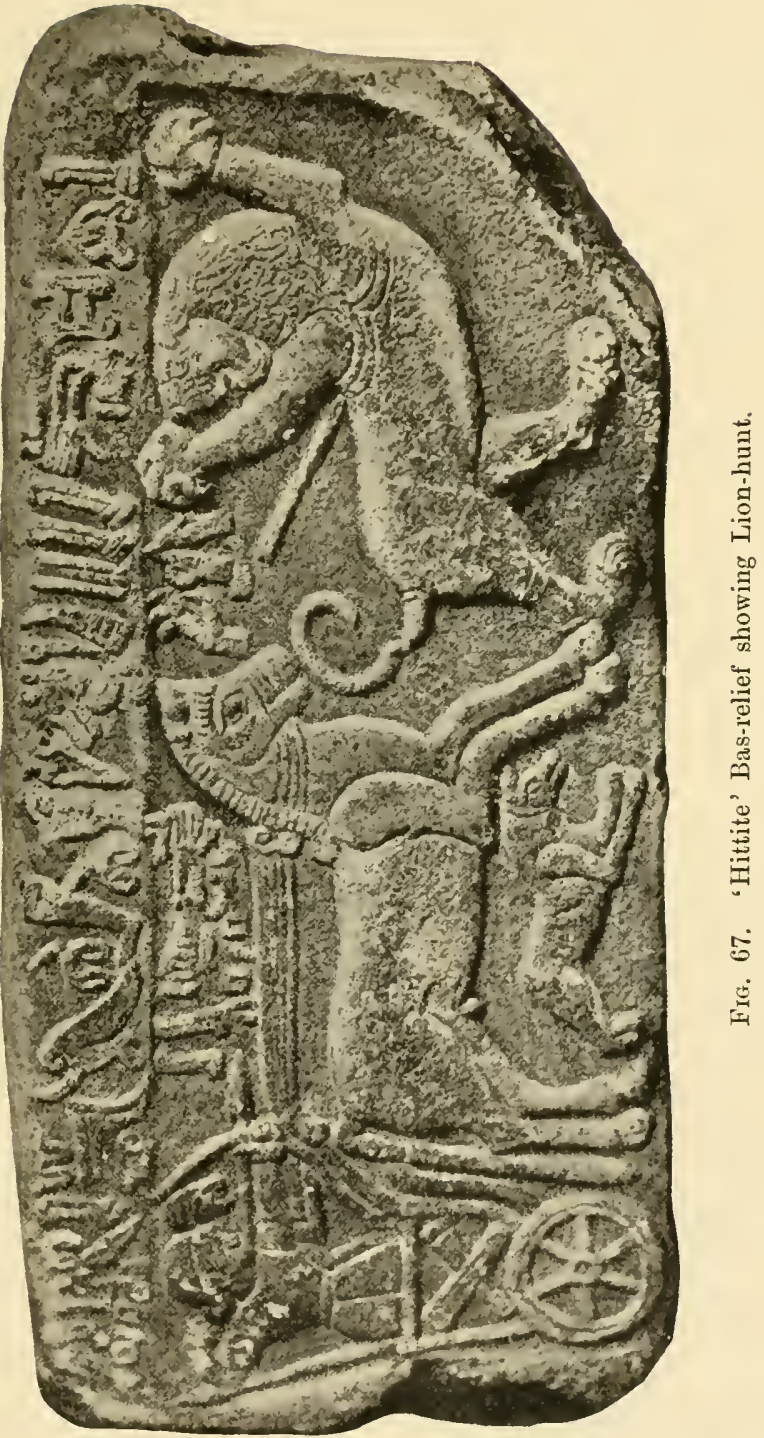


Jensen has identified a colt's head symbol found on several so-called Hittite inseriptions as Mut(d)allu, the name of several kings mentioned in Assyrian inscriptions. I here reproduce (Fig. 67) a bas-relief found near Malatya (the ancient Melitene) in 1894. It is assigned to the eighth century B.c. ${ }^{1}$ and represents a lion-hunt, but the conventional drawing of the horse does not enable us to judge of the effect produced on Hittite horses by the blood stock imported through Solomon. Professor Owen was the first to point out that the horse does not appear at all early on Egyptian monuments, and his acute observation has been amply verified by later inquiry. It is now certain that the horse and the chariot appear for the first time only on the monuments of the eighteenth dynasty. The first mention of a chariot occurs in the reign of Aahmes I, a king of the seventeenth dynasty and the expeller of the Hyksos. This king cannot have begun to reign earlier than B.C. $1587^{2}$, and possibly his reign falls considerably later. The pictograph for the chariot shows a wheel with four spokes. The testimony of the Egyptian monuments is quite in accord with that of the Book of Genesis, which represents the Egyptian monarch as bestowing every sort of domestic animal except horses upon Abraham, who according to the traditional chronology flourished in the eighteenth century B.c.

It has long since been suggested that the Egyptians owed the horse to their Hyksos conquerors, but this has never been proved, though it seems certain that the horse was introduced during the dark period between the Middle and the New Empire. 'The best authorities are agreed that the terms for horse which became ssmt and sinsm in Egyptian, and which also appear in Canaanite and Aramaic, are loan words, but whence borrowed no one yet knows ${ }^{3}$. The two words for wheel carriages-merkobt (cf. Sem. merkab), and the agolt (cf. Sem. agala)-were likewise

I Hilprecht, op. cit., p. 779, with the figure, for permission to copy which I am indebted to the great kindness and courtesy of Messrs A. J. Holman and Co., the well-known American publishers.

2 Prof. Flinders Petrie dates his reign as B.c. 1587-62 (Hist. of Egypt, Vol. II. p. 29).

3 Erman, Life in Ancient Egypt, p. 517. 
foreign words, perhaps Semitic, as Erman holds, but possibly borrowed by the Semites also. The word katana, charioteer, is foreign. It is thus certain that the Egyptians borrowed the horse and the chariot from some neighbouring people. The borses are represented as spirited animals pawing the ground with impatience, and carry their tails just like the well-bred Arab of to-day (Fig. 68). The royal stud was an establishment of great importance, and the office of First Charioteer (hatana) to his Majesty was held even by princes. 'The king's favourite horses — "the first great team of His Majesty"-bore fine-sounding names (strongly contrasting with the simple nomenclature of the horses of the Homeric Acheans), such as "Amon bestows strength," and "Amon entrusts him with victory," the latter being termed in addition, "Anat (the war-goddess) is content." 'The horses are usually painted brown on the monuments, though in a few instances however we meet with a team of white hor'ses, as for instance in a tomb at 'Em-nud'em. 'The occasional occurrence of light-coloured horses on Egyptian monuments is a clear indication that some of the horses employed in Egypt were derived-though we know not when-from western and upper Asia. We have some evidence which points to Mesopotamia as the probable source, for an Egyptian inscription mentions the importation of horses from Sangar ${ }^{1}$, which is identified with the modern Sindjar, the mountainous region between the Euphrates and Tigris, in which, as we have seen above (pp. 183-4), light-coloured horses, in spite of the constant infusion of bay Arab blood, are still practically universal.

There are no representations of Egyptians on horseback, and with the exception of a few very doubtful allusions in documents there is no evidence that they ventured to mount the horse at all until a very late period ${ }^{2}$.

1 Erman, Life in Aneient Eyypt, p. 517.

2 Erman, Aegypten (Eng. trans.), p. 493. A. v. Kremer holds that the Hebrew and Aramaic names of the horse (sus) point to their being loan-words from Indo-Germanic (Skt. açvas, Zend aspa, etc.), and that Arabic faras (Hebr. paras) points to the Persian, though F. Hommel places the horse amongst the animals domesticated by the original Semites (Schrader, Preh. Antiquities of the Aryan Peoples, p. 43, Engl. trans.). 
To the acquisition of horses was plainly due the great conquests of the monarchs of the eighteenth and nineteenth dynasties, such as Rameses II (called Sesostris by the Greeks), who pushed his conquests into far regions of Asia and Africa. It may even turn out that so far from the Egyptians having obtained the horse from the Hyksos, their successful revolt and final expulsion of that people was due to the fact that the latter had no horses, whilst the Egyptians had been able to obtain these animals from a neighbouring region. But though the king had a numerous body of war-chariots, it must not be supposed that the horse was generally used by the Egyptians for any other purpose than war. The king and his nobles rode in chariots, but the ordinary people used the ass, known in Egypt for many centuries before the horse. Wre are told that "Pharaoh made Joseph ride in the second chariot that he had"," and those Egyptians who bought with horses corn from Joseph ${ }^{2}$ were probably the wealthy class who would be obliged to furnish chariots and horses to the king in time of war. When Pharaoh pursued the Israelites he took with him six hundred chosen chariots $^{3}$, which probably represent the standing force of war chariots kept in readiness.

Achilles is represented in the Iliad $^{4}$ as declaring that no gifts from Agamemnon can assuage his wrath, not even if he gave him all the revenue of Orchomenus or Egyptian Thebes"Thebes of the hundred gates, whence sally forth two hundred warriors through each with horses and chariots," but in such a passage we may well make allowance for considerable poetic exaggeration.

It is now plain that Egypt did not get from the Arabs or from any other Semitic people the horses which she was exporting into Asia Minor in the tenth century B.C., and we know not how much earlier. As she was sending them into regions

1 Gen. xli. 43.

2 Gen. xlvii. 17.

3 Ex. xiv. 7. "Six hundred chosen chariots, and all the chariots of Egypt." But the latter clause may well mean, even "all the chariots of Egypt," from which it would follow that six hundred chariots was the full number that the king could put in the field, a very likely figure.

$+1 \mathrm{x} .381$. 
where the upper Asiatic horse had by that time been long in use, it is clear that the Egyptian horses for which great prices were paid must have been superior in quality to the native horses of western Asia. But as the Egyptian horses were almost always of a dark colour, and as we have shown that the few white horses seen on the monuments were probably derived from Asia, it follows that the Egyptian horses so highly valued by the kings of Syria and the Hittites were of a dark colour. These horses must have been bred in Africa, but, as Egypt could not breed them herself in sufficient numbers for export, she must have drawn her supply from neighbouring peoples. She could not have obtained them from any of the tribes which dwelt in North-east Africa between the Nile, the Red Sea, and the Indian Ocean, for Strabo, who had very full information respecting all the nations of that area, demonstrates clearly that down to the Christian era not one of these tribes used either the horse or the camel.

But on the west bank of the Nile it was far different. The Ethiopians indeed and the Nubians, who dwelt on the left bank of the river, had no horses, as seems absolutely certain from Strabo's account of these peoples ${ }^{1}$, a fact which, taken in conjunction with the complete absence of the horse amongst all the peoples lying between the Nile and the Indian Ocean, demonstrates that there is no historical foundation for M. Sanson's E. c. africanus (the breed of Dongola) which according to that writer originated in North-east Africa, "probably in Nubia" (p. 2). But on the other hand it can be proved that all the Libyan tribes who lived between the Nile and the Atlantic were not only drivers of horses from before the dawn of history, but that they also possessed the best breed that the world has known.

In the Odyssey when the disguised Odysseus pretends that he is a Cretan, he relates how after returning home from Troy to Crete, a few days later he took part in a disastrous piratical expedition to the mouth of the Nile: "We came to the fairflowing Aegyptus, and in the river Aegyptus I stayed my 
curved ships. Then verily I bade my dear companions to abide there by the ships, and to guard them, and I sent forth scouts to range the points of outlook. But my men gave place to wantomness, being the fools of their own force, and soon they fell to wasting the fields of the Egyptians, exceeding fair, and led away their wives and infant children and slew the men. And the cry came quickly to the city, and the people hearing the shout came forth at the breaking of the day, and all the plain was filled with footmen and horsemen and with the glitter of bronze. And Zeus whose joy is in the thunder, sent an evil panic upon my company, and none durst stand and face the foe, for danger encompassed us on every side. There they slew many of us with the edge of the sword, and others they led up with them alive to work for them perforce. But as for me Zeus himself put a thought into my heart; would to God that I had rather died, and met my fate there in Egypt, for sorrow was still mine host. Straightway I put off my well-wrought helmet from my head, and the shield from off my shoulders, and I cast away my spear from my hand, and I came over against the horses of the king, and clasped and kissed his knee, and he saved me and delivered me, and setting me on his own chariot took me weeping to his home ${ }^{1}$."

There can be no doubt that the place where the Greeks are supposed to land was the western mouth of the Nile, that nearest to Crete. The natural advantages of this spot led Alexander to plant there the famous city called after himself, to this hour a witness to his political as well as military genius. The city was built close to the village of Rhacotis, which later on became part of Alexandria. Strabo ${ }^{2}$, who had long studied in the great library of Alexandria, tells us that the ancient kings of Egypt had kept a guard at Rhacotis to check the descents of the Greeks:- "The country about the village was given up to herdsmen, who were also able from their numbers to prevent strangers from entering the country."

I Od. XIv, 267:

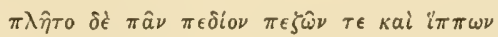
$\chi a \lambda \kappa o \hat{v} \tau \epsilon \sigma \tau \epsilon \rho \circ \bar{\eta} s$.

779. 
Alexandria was washed on the south by the lake Mareotis or Marea on which stood the town of the same name. Now not only is it probable that the Delta itself was in part peopled by Libyans, but beyond doubt in that part of Egypt which bordered on the lake Mareotis the population was Libyan, for Herodotus states that "the people of the cities of Marea and Apis, who live in the part of Egypt that borders Libya, took a dislike to the religious usages of the country concerning sacrificial animals, and wished no longer to be restricted from eating the flesh of cows. So as they believed themselves to be Libyans and not Egyptians, they sent to the shrine of Ammon in the Libyan desert to say that, having nothing in common with the Egyptians, neither inhabiting the Delta, nor using the Egyptian tongue, they claimed to be allowed to eat whatever they pleased." Their request, however, was refused by the god, who declared in reply, "that Egypt was the entire tract of country which the Nile overspreads and irrigates, and the Egyptians were the people who lived below Elephantine, and drank the waters of that river."

Not only in the time of the xxth dynasty did the Libu or Libyans make constant incursions into Egypt, but earlier still, in the reign of Rameses II (circa 1300 B.C.), the third king of the xixth dynasty, the Libyan tribes had entered Egypt but were repulsed. Thus, as far as our knowledge extends back into the annals of the new Empire, the Libyans are scen periodically swooping down upon the rich and tempting valley of the Nile, and we may conjecture without rashness that such too had been their practice throughout unrecorded generations.

The people of Marea and Apis declared that they were Libyans and had nothing in common with the Egyptians. Their statement is amply confirmed by the testimony of Strabo that the inhabitants of that district were sturdy herdsmen, and by the Book of Genesis ${ }^{1}$, which explicitly states that "every shepherd is an abomination to the Egyptians." That Marea was at all times the point at which the Libyans threatened Egypt is demonstrated by the fact that Psam- 
metichus I planted here a colony of Greek mercenaries to keep in check the encroachments of his restless neighbours.

We may therefore conclude that the people upon whom the company of Odysseus made a descent, and who are represented as rich in cattle and possessing chariots and horses, were the Libyans of the district of Marea ${ }^{1}$, those stout herdsmen, who, according to Strabo, were well able to ward off Greek pirates.

This conclusion gains support from a chariot found in a tomb in the Necropolis of Thebes, and now in the Archaeological Museum at Florence. Egyptologists hold that it cannot be later than the fourteenth century B.C. and that it is not of Egyptian manufacture, but rather imported from some northern country. The vehicle (Fig. 69) has four-spoked wheels and is of remarkably light construction, in this respect coinciding completely with chariots of very light weight recorded in Egyptian documents, and with the ordinary Egyptian chariots seen on the monuments of the xixth dynasty, such as that of Seti I, the predecessor of Rameses II here figured (Fig. 68).

The body of the chariot ${ }^{2}$ consists of a floor, in length about thirty-three inches, in breadth about sixteen inches, and is formed by two parallel bent rods, pinned together with lumps of wood or bone iu between, leaving intervals for leather meshwork, which was lashed in through ten holes in each of the parallel rods, while the back-piece is formed of a fairly solid board about four inches broad, to the front of which, through holes, the leather meshwork is lashed, and underneath which the butt of the pole is fastened, which does not project behind, but is morticed into the back-piece of the body. The latter is supported by the pole and by the projections of the frame, which rests on sockets attached to the axletree. The front of the body consists of three bent rods, meeting and lashed

1 Ridgeway, Early Age of Greece, I. pp. 215-16.

2 The description here given is from the very careful notes made for me by my friend R. S. Conway, Litt.D., Professor of Latin, Victoria University, Manchester, who made most careful observations and measurements on the spot, but as the chariot is hermetically sealed up inside a glass case the measurements are approximate. 
together at the highest point, which is about thirty-two inches vertically above the floor; the shortest rod bends forwards, the other two bend outwards, downwards and backwards, so as to reach the back bar of the floor, but not quite at its outer ends, each rod standing in a kind of socket.

The axletree is seventy-seven inches long and is one and a half to two inches in diameter. The wheels are thirty-eight inches in diameter, and are four-spoked, the spokes fitting into a nave, formed by a hollow wooden cylinder about nine inches long, through which runs the axletree; the wheels are kept in place by pegs (linch-pins) outside, and on the inside by the sockets which support the frame of the body. Both the spokes and felloes are about one and a half inches in diameter.

The pole is about six feet long, and there are in it two holes near the extremity, in one of which is a peg to which the yoke is lashed. It is about two inches thick at the point, but is probably three inches at the thickest part. It is bent into an elbow, where it meets the body and there flattens out to a breadth of about four inches, and it is dovetailed into the backpiece of the body, whilst in front it is lashed to the frame of the body and to a curving upright rail which supports the upper rim (corresponding to the antyx in the Greek chariot).

The extreme length of the yoke is thirty-two and a half inches, and as now arranged it is lashed to the nozzle of the pole and to a peg which pierces the pole just short of the yoke. At the end of the curves there are bone studs. It consists of a flattish rod, tapering from about two and a half inches in the centre to about one inch at the horns. It is not more than one and a quarter inches thick vertically at any point. There are two $Y$-shaped objects at present hanging from the horns of the yoke; their arms are pierced with holes, and the height of the whole is seven inches, the width inside from hole to hole not being more than four inches, and the tail ends in a large round bone stud one and a half inches in diameter. These have been termed collar-pieces, but their size forbids their being so used even for very diminutive horses.

The Egyptian chariots seen on the monuments had wheels of four, six or eight spokes, though the six-spoked are the 


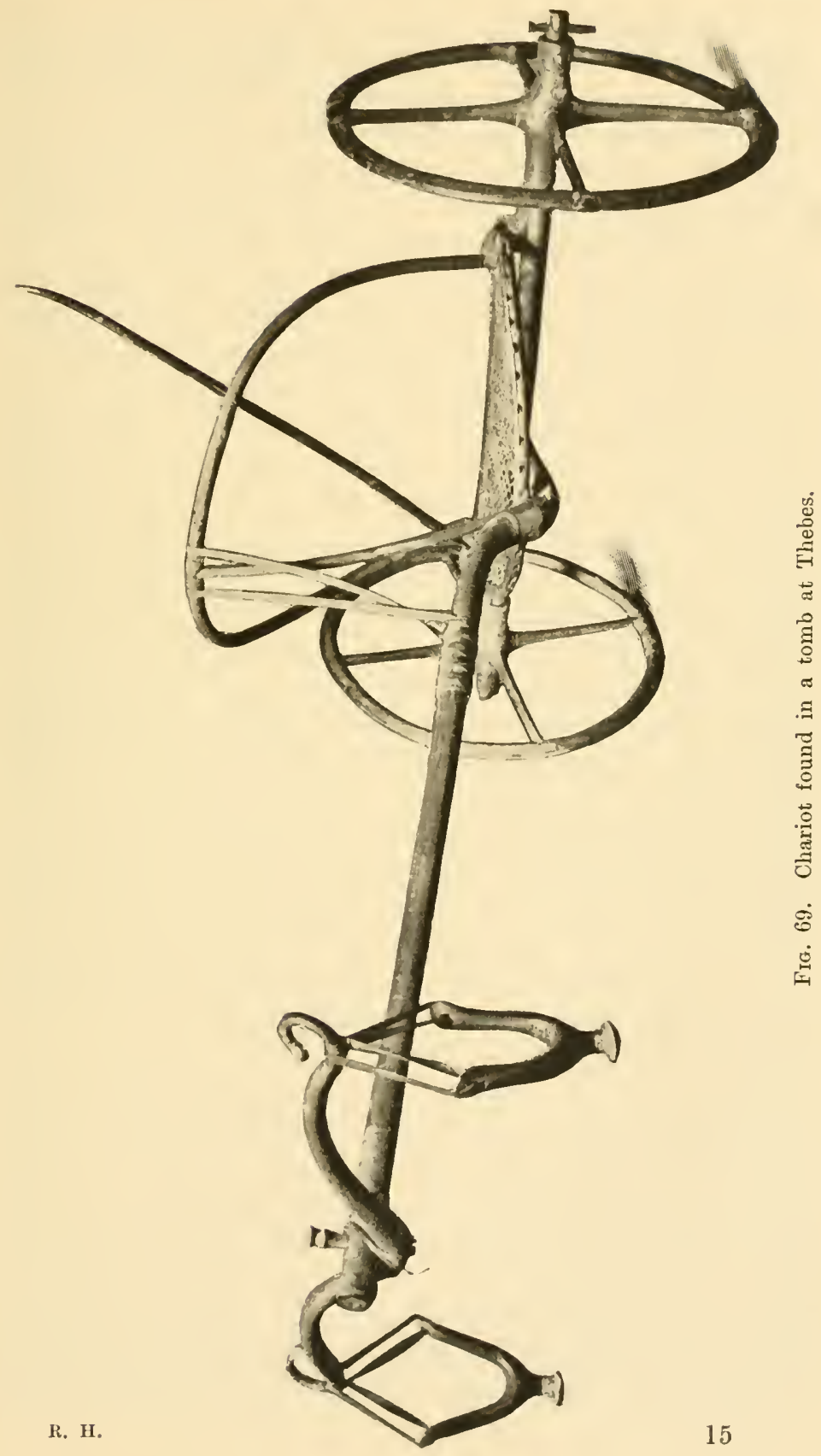


more common. It seems certain that the simple four-spoked wheel is earlier than those with six, eight, and twelve spokes. Whilst it is quite possible that the Florentine chariot is not strictly Egyptian, it is very improbable that it is of northern origin, for the chariot is entirely composed of wood joined with pegs or studs of bone, not a single scrap of metal of any kind-copper, bronze, or iron-being used in its construction. Now the Egyptians had been using copper from predynastic times, and as at the time of the exodus, according to the Book of Joshua, the Canaanites had chariots of iron ${ }^{1}$, for "the children of Joseph said, The hill is not enough for us; and all the Canaanites that dwell in the land of the valley have chariots of iron," and "Judah ${ }^{2}$ could not drive out the inhabitants of the valley because they had chariots of iron," and as Jabin", king of Canaan, "had nine hundred chariots of iron," and as moreover all the peoples of Asia Minor had been employing copper for many centuries, and by 1400 B.C. some of them were using not only bronze but even iron, it is most improbable that either Egyptian, Canaanite, Syrian, or Hittite, was the maker of the Theban chariot. On the other hand, since the Libyans, who furnished chariots to the army of Xerxes (480 B.c.), had not even weapons of metal, but only carried javelins with the points hardened in the fire ${ }^{4}$, it is clear that if they were not using metal for their cutting weapons in the fifth century B.C., it is most improbable that they were using metal to fasten together their chariots, and it is much more unlikely that they would have been employing copper or any other metal in building chariots, such as those which are represented as routing Ulysses and his company somewhere toward the close of the second millennium B.c. It is obvious that a chariot of such light construction with wheels unshod with metal tires, such as those which protected the Homeric chariot-wheel and probably the "chariots of iron" of the Canaanites, would have been perfectly unfit for stony or hilly countries like Palestine and other parts of Asia Minor, though it would be admirably suited for the sandy plains of Libya. The evidence therefore all points to the Florentine
1 xvii. $16-18$.
2 Judges i. 19.
3 Judges iv. 3.
4 Herod. vir. 71. 
chariot being of Libyan, rather than Asiatic origin, a conclusion supported by the fact that it has (like the chariots scen on some Egyptian monuments and on the grave-stones of Mycenae, p. 108) four-spoked wheels instead of whecls of six and eight spokes, such as are seen on Hittite, Assyrian, and some Egyptian monuments, and such as the eight-spoked chariots of the Homeric Acheans in the early Iron Age. Moreover, the fact that the yoke was originally covered with morocco, for the manufacture of which the Libyans had long been famous in the fifth century B.C.', also points to a Libyan origin.

It is therefore probable that the Egyptians obtained their light four-spoked chariot from the Libyans and along with it the horse.

Having once obtained the primitive Libyan chariot with a four-spoked wheel and no metal, the Egyptians gradually improved its construction by increasing the number of spokes in the wheel to six (Fig. 68) and even to eight and by using metal. In $1902 \mathrm{Mr}$ Howard Carter and Mr Percy E. Newberry excavated (at the cost of Mr Theodore M. Davis) the tomb of Thothmes IV (circa 141t--1383 B.C.), at El Molûk. It contained along with many other objects the remains of the king's chariot. "Although the wheels and several other parts of the chariot are missing, through its having been broken up and partially destroyed by the ancient plunderers of the tomb, the fragments that remain and the representations of the king's war chariot in the scenes modelled in stucco on the framework of the 'body,' give us valuable information respecting its structure?."

The 'body' consisted of a semicircular framework, open at the back, with a floor for the charioteer to stand on; the body of the chariot was supported by the pole which rested on the axletree, and to steady it was strapped on either side of the axletree by bands of leather. It was placed as far back as possible, so as to take the weight of the charioteer, and thus relieve the pole and yoke. The butt of the pole was dovetailed

I Herod. Iv. 189.

2 The Tomb of Thoutmosis IV, London, 1904. Mr Davis has just found (Times, $10 \mathrm{Mar}, 1905)$ a complete chariot having wheels with wooden tires and six spokes, in the tomb of the parents of Teie queen of Amon-hotep III. (See Addenda.) 
into a socket at the back of the body, and firmly secured by leather thongs to the front part, and in order to prevent it slipping back two straps were fixed into the rim and tied to the pole. The floor was made of leather meshwork. The axletree and wheels were of wood; the latter having eight spokes and tires of metal, and being secured to the axle by means of metal axlepins. The pole was of wood covered with leather, and it was bent into an elbow at about one-fifth of its length from the end, and was supported by a wooden yoke. The horses were yoked to the chariot by the following harness, made of leather and probably ornamented with leather bosses: (1) the breastharness with girth and yoke-saddle; (2) the bridle, nose-strap, forehead-band, the three cheek and one neck-strap; (3) the reins, which were fixed to the nose-strap and passed through a loop attached to the breast-harness and girth. The horses seem to have been controlled by the nose-strap and not by a bit. The charioteer carried a leather whip with a wooden handle. "Attached to the body of the chariot on the outside were a bow-case and two quivers, and on the inside a leather pocket or pouch with an embossed flap to cover it. The horses' saddles and the pole were of wood covered with red leather."

A comparison of this chariot with that at Florence shows that in structure they are essentially the same; the shape of the body with its leather meshwork floor, the method of morticing the pole into the back-piece, the shape of the pole, the leather covering of the pole and yoke, the wooden axletrees and wheels are found in each. The only points of difference are the number of spokes in the wheel and the use of metal, but it has to be remembered that as the wheels are missing in the chariot of Thothmes IV, the number of spokes and the use of metal tires rest only on conjecture.

The close resemblance between the Florentine chariot and that of Thothmes IV renders it highly probable that the Egyptian chariot was borrowed from the Libyans under the xviIth dynasty, and that it was gradually developed under the Xvinth dynasty by means of metal fittings until it arrived at the form in which we find it in the tomb of Thothmes IV and in the bas-relief of Seti I (Fig. (68), the second king of the 
xixth dynasty and predecessor of Rameses II. Moreover the finely-shaped horses seen under the chariot are clearly not to be identified with the horses of upper Asia, whilst, as already pointed ont, their dark colour is in itself a sufficient indication that they are not of the upper Asiatic stock, and proves that horses of a bay or brown colour existed in Egypt 1500 years before the Arabs possessed a horse. Furthermore the horses of Seti I (Fig. 68) carry their tails like the pure-bred Arabian of to-day, but, as we have seen, this is one of the characteristics that sharply distinguish the Kohl breed from the upper Asiatic horses. I have already pointed out (p. 3) that it has been assumed by M. Piètrement and others that the horse was brought into Egypt by the Hyksos, who are further assumed to have been Mongols, and that M. Piètrement has gone so far as to give the name of E. c. mongolicus to the race termed africanus by $\mathbf{M}$. Sanson, and assumed by him (wrongly as we have just seen) to have originated in North-east Africa. Now if the Hyksos were Mongols, and brought the horse from Central Asia into Egypt, we ought to find the characteristic upper Asiatic horse on the Egyptian monuments, but, as I have just pointed out, the Egyptian horses differ essentially in colour, shape, and fashion of carrying the tail from all upper Asiatic horses of which we have any knowledge, whilst it has been demonstrated that from at least B.c. 1000 there had been a constant demand in Asia for horses of this type, and that they have been continually passing from Egypt into Palestine and Arabia, and through these two regions into all western, central, eastern, and southern Asia. Moreover there is not a scintilla of evidence for the theory that the Hyksos were Mongols. On the other hand the proved facts relating to the history of the horse are in complete accord with the scanty historical data which we possess concerning the Hyksos. For these we are indebted to Manetho, the Egyptian priest, who, after the conquest of Egypt by Alexander the Great, compiled in Greek from the ancient records of his race a history of Egypt from the earliest times, the value of which even in relation to the earliest dynasties has been strangely confirmed by the excavations of recent years, even king Menes, so long supposed to have been merely a myth, having been now proved to 
have had a very real personality. Unfortunately the work itself has been lost and our knowledge of it is only derived from fragments embodied in the writings of other ancient historians. Josephus ${ }^{1}$ has fortunately preserved for us Manetho's account of the Hyksos, and this supplemented by one or two Egyptian monuments is practically all the evidence that we possess.

In the Second Book of his Egyptian History Manetho wrote as follows: "In the time of this king (Timaeus), for some reason or other God was displeased with us, and from the eastern quarters, contrary to all expectation, men of a race not marked by any distinctive appellation ${ }^{2}$ became emboldened and marched against our land and easily subdued it by their force without fighting any battle. And having got into their hands the leading men of the land, they savagely both burned the cities and demolished the temples of the gods, and treated most cruelly the people of the land, slaying some and enslaving the children and wives of others. Finally the invaders took as king one of themselves named Salitis. He dwelt in Memphis, and made tributary both the upper and the lower country, and left garrisons in the most suitable places. He took special precautions to fortify his eastern frontier, foreseeing that, as the Assyrians were waxing in power, they would one day desire to invade his kingdom. Having found in the Sethroite nome on the east side of the Bubastic river (i.e. the Bubastic arm of the Nile), a city most advantageously situated and named Avaris from some ancient sacred legend, he fortified it very strongly with walls and planted in it a force of 240,000 armed men to defend it. Thither in the summer season he repaired, partly to collect the food tribute and to pay his troops, partly to train them in order to strike terror into those beyond his borders. He reigned nineteen years and then died, and after him another king, by name Beon, reigned for forty-four years. After him another king named Apachnas reigned thirtysix years and seven months. Then Apophis reigned sixty-one years, and Iannas fifty years and one month. After all these also reigned Assis forty-nine years and two months. These six were the first amongst them who became rulers, continually

1 Contra Apionem, I. 14.

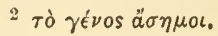


desiring more and more to eradicate the stock of Egypt. 'Their race was collectively termed Hyksos (' $\Upsilon \kappa \sigma \omega$ 's), which signifies Shepherd Kings, for hyk in the sacred dialect denotes a king, and sos ineans a 'shepherd' and 'shepherds' in the vernacular, and so the compound Hylisos is formed. Some say that they were Arabs. In another copy it is stated that by the term Hyksos is indicated not 'Shepherd Kings,' but 'shepherd captives,' for the words $y k$ and $A k$ in Egyptian, when aspirated,

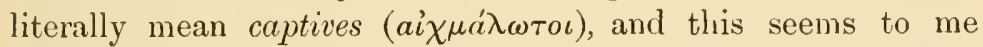
(i.e. Josephus himself) more plausible and more in keeping with the ancient history. Manetho states that these aforementioned kings-the so-called Shepherd Kings-and their descendants were masters of Egypt for five hundred and eleven years. But after this, says Manetho, both the kings of the Thebais and of the rest of Egypt revolted against the Shepherds and a great and protracted war broke out. But in the reign of a king named Misphragmouthosis, Manetho says that the Shepherds were defeated and were expelled from all the rest of Egypt, and they were shut up in a certain place which had a circumference of 10,000 ploughgates (ápoupai). Now this place was named Avaris, and Manetho says that the Shepherds had surrounded it with a high and strong wall for the security of their property and their plunder. But Thoumosis (Thothmes) attempted to besiege it and take it by storm, and beleaguered the walls with an army of 480,000 men. But just as he had despaired of reducing them by siege, they capitulated on condition that they would be permitted to depart unharmed whithersoever they pleased. In accordance with these terms they departed with all their families and possessions, in number not less than 240,000 , and made their way across the desert into Syria. But through fear of the power of the Assyrians, who were at that time the masters of Asia, they built in what is now Judaea a city of sufficient size to contain this multitude of people and named it Hierosolyma (Jerusalem). But in another book of his Egyptian History Manetho says that this nation-the so-called Shepherds-are described ( $\gamma \in \gamma \rho \alpha \dot{\phi} \theta a \iota$, i.e. depicted) as captives in some of the sacred (i.e. written in hieroglyphs) books, and he is right in so saying. For as a matter of fact the 
feeding of flocks was the hereditary calling of our remotest ancestors, and they lived a nomadic life, and again they were not unreasonably styled captives by the Egyptians, since our forefather Joseph told the king of the Egyptians that he himself was a captive, and later on sent for his brethren to come into Egypt on the permission of the king."

Manetho's statement is a plain, straightforward narrative, containing nothing marvellous or incredible. Manetho himself seems to have given but a single explanation of the name Hyksos, for the alternative derivation of the name preferred by Josephus seems simply based on Manetho's statement elsewhere in his writings that in the hieroglyphics the Hyksos were represented by a pictographic determinant showing a man bound as a captive, a fact which does not necessarily mean that the name of the people so represented meant 'captive,' but that they had been conquered by the Egyptians. Manetho's account of the Hyksos resembles in so many details the story of the Hebrews and their connection with Egypt as given in the book of Genesis, that even if we do not at once identify the exodus with the expulsion of the Hyksos, it is at least highly probable that the Hyksos, whom Manetho says were regarded as Arabs, were of the same race as the Hebrews, who were simply an Arab tribe. That the Semites have for long ages been constantly pressing into Palestine and Egypt and the whole of North Africa is a matter of familiar history, and there seems to be no reasonable doubt that the Semitic element was a most important ingredient in that strange blend known to us as the ancient Egyptians. According to Manetho the Hyksos were in Egypt from first to last five hundred and eleven years, although their own dynasty, which only arose at a late considerably later than their first arrival and ended a considerable time before their final expulsion, only lasted two hundred and sixty years. As it is currently held ${ }^{1}$ that they were expelled by Aahmes I, probably about 1580 B.c. or later, their first appearance in Egypt may be set at the earliest about 2100, but quite possibly considerably later.

1 Flinders Petrie, History of Egypt, Vol. I. p. 233. 
As the true Hyksos dynasty was only established at a period long posterior to the first coming of the folk themselves, we may infer that their occupation of Egypt was a process of gradual infiltration, and was not effected by any organised invasion under some great king, but rather by the constant arrival of fresh clans, who made their way across the desert with their flocks. In the stories of Abraham and Jacob we have excellent illustrations of the manner in which Arab sheikhs with their followers and flocks and herds kept percolating not only into Palestine but even into Egypt itself at the very epoch when the Shepherd chiefs are said by Manetho to have been dominant in the latter country. The migration of Abraham into Egypt, which according to the traditional chronology took place about B.C. 1900, and that of his grandson Jacob about a century later, well exemplify the infiltration of Semitic clans not as yet combined under any one great king, and are in complete harmony with the manner in which the Hyksos seem to have gradually got their hold upon the land of the Nile.

Writing of the Hyksos, Prof. Flinders Petrie remarks that "we cannot inprove on the origin of the name given by Manetho, hyk or heq, a prince, and sos or shusu, the generic name of the shepherds or pastoral races of the castern deserts. On later monuments the Shasu are represented as typical Arabs.". This usage of heq is, like that of the heq setu or "chief of the deserts," the title of the Semitic Absha in the xith dynasty, and of Khyau before him. The evidence of the physiognomy of many statues and sphinxes which have been attributed to this period has been adduced by certain writers in favour of a non-Semitic or Mongolic origin for the Hyksos, but these monuments are now regarded as being probably far older than the Hyksos period $^{2}$.

Messrs Newbury and Garstang ${ }^{3}$ have recently identified the Hyksos with the Kheta or Hittites, whom they describe as "a mixed Asiatic people moving westward, mingling freely with the tribes and peoples whose country they overran, but

1 History of Egypt, Vol. I. p. 237. $\quad 2$ Neyer cited by Petrie, loc. cit.

3 A Short History of Ancient Egypt, p. 65 (1904). 
dominant always, if only by reason of the formidable engine of war, the chariot and horses, which they introduced to Western Asia," and they regard as Mongolian the master race in "the hordes of Semite-Hittites," which according to them constituted the Hyksos ${ }^{1}$. It must be remembered that although the story of the purchase of the Cave of Machpelah by Abraham from Ephron the Hittite is one of our few reliable documents relating to that people, and though the children of Heth are represented as dwelling in Canaan and as being the occupants of the land before the coming of Abraham, yet there is not the slightest evidence that they any more than Abraham possessed a single horse. Again, if they were Mongols who had come down throngh Armenia and brought the horse with them into Egypt, the horses seen on the Egyptian monuments ought to resemble the horses of upper Asia in colour, form, and fashion of carrying the tail, in all which points they differ completely, as has been already pointed out. Finally, if Jensen is right in his view, that the Hittites were Indo-Europeans and spoke a language akin to Armenian (p. 214), this would be fatal to a Mongolian origin for that people.

The balance of evidence is thus clearly in favour of the Hyksos being Semites and neither MLongols nor Indo-Europeans; it may be even worth while to consider whether Manetho's account of the Hyksos' occupation of Egypt may not actually refer to the story of the Hebrew immigration into and their subsequent expulsion from that country. The traditional dates for Abraham and Jacob fall within the period during which, according to the computations of modern Egyptologists, the Hyksos were settled or settling in Egypt. We may even point out that if we date the exodus about B.c. $1400-1350$ and reckon back five hundred years-the duration of the Hyksos period according to Manetho-we arrive at about B.C. 19001850 , the traditional date for the migration of Abraham into Egypt. The coincidence in date is very striking, and it is not very probable that two sets of shepherd immigrants, who are represented as living in the same part of Egypt, as leaving Egypt 
under a compact with the Egyptian king, and in each case making their way across the desert into Syria and there settling, should during the same period, and that too a period extending over several hundred years, have played an important part in the history of Egypt. We certainly do not hear of any Hebrew kings, but it must be remembered that the Hyksos dynasty, according to Manetho, had only six monarchs. But if there is no mention of Hebrew kings in Egypt, the story of Joseph indicates that at least one Hebrew became the Grand Vizier or mayor of the palace, and that in him was centred the whole power and administration of the kingdom, a story which curiously illustrates the statement of Manetho that the Hyksos after their coming got the rulers of the land into their hands.

It is now clear that the Hyksos were at least a Semitic pastoral tribe, even if they were not actually identical with the Hebrews. But if they were Semites, it is most improbable that they possessed horses when they invaded Egypt, for, as I have shown already, the book of Genesis renders it certain that the Semites of Mesopotamia had no horses in the time of Abraham; the Babylonian monuments make it probable that the horse only became known in that region shortly before B.C. 1500 ; it has beeu demonstrated that the Arabs of the Peninsula did not possess horses before the Christian era, whilst the story of Abraham implies that the king of Egypt who gave him hospitality did not possess any horses any more than did the Hittites of Canaan from whom the patriarch purchased the Cave of Machpelah. On the other hand, so far as the evidence of Genesis goes, it would appear that by the time of Jacob (B.C. 1800-1700) a native Egyptian king possessed horses and chariots. It would thus seem that some time in the eighteenth century B.C. the native Egyptian kings (such as those of the Thebaid) and others mentioned by Manetho (supra p. 231) had already become possessed of horses and chariots. But as neither Arabia, nor Babylonia, nor the Semitic tribes of Palestine possessed the horse, the Egyptians could not have obtained that animal from any of those regions, and must have procured it from their neighbours in Africa. But, as the horse was not bred by the peoples east of the Nile, even at the time of 
Christ, the Egyptians must have procured it and the chariot from the Libyans. We may go still further and suggest that it was the acquisition of the horse and the chariot from Libya which enabled the kings of the Thebaid and other kings from the west side of the Nile to master and to expel the Hyksos. As the Semites from the east, so the Libyans were always pressing in from the west, and it is not unlikely that the great xvith dynasty which expelled the Shepherds may have been partly Libyan in origin.

The statement of Manetho that it was the kings of the Thebais (upper Egypt) who were the chief factors in the expulsion of the Hyksos with the help of the chiefs of some other district or districts of Egypt seems absolutely true, for beyond question 'Thebes was the seat of the new Empire that arose on the overthrow of the Hyksos. Memphis had been the chief seat of the old monarchy, but it fell into the shade under the great xvinth, xvinth, and xixth dynasties. It seems probable from the statement of Manetho that the Hyksos kings, though they had control of Memphis and middle Egypt as well as the lower country, were never able to occupy permanently Thebes and upper Egypt, but had to rest content with receiving tribute from that province. The Hyksos were thus masters of the region lying on the eastern side, or, as Strabo would say, the Arabian side of the Nile as far south as Memphis. It is clear that the revolt must have originated and gathered to a head in that part of Egypt not occupied by the Hyksos. The other kings who assisted the Thebaid chiefs in the expulsion of the Hyksos must have lived on the westem or Libyan side of the Nile, and it is probable that the Thebaid kings once had their homes on that side also, for although the city of Thebes in its great days lay on both sides of the river, yet since the Valley of Tumbs, in which are buried the kings of the great dynasties of the new Empire, is on the Libyan side, it is probable that the original home of these monarchs lay on that side also, for the tombs of great families are usually placed at the spot where the founders of the race harl dwelt and risen to importance. Thus the tombs of the present Tartar dynasty of China are not at Pekin but at Mukden in Manchuria. It is therefore not 
unlikely that the great dynasties that reigned at Thebes and pushed their conquests far and wide had come from the Libyan side of the Nile. But as it is with the rise of the Thebaic kings who expelled the Hyksos that the horse and chariot first appear in Egyptian history, and as it has been shown that the Egyptian chariot was probably Libyan in origin, there is a very high probability that the horses and chariots which enabled the kings of the new Empire not only to expel the Hyksos but also to extend their conquests into Asia, were the gift of Libya and not of the Semitic Hyksos.

Whether the Hyksos were Hebrews or some other Semitic people, it matters little to our argument. If Manetho is right in identifying the Hyksos with the Semites who settled in what was afterwards Judaea, our argument that the Hyksos had not bestowed on Egypt the gift of the horse is strengthened, for, according to the Old Testament, the Israelites had no chariots and horses when they left Egypt, and, as it has been pointed out already (p. 226), they found great difficulty in their war's against certain tribes in Canaan because these people possessed chariots, and chariots too not merely of wood or fitted with copper like those of Egypt, but strengthened with iron, a metal which had not as yet come into use in Egypt. If, on the other hand, the Hyksos were not Hebrews but another Semitic tribe which after its expulsion from Egypt made its way into Palestine and Arabia, it is equally certain that they had no horses, since none of the Arab tribes possessed horses till many centuries later. Furthermore, if the Hyksos are the same as the Israelites, our suggestion that the Egyptians had been enabled to expel the Hyksos because the former had acquired the new and powerful engine of war-the horse and the chariotlikewise gains strength, for, as we have just seen, the Israelites at the time of the exorlus had neither horses nor chariots.

It is not without significance that horses should have been regarded in Homeric times (p. 219) as the special characteristic of Egyptian Thebes in her palmy days. That the fame of her horses and chariots had thus echoed across the Aegean is no slight indication that the secret of her power lay in her horses and chariots. The other kings who assisted the Thebaic 
monarchs in their revolt against the Hyksos, and who probably dwelt on the west bank of the Nile, may have been Libyan Egyptians, such as those who are represented in Homer as repelling with chariots and horses the piratical descent of Odysseus and his comrades at the mouth of the western branch of the Nile.

Let us now turn to the evidence respecting the horsebreeding and horse-riding of the Libyan tribes in later times, but prior to the Arab conquest. The Libyan tribe of Marmidae occupied all the region between the temple of Ammon and the frontiers of Cyrene. West of them lay the Nasamones and the Psylli, behind whom lay the eastern part of the great tribe of the Gaetuli, behind whom again came the Garamantes ${ }^{1}$. Herodotus $^{2}$ tells us that these Garamantes, who lived in the modern Fezzan, had four-horse chariots in which they chased the Troglodyte Ethiopians, "who of all nations whereof any account has reached our ears are by far the swiftest of foot." These Troglodyte Ethiopians (as we know from Strabo ${ }^{3}$ ) dwelt on the Nile southward from Syene (Assouan), and it was over a portion of them reigned Candace, "queen of the Ethiopians," who is mentioned in the Acts of the Apostles ${ }^{4}$ in the story of the baptism of her eunuch by Philip the Evangelist. As she and her nation had proved a real danger to the Roman control of Egypt, and as Psammetichus I had found it necessary to plant a strong garrison at Elephantiue to check the Ethiopians in the seventh century B.C. we may safely infer that Egypt was always liable to invasion from this side. If the Libyan tribes like the Garanantes were in touch with the Ethiopians, and there is reason to think that there is a considerable Libyan element in the population of that region, it is not at all unlikely that bodies of invaders, partly Libyan, partly Ethiopian, may have made their way into Egypt from the south from very early times.

Next to the Marmidae came the territory of Cyrene, founded B.C. 632 by Battus, from whom Callimachus the poet traced his lineage. "The city flourished," says Strabo", "from the
1 Strabo, 837.
2 Iv. 183.
$3820-1$.
4 viii. 27.
5837. 
excellence of the soil, which was peculiarly adapted for the breeding of horses and the growth of fine crops." South of the Cyrenaica dwelt the Libyan tribes of the Nasamones and the Psylli, behind whom lay the Gaetuli, south of whom in turn lived the Garamantes as already mentioned.

Next to the Cyrenaica on the west came the territory of Carthage (founded B.C. 8:6), which bordered on that of the great tribe of the Masylii. In the interior of their land was Cirta (Constantineh), the residence of Masinissa (the Numidian monarch so famous in Roman history as a cavalry commander) and his successors. It was a very strong place, well provided with everything, which it principally owed to Micipsa, who had planted a colony of Greeks there, and raised it to such importance that it could put into the field ten thousand cavalry and twice that number of foot. Next Strabo ${ }^{1}$ states that above the sea-coast from Carthage to Cephalaea on the one side, and to the territory of the Masaesylii on the other, lay the territory of the Libyphoenicians, which extended inland up to the mountain region occupied by the Gaetuli, beyond whom lay the Garamantes, of whom we have already spoken, and who were said to be fifteen days' journey from the temple of Ammon (in the Oasis of Sûva). "Between the Gaetuli and the coast of our sea there are many plains and many mountains, great lakes and rivers. The inhabitants are simple in their mode of life and in their dress; they marry numerous wives and have numerous children; in other respects they are like the nomad Arabs. The hoofs both of horses and oxen are longer than in other countries. The breeding of horses is most carefully seen to by the kings; so much so that the number of colts is yearly estimated at one hundred thousand?"."

West of the Masylii lay the Masaesylii, next to whom came the great tribes of the Mauri, who occupied all the region as far as the ocean. Strabo states ${ }^{3}$ that "although the Nauri inhabit a country the greatest part of which is very fertile, yet the people in general continue even to this time to live like nomads. They bestow care to improve their looks by plaiting their hair,

1 Strabo, 834.

2835.

3827. 
trimming their beards, by wearing golden ornaments, cleaning their teeth, and by paring their nails; and you would rarely see them touch one another as they walk, lest they should disturb the arrangement of their hair." "They fight for the most part on horseback with the javelin, and ride on the bare back of the horse with bridles made of rushes. They have also swords. The foot-soldiers present against the enemy, as shields, the skins of elephants. They wear the skins of lions, panthers, and bears, and sleep in them. These tribes and the Masaesylians next to them, and for the most part the Libyans in general, wear the same dress and arms, and resemble one another in other respects; they ride horses which are small but spirited, and so docile as to be guided by a switch, and which have neckbands made of wood or of hair, from which hangs a leading rein. Some follow like dogs without being led. The riders carry a small shield of leather, and small lances with broad heads. Their tunics are loose with wide borders; their cloak is a skin, as I have said before, which serves also as a breastplate. The Pharusii and the Nigretes, who live above these people, near the western Ethiopians, use bows and arrows like the Ethiopians. They have chariots also armed with scythes. The Pharusii rarely have any intercourse with the Mauritanians in passing through the desert country, as they carry skins filled with water fastened under the bellies of their horses. Sometimes indeed they come to Cirta (Constantineh), passing through places abounding with marshes and lakes. Some of them are said to live, like the Troglodytes, in caves dug in the ground."

The neckbands of the Libyan horses remind us at once of the practice of the Anazah tribes of Arabia, where, in the desert, every horse has a cord tied round its neck to fall about halfway between the head and the shoulders. This is a common cord, "about the thickness of a man's little finger, and fastened in a knot of two turns, and is convenient to take hold of if a horse requires to be caught." It is not improbable that the Arabs borrowed this practice from the Libyans along with the North African horse.

1 Upton, Gleanings from the Desert of Arabia, p. 382. 
Livy ${ }^{1}$ has left us a vivid picture of the wild Libyan horsemen and their famous steeds: "The Numidians mounted their horses and began to ride up towards the enemies' outposts, but without attacking anyone. At first sight nothing could be more contemptible: horses and men alike were small and slight (paulluli et graciles); the rider without girdle, and unarmed save that he carried darts. The very galloping of the horse without a bridle was ungainly, as they gallop with outstretched heads and stiff neck. They purposely increased the

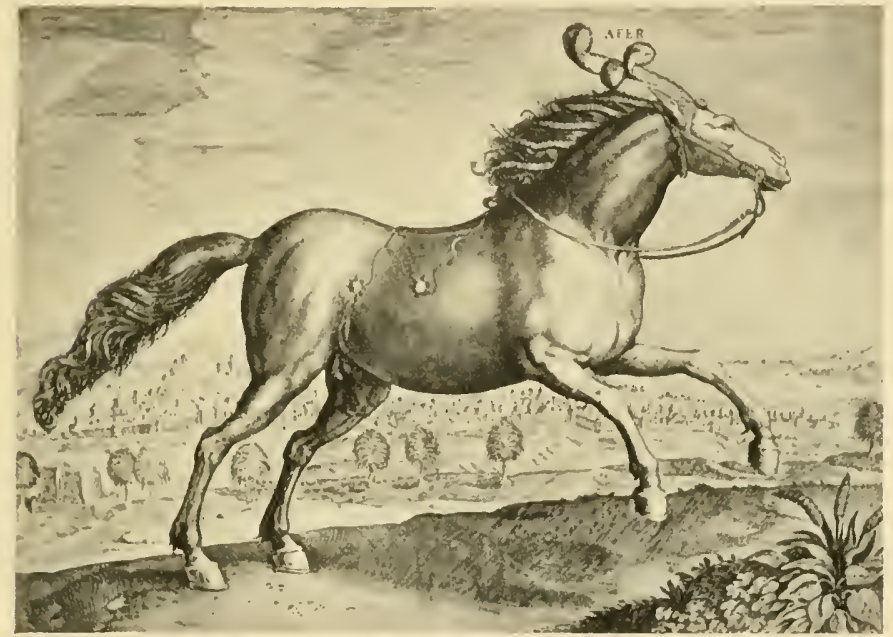

FIG. 70. The Barbary Horse.

contempt thus inspired by tumbling off their horses and making an exhibition of themselves in sport." The description of the slightly built horse bred in Libya many centuries before the Arab conquest of North Africa puts it beyond doubt that they were the same breed as that found ever since in Barbary and Morocco, and which have been bred by the Arabs of South Arabia only since the early centuries of the Christian era. I here reproduce (Fig. 70) the Afer (Barbary horse ${ }^{2}$ ) and

$1 \mathrm{xxxv}, 11$.

2 I learn from Mr Walter Harris, M.A., Gonville and Caius College, Cambridge, the well-known traveller and author of Tufilet, that the modern Berber words for a horse are 'avis' and 'agmer.'

R. II. 
(Fig. 71) the Maurus (Morocco horse) depicted by Stradanus (an artist who lived in the latter half of the sixteenth century) in the Equile Johannis Ducis Austriaci ("The Stable of Don John of Austria").

Writing two centuries later than Strabo and Livy, Pausanias says" that "when the Mauri took up arms against Rome, Antoninus drove them out of all their land and forced them to flee into the uttermost parts of Libya as far as Mount Atlas and the peoples who dwell in that mountain. These Mauri form the

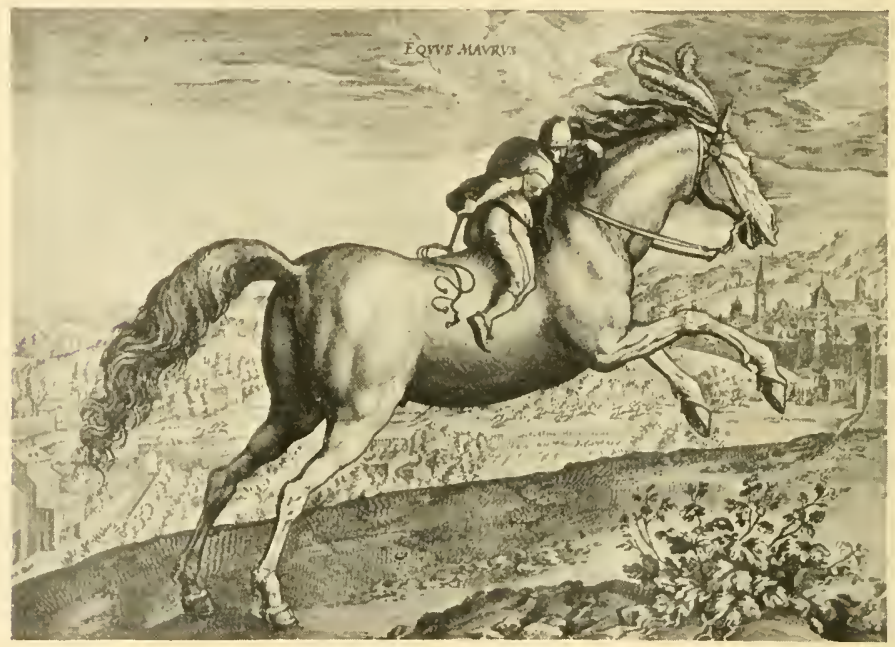

Fig. 71. The Moorish Horse.

greatest part of the independent Libyans; they are nomads, and are harder to combat than the Scythians, inasmuch as they roam, not on waggons, but on horseback, they and their women." But certain relics from Egypt furnish some evidence that Libyan women rode on horseback at least eight centuries before Pausanias wrote, and also that the Libyan horses were of a dark colour, like those seen on almost all Egyptian paintings down to a late period. At Daphnae (the Tahpanhes of the Bible, mod. Defenneh) in the sandy desert between the Suez Canal and the cultivated Delta, Psammetichus I (B.C. 665) 
planted guards against the Syrians, as he also did at Elephantine against the Ethiopians and at Marea against the Libyans'.

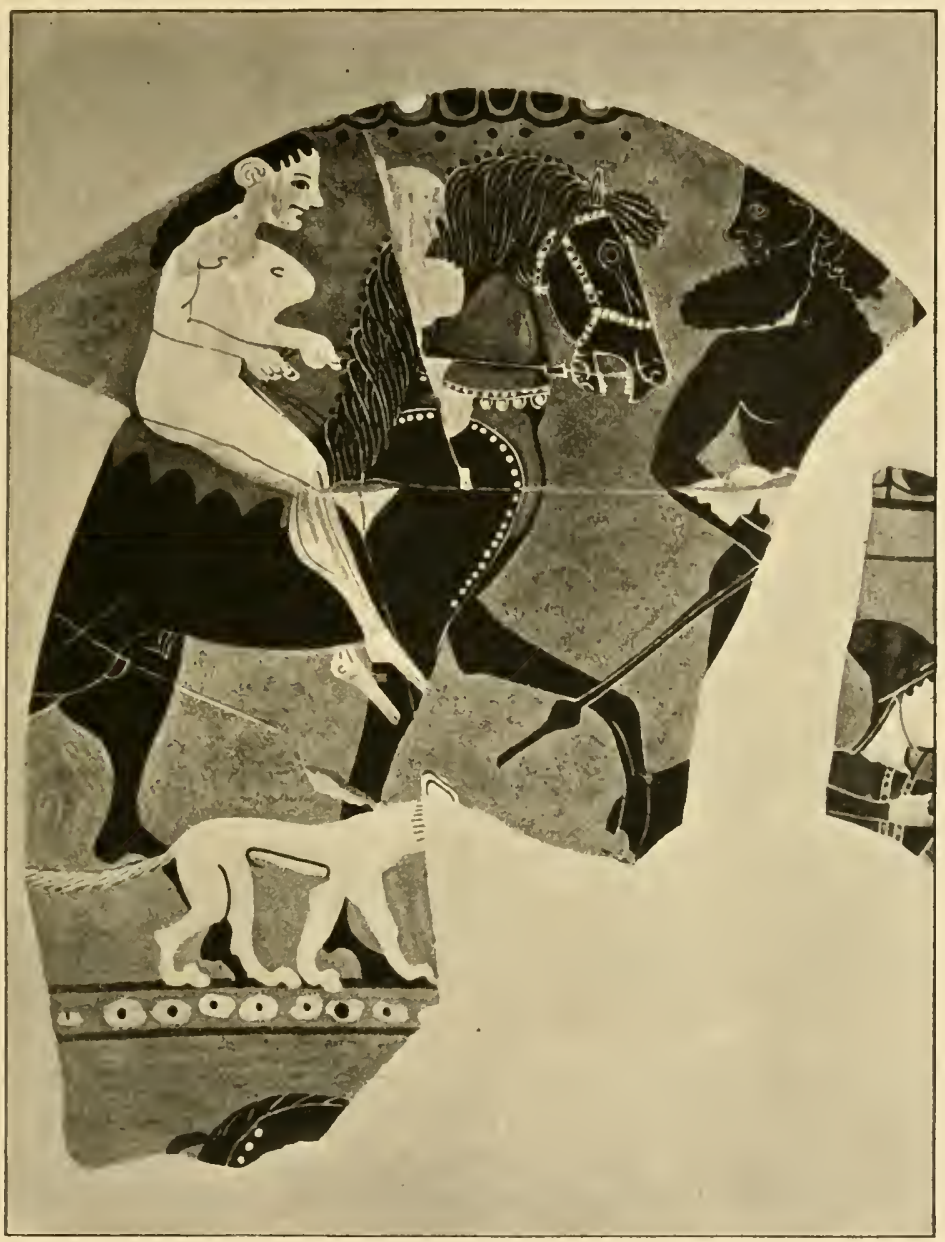

FIG. 72. Libyan woman on horseback.

The guards planted at Daphnae were the Ionian and Carian mercenaries by whose aid he had seized the throne".

1 Flinders Petrie, Tanis, Part Ir., Nebesheh $(A \mathrm{~m})$, and Defenneh (Tahpanhes), pp. 47 sqq.; cf. Herod. II. 107.

2 Herod. II. 15t. 
Here the Greeks throve until they were deported to Memphis ${ }^{1}$ by Amasis (about B.c. 570-565). The Greek pottery found on the site, and which seems not to have been imported but made on the spot, must fall between B.c. 664 and B.c. 570 . Various fragments of pottery show beantiful dark holses ridden by both men and women. On three fragments are represented nude women on horseback, one of which is here shown (Fig. 72)". The woman is painted white except her hair, her horse is dark, her dog painted white runs beside her; behind flies an eagle, whilst in front of the horse is a bearded man painted all in black $^{3}$. Other fragments from Daphnae ${ }^{4}$ also show men on horseback, rider and steed alike painted black. A glance at the figure will make it clear that the bearded man is neither an Egyptian nor an Oriental; it is also certain that whilst women in both Asia Minor and Egypt were always well draped, so too in neither region did women ever ride on horseback. We have likewise seen that the Egyptian men practically are never seen on horseback. It seems clear then that the naked bearded barbarian men and the Amazons ${ }^{5}$ riding on

1 Herod. II. 154.

2 Petrie, op. cit. (described by Dr A. S. Murray), Pl. xxıx. fig. 4; Antike Denkmäler, n. 21, 2 (from which my figure is reproduced). The no. in Brit. Mus, is B $116 \mathrm{~b}$. The other two similar fragments are in the same case.

3 The fact that the woman on horseback is painted white, whilst the man is painted dark is not a mark of any difference of race but simply of sex. After the transition from the archaic vases with figures in black painted on white ground to those with black figures painted on the red clay of the vase, white was used to indicate the bare skin of women. As the Daphnae vases are early representatives of the new technique, it is not improbable that the Greek painters borrowed the idea from the Egyptians, who had long practised it. For example in the beautiful "Book of the Dead" known as the papyrus of Ani in the British Museum, Ani himself is always represented with a dark face, whilst his wife's skin is always painted white, i.e. the man was sunburut, the woman lived in the shade; in Plato's words the one was $\dot{\eta} \lambda \iota \omega \mu \dot{e} \nu$ os, the other '́ $\sigma \kappa \iota a \tau \rho \circ \phi \eta \kappa v i a$.

As the men seen on vases or other Daphnae fragments are painted black we may be certain that the white nude figures are women and not men or boys.

+ Petrie, op. cit. Pl. xxxi. figs. 13, 14.

5 The Greeks held that there were Amazons in Libya as well as in the region round the Black Sea. As the Sarmatian women who hunted on horseback with their husbands gave rise to the myth of the eastern Amazons, so the fable of the Amazous of Libya arose from the horse-riding Libyan women (cf. Ridgeway, Early Age of Greece, Vol. I. pp. 651-2). 
beautiful dark horses ean be no other than Libyans, who at the time when these vases were painted were a standing danger to the Egyptians, and must have been perfectly familiar to the Greeks who were employed to secure the Egyptian frontiers. The Scythian women, however, even down to the second century A.b. had not learned to ride, as do the Tartar women (cf. p. 139) of to-day, but they still travelled from place to place in their waggons as in the time of Herodotus.

We have seen that the setting on of the tail is a characteristic of the pure-bred Arab and his well-bred derivatives, a point to which great attention is paid by horse-fanciers in Westem Asia and India. Though mfortunately in none of the Daphnae pictures of horses ridden by women has the tail survived, yet on two other fragments ${ }^{1}$ we can clearly see that the horses' tails are set on high like those of well-bred Arabs and the horses seen under the chariot of Seti I (p. 217). Again, the Daphnae pottery² yields the earliest known representation in painting of the winged horse Pegasus, whose birthplace according to the legend was the Libyan desert. The winged steed was naturally modelled after the fleetest courser known to the artist, who has simply added wings to indicate his supernatural swiftness. In the Pegasus of the Daphnae vase the tail is elearly set on high. It is now plain that as in the Egyptian paintings of the New Empire so in the sixth century B.c. the high set of the tail, as well as the dark colour - two of the features of the Kohl breed of Arabia-characterised the horses of North Africa.

In the small lightly built and docile horses of the Libyans we recognise the light built Barb and 'Arab' of to-day, a horse of matchless swiftness, when carrying a light rider, such as the typical Numidian horsemen described by Livy (cf. p. 241), but not well adapted for a heavy weight or for draught purposes. The horse ridden by the Libyan women on the Daphnae fragments is not a thoroughbred, but a fine cross-bred horse. We have seen proof that the great desire of the ancients was to

1 Brit. Mus., B 129, 10 (two horsemen); B 125, 8 (a horse with the upper part of tail well defined, though a portion is lost).

2 Brit. Mus., P 105. 
obtain horses of large size, and we shall presently find that the same principle has been always at work in medieval and modern times. Thus in the Iliad the horses of Rhesus are commended by Dolon as 'the largest' that he had ever seen, and the Nisaean horses of the Persian kings were 'the largest' in Asia. Again, we have seen that in modern times the Arab tribes of the Persian Gulf have fatally injured their fine breed of horses by crossing it with large Persian strains in order to produce for the Indian market animals capable of carrying greater weight, and we have also noticed that Niebuhr in the eighteenth century preferred the half-bred horses of Syria to the Kochlani (p. 167). It is more than probable that the same principle was at work in Egypt from a comparatively early date, and also in those parts of North Africa occupied by Greek and Phoenician colonies. It will be presently shown that long before the Christian era horses were imported into Libya from Europe, and that in Roman times the North African horses crossed with Spanish blood were especially esteemed. It is therefore probable that in the horses of the Daphnae fragments the Greek vase-painter has pourtrayed animals produced by crossing the Jibyan and the Asiatic horse, and we shall furnish evidence of similar half-bred horses at Carthage, in Sicily, and in Greece by the fifth century B.C. In fact the horses of Daphnae, Carthage, Sicily, and Greece stood to the small slender uncrossed horses of the Numidians in much the same relation as do the coarse Arabian horses found to-day in Syria and Irak to the pure-bred Keheîlans.

It is now clear that for many centuries before the Arabs ever owned a horse, all the Libyan tribes possessed a most notable breed, which in size, shape, speed, colour, and docility, very closely resembled the Kohl breed of Arabia. As it has been shown that Egypt was exporting horses into Asia Minor in the time of Solomon, and that Arab tradition points to Egypt as the region from whence the best horses were obtained in the time of Muhammad, and as Egypt derived her horses in great part from Libya, we are justified in concluding that the ancestors of the Kohl breed of Arabia came from North Africa. This conclusion is strongly corroborated by a fact already 
mentioned. It will be remembered that Al Khamseh is unknown in North Africa. Yet if the Kohl breed had been developed in Arabia, and had been brought by the Arabs into North Africa at the time of their conquests or at a later period, the fivefold division of their famous breed would have been most religiously preserved by the Arabs in their new homes. On the other hand, if the Kohl breed really originated in North Africa, being merely the ordinary horse of that region, there would have been no reason for dividing it into special families, for it is only when a strain of special quality is introduced from elsewhere that people begin to pay attention to pedigrees, as in the case of our own thoroughbreds. If the Arabs derived their Kohl breed from North Africa, there would have been every reason for paying great attention to purity of race and carefully discriminating between different sub-families sprung from a common stock, in some instances crossed with Asiatic horses.

This is in perfect accord with the statement of Abd-el-Kader that the five families of $\mathrm{Al}$ Khamseh are but ramifications of the ancient Ahwaj race, which, though not to be found anywhere in Arabia, is said to still exist in the Sahara. The historical evidence therefore is unanimous in pointing to North Africa as the source of the Arabian Kohl breed.

The Libyans had domesticated horses at a very early period and had learned not only to drive them in pairs under very light chariots, but had also invented the four-horse chariot. Moreover, they soon learned to ride these horses, for if their women habitually did so in the seventh century B.c., we may infer, not unreasonably, that the men had learned to ride at a still earlier period.

The Libyans who furnished horses and chariots to Xerxes in B.c. 480 must have come from the country bordering on Egypt and were therefore probably the Marmidae. By the time of Christ the chariot had been discarded by all the Libyans with the exception of the Pharusii and the Nigretes who lived sonth of the Atlas, and who probably only retained them (like the Persian and Seleucid kings) because the chariot when fitted with scythes was still thought to be a valuable engine in war. 
Strabo, unfortunately, does not give us any information respecting the colour of the Libyan horses, but we can infer from the pottery pictures of Daphnae that they were of a dark colour, which harmonizes well with the fact that the horses on Egyptian monuments are usually painted brown. As it will be remembered that dark colour is the characteristic of the pure-blooded Arabian, and that the grey and white Arabian horses come from regions where Turcoman horses have been in universal use, the agreement in colour between the Arab horses of the Kohl race, and those of ancient Libya, and the Egyptian monuments indicates clearly that the Arabs have not derived their famous breed from the dun or white horses of Persia and Upper Asia, but from a dark-bay stock of Libya.

Turning to the North African horses of to-day, we find that in the Barbary States the prevailing colours are dark-bay, brown, chestnut, black and grey. In Morocco the horses are said to be of every colour, but black and chestuut are considered the best. The black colour as well as grey is probably dne to importations from Europe and Asia dating from a long time back down to recent times. In the last ceutury the Sultan of Ducaila imported a black English thoroughbred stallion and thereby obtained a splendid breed". On the other hand we find the Roman Senate sending to Masinissa, the Numidian king, two military cloaks fitted with two golden brooches each, two horses fully equipped, and two sets of cavalry accoutrements, including breastplates $^{2}$. Plainly, then, from the second century B.c. the Barbary horses could have been crossed with the heavier and stronger strain of Italy. In later centuries the Barb has been largely crossed with imported Syrian Arabs, which of itself is sufficient to account for the occurrence of grey and black amongst them. The Barbs of Algeria have in modern times been much crossed with French and English blood, and have consequently lost a good deal of their original type. It is only in Morocco that it has been kept at all pure, for few horses are imported into that comtry. The Morocco Barbs are excep- 
tionally hardy, enduring and useful animals, and this breed is officially preserved by the reigning sultan ${ }^{1}$.

The Barb ranges from 14 to 15 hands high, but is said to be a little smaller than the Arab, with flat shoulders, round chest, joints inclined to be long, and the head particularly beautiful.

In the sandy plains south of the Atlas (the ancient home of

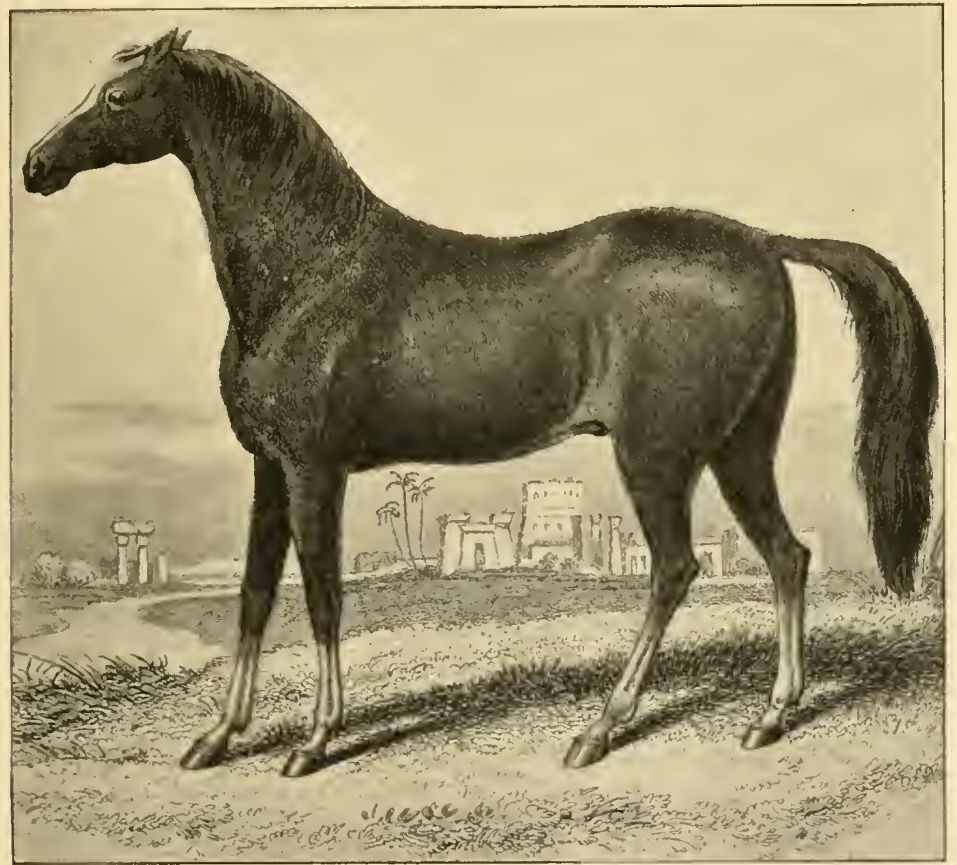

F16. 73. Dongola Horse.

the Pharusians and Nigretes), the Mograbins of the West rear horses, which are brown or grey, known as Shrubat-ur-Reech, "Drinkers of the Wind; they are rather low, shaped like greyhounds, and destitute of flesh2."

The horses found in the region of Dongola are bay, black, and white, but not grey, and never dappled. The blacks are

1 Hayes, Points of the Horse, pp. 627-8.

2 Hamilton Smith, p. 227. 
the finest; they have all white legs (Fig. 73), sometimes the white extending over the thighs and occasionally over the belly ${ }^{1}$.

We have seen at an earlier stage that the presence or absence of hock callosities has been generally taken as one of the chief means of differentiating Equus caballus from the asses and zebras (p. 16). It is therefore to be carefully noted that, whilst the hock callosities are present in Prejvalsky's horse, and are of specially large size in domestic horses of heavy breeds, according to Sanson ${ }^{2}$ they are frequently absent in North African horses (as is the case with Ewart's 'Celtic' pony). The presence therefore of such hock callosities in Arab horses of a coarser type may be due to their having in their veins a considerable admixture of Asiatic blood, as is certainly the case with many 'Arabs' from 'Turkish Arabia, and the tribes of South Arabia, which border on the Persian Gulf (pp. 183-6).

It has already been pointed out that white feet and a star or blaze on the forehead are characteristic of the pure Anazah bay horses, and it has also been shown that the fine black horses with white feet-the best bred by the Turcomans-are the result of crossing the horses of Upper Asia with so-called Arab blood (p. 133), that black horses are never found in Al Khamseh, and that the best black horses found in Syria belong regularly to the Jelfon breed; it has also been shown that the 'Arab' horses sent in large numbers into Egypt are exported from Syria, where a large proportion of the horses are grey, such horses being the result of crossing common Turcoman mares with pure Arab horses. It is therefore more than probable that all the black, grey, and white horses of North Africa have been derived either from Syrian and other horses of impure breed, or else have resulted from the blending in Africa itself of Asiatic and European horses with a native dark breed. As we have already seen that there were no horses in all North-east Africa or in Nubia down to the time of Strabo,

1 Hamilton Smith, op. cit. pp. 229-30, Pl. 10*, from which my illustration is copied.

2 Zootechnie, Vol. IIr. p. 53 (ed. 4). Under the heading of "caractères zootechniques généraux" he says that "les membres postérieurs sont dépourvus de châtaignes" in the "Race africaine" (E. c. africanus). 
and as we have now shown that grey horses and black horses with white feet result from crossing the Upper Asiatic and the so-called Arab, it follows that the breed of Dongola is not a primeval stock (E. c. afiricamus) as was held by Sanson, but only a blend of comparatively modem origin.

It is now clear that Egypt could have obtained from the Libyans the horses which she exported into anterior Asia in the tenth century B.C., and it is likewise certain that when the Greeks planted Cyrene in B.c. 632, they found the Libyans not only employing the two-horse and four-horse chariot, but also generally riding on horseback. Herodotus explicitly tells us that "the Greeks learned from the Libyans to yoke four horses to a chariot." It is therefore not without significance that the four-horse chariot and the ridden horse (keles) were only given places in the Olympic contests (the former in B.c. 680 , the latter in B.c. 648 ) in the same century that saw the founding of Cyrene. The four-horse chariot does not seem to have been ever employed by any of the peoples of Upper Europe, by Vedic Aryans, Persians, Assyrians, Canaanites or Egyptians or by the Homeric Acheans. For although in two passages of Homer mention is made ${ }^{2}$ of "four male horses yoked together," these only refer to the occasional practice of attaching one trace-horse or two to the regular pair, under special circumstances, either in war or for racing, an idea which may very well have been borrowed from Libya long before the foundation of Cyrene, for it is plain from Homer that the Homeric Greeks were well aequainted with that country. Moreover, it is very significant that one of the passages from Homer where mention is made of a four-horse chariot is a simile, whilst the other does not refer to a contemporary event, but is in a tale of a bygone age when king Augeas reigned in Elis before Pelops and his Acheans came and conquered the old Pelasgian inhabitints. Nestor relates how Neleus, the Pelasgian king of Pylus, had sent a four-horse chariot to Elis to race for a tripod and how Augeas had kept the horses and sent back the charioteer without them. But as the legends of the Bronze Age of Greece have frequent 
references to intercourse with Libya, we need not be surprised if the practice of yoking four horses abreast had been learned from that land. On the other hand it seems clear that the Achean conquerors clave fast to the practice of the region from whence they had come and continued to use only their national two-horse cars. In the chariot-race at the funeral games of Patroclus there is not even a hint of the use of the four-horse chariot or even of a trace-horse, a fact which contrasts strongly with the constant appearance of the quadriga on the blackfigured vases dating from the seventh century B.c., when the four-horse chariot had been reintroduced.

Not only is it probable that the Greeks first learned the use of the four-horse chariot from Libya, but it is also not unlikely that it was from the same region that they first learned to mount on the back of the horse. Although the Homeric Acheans never normally rode their dun-coloured horses any more than they drove them in teams of four when they raced or went to battle, yet there is at least one simile in the Homeric poems which shows that riding on horseback was by no means unknown to the poet. Thus Odysseus, when his raft was sliattered, "bestrode a single beam, as one rideth on a courser (keles) and stripped him of the garments which fair Calypso gave him ${ }^{1}$;" and in another simile, in the Iliad, if we do not hear of riding on horseback we have the earliest picture of a circus-rider,-_" a man right well skilled in horsemanship, that couples four horses out of many, and hurrying them from the plain towards a great city drives them along the public way, many men and women marvelling at him, and unerringly ever he leaps and changes his stand from horse to horse, while they fly along2." Now when we bear in mind that the first horse ever ridden according to Greek legend was Pegasns, that this famous steed was born in Libya, and that he was obtained there by Perseus, the renowned king of Mycenae, in the Bronze Age, before the coming of the large-limbed, fair-haired Acheans from central Europe, it is not strange that the Greeks of the Homeric (Iron) Age knew that the horse could be ridden as well as driven, although the new 
lords of Greece did not ride their dun-coloured horses, but only drove them in pairs under chariots. From the great docility of the Libyan horse and his descendants it is highly probable that the Libyans from its first domestication could mount it without difficulty, and as they themselves (cf. p. 241) were small, lightbuilt men, their horses could carry them with ease at a date when the European horses, which were not so tall as the Libyan, could not carry for any great distance their large-limbed masters, such as the Sigynnae in the fifth century B.c. or the Acheans some seven centuries earlier. It is thus not at all unlikely that it was from Libya that the practice of riding on horseback first became known to the inhabitants of Greece.

The islanders from Thera, who planted Cyrene, were not slow in fulfilling the prophecy of Medea that "instead of shortfimed dolphins they should take to themselves fleet mares, and reins instead of oars should they ply, and speed the whirlwindfooted car," for Cyrene soon became famous as "the city of fair steeds and goodly chariots." Pindar glorified her king, Arcesilas, for his victories in the chariot-race, and later her native poet, Callimachus, sang of his "home famed for her steeds ${ }^{3}$." When Alexander had conquered Egypt and conceived the idea of visiting the shrine of Ammon, the Cyreneans sent envoys to make submission to the world-conqueror, bringing a crown and rich gifts amongst which three hundred war-horses figured prominently*

Still earlier than the Greeks the Phoenicians had begun to plant colonies along the coast of North Africa, and they therefore soon became possessed of the noble horses of Libya. When Carthage, in the fourth century B.c., first began to coin money it is significant that she placed the horse and palm-tree on her coins (Fig. 74), whilst the horse alone is seen on the issues of Panormus, her most important settlement in Sicily.

It will be noticed that the horses seen on these coins are not pure-bred, but rather fine cross-bred horses, like the horse ridden by the Libyan woman (p. 244). In reference to that
1 Pind. Pyth. Iv. 17.
3 Strabo, 837.
2 Ib. Iv. 1 .
4 Diod. Sic. xhix. 2. 
horse and the others pourtrayed on the pottery from Daphnae I have pointed out that, as in modern and medieval times people have bred horses for practical purposes rather than for speed alone, so the ancients were actuated by similar motives. No doubt the same reason influenced the Carthaginians, both in Africa and Sicily, and we shall see that the Sicilian and other Greeks of the fifth century B.c. and the Romans of the Republic and Empire were affected by the same considerations, though for purely racing purposes the Romans gave preeminence to the pure African horse.

We have seen that the high set of the tail is one of the characteristics of the Kohl breed (Fig. 58). The tail of the well-bred horse on the Carthaginian coin of Panormus (Fig. 74) indicates that this was already a feature of Libyan horses in the fifth century B.c.

At how early a date the Libyan horse made its way into Spain it is impossible to say, although from certain Greek legends, to one of which we have already referred, the Iberians may have known of the famous fleet steeds of the Libyan shore for many centuries before the date of the Carthaginian settlements in the peninsula in the third century в.c. There is, however, the clearest evidence from the Roman historians that the Libyan horses had been brought over to Spain in large numbers by 219 B.C.

When Hannibal in that year prepared to march into Italy with 90,000 foot and 12,000 cavalry, a very considerable proportion of the latter consisted of Numidians, who rode their own native horses, without bridles, whilst the remainder was composed of Spauish horsemen who rode with bridles.

The Romans first became acquainted with the Numidian horses and horsemen, whom afterwards, to their cost, they were to know too well, at the moment when Hamibal after seizing the passage of the Rhone was slowly ferrying his thirty-seven elephants across that river. On learning that Scipio had disembarked his army at the Massaliot mouth of the Rhone, Hannibal despatched a body of five hundred Numidian horse to reconnoitre. Scipio had also sent his cavalry forward with a like object. As soon as the Numidians met the enemy they 
charged with their wonted impetuosity, and a desperate encounter took place, but after some two hundred had fallen on either side, the Romans eventually drove their assailants back to Hannibal's camp ${ }^{1}$.

As soon as he crossed the Alps and descended into Italy the cavalry skirmish at the Ticinus (Ticino) demonstrated that

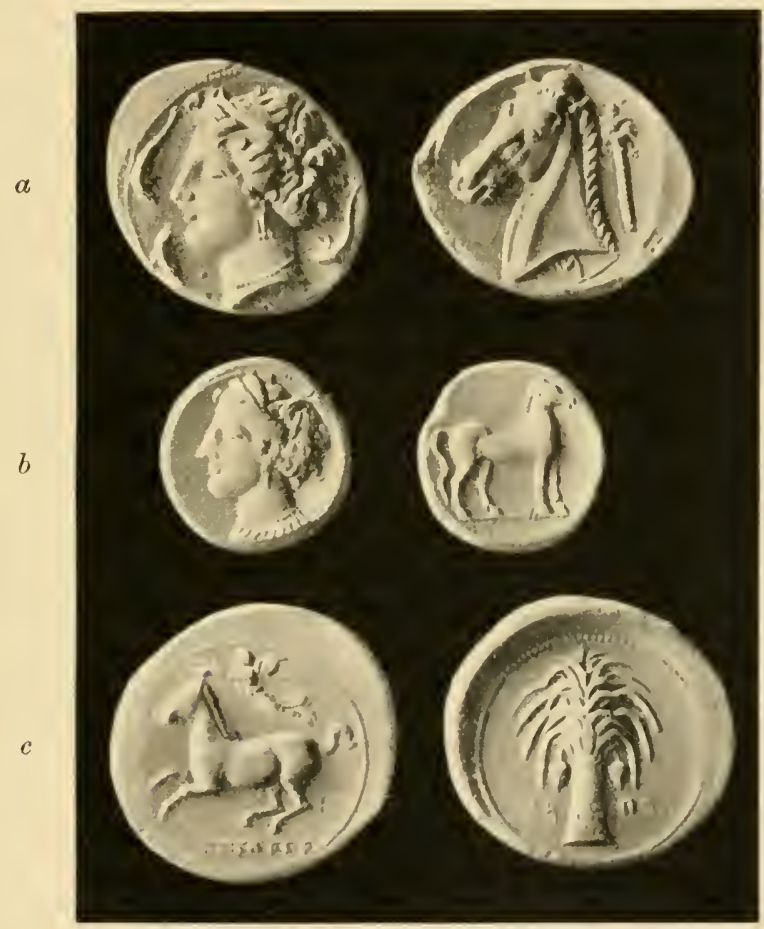

Fig. 74. Carthaginian Coins ( $a$ and $c$ Carthage, $b$ Panormus).

the Carthaginian cavalry was far superior to that of the Romans and the Gallic cavalry serving with them, the latter in turn being inferior to that of the Romans.

Though Livy gives no description of the horses ridden by the Numidians in Hannibal's army there can be no doubt that they brought their own horses with them, as was the case 
with a body of eight hundred of the same bold horsemen who, after the Roman conquest of North Africa, served with the Romans in their campaign against the Ligurians, and saved the Roman consul and his legions from a complete defeat. Livy's graphic description of these Numidians and their small slightly built horses has already been given (p. 241).

Hannibal had committed the care of Spain to his brother Hasdrubal, and had left him, in addition to a large body of African infantry, a force of cavalry composed of three hundred Libyphoenicians and eighteen hundred Numidians and Mauritanians from the region bordering on the Atlantic ${ }^{1}$. Over two thousand Libyan horses were thus at this time alone sent into Spain and kept there permanently. As probably most of them were stallions, since the Numidians and Moors did not use geldings and kept their mares for breeding, the influence which these two thousand horses exercised on the native breed within a short time must have been very great. For it is more than likely that the Spaniards would have sought eagerly to obtain the services of superior sires for their mares.

IVe need not then be surprised that at the time when Posidonius, the Stoic philosopher who travelled in western Europe about 90 B.c., visited Spain, the Iberians and Celtiberians possessed horses of fine quality more or less impregnated with Libyan blood. He tells us that the Iberians used "cavalry interspersed among their footmen, that their horses were trained to traverse the mountains, and to sink down on their knees at a word from the rider, in case of necessity. They had also a practice not confined to them-two men mounted one horse so that in the event of an engagement one might be at hand to fight on foot." He does not mention the colour of the ordinary Iberian horses, but he gives us the very important information that the horses of the Celtiberians, who occupied northern Spain, were "rather starling-coloured" (i.e. dark grey flecked with white), but that they lost that colour when transported into southern Spain, and he compared them to the Parthian horses, "for indeed they are superior to all other breeds in fleetness and endurance." 
We can at least gather from the statement of Posidonius that the Celtiberian horses, that is, those of northern Spain, differed essentially in colour from those of the Iberians, that is from the horses of Andalusia and other parts of southern Spain. But as the former seem to have been grey, it is clear that the latter were not that colour, but were probably monochrome.

Unfortmately Strabo gives us no information respecting either the colour or form of the wild or feral horses which he mentions incidentally. We have therefore no means of judging whether they were more akin to the horses of the South or to those of the North, but, as in modern times dun-coloured horses (not unfrequently with a dorsal stripe) are found in the sierras of Spain, it is not unfair to infer that the old dun-coloured horses of upper Europe and Asia formed the substrate of the grey Celtiberian horses, just as the npper Asiatic dun horse is a main element in the grey horses of western Asia at the present day. Whether these dun horses were indigenous in Spain or brought in by the Celts in their invasion in the sixth century B.C., or whether they were of the heavy type, or a light type such as the 'Celtic' pony, it is of course impossible to say. A well-known story told by Pliny ${ }^{1}$ indicates that horses of extraordinary fleetness were bred in Lusitania, for the tale went that in the region of the town of Olisipo and the Tagus the mares were impregnated by the West Wind and brought forth an offspring of surpassing fleetness, which however lived only for three years. From this we may fairly infer that a very swift breed of horses existed in that part of Portugal, and that they were not the ordinary slow upper European horse; but whether they were a slight built indigenous race connected with the 'Celtic' pony, or whether they were the descendants of horses introduced from Libya, it is of course impossible to say. On the other hand, we also learn from Pliny ${ }^{2}$ that north-

I H. N. vII. 166: constat in Lusitania circa Olisiponem oppidum et Tagum amnem equas Favonio flante obversas animalem concipere spiritum, idque partum fieri ct gigni pernicissimum ita, sed triennium vitae non excedere. Cf. Tasso, Gerusalemme Liberata, canto vr.

2 loc. cit.: in eadem Hispania Gallaica gens et Asturica equini generis,-hi R. II. 
west Spain produced a breed of horses, those of Gallaecia (Galicia) and Asturia (Asturias), the former known to the Romans as celdones (Galicians), the latter (which were of smaller size) as asturcones (Asturians). The pace of these horses was an easy amble, but we are not told their colour. It has been universally held up to the present ${ }^{1}$ that "when the Saracens conquered Spain in the eighth century they brought from Africa many saddle-horses of the Eastern type, which, later on, were crossed with the heavier native Spanish horses." But the evidence just cited renders it certain that the fine docile breed of Libyan horses had been planted in Spain some ten centuries before the Saracen conquest, and some three or four before the Arabs ever owned a horse.

The Barbary blood in the horses of Andalusia and Grenada was largely reinforced by the Saracen conquest, for the Moors, like their ancestors who served in Hannibal's army, brought over with them their own native horses.

Let us now examine the colours of the modern Spanish breeds of horses. It is of course in southern Spain that the Barbary blood especially prevails, and through the Middle Ages down to our own times the horses of Andalusia, Grenada, and Estremadura have been especially esteemed. The predominant colour is bay, next to which come black and grey. According to a Spanish proverb, "a mulberry-black horse is what everyone should wish for, though few may possess." Black horses without a white mark or with only a star in the forehead are especially valued.

Early writers, such as Absyrtus, note that Libyan horses "be of like goodness, and of like shape to the Spanish, save that the Libyans be stronger made, longer bodied, thicker ribbed, and broader breasted." This similarity was doubtless due not only to the fact that Libyan horses had been imported into Spain, but that later on, as certain writers tell us, Spanish horses were imported into North Africa and crossed with the

sunt quos celdones vocamus, minore forma appellatos astureones, - gignunt quibus non vulgaris in cursu gradus, sed mollis alterno crurum explicatu glomeratio, unde equis tolutim capere incursum traditur arte.

1 Hayes, Points of the Horse, p. 508 (ed. 3). 
native horses there. It was the fine-bred Andalusian horse which was termed the Spanish jennet by our older English writers, as is clear from Blundeville's description of that animal : "The Jennet of Spaine is finclie made, both head, bodie, and legs, and very seemlie to the eie, saving that his buttocks be somewhat slender, and for his fine making, lightnesse, and swiftnesse withall, he is verie much esteemed, and especiallie of noble men, as Camerarius saith, which Oppianus also affirmeth, saieng: that the Jennet in swiftness passeth the Parthians and

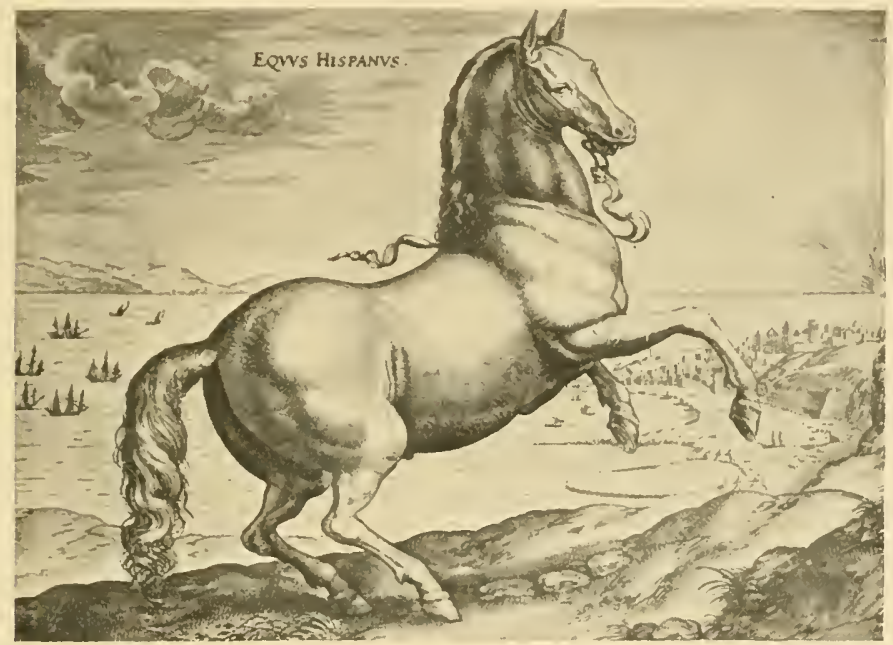

FIG. 75. The Jennet of Spain.

all other horses whatsoever they be, even so far as the Egle exceedeth all the birds in the aire, and as the Dolphin passeth all the fishes in the sea, but therewith he saith that they be but small of stature, of small strength, and of small courage, all which things seeme to agree verie well with those Jennets that be brought hither into England, unlesse it be the last point. For I have heard some of the Spaniards to set such praise on their. Jennets' courage, as they have not letted to report, that they have carried their riders out of the field, I cannot tell how manie miles, after the Jennets themselves have been shot cleane through the bodies with Harquebushes. 
Which report I have heard to be true by divers of our owne souldiers, which if it be true in deede, it doth better countevaile their small stature and little strength, which is manifest to all men's eies that do behold them."

This description is admirably illustrated by Stradanus' drawing of the 'Hispanus' here reproduced (Fig. 75).

The horses of northern Spain are grey and rufous-grey, and are of a smaller size than the Andalusian ${ }^{1}$. In them we have no difficulty in recognizing the Celtiberian, Galician and Asturian breeds of Strabo and Pliny. In the dun-coloured ${ }^{2}$ animals (often striped) of the sierras we have the less modified descendants of the old European horses, but in view of the continual intercrossing for many centuries of the Libyan and European blood, and in face of the facts relating to the dun-coloured striped horses of Kattywar (p. 157), it would be rash to assume that these striped dun horses of Spain are really pure representatives of the old dun horses of Europe.

The curious statement that the Celtiberian horses lost their distinctive speckled coats when removed into southern Spain is readily explained. The actual horses exported did not change their colour, but as they became mixed with the dark Libyan stock in that region, the latter blood predominated and the grey horses merged into the dark bay and black.

The horses of the Asturias and other mountainous areas of Spain are probably descended from the old European largeheaded horse, which may have continued in a wild state in Spain down to the Christian era, since Posidonius mentions horses among the wild animals of Spain. Of course these horses may have been simply feral horses, but on the other hand there is no reason why genuine wild Equidae should not have still survived in wild and mountainous districts.

We have seen that Strabo compared the Celtiberian horses, that is, the horses of northern Spain, to the Parthian horses, which were the descendants of the Nisaean horses, the best in Asia in the fifth century B.c.; it has also been shown that

1 Hamilton Smith, op. cit. p. 247.

2 Isidore of Seville (Origg. xIr. 1) says that dun (cinereus) horses are the worst (but ef. p. 348). 
the Libyan horses were being imported into Asia Minor through Egypt at least as early as 900 B.C., and additional evidence will soon be offered to show that the Libyan dark bay horses with a star in the forehead were known in north-west Asia Minor by at least 1000 B.C.

It has been demonstrated that in western Asia bay predominates largely among the pure North African breed of the Anazah tribes, and that all the breeds of western Asia which have originated from the light-coloured upper Asiatic horse by the admixture of Arab, i.e. Libyan, blood are generally grey, rufous-grey, iron-grey, and black, as are to-day the horses of northern Spain which are derived from the old European lightcoloured horse improved by Libyan blood.

As then the crossing of the bay Libyan blood with the duncoloured horse of Asia and Europe has produced the same results in Spain and western Asia, we are justified in concluding that grey horses are not an original stock as has been held by some, but are the result of the crossing of Libyan and Asiatic blood. The same holds true of black, for it is found in the areas where the two primitive stocks overlap, whilst it seems unknown among true Asiatic-European horses on the one hand, and pure Libyan horses on the other. We shall soon see that among the feral Pampas horses, which are descended from Andalusian ancestors, barely one in two thousand is black. It seems certain that the grey and black element in the horses of Andalusia and possibly even in those of Morocco, is derived from the grey half-bred horses of the Asturias and Murcia. Again, as it has been shown (p. 157) that the dun-striped horses of Kattywar are the result of crossing the upper Asiatic dun horses with Libyan blood, so too the striped dun horses of the sierras of Spain are probably due to crossing the old dun European horse with the same Libyan stock.

South America indeed not only had fossil horses, such as the small Hippidium of the Pampas of Argentina and varions long-limbed species, but (unlike North America) had horses at the first advent of man, as is proved by the existence of horse remains associated with worked stone implements, pottery 
and fire refuse in the lake formations of the Upper Pleistocene $^{1}$. But nevertheless there seems no doubt that it was extinct before the coming of the Spaniards, and that the Pampas horses of South America are all descended from Andalusian horses introduced by the Spaniards in 1535, when the city of Buenos Ayres was founded by Don Pedro de Mendoza. 'The place, however, was almost immediately deserted, the inhabitants passing over to Paraguay by water in such haste, and with such lack of means of transport, that they were unable to carry along with them all the horses brought from Andalusia; five mares and seven horses were left behind on the plain. The city was refounded in 1580 by Don Juan de Garay, accompanied by sixty colonists from Paraguay. "These individuals found that a considerable breed had already sprung from the above-mentioned mares, and set about domesticating those which they were able to catch ${ }^{2}$." The ministers of State opposed this, asserting that they belonged to the king. After protracted litigation it was decided in $\mathbf{1 5 9 6}$ that the wild horses should be the property of whosoever should take the trouble to capture them. This is the origin of the innumerable herds of wild horses which are met with to the south of the La Plata as far as Rio Negro, and even throughout Patagonia. These horses were at first, as now, called alzada and cimarrona, but the Querandese (commonly known as Pampas Indians) having given them the name of baguulada, the Spaniards adopted this name, and these horses are generally known as baguales.

In Azara's time there were also baguales to the north of the river La Plata. These horses seem to have descended from some mares abandoned by the Spanish settlers of San Juan Bautista, a town founded by John Romero in 1553, right opposite Buenos Ayres, where the San Juan debouches into the La Plata. It was soon attacked by Indians, and the inhabitants crossed the river into Paraguay and were obliged,

1 H. F. Osborn, The Century Magazine, Nov. 1904, p. 13; Sir H. H. Johnston, British Mammals, p. 274.

2 Azara, Natural History of the Quadrupeds of Puraguay and the River La Plata (translated by W. P. Hunter), pp. 4-5. 
in their hasty flight and from want of vessels, to leave their mares behind them.

The buguales form immense herds, sometimes numbering 12,000 according to Azara. They frequently entice away domestic horses, who remain ever after with their wild comrades. Travellers often used to find themselves unable to continue their journey, their relays of fresh horses, which were always driven loose before them, being enticed away by the wild horses. The baguales' mode of attack is not in line of battle, but some precede the others, forming a vanguard, and the rest follow in a column, which is never broken or interrupted, and at most only changes its direction if they are frightened ${ }^{1}$.

Azara estimates the proportion of bays amongst these horses to be about ninety to ten zains, that is, entirely dark-coloured without any white; and there is not one black in two thousand; pied and greys occur sometimes, but are then invariably individuals escaped from domestic conditions. ${ }^{2}$. As the grey and rufous-grey horses of the Asturias stock are very common in the hills and northern states of South America, the grey horses which occasionally occur on the Pampas are probably of this breed.

Now as the Pampas horses have been living under natural conditions for the last three centuries, and do not show any tendency to grey, black, or pied, whilst bay forms their universal colour, it seems clear that the latter is the inherent colour of the Libyan horse, and that it does not tend to black, grey, or pied, except when crossed with the European-Asiatic stock.

The history of the domestic horse in North America is in many respects closely parallel to its story in the southern part of the same continent. Although North America, as we have seen (pp. 6, 7), played a leading part in the evolution of the Equidae, and although in the early Pleistocene period owing to the favourable conditions of environment there were great numbers of and several kinds of horses, such as $E$. complicatus 
(about the size of a small Western broncho originally found near Natchez and now traced all over the Southern States from the isles of the Gulf of Mexico to South Carolina), $E$. pectinatus (a large horse with very elaborate grinders found in the North-Eastern and Middle States), E. pacificus (found on the coast of California and Oregon, perhaps the closest of all fossil horses to E. caballus), and E. excelsus (Nebraska), there is as yet no evidence that the indigenous horses had survived down to the first arrival of man in that continent. But it would be rash to dogmatise on this point since in a part of a quarry in Nebraska where Prof. Osborn and his associates on the Whitney expedition obtained the remains of hundreds of $E$. excelsus, "all the large limb bones were found broken in two." "This,' says Prof. Osborn", "suggested to me the possibility that these large bones, the only ones known to have contained marrow, had been broken by man, who was primitively a great marrow-eater, but we searched in vain for any collateral evidence of this hypothesis. To my knowledge, no human remains have been found associated with those of the fossil horse in North America; but I confidently expect that such association will be discovered, as it has been in South America."

It is therefore absolutely certain that there were no horses in North America at the time of its discovery by Columbus. Indeed it seems likely that the Indians would have domesticated the indigenous horses, if any such still survived, since they were so quick to tame and utilise at a later date the feral horses of the western prairies. It is with the latter horses and their origin that we are now concerned. It seems certain that the thousands of wild horses that down to sixty years ago roamed the western prairies, were all descended from the horses introduced by the Spaniards, and that accordingly their history is very much the same as that of the baguals of the Pampas. But, whilst we know definitely that the Pampas horses are all sprung from a dozen Andalusian horses, we have no such explicit statements respecting the ancestry of the wild 
horses of North America. Again, whilst the Pampas horses show a remarkable uniformity of colour, it was very different with their kindred in the North, for they appear to have worn coats of many colours in the vast area over which they ranged from Mexico to the Red River (since, according to Dr Richardson ${ }^{1}$, they never seem to have advanced beyond the 52nd or 53rd degree of latitude). Thus, according to Catlin $^{2}$, these wild horses were of all colours-black, grey, roan, and roan pied with sorrel-and F. Micheaux ${ }^{3}$ describes two wild horses from Mexico as roan, whilst Darwin ${ }^{4}$ on the authority of Dr Canfield says that in certain parts they are mostly duns and striped, and Osborn states that "in Mexico and various other parts of America, the descendants of the horses introduced by the Spaniards are frequently of a dun colour with distinct dorsal, shoulder, and leg stripes." Since Darwin adduced these dun-coloured horses of Mexico as cases of reversion to the dun colour of a primitive ancestor, and as the same horses are still being constantly cited in support of the same doctrine, it is most important that we should ascertain as far as passible the history of the horses of Spanish descent in Mexico and other parts of North America. This is all the more desirable in view of the facts which we have already elicited concerning the striped horses of Java and the duncoloured and striped horses of Kattywar also eited by Darwin, and generally accepted without question as instances of the survival of or reversion to the primeval livery of the horse. It will be noticed that the contention of Darwin and othersthat in the dun-coloured horses of Mexico and Texas we have instances of reversion-assumes that no horses of a dun-colour and having stripes were introduced into North America by the Spaniards. In fact Darwin tacitly assumed that as the Pampas horses are all sprung from Andalusian horses which are normally of a dark colour, the Spaniards brought none others than dark

I Fanna Boreali-Americana (1829), 1). 231.

2 Indian Tribes, Vol. Ir. p. 57 (cited by Darwin).

3 Travels in North America (Eng. trans.), p. 235 (cited by Darwin).

4 Variation, Vol. I. p. 64.

5 The Century Magazine, November, 1904, p. 14. 
Andalusian horses to Mexico and Texas. But it would be just as absurd to assume that because amongst the hills and northern states of South America grey and rufous-grey of the Asturian breed are very common, we have here instances of reversion. We have just seen that in addition to the fine dark horses of Andalusia (which have shown no tendency to revert to dun on the Pampas) Spain also possesses horses of all sorts of colour's-dun, white, dun with stripes, various sharles of grey, rufous-grey or roan, brown and black-and we were enabled to conclude that all these colours except dun and white and possibly striped dun were due to the intermixture of the Libyan and European-Asiatic horses. IVe also saw that when pied and grey horses were met on the Pampas, they were not reversions or 'sports,' but were invariably animals which had escaped from domestic conditions and were almost certainly of the Asturian and Murcian stocks. Bearing therefore in mind that the horses introduced by the Spaniards into the northern parts of South America were of light and mixed colours, we must be prepared to find that horses of a similar Asturian or Murcian origin as well as Andalusians were brought by the first Spanish settlers to San Domingo, and later to Cuba (settled in 1511), by Cortes to Mexico in 1519, and still later to Florida and to the western bank of the Mississippi. We need not then be surprised, if the descendants of these Spanish horses wear liveries of all coloursblack, grey, roan, and roan pied with dum (sorrel), dun, and striped dun-just like the horses of the northern states of South America descended from the breeds of northern Spain.

We must not then hastily assume that the dun horses often with stripes found in Mexico and the Western States are instances of a reversion to a primal colour, when it is far more probable that they have simply retained the livery which duncoloured striped ancestors brought with them from the sierras of Spain. If it can be shown that the Spanish Conquistadores carried into Mexico and 'Texas not only Andalusian horses, but also those of inferior breeds, we shall have an easy explanation of the many colours (including striped dun) found to-day in their posterity. Fortunately we have the clearest evidence 
respecting not only the first introduction of horses into Mexico, but even minute descriptions of the animals themselves, whilst there is also reliable evidence for the first carrying of horses to the western bank of the Mississippi, though unfortunately we have no details respecting the colour or colours of these animals. This however is of no great matter since it can be shown that they were the same kind of animals as those brought to Mexico.

After Columbus had discovered the New World, the Spaniards first settled in Hispaniola (San Domingo), and hither horses were introduced very soon, for beyond doubt they were already in that island when Diego Velasquez crossed over to Cuba in 1511 and conquered that island with little opposition. As the islands formed the base for all subsequent expeditions to the northern parts of South America, to Darien, to Yucatan, to Mexico, and to Florida and the lands beyond the Mississippi, we need not be surprised to find horses of the same kinds in modern times in the northern parts of South America, in Mexico, and the Western States.

The difficulty of transporting horses from Spain to Hispaniola and Cuba in the small ships of the time naturally rendered these animals very scarce and very dear for some time in the islands, as is put beyond all doubt by the fact that when Hernando Cortes set forth (1519) from Cuba to conquer the empire of Montezuma he was only able to take sixteen horses with him. From the statements contained in the depositions at Villa Segura, it appears that the cost of the horses for the expedition was from four to five hundred pesos de oro each ${ }^{1}$. Bernal Diaz, Cortes's comrade, who wrote the immortal account of the conquest of Mexico ${ }^{2}$, was a lover of horses and he has given us in his work a minute account of each of the sixteen horses brought to Mexico. There were eleven horses and five mares and these were of many different colours. There were only two jennets, that is, fine-bred horses, the rest being cross-bred animals. Cortes himself had a chestnut 'without any white' (zaino), there were two termed simply 'chestnut' (castaño), three

1 W. H. Prescott, The Conquest of Mexico, Vol. I. pp. 260-1, note.

2 Bernal Diaz, La Conquista de Nueva-España, cap. xxır. 
'dark chestnuts' (castaño escuro), two bright 'chestnuts' (castaño claro), and one 'perfect chestnut' (perfecto castaño); there were three 'greys' (rucia), all being mares, one of which is clescribed as very heavy (muy poderosa); and there was one 'all dark sorrel,' mane and tail included (alazan tostado), and there was an 'egg-coloured' (overo), i.e. light yellow-dun, and a 'light yellow-dun' somewhat blackish-red above (overo algo sobre morcillo), and one 'dark'-coloured (escuro). As this passage has such an important bearing on the history of the horses not only of Mexico but also of the northern parts of South America, and the Western States of North America, and as it has hitherto escaped the notice of those who have written about American horses, I subjoin the original in a footnote ${ }^{1}$.

1 El capitan Cortés, un caballo castaño zaino, que luego se le murió en San Juan de Ulúa.

Pedro de Albarado y Hernando Lopez de Avila, una yegua castaña muy buena, de juego y de carrera; y de que llegamos á la Nueva-España el Pedro de Albarado le compró la mitad de la yegua, ó se la tomó por fuerza.

Alonzo Hernandez Puertocarrero, una yegua rucia de buena carrera, que le compró Cortés por las lazadas de oro.

Juan Velazquez de Leon, otra vegua rucia muy poderosa, que llamábamos la Rabona, muy revuelta y de buena carrera.

Cristóbal de Oli, un caballo castaño escuro, harto bueno.

Francisco de Montejo y Alonso de Avila, un caballo alazan tostado: no fué para cosa de guerra.

Francisco de Morla, un caballo castaño escuro, gran corredor y revuelto.

Juan de Escalante, un caballo castaño claro, tresalvo: no fué bueno.

Diego de Ordás, una yegua rucia, machorra, pasadera aunque corria poco.

Gonzalo Dominguez, un muy extremado jinete, un caballo castaño escuro muy bueno y grande corredor.

Pedro Gonzalez de Trujillo, un buen caballa castaño, perfecto castaño, que corria muy bien.

Moron, vecino del Vaimo, un caballo overo, labrado de las manos, y era bien revuelto.

Vaeno vicino de la Trinidad, un caballo overo algo sobre morcillo: no salió bueno.

Lares, el muy buen jinete, un caballo muy bueno, de color castaño algo claro y buen corredor.

Ortiz el músico, y un Bartolomé García, que solia tener minas de oro, un muy buen caballo escuro que decian el Arriero: este fué uno de los buenos caballos que pasamos en la armada.

Jnan Sedeño, vecino de la Habana, una yegua castaña, yesta yegua parió en el navió. Este Juan Sedeño pasó el mas rico soldado, que hubo en toda la 
Cortes set sail from Cuba for Yucatan in February, 1519, with 663 men, 200 Indians, and sixteen horses. In his first battle two horses were killed and in the second another, and all the survivors were more or less severely wounded. Cortes later on was joined by Alvarado at Vera Cruz with twenty horses and one hundred and fifty men. Cortes had mortally offended the governor of Cuba by reporting direct to Spain, and the latter sent out a force under Narvaez, who was to supersede Cortes and send him back in chains to Cuba. Narvaez had eighteen vessels, which carried nine hundred men, of whom eighty were cavalry. Cortes by this time had only five mounted men, but by a successful night attack he captured Narvaez and his whole army. The common soldiers were only too ready to transfer their allegiance to so vigorous a captain as Cortes, and the latter had now eighty-five horsemen. The conquest of Mexico was accomplished in 1521, and adventurers from Spain soon poured in, bringing other horses from the Antilles from time to time.

We need not hesitate to believe that the horses brought by Alvarado and Narvaez were of the same kinds and colours as those of Cortes, the colours of which we have just enumerated. As Cuba had been settled from Hispaniola and by 1538 had already great numbers of horses, we may safely assume that the horses brought to Darien, if not by Balboa (1510) most certainly by Pedrarias, who was established there before Cortes sailed for Mexico, and the horses brought into Peru by Pizarro in 1526 were of the same kinds and colours as those described by Bernal Diaz, and in some of which we have recognized the descendants of the ancient grey horses of the northern parts of Spain and of the dun-coloured horses of the same country. We need not then be surprised to find horses of many colours including (striped dun) in Mexico and in the Western. States, and it is now certain that the dum horses with black stripes which Darwin and so many others have supposed

armada, porque trujo un navío suyo, y la yegua y un negro, é cazabe é tocinos; porque en aquella sazon no se podia hallar caballos ni negros sino era á peso de oro, y á esta causa no pasaron mas caballos, porque na los habia. For fuller explanation of the horses' colours see Addenda. 
to be instances of reversion to the ancestral type are nothing of the kind, but only the continuance of characteristics brought by the ancestors of such horses from Spain to Hispaniola, and Cuba, and thence into Mexico.

It is absolutely certain that the horses of the northern parts of South America, to which we have already referred (p. 266), are descended from animals first brought to those regions by the Spanish colonists. That such was the case not only with the Isthmus of Darien, and the adjacent regions, but also with Peru, is beyond doubt. Francisco Pizarro, the conqueror of the kingdom of the Incas, was already in Hispaniola in 1510, for in that year he took part in an unfortunate attempt to plant a colony at Uraba on Terra Firma. In the following year he was at Darien with the famous Vasco Nunez de Balboa, and accompanied that bold cavalier when he scaled the mountain ridge of the Isthmus and was the first European to gaze on the limitless expanse of the Pacific. After the gallant Balboa had been put to death by his rival Pedrarias, Pizarro attached himself to the latter, who with a view to pushing forward the discovery of new lands for plunder on the western coast, transferred the capital of the colony from Darien to Panama in 1519, at the very time that Cortes had set forth to subdue the Aztec empire. Pizarro started on his first expedition southwards from Panama in 1524 with about one hundred men in two small vessels, but he does not appear to have had any horses. However, in his second attempt to reach the realms of gold, in addition to one hundred and sixty men he had been able to procure a few horses at Panama ${ }^{1}$. There can be no reasonable doubt that these horses, like those brought by Cortes to Mexico, had come from Hispaniola or Cuba, and were of the same kind. The important aid rendered to Pizarro by these horses in his wars with the Indians is probably familiar to most readers, for the natives at first supposed that the Spanish cavaliers were a kind of centaurs, and Pizarro was able to extricate his forces from one dangerous position by the consternation that seized the Indians when a cavalier fell from his horse, as they were 
not prepared for the division of what seemed a single being into two ${ }^{1}$.

We thus obtain an easy explanation of the reason why the horses of the northern parts of South America resemble so closely in their colours those of Mexico.

There is another source other than the horses brought into Mexico from which may have sprung wholly or in part the wild horses which formerly roamed Texas and the other regions west of the Mississippi. Ferdinando de Soto had gone to the Spanish Indies when Perlrarias was governor "and there he was without anything of his own save his sword and target." Pedrarias made him captain of a troop of horsemen (which clearly shows that there were already horses at Darien), and by his commandment he went with Pizarro to the conquest of Peru. He was at the capture of the Inca Atahualpa and at the taking of Cuzco and got a goodly share of the booty. $\mathrm{He}$ then married the daughter of Pedrarias, and the emperor Charles $\mathrm{V}$ made him governor of the island of Cuba and Adelantado or President of Florida 2 .

In April, 15:38, he sailed from San Lucar in Spain to Cuba and Florida with an armament of 600 men. He arrived at Santiago in Cuba on Whitsunday, and "as soon as they came thither a gentleman of the city sent to the seaside a very fair roan horse, and well furnished for the governor, and a mule for Donna Isabella, and all the horsemen and footmen that were in the town came to receive him at the seaside." The chronicler then states that "in this country (Cuba) there are many good horses, and there is green grass all the year. There be many wild oxen and hogs whereby the people of the island are well furnisherl with flesh"." Having sent his ships to Havannah "the governor and those who stayed with him bought horses and proceeded on their journey. The governor's company

1 Preseott, op. cit. Vol. 1. p. 252.

2 The Discovery and Conquest of Terra F'lorida by Don Ferlinando de Soto and six hundred Spaniards, his followers, written by a Gentleman of Elvas, employed in all the action, and translated out of Portuguese by Richard Hakluyt (reprinted from the ed. of 1611 by W. B. Rye: Hakluyt Society), p. 4.
3 Ibid. p. 17.
Ibid. p. 19. 
which went by land were one hundred and fifty horsemen ${ }^{1}$." De Soto and his company reached Havannah in March, 1539, and on May 30th they landed in Florida. "They set on land two hundred and thirteen horses, which they brought with them, to unburden the ships that they might draw less water ${ }^{2}$." The horses were weak with travelling upon the sea. It was not the first time that horses had been in Florida, for in 1525 Allyon had sailed thither with six ships, carrying five hundred men and between eighty and ninety horses, but the expedition met with nothing but disaster and the remnant got back to San Domingo. In 1527 preparations were made in Spain for a fresh expedition to Florida. Pamphilo de Narvaez set sail from San Lucar in 1527, and after wintering at Cuba he landed in 1528 at Santa Cruz in Florida. He and his comrades were reduced to great straits and had to kill a horse for food every third day, while they were constructing at Baya de Caballos frail vessels in which they hoped to reach the Spanish settlements, but most of them were lost at sea.

De Soto's men discovered the site of Narvaez' camp at Alpaca and found there skulls of horses ${ }^{3}$. The horses brought by Narvaez cannot then have contributed any element towards the equine population of America. After three years' wanderings, in which he committed the most wanton cruelties on the Indians, de Soto reached the Mississippi, which he crossed about lat. $35^{\circ} \mathrm{N}$. in 1541 . "He desired to send news of himself to Cuba that some supply of men and horses might be sent unto him." By this time he had lost two hundred and fifty men and one hundred and fifty horses. ${ }^{4}$. He wintered in Autiamque and in the next year (1542) he departed from it to see Nilco, which the Indians said was near the great river, "with determination to come to the sea and procure some succour of men and horses, for he had now but three hundred men-of-war and forty horses, some of them lame, which did nothing but help to make up the number: and for want of iron they had gone above a year unshod, and because they were used to it in the plain country, it did them no great harm ${ }^{5}$."

1 Hakluyt, op. cit. p. 21.

2 llid. p. 25.

3 Ilid. p. 43.

${ }^{4}$ Illid. pp. 111-12.

5 Ibid. p. 115. 
De Soto died by the Mississippi, and to conceal his death from the Inclians, whom he had persuaded that he was immortal, his followers by night cast his body into the Father of Waters. His goods were sold by auction: they consisted of two men slaves, two women slaves, and three horses and seven hundred hogs, the posterity of the sows which he had brought from Cuba to Florida. "For every slave or horse they gave two or three thousand ducats : two hundred ducats for a hog ${ }^{1}$." Luys de Moscoso now took the command and determined to return to Minoya and to make ships there. "They shipped twentytwo of the best horses that were in the camp: the rest they made dried flesh of "." They made their way down the river with great difficulty, fighting agaiust the river-side natives. Finally, as the canoes in which they were conveying the horses made such slow progress, Luys de Moscoso determined to go on shore and kill them. "As soon as they saw a place convenient for it, they went thither and killed the horses and brought the flesh of them to dry it aboard. Four or five of them remained on shore alive: the Indians went unto them after the Spaniards were embarked-the horses were not acquainted with them and began to neigh and run up and down in such sort that the Indians, for fear of them, leaped into the water, and getting into their canoes went after the brigandines, shooting cruelly at them ${ }^{3} . "$

According to another accomt of the expedition, written by Hernandez de Biedma 4 , when de Soto landed in Florida he had six hundred and twenty men and two hundred and twentythree horses ${ }^{5}$. He says that when they came to the great river "we resolved to make four large pirogues, each capable of containing sixty or seventy men and five or six horses, and we spent twenty-seven or twenty-eight days in constructing them." The river was crossed where it was about a league broad and the depth from uineteen to twenty fathoms. In their subsequent wanderings they reached a place where the

1 Hakluyt, op. cit. pp. 126-7.

Ibid.p. 148.

3 Ibid. pp. 153-4.

4 This account is given by Rye in an appendix to his reprint of Hakluyt's translation of The Discovery, pp. 173 sqq.

5 Ibid. p. 178.

R. H. 
Indians made abundance of salt (salt springs?), and they spent six months in the construction of the brigandines: "we took with us some canoes, into which we put twenty-six horses."."

There is no reason why the half-dozen horses thus abandoned on the bank of the Mississippi should not have become the progenitors of all the wild horses of Western America. It is clear that the Indians did not kill them at once, and the horses would thus have had time to escape into the open country, where it would be difficult for the natives to capture or slay them. There was no greater likelihood of their being killed by the Indians than there was in the case of the oft-cited animals abandoned at Buenos Ayres and San Juan Bautista, when these two infant settlements were attacked by Indians. Only one doubt remains. On which bank of the Mississippi were the horses deserted? The chronicler gives no direct statement, but as the brigandines were built on the western bank, and as the writer does not state that they had crossed to the other side when Luys de Moscoso determined to kill the remnant of the horses, it is probable that the horses were abandoned on the western bank of the great river. As all de Soto's horses like those of Cortes were brought from Cuba, the colours of these animals would have been the same as those of the horses which formed the parent stock of Mexico. Accordingly, even if the horses of the Western States are sprung from de Soto's animals, and not from feral horses from Mexico, the occurrence of dun with stripes in such animals is not to be regarded as a reversion to a primitive ancestor.

The horses of Sardinia and Corsica, as might naturally have been expected, show much North African blood. The Sardinian seldom exceed 13.2 hands $(135 \mathrm{~m}$.), and are in colour black, chestnut, and bay, but rarely grey ${ }^{2}$, whilst the Corsican range from 11.2 hands to 13.2 and are black, chestnut, sometimes bay, but rarely grey ${ }^{3}$. They are steady, active and courageous, and capable of enduring cold and hunger.

The horses of Sardinia and Corsica had well-known characteristics in medieval times, for Stradanus gives a picture of

1 Hakluyt, op. cit. p. 199.

2 Cuyer and Alix, Le Cheval, p. 632.

3 Ibid. p. 613. 
the 'Sardonicus' (here reproduced, Fig. 76); whilst Bluudeville says that "the horses that come out of the Isles of Sardinia and Corsica, as Volaterranus saith, have short bodies and be very bolde and couragions, and muquiet in their pace, for they be of so fierce and hote cholerike complexion, and therewith so much used to rumning in their countrie, as they will stand still on no ground, and therefore this kind of Horse requireth a discreete and patiente rider, who must not be overhastie in correcting him, for feare of marring him altogether."

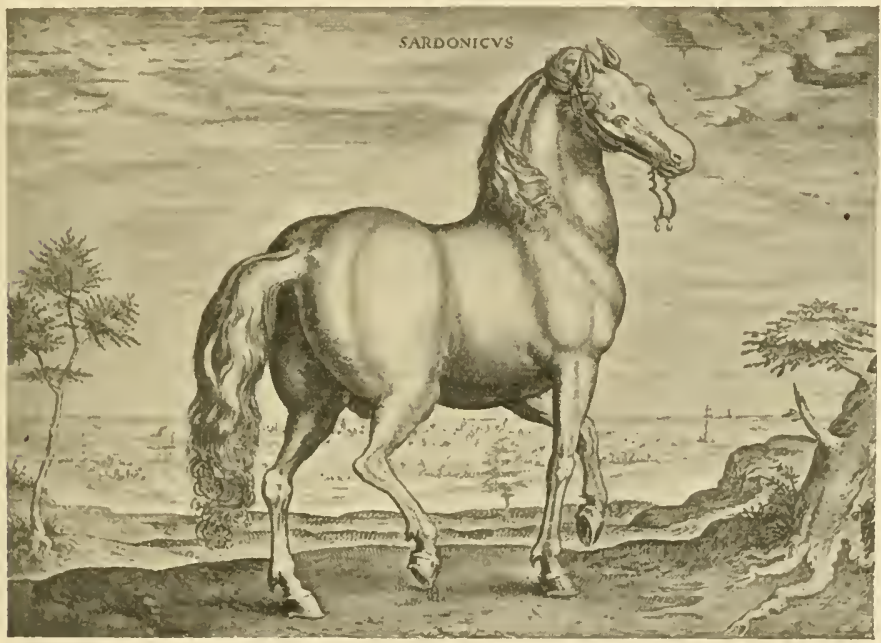

FIG. 76. The Sardinian Horse.

The Carthaginians had occupied Sardinia from an early time and it is probable that Libyan horses were introduced into that island by them. Whether this be so or not it seems probable that Libyan blood had got into both islands from a comparatively early period, and that partly from it originated the modern breeds.

The prevalence of black, chestnut, and bay, and the rarity of grey shows that although the Libyan blood had been crossed with European, the former was really the chief element in the blend. 
Corsica was noted in the sixth century A.D. for a very diminutive breed of ponies, for Procopius ${ }^{1}$ states that in that island "just as human beings become dwarfs, so are there herds of horses which are but little taller than sheep."

The horses of Sicily to-day resemble closely those of Sardinia both in colour, conformation, and character, being black, chestnut, and bay, but rarely grey. As the Carthaginians from an early period had factories in Sicily, and as there was a vast trade between the Cyrenaica and the Greek cities of that island, it seems highly probable that the famous horses of Sicily, which so often carried off the prizes at the great games of Greece, were largely of the Libyan stock. It is very noteworthy that of the fourteen victories with horses and mules celebrated by Pindar, twelve were carried off by animals from Sicily and Cyrene, two only falling to Greeks of Greece proper-Megacles of Athens and Herodotus of Thebes. Syracuse, Agrigentum, and Camarina were specially distinguished for their horses, and Pindar praises Psammis of Camariua "as a man most zealous in the breeding of horses," and it would appear that he had actually entered at the same time at Olympia a chariot, a mule-car, and a race-horse.

Agrigentum continued to be devoted to horses until its destruction by the Carthaginians in 405 B.C., for when a citizen named Exaenetus won the chariot-race at Olympia in 412 B.c., he was met on his return and escorted into the city by three hundred chariots each drawn by two white horses. The city was likewise famous for the splendour of the monuments reared over successful race-horses 2 .

The coinage of the Sicilian cities amply proves their pride in their horses. Victories in the great contests are frequently commemorated in their types. Thus some Agrigentine coins have a quadriga driven by winged Nike, suggested by such a victory as that of Exaenetus, whilst in the earliest issue of Syracuse (before 500 B.C.) the tetradrachms bear a four-horse chariot, the didrachms a man riding one and leading a second

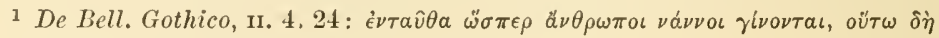

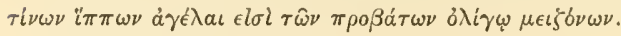

${ }^{2}$ Diod. Sic. xIII. 82. 6.
} 
horse, and the drachms a horseman. Gela not only prided herself on her racing successes, but on what was far more important, her fine cavalry, for her coins show a four-horse chariot with Nike floating above, and very constantly an armed horseman, spearing a prostrate foe, or else striking downwards

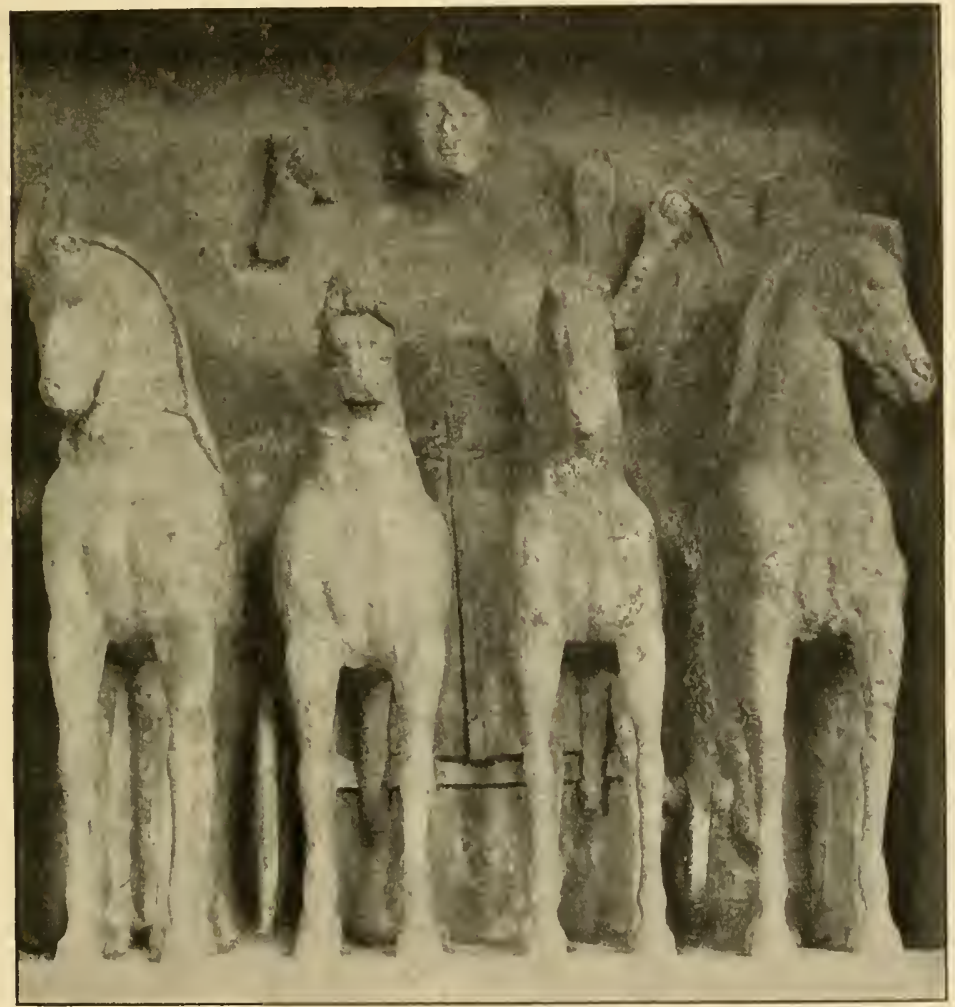

FIG. 77. Archaic Metope, showing a Quadriga; Selinus.

with his spear. These coins give us some of the earliest numismatic representatious of riding. But by far the earliest representation of Sicilian horses now extant is the quadriga on one of the metopes of the archaic temple of Selinus (founded B.C. 628), which date from the latter half of the seventh century B.c. The metopes, which are in high relief and extremely vigorous in execution, have a special interest as they are the 
most ancient extant specimens of Greek sculpture of the historical period. The quadriga relief which represents a chariot and horses in elevation (Fig. 77) is the most remarkable. The Sicilian horses, to judge by the monuments just cited, as well as the Carthaginian issues of Panormus (Fig. 74 $b$, p. 255), were cross-bred animals, for doubtless the desire to obtain strength made the Sicilians prefer half-bred to pure Libyan horses.

It seems almost certain that the white horses which the Sicilian Greeks, like so many other peoples, esteemed for their colour far beyond their true merits, were derived from central Europe, for we have already seen that Dionysius, the despot of Syracuse, purchased some of their best strain from the Veneti, who certainly possessed white horses. In the fourth century A.D. the Sicilian horses were nearly as much esteemed for the circus as the Cappadocian and Spanish ${ }^{1}$.

South Italy shared with Sicily the fame of her riding horses, and from at least the sixth century B.c. the great cities of Magna Graecia, such as Sybaris, Croton and Tarentum, were renowued for their cavalry, which formed their chief arm in war. Before the fall of Sybaris (510 B.c.) five thousand of her citizens used to ride on horseback in procession on high festivals.

They taught their horses to dance to music at their banquets, an accomplishment which brought about the destruction of Sybaris, as the Crotonians before the great battle in which the Sybarites were destroyed caused flute-players to play one of the tunes to which the Sybarite horses were accustomed to dance. As soon as they heard the tune they stood on their hind legs, unseating their masters and rendering them an easy prey to their foes ${ }^{2}$. We have noticed as we advanced that extraordinary docility characterised the Libyan horse and its derivatives, such as the Arab, the Turk of Western Asia, and the little ponies of Java, and we are told by Ibn Batuta $^{3}$ that he saw horses (which were certainly Arab) dancing before the Arab sultan of Sumatra, and that he had already seen

1 Veg., Ars Vet. 1v. 6, 2: Cappadocum gloriosa nobilitas, Hispanorum par vel proxima in circo creditur palma, nec inferiores prope Sicilia exhibet circo.

2 Athenaens, xir. 520; Pliny, H. N. vilr. 157.

3 Voyages, Vol. vi. pp. 236-7. 
a similar performance taking place before a king of Southern India, where, as we have seen, all the horses were imported from Arabia: again, the Iberian horses, i.e. the horses of Southern Spain, derived directly from Libya, were noted for the same docility, and their descendants, the Pampas horses of South America, retain that quality, whilst the dancing and

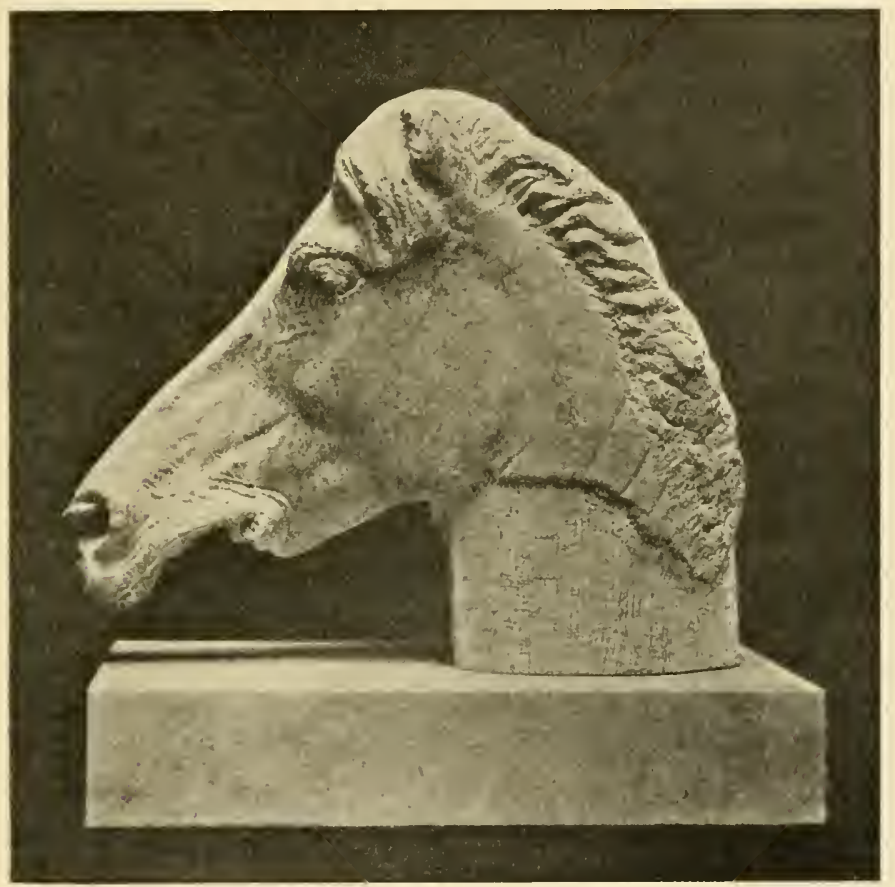

Fig. 78. Fragment of Sculpture from Tarentum (4th cent. B.c.).

performing horses in modern hippodromes seem always to be Arabs. The extreme readiness of the Sybarite horses to learn dancing itself points to their having in their veins a considerable infusion of Libyan blood.

Thurii, which was founded on the ruins of Sybaris in $4+3$ B.C., revived the horse-breeding tradition of the older town, and it is most important to note that according to 'Tacitus ${ }^{1}$ 
the Romans first learned horse-racing (certamina equorum) from that city. The Tarentines especially prided themselves on their horsemen, which formed their chief arm in war and one of which was the type on their coins from the end of the fifth century B.c. down to the Roman conquest in B.c. 272. That the best horses of Tarentum were well-bred with a large admixture of Libyan blood is put beyond doubt by a marble fragment procured near Tarentum ${ }^{1}$ and now in the British Museum (Fig. 78). The length of the horse's head from the end of the mane over the forehead to the lip is $0.46 \mathrm{~m}$, the height from the bottom of the cheek-bone to the top of the head is $0.34 \mathrm{~m}$.; the lower lip is gone, and the ears are broken. The bridle, as usual in such cases, was probably added in bronze, as is shown by rivet-holes. From a comparison with Tarentine coins and other considerations the fragment may be placed in the latter half of the fourth century B.c. The head differs from that of the horse of Selene from the Parthenon (p. 299) in the greater length of its fore-part, from which Prof. Michaelis was disposed to infer that the Tarentine horse was of more slender proportions, and furthermore it shows more faithful representation to nature than is seen "in that wonderful combination of idealism and realism which is so conspicuous in the head of Selene's horse." The bony ridge below the eye, to which are attached the masseter and zygomatic muscles, is more strongly marked in the Tarentine than in the Parthenon horse; the nose is slightly curved, the eye is large though not so prominent as in the latter, whilst on the other hand the eyes of the famous bronze horses from St Mark's at Venice lie deep in their sockets, and are overshadowed by rather strongly marked brows. The mane in the Tarentine fragment is cut short, but is not so stiff as is usual with Attic horses, and it falls more freely, hanging in a double forelock over the forehead, as is also the case in several slabs of the Parthenon. If we compare the Tarentine head with that of one of the colossal horses from the Mausoleum (p. 305) and with that of a horse from the Amazon frieze of the, same monument, we at once see that the ideal Tarentine horse in the second half of the fourth century B.c.

1 A. D. Michaelis, Jour. Hell. Stud., Vol. III. (1882), pp. 234-9, Pl. xxıv. 
was a far better bred animal than the ideal Asiatic horse of the same period. The Tarentine fragment is held to have been part of a chariot group, but there is no reason why it may not have been part of a monument erected over a favourite horse, as

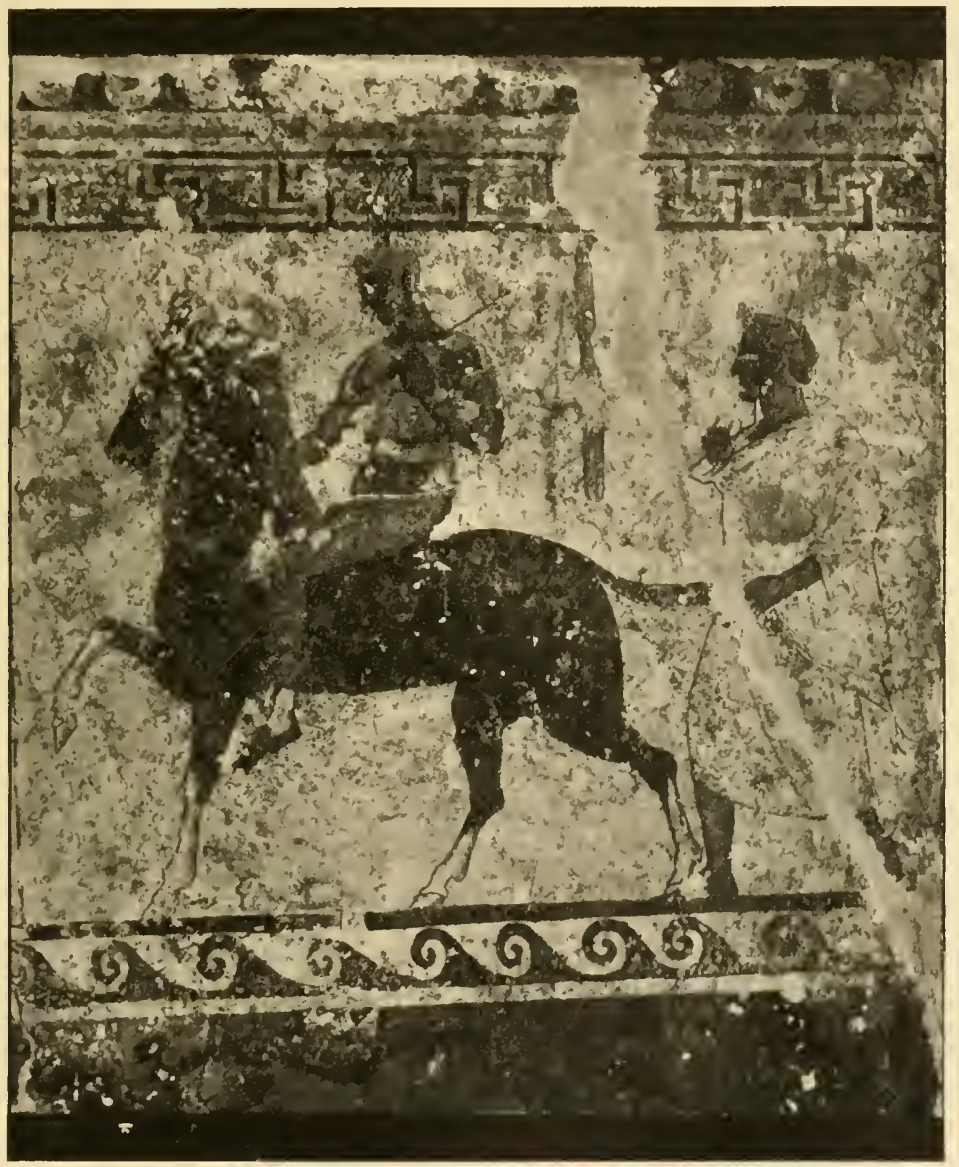

FIg. 79. Fresco showing a Samnite warrior: Paestum.

was the fashion at Agrigentum (p. 276), or it may have formed part of a dedication, such as a group of horses and eaptive women-the work of Agelaidas of Argos-dedicated at a much earlier period by the Tarentines to celebrate their victory over their inveterate foes the Messapians. 
We are fortunately not without good evidence for the colour of the best horses of Southern Italy in the fifth century B.C., and by implication also of those of Sicily. A fresco from Paestum now preserved in the Naples Museum ${ }^{1}$ shows a Samnite warrior on horseback (Fig. 79). The horse is bay with white stockings. As the painter would take for his model the most typical war-horse of his own time and country, it is clear that the best horses of Southern Italy at that date were good cross-bred horses full of Libyan blood, as we had already inferred from the marble horse's head from Tarentum. We shall soon find that the typical South Italian horses of to-day are also bay in colour. It is most interesting to find that Virgil represents as mounted on such a horse as that ridden by the Samnite warrior in the fresco not merely the Roman youth who took part in the Trojan game, but also Turnus, king of the Rutuli, a fierce warlike tribe of the same Umbro-Sabellian stock from which the Samnites were sprung ${ }^{2}$. In Virgil's day this colour was closely associated with the best horses of Thrace, where, as we shall soon find (p. 304), much fine blood had been introduced from the south by the fourth century B.c. The Roman youth described by Virgil " rode a Thracian steed of two colours, as he had white markings-a white forefoot and a white mark on his forehead ${ }^{3}$," whilst Turnus' charger is also described as a Thracian steed with similar white markings". But, as we have seen that bay with white feet and a star in the forehead is a regular concomitant of the North African horse

1 E. Neville-Rolfe, Handbook to the Naples Museum, p. 19. I am indebted to my friend Mr G. P. Bidder, M.A., Trin. Coll., Camb., for calling my attention to this fresco.

2 Ridgeway, Early Age of Greece, Vol. I. p. 257.

3 Virg. den. v. 565-7:

quem Thracius albis

Portat equus bicolor maculis; vestigia primi

Alba pedis, frontemque osteutans arduus albam.

4 Virg. Aen. Ix. 48 :

Improvisus adest, maculis quem Thracius albis

Portat equus.

In Georg. III. 82 he puts bay first, grey second, and white and yellow-dun last: Honesti spadices glaucique; color deterrimus albis et gilvo. Cf. Varro ap. Non. 2,87 : equi colore dispares item nati, hic badius, iste gilvus, ille murinus. 
and his derivatives, it is not surprising that Tarentum, Croton, Sybaris, and later 'Thurii were fumous for their cavalry.

It is very significant that the best Italian horses in Roman times were those bred in Apulia, where, as Varro' tells us, herds of brood mares were pastured. When speaking of noble breeds of horses he only mentioned the names of two Italian kinds ${ }^{2}-$ the Apulian and Rosean. The Apulian thus stands first of those of Italy, the Rosean horses bred in the fertile district near Reate being placed sccond, whilst he does not even allude to any breed in Northern Italy. The same practically holds true at the present hour, for Calabria still breeds excellent bay horses, which are of a finer build than those of Central Italy, as for example the horses of the Roman Campagna ${ }^{3}$.

The superiority of the horses of Southern Italy continued right down through the Middle Ages, the stock being reinvigorated from time to time by fresh importations from North Africa, especially during the period of Saracen domination, and also from Spain at the time when Naples was closely connected with that country. The fame of the horses of Naples was spread all over Europe, and not only does Stradanus include the Neapolitanus in the 'stable' (Fig. 80), but Blundeville in 1580 exhorts horsebreeders, if possible, to procure a Neapolitan stallion, and elsewhere he thus praises this horse: "The Napolitan, which we commonlie call a courser of Naples, is a trim Horse, being both comelie and stronglie made, and of so much goodnesse, of so gentle a nature, and of so high a coureage as anie Horse is, of what countrie soever he be. He is easilie knowne from all other Horses, by his no lesse cleane, and strong making, his limmes are so well proportioned in everie point, and partlie by his portlinesse in his gate, but chieflie by his long slender head, the nether part whereof, that is to say, from the eies downward,

1 Re Rust. II. 7: Horum equorum, et equarum greges qui habere voluerint, ut habent aliqui in Peloponneso et in Apulia, primum spectare oportet aetatem, quam praecipiunt videndum ne sint minores trimae, maiores decem annorum.

2 Id. 11. 7, 6: de stirpe magni interest qua sint, quod genera sunt multa. Itaque ad hoc nobiles a regionibus dicuntur, in Graecia Thessalici, a terra (Apulia) Apuli, ab Rosea Roseani.

3 This fact I owe (through my friend Mr G. P. Bidder, M.A., Trin. Coll., Camb.) to Mr E. Neville-Rolfe, H. B. M. Consul for Southern Italy. 
for the most part is also somewhat bending like a Hawke's beak, which maketh him to rein with the better grace, and yet the Italians do both write and saie, that these coursers be nothing so strong now, as they have been in times past, partlie perhaps for that like industrie of late daies hath not beene used in breeding them, as in times past, and partlie for that nature doth decaie everie day more and more, as well in man as in beast. But howsoever they be, in mine opinion, their gentle nature and docilitie, their comelie shape, their strength, their courage, their sure footmanship, their well reining, their loftie pace, their cleane toothing, their strong gallopping, and their swift running well considered (as which things they have in maner by nature) they excell numbers of other races, even so farre as the faire greihounds the fowle Mastiffe curres."

In modern times the horses of Naples are partly imported, partly native-bred ${ }^{1}$. The little carrozzella horses are not Italian, as the best come from Sardinia (supra, p. 274), and the others from Tunis; the latter being known as 'Turkish horses' (cavalli Turchi). The carrozzella ponies seldom exceed $14 \cdot 2$ hands; they cost from $£ 6$ to $£ 16$ at three years old when they are taken into work. They are regularly driven with a nose-band, and not with a bit, though some of the nose-bands furnished with teeth (morgi dentati) are as severe as any bit ${ }^{2}$. The native horses of Naples (cavalli nostrali) are bred in Salerno and Calabria and run to fifteen hands high, the average being about $14 \cdot 2$ to 143 . The outside price is about $\mathfrak{£} 40$. The principal horse-fair is at Foggia. The Calabrian horse is usually a dull bay with a black stripe down the back, black legs, and a tan muzzle.

As the records of Roman history belong to a period considerably later than that from which we have very full and comparatively complete documents for the history of Sicily, the

1 For this information respecting the Neapolitan horses of to-day I am indebted to Mr E. Neville-Rolfe, B.A., H. B. M. Consul for South Italy, through my frieud Mr G. P. Bidder, M.A., Trin. Coll., Camb.

${ }^{2}$ For this information I am indebted to Mr G. P. Bidder, who has taken much trouble to get me information about the structure and use of the noseband. He tells me that the riding-horses are controlled by the bit, and that carriage-horses are driven with bits and English harness. 
Greek colonies of Southem Italy, and for Greece itself, we shall now resume the history of the horse in Greece proper, and then take up the story of that animal in Central and Upper Italy.

We saw that the horses of the Acheans bred in Thessaly and Elis were din coloured, and that they were not ridden, but driven in pairs under chariots. But the horse and the chariot had already been known in the Bronze Age (Hycenean period), before ever the sons of the Acheans had come. This is proved by the grave-stoues found on the acropolis of Mycenae over the

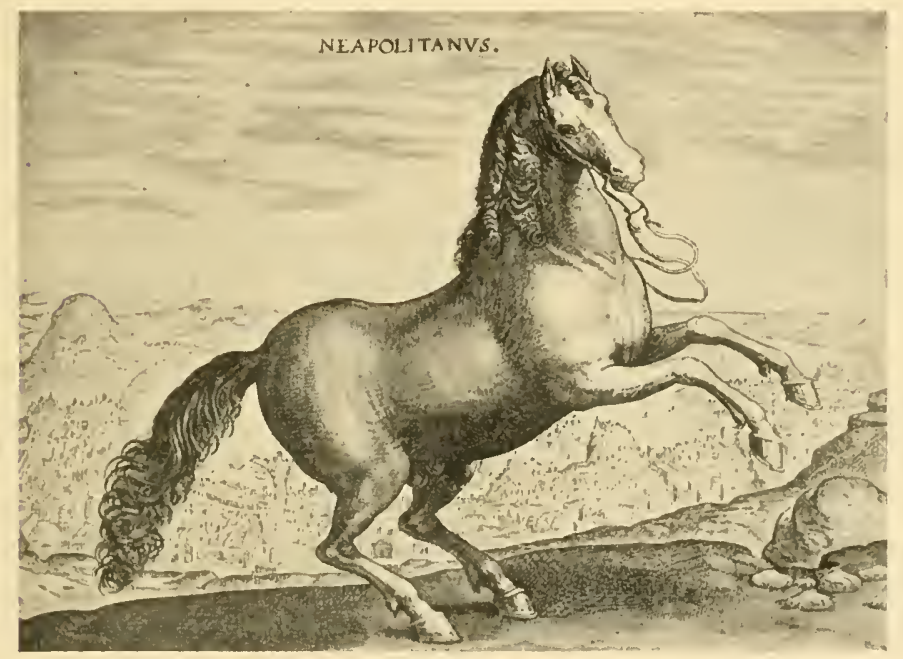

FIG. 80. The Neapolitan Courser.

famous shaft-graves which contained the rich treasures buried with the royal Perseid house, which had reigned in the Bronze Age in Argolis. Several of their stelae (Fig. 47, p. 107) show in low relief a two-horse chariot in which is seated some personage, not unlikely the ancient chief whose mouldering bones were uncovered by Schliemann. Moreover the Homeric poems have at least one reference to the horses kept by the men of the pre-Achean time. The Iliad ${ }^{1}$ speaks thus of one steed of that bygone age: "Not even if he drove at thy back divine Arion, 
swift steed of Adrastus that sprang from the gods." A line in the lost epic called Thebais told how "Adrastus fled from Thebes wearing sorry garments, and with him dark-maned Arion." According to Antimachus Adrastus "was the first of the Danaans that drove two high-praised steeds, fleet Caerus and Thelpusian Arion, whom, near the Oncean grove of Apollo, Earth herself brought forth a wonder for mortals to see." According to another statement Poseidon himself was the father of Arion, which is not without significance, as we shall soon find the same god as the father of Pegasus by the Gorgon Medusa.

According to these stories it was only in the days of Adrastus-about 1350 B.C., if we follow the traditional chrono$\log y$-that the horse and chariot first got into Peloponnesus. The fact that a divine origin is ascribed to Arion seems to indicate that the horse had hitherto been as unfamiliar to the people of Argolis as it was to the Aztecs when Cortes landed with his Spaniards and his horses in Mexico. Arion is described as 'dark-maned,' which indicates that his body colour was lighter than his mane and tail, a feature common both to the dun-coloured horses of Europe and Asia and to the bay horses of North Africa.

It is worthy of notice that the wheels of the chariots on the Mycenean grave-stones (which may be assigned to the fourteenth century B.c.) have only four spokes like the chariot found in a tomb at Egyptian Thebes (p. 225) said to be about the same period, and in this respect they stand in contrast to the Homeric chariot with its eight-spoked wheels.

Centuries before the planting of Cyrene the Greeks had a firm belief that by the side of the Atlantic were bred steeds of surpassing swiftness. Already we have read in Homer of swift horses begotten by the west wind and foaled by a harpy beside the stream of Ocean. But still more siguificant is one of the most familiar of Greek legends, the myth of Pegasus, the first of all horses that bore a rider on his back. The renowned winged steed, begotten by Poseidon himself on the Gorgon 
Medusa, was born in Libya, where he had sprung from the body of his mother, when that monster fell to the sword of Perseus ${ }^{1}$. Thus, then, this most famous of stories shows clearly that the early Greeks held that not only the best of all horses were bred in North Africa, but also that the Greeks knew not how to ride on horseback until they had borrowed that practice along with the Libyan horse, which was a little taller and infinitely superior in speed to the little dun horses of Europe. So great a feat was the mounting on horseback considered that Athena herself, according to the myth, had to bridle and subdue Pegasus for her favourite Bellerophon of Corinth ${ }^{2}$.

In each case Poseidon-who was the chief deity of Libya, as well as of the indigenous population of Greece-is represented as the sire of these, the most famous horses of early Greece. The eridence of the myths, as far as it goes, taken along with that of the chariot-wheels, points to North Africa as the region from which the Greeks of Peloponnesus first heard of the horse and the chariot, and later on learned the art of mounting the horse itself.

This view is confirmed by certain pieces of evidence derived from recent discoveries in Crete and Cyprus. Even if the Libyan horse had never been seen on the mainland of Greece by Homeric times it is not at all improbable that it was known in Crete and Cyprus, which were not only in close communication with Egypt for many centuries before the Achean conquest of Greece, but had also constant intercourse for trading purposes in Homeric days with the coast of Libya, as is proved by more than one passage in the Odyssey ${ }^{3}$. We have seen that the Mycenean chariot (Fig. 47), like the Libyan and the earliest Egyptian chariot (pp. 224-5), had only four spokes. It is therefore interesting to find that not only are the chariots in the pictographs found by $\operatorname{Mr}$ A. J. Evans in the palace of Cnossus furnished with four-spoked wheels, but that similar chariot-wheels appear on the vases of the late Mycenean period found at Enkomi (Figs. 81-2) and Curium in Cyprus. We

1 Apollod. II. 3. 2.

2 Paus. II. 4. 1.

3 Iv. 85 , xiv. 295 , xvir. 442 sqq.

4 Excavations in Cyprus, by A. S. Murray, A. H. Smith, and H. B. Walters 
further saw that the earliest representations of Pegasus are found on the pottery from Daphnae (p. 245), and that the winged steed carries his tail like the pure-bred 'Arab,' from which we were led to conclude that the swift Libyan horse had been taken as a model for the winged steed. A vase from Enkomi and another from Curium show horses which carry their tails in the true North African fashion. This clearly

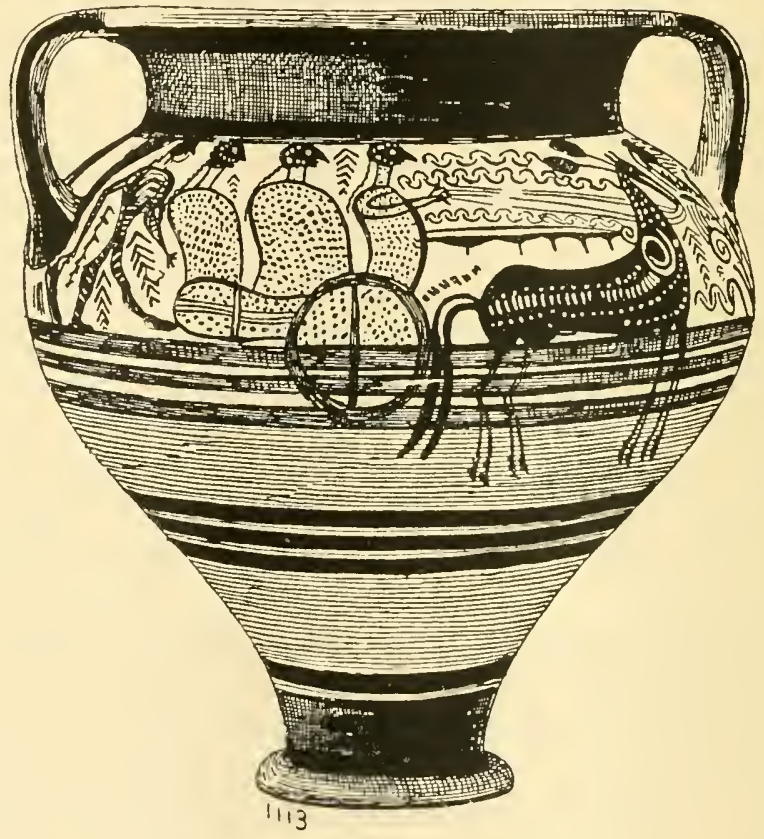

F1G. 81. Vase from Enkomi, Cyprus.

demonstrates that about B.c. 1000 the Libyan horse was familiar to the Cypriote vase-painter, although a fragment of another vase (Fig. 82) indicates that he was also acquainted with horses of the ordinary European-Asiatic type, as is shown by the way

(1900), p. 49, nos. 981, 1113 (Enkomi), p. 73, no. 136 (Curium). The chariot shown on the carved ivory combined draught-board and box (op. cit. p. 12) found at Enkomi, has wheels of six spokes like the common Egyptian form of chariot evolved from the earlier four-spoked wheel (supra, p. 221). 
in which the tail is set on and carried. As the myth of Pegasus does not appear in Homer, and as the Cyprus paintings come at the close of, or after, the Homeric period, the appearance of the Libyan horse on such vases is quite in accord with the literary data.

Meanwhile the Acheans had come down from central Europe with the dun-coloured horses of that region yoked to chariots with wheels of eight spokes. In Homer only dun-coloured horses are known in Greece itself; white horses, though known in Thrace, apparently not yet having been imported into Greece, while the one bay horse mentioned, of which we shall speak at greater length, was bred in Asia.

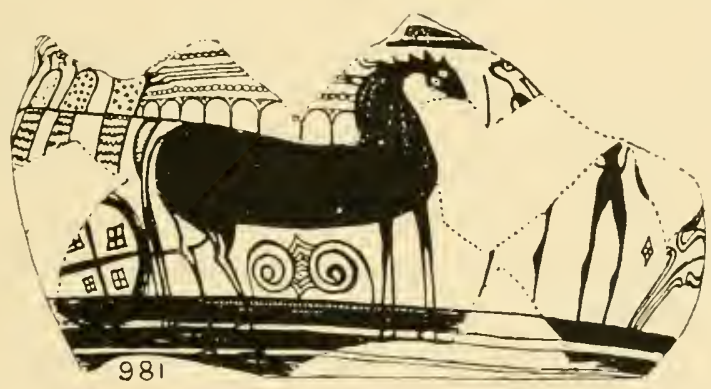

FIG. 82. Vase fragment from Enkomi, Cyprus.

We have seen that by the tenth century B.c. Libyan horses were being imported from Egypt into anterior Asia for the kings of Syria and the Hittites, and we have found that bay or chestnut colour, frequently accompanied by a white mark on the forehead and white 'stockings', is the characteristic colouring of the Libyan horse and his purest derivatives down to the present day, being thus clearly distinguished from the lighter coloursdun, rufous-grey, grey, and white-which form the liveries of horses either of pure Asiatic and European ancestry, or with but a small infusion of Libyan blood. Now the Iliad yields at least one piece of evidence that the Libyan horse had made its way not only into Syria and the land of the Hittites, but even as far as the north-western corner of Asia Minor before 1000 B.C.,

R. H. 
though it was then extremely rare and therefore very much coveted by horse-fanciers. Like Pegasus and Arion, and, indeed, like most things strange and rare, brought from distant lands, this strain was held by the Homeric Greeks to be of divine origin.

The Trojans are regularly spoken of as "tamers of horses"

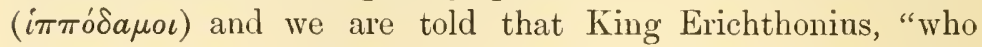
became richest of mortal men," had "three thousand mares that pastured along the marsh meadow, rejoicing in their tender foals. Of them was Boreas enamoured as they grazed, and in semblance of a black-maned horse he covered them. Then they, having conceived, bare twelve fillies. These, when they bounded over Earth, the grain-giver, would run upon the topmost ripened ears of corn and break them not; and when they bounded over the broad backs of the sea, they would run upon the crests of the breakers of the hoary brine. Erichthonius begat 'Tros, the father of Ganymede, who was caught up by the gods to become the cup-bearer of Zeus."."

There can be little doubt that these horses were of the European-Asiatic stock. Since horses from the Ocean and from Libya are described as the offspring of Zephyrus, the West Wind, and of Poseidon respectively, so the Boreas-sprung horses of the rich plains of the Troad, peopled by Dardanians and Mysians, who had crossed over from Thrace-the home ${ }^{2}$ of Boreas, the North Wind-were plainly regarded as of Thracian origin.

Though Tros had inherited so excellent a breed of horses from his father Erichthonius, he was able to introduce a far better strain into his stud. In his combat with Aeneas Diomede especially wished to capture the horses of the Trojan hero, for, said he to his charioteer, "they are of that breed whereof far-seeing Zeus gave to Tros as recompense for Ganymede, his child, because they were the best of all horses beneath the daylight and the sun. That blood Anchises king of men stole of Laomedon, privily putting mares to them, whereof a stock was born to him in his palace, even six; four kept he himself and reared them at the stall, and the other twain gave he to Aeneas, deviser of

1 Iliad, xx. 219 sqq.

2 Iliad, xiv. 395, xxir. 692. 
rout. Them could we seize we should win us great renown ${ }^{1}$." Diomede accomplished his desire, and the horses of Aeneas became his. One of them is described "as bay all the rest of him, but in the forehead marked with a white star round like the moon ${ }^{2}$." In the chariot-race at the funeral games held in honour of Patroclus Diomede drove these horses and they easily carried off the first prize $^{3}$ from the other Achean chiefs, whose horses had all been bred in Greece ${ }^{4}$ and, as we have seen, were all dun-coloured (xanthos). As this is the only bay horse mentioned in Homer, and as it stands in strong contrast to the dun-coloured horses of Achilles and the other Acheans, and to the white horses of Rhesus from Thrace, we may reasonably infer that in this rare strain declared to be sprung from the gods we have the earliest mention of the bay horses of North Africa. But as Pegasus, the winged horse of Libya, was the offspring of Poseidon himself, the poet's reason for ascribing a divine origin to the dark-bay steeds is now obvious.

In the determination of Anchises to obtain by fair means or foul the services of a first-rate sire for his mares we see the same anxiety as is now evincer by Arabs of other tribes to obtain the use of Anazah stallions, and by Turcomans and Kurds to secure the use of Arab sires for their mares.

We have thus important indications in the Homeric poems that the best horses known to the inhabitants of Greece at the end of the second millennium B.c. were those of Northern Africa; we have also adduced evidence to show that a like belief was held at a later period, and coupled with a further belief that the first horse that was ridden came from the same region. This belief, taken together with the fact that the race with ridden horses was only added to the list of contests at Olympia at a time when not only had the Greeks become well acquainted with North Africa but were already establishing themselves in the Cyrenaica, leads us to conclude that the Greeks not only

1 Iliad, v. 265 sqq.

2 Iliad, xxıI. 454-5, фоîv $\xi=$ 'date-palm,' hence 'date-coloured ' like Arab. ku-mait (p. 177), and Lat. spadix (borrowed from Sicily) = 'date-palm' and Lat. badius (whence It. baio, Fr. baie, Eng. bay) from Gr. $\beta$ äis (from Coptic bai) = 'palm-branch,' and must therefore mean either bay or chestnut (cf. $\pi v \rho \rho \delta s$ ).

${ }^{3}$ Iliad, xxr1r. 512 sqq.

+ Iliad, xxin. 287 sqq. 
learned from Libya to yoke four horses to a chariot, as stated by Herodotus, but also learned from thence to ride on horseback.

Nor need we be surprised if the Libyan blood had made its way into Asia Minor at a date anterior to its first advent into Greece, for, as we have seen, the Libyan horses could pass by land into Asia Minor, whilst the broad expanse of sea between Africa and Greece would interpose a formidable barrier to the transport of horses, at least in any quantity, from Libya to Greece, in the days when only ships of small tonnage sailed the seas.

It may naturally be said that, if at a comparatively early period the Libyan strain had made its way into Greece, where dun-coloured horses were in general use, we ought to find indications of cross-breeding in the colours, such as have been furnished by the existence of black and grey horses at different points in our wanderings through Asia, Africa, and Spain. First of all let us deal with the question of white horses, which cannot be regarded as tests of cross-breeding, but which must have come down into Greece from Illyria or Thrace, where they were already known in Homeric days; and then we shall proceed to the evidence for black and grey horses in post-Homeric and classical times. The names of heroes, which occur in early legends, prove that very soon after Homeric days both white horses and black horses, as well as dun-coloured, had become known in Greece. Thus a famous hero, worshipped at Daulis in Phocis, was called Leucippus ("He of the White Horses"), whilst there was a Theban worthy by name Melanippus (" $\mathrm{He}$ of the Black Horses").

Now since the myth of Pegasus and the type of Mycenean chariot-wheel indicate that the Greeks early knew the horse of North Africa, and the Homeric poems make it certain that the Acheans had plenty of dun-coloured animals, and as the black horses of Greece must have been a cross similar to those already enumerated, the evidence of Homer and the later myths seems perfectly correct.

At what date cavalry began in Greece to replace the chariot in war it is difficult to say with precision, but various considera- 
tions render it certain that it was a fully recognized military arm in the seventh century B.c. It will be remembered that the race with the ridden horse was instituted at Olympia in B.C. 648 , a fact in itself sufficient to prove that the riding of horses had become a matter of great importance by that time. Moreover when Solon constituted his four new classes at Athens in the beginning of the sixth century, the second, termed the Knights ('I $\pi \pi \epsilon \hat{\imath} \varsigma$ ), was composed of those who had sufficient property to keep a horse, and serve the State on horseback in time of war. The Knights naturally were a very aristocratic body, and in the subsequent political struggles they are always found on the conservative side. Just as the medieval gentleman was known by his horse, his hound, and his hawk, so the keeping of horses was the mark of an aristocrat at Athens and in other parts of Greece; and as the effigy of a medieval knight is often distinguished by his hound at his feet, or sometimes by his falcon on his wrist, so a horse's head often occurs on Athenian tombstones, indicating that the dead was of a knightly family. Nor was this exceptional. Pausanias" the traveller "saw not far from the river Crathis in Achaia a tomb on the right of the road with a faded painting of a man standing beside his horse." The hound too occasionally got his place on his master's tomb. At Tritia in Achaia the same writer saw a remarkable monument of white marble, adorned with paintings by the eminent artist Nicias: "An ivory chair is seen with a comely young woman seated on it: at her side stands a maid-selvant with a parasol. A young and beardless man stands erect, wearing a tunic with a purple robe over it: beside him is his servant holding his darts, and with some hounds in leash. I could not learn their names, but anyone could guess that a husband and wife are here buried together"."

The archaic black-figured vases $^{3}$ and those of succeeding

1 vil. 25. 13.

2 vir. $22,6$.

3 British Museum Cat. of Greek Vases, Vol. II. nos. 130, 132 (both show bigae), no. 133 (two youths riding a horse-race), nos. 135, 374, 375 (fight between two warriors on horsehack), nc. 581 (third horse white), nos. 606, 545, 546,547 (third horse white). 
styles furnish some evidence respecting chariots and horses from the seventh century onwards. As the four-horse chariot and the ridden horse had been added to the Olympic contests in the seventh century, it is but natmral that four-horse chariots and horsemen as well as two-horse chariots often occur on the black-figured and later vases. The horses on the archaic vases are always rendered in black like the chariots and men, but as time goes on we meet representations of chariots in which one of the four horses is white. On a vase representing the death of Hippolytus ${ }^{1}$ the quadriga is drawn by two white and two yellow horses. On another vase the quadriga of Helios is drawn by two black and two white horses. On the earlier vases the chariot wheels are either four-spoked or of an ancient form which has no spokes, but has a diametrical bar crossed by two other's at right angles, whilst on the later vases eight-spoked wheels make their appearance.

When we remember that white horses were held sacred among the Germans, Illyrians, and medieval Tartars, and that the sacred chariot of the Persian Zeus was drawn by sacred white horses, we are not surprised to find that in a representation $^{2}$ of a Gigantomachia Zeus is seen in a chariot drawn by four horses of that colour. Moreover, just as the Illyrians and Persians sacrificed white horses, so did the Greeks of the fifth century B.C., in the ratification of solemn oaths ${ }^{3}$.

As the vase-painters had no hesitation in representing Achilles in a four-horse chariot, although in Homer that hero like all other Acheans drives only a pair, and as also the painters pourtrayed ancient worthies in contemporary armour rather than in the equipment of the Mycenean and Homeric periods to which they were supposed to belong, so they took for their models the chariots and horses of their own day. The same, as we shall see, holds equally true of the great dramatists, who had as little scruple as Shakespeare and his

1 British Museum Cat., Vol. Iv. nos. 279, 305, 258, 487.

2 British Museum Cat., Vol, iv. no. 237.

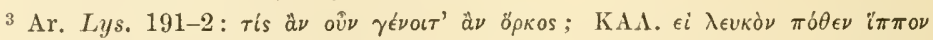

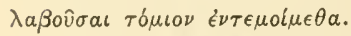

${ }^{4}$ British Museum Cat., Vol, II. no. 239. 
contemporaries in committing anachronisms. As then both dark, yellow, and white horses appear on the vases, we may infer that not only the old dun, but also white and darkcoloured horses of various hues were very common in Greece by the sixth century B.c. This inference is fully borne out by the literary remains. Thus not only are Castor and Pollux described as riders of white horses by Ibycus ${ }^{1}$ and Pindar ${ }^{2}$, but the same epithet is applied to the goddess Persephone by Pindar ${ }^{3}$ and to the Day by Aeschylus. ${ }^{4}$. As I have already pointed out, the sanctity of white probably gave to white horses a fictitious reputation, and accordingly the epithet 'white-horsed' is applied to the Thessalians ${ }^{5}$ and Thebans ${ }^{6}$ by Pindar.

The vase showing the death of Hippolytus makes it plain that dun horses continued to be used as in Homeric days, an inference fully borne out by the fact that Xanthippus (" $\mathrm{He}$ of the Dun Horses") was a regular name in the great Attic family of the Alcmaeonidae, the father of Pericles the famous statesman being so named. That horses of good blood had raced and won at Olympia before the close of the sixth century may be inferred with certainty from a group of sculpture-the work of the famous artist Ageladas-dedicated at Olympia by Cleosthenes of Epidamnus in Epirus, who was victorious with the four-horse chariot in B.C. 516. He set up statues of his chariot and horses, of himself and his charioteer. "The names of the horses also are inscribed: Phoenix (Bay) and Corax (Ruven) and on either side of them the side-horses Cnacias (Dun) on the right and Samus on the left." This Cleosthenes was the first horse-breeder in Greece who dedicated his statue at Olympia7. The names of the two yoke-horses-the most important and therefore the best-demonstrate that they had a good infusion of Libyan blood. The description of the chariotrace at Delphi given by Sophocles in his Electra ${ }^{8}$ affords some information about the colours of horses in the fifth century, for, as the poet introduces Ismene ${ }^{9}$, the daughter of Oedipus,

\footnotetext{
1 Fr., 16.

2 Pyth. т. 66.

3 Ol. vi. 95.

+ Persae, 386 ; cf. Soph. Ajax, 673.

5 Pyth. Iv. 117.

${ }^{6}$ Pyth. 1x. 86.

7 Paus, vi. 10. 6-8.

$8701 \mathrm{sqq}$.

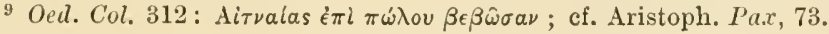


riding on an Aetnaean steed, a breed which only became famous after Hiero of Syracuse (B.c. 478-467) had founded the city of Aetna, we may confidently assume that in his account of the chariot-race and horses he is simply describing those of his own time. There were ten entries for the race, one Achean, one Spartan, two Libyans, Orestes with a team of Thessalian mares, an Aetolian with dun-coloured mares, a Thessalian from Magnesia, an Aenian (also from Thessaly) who had a team of white horses, an Athenian, and the tenth was a Boeotian. It is unfortunate that, though he introduces two Libyan charioteers, he does not tell us the colour of their horses. Yet, since he specially mentions both the white team from Thessaly and the dun-coloured from Aetolia, it is probable that the Libyan horses were neither of these colours, but were bay or some other dark hue.

In his comedy of the Clouds (в.C. 423) Aristophanes introduces a young spendthrift, who by his passion for horse-racing has overwhelmed his father in debt. 'The latter is sued by Pasion the money-lender for a sum of twelve minae, which he had borrowed to purchase for his son a 'starling-coloured'

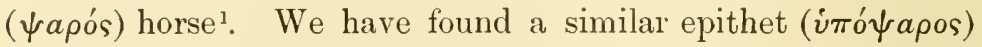
applied by Strabo to the horses of the Parthians and to those of northern Spain. The excessive price paid for the horse (which was four times the amount of the normal ransom of the heavy-armed soldier during the Peloponnesian War) shows that the animal was plainly first-rate according to the Greek standard of that day; but as 'starling-coloured' means that the animal was a bluish-black with light-coloured speckles all over, in other words, iron-grey, and as we have found this and other shades of grey to be the regular outcome of crossing the Asiatic-European horse with Libyan blood, we may safely conclude that the best horses of the day were the result of crossing the old dun horses of Greece with the blood imported from Libya. The literary evidence is amply corroborated by the

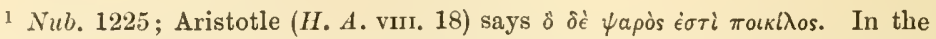

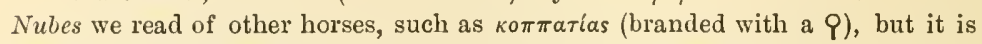
possible that it might refer to a blaze down a horse's face; also of a $\sigma \alpha \mu \phi b \rho a s$ (branded with the letter San), but this also might mean some kind of blaze. 
monuments. We naturally turn to the horses sculptured by Pheidias to adorn the Parthenon,- - to the immortal steeds of Selene and Helios on the east pediment, and to the mortalridden horses of the frieze (Fig. S3). Pheidias naturally modelled his immortal steeds after the best living horses which he had seen, and these, as we have just shown, must have been good cross-bred horses. A glance at the head of Selene's horse

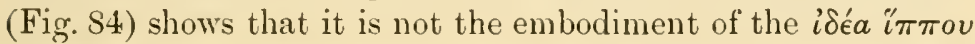

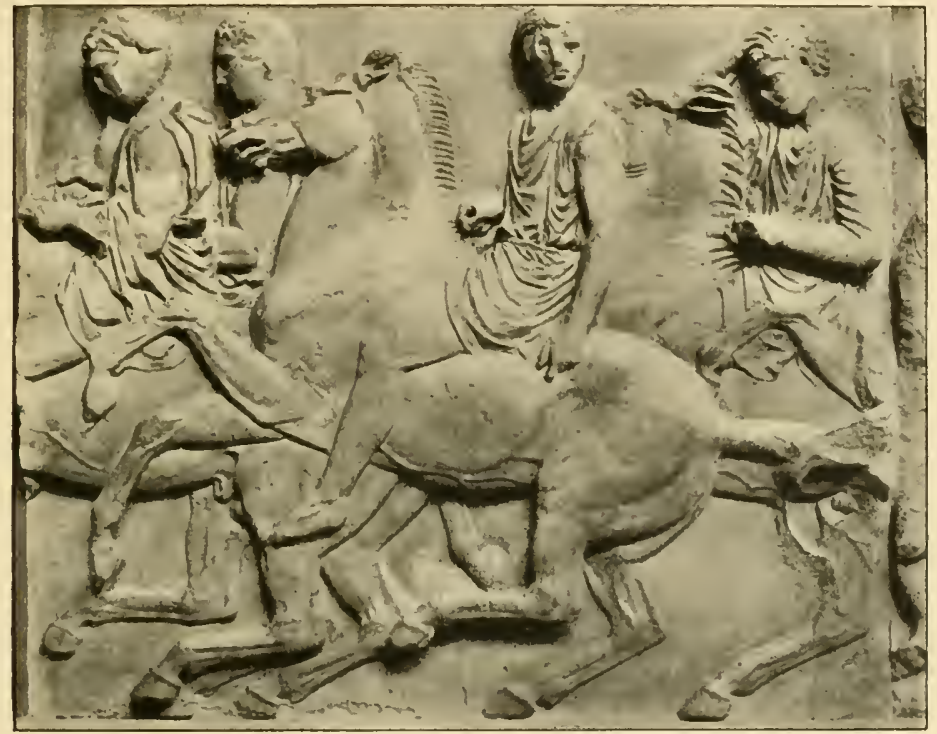

Fig. 83. Greek Horsemen from the Parthenon.

(the Urpferd) as Goethe held, but is rather modelled after a good half-bred horse, probably such an animal as that for which Pheidippides paid twelve minae. The head is long, the cheek and jaw refined, the eye large and prominent, and the nostril well shaped'. We shall presently find that great length of

1 There are earlier remains of horse-sculptures from the Acropolis, and Olympia has also yielded similar remains. Strongylon (who made in bronze a representation of the Wooden Horse of Troy, the base of which has been found on the Acropolis of Athens, apparently dating from the last quarter of the fifth century B.c.) was famous for his sculptures of horses and bulls. 
head is a characteristic of the progeny of thoroughbred and ordinary horses in modern times.

If further proof is required that by 400 B.C. the Greeks had plenty of well-bred horses, Xenophon' ${ }^{1}{ }^{2}$ description of the points of a good war-horse will suffice. The first points to be looked to in the colt are his hoofs, which were naturally of especial importance, as the Greeks never shod their horses, in consequence of which the Athenian cavalry horses suffered greatly in the latter part of the Peloponnesian War, after the Spartans had occupied Decelea. As the Athenian cavalry had to be constantly scouting, their horses' hoofs got worn down on the hard ground, and their animals fell lame2. "Thick hoofs are to be preferred to thin ones, for they give a firmer tread, and they ought to be high both before and behind, for high hoofs raise the frog far above the ground; but low ones tread equally on the strongest and softest part of the foot like in-kneed men." An older writer, Simo, cited by Xenophon, declared that horses with good feet may be known by the sound, and Xenophon commends this as a just observation, for, says he, "a hollow hoof rings against the ground like a cymbal ${ }^{3}$. The colt's pasterns must neither be too upright like those of a goat, which renders him uncomfortable for riding, nor too sloping, for then he will scratch and gall his fetlocks when ridden among clods or over stones; he must have plenty of bone in the leg, supple kneejoints, strong shoulders, a broad chest, which is a mark both of beauty and strength, as it keeps the legs wide apart; the neck as it rises from the chest should not fall forward like that of a boar, but it should grow upwards like that of a cock, and should have an easy motion at the parts about the arch; the head should be bony, the cheek small, for then he can see things immediately before his feet, his eye should be prominent,

1 De Re Equéstri, 1.

2 Thuc. vir. 27.

3 This phrase puts it beyond all doubt that the words $\chi a \lambda \kappa o$ ко "horses that stamp with hoofs of bronze" (Ar. Eq. 552), of ten quoted to prove that the Greeks shod their horses, simply refer to the ringing sound like that of a bronze cymbal produced by the hollow hoof. As Pindar uses the same

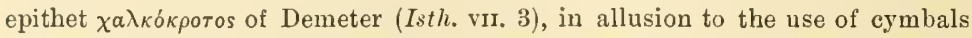
in her worship, it is clear that Aristophanes, like Xenophon, means that the horse-hoofs ring like cymbals. 
and his nostrils wille. When the upper part of the head is somewhat large and the ears rather small a horse's head is more like what it ought to be." These words of Xenophon would serve well for a description of the head of Selene's steed. "A high shoulder makes the rider's seat more secure and makes the shoulder appear more firmly attached to the body; a double back, that is, when the flesh rises on both sides of the spine, is much softer to sit upon and more pleasing to the eye than

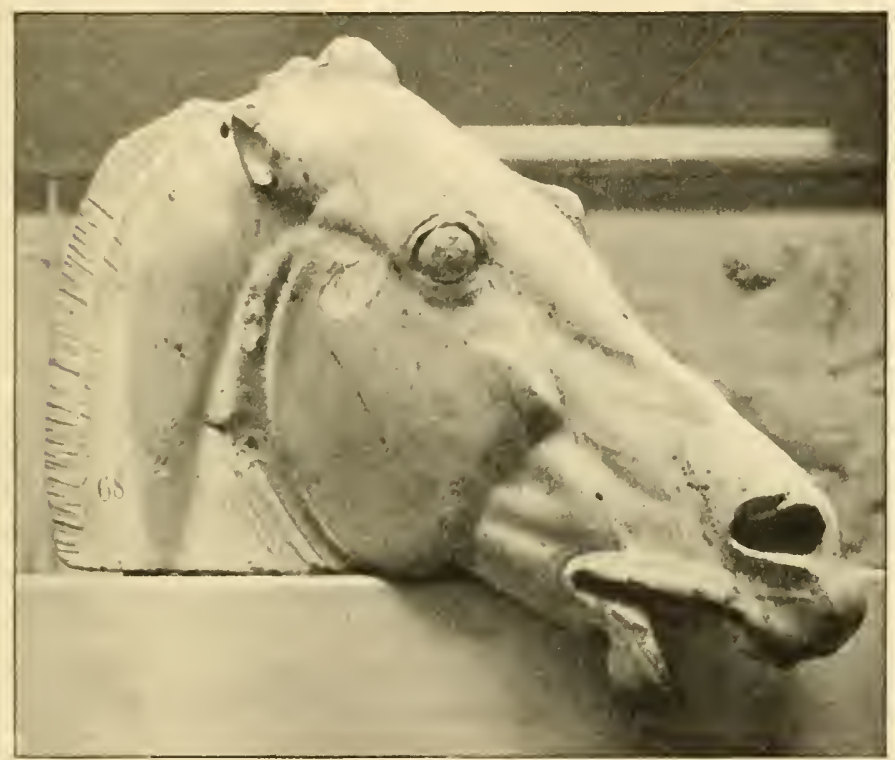

FIG. 84. Head of the Horse of Selene: Parthenon.

a single one." As the Greeks did not use saddles, they had every reason to dislike a horse 'as lean as any rake.' "The colt should have a good barrel, both for appearance and for easiness of riding; the loins should be short and broad, for then the horse more easily raises his fore-parts and brings forward his hinder ones; his haunches should be broad, and well covered with flesh; and if these parts are compact, they will be the lighter for running and make the horse much swifter; the thighs should be broad and straight, for in that case he will set 
his hind legs well apart and will thus have a quicker and firmer step, a better seat for a rider, and will be better in every respect."

The description of the head shows that Xenophon knew what a well-bred horse was like, and indeed by his day it is highly probable that the best horses in Greece were more and more saturated with Libyan blood. We saw that various shades of grey, then black, and finally chestnut and bay are the sure tokens of the gradual increase in the amount of Libyan blood in the horses of Asia, North Africa, and Spain. We have had already clear evidence of grey and black horses in Greece, but it is not until the fourth century B.c. that we have undoubted mention of chestnut. That the Greeks of the fourth century B.C. had chestnut horses with yellow manes is rendered certain by a famous story told by Plutarch ${ }^{1}$, how on the eve of the battle of Leuctra Pelopidas dreamed that he saw the danghters of Scedaus lamenting round their graves, and that their father urged him, if he wished for victory on the morrow, to sacrifice a fair-haired ( $\left.\xi a \nu \theta \eta^{\prime}\right)$ virgin to his daughters. Pelopidas told his dream to the seers and chiefs, and they long disputed, one party urging a human sacrifice, the other maintaining that such acts found no favour in the sight of the Father of all. At that moment a filly with bright yellow mane came galloping up and stopped short before them. Theocritus the seer cried out to Pelopidas, "Here is the victim you want. Let us wait for no other virgin; take thou and use God's gift." Again, Aristotle $^{2}$ when describing the colour of the bisons (bonasi), which still survived in Paeonia down to his day, says that the colour of their hair was a mixture of ash-colour and red, not such as that of the horses termed paroai, that is, of the colour of the paroas, a reddish-brown snake, sacred to Aesculapius. As red (purros) is the term used for a bay horse in Revelation, it is probable that the Greeks used paroas to distinguish chestnut from bay.

As in Homeric days Thessaly had excellent dun and dappled-dun horses, so her horses and cavalry enjoyed great

1 Pelop. 20-2.

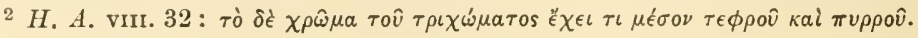


reputation in Greece in classical times. Not only do Thessalian horses figure in the lists of wimners at Olympia, but the Thessalian cavalry were by far the best in Greece. We have just seen that Pindar speaks of the Thessalians as riders of 'white horses,' and that Sophocles represents a chariot from Thessaly as drawn by white horses. Probably soon after Homeric days, the white horses of Thrace had made their way into Thessaly, and they doubtless were improved by superior blood from the south in later times, for not only was Thessaly noted for white horses, but also for grey, a sure indication of crossing with Libyan blood, since Statius describes the Thessalian mares of Admetus as white spotted with black, i.e. 'flea-bitten grey1.' Moreover, the studs of Thessaly probably exercised a most important influence on the horses of Macedonia and the rest of the upper Balkan. No better illustration of the horses of that region in the fifth century B.C. can be given than the coins of Poticlaea (B.C. 490-432) which show Poseidon Hippios (of the Horse) mounted on horseback with his trident levelled against some foe (Fig. 85). The type ${ }^{2}$ was doubtless suggested by the image of Poseidon which stood in front of the city, and we may reasonably believe that in the horse on which the god is seated the

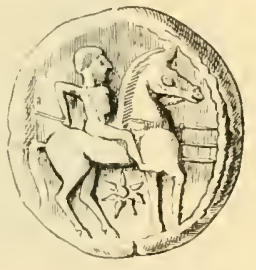

Fig. 85. Coin of Potidaea. artist has pourtrayed the best bred horse with which he was acquainted.

In Strabo's time ${ }^{3}$ (A.D. 1) large numbers of good horses were bred in Greece, especially in Peloponnesus. Arcadia was much noted for its horses. It was then a mere solitude, as many of its ancient cities had been destroyed by constant wars, and the inhabitants of many others had been deported to Megalopolis when that city was founded by Epaminondas to be a bulwark against Spartan aggression. There were therefore widle expanses of pastures given up to herds of mares. On

1 Thebais, vi. 336 : noctemque diemque

assimulant, maculis internigrantibus albae.

2 Head, Hist. Numorum, p. 188 ; Herod. vir. 129.

3378. 
this account, says Strabo, the Arcadian breed of horses is most excellent, as is likewise that of Argolis and that of Epidaurus. Doubtless it is one of those famous Arcadian horses that we see on a medal dedicated "to the Arcadians" by one Veturius, sometime after the establishment at Mantinea of the cult of Antinous, in the reign of Hadrian ${ }^{1}$. That bay was the colour of the best Argive and other horses of the Roman world is rendered certain by the description of the steed of Gnaeus Seius, whose owners from Sejus down to Antony came to such miserable ends, that he gave rise to the proverb used of an unlucky man, He has Seius' horse in his stable. 'This horse bred in Argos was of first-rate strain, of " unusual size, carried

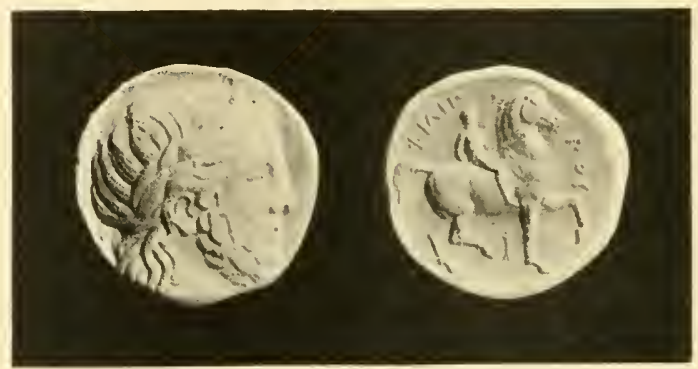

FIG. 86. Coin of Philip II of Macedon, showing a jockey on a race-horse.

his neck well, was of a bay colour, had a flowing mane, and far excelled in every other good point that a horse can have." As in Homeric days, so in later times, mule-breeding was carried on in all parts of Peloponnesus, except in Elis ${ }^{3}$, and flourished especially in Arcadia ${ }^{4}$. The large uninhabited areas in Aetolia and Acarnania in Strabo's time rendered this district no less suited for horse-breeding than the plains of Thessaly ${ }^{5}$. Thrace had been famous for its horses and chariots in Homeric days. At what time the horseman finally displaced the chariot we have no means of judging, but it is probable that from at least the sixth century the war-chariot had been superseded by mounted men. In the

1 Head, Historia Numorum, p. 373.

2 Aulus Gellius, Noct. Atl. IIr. 9. 3: magnitudine inusitata, cervice ardua, colore poeniceo, etc.
3 Paus. v. 9.2 ; cf. v. 5.2.
4 Strabo, loc. cit.
5 Ibid. 
times anterior to Philip II (B.c. 359-336) the military force of Macedonia seems to have consisted, like that of Thessaly, in a well-armed and well-mounted cavalry, formed from the substantial proprietors of the country, and in vast numbers of targeteers $^{1}$. But until Philip formed his famous phalanx after the model of the 'Theban system established by Epaminondas, the Macedonian infantry was little more than a rabble of shepherds and cultivators. Philip did not merely discipline this raw material into the best infantry that the world had yet seen, armed with the sarissa, a pike 21 feet in length, but he paid equal attention to his cavalry, and it was to this arm that he owed largely his superiority over the autonomous

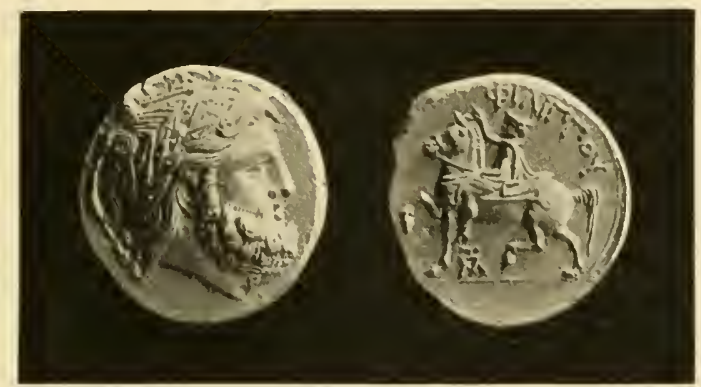

FIG. 87. Coin of Philip II of Macedon, showing a horse-soldier.

States of Greece and the Illyrians and Thracians. When Philip came to the throne he bestowed great care upon all that appertained to horses and horse-racing. He sent both chariots and ridden horses to compete at Olympia, and, according to Plutarch ${ }^{2}$, he celebrated his victories in the chariot-race on his coins (probably in the biga on the reverse of his gold staters), and he commemorated his victory in the horse-race ${ }^{3}$ by placing on his silver tetradrachms a representation of the winner ridden by a naked boy-doubtless the jockey-bearing a palm or crowning his horse (Fig. 86). The news of this victory reached

1 Demosth. Philippic rir. p. 123.

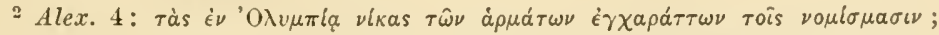

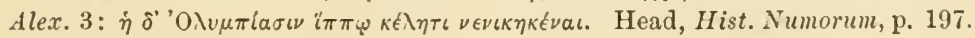

3 Ibill. 
him at the same time as that of Alexander's birth. The jockey was evidently a boy ${ }^{1}$ selected for his light weight, for he is much smaller in proportion to his horse than is the Macedonian trooper (Fig. 87). This difference is possibly due not simply to the fact that one is a full-grown man, and the other a boy, but also to the superior size of the race-horse, which is shown by the set-on of its tail and other points to be a far better bred animal than the ordinary cavalry mount. Others of his coins represent one of his famous Macedonian horse-soldiers, bearded, wearing a hat and cloak (Fig. 87). His cavalry was of two kinds-the Sarissophori or Lancers, apparently light-horse, armed with the sarissa, but probably in this case not more than 14 feet long, and the heavy cavalry who carried, not a javelin for throwing, but the xyston, or pike, suited for thrusting in hand-to-hand fight.

But apparently the best Macectonian horses were imported from lands further south, if we may judge by the fact that Bucephalus, the famous charger of Alexander, was bred in Thessaly by Philonicus of Pharsalus. Alexander when a boy saw him and purchased him from his breeder for sixteen talents. The horse derived his name either from his appearance, or from a brand on his shoulder in the form of a bull's head'.

When Alexander succeeded his father all he had to do was to perfect the military organization which he had inherited. In his vast conquests it would appear that his cavalry was even superior in efficiency to his infantry. The heavy cavalry, which had from of old formed the chief arm of Macedon, and which har been supplemented by the Sarissophori, were known as the Companions. According to Arrian $^{3}$ at the battle of Arbela there were eight distinct squadrons of the Companions, most of which, if not all, were named after different districts or towns. There was a distinguished royal squadron called the Agema, or leading body, at the head of which Alexander generally charged. Alexander divided these squadrons into half-squadrons in 330 B.C.

Not only was the cavalry furnished by Macedonia proper,

1 Cf. Waldstein, Art of Pheidias, p. 415.

2 Pliny, H. N. vill. 42. 64.

3 Anab. 1. 2. 89. 
but also by the region known as Upper Macedonia, a fact in complete harmony with the evidence of Herodotus, that in the fifth century B.C. all the peoples south of the Danube had discarded the war-chariot, which was only retained owing to

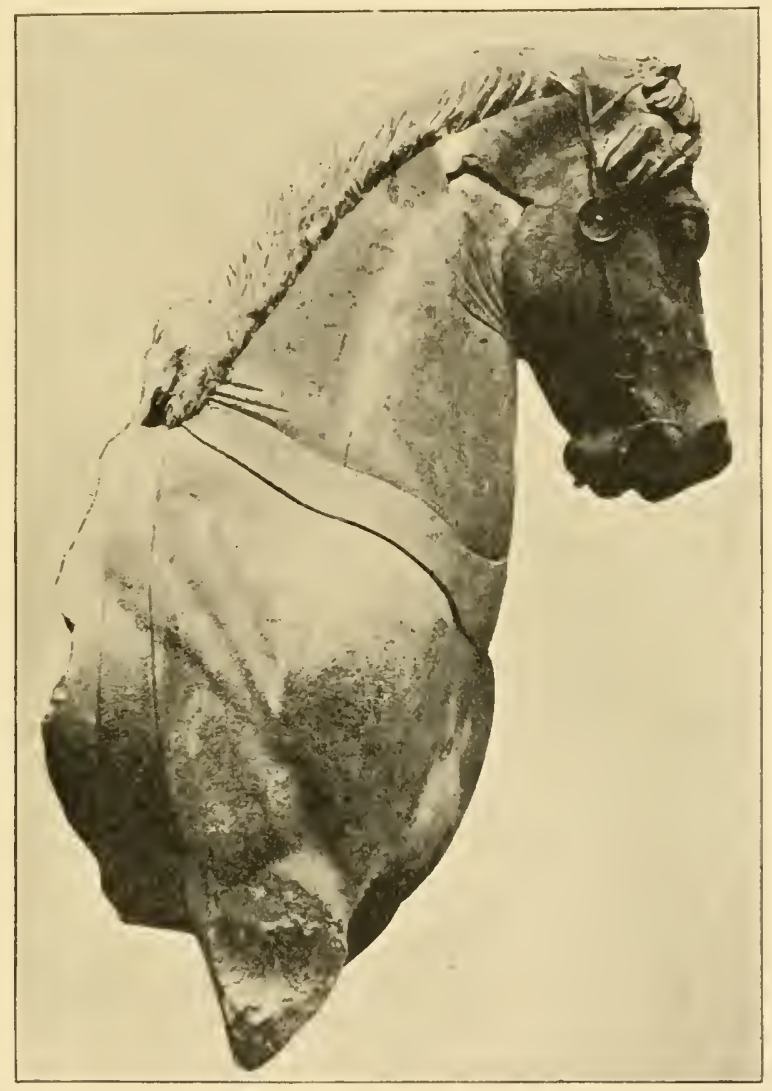

Fig. 88. Head of one of the Horses of the Quadriga from the Mausoleum at Halicarnassus.

the small size of their horses by the people north of that river.

The conquests of Philip and his great son must have done much to improve the native Macedonian horses. The former became master of Thessaly and the Thessalian horses, whilst

R. H, 
the latter secured possession not only of the best breeds of Asia, but was able to add to his stud the best blood of Libya, for instance when he marched into Egypt the Cyrenians sent him a present of three hundred horses, doubtless the best that their land could furnish. The effect of this may be traced in the fact that Thrace and Macedonia continued to be famous for their horses under the Roman domination, and, as we have already seen (p. 282), the Thracian horses were noted for their dark colour, with white feet and a white mark on the forehead ${ }^{1}$, whilst in Byzantine times the emperors of the East kept large studs of brood mares in that region ${ }^{2}$.

In Alexander's time the best horses of Asia were stronglybuilt animals, showing not much breeding, if we may judge from a fragment of one of the horses (Fig. 88) from the famous chariotgroup that once surmounted the Mausoleum (built B.c. 351341) at Halicarnassus. This with the other surviving fragments of the sculptures is now in the British Museum. Thus the successors of Alexander, whether in Egypt, Asia, or Europe, were equipped with the best war-horses that the world had yet seen, and the Seleucid kings of Syria, who had become the masters of the famous Nisaean race (pp. 192-3), paid great attention to the breeding of horses, a circumstance which probably led them to place a mare suckling her foal as a favourite type on their coins. In the struggle of Rome against the Macedonian and Asiatic monarchs the superiority of the latter in cavalry was one of the chief difficulties with which she had to contend.

Let us now return to Italy and trace as far as we can from the scanty records the history of the horse at Rome and in Upper Italy.

I have already shown that from the early Iron Age the Umbrians had been using chariots. Accordingly we would be almost justified in assuming that the Romans had done the

J Virgil, Aen. v. 565:

quem Thracius albis

portat equus bicolor maculis, vestigia primi

alba pedis, frontemque ostentans arduus albam.

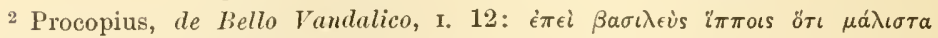

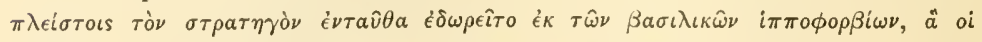

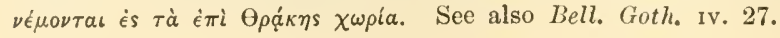


same, for the Patricians were Sabines in origin, the latter being an Umbro-Sabcllian tribe. But the terminology of the chief offices of State under the Republic renders it probable that in early days the leading men of the State rode in chariots and not on horseback. The Consuls, Praetors, and Aediles were termed Curule (from currus, a chariot), and they had chairs called sellae curules ("chariot chairs'), and horses termed Equi curules' ("chariot horses'), were supplied to them at the public expense, even at a time when consuls and everyone else rode on horseback. This seems to point to a time when the chiefs went to war in chariots as did the northern Gauls down to the third century B.c. In the fact that the victorious general down to late times rode in a chariot to the Capitol we may recognise a survival from the time when the chief who had gone forth to do battle in his war car on returning victorious drove his chariot in triumph through the city ${ }^{2}$.

All this indirect evidence is strongly eorroborated by the fact that the Romans in their campaigns against Pyrrhus in Lucania ( 278 B.c.) used two-horse chariots of peculiar equipment against that king's elephants ${ }^{3}$.

We have seen that not only the Illyrians, but also all the Celto-Teutonic peoples of Upper Europe regularly sacrificed horses. It is therefore but natural to find that the Romans, whose upper classes at all events were closely related to the Celto-Teutonic peoples, should have had the same practice, for Pliny ${ }^{4}$ especially points out that when a horse was sacrificed on public solemnities the flamen was forbidden to touch it. Whether the Romans preferred white horses for sacrifice like the Illyrians, Greeks and Persians, we cannot say, but it is absolutely certain that they used them to draw chariots on solemn occasions. Thus the Senate decreed that Julius Caesar after his return from Africa should ride in a quadriga drawn by

1 Livy, xxıv. 18.

2 The dismounted chariot seat would not unuaturally be used as a seat of dignity.

3 Vegetius, 11r. 24. 12.

${ }^{4} H$. N. xxvir. 9: damnat equinum tantum inter venena, ideo flamini sacrorum equum tangere non licet, cum lomae publicis sacris equus immoletur. 
white horses ${ }^{1}$. The Romans so firmly believed in the superior fleetness of horses of that colour that "to outstrip with white horses" became a proverbial expression for an easy victory ${ }^{2}$, and Virgil ${ }^{3}$ represents Turnus, king of the Rutuli, as drawn by horses "which surpassed in whiteness the snow, in fleetness the wind."

At what time the Romans began to ride on horseback it is impossible to say, but apparently they had begun to do so early in the regal period. The original legion was said to have been supplemented by three centuries of horsemen-the Ramnenses, the Titienses, and the Lucres each supplying one hundred men. In the constitution of Servius Tullius eighteen centuries of horsemen were included amongst the ninety-eight centuries of the First Class. The Romans owed little to their cavalry in their conquests in Central Italy and at no time in their history did their strength lie in their horsemen. The conquest of Tarentum and the rest of Southern Italy furnished the Romans with horses of a better quality for cavalry purposes, and as I have already mentioned, it is very significant that the best horses of Italy in Varro's day were the horses of Apulia, no donbt descended from the famous breeds developed

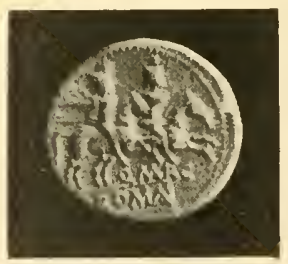

FIG. 89. Roman Denarius. by the Greeks of Southern Italy from constant importation of Sicilian and Libyan horses. It is not without significance that when the Romans for the first time issued silver money in 268 B.c.-four years after the conquest of Southern Italy - they placed on their coins Castor and Pollux (Fig. 89), a type borrowed from coins of Tarentum or Bruttii. It was but natural that the Romans should keep bringing up the good horses of Apulia to improve

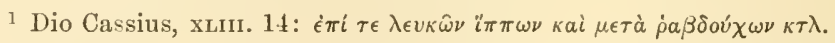

2 Hor. Sat. 1. 7. 7-8: Sisennas, Barros, ut equis praecurreret albis; ef. Plaut. Asin. 11. 2. 12: nam si se huic occasioni tempus subterduxerit, nunquam edepol quadrigis albis indipiscet postea.

${ }^{3}$ Aen. xir. 84: qui candore nives anteirent, cursibus auras. These white horses are said to have been the gift of Orithyia, the wife of Boreas, the North Wind. But Virgil as the practical farmer (p. 282) knows that white and dun horses are inferior to bay. 
the native breeds of Central and Upper Italy, and I have shown on an earlier page that in 218 B.c. the horses of the Roman cavalry were superior to those of the Gauls of Northern Italy.

We have already seen that from the outset of the Second Punic War the Roman cavalry was inferior to the Numidian and Spanish horsemen in Hannibal's army, and it is highly suggestive that as soon as Scipio conceived the idea of carrying war into Spain, his first care was to secure the alliance of Syphax, the Numidian king, and to enter into relations with the Masaesylian Massinissa. Indeed it was in no small degree to the aid of the latter, who joined Scipio with a few followers when that general landed in Africa in 204 B.c., that the Romans were ultimately successful in the closing scene of the drama which culminated in the battle of Zama (B.C. 202).

"The Romans made a province of that part of the country which had been subject to Carthage, and made over the rest to the rule of Masanasses (Massinissa) and his descendants, begimning with Hicipsa. For the Romans paid particular attention to Masanasses on account of his great abilities and friendship for them, for he it was that formed the nomads to civil life and directed their attention to husbandry, and he taught them to be soldiers instead of robbers"." During the years that intervened between Zama and the final destruction of the hapless city Massinissa and his Numidians effectually kept Carthage from regaining anything of her ancient power:

Before Massinissa died (B.C. 141) he had so extended his kingdom that it completely enveloped the Roman province, since it reached even as far as the western Syrtis, and exceeded both in extent and population the territory ruled by Carthage, even in the zenith of her power. Carthage once destroyed, the Romans began to look with alarm upon the kingdom of Numidia, with its vast hordes of swift horsemen. On Mlassinissa's death Scipio Aemilianus har constrained his three sons to share the kingdom, but as two of them soon died, the whole had lapsed to the survivor Micipsa. This able man improved his father's capital Cirta (Constuntineh), and established there a colony of Greeks, and he raised it to such importance that it could pat in the

\footnotetext{
1 Strabo, 832.
} 
field 10,000 horse and twice that number of infantry. Micipsa had two legitimate sons, Adherbal and Hiempsal, and a bastard, Jugurtha, who far exceeded the others in energy and ability. Micipsa at his death divided the kingdom between all three, but quarrels soon broke out, and Jugurtha in no long time became master of the whole. Then commenced the long struggle between Rome and Jugurtha in which the latter routed the Romans more than once, and even made a consular army pass under the yoke. It was not until Rome had found a military genius in Gaius Marius, a rude soldier of fortune, and had been induced by him to remodel her whole military system, that Jugurtha was at last vanquished and led in triumph to the Capitol. I have alrearly shown that Micipsa and his successors paid great attention to the breeding of horses and that no less than 100,000 colts were bred annually in their dominions. It was by means of his overwhelming superiority in cavalry that the Numidian king was able for so long to bid defiance to the legions of Rome.

In B.C. 125 the Romans had for the first time permanently established themselves in Gaul, after the overthrow of the powerful Ligurian tribe of Saluvii ${ }^{1}$, and we have seen how in one of their campaigns against the Ligurians a Roman army had been saved from destruction by a body of Numidian cavalry in the Roman service.

When Julius Caesar commenced his war of conquest (B.C. $60-56)$, he found that the chief strength of the Gauls lay in their cavalry, which was composed of the ruling class who had crossed the Rhine and become the overlords of the indigenous population, the latter forming their serfs and dependents and following them to war. The Gauls, as has been repeatedly shown, possessed horses of fine quality, derived from southern lands at great cost. The conquest of Spain had supplied the Roman army with some good horses and cavalry, and now the

1 W. H. Hall (The Romans on the Riviera and the Rhone, pp. 49, 53, etc.) gives the best account of the Ligurians and the Roman conquest. As these pages are passing through the press, the news of the sudden death of my gifted friend has reached me. The memory of his rare qualities of heart and brain will be long cherished by his many friends. 
subjugation of Gaul gave her henceforth, until the barbarians burst through her fronticrs, a practically unlimited supply of serviceable horses. In the time of Augustus the ordinary carriage horse and hackney used at Rome and in Central Italy was a pony ${ }^{1}$ termed mammus ${ }^{2}$. As the word is Celtic, it would indicate of itself that the Romans obtained these animals either from Cisalpine or Transalpine Gaul or from both, even if they were not distinctly alluded to as Gallic in the literature of the time $^{3}$. In their campaigns against the Germans in the first century of our era the Romans seem to have relied entirely on the Gallic provinces for their supply of war-horses ${ }^{4}$, whilst St Jerome ${ }^{5}$ writing in the fourth century after Christ, mentions the high value set by worldly men upon Gallic geldings. We shall soon adduce evidence to show that the Roman manni were bred by the Ligurians in what is now north-west Italy and Provence, of which region they were one of the chief productions for export in the first century B.c. (p. 321). The Romans had used geldings for pack-horses from at least the first ${ }^{6}$ century B.C. and we know not how much earlier. Indeed Cantherius', 'a gelding,' means properly a 'pack-animal' and got its secondary meaning from the circumstance that such animals were usually unsexed (cf. p. 167).

1 Isidore, Orig. xı1. 1, defines mannus as equus brevior, quem vulgo brunitum, vel brunitium vocant. Brunitum vel brunitium are emended to burrichum vel

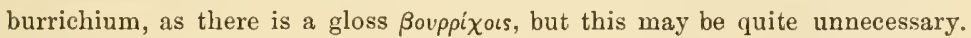

2 Lucr. IIr. 1076: currit agens mannos ad villam praecipitanter; Prop. rv. 8. 15: huc mea detonsis avecta est Cynthia mannis (where detonsis means "with hogged manes"); Hor. Od. 1II. 27. 6: rumpat et serpens iter institutum, si per obliquum similis sagittae terruit mannos; Id. Epod. 4. 14: et Appiam mannis terit; Id. Ep. 1. 7.76: impositus mannis; Ovid, $A m .11 .16$ fin.: rapientibus esseda mannis ipsa per admissas concute lora jubas; Sen. Ep. 87: ita non omnibus obesis mannis et asturconibus et tolutariis praeferres unicum illum equum a Catone descriptum?

3 Hor. Od. I. 8. 6: cur neque militaris inter aequales equitat, Gallica nec lupatis temperat ora frenis.

4 Tac. Ann. 11. 5 : fessas Gallias ministrandis equis.

5 ad Zech. ix. 9.

${ }^{6}$ Varro, R.R. 11. 7. 15, but the cantherii mentioned by Plautus (died 187 B.c.) may be simply pack-animals, not unsexed.

7 From Gk. $\kappa a \nu \theta \dot{\eta} \lambda$ cos = pack-ass (from $\kappa a \nu \theta \eta \dot{\lambda} \lambda \iota a$, 'panniers '); ef. Cic. $N . D$. Irr. 5. 11. 
As by the end of the Republic and the first century of the Empire Rome was mistress of a large part of the known world, and was in a position to obtain not only the best horses within her own wide bounds, but also to acquire their best steeds from those tribes who did not own her sway, and, as in the first century of our era, chariot-racing had become a furious passion at Rome, and immense sums were spent on it by the four great factions of the Blue (Veneta), the Green (Prasina), the White (Albata), and the Red (Russata), so named from their distinctive colours, it is obvious that if we could ascertain what was the best breed of racers at this time, we would be justified in concluding that this was the best in the known world!

In 1903 several fragments of a long Latin² inscription were found at Rome, built into a wall to the north of the castle of St Angelo. They turned out to be part of a document of which other fragments had already been published ${ }^{3}$. The inscription had been set up in honour of Avilius Teres, a renowned charioteer in the second half of the first century A.D., and it contains a recital not only of his racing career and how he first drove for the Blue (Veneta) and then changed to the Green (Prasina), but what is more to our purpose it gives a list not only of the horses' names which he steered to victory, but also mentions the breeds to which each belonged. Although the inscription is very incomplete, yet in forty-two cases adjectives giving the horse's nationality can be read. Thirty-seven horses are described as Afer, i.e. from that part of Libya comprised in the Roman province of Africa and in the modern Barbary States; one is styled Maurus, Mauritanian, one Hispanus, one Gallus, and two Lacones, i.e. Lacedaemonian. Consequently thirty-eight out of forty-two are actual North African horses, whilst from what we have seen of the history of the horses of Spain we know that the South Spanish horses at this time were almost purely Libyan, and Caesar's evidence respecting the Gallic horses and the constant importation of first-rate horses from the south by the Gauls in the two centuries before Christ

1 Suet. Calig. 55 ; Vit. 7.14 ; Dom. 7.

2 Revue Archéologique, 1903, Juillet et Août, no. 160, p. 160.

3 Corp. Inscript. Lat., vi. 10053, 10054, 33943. 
make it equally plain that the excellence of the Gallic horse was due to his Libyan ancestry. Finally, the history of the horses of Greee renders it certain that the best breeds of that country were saturated with the Libyan blood.

The absence of all mention of any Asiatic horses-Parthian, Armenian, Cappadocian, or Arab-is the clearest proof that the racing men of the time did not look to Arabia or any other district of Asia for horses of preeminent speed, and this completely corroborates the evidence of Strabo in the first part of the same century that the Arabs neither bred nor kept any horses at all. It is now beyond all doubt that from the dawn of history down to the early centuries of our era the Libyan horse surpassed all others in swiftness, and that no horse was able to compete with him save those of Spain, Gaul, and Greece, which were themselves wholly or in great part sprung from the same blood.

Of course a very different class of horse from the prizewinners of the circus was required for war, hunting, and other practical purposes, and for such the horses of the Parthians, so highly commended by Strabo, aud other good breeds of Asia Minor, Greece, and Italy, which we have shown to have been the result of crossing the Asiatic-European horse with the Libyan, were admirably adapted.

For the chief breeds of horses in the second century after Christ we have the evidence of Oppian, who flourished about 180 A.D. In his treatise on Hunting (Cynegetica ${ }^{1}$ ), he says that though each country has its own breed of horses, he will only mention the most important, and then enumerates the Etruscan, Sicilian, Cretan, Mazicean, Achean, Cappadocian, Mauritanian, Scythian, Magnesian, Epeian, Ionian, Armenian, Libyan, Thracian, and Erembian. His enumeration is not according to order of merit or geographical position, but to meet the exigencies of the hexameter metre. The horses of Libya (by which he probably means the Cyrenaica), the Mazicean² (Numidian), and

1 I. $166-200$.

2 The Mazices of Oppian are the same Numidian tribe as the Mazaces and Mazices of Caesar and Suetonius, and are to be identified with the Libyan tribe of Maxyes, who, according to Herodotus (Iv. 191), lived west of the river Triton. 
Mauritanian horses are mentioned separately, in addition to the well-known old breeds of Greece and Asia Minor.

It is very significant that in his wide survey of the best breeds of horses Oppian is silent respecting the Arabs, and from this we are justified in inferring that down to the second century A.D., even if the Arabs had by that date begun to breed horses, their steeds were not yet recognized as of any special merit.

It will be noticed that the only Italian breed mentioned is the Etruscan, from which we may infer that for practical purposes it had by that date overshadowed the Apulian breeds. We have seen that in Spain, Africa, and in Western and Central Asia black horses are a regular result from the blending of the African with the European-Asiatic horse, and it is probable that the same holds true for Italy. Down to modern times 'Tuscany, Ancona, and the region of Bologna have been noted for fine breeds of black horses, all of which have been much influenced by African blood derived from Lower Italy. But as the horses of Tuscany were the best Italian breed known to Oppian, it is not unreasonable to conclude that from these horses are descended, in part at least, some of the fine black horses of modern Tuscany. Horses of similar colour but heavier build are found in Lombardy, but these are probably in good part descended from heavy horses brought by the Teutonic invaders of that region, of whose horses we shall soon speak. These horses of Lombardy have been much influenced in later centuries indirectly by Libyan blood through Turkish and Hungarian horses and also by the admixture of heavier horses from Upper Europe (p. 362). Stradanus pourtrays in his Insuber (Fig. 90) a typical example of the Lombard horse of the 16th century.

Let us now return to Central and Upper Europe. We saw that the horses on the north side of the Danube were remarkable for their small size in the 5th century B.C., and that down to the time of Caesar the Germans still possessed only their primitive, unimproved, large-headed horses. But as the Gauls beyond the Alps had shown the keenest desire to improve their native breed by importing horses of superior blood at great cost 
from southern lands, we might assume even without evidence that the Gauls of the lower Danube had for several centuries before Christ been importing horses of improved kinds from Macedonia, Epirus, and Thessaly. But there is not wanting evidence that for a good many centuries before our era the Celts, who dwelt in what is now Styria ${ }^{1}$, had begun to ride on horseback. At Strettweg, near Judenburg, in that province, a cremation grave of the early Iron Age-formed of large round stones-contained a remarkable series of objects, the most

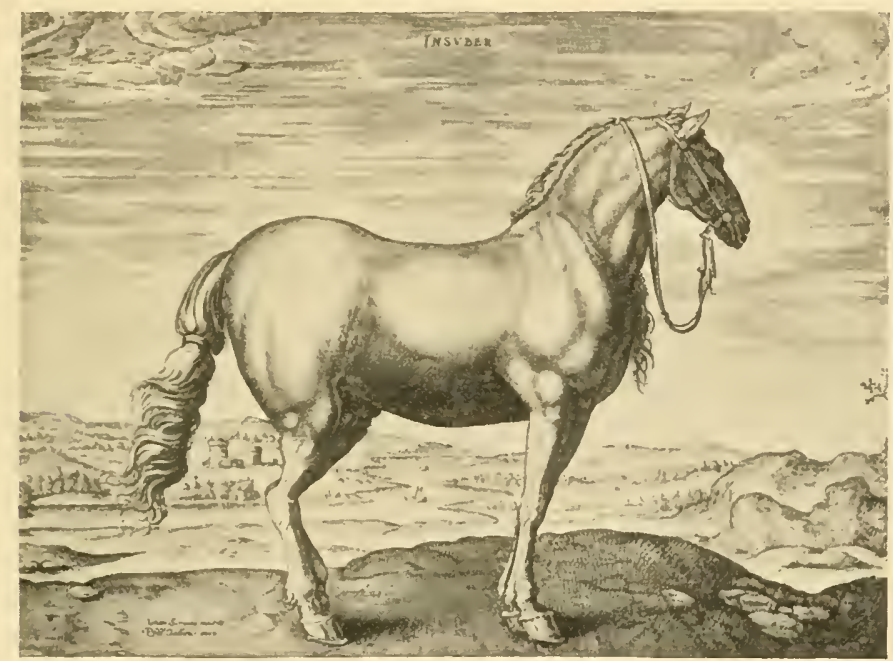

FIG. 90. The Lombard Horse.

interesting of which was a small bronze waggon. The vehicle is a simple platform on four wheels, each of which has eight spokes. At each end are the heads of two animals: on the middle of the car stands a woman, nude save for a girdle; there are four figures of men on horseback, each of whom carries a round shield with a central boss and wears a conical cap. There are altogether thirteen figures on the waggon. In this vehicle we have probably a model of the waggons on which the Celtic tribes conveyed their women and children as they

1 Ridgeway, Early Age of Greece, Vol. I, p. 428. 
wandered into southern lands. The occurrence of horsemen dressed and armed in the fashion of the early Iron Age proves that the Gauls on the north-east of the Adriatic had learned by that time freely to ricle on horseback. But as the tribes on the north side of the Danube continued to fight in chariots because their horses were so small, we may infer that the Celts of Styria had been able to obtain horses of a better kind from the lower Balkan peninsula.

It was almost certainly owing to this advantage that the Gauls of that region had been able to develope a very remarkable cavalry organization, which formed the chief element of success in their invasions of Macedonia and Greece. 'The description of the admirable cavalry system of those who invaded Greece and got as far as Delphi in 279 B.c., demonstrates that they had long before procured good strains of horses from Macedonia and northern Greece, and had learned to ntilise them, just as quickly as at a later time did their kinsfolk in Gaul, as soon as they had obtained horses of superior quality from Italy or Spain: "When Brennus persuaded his people to invade Greece the assembled army numbered one hundred and fifty-two thousand foot, and twenty thousand four hundred horse. But though that was the number of cavalry always on service, the real number was sixty-one thousand two hundred; for every trooper was attended by two serfs, who were themselves good riders and were provided with horses. When the cavalry was engaged, the serfs kept in the rear, and made themselves useful thus: If a trooper (oi i $i \pi \epsilon \dot{v} o \nu \tau \epsilon$ ) had a horse killed, the serfs brought him a fresh mount: if the trooper himself was slain, the serf mounted his master's horse; but if both horse and man were killed, the serf was ready mounted to take their place. If the master was wounded, one of the serfs brought the wounded mau off the field to the camp, while the other took his place in the ranks. These tactics, it seems to me, were copied by the Gauls from the Persian corps of the Ten Thousand, known as the Immortals. The difference was that in the Persian corps the places of the dead were filled up by enlistment after the action, while with the Gauls the squadron 
was brought to its full strength on the field of battle. This organization they called trimarcisia ('three-horse' system) in their own tongue; for you must know that the Celtic for a horse is marca!"

This valuable passage gives us a picture of a society and a military organization closely resembling the feudal system that sprang up in all the countries conquered by the Teutonic tribes after the downfall of the Roman Empire. We have here the medieval knight attended by his squires, though in the present case the latter are not freemen, but belong to the conquered people, and have to follow their lord to war. But the institution here set forth did not belong merely to the Gauls of the Danube, for it would appear that wherever the Celto-Teutonic tribes from Central Europe pushed their conquests, they established a like system. The squires, here termed serfs $\left(\right.$ douloi $\left.i^{2}\right)$ or bondsmen, are identical with the ambacti ${ }^{3}$ of Gaul in Caesar's time, where there was a ruling class of knights (equites) who had passed over the Rhine and conquered the old melanochrous population of France, the latter becoming the vassals and dependents of their Celtic conquerors. These Celtic lords spent all their time in war, and the greater each was in birth and power, the more ambacti or clientes had he around him. That the institution of ambucti was no new feature among the Celto-Teutonic tribes is shown by the fact that Ennius ${ }^{4}$, the father of Roman epic poetry (239-169 B.C.), knew of it as a Gallic term.

I have elsewhere ${ }^{5}$ shown that the fair-haired Acheans of Homeric Greece had come down from Central Europe into Greece, and conquered the old dark Pelasgic inhabitants, making them into their vassals and dependents, and compelling them to follow them to war. We have seen, on an earlier

1 Paus. x. 19. 4 sqq. (Timaeus, of Locri, was probably Pausanias' anthority).

2 For this use of $\delta \circ \hat{\nu}$ os (and $\delta o v \lambda \epsilon i a$ ) for a serf or vassal population ef. Aristotle, Pol. II. 5. 22 ; Thuc. v. 23.

${ }^{3}$ Caesar, B. G. r. 15: plurimos circum se ambactos clientesque habent. With ambactus of. Gothic andbahti = service, andbahts = servant.

${ }^{4}$ Paul. ex Fest. p. 4 (Müller) : ambactus apud Ennium lingua Gallica servus appellatur.

5 Ridgeway, Early Age of Greece, Vol, 1. pp. 337 sqq. 
page, how one of these dependents of Agamemnon had to purchase exemption from following his lord to Troy by presenting him with a famous mare.

It is clear then that long before the Christian era the plains of the Danube were producing horses of excellent quality, and this they continued to do under Roman rule ${ }^{1}$. The Huns of course brought their own hardy horses from the steppes, but it is almost certain that these were soon improved by crossing with the already improved breeds developed by the old Celtic occupants of that region. Certainly by the fourth century A.D., when Vegetius ${ }^{2}$ wrote, the Huns were famous for their horsemanship, and he praises the horses of the Huns and other northern peoples for their hardiness and freedom from disease, though left out on pasture through the winter frosts, and never stabled. He remarks that from the example of the Huns the Romans of his own time, who wished to save expense in matters of careful grooming and horse-doctoring, pretended to follow the example of the Huns, whose horses, though left uncared, had such excellent constitutions ${ }^{3}$. But Vegetius points out that the northern horses were naturally of a hardier stock, whilst the Roman horses were not only of a more delicate constitution, but were reared more tenderly, being housed from the time they were foals.

Accordingly when he describes the chief breeds of horses fitted for the war, the race-course, and for the road, he puts the Hunnish horses at the head of the war-horses, next in order being the Thuringian and the Burgundian, and thirdly the Frisian ${ }^{4}$. $\mathrm{He}^{5}$ gives a very full account of the Hunnish horse, which I give here in Thomas Blundeville's admirable version.

1 E.g. Dalmatian and Epirote horses (Veg. Ars Vet. Iv. 6).

${ }^{2}$ Re Mil. IIr. 26. $15 . \quad{ }^{3}$ Ars Veterinaria, I1., prol., sect. 1.

4 Veg. Ars Veterinaria, Iv. 6. 3. The mss. read Frigiscos. The Frigisci cannot mean anything else than Frisian, for they must be a northern breed owing to their association with Toringos.

5 Ars Vet. Iv. 6. 5: Hunniscis grande et aduncum caput, extantes oculi, angustae nares, latae maxillae, robusta cervix et rigida, iubae ultra genua pendentes, maiores costae, incurva spina, cauda silvosa, validissimae tibiae, parvae bases, plenae ac diffusae ungulae, ilia cavata, totumque corpus angulosum, nulla in clunibus arvina, nulli in musculis tori, in longitudine magis 
"The Hungarian hath a great and hooked head, and his eyes stand almost without his head, his nostrils are narrow, and his jaws broad, his neck is long and rough, with a mane hanging down nearly to his knees, he hath a large bulk, a right back, a long bush tail, his legs be strong, his pasterns small, and his hoofs full and broad, his guts are hollow, and all his body is full of empty corners, his buttocks are not filled with fat, neither do the brawns of his muscles appear, of stature he is more in length than height, and therewith somewhat

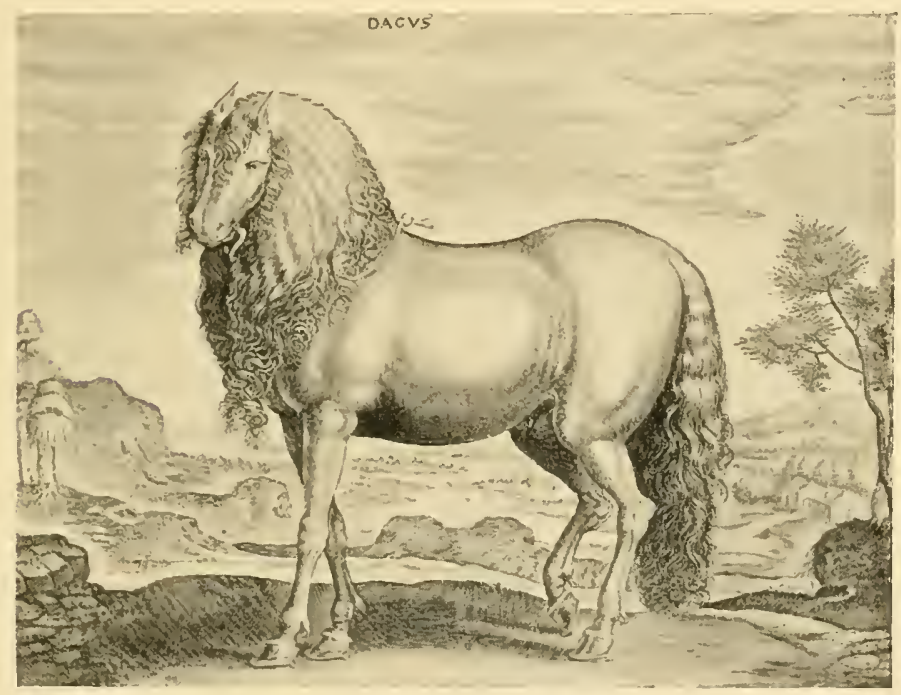

Fig. 91. The Hungarian Horse.

side-bellied, his bones are also great, he is rather lean than fat, which leanness is so answerable to the other parts of his body, as the due proportion observed in his deformity, maketh the same to be a beanty. And as tonching his inward disposition, he is, as Vegetius saith, both temperate and wise, and able to abide great labour, cold and hunger, and very meet for the war." "Camerarius also saith that they be very swift, and

quam in altitudine statura, propensior venter, exhanstus, ossa grandia, macies grata, et quibus puleritudines praestat ipsa deformitas: animus moderatus et prudens, et vulnerum patiens. 
if they be provoked by some injury, they will both bite and strike, otherwise not. Their pace is a trot."

The Hungarian horses have been continually improved by the introduction of Libyan blood, derived largely in later centuries through Turkish channels. Accordingly it is not surprising that the Hungarian horse, drawn by Stradanus (Fig. 91), in the "Stable of Don John of Austria," shows little resemblance to the animals described by Vegetius except as regards the copiousness of the mane and tail, which were probably inherited from the ancient horses of the Danubian region. The old Hungarian horse was usually of a bay colour and without any white on the legs, but grey, dun, and chestnut were likewise often found. Since the early part of the last century this type has been entirely changed owing to the constant importation of English thoroughbreds, when the Government began to breed for military purposes and encouraged the farmers to do likewise. "In almost all cases the Government stallions were half-bred English, and these were placed at breeding depôts all over the country ${ }^{1 . "}$ As is well known, Hungary at the present time supplies some of the best cavalry horses in the world.

I have already pointed out that the black horses of Western Asia, Spain, and Italy all result from a mixture of the African bay with the indigenous horses of Asia and Europe. If this principle is sound, the same colour ought to characterize strongly the horses of the Upper Balkan and Danubian regions. But large black horses are so distinctive a feature not only of this area, but also of those lying to the east, that the cavalry of Austria and Russia has been regularly mounted on horses of this colour. Our evidence now makes it clear that black is not an original colour of the horse either in Europe, Asia, or Africa, but that it is an artificial product arising from the mixing of the African stock with the Asiatic-European indigenous horses in the three southern peninsulas of Europe, in Syria, Anatolia, and other parts of Western Asia.

Let us next pass into Northern Italy and France. Now

1 Hayes, Points of the Horse (ed. 3), pp. 531-2, embodying the notes of Mrr Reynolds (M.R.C.V.S.). 
since the horses of the Celtiberians, who occupied all Northern Spain, were iron-grey, and as the horses of Southern Spain were bay, and oceasionally black, and as the Gauls were importing horses of superior blood from the south from 172 B.c. and probably much earlier, and in Caesar's time were paying large prices for horses from southern lands, it is but reasonable to expect that some of the oldest breeds in France should show characteristics similar to those of the cross-bred horses of Spain.

All French authorities are agreed that the fine breeds (races légères), of which there were several of great antiquity and excellence in France, are derived from the 'Oriental' or 'Arab,' or in other words from the Libyan horse. In Strabo's time $^{1}$ the Ligurians were noted for a particular breed of horses called ginni, i.e. jemnets, which the geographer (probably following Posidonius) mentions amongst the chief products and exports of that region. That these jennets were not mules but ponies is made absolutely certain by the statement of Aristotle $^{2}$ that "the animals called ginni are stunted loorses and bear the same relation to horses that dwarfs do to wellgrown men." It is therefore certain that the Ligurians had an excellent breed of ponies before the Christian era, and as these ponies were sent down into Italy, we can have little doubt that they were the manni of the Roman writers of that period. The Ligurians, who lived on the Italian side of the Alps, in their struggle against the Romans seem to have had no cavalry, but when in 125 B.C. the Romans undertook for the first time to carve out a province on the Gallic side of the Alps, they came into contact with the powerful tribe of Saluvii, whose eapital was Arelate (Arles), and who were well mounted on the horses which they bred in the plains east of the Rhone.

To-day in the same district we meet the horse known as the Camargue. It is reared in a half-wild state, and its origin is ascribed "to the introduction of Arab or Numidian blood in the neighbourhood of Arles in 125 B.C., when Fulvius Flaccus, the Roman general, occupied the country." 
The original Libyan blood thus obtained is supposed by French writers to have been angmented by the establishment of the colony of Julia (circ. 24 B.c.), and later at the time of the Saracen occupation of Provence (730 A.D.), and later still at the time of the Crusades. The Camargue is a small horse $(1 \cdot 32-34 \mathrm{~m}$. $=13 \cdot 1$ hands). His head is a little big, but well set on. His feet are large and often flat; his coat, is always grey. His head and feet point clearly to his European ancestry, whilst the modification of his colour points equally clearly as in the horses of Northern Spain, Syria, Mesopotamia, and Asia Minor, to his Libyan blood.

As we have shown that not only were Gallic chieftains importing horses across the Alps long before the Roman occupation of Provence, but that the Celtiberians by the beginning of the first century B.c., and we know not how much earlier, possessed a breed of grey horses, it is more than probable that Libyan blood had been introduced into the region of the Rhone at a time long anterior to 125 B.c. Again, as we have seen that the osseous remains of the horses used by the Helvetians in the first century B.c. (p. 93) are declared by Dr Marek to agree in their fundamental characters, size excepted, with the so-called Oriental races of horses, whose typical representative is the 'Arab,' and as this Helveto-Gallic horse was 1.35 to $1.41 \mathrm{~m}$. in height, almost the same as that of the modern Camargue, we are led to conclude that the Ligurian ginni of Strabo's day were not only the ancestors of the modem Camargue but were the same breed as the horses whose bones have been found in the settlements of the La Tène period.

The crossing of the Camargue with the Arab in modern times has given excellent results ${ }^{1}$.

The Basses Pyrénées and the Hautes Pyrénées are the seat of an ancient breed known variously as that of Navarre, Tarbes, or Bigourdan². It was derived from Andalusia according to some at a period later than the Arab conquest of Spain, according to others at the same time, but from what we have already seen it is probable that it had imbibed much Libyan blood 
at a far earlier date. In form it is said to fall abont midway between Arab and Andalusian. The breed was decadent by the close of the eighteenth century, and has since then been greatly modified by being crossed with Arab and English thoroughbred stallions, the former being used exclusively under the Empire and the Restoration, but in 1833 the English horses were intrortuced, and since then the horse of Bigourdan has gradually supplanted that of Tarbes, being taller than the latter. The crossing has increased its height, which is now $1.60 \mathrm{~m}$. (16 hands), and its head is longer than that of the thoronghbred.

In the Eastern Pyrenees we meet the horses of Ariège, which are reared on the plateau of Laderg, at a very considerable height above sea-level. They have all the characteristics of a mountain type-being ugly and angular, but very hardy and useful. Their relatively large size $(1 \cdot 45-50 \mathrm{~m} .=15$ hands at most) is due to the excellence of the mountain pastures. "Everything points to the belief that they are Spanish in origin," for they preserve in great part the character of the Andalusian. The coat is generally black ${ }^{1}$.

The Limousin horse was the glory of old France, for it was esteemed above all others for the saddle, and the royal stables were filled with animals of this breed. The majority of hippo logists are agreed in dating the origin of the Limousin stock to the conquest of Spain and Southern France by the Saracens in the beginning of the eighth century A.D. It has the distinctive characteristics of the Barb. The chief centre for its breeding was in Haute Vienne. It was in full decadence in 1770, and in modern times it has been much crossed with Arab, Spanish, and English thoroughbred blood, and has consequently lost its ancient shape and qualities. Since 1830 English thoronghbreds have been exclusively used and have given the race greater size, but not so good a barrel.

The Auvergne horse is also 'Oriental,' i.e. Libyan, in origin, being absolutely identical with the horse of Ariege, its colour being generally black. They are not so fine as the Limousin,

1 Cuyer and Alix, op. cit. p. 609. 
for the head is larger in proportion to their size, but in modern times they have been modified by English thoroughbred blood ${ }^{1}$.

The Landes furnish a breed of horses without doubt partly Libyan in origin. They are reared in a half-wild state, dependent entirely on the scanty pasture of their native wastes. They are of small size $(1 \cdot 10-30 \mathrm{~m} .=11-13$ hands $)$ with small square heads. They are hardy and untiring. The results from crossing them with big breeds, especially the English thoroughbred, have always been bad, but when these little mares are mated with an Arab, whose height and feeding is much more on a par with their own, the results are excellent.

The horses bred in Bas-Medoc are the result of crossing the indigenous mares with English thoroughbred or Anglo-Norman stallions. Their height should make them suited for cavalry of the line, but in every other respect they are ill-suited for this purpose, being ugly, awkward, nervous, and bad-tempered ${ }^{2}$.

The horses of Morvan (whose seat is in Saône-et-Loire and Nievre) are 'absolutely identical' with the horses of Auvergne and those of Ariège (Eastern Pyrenees). This breed had a great reputation under Louis $\mathrm{XV}$, and is still valued, though degenerate ${ }^{3}$.

Though the departments of Western France supply but few fine horses, yet Brittany from time immemorial has had an excellent breed, 'absolutely identical' with that of Morvan, Auvergne, and Ariège. The best French authorities maintain that the Breton horses are 'Asiatic,' i.e. Libyan, in origin. According to M. Sanson the introduction of this type must go back to the Celtic epoch, and he places it under his E. c. hibernicus (p. 2). These horses, known as bidets, are reared everywhere in the mountains and plains of Brittany, especially near Guingamp, Cartaix, Loudeac, Brest, Morlaix, and Redon. They have short, square heads, and they do not exceed $1.50 \mathrm{~m}$. (15 hands) in height. They have been spoiled to a certain extent by the introduction of English thoroughbred stallions ${ }^{4}$.

This breed, which thus extends right across France, from Ariège through Auvergne, and down the Loire into Brittany,

\footnotetext{
1 Cuyer and Alix, op. cit. pp. 605-6.

2 Cuyer and Alix, op. cit. p. 609.

3 Cuyer and Alix, op. cit. p. 617.

* Cuyer and Alix, op. cit. p. 614.
} 
we shall find to be of great importance when we come to inquire into the origin of the Irish Hobby and Ewart's Celtic pony (p. 18).

The little horses of the Meuse, Moselle, and Meurthe (the ancient province of Lorraine), are held by Sanson to be 'Arab' in origin. They have great toughuess and endurance, though ugly in shape. They are now only to be found amongst the poorest people. Their decadence commenced with the introduction of Ukraine blood in 1757, and has been aggravated by the introduction since 1807 of Belgian, Percheron, and AngloNorman blood.

Alsace formerly possessed a breed of small horses of 'Asiatic' type, but at the present day the Alsatian horses are of little value'.

The breeds of which we have just been speaking are all of a dark colour, like the horses of North Africa and Andalusia, from which they are sprung, and indeed they are commonly black. But, as in Spain we found not only the pure or almost pure Libyan horse of a dark colour, but also a grey breed, partly Libyan and partly derived from the old European stock, which still exists in Northern Spain, the land once ocenpied by the Celtiberians, and as we have already found such a grey breed in Provence, it is but natural that breeds of a similar origin and colour may be found in Central France also.

The most famous of all the French half-bred or intermediary horses is the Percheron, who is as much renowned in his class as the English race-horse is in his. The centre of production of the Percheron is what was formerly the little province of Le Perche, distributed now between the departments of Orne, Sarthe, Eure-et-Loire, and Loir-et-Cher, the actual geographical area of the breed only covering a portion of each of these departments ${ }^{2}$. The principal breeding centres are Mortagne, Bellesme, Saint-Calais, Mont Doubleau, and Courtomer. There are two kinds of Percheron, the little and the big. It is the small or Percheron postier, that was so universally used for posting and for coaching. 'The head is a little large, souvent 
camuse, the forehead large, the eye small but quick and intelligent, the neck of moderate length with a long fine mane, the back short, the croup round and muscular, and well-rounded sides, the tail set a little low, strong legrs with large joints, short pastems. It is generally grey. The little Percherons horse the Paris omnibuses and the French artillery. Various theories have been advanced touching the origin of the Percheron, some holding that he is an Arab become heavy under a particular kind of work and feeding in the course of some centuries, others consider him the outcome of the blending of the Breton with the Boulonnais, whilst M. Sanson ${ }^{1}$ makes it into a separate species, E. c. sequanius, and holds that it developed in the Parisian basin of the Seine (Sequana). MAI. Cuyer and $\mathrm{Alix}^{2}$ accept this view, believing it to be confirmed by the discovery at Grenelle of a skull of Equus caballus, the only quaternary skull of Equidae known up to the time when they were writing (1884), of which the typical characteristics are those of the Percheron breed. Though it is possible that this skull may be that of a cross between the 'Celtic' pony and the heavy built horse of the Solutré type, yet the grey colour of the Percheron taken in conjunction with that of the Camargue, and the same colour in the horses of Northern Spain, about whose ancestry we are fairly certain, render it far more likely that the Percheron is the outcome of blending the old heavy European horse with Libyan blood derived through Spain and Italy.

There are also horses known as the large Percheron, but they must not be confounded with the small or true Percheron, for in the plain of Chartres there are horses of various other breeds, some of them very large and heavy-Breton, Boulonnais, Flemish, Picard, Norman-but as the mode of rearing tends to assimilate all these horses to the older breed, they are commonly called Percherons and sold as such.

It will be remembered that by 100 A.D. the German tribe of Tencteri, who had settled on the left bank of the Rhine, were distinguished from all other German tribes by their love of 
horses and their finely organised cavalry (p. 115). It was pointed out that their superiority in horses over their kindred was due to the fact that they had been able to obtain a better class of horses from their Gallic neighbours, who had been importing at great cost fine horses from southern lands long before the time of Caesar. By the third century the Tencteri, like the Ubii and other tribes, who dwelt on the left bank of the Rhine, had lost their identity under the common term of Franks, which had gradually supplanted the older name of Germans' ${ }^{1}$ But their kindred on the other side of the Rhine from the Main down to the sea maintained their autonomy in their ancient seats from which they were one day destined to sally forth to conquests pregnant with empire. Next to the Franks on the east lay the 'Thuringians, whilst on the south from the Main as far as Basel came the Burgundians. As the Tencteri had been able to obtain superior horses and to organise a fine cavalry in the first century A.D., it was but natural that some of the other tribes should soon follow their example. It is not then surprising to find that Vegetius" (circ. 380 A.D.), in his list of breeds suited for war, places the Thuringian and the Burgundian next after the Hunnish, and gives the third place to the Frisian. Unfortunately, Vegetius does not mention the characteristic colour or colours of these different breeds of war-horses, but it is not improbable that many of them were already of a dark colour. Certainly by the beginning of the sixth century a dark colour with blaze on the face characterised the best Roman war-horse of the day. This is rendered clear by the story of the famous fight which took place near the Tiber, when Belisarius, Justinian's great general, with a thousand of his cavalry came suddenly upon a party of the Goths, who were bent on the capture of Rome and had already crossed the river. Belisarius himself fought like a

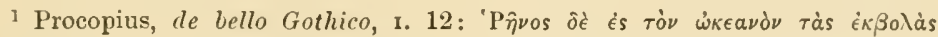

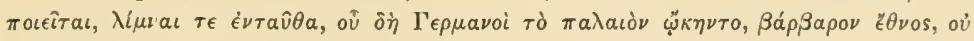

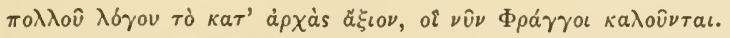

${ }^{2}$ Ars Veterinaria, 1v. 6. 2: ad bellum Hunniscorum longe primo docetur utilitas patientia laboris, frigoris, famis. Toringos deinde et Burgundiones iniuriae tolerantes. Tertio loco Frisiscos non minus velocitate quam continuatione cursus invictos. Postea Epirotas, Samaricos, ac Dalmatas, licet contu. maces ad frena, habiles armis [ac bellis] asseverant. 
common soldier. "He happened to be riding at that moment a horse well tried in war and who knew well how to carry his rider through in safety. All his body was dark-coloured, but his face from the top of his head to the nose was pure white. Such a horse the Greeks called phatios ('bald') and the barbarians balas ('bald'). This horse was recognised by deserters from Belisarius, who had joined the Goths, and they immediately shouted out, "Strike the bald-faced horse." Nothing but the devotion of his body-guard saved Belisarius and his noble charger"

The gallant war-horse here described must have differed essentially from the ordinary post-horses of the day, which were kept at the public expense along the great roads of the Empire, and on which Belisarius himself once made a memorable journey, when Justinian, on hearing that the Persians had invaded his dominions, sent Belisarius to oppose them. "Riding on the public horses which are commonly known as veredi (German Pferd), inasmuch as he had no army with him, with great speed he reached Euphratesia 2."

As we may assume that Belisarius' well-tried charger is a fair representative of the best war-horse of the time, it is now clear that already by the beginning of the sixth century a dark-coloured animal, probably either dull black or darkbrown with a white blaze on the face,-features which we have seen to characterise the large cross-bred horses of Asia, North Africa, and Spain-was already the typical war-horse of Europe; and it is not improbable that the Thuringian, Burgundian, and Frisian horses, so highly praised as war-horses by Vegetius, may well have been of a similar dark colour, especially in view of the fact that from before the Christian era the fine cross-bred horses of Northern Spain were iron-grey, a colour which easily passes into black. The Roman contorniates (Fig. 92) of the

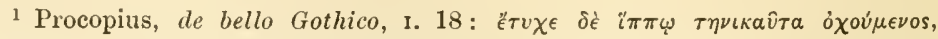

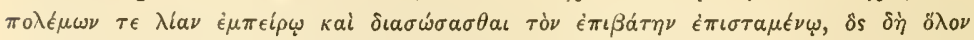

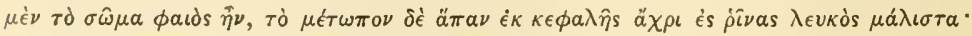

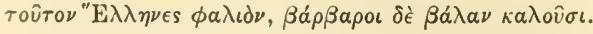

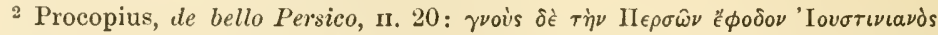

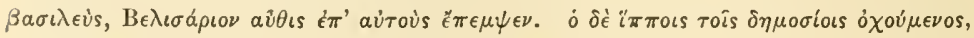

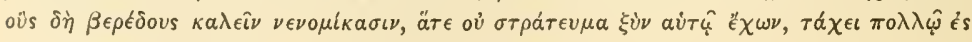

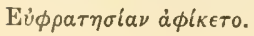


fourth century A.D. give us representations-probably more or less faithful-of the war-horses in use when Vegetius was writing. The passage of Procopius just cited shows that the Goths who marched on Rome in Justinian's reign (.527-565) were amply supplied with eavalry, their nobles apparently being all mounted men.

On the other hand the Franks and their kinsmen and neighbours, the Angli and the Werini, do not appear to have kept horses or taken to cavalry till a time much later than the peoples of whom we have spoken. Indeed it will presently be

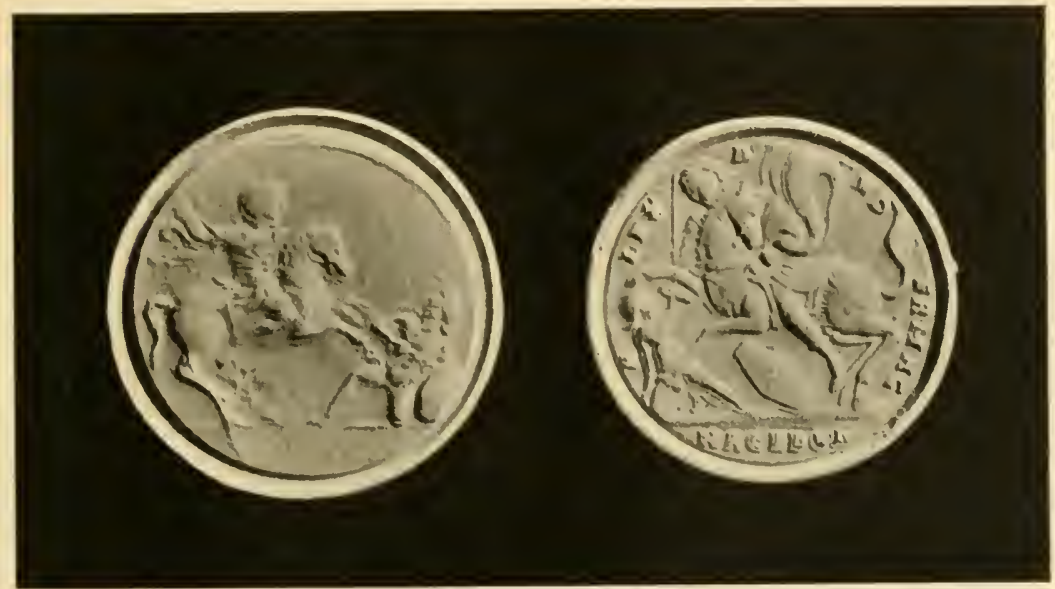

Fig. 92. Roman Contorniates; 4th century A.D.

macle clear that the Angles at the time of their settlement in Britain had no cavalry, and that their neighbours the Werini, when attacked by an expeditionary force of Angles from Britain, did not employ any horsemen.

It is highly probable that the Franks had not cavalry until under Clovis (481-511) they marched against the Thuringians, defeated and slew their king, and reduced the whole nation to subjection; and later on making war on the Burgundians reduced them likewise, and treating them as "captives of the spear" compelled them thenceforth to serve with them in war, and took over all the territory which the Burgundians pre- 
viously held, and rendered it subject to tribute'. When later on the Franks invaded Italy, it is not improbable that the inconsiderable body of cavalry which accompanied them may have been furnished in part at least by the Thuringians and Burgundians, for the use of cavalry seems at that time to have been quite alien to their national method of warfare. This small body of horse alone carried spears. All the rest were footmen, who had neither bows nor spears, but each had a sword, a round shield (aspis) and a double-axe (pelekys), which had a thick iron head very sharp at each end, and a short wooden helve. This they hurled against the enemy at the first onset, and then fell upon them with their swords ${ }^{2}$.

After their return from Italy, where numbers of them through climatic conditions unfavourable to their race had dier of dysentery, they occupied Provence, captured Marseilles and other places on the seaboard, and got control of the sea in that quarter. Their chiefs settled at Arelate (Arles), and there presided at horse-races and issued gold solidi from the proceeds of the Gaulish mines, stamped with the effigy of the Frankish king instead of the head of a Roman emperor ${ }^{3}$.

The race-horses viewed by the Franks at Arles were probably of the light, swift stock bred by the Ligurians from at least the second century B.C., descendants of which we have recognised in the grey Camargues of to-day. Thus by the sixth century the Franks had got possession not only of the warhorses of the Thuringians and Burgundians, but also of the light fast horses of Provence, and the good geldings of Northern France commended by St Jerome two centuries earlier. It was but natural that the Franks and other tribes like them, who had been slow to adopt cavalry, should from that time forth begin to employ the new arm. We know from Bede that the Angles began to use saddle-horses in the seventh century, and, if the island-dwellers took thus to riding, it is probable that their kinsfolk on the Continent had begun to ride and to breed horses of the Burgundian, Thuringian, and Frisian stocks at a still earlier date. It is from these that the large black

1 Procop. de bello Gothico, I. 13.

2 Ibid. II. 25.

3 Ibid. IIr. 33. 
horses, for which Germany, Flanders, Holland, Friesland, and Denmark have been famous from the early Middle Ages, are all descended.

The need of horses capable of carrying men of large size led to continual efforts to breed larger and stronger horses, which were rendered still more necessary by the fact that from the early centuries after Christ horsemen began to wear some form of defensive armour. This in the north took the form of a hauberk or shirt of mail, and added to the weight which the steed had to carry.

The history of Teutonic chivalry is closely bound up with that of these great horses, whose pedigree we trace from the horses of the Tencteri, in whose equestris disciplina we can recognise the first germ of that military system which was to dominate all Europe through many centuries. A chief feature of the feudal system was that he who possessed a certain amount of land should serve as a fully-armed horse-soldier. We have seen that among the Tencteri in the time of Tacitus horses were bequeathed along with the slaves, the dwelling and the usual rights of iuheritance, not to the eldest son, as was the other property, but "to the most warlike and courageous," and it was to the same people the historian probably referred when he stated that the bridegroom brought such gifts as a caparisoned horse, a shield, a lance, and a sword, or in other words the full equipment of a horse-soldier. The laws of the German tribes show us the transition from the tribal system into feudalism. Thus in the "laws of the Anglii, and Werini, that is the laws of the Thuringians" (which as they stand were probably promulgated by Charlemagne in 802 , though the institutions which they reveal go back to a much earlier period), it is ordained that "to whomsoever the inheritance in the land shall come, to him ought to pertain the coat of mail, i.e. birnie, and the avenging of the next of kin, and the payment of wergelt ${ }^{1}$."

Since in the time of Tacitus the German did not hold land in severalty, that writer does not mention any obligations connected with the possession of land, but we are told that the

1 Pertz, Mon. Hist. Germ., Leges, Vol. Iv. pp. 118 sqq. 
horses went to the most valiant son. But by the time when the laws of the Thuringians had taken the shape in which they were ratified by Charlemagne the hauberk goes along with the land, though we hear nothing about the horses. Yet already when Vegetius was writing (circ. 380 A.D.) the Thuringian shared with the Burgundian the place of honour amongst all warhorses next after the Hunnish. But as the hauberk was essentially the equipment of a horseman, we have now reached the period when the possession of land, of a hauberk, and of horses entailed certain obligations. Here then already well developed is the great system of chivalry which dominated medieval Europe, and has left its imprint on the national life of most European countries down to this very hour. The principle that he who possessed a certain amount of land must serve as a warrior, wearing a coat of mail and mounted on a horse, had evidently been fully developed by the 'Teutonic tribes at least a century (and probably much earlier) before the time of Charlemagne. And well was it for the world that this was so, for in the seventh century had arisen the most terrible enemy that Europe had ever known. Muhammad had founded a new religion, and the conquering bands of Arabia had rapidly overrun a great part of Asia, conquered Egypt, and become masters of North Africa west of the Nile (A.D. 647-709). Here, as we have seen, they became possessed of the splendid horses of Libya, and soon they crossed into Spain to bear northwards the Crescent (A.D. 710). By the beginning of the eighth century the Saracens had become firmly established in Spain, and had begun to advance into Gaul, and even to threaten the great empire of the Franks. The torrent poured over the Pyrenees and down upon Septimania. Narbonne fell at once, and its fall settled the fate of the surrounding region, and at once the Saracen domination superseded that of the Visigoths as it had done in Spain. The Saracens soon threatened Aquitania, then ruled by Eudes, formerly Duke of Toulouse, and who had been the rebellious vassal of the three weak Merovingian kings, whom Charles, the mayor of the palace, had crowned. Eudes vanquished the Saracens on the field of Toulouse, and for a brief season their progress was checked. But soon 
fresh bands swarmed over the Pyrenees, and Eudes, pressed hard, had to purchase peace from one of the Saracen captains, by name Munuza, by giving him his daughter Lampagie in marriage. But this only gained him a short respite, for Mummza was soon defeated by Abdalrahman, a chicftain of the Spanish Saracens, who in his turn invaded Aquitania. Eudes was involved in war against the invincible Charles, now head of all the Franks, at the moment that he was threatened in the south by the common enemy of all Christendom. His army was annihilated before Bordeaux, and the Moslems reduced that city to ashes. Aquitania was ravaged and its people massacred. In this sore strait Eudes determined to submit to Charles rather than to the infidel, and he betook himself to the Court of the former, acknowledged him as his suzerain, and asked for and obtained the aid of the Franks. Charles roused all the warriors of Neustria, Austrasia, and Western Germany. His appeal met with a hearty response, and men flocked to join his standards. On the plains of Poictiers in October, 732, the Franks met the Saracen host. For seven days the armies watched each other without joining battle. At last the Moslems drew up in battle array on the plain, and Abdalrahman's cavalry, mounted on the light, swift horses of Barbary, commenced the fray by a rain of arrows, and then poured down like a whirlwind on the Teutonic host. The Franks, large of limb and clad in mail, sat immovable on their northern horses, which were of a heavier build than those of their foes, and opposed a compact and unbroken fiont to the repeated charges of the Saracens. Then a war-cry was heard in the rear of the Moslem army, for Eudes and his Aquitanians had turned the enemy's flank, and fired their camp. To meet this sudden danger part of the Saracens wheeled round, and thus their line became broken and disordered. Charles ordered his men to advance, and the men-atarms of Germany fell upon the light Saracen horsemen, and mowed them down with their battle-axes and huge swords. Abdalrahman fell in a vain attempt to rally his troops'. Night alone stayed the slaughter. When the sun rose, nought

3 Isidor. Pac. c. 59: gens Austriae mole membrorum praevalida et ferrea manu perardue pectorabiliter ferientes regem inventum exanimant. 
of the Saracens could be seen but heaped-up carcases as far as eye could reach. The flood tide of Saracen conquest had spent its force against the immovable bulwark of Teutonic chivalry, never more to return. Western Christendom was saved, and no small part of that deliverance was due to the stout horses which carried the mail-clad Frankish warriors, for without good horses the northern host must have fallen before the swift horsemen of Africa as inevitably as the Romans and Gauls were routed by Hannibal's Numidians more than nine centuries before. But the Franks rode upon the descendants of those horses which from the second century before Christ the Gauls had kept steadily importing from the south, and whose blood the Tencteri had later on acquired.

We have seen that the large old breeds of Germany and Denmark are included by Sanson in his E. c. germanicus and the horses of Friesland, Holland and Flanders under his E. c. frisius (p. 2). He considers that when the barbarians of Germany and Scandinavia fell upon the Roman world in the early centuries of our era, these horses passed with them into their new settlements, - with the Angles and Saxons into Britain, with the Northmen into Normandy, with the Burgundians into France and Switzerland, into Italy with the Lombards, and finally into Spain and North Africa with the Vandals. But the historical evidence has made it clear that this breed of horse was not developed in North Germany or Scandinavia, where we have seen that it was only at a comparatively recent date that the grey and black horses began to supersede or supplement the old dun and white horses of the North.

In Caesar's day the Germans possessed no good horses (p. 114), and when Tacitus wrote only tribes such as the Tencteri, who were in close contact with the Gauls (p. 115), had been able to acquire good horses and organise a cavalry. As the latter historian in his account of Germany carefully describes the military resources, arms and dress of each tribe, we may safely infer that, when he does not call attention to their horses, such tribes did not possess any, or at least any of 
superior quality. Thus when treating of the Frisians ${ }^{1}$, he says nothing about horses, but when he proceeds to the great nation of the Chauci ${ }^{2}$, the next neighbours of the Frisians, he mentions that they used horses in warfare, though his words clearly indicate that they had no organised cavalry like the Tencteri. The Langobardi (Lombards), though characterised as vigorous warriors, able to maintain their independence in the midst of powerful neighbours, are enumerated amongst a number of North German tribes "none of whom have any noteworthy feature ${ }^{3}$," and several of which, such as the Anglii and Varini, did not possess horses even in the 6th century A.D. Again, thongh Tacitus ${ }^{4}$, like Pliny ${ }^{5}$, knows of the Vandals, he makes no mention of cavalry or horses in connection with that nation. It is therefore clear that the Angles did not bring the large black German horse with them into Britain, when they colonised that island, and it is very improbable that the Northmen brought them to Normandy, for their famous chieftain Hrolf the Ganger is proved by his surname to have habitually travelled and fought on foot, a practice which can only be ascribed to the want of horses, or to the circumstance that any horses which the Northmen then possessed were only the old North European animals, not suited to carry men of large stature in war. The good horses of the Burgundians, the Thuringians, and the Frisians must have been either obtained from Gaul, or have been developed out of good horses derived from Gaul, between 100 A.D. and the time of Vegetius. If then the Lombards and Vandals brought large black horses into Italy, Spain, and Africa, they must have acquired these animals from the Thuringians, Burgundians or Frisians after the time of Vegetius. But, as we have good evidence that the Gaulish horses were the result of crossing the old European horse with North African blood derived through Spain and Italy, it is clear that Sanson's E. c. germanicus and E. c. frisius are in no sense separate species or varieties, but merely breeds obtained by crossing the European and African horses, by artificial selection, and by the conditions of climate and pasture.
1 Germ. 34.
2 Ibid. 35.
${ }^{3}$ Ibid. 40.
+ Ibid. 2.
5 H.N. Iพ. 14. 28. 
Moreover, it has been shown that horses of increased size and black or dark-coloured were bred in Mediterranean lands long before the Christian era by crossing the Libyan horses with those of Upper Asia and Europe.

As time went on the desire for horses of great size steadily grew, for the hauberk towards the close of the 12th century gave way to armour of interwoven chain, whilst the latter in its turn from 1300 onwards was gradually superseded by plates of metal, until by the beginning of the 15 th century the knight

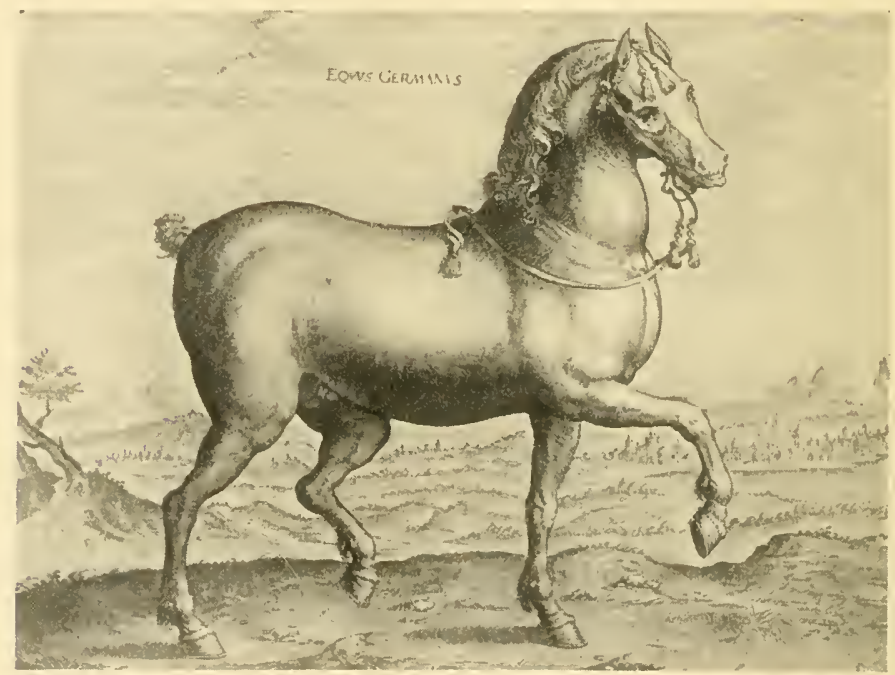

Fig. 93. The German Horse.

was sheathed from head to foot in a complete panoply of plate armour. As has been well pointed out, this ever-increasing weight of armour demanded horses of increased size and strength, and to this cause is undoubtedly due the development of the large breeds of Flanders, France, Friesland, and Germany, which by the 16th century were capable of carrying a rider who with his own armour and that of his steed weighed about 32 stones.

Blundeville thus describes the German horse, termed by him the 'High Almaine': "The Almaine is commonlie a great 
horse, and though not finelie, yet verie stronglie made, and therefore more meete for the shocke than to pass a cariere, or to make a swift manege, because they be verie grosse and heavie, yet by industrie they are made lighter behind than before: for their rider's do use in their maneging to make them to turn alwaies with their hinder parts, and not with their fore parts:...The desposition of this Horse (his heavy mould considered) is not evill, for he is verie tractable, and will labour indifferentlie by the way, but his pace for the most part is a verie hard trot."

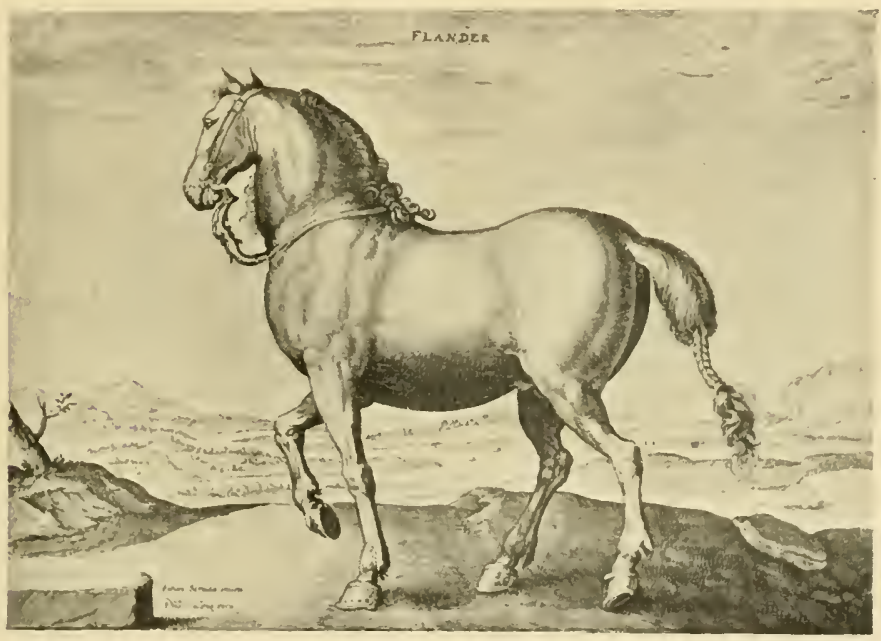

FIG. 94. The Flanders Horse.

Stradanus' drawing of the German horse, here reproduced (Fig. 93), adnirably illustrates Blundeville's words.

As might have been expected, the horses of the Low Countries were very similar to the German. They are especially interesting for our purpose, inasmuch as it was on the Lower Rhine that the German tribes first obtained horses of a superior kind to mount an organised cavalry. Blundeville speaks thus of the Flanders horse: "The Flanders Horse in his shape, disposition, and face, differeth in a manner nothing from the Almaine Horse: saving that for the most part he is of a greater stature, and more puissant. The Mares also of

1. H. 
Flanders be of a great stature, strong, long, large, fair, and fruitfull, and besides that, will endure great labour, as is well seen, for that the Flemings do use none other draught, but with those Mares in their wagons, in the which I have seene two or three Mares to go lightlie alwaie with such a burthen, as is almost incredible." I here give a reproduction of Stradanus' drawing of the Flemish horse (Fig. 94).

Under the names of Sicamber and Juliacus two horses almost identical with the High Almain and Flanders breeds are given by Stradanus and here reproduced (Figs. 95, 96).

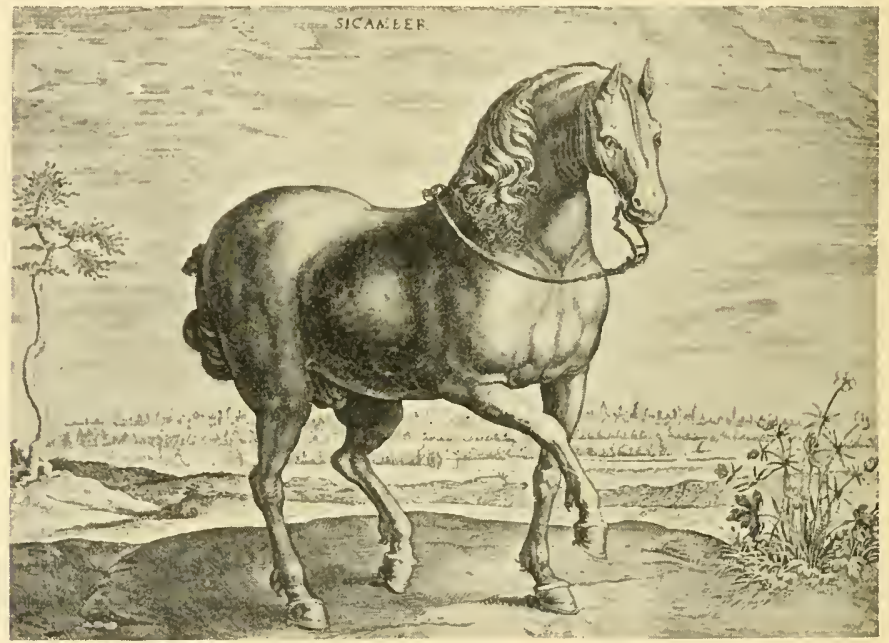

FIG. 95. The Horse of Cleves'.

These horses are of peculiar interest for our investigation. The Sicamber is the horse bred in the district on the left bank of the Lower Rhine occupied at the beginning of our era by the German tribe of the Sicambri, who came immediately north of the Tencteri. The Juliacus is so termed because it was bred in the district round the ancient Juliacum (Juliers), which stood in the hilly country in the district held by the Tencteri and Sicambri. The distinctive tribal names of Sicambri and Tencteri disappeared later on under the general appellation of

1 Doubtless it was such an animal that suggested Henry VIII.'s remark about Anne of Cleves. 
Ripuarian Franks. In medieval times the duchy of Cleves ronghly corresponded to the ancient territory of these two tribes.

We have thus a breed of great horses developed in the very district where the Tencteri, in the century after Christ, were the first of all the German tribes to discard the old indigenous small ugly horses in favour of a superior breed obtained through Gaul where fine breeds had been produced by crossing the old European horses with Libyan blood from Mediterranean lands,

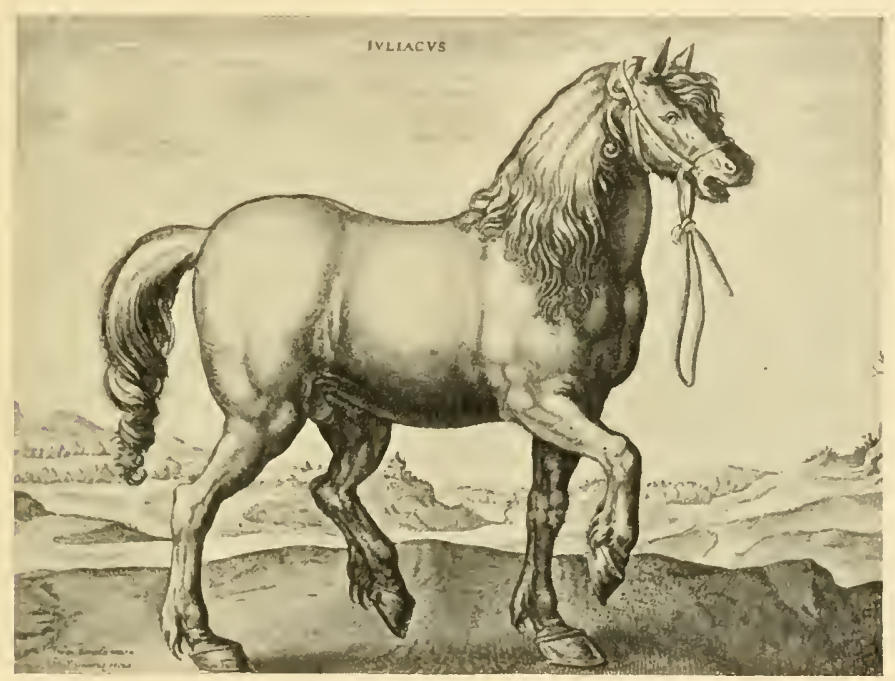

FIG. 96. The Horse of Juliers.

and to develope that organised cavalry system which was the starting-point of Tentonic chivalry. It is more than probable that many of the stout horses that carried the Frankish warriors to victory at Poictiers were the posterity of the first horses which the Tencteri had acquired from the Gauls, and some of whose blood may have been derived from the twenty horses brought back from Italy by the Gallic chieftains in 172 B.C.

We have seen that already in the fourth century A.D. Vegetius praised the Friesland horses, and though by the later medieval period they were not so much esteemed as the 
horses of Flanders and Germany, they evidently still had great merits, since Stradanus, in the "Stable of Don John of Austria," shows one of these animals (here reproduced, Fig. 97), and Blundeville gives a description of this breed: "The Frizeland Horse is no verie great Horse, but rather of a mean stature, being therewith strong and well compact togither, and hath verie good legs. And Vegetius saith that the Frizeland Horses be verie swift in running, and able to maintaine a long course. And indeed I have seene of them myself, that would make a

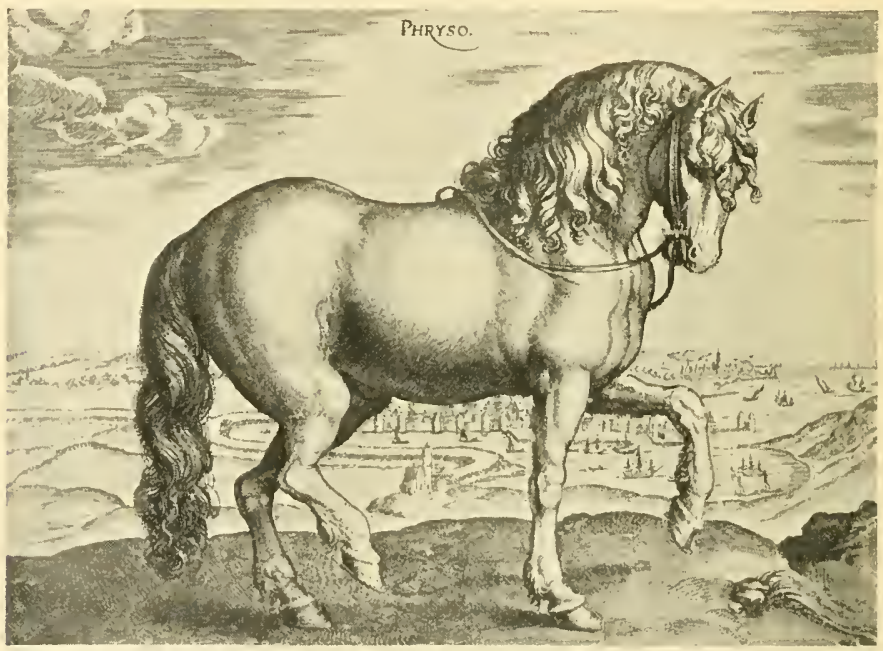

F1c. 97. The Friesland Horse.

good cariere and manege verie well, and also do the curvet so trulie as anie jennet of Spain." Blundeville adds that "the disposition of this horse is so devilish that he requires extreme care in breaking and handling. The pace of this horse is a good comely trot."

New conditions of life required a different animal, and by breeding the old war-horse was gradually modified into a stately coach-horse and into an animal suited to mount the new cavalry.

Down to the last century the Friesland horse, also known as Dutch, was the noblest breed of black horses in Europe, being 
commonly called 'Hart-draver,' i.e. Fust-trotter, and from them were derived the Norfolk and Russian Trotters. The Friesland Carabiniers were formerly mounted on them'.

Indeed down to modern times the Dutch, Hanoverians, and Hessians mounted their light cavalry on black horses of a lighter type from Holstein and Denmark, whilst they drew remounts for their heavy cavalry largely from the heavier black horses bred in Westphalia?

The horses of Holstein and Jutland were very similar to

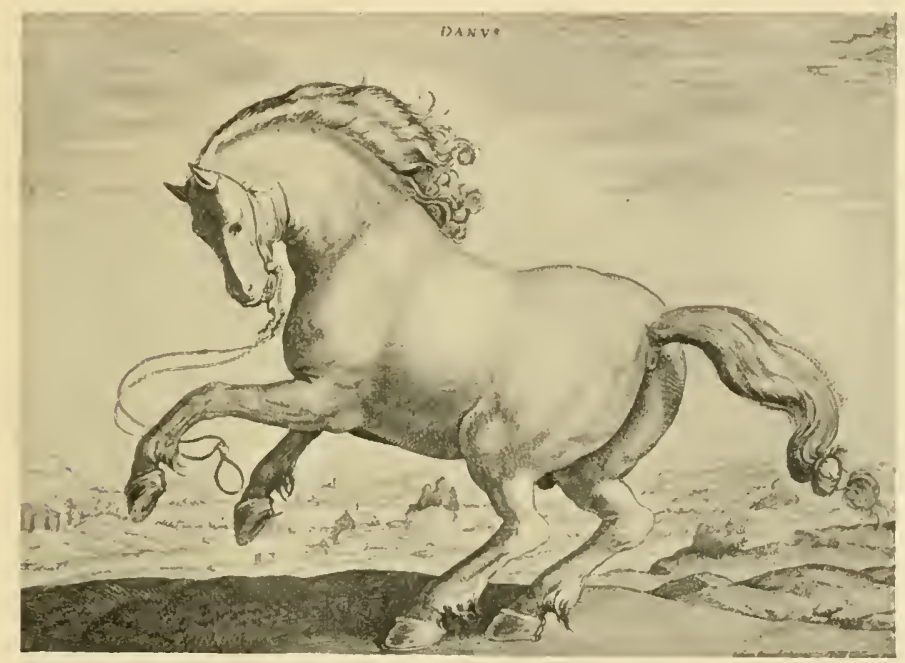

F16. 98. The Danish Horse.

those of the neighbouring lands, as is obvious from the drawing of the Danish horse (Danus) given by Stradanus and here reproduced (Fig. 9S).

The ordinary agricultural horses used in modern Belgium are of the same type as the Dutch and Frisian.

Let us now pass to the horses of modern Germany and contiguous lands. As in medieval times military necessities influenced almost entirely the type of horses bred in Germany, so is it to-day. The Rhine Provinees, where the breed of great

1 Hamilton Smith, op. cit. p. 271. 
war-horses developed, are still the principal centre in Germany for the breeding of heavy horses, but the number bred even there is but scanty, for as late as 1897 only 9 per cent. of the cart-horses in that area were home-bred ${ }^{\text {. }}$.

The lighter breeds developed out of the old great horses to meet the needs of altered conditions of warfare, and the requirements of coaches and carriages (termed intermediary breeds by some foreign writers) are held by Sanson to be simply varieties of his $E$. c. germanicus. They inhabit all North Germany, the chief centre of production being SchleswigHolstein, but they are diffused through Mecklenburg, Oldenburg, Hanover, Jutland ${ }^{2}$ and other areas. Though they have all a family likeness, they can be divided into three principal groups-Hanoverian, Mecklenburg, and Danish.

When armour was discarded completely in the latter half of the 17 th century, the great horses that carried the men-at-arms of older days were no longer fitted for the new cavalry. Hence attempts were soon made to modify the old breed by an admixture of southern blood and thus to obtain strong but lighter horses capable of carrying a soldier not encumbered with armour.

The Hanoverian breed owes its origin to our Hanoverian kings, by whose influence many English thoroughbreds were sent from England from the time of George I down to 1837. The Hanoverian hor'ses are bred on the fertile pasture of the Elbe, the Weser, the Ems, and their affluents, the chief horsebreeding centres being the districts of Stade and Celle ${ }^{3}$. The object of the breeders has been to produce strong half-breds of high quality, the lighter specimens of which are adapted for saddle-horses, the heavy to serve as coach-horses. Althongh well-bred, they are big and heavy and are used more for draught than for saddle. The old Hanoverian horse may be said to have disappeared since 1746 .

Near Osnabruck is the stud of Drenthe horses, which originally came from Drenthe in Holland. They are black and they supply London with funeral horses".

\footnotetext{
${ }^{1}$ Hayes, op. cit. p. 517.

2 Cuyer and Alix, op. cit. p. 624.

${ }^{3}$ Hayes, op. cit. p. 513.

${ }_{4}$ Hayes, op. cit. pp. 514-5.
} 
The Mecklenburg horses formerly comprised a type for carriages of luxury, a type for the saddle, and a common type, but the latter has now disappeared. The best class of the old Mecklenburg were trotters, but the old type has been so modified by English blood as to approach the latter closely. At the present time almost all the superior horses bred in Mecklenburg are sold as hor'ses imported from England'.

The principal centre of production of the Danish horses is the border of Oldenburg. The Oldenburg horses have many

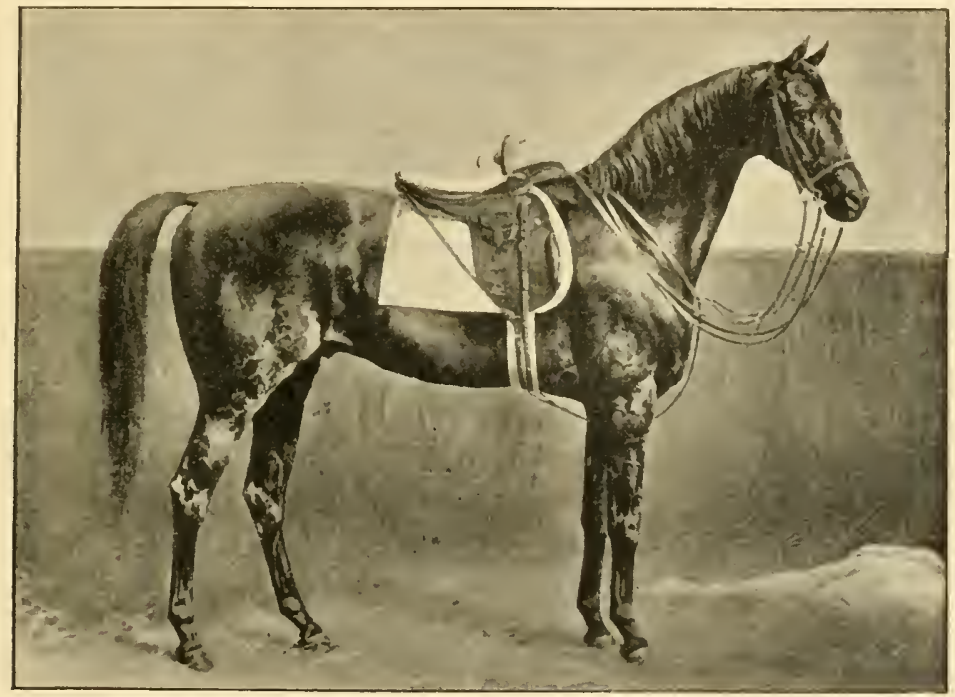

Fia. 99. The East Prussian Horse.

grave defects-heavy heads, weak backs, bad ribs, long legs covered with hair in the lower parts, flat feet, brittle hoofs, and want of endurance. They make carriage horses, very fow being fit for the saddle, but to-day they are really farmers' horses ${ }^{2}$.

In the 17th and 18th centuries the old Danish horses (Fig. $98)$, which though sturdy were somewhat small, were much modified and increased in size by the introduction of Spanish,
1 Hayes, op. cit. p. 516.
2 Hayes, op. cit. p. 517. 
Neapolitan, Turkish, English, and Dutch blood, and the superior Danish horses thus produced had a very high reputation ${ }^{1}$.

In certain coast districts are found small ponies, which are generally of a grey colour, and resemble Iceland ponies. These animals, which live entirely in the open and in a semi-wild state, are probably in large part descended from the fallow-dun and white horses of the age of Beowulf, their grey colour being due to the cross with southeru blood.

The East Prussian (Fig. 99) are the best horses in Germany, and they "bear somewhat the same relation to other German horses as Irish horses bear to English horses?" The chief centre is the stud of Trakehnen, from which the famous breed derives its name. It was founded in 1732 by Frederick William I, the father of Frederick the Great. Its original stock consisted of 1101 animals from the then royal studs, but the importation of some Arabs and many English thoroughbreds has greatly improved the East Prussian breed. The Trakehnen horse has a good temper, great endurance, a fine head, a well-formed tieck, a strong back, and he is well ribbed-up. As a rule the depth and slope of his shoulders are not satisfactory, he is inclined to be rather long-legged, and he looks a little too light for his height.

Wirtemburg possesses a notable breed of horses, the best of which result from imported Arabs with an admixture in a small degree of the English thoroughbred and the Trakehnen. This breed is the outcome of the royal stud established at Stuttgard ${ }^{3}$ in 1817.

Through the introduction of English thoroughbreds the Bavarian horses have been entirely modified and are chiefly 'Oriental' in origin. 'The best specimens are larger than the Arabs and are less troublesome than the true English thoroughbreds ${ }^{4}$.

Switzerland possesses several breeds of heavy horses, apparently derived from the old medieval black war-horses, which in their turn were probably descended from the horses of the Burgundians praised by Vegetius. Of these the Laumont breed,
I Hayes, op. cit. pp. 524-5.
2 Hayes, op. cit. pp. 510-1.
3 Cuyer and Alix, op. cit. p. 626.
4 Cuyer and Alix, op. cit. p. 626. 
found in the Bernese Jura, is an excellent draught-horse, whilst the black Erlenbach is more elegant and would almost make a trotter ${ }^{1}$.

Austria-Hungary possesses many good horses, but with those of Hungary we have ahready dealt. The horses of Austria may be classed as (1) indigenous breeds about 14 hands high, rather angular in shape (reminding us of Vegetius's description of the Hunnish horses, p. 319), good workers, and closely resembling the ponies used by Russian peasants ${ }^{2}$. It seems certain that in these animals we have the descendants of the ancient ponies of the Damubian region, such as those driven by the Sigynnae, and their resemblance to the country ponies of Russia confirms the conclusion that we have in them the old European-Asiatic horses more or less modified by crossing with superior blood. (2) There are half-bred saddle and carriage-horses, and (3) special breeds of which the most notable are the following.

The Haflinger ponies are used in the mountains; they are about 13:3 hands high, and are used for dranght and riding, at which they excel as they are extremely sure-footed. They are very slow, but very safe.

The Bosnian ponies are from 12 to 13 hands high and are strong, hardy, and enduring.

The Kladrub breed, so called from the imperial stud at Kladrub in Bohemia, is likewise often termed the large Spanish. From the close connection between Austria, Spain, and Italy during the reigns of Charles $V$ and some of his successors, many horses were imported into Austria and Bohemia from the former commtries, and from these has resulted the Kladrub breed which is used only for imperial purposes and by the archbishop of Olmutz in Moravia. The chief characteristics of this breed are their Roman noses, arched necks, heavy crests, great height (the most valued standing from 17 to is hands high), extravagant action, and the perpendicular position of their necks when in harness. This characteristic they probably inherit from their Spanish ancestors, which had similar conformation and action. As these characteristics are greatly admired, they have naturally been accentuated by artificial

1 Cuyer and Alix, op. cit. p. 653.

${ }^{2}$ Hayes, op. cit. pp. 526-7. 
selection. They are bred only in two colours-black and white. The Austrians regard them as the finest and handsomest type of carriage horse in the world, though their trotting speed is limited to two or three miles an hour'.

The Lippizaner horses, bred at Lippiza near Trieste, are chiefly of Eastern origin. Their proper colour is grey, which is now more or less varied, owing to crosses with English halfbreds, which have unfortunately altered the former type a good deal. They are generally not over 15.1 hands. They are greatly used in the imperial stables, and in some parts of Austria, as carriage horses, not being well adapted for the saddle.

The Pinzgauer, so called from Pinzgau in Styria, are Friesland in origin, and they are used as draught-horses all over the Austrian empire. Their typical colour is red-roan with characteristic bay spots on the haunches: "they resemble Suffolk Punches by their shape and by the absence of long hair below the knees and hocks. They stand about 16.2 hands high"."

It is now clear that all the good breeds of Germany, the Low Countries, Denmark, Switzerland and Austria, whether they be heavy, light, or intermediate, all owe their superiority to the fact that they are either almost wholly derived (like the Wiirtemburg, and Trakehnen) from Libyan ancestry, or else have that blood in their veins in varying degrees, due account being also taken of the condition of climate and soil under which certain breeds have long lived.

We saw at an earlier stage that the horses of Scandinavia, at the date when Beowulf was composed, were dun, apple-dun, and white, that in the list of gods Heimdal rode on a yellowmaned horse, Odin on his grey steed, eight-legged Sleipnir (Fig. 1(00), whilst in the later list of horses names such as Hrafn (raven) and Soti (sooty) occur, showing that black horses had by that time come into the possession of the northern peoples. That such horses were obtained from the countries lying south of the Baltic we can have no doubt after the evidence for the origin of black horses which we have passed in review. But 1 Hayes, op. cit. pp. 526-7.

2 Hayes, op. cit.pp. 527-9. 
the black horse though greatly esteemed never managed to get a strong foothold in Scandinavia, for, as has been pointed out, the Norwegian and Icelandic ponies continued to be dun, skewbald, and piebald down to the present, and there is good evidence that even in the sixteenth century, when large black horses were very general all through the Low Countries, Denmark and Germany, many Swedish horses were not very fur removed in colour from what they had been in the days of Beowulf.

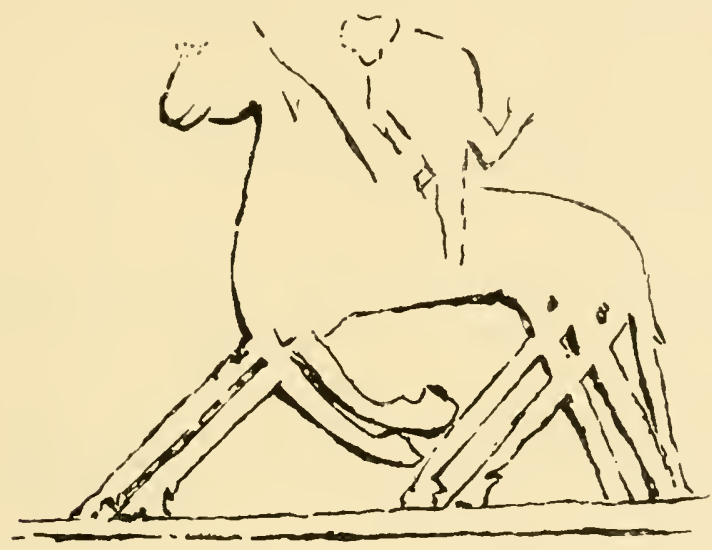

FIG. 100. Sleipuir, the grey eight-legged horse of Odin ${ }^{1}$.

(From a Swedish rock-carving.)

Olans Magnus ${ }^{2}$ says that the horses of Sweden were particularly well adapted for travelling through marshy, hilly, and forest country, that the Norwegian horses were of moderate size, strong, and courageous, and particularly excellent in mountains and rocky ground, that the ponies of Oeland were very diminutive and therefore of little use, and that any good

1 From a photograph kindly sent to me by my friend Dr Oscar Montelius, Director of the Stockholm Museum. The grotesque conception of a horse with eight legs to give him extra speed may have been suggested by a two-horse chariot. On the earliest British coins (Evans, Coins of the Ancient Britons, Pl. I) the two horses of the biga on the coins of Philip II of Macedon have been converted into a single horse with eight legs.

2 Gothorum Sueonumque Mistoria, Lib. xvir. cap. 8 (ed. Rome, 1555). 
ones amongst them were of a different breed, whilst he characterises the Finnish horses as of excellent quality. He states that horses of very large size were bred in Scandinavia, especially in the kingdom of the Vestrogoths (Gothland), where they were reserved entirely for war, and he says that they bore comparison with the noble horses of Spain, Naples, France and Germany, though he admits that in speed they could not contend with the horses of Africa, Numidia, or Turkey, yet they compensated for this defect by their superior strength. There can be no doubt that these large war-horses of Scandinavia were black, as were the largest and strongest horses of Europe and Western Asia, for Olaus Magnus, when discussing the marks of a strong horse (valens equus), and placing horses in order of merit according to their colours, set the black at the head of his list: "The black, the red, the bay, the bay of the colour of the date or of the chestuut (the colour which Virgil commends in the Georgics), the golden (golden bay), the rosy, the myrtle-coloured, the iron-grey or dappled grey, the patched (i.e. pied), the silver-grey, the flea-bitten grey, the colour composed of black and bay. The ashy-coloured which is the livery of the wild horses is the worst, as Isidore says, but it is best when it is marked with a broad black dorsal stripe. A white horse is seldom good for travellers because of the onset of robbers, who watch the roads from lofty fastnesses, and it is dangerous for wayfarers to tempt them by riding white horses, as it were by lighting a candle in the dark ${ }^{1}$."

It is thus clear that the horses obtained by crossing the old European blood with the Libyan were the best, whilst the old uncrossed dun horses and white horses were the least esteemed,

1 Olaus Magnus, Gothorum Sueonumque Historia, xvir. cap. 9 (ed. Rome, 1555): Adhuc de aliis signis valentis equi...colore niger, rufus, balius sive badius spadicus palmae colore, vel castaneae quem Virg. in Georgi. commendat. Aureus, roseus, myrteus, glaucus, vel oculis variis quasi pictus. Sartulatus, canus, guttatus, varius ex nigro badioque distinctus. Cinerius qui equis sylvestribus convenit deterrimus ut Isidorus dicit, sed optimus quando lata linea nigra in dorso notatur. Candidus equus raro est bonus viatoribus ob insultum latronum ex castris eminentioribus itinera contemplantium: quos periculosum est (tanquam lucerma in tenebris accensa) candidis equis ad spolian. dum itinerantes provocare. 
the dun with a dorsal stripe being, as in Iceland, in Norway, and in Kattywar, the best of the duns; and as in Java, in India, and in Tibet, pied horses have arisen with the crossing of Upper Asiatic with 'Arab' blood, so in Sweden pied horses made their appearance along with the intermixing of the indigenous northern horses with those of Africa.

Stradanus does not show us a typical Swedish horse, but Blundeville has left us an excellent description from personal observation: "The Sweacian or Sweathland Horse, so farre as I ean conjecture, by those that the King his ambassador's have of late daies brought with them into this realme, whereof I am sure there be divers here yet remaining, is no great or strong Horse, but of a meane stature and strength, and I fear me scant well conditioned, and I am induced to think so the rather, for that they be most commonlie pied, and of two sundrie colours: or their legs at the least be all white, even up to the belly, their bodies being of another colour, which as Grison saith, is a sign of small force: albeit the gentlemen in that countrie delight much to have their horses of divers colours, and to weare as it were diverse liveries. Besides that, manie of them be wall eied, which is also a token of a shrewd and stubborne disposition. Notwithstanding I have seene of them with good handling to make an indifferent good manege, whereby I take them to be docible."

As the horses seen by Blundeville had been brought over by Swedish ambassadors, we may safely assume that they were good specimens of the typical horses of Sweden at that time.

In Blundeville's description we at once recognise a type of animal well known still in Sweden, Norway, and Iceland, and which are commonly piebald, skewbald, white, or dun with stripes on the back, and not unfrequently with markings on the face and legs.

As piebalds and skewbalds commonly occur among the ponies of Java and not unfrequently amongst the countrybreds of India, both of which are the result of crossing Upper Asiatic and Arab (i.e. Libyan) blood, as also the dun-coloured striped horses of Kattywar have a similar origin, and as it is almost certain that the same holds true of the piebald tangums 
of Tibet, we may safely conclude that the Swedish pied horses are descended from the old European dun-coloured horse, crossed with Libyan blood. How that blood has got into Scandinavia and Iceland we shall see when we have first dealt with the horses of the British Isles.

Before passing from the Continent to the British Isles we shall briefly sketch the history of the chief Russian breeds of the present day. Russia in Europe contains about twenty-three millions of horses, divided by MM. de Simonoff and de Moerder ${ }^{2}$ and by Capt. Hayes ${ }^{2}$ into (1) stud horses, (2) agricultural horses, (3) horses bred on the steppes under improved conditions, and (4) half-wild horses. (1) Of stud-horses the Orlov Trotter is the best. This breed was founded by Count Alexis OrlovTchestmensky in the government of Voronej to the south of Moscow. Up to that time there had been no breed of Russian Trotters, but in $\mathbf{1 7 7 5}$ Orlov imported from Greece a horse called Smetanka, described as a pure-bred Arab by Russian authorities, though Sanson and other French writers speak of him as a Barb, but of course for our argument it makes no difference. From the union of Smetanka with a Danish cart mare sprung the stallion Polkan, who by a Dutch mare became the sire of Barrs in 1784. From three sons of Barrs all Orlov Trotters are descended. The Dutch dam of Barrs was of the black hartdraver breed (p. 341) famous for its trotting powers, and which we shall soon find to be related also to the Norfolk Trotter. The dam of the first of Barrs' sons was by an Arab and out of a Mecklenburg mare; that of the second was an English thoroughbred; and that of the third was out of a Mecklenburg mare by a horse named Felkerzamchik, who was the son of Smetanka by an Enghish thoroughbred mare. In 1772 Orlov possessed 20 English stallions and 32 mares, 12 Arab stallions and 10 mares, 3 Persian stallions and 2 mares, 1 Dutch stallion and 8 mares, 1 Danish stallion and 3 mares, 1 Mecklenburg stallion and 5 mares, as well as some other stallions and

1 Les Races Chevalines (cited by Hayes).

2 Points of the Horse (ed. 3), pp. 540-3; cf. Major J. Moore, "Horses of different countries, and supply with relation to military services," Jour. United Service Inst. 1905, p. 235. 
17 mares. "As might be expected from their breeding, the Orlov Trotters are of no distinctive type, and are divided into heavy and light 'Trotters. 'The majority of them indicate the possession of vulgar relations, by their large and hairy fetlocks, fiddle heads and goose rumps. As usual the cart-horse strain comes out in the head, legs, and setting-on of the tail ; and the Eastern blood in the borly."

(2) There is only one heavy Russian breed of draughthorses-the Beetewk, called after the river of that name, on which stands the Voronej village of Shukavka. In 1712 Peter the Great was so struck by the good qualities of the horses of that locality that he imported Dutch stallions to improve the breed, and later on it was crossed with the Orlov Trotter. (3) There are many private breeding farms in the steppes of the Don, Volga, Dnieper, and other parts of Little Russia, which supply the Russian army with most of its remounts. These horses have a good proportion of Arab and thoroughbred English blood in them, are essentially saddle-horses, and as they are brought up on the wild steppes are extremely hardy and very enduring.

(4) The Kalmucks and Kirghis keep many horses in a semiwild condition. They are coarse-bred animals, being chiefly descended from the ancient horses of the steppes (pp. 131-2), and have been far less improved by imported blood than the horses of Little Russia. The Kalmuck horses are about 15 hands high, and many of them are bought as remounts for the Russian cavalry. They are bred in the district between the rivers Volga and Ural. The Kirghis horses, bred in the steppes north-east of the Caspian, have been still less influenced by foreign blood; they are ponies rarely exceeding $14 \cdot 1$ hands in height ${ }^{1}$.

It is thus clear that the more Libyan blood any Russian horse has in its veins, the better it is, and that the nearer it approaches to the original Asiatic-European type, the less valuable is it for the service of man.

When Caesar invaded Britain he found the Belgic tribes, who occupied the south-eastern portion of the island, employing not only cavalry like the Gauls, but also war-chariots,

1 Hayes, op. cit. pp. 551-8. 
which, as we have already seen, the Romans regarded as a most formidable weapon (p. 98). The tribes of the northern parts of the island used only war chariots, as we have learned from Dio Cassius, owing to the diminutive size of their horses. From these circumstances we may not unreasonably infer that, whilst the older tribes of the island used probably the Celtic pony which still lingers in the Hebrides, Connemara, the Shetlands, the Faroe Islands, and Iceland (probably even then more or less mixed with the large-headed Equus caballus of Europe and Asia), the Belgic tribes not only employed the latter under chariots, but had also imported from their kinsmen on the other side of the Straits some of those excellent horses largely of North African blood, which the Gauls, as we have seen, possessed in abundance and on which their cavalry was mounted at the time of Caesar's conquest (p. 99).

We may fairly infer that the horsemen of the Belgic tribes of Kent were mounted on the same kind of horses as their kindred on the other side of the Straits, the best of which, as we have seen, were probably blacks and greys. Though unfortunately Caesar has left no description of the colours of the British horses, yet when we come to deal with the early Irish horses, we shall be able to adduce some evidence to show that already in Roman times horses saturated with Libyan blood and black and grey in colour, like the best horses of Spain and Gaul, were already domiciled in the British Isles (p. 397).

During the Roman occupation the British horses seem to have been of no large size, if we may judge by the iron horseshoes found at Silchester and elsewhere, and which are possibly to be ascribed to Roman times. As the Caledonians and Meatae were certainly still using very small horses in the second century A.D., we may infer that as a rule the horses were nothing more than small ponies, though in the south and east and in other parts in the vicinity of Roman stations the native horses were probably improved by imported animals from the Continent.

The Teutonic tribes who settled in England in the fifth century A.D. were for the most part essentially seamen and 
foot-soldiers, in spite of the fact that the names of Hengist (ef. Germ. hengst = stallion) and Horsa indicate a love for the noble animal, though the veneration in which white horses were held by the German tribes may sufficiently explain the popularity of horse names among chieftain families. But it must be carefully borne in mind that Hengist and Horsa were neither Angles nor Saxons, but Jutes ${ }^{1}$, and it is not impossible that that tribe may have begun to use horses at an earlier period than their kinsmen and neighbours. Though from the names of Hengist and Horsa and from the existence of the famous White Horse cut in the chalk in Berkshire, it has been commonly assumed that the Saxon banners bore the device of a white horse, there is not the slightest evidence that such was the case.

Procopius ${ }^{2}$, writing in the 6 th century A.D. in reference to a war which arose between the Angli settled in Britain and the Varni who divelt on the east side of the Rhine, in consequence of the king of the Varni having repudiated his betrothal to an Anglian princess, thus describes the formel: "These islanders are the most valiant of all the barbarians with whom we are acquainted and they fight on foot. For not only do they not know how to ride, but it is their lot not even to know what a horse is like, since in this island they do not see a horse, not even in a picture, for this animal seems never to have existed in Brittia. But if at any time it should happen that some of them either on an embassy or for some other reason should be living with Romans or Franks or with any one else that hath horses, and it should there be necessary for them to ride on horseback, they are unable to mount, but other men have to help them up and set them on the hor'ses' backs, and again when they wish to dismount they have to be lifted and set down on the ground. Neither are the Varni horsemen, but they too are all infantry. Such then are these barbarians."

Procopius is of course quite mistaken in the belief that there never had been horses in Britain. But, though the Byzantine Greeks of the 6th century knew but little about

1 Cf. Bede, Ecc. Hist., chaps. xiv-xv.

2 De bello Gothico, Iv. 20.

R. H. 
Britain under its new occupants, yet they were well acquainted with the various Teutonic tribes, and accordingly we may place full credence in his description of the inethods of walfare of the Angles and Varni, who are the same as the Werini of the Leges Burbarorum (p. 3:31). For though so great an authority as $B^{1} e^{1}$ renders it certain in more than one passage that the Angles had some saddle-horses before the middle of the seventh century A.D., the statement of Procopius is completely corroborated by the Anglo-Saxon graves; for although his weapons, shield, and other gear were always buried with the warrior, be he Angle, Saxon, or Jute, the occurrence of horse-bits and other horse-trappings is of extreme rarity, a fact in strong contrast to the contents of the Scandinavian barrows of Scotland, in which the bones of the horse are found along with those of his master. It would thus appear that the Anglo-Saxons chiefly used horses for carrying goods on packs (for ploughing was still the province of the ox), and if they did ride them, they simply employed them, as did the German tribes in Caesar's day and the Norsemen of the Viking period, for locomotion, and they never fought from horseback, but always did battle on font, a practice which lasted down to the Battle of Hastings. Harold himself is represented on the Bayeux tapestry as fighting on foot at the moment when he was struck in the eye by the fatal Norman shaft. Indeed, William's victory was due to the fact that he charged the Saxon footmen with a large force of mail-clad warriors mounted on stout horses of the same stock as those which three centuries earlier had stood firm against the Moslem onslaught at Poictiers.

The Normans thus introduced into England that large and heavy breed of horses which had been steadily developed for twelve centuries in North-western Europe for the purpose of carrying on their backs large men heavily armed. Moreover, they are represented on the Bayeux tapestry as riding in deepcurved saddles, such as those which, according to Giraldus (infra, p. 389), they brought to Ireland a century later and which were fitted with stirrups. They themselves were clad in hauberks, and wore boots fitted with prickspurs.

1 Ecclesiastical History, chaps. v. xiv. 
These Norman war-horses are referred to in a very important statement of William Stephanides, a monk of Canterbury, who, writing in the first year of Henry II (11.54), says that, "without one of the London City gates is a certain Smooth field. Every Friday there is a brave sight of gallant horses to be sold. Many come out of the city to buy or look on-to wit, earls, barons, knights, and citizens. There are to be found here maneged or War Horses (dextrarii), of elegant shape, full of fire and giving cvery proof of a generous and noble temper; likewise Cart horses, Horses fitted for the Dray, or the Plough, or the Chariot." But though there were thus a certain number of war-horses in the country, the vast majority of English horses continued to be of small size and little suited to carry men-at-arms. This is clearly shown by the continuous efforts made by Kings and Parliaments from Henry II to Elizabeth to promote the breeding of 'great horses,' i.e. warhorses, commonly termed dextrarii (destriers), and magni equi, in medieval Latin documents".

The change in fashion and weight of armour which we have noticed on the Continent, went on pari passu in England, the Norman hauberk yielding to true chain-mail about 1190 , the latter giving way in its turn from 1300 to plate armour, which became completely universal from about 1410. As on the Continent so in England, the increase in the weight of armour called for an increase in the size and strength of the horses.

There was no native English breed fitted for such a burden until they were improved by foreign blood, and to this end the English monarchs from time to time imported horses from the Continent. Thus the Exchequer Rolls for 1160 show that an allowance of one mark was made to W'illiam de Sancto Mauro, the sheriff of Hampshire, "for the maintenance at Winchester of the King's (Henry II's) horses, which the Treasurer had brought with him from beyond sea." "These horses were doubtless in

1 Sir W. Gilbey, The Great Horse, p. 16.

2 Sir W. Gilbey, The Great Horse, p. 15.

3 Madox, History of the Exchequer, Vol. I. p. 367; Mag. Rot. 21, H. 25, 12 a; Gilbey. loc. cit. 
charge of the King's serjeants at Winchester, for another entry in the same document mentions an allowance being made to Galfridus filius Azonis, sheriff of Hampshire, for "the livery of the serjeants that look to the King's (Henry II's) horses at Winchester." We do not know for what purpose or from what country these horses were imported. It is probable that they were brought from Normandy or some other part of France. But an entry in the Exchequer Rolls of the reign of Stephen shows that the King used to send round stallions, probably from Winchester, to serve his mares, which were kept at his various manors. For Warin, sheriff of Wiltshire and Dorset, was allowed thirty shillings and threepence for the livery of one of the King's servants, whilst he was at Gellingham with a stallion to serve the King's mares ${ }^{2}$. But in the reign of King John no less than one hundred stallions of large stature were imported from the Low Countries-Flanders, Holland, and the banks of the Elbe-and it is, says Sir Walter Gilbey, "from the blending of these sires with English mares in the lowland and shire counties that some strains at least of our modern heavy horses must be held to date their origin."

It will be at once observed that these stallions of large stature were procured from the very regions where we first hear of a superior breed of horses (obtained through Gaul) in the hands of a German tribe, who, in the first century after Christ, had in their equestris disciplinc laid the foundations of Teutonic chivalry-the regions where the Frisians and Thuringians had already notable horses in 380 A.D.

But the improvement in size of the native English horses was very slow, as is shown by various Acts of Parliament made from time to time. In fact at no time in medieval England was there a large supply of war-horses, as is shown by the high prices paid for great horses. Out of a total of fortyeight horses belonging to baronets, knights, esquires, and ralets, either of the King's (Edward I's) household, or not belonging to it, many of which were killed at the Battle of 
Falkirk in 1298, aud whose values and colours are given in documents printed by Bain ${ }^{1}$, the proportion of colours is as follows : One dun horse with star in forehead, one pied white charger, one fawn hackney with star in forehead and three white feet, one rough liard hackney, two grey horses, three powis pommele (one horse, two hackneys); nine ferrand pommele comprising one charger, three horses, five hackneys; nine black comprising three chargers (one with four white feet), five horses (one of which had a star and four white feet, another three white feet), and one black bauzan hackney; two sorrel comprising one bauzan horse, and one sorrel hackney with a star; nineteen bays comprising one brown bay charger, one brown bay hackney, one dark bay horse, one bay bauzan horse, three bay chargers (one with a white hind foot), six bay horses and six bay hackneys. Of the nine chargers three were black, four bay, one ferrand pommele (iron grey), and only one white pied, but no dun or sorrel. Of the twenty-two horses not described as chargers or hackneys eight were bays of various shades, one sorrel, five black, one dun, and six greys of different shades; of the seventeen hackneys there were seven bay, one sorrel, one black, eight grey of different sharles and one fawn with star in the forehead and three white feet. The black supply the largest proportion of chargers and 'horses,' and the smallest of hackneys, which shows that they were the heaviest horses. Bay with less than half of the whole, has nearly half the chargers, and more than onc-third of the hackneys, whereas black only furnished oneninth; grey out of a total of fifteen supplied one charger, six horses, and eight hackneys. Grey thus, though less than onethird of the whole, supplies nearly half the hackneys. It will be noticed that eight of the nine chargers are dark-coloured.

When we come to the values of the horses we find that the bay charger with a white hind foot was worth 100 marks, a black charger 60 marks, the white pied also 60 marks, and a ferrand pommele charger 45 marks. The prices of 'horses' ranged from 70 marks (a black with star in forehead and three white feet) down to 5 marks; hackneys range from 20 marks

1 Calendar of Documents relating to Scotland (Edinburgh, 1884), Vol. 1I. pp. $257-8$. 
to 5 marks. The bay charger with the white foot was therefore worth nearly one-third more than any other horse in the list. This animal belonged to the King and was ridden by Sir Eustace de Hecche.

Our analysis shows that the black horses were the heaviest, and that in several cases they had the star and white feet characteristic of the North African horse; the bay supplied chargers in proportion next after the black (including the most valuable one), the grey furnished the largest proportion of hackneys, the bay coming second in that respect, the bay and grey together supplying 15 out of 17 hackneys. But, as we saw that in Western Asia grey was the result of the blending of the bay Libyan with the horse of Upper Asia, we nıay infer that as the bays and greys supply nearly all the hackneys, the light built horses of the day were largely the outcome of North African blood.

The fact that dun and sorrel have only three representatives shows that the best horses of the age were not a development of the old North European horse, but were largely the outcome of North African blood. Indeed, as the dun in the list had a star in the forehead, it was evilently not pure, but had a cross of North African blood in it, which accounts for its being valued at 20 marks. The same is probably true of the fawn hackney with a star in its forehead and three white feet. The results thus obtained harmonise completely with the order of merit in which horses of different colours are placed by Olaus Magnus (p. 348), for the black stands first in popularity as a war-horse, the bay second, then the various shades of grey, whilst dun including sorrel comes last in the list.

The scarcity of good horses in this and in subsequent reigns is proved by the enactments passed by Edward $\mathrm{III}^{1}(1327-77)$ and Richard II to promote the breeding of such horses. The former spent large sums in the purchase of horses from the Low Countries, buying to the amount of 25,000 florins from the Count of Hainault. The King kept large studs of warhorses at the various royal manors, such as Windsor, Odiham, Woorstock, and Waltham, the sheriffs of the various counties

${ }^{1}$ Sir W. Gilbey, op. cit. p. 19. 
having to bear a proportion of the expense. But even thus the native supply was not sufficient for the needs of the French war, for on the eve of the campaign of Crecy Sir John de Brocaz and his son Oliver were employed to buy horses for the King in Gascony. Indeed it is not without significance that the great English victories over the French were due rather to the bowmen than to men-at-arms.

We get a glimpse of the horses ordinarily in use in England at that time from Chaucer, though unfortunately he describes only a few of the steeds ridden by that immortal company of pilgrims who rode forth from the Bell at Southwark on a fine April morning. The knight rode on a good horse, no doubt a 'great horse' able to carry a man in armour, whilst of the Clerk of Oxenford it is said that "as leane was his horse as any rake." The Wife of Bath wearing 'great spurs' rode astride of an 'amblere', and the Shipman from Dartmouth sat on "a rouncy as he couth"," the Ploughman rode 'a mere", the Reeve "sat upon a fit good stot that was all pomely gray, and highte Scot5." On the other hand in the Knight's Tale the poet represents the "king of Ynde as riding on a horse of baye."."

The improvement in the breed of English great horses seems to have been counteracted by the Wars of the Roses, for during that troublous time both factions seized without ceremony any horse suited for military purposes, and accordingly the owners of such to save themselves seem to have exported them to the Continent, as is proved by the preamble to the Act passed in the eleventh year of Henry $\mathrm{VII}^{7}$ (1496) forbidding the export of horses and of any mare of the value of six shillings and eightpence, for it is stated that "not only a small number of good horses were left within the realm for the defence thereof, but also that great and good plenty of the same were in parts beyond the sea which in times past were wont to be within this land." In consequence of this enactment horses becane much more numerous, and Polidore Virgil says that at this time the English were wont to keep large herds of horses in pastures and common fields; and when the harvest was
1 Prologue, 1. 286.
2. 469.
3 l. 88.
$\$ 1.541$.
51.615 .
$61299-1300$.
7 Gilbey, op. cit. p. 20. 
gathered in, the cattle of different owners fed promiscuously together; for which reason the practice of cutting horses was introduced ${ }^{1}$.

Under Henry VIII energetic steps were taken not only to restrict the exportation of horses to the Continent but also to Scotland and to promote the breeding of powerful horses. The King himself set the example, for according to Holinshed ${ }^{2}$, he "erected a noble studderie for breeding horses, especially the greater sort, and for a time had verie good success with them. The officers however seemed weary, and procured a mixed breed of baser races, whereby his good purpose came to little effect." But royal example apparently did not suffice, and resort was had to compulsion. In 15:35 "for that in many and most places of this Realm, commonly little Horses and Nags of small stature and value be suffered to depasture, and also to cover Mares and Felys of very small stature, by reason whereof the Breed of good and strong Horses of this Realm is now lately diminished, altered and decayed, and further is likely to clecay, if speedy Remedy be not sooner provided in that Behalf," it was enacted that "all Owners or Fermers of parks and enclosed grounds of the extent of one mile in compass, shall keep two Mares, being not speyed, and able to bear foals of the altitude or height of thirteen handfuls at least upon pain of $40 \mathrm{~s}$." A penalty of $40 \mathrm{~s}$. was likewise imposed on "lords, owners, and farmers of all parks and grounds enclosed as is above rehearsed, who shall willingly suffer any of the said mares to be covered or kept with any Stoned Horse under the stature of fourteen handfuls."

It was also enacted that all prelates and nobles whose wives wore French hoods or velvet bonnets should maintain stallions of the required standard.

Further steps were taken in 1541 when it was enacted that "no person shall put in any forest, chase, moor, heath, or waste (where mares and fillies are used to be kept), any stoned horse above the age of two years, not being fifteen hands high, within the shires and territories of Norfolk, Suffolk,

1 Gilbey, op. cit. p. 20.

2 Vol, vi. p. 3 (London, 1807).

${ }^{3}$ Gilbey, op. cit. pp. 23-4. 
Cambridge, Buckingham, ete.," and it was further enacted "that if in any of the said drifts, there shall be found any mare, filly, foal, or gelding that then shall be thought not to be able nor like to grow to be able to bear foals of reasonable stature, or not able nor like to grow to be able to do profitable labours, by the discretions of the drivers aforesaid or of the more number of them, then the same driver or drivers shall cause the same unprofitable beast, and every of them to be killed, and the bodies of them to be buried in

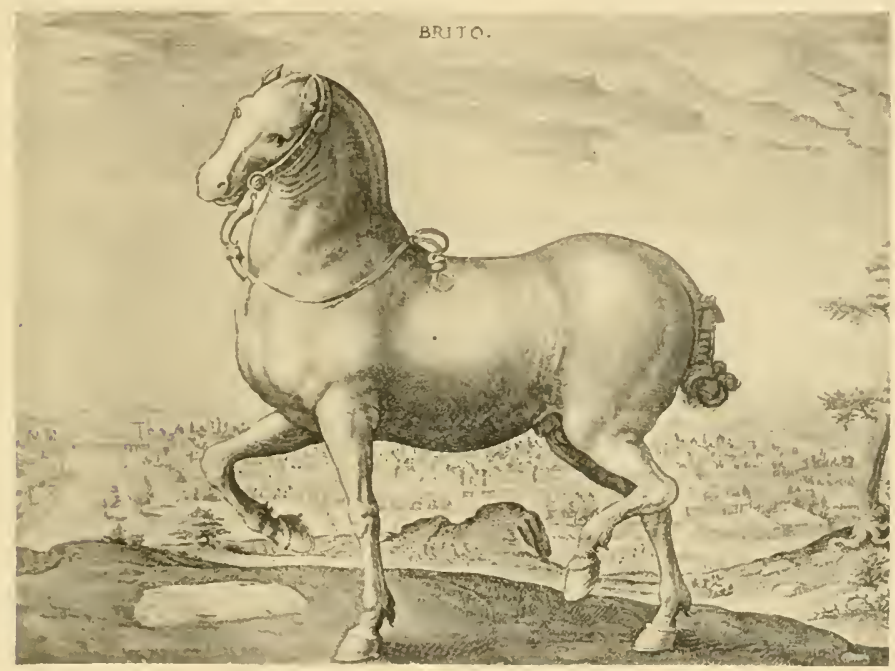

Fig. 101. The English Horse.

the ground or otherwise bestowed, as no annoyance thereby shall come or grow to the people, there near inhabiting or thither resorting." Topsall ${ }^{1}$ writing in the sixteenth century is then perfectly correct in stating that "Brittaine breedeth little horses and amblers."

By the middle of the fifteenth century the British horses were held in repute on the Continent (though it must be remembered that the Irish Hobbies were known in France as 'English' Hobbies'2). Nor was their fame confined to Upper Europe, for according to Sir John Hawkewood ${ }^{3}$, English horses

${ }^{1}$ History of Animals, p. 285. ${ }^{2}$ See pp. 388 su. $\quad{ }^{3}$ Gilbey, op. cit. p. 20. 
were songht for breeding purposes in the states of Northern Italy. It is but natural therefore to find a specimen included in the "Stable of Don John of Anstria." The drawing by Stradanus here reproduced (Fig. 101) shows that the typical British horse (Brito) was much lighter in build than the contemporary horses of France, the Low Countries, and Germany, though he was far stronger than the Neapolitan Courser, the typical horse of Southern Italy. Stradanus' drawing of the typical horse of Northern Italy (Insuber) shows (Fig. 90) that the breeders there aimed at producing a horse of a stronger frame than the Neapolitan, but not so ponderous as the warhorses of Upper Europe. This fact may explain why the horsefanciers of Upper Italy were anxious to add British horses to their studs.

Ralph Holinshed's description of the English horses of the time of Elizabeth forms the best comment on Stradanus' picture of the British horse: 'Our horses,' says the chronicler', "are high, and although not comonlie of such huge greatness as in other places of the maine, yet, if you respect the easinesse of their pace, it is hard to saie where their like are to be had. Our cart or plough horses (for we use them indifferently) are commonlie so strong that five or six of them (at most), will draw three thousand weight of the greatest tale with ease for a long journeie-although it be not a load of common usage which consisted only of two thousand, or fifty foot of timber, forty bushels of white salt, or six and thirty of baie, or five quarters of wheat, experience dailie teacheth, and I have elsewhere remembered. Such as are kept for burden will carie four hundred weight commonlie withont any hurt or hindrance." He adds that the Queen and the nobility used carts to convey baggage, the former on her progresses requiring 2,400 horses, which had to be supplied by the adjacent districts, and that "the ancient use of somers and sumpter horsis" had been 'utterly relinquished,' "which causeth the trains of our princes in their progresses to show far less than those of the kings of other nations."

1 Chron., Bk. Ir. chap. I (Folio ed. London, 1587). 
No better example of the English great horse of Elizabeth's time can be found than the contemporary picture of the bay horse with a white star in his forehead carrying his master, Sir Walter Hungerford, reproduced by Sir Walter Gilbey in his admirable little book ${ }^{1}$. Sir Walter Hungerford had challenged any man in England, "not above his betters," "to show the best horse for a man of arms, a greyhound for a hare, and a haucke for the reyver to win III hundred pounds." Sir Walter Gilbey points out that "though the hair both of the mane and legs has been manipulated to suit the fashion-the tail still shows the characteristic abundance. Sir Walter Hungerford's horse is certainly of the type of Albert Durer's Great White Horse, though it shows more evidence of spirit and high action." The explanation of its superiority is probably due to the English horse having in his veins more North African blood, as is indicated by his bay colonr and star in the forehead.

Thomas Blundeville, in the book so often cited in these pages, gives us a valuable glimpse of English horse-breeding in his own day: "some men have a breed of Great Horses meete for warre and to serve in the field. Others have ambling horses of a meane stature for to journey and travel by the waie. Some again have a race of swift rumners to run for wagers or to gallop the buck. But plain country men have a breed only for draftes or burden." Though after describing the great horses and great mares, he adds, "but now to content the country man his desire, which seeketh to breed horses for draught or burden, where should I wysh him to provyde hymselfe of Mares and Stallions better than here in England," nevertheless in the second edition his patriotism yields to his sense of truth and he adds "that he (the country man) maie easilie find a number of strong jades more meet for that purpose than for the saddle, and all for lack of good order of breerling, which if it might be once observed in this realme, I believe there would be so good and so fair horses bred heare as in anic place in Christendom," and finally, he recommends in the same edition, the breeder "that seeketh to have a race 
of good horses meet to serve in the field to get a Neapolitan stallion, if it be possible, if not let him take the high Almaine, the Hungarian, the Flanders, or the Frizeland Horse, so that he be of convenient stature well proportioned and meet for the purpose. The mare should be of an high stature, stronglie made, large and fair, and having a trotting pace, as the mares of Flanders and some of our own mares be. For it is not meet for divers respects that horses of service should amble."

He thus admits the bad quality of the ordinary English horses, which Topsall describes as amblers, whilst by recommending the breeder to obtain, if possible, a Neapolitan stallion he recognises as fully as did the Gauls in the second century B.C., and the Arabs and the Turcomans of modern times, that the surest way of improving the indigenous horses of Europe and Asia is to keep constantly introducing North African blood. But, in spite of warnings such as Blundeville's, the breeding of great horses continued to decay. That writer had himself noticed the breeding of horses for hunting and racing in his own day, and this tendency greatly increased under James I, to whose love of raciug was due the importation of the first Arabian horse into Eugland, a circumstance to which we shall presently return. No better proof of the decadence into which had fallen the breeding of great horses during the reign of James I can be found than the following extract from the Breviary of Suffolk, written by Robert Reyce (a native of Preston, near Lavenham, where he died in 16:38), and which he dedicated to Sir Robert Crane, of Chilton, near Sudbury, February 9th, 1618.

"Among the many ornaments of this shire, I may not omitt to speake here of the horse, for the breeding whereof this country hath many apt places of most profittable vse, wherein some chuse the low and fruitful grounds, the fertility of which soile being a rich black mould, they deem most fit for these purposes; butt experience teacheth that the low grounds

1 The us. is in the British Museum (Harl. 3373) and was published with notes by Lord Francis Hervey in 1902 (Murray). I am indebted for this extract to my friend Sir Ernest Clarke, M.A., St John's College, Cambridge. The passage here cited is from p. 42 of the printed book. 
seldome or never do afford a strong colt for service, or of quick life or spirritt, butt onely such as are fitt for burden and draught, the better sort for their breed as near as they can well make choice of is knowls or the height of hills, where good ground is with plenty of pasture, from whence they find that because of the aire aboue is there alwaies fresh, pure, and transparent, and the soile beneathe is firme, and almost stony, the colt here bred is most puissant, and strong for service, of quick life, and spirritt, of high pride, and most comely shape. Now albeit I cannot speake much of the excellency of this country bred horse, not because here wanteth fitt places, and meanes for the generation of so generous a creature, butt men are nott so industrious and skillful in this most excellent quality, yett haue I just cause to commend those here, that by all good meanes do preserve, and maintaine the breed of horses, among which I hane seen and well observed, nott some butt many horses here bred of good shape and quick sperit, which hane for readines in all points of service nott a meane recommendation. And of those I hane seen coming over beyond sea, have been admired for their painfull travell in long journies, their firme carriage in time of service, their quicknes, and realines in all necessities, butt of all for their continnance in time of battle, never giving in, butt when other the choicest of all other comntries, especially if the march have bin anything long, or the skirmish any thing hott, haue soon fainted, and tyred; these have been still noted to bee yett most fresh, carrying their riders with nott a little creditt, and estimation, which if it were of our better sort here well weighed, would encourage every man to breed, and having bred to make much of so special a worth which every country cannott speake of, butt such is our slothfullness here in this respect, that for the most part wee rather desire to bee furnisht from our dear faires with the refuse of other comntries, though after our long labour, and great cost wee commonly meet with pampered counterfeit, or deceit. Now for our horses of burden or draught, experience of long time teacheth us, how vncertaine this proofe is of that which wee pay so dear for at other hands, causeth us to esteeme our owne home bred the more, which every way proveth so well 
for our owne use and profitt, that our husbandmen may justly compare in this respect with any other country whatsoever, albeit they often complain that many vain sports and idle occasions did never in any age consume more good horses than this age doth, which otherwise might prove of great use to them and the common wealth."

To this passage we shall return when we deal with the Suffolk Punch, for the elucidation of whose history it has a special value.

But protests were of no avail, for racing had got too strong a hold on the wealthier classes, and they paid less and less attention to the breeding of war-horses. Sir Edward Harwood ${ }^{1}$ presented to Charles I a memorial setting forth the great scarcity of good and stout horses for the defence of the kingdom, insomuch that it was a question whether it could have furnished two thousand that would have been equal to two thousand French, and he ascribed this state of things to the popularity of racing and hunting, which called for lighter and swifter horses. But the times were troublous, and nothing was done, though Charles himself was fond of great horses, on one of which he is represented on the Great Seal². Oliver Cromwell $^{3}$ in Vandyck's portrait is seated on a great horse of a light colour, which is noteworthy in view of the fact that from this time onwards the terms great horse and black horse seem synonymous. But when Oliver Cromwell formed his Ironsides-the most powerful military weapon that the world had yet seen-he dealt a fatal blow to the use of great horses in war. Since his Ironsides wore buff coats instead of armour, lighter and more active horses sufficed to mount them, and to their greater mobility their success was largely due. In vain the Duke of Newcastle in $165 \mathrm{~s}$ held a brief for the heavy horses of the North against the light breeds of Mediterranean lands. With the final disappearance of armour the heavy black horse was relegated to the coach, the waggon, and the plongh. The roads were very bad, and accordingly horses of great strength were required to drag through the sloughs the carriages of the nobility and the stage-coaches which had
1 Gilbey, op. cit. p. 39.
2 16. p. 40.
${ }^{3}$ Il. p. 42. 
begun to run in 1670. Probably one of the latest representations of the Great Horse used as a charger is the famous statue of William III in Dublin (Fig. 102). The king though garbed like an ancient Roman is mounted on a horse of great stature and of massive build. For two centuries the sculptor of this ponderous steed has been the butt of Irish humorists, who, surrounded by the best horses in the world, could not imagine

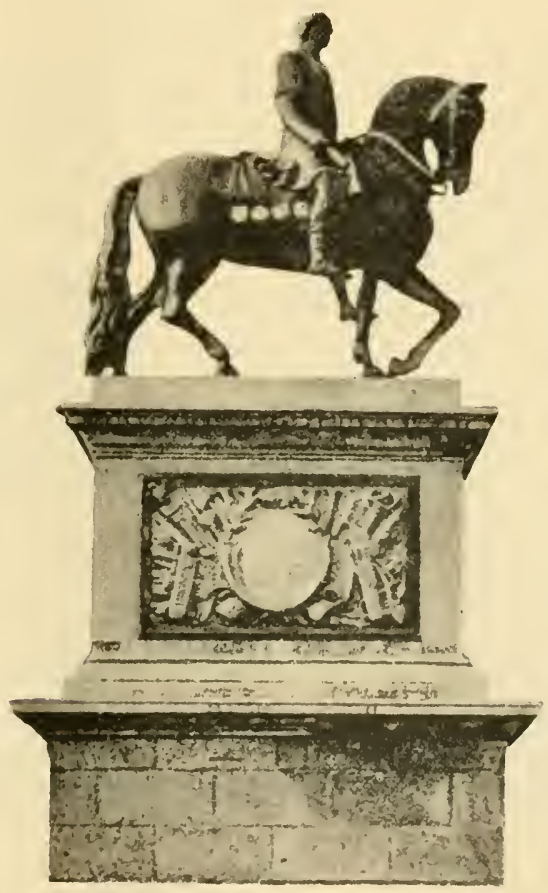

Frg. 102. King William III on a Great Horse; College Green, Dublin.

the hero of the Boyne to have ridden a cart-horse, and accordingly regarded the animal as merely the offspring of the artist's imagination. But the late Viscount Powerscourt some years ago pointed out that he had seen horses of exactly a similar type used by farmers in Holland ${ }^{2}$, and he suggested that the

1 Lord Powerscourt could not find the reference to a Dublin daily paper, in which his letter appeared, but in August (1903) he sent me the statement, which I have given above. 
proportions of the horse were not due to the clumsiness of the sculptor, but to the fact that King William rode on a Dutch horse. From what we have seen above of the history of the horses of the Low Countries and of England, we need have no hesitation in concluding that William of Orange rode one of the Great Horses of his country, and that when the statue was erected a few years after his overthrow of James II, the artist modelled the king's steed from a real charger.

Arthur Young, writing at the close of the eighteenth century, declares that in England and Scotland there were only two kinds of cart-horses worthy of attention-the large, black, old-English horse, "the produce principally of the shire counties in the heart of England, and the sorrel-coloured Suffolk Punch, for which the sandy tract of country near Woodbridge is famous." Young rightly regarded the Clydesdale breed as simply the Scotch variety of the Great Horse. According to Mr Reynolds, black and grey were held to indicate purity of breeding in the shire horse, whilst I may also point out that shire horses, like the great horses, frequently have stars or blazes on the face and white stockings. The great tendency to such markings in the shire breed is clearly demonstrated by the fact that seven out of eight of these horses figured by Sir Walter Gilbey ${ }^{1}$ are thus distinguished. The same features characterise 'Stroxton Tom' (Fig. 103), the champion stallion at the London shows of the Shire Horse Society in 1902 and 1903. In these markings as well as in their dark colour we have clear proof of that North African blood which began to be infused into the horses of North-western Europe from about the second century B.c.

But the military career of the English black horse did not terminate completely with the disuse of ar'mour, for his qualities as a war-horse were too great to be overlooked, and all that was needed was to render him lighter and more active by the infusion of better blood. Hence it comes to pass that all our heavy cavalry, with the exception of some regiments mounted on bays and greys, has continued down to our own times to be mounted on black horses ${ }^{2}$. The infusion of thoroughbred blood 
went on so constantly that by the michlle of the last century the Life Guards were mounted on either three-quarters or halfbred black horses. It is important to note that this large infusion of North African blood was effected without any change of colour, a fact which strongly corroborates my doctrine that the black breeds of the world are the result of mixing the African blood with that of the horses of Europe and Asia.

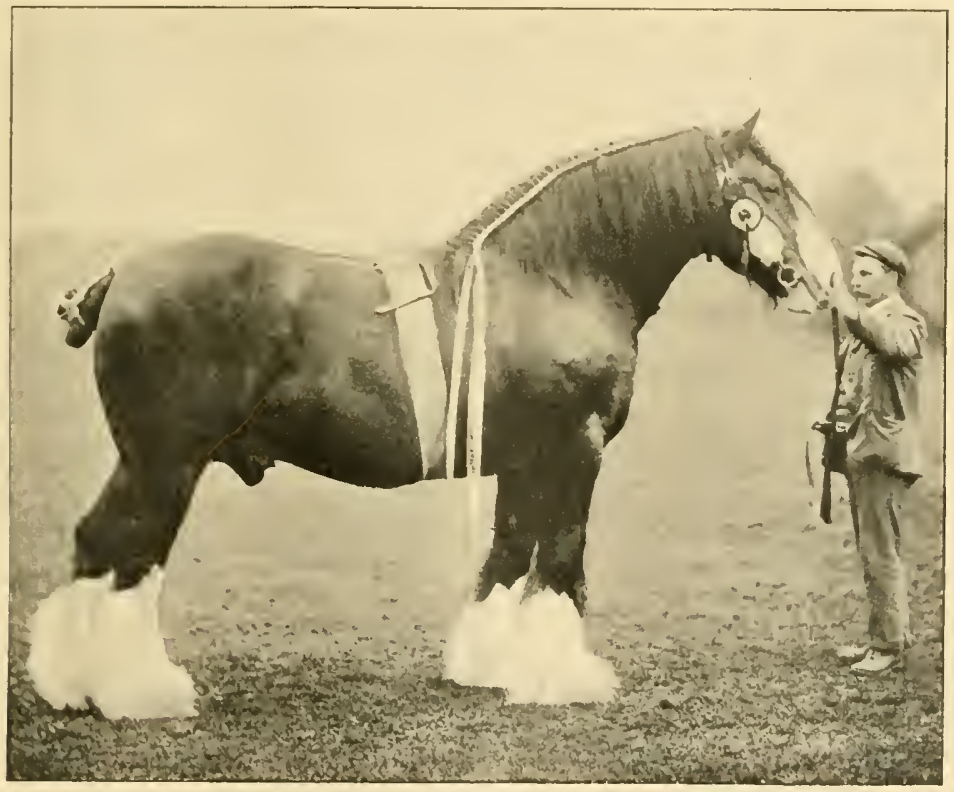

FIg. 103. Shire Stallion, 'Stroxton Tom ','

The Black Horse, as improved by continuous infusion of North African blood, thus kept his place in war, but his relation who had not been so ennobled, after having been thrust from his once proud post amidst the clash of arms and the blare of trumpets in the van of a charging host, and when he seemed destined for ever to serve his country only in the prosaic paths of peace, has after two centuries been suddenly restored to his

${ }^{1}$ I am indebted to the Shire Horse Society for the fine photograph from which my illustration is taken and for permission to reproduce it.

R. H. 
ancient heritage of service on the battlefield. Taught by the experience of the Boer war and the part played by the 4.7 inch guns at Ladysmith, our War Office has now furnished the First Army Corps with a brigade of heavy guns, each of which is drawn by six Shire horses, not ridden however but led by the drivers.

Arthur Young considered that the only other British carthorse worthy of mention along with the large old-English black horse was the sorrel-coloured Suffolk Punch, for which the sandy district round Woodbridge is especially noted. The origin of this famons stock has never been clearly traced, not even by Mr. Herman Biddell in the Suffolk Stud Book'1 : in his summary of his history of the breed he states that "the original, or what may be called the indigenous stock, dates as far back as the year 1700," and he assumes that "at the commencement of the century it was as distinct a breed as it was when Arthur Young, who was born in 1740, was old enough to make observations on agriculture, for that writer speaks of them as a distinct type, which had been the character of the breed beyond the recollection of any man then living, and Young seems to have been unable to gather any information regarding their origin or introduction." According to Arthur Young the typical old Suffolk horse was "sorrel colour, very low in the fore-end, had a large misshapen head, with slouching heavy ears, a great carcass and short legs, an uglier horse," as the author says, "could hardly be viewed."

The large head, thick body and sorrel colour all point to the animal having been chiefly developed from old European horses of the Solutré type. Mr Biddell holds that "we have reliable data for assuming that the breed of Suffolk horses has been in the easteln part of the county for one hundred and eighty years; how much longer no one can tell." The extract from Robert Reyce's Breviary of Suffolk given a few pages back enables us to carry back the history of the great horses of Suffolk a century earlier than Mr Biddell. Although Reyce

1 Vol. I. p. $72(1880)$. I am indebted for this extract as well as that from Reyce to my friend Sir Ernest Clarke. Mr Biddell has also written an excellent section on the history of the Suffolk Punch in Heavy Horses (Live-Stock Handbooks, No. III.), pp. 37 sqq. 
says that little heed was paid in Suffolk to horse-breeding, he commends a few who did take care to preserve and maintain the breed of horses, amongst which he had seen "not some but many horses here bred of good shape, quick spirit, which have for readiness in all points of service not a mean recommendation," but he considered that they were not so good as some of the imported foreign horses which he had seen. The best Suffolk horses were bred in parts of the county "where there were knowls or the heights of hills, where good ground is with plenty of pasture," and where "the air above is always fresh, pure, and trausparent, and the soil beneath is firm and almost stony." "The colt here bred is most puissant and strong of service, of quick life, and spirited, of high pride, and most comely shape." The district round Woodbridge tallies well with Reyce's description of the kind of country which produced the best horses in Suffolk. From what we have seen there can be no doubt that an English breed of great horses had been largely obtained from Flanders, where, to this day, fine cart-horses of light dum, sorrel, and chestnut colour are not uncommon. Nor is there wanting actual proof that sorrel was a recognised colour of certain great horses in England at the time when Reyce lived and wrote.

Thomas Blundeville ${ }^{1}$ devoted a chapter of his work to the colours of horses, and though his theory of the diversity of colours will hardly convince the modern reader, his evidence tonching the colours of the great horses of his own time is none the less valuable. "The colours depend on the preponderance of the elements. If earth preponderates, then is he dull and black and russet. For if he hath more of the earth then of the rest, he is melancholly, heary and faint-hearted, and of colour a blacke, a Russet, bright or dark donne. But if he hath more of the water, then is he phlegmatic, slow, dull, and apt to lose fleashe, and of coulor most commonly milk white. If of the air, then is he sanguine and therefore pleasant, nymble, and of temperate moving, and of coulor is most commonly a bay. And if of the fier, then is he cholorique

1 op. cit. chap. 9 (1st edition, in Cambridge University Library). 
and therefore light, and fiery, and a sterer, and seldom of any great strength, and is wont to be of coulor a bright sorrel. But when he doth participate in all the four elementes, equally and in due proportion, then is he perfect and most commonly shall be one of these couloures following. That is to say, a browne baye, a dapple graye, a blacke full of silver heares, a blacke lyke a moore, or a fayre rone, which kinds of horses are most recommendable, most temperate, strongest, and of gentellest nature. And next to these are such as be most like in coulor to them: as the bright bay, the darke bay, that hath neyther learing looke, mealy nose, nor white flanke. The bright sorrel, the flye-bitte white, the white liard like silver, having his outermost partes blacke, as tips of his eares, his mane, his tail, al fowre feet, and if he hath a lyst from his mane to his tayle, he is so much the better. To these also may be addid the aubye graye having al his fete striped. And note this, that as all welcoulored horses are so much the better for having some sygne of adustion, that is to say, some blacke marke at the leaste in theyr nethermoste partes; so of all euill coulored horses those are best which have theyr outermost partes blacke. But if he be a bright sorrel, a brown bay, with reddy flankes, a perfect blacke, or anye other coulor betokeninge coulor adust: then to mitigate his fearnes, he hath to have some whyte marke. Wherefore syth good markes be as necessary as good coulors, I will intreat of them particularlye in the next chapter folowing."

Since Blundeville regards sorrel-coloured horses as the worst type of great horse, the words of moderate commendation, in which Reyce in spite of his patriotism speaks of the great horses bred in Suffolk, would be very suitable to sorrel-coloured great horses, if such were then bred in Suffolk. All these various considerations taken together render it probable that the Suffolk Punch, of the time of Arthur Young, was the lineal descendant of the 'puissant colts' which were bred on the 'knowls' of Suffolk, and which though of good quality were not equal to the fine continental war-horses.

It thus follows that whilst the shire horses are descended from the great English war-horse of a dark colour, the Suffolk 
Punch is sprung from the sorrel variety of the same great horses. But, as we have traced both these types to the large breeds gradually developed in Upper Europe from the second century B.C. by the blending of North African blood with that of the old European horses, our best English breeds of carthorses owe their excellence to the North African horse.

Blundeville's remarks on the colour of horses are of great importance. Of the four classes of horses in which one element preponderates, the best-that in which the air predominatesis most commonly a bay, whilst the worst is a bright sorrel. But from our previous investigations we have found that bay is as distinctly a mark of African blood as dun and white are of that of Upper Europe and Upper Asia. Blundeville's perfect horse-he in which the elements were kindlier mixed-was usually browu bay, dapple grey, black flecked with white, black like a Moor, or a fair roan, "which kinds of horses are most recommendable." And next to these are such as be most like in colour to them, as the bright bay, the dark bay, that hath neither learing look, mealy nose, nor white flank, with bright sorrel, the fly-bitten white, the white with black points, and with a dorsal stripe if possible, and the aubye graye with its feet striped.

But as we have seen that bay and brown are characteristic of the North African horse, whilst black, dark grey, and grey are always found, whether in Asia or Europe, where the African blood has been blended with that of the indigenous horses of those regions, it is clear that the best horses of medieval Europe, which according to Olaus Magnus and Blundeville were regularly of dark colours, owed their superiority over the pure white and the various shades of dun to the fact that they were saturated with North African blood, whilst the latter had very little of it in their veins.

Blundeville in his second chapter enumerates "which horses be well marked, and which be not. The horse that hath any white mark is called of the Italians Balzano, but specially when he is white-footed. And of white-feeted horses there be IIII good and VIII bad. These are those which have either white off forefoot, or a white near hind foot, or both 
hind feet white, or all four feet white; but note that such white must not mount above the pastors, and such horses be not caled Balzani, but Calzeti, which is as much to say in English as hosed." Space does not permit the enumeration of the bad kinds of leg-marks, but Blundeville makes the very important statement that "It is an excellent good mark also that a horse have a white star in his forehead, or a white List or fillet coming down on his head without touching his brow, and not fully arriving to his nose." But, as we have seen that a white star in the forehead and white bracelets are the constant concomitants of the bay colour in the North African horse, the occurrence of white marks in horses of the colours mentioned by Blundeville is a clear indication that they have North African blood in their veins.

The later history of the Suffolk Punch offers an unexpected corroboration of this inference. The original breed had certain characteristic points - a low, plain fore-end, a sorrel colour, short legs, bent hocks, and a facility for drawing, which as far back as 1740 was reckoned the principal test of merit'. Every well-bred Suffolk horse of to-day is descended from a nameless stallion of the 'old breed' foaled in 1768 and which belonged to a Mr Crisp of Ufford, near Woodbridge. He was

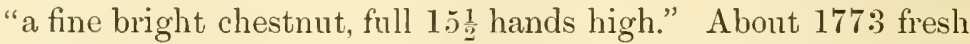
blood was introduced-a Lincolnshire trotting horse, a stallion short-legged, low, and chestnut in colour, which very soon blended completely with the old, with the result that the breed had more action and was smarter to look at, though in its prominent features the breed was not greatly altered. At the beginning of the nineteenth century another foreign stallion, also chestnut, was introduced, and he exercised a considerable influence on the breed; the chief points in the new cross being a little more size and a little less symmetry. About the same time another foreign element was engrafted on the Suffolk stock, a stallion with less of the characteristic type of the old breed than the other two sires, for he was bay, and those of his offspring which were chestnut were very dark, and had in most 
cases white legs. "This was a more violent cross than either of the others, and accordingly made less way; the impression was more transient and the influcnce exercised sooner obliterated. The horse himself was a bay with great bone and action. The colour, the white leg, the rare bottom were the symptoms which betokened the traces of the blood of the Shadingfield stock. The stock were a light-hearted, high-spirited race, but they were too often fiery tempered." But, as we have seen that chestnut is a characteristic of the

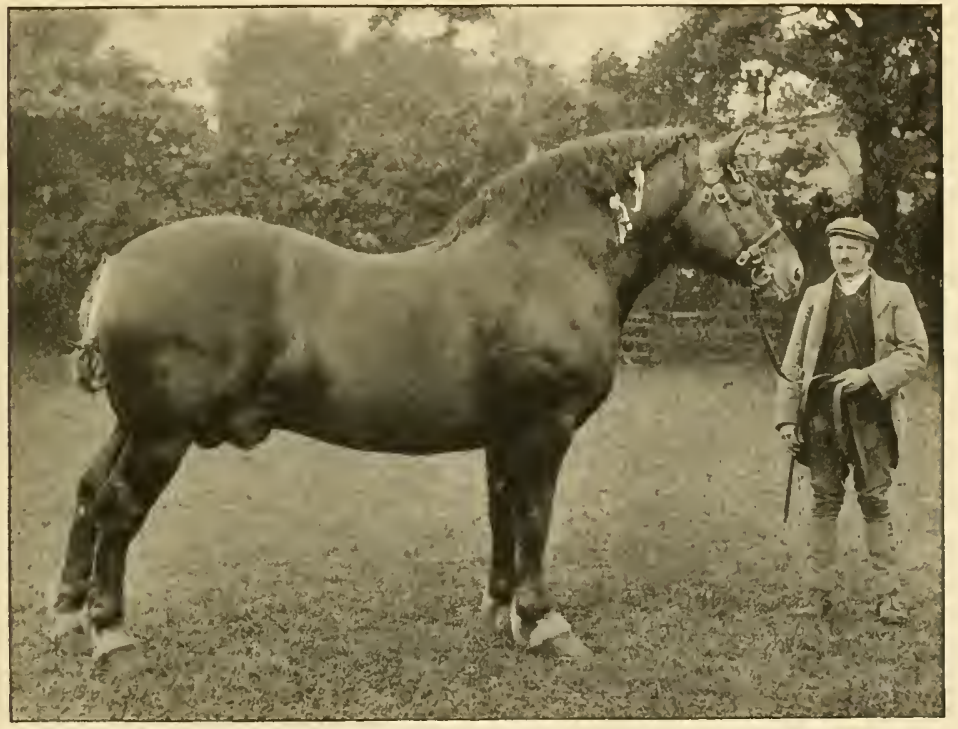

Fig. 104. Typical Suffolk Punch, 'Saturn.'

North African horses, and that the Burgundian breed-one of those developed from the infusion of Libyan blood into the horses of the North-was said to be of a chestnut colour, the improvements produced in the Suffolk Punch by the chestnuts introduced by $\mathrm{Mr}$ Blake and Mr Wright were due to the fact that the cross had in it more African blood than the old stock. Again, since bay is the grand characteristic colour of the North African horse, the Shadingfield stallion, with his grand action and high spirit, had still more of the same blood in him, 
whilst it is of the highest importance to note that his descendants regularly had the white stockings so distinctive of the North African stock. We are thus able to substantiate our conclusion that the existence of white marks on the legs and in the faces of bay and similarly coloured horses is due to the presence of Libyan blood.

I learn from one of the chief Suffolk breeders, Mr Alfred J. Smith of Rendlesham, near Woodbridge, that at the present day breeders "object to a horse with white stockings, though we sometimes get one with a white foot, but not very often, and we also object to too much white on the face: a good whole-coloured red chestnut is what we like best." In the Suffolk Stud Book one of the conditions of entry is that "no horse otherwise than a chestnut colour shall be admitted, but white or silver hairs well blended with chestnut shall not be held to be ground of objection provided the quantity does not amount to a decided roan." I here figure (Fig. 104) Mr Alfred J. Smith's 'Saturn,' the winner of twelve championships and special prizes and twenty-two first prizes ${ }^{1}$.

We have learned from Blundeville (p. 363) that in his day there were those who bred light and swift horses for racing and galloping the buck. But it must not be supposed for a moment that these light, swift horses sprang from "a pure well of English undefiled," for in Elizabeth's reign both the North African horse and his Turkish offshoot were well known in England. Thus Shakespeare represents Bolingbroke as riding on "a roan Barbary horse" ; Othello" is referred to as a "Barbary horse"; and in Hamlet" Barbary horses are also mentioned.

In adding a chapter on the various breeds of horses to the second edition of his work in 1580, Blundeville declares that he

${ }^{1}$ I am indebted to Mr A. J. Smitlı for the loan of the photograph from which the illustration is taken.

2 Rich. II., v. 5.

${ }^{3}$ Othello, I. 1.

${ }^{4} \mathrm{v} .2$. Shakespeare twice mentions roan horses (once as already cited, once in $1 \mathrm{Hen}$. IV., "Give the roan horse a drench"); twice he mentions bay (" a bay trotting horse," Lear, In. 4; "a bay courser," Tim., I. 2). He also mentions a team of four white horses in Timon, doubtless following a classical source. 
means "not here to treat of all the kinds of Horses that be in the worlde," but that he "will onlie talke of the most worthie, and speciallie of such as have been knowne of late daies by good experience, to prosper verie well in this lande, and bee not unknowne to the most part of the Gentlemen of this Realme, which kindes be these here followinge." These are "the Turk, the Barbarian, the Sardinian, Napolitain, the Jennet of Spaine, the Hungarian, the high Almaine, the Frizelande Horse, the Flanders Horse, and the Irish Hobbye." With reference to the Barbary horse he says that "those Horses that we commonlie call Barbarians, do come out of the King of 'T'unnis land, out of Massilie Numidia, which for the most part be but little Horses, but therewith verie swift, and able to make a verie long cariere, which is the cause why we esteeme them so much."

Gervase Markham, early in his book called Cavalarice, or the English Horseman, in eight books, each dedicated to a distinguished personage (including James I and Henry, Prince of Wales), writes" : "Againe for swiftnesse, what Nation hath brought forth that horse, which hath exceeded the English? For thereof we have this example: when the best Barbaries that ener were in my remembrance were in their prime, I sawe them oner runne by a blacke Hobbie at Salisburie of Maister Carltons, and yet that Hobby was more oner runne by a horse of Maister Blackstone called 'Valentine,' which 'Valentine' neither in hunting nor running was ever equalled, yet was a plaine bredde English horse both by syre and damme: to descend to our instant time, whateuer men may report or imagine, yet I see no shape which can perswade me that 'Puppie' is any other than an English horse: and truly for running I holde him peerlesse. Again for infinite labour, and long endurance, which is easiest to be discerned in our English hunting matches, I haue not seene any Horse able to compare with the English Horse, so that I conclude the English horse is of a tollerable shape, strong, valiant, swift, and durable."

From this it is clear that it was for their racing capabilities that the Barbary horses were valued in England, and we need

${ }_{1}^{1}$ For this extract I am indebted to my friend Sir Ernest Clarke. 
not doubt that the light, swift horses bred for racing and hunting had a good deal of Barbary blood in their veins, and that such too was the case with those horses claimed as purely English by Markham. That the Turk also had been imported into England more than a century before the arrival of the oft-mentioned Byerley Turk in 1689 is put beyond doubt by Blundeville, who states that the horses which he had seen "come from Turkey, as well into Italie, as hither into England, be indifferentlie faire to the eie, though not verie great nor stronglie made, yet very light and swift in their running, and of great courage." The Turk therefore as well as the Barbarian probably had a considerable influence on the racers and hunters of the day.

There is therefore no need to assume, as has been done by at least one leading authority, that Arabian horses had been imported long before 1616, when King James I bought an Arabian from $\mathrm{Mr}$ Markham. With reference to this famous animal and the large price paid for him, my friend Sir Ernest Clarke has sent me a valuable historical note, which I here give in full :

The Fourth Edition of Volume I. of the General Stud-Book, published by Weatherbys in 1868 (Query a copy of the First Edition, published in 1808), says at the head of the Fourth Part:

"Arabs, Barbs and Turks."

"King James I bought an Arabian of Mr Markham, a Merchant, for 500 guns., said, but with little probability, to have been the first of that Breed ever seen in England."

The original foundation for this figure of 500 guineas (which has been faithfully copied in all the books of reference) is probably the following reference to the horse in question made by that famous equestrian, the Duke of Newcastle, in his "New Method of Dressing Horses" (T. Milbourn, 1667):

"(p. 7:3) I never saw any but one of these Horses (Arabian) which Mr John Markham, a Merchant, brought over and said $\mathrm{He}$ was a right Arabian; He was a Bay, but a little Horse, and no Rarity for Shape; for I have seen 
many English Horses farr Finer. Mr Markham sold him to King James for Five Hundred Pounds; and being Trained up for a Course, when he came to Run, every Horse Beat him."

Newcastle had been appointed in March, 1637, Governor to Prince Charles, afterwards King Charles II, whom he taught to ride: and he celebrates the progress in equitation of his Royal pupil in the Preface to his well-known Book on Horsemanship, published at Antwerp in 1658. Presumably Newcastle must have had an intimate knowledge of the Royal Stables at this time. But prices mentioned in conversation as given for Horses, were probably then, as now, not very reliable; and as a matter of fact, the exact price (£154) given for this Horse is recorded in the Exchequer of Receipt, Order Books preserved in the Public Record Office.

Subjoined is the actual entry:

"11 July, 1616-An Account of such horses bought for the King and Queens Majesty's service since the 11th July 1616 and how the sum of $400 l$, impressed to the Rt. Hon. the Earl of Buckingham, Master of your Majesty's Horse towards the buying of horses for your Majesty's use hath been disbursed : viz.

"Item the 20th of December, 1616, paid to Master Markham for the Arabian Horse for His Majesty's own use, 154.0. 0.l."

"Item. The same day paid to a man that brought the same Arabian horse and kept him, 11. 0. 0.l."

In these same Accounts the prices of Geldings bought for the Royal Stables are as follows:

$£ 17$; £15; £15. 8. 0 ; £26. $13.4 ; £ 20 ; £ 18 ; £ 16.10 .0$; $£ 16 ; £ 16 ; £ 12 ; £ 13.6 .8 ; £ 16 ; £ 14.7 ; £ 15 ; £ 16 ; £ 14 ;$ $£ 18 ; £ 14 ; £ 16 ; £ 16.8$. 0 .

Special prices are paid for

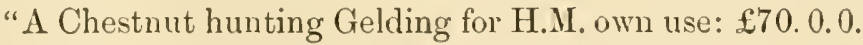

3 large grey gldgs. for H.M. coach $£ 90$ (£30).

For H.M. own Saddle £40. 0. 0. 
Large grey mare to be sent to H.MI. Race at Tutbury, £20. 0. 0."

The price of $£ 154$ given to "Master Markham for the Arabian Horse for His Majesty's own use" was therefore quite exceptionally high; and 500 guineas as a price for a Horse in those days is inconceivable.

It has been supposed by many that the 'Master Markham ' in question was Gervase Markham, who amongst very numerous books on a great variety of subjects, wrote the well-known treatise called 'Cavalarice' mentioned above (p.37 7 ). The Duke of Newcastle speaks, however, of 'John Markham, a merchant,' who brought the horse over, presumably from the East, saying he was a 'right Arabian,' though the Duke did not think much of him, as being small, and having ' no rarity for shape.'

As the evidence puts it beyond doubt that no Arab horse had been imported into England prior to 1616, the excellent English hunters (such as the chestnut for which King James I gave 70 pounds) able to beat Barbarie horses and an Irish Hobbie, probably derived their good blood from those Barbary and Turkish horses, commonly imported into England during at least the second half of the sixteenth century.

Since, according to Blundeville, not only Barbary and Turkish, but also Spanish, Neapolitan, and Sardinian horses were known in England in 1580, we now understand how it was that the supply of light-built, swift horses of the hunter class bad by the middle of the reign of Charles I increased so much as to excite the alarm of old-fashioned cavaliers like Sir George Harwood. It was the abundance of such horses that enabled Cromwell to provide excellent 'mounts' for his Ironsides at a cost of about 18 pounds each, though he himself was quite ready to pay 60 pounds for 'a black horse,' which may have been, as supposed by Sir W. Gilbey, 'a great horse.'

But it is to the reign of Charles II that the real origin of our English thoroughbred must be ascribed. Although we have abundant proof of the importation of Barbary, Turk, Neapolitan, and other foreign stallions, we do not hear of the importation of a single mare of any of these breeds, and though 
it is always daugerous to argue ex silentio, the readiness with which Arabs will sell colts, and their reluctance to part with mares is a fact so well known in modern times (p. 168) that we may safely assume that a like objection to sell mares prevailed in North Africa and the Orient in medieval days.

But Charles II sent his Master of the Horse, Sir John Fenwick, to the Levant, and he was there able to purchase brood mares as well as stallions, principally Barbs and Turks'. It is to these mares (known as the King's mares) we must trace the real origin of our English thoroughbred, for it is now practically admitted that our racing stock is purely foreign in origin, since, with the remarkable exceptions of Sampson and Bay Malton, in each of which there was a slight cross of vulgar blood, no horse of mixed lineage has been able to beat one of pure North African blood. This is in complete agreement with what we have learned of the Arab and his derivatives in Western Asia, for it is fully recognised that the pure Al-Khamseh horses of Central and Southern Arabia are superior to the so-called Arabs of Syria, Mesopotamia, and Persia, in which there is commonly a considerable admixture of Upper Asiatic blood.

As the Arab from his ancient practice of tracing his own pedigree through females is inclined possibly to lay too great stress on descent through mares, so the English from their rooted belief in male descent have generally thought only of the stallions and have unfortunately paid too little heed to the mares. The stud-book shows the names of no fewer than 174 so-called 'Eastern' sires, of which 89 are elassed as Arabians, 47 as Barbs, 32 as Turkish, 4 as Persian and 2 as foreign horses not more closely defined ${ }^{2}$. The importation of all these dates from the reign of James I downwards. But even in the case of the mares imported by Charles II neither names nor any other details seem to have been recorded. It is tolerably certain that soon after the arrival in this comtry of these Royal mares the king possessed the best breed of running horses in the kingdom. At his death, when his stud was broken up, these mares were eagerly sought by the principal breeders of the time, and after-

1 Youatt, The Horse, p. 65.

2 Charles Richardson, The English Turf (1901), p. 282. 
wards in many cases became known by the name of their owners or their owners' stud. 'Thus we hear of the D'Arcy Royal mare, the Sedbury Royal mare, the Why Not Royal mare in the pedigree of Eclipse ${ }^{1}$, in which figure altogether six Royal mares. It is unfortunate that we have no record of the colours of these Royal mares or their female progeny, but from what we have learned of the practice of the Arabs and other peoples (p. 188), we may take it as certain that the mares sold in the Levant to Sir John Fenwick were not likely to be superior in blood to the imported stallions, and were probably inferior. It will be remembered that the horses of the Levant, Irak and other parts of Western Asia are generally inferior to the pure-bred horses of the Anazah tribes, and that they are commonly grey, white, or black, and we arrived at the conclusion that such horses had in their veins more or less. Turcoman blood; we also saw that yellow was a usual colour amongst the common Turcoman horses. As might naturally have been expected, the stallions imported from the Levant were generally of a light colour. This fact is clearly established by the pedigree of Eclipse from whom most of our modern race-horses are descended. The pedigree includes the Byerley Turk (1689), the Lister Turk imported by the Duke of Berwick also in the reign of James II, and sold by the Duke to Mr Lister of Lincolnshire, Lord D'Arcy's White Turk, and Lord D'Arcy's Yellow Turk, imported in the last decade of the seventeenth century, Bay Malton (1705), Grey Wilkes, Coneyskins (1712) a grey horse, son of the Lister 'Turk, Grey Hautboy, Hutton's Bay Barb (imported 1720), Hutton's Grey Barb, the Godolphin Barb (a brown bay with some white on his off hind heel), and Bald Galloway.

It has long since been generally recognised that Eclipse owed his excellence to his great-great-grandsire the Darley Arabian, probably the only pure-bred Anazah horse in our stud-book. But it is worthy of notice that only one strain of this famous Eastern horse is to be found in the pedigree, while there are no fewer than nine strains of Hautboy, who represents

1 Charles Richardson, The English Turf (1901), pp. 286-7. The author has compiled a most useful pedigree of Eclipse. 
the blood of D'Arcy's White Turk, five of the Lister Turk, six of Spanker, who was son of D'Arcy's Yellow Turk, and two of the Leeds Arabian!. Spiletta the dam of Eclipse was bay, his sire Marske was brown, whilst he limself was chestnut. But we have learned above (p. 174) that brown is not found in AlKhamseh, but only in the inferior strains, that dun is essentially a liadish colour, and accordingly the Yellow Turk who contributed so much towards the blood of Eclipse was a Turkish horse of very doubtful lineage; and we have also shown that

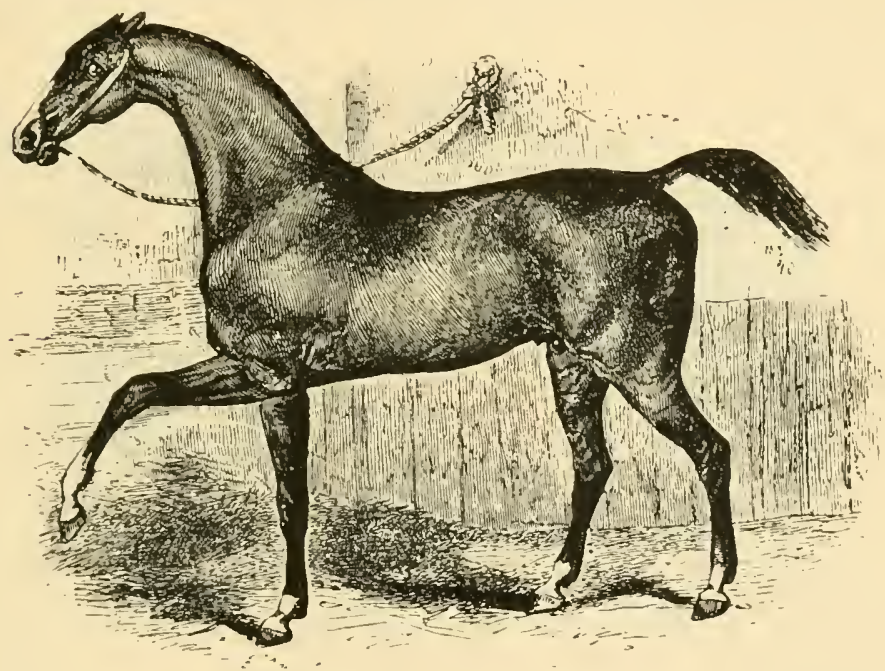

FIG. 105. Flying Childers.

greys and whites, even when reckoned in Al-Khamseh, must be regarded as impregnated with Upper Asiatic blood (p. 174). We also suspected (p. 187) that chestnut might prove to be the outcome of an admixture of Upper Asiatic blood with the Libyan; and the case of Eclipse, who was the outcome not only of several bay ancestors, but also of the Yellow Turk, and others whose purity of blood we have shown to be very doubtful, points to the same conclusion.

The evidence of the colours of the imported stallions renders

1 Charles Richardson, The English Turf (1901), p. 287. 
it highly probable that the mares acquired by Charles II were not more choice in quality and colour than were their mates. The Darley Arabian (1710) was purchased in Aleppo by the brother of his owner, Mr Darley. As he had been bred in the desert of Palmyra it is probable that he may have been of full Al-Khamseh blood. This horse by name Ras-el-Fedowi ('The Headstrong') was dark bay, as is shown by his portrait, still at Alby Hall. His immediate descendants were the Devonshire or Flying Childers (Fig. 105), who was bay, and whose portrait is preserved at Chatsworth, the Bleeding Childers,

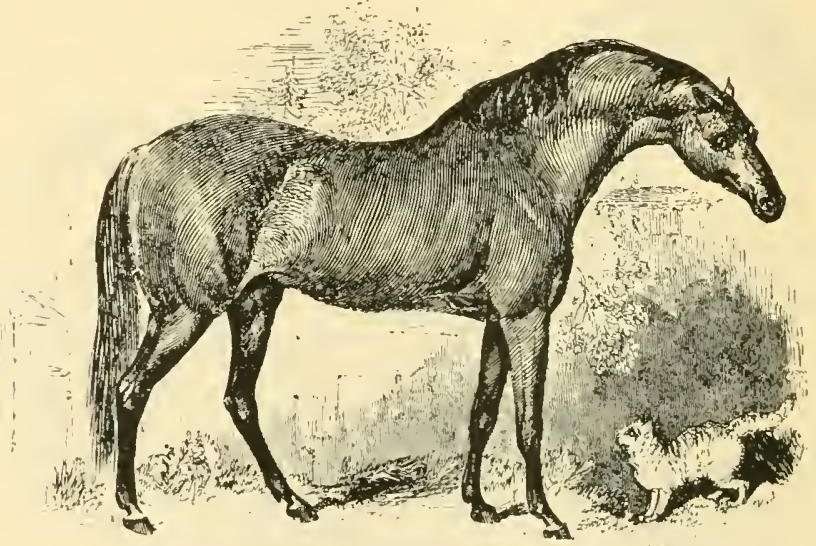

Fis. 106. The Godolphin Barb.

or Bartlett's Childers (who was never trained), Amazon, and many others. From the two Childers were descended another Childers, Blaze, Sampson, Eclipse, and many other good horses. Eclipse in turn became the sire of 334 winners of races. The Godolphin Barb (Fig. 106), purchased in Paris as he was drawing a water-cart, was presented to Lord Godolphin (who termed him an Arabian ${ }^{1}$ ) some twenty years after Mr Darley had imported his Arabian. He died in 1753, and is buried under the stable gateway at Gog-Magog, near Cambridge.

I The inscription on his tombstone is as follows: "The Godolphin Arabian, died 1753, aged 29 years." Richard Berenger, Gentleman of the Horse to George III, emphatically denies that the famous horse was an Arabian (History and Art of Horsemanship, 1771). 
It has been long remarked that although in its early days our racing stock showed numbers of blacks, greys, and whites, it has gradually become almost entirely a race of bays and chestnuts. It has also been pointed out that the strain of the Godolphin Barb, which had exercised so great an influence in the early period, has for the last half century given place to that of the Darley Arabian.

In 1786 two English thoronghbred sires, Messenger and Shark ${ }^{1}$, were exported to America and laid the foundation of the thoroughbred stock in that country, and since then the

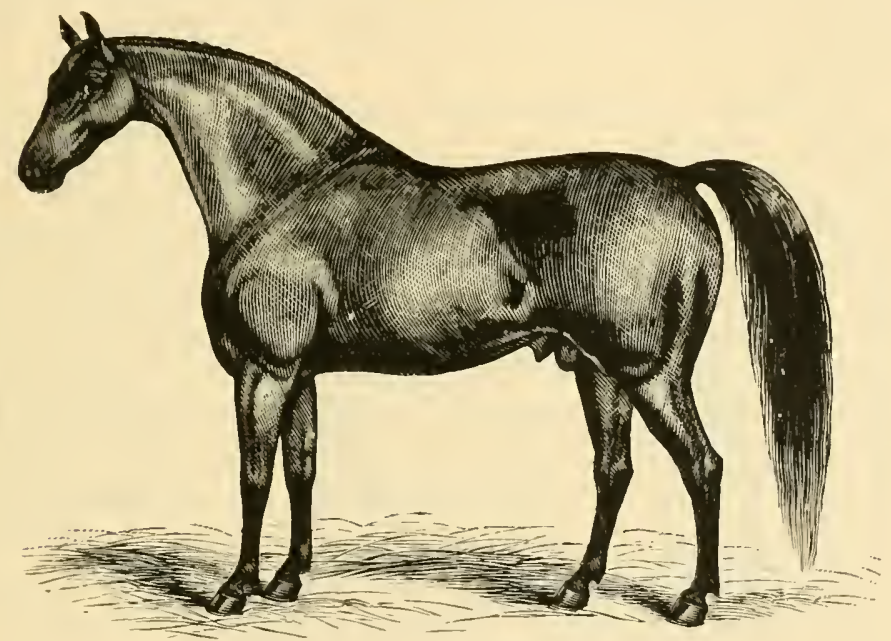

Fig. 107. Yorkshire Coach-Horse.

Americans have constantly kept importing good English sires. The Australian thoroughbreds are likewise English in origin, but owe to a recent infusion of fresh North African blood their sound constitutions for which they are famous.

It is from a judicious blending of thoroughbred blood with the old great horse that several of our most useful breeds have come. We saw that when the great horse was discarded by the soldier he was utilized to drag the heavy coaches of the seventeenth century through the sloughs and ruts of the highways of that time. The desire to obtain a horse which would combine greater speed with strength led to the crossing of

1 John H. Wallace, The Horse of America (1897), pp. 222-31, 303, etc.

R. H. 
Yorkshire cart-mares with a Barb, from which sprung the wellknown Cleveland Bays, which almost always had a black dorsal stripe'. That bay colour accompanied by such a mark should result from the introduction of Barb blood is a very important fact. But, as greater speed in coaching was required, the Yorkshire coach-horse (Fig. 107) ${ }^{2}$ was developed by crossing Cleveland Bays with thoroughbred blood.

The old English roadsters-the Norfolk Trotter (which owed its trotting qualities to blood imported from the Low Countries, p. 341) and the Hackney-after frequent crossing with thoroughbred blood have given us the modern Hackney (Fig. 10s).

According to so high an authority as Col. St Quentin ${ }^{3}$ the Irish horse-breeding at the present time "is the wonder and envy of continental nations, who support their breed by State aid," and he attributes to the limestone subsoil of the great central plain of Ireland "the indisputable excellence of our indigenous breed," and he holds that "it is an undoubted fact that blood carries more weight comparatively under a strain than bone, and to blood alone I feel assured is due their speed and stamina, and that it makes them what they are, the best in the world." Sir Walter Gilbey ${ }^{4}$ holds the same view respecting the value of the Irish limestone subsoil. As the typical Irish horse is "the best in the world," in the opinion of one who though he in the extract just given identifies himself with Ireland is nevertheless an Englishman, it is of special importance for the present inquiry that we should know its origin. Though for the last 150 years many high-class thoroughbred stallious and mares have been imported from England into Ireland, and though the Irish Parliament voted money for the improvement of horse-breeding, the Irish horses were famous long before the Godolphin Barb, the Darley Arabian, and the Byerley Turk, or even the Markham Arabian were heard of.

1 Hayes, Points of the Hor'se, p. 332.

2 I am indebted to the Royal Agricultural Society (through Sir Ernest Clarke) for permission to use this and the following illustration.

3 Reports by the Commissioners appointed to inquire into the Horse-breeding Industry in Ireland, 1897, p. 6.

+ Young Thoronghbreds, pp. 27 sqq. 
In 1673 Sir William Temple met a French buyer who harl purchased twenty horses in Ireland for the French army at from twenty to sixty pounds a-piece ${ }^{1}$.

Aceording to the historical evidence laid before the Royal Commission on Irish horse-breeding by Dr Michael Cox ${ }^{2}$ it appears "that at a very early date much attention was devoted to horse-breeding in Ireland, and that a distinct type of animal was established in the country, the superiority of which is attributed to the importation from Spain of sires of Eastern

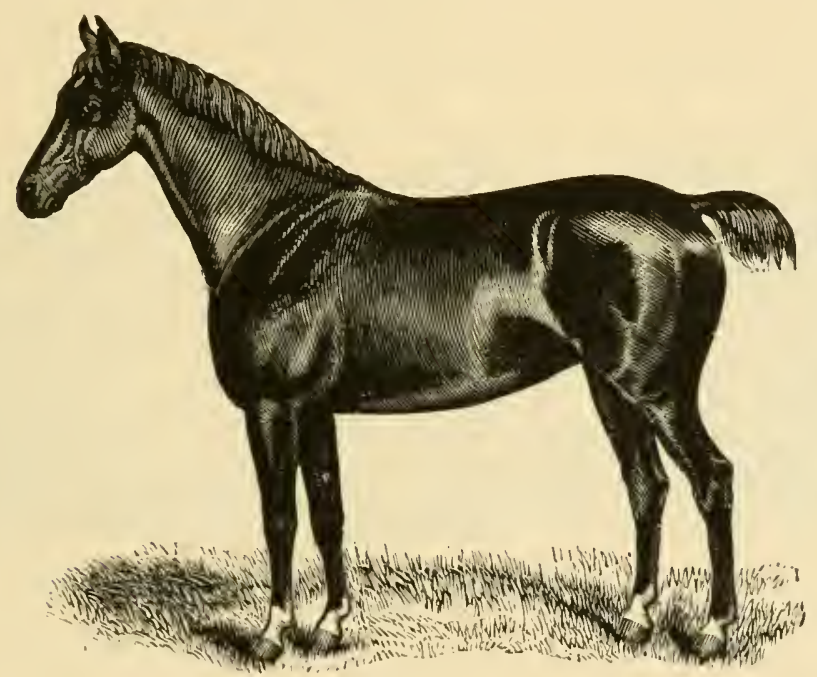

F1:. 108. A Hackney Mare.

origin"; whilst according to the information supplied to the same body by Mr Matthew Kenny the "old Irish mare" was small, clean legged and hardy, and the same authority holds that "this breed originated in the numerous Spanish stallions brought to Ireland in the sixteenth century. There was a regular trade between the south and west of Ireland and Spain for many centuries, Ireland exporting wool, hides, and butter, and receiving in return wine, eloth, horses, and specie. The class of Spanish horse introduced was the Andalusian Barb. 'To this element

1 Dr Michael Cox's evidence before Commission, op. cit. p. 6 .

2 Reports, p. 6. 
may be attributed the extraordinary endurance of the Irish hunter of the present time," but it is important to observe that the writer admits "that the outward and apparent influence of Spanish blood can at present be only recognized in the Connemara pony."

Irish horses were evidently in demand in England for racing, and we learn from the passage of Gervase Markham cited above (p. 377) that he had seen a black Hobbie beat the best Barbs which had been in England in his own day. Markham's statement has the further interest that he mentions the colour of this excellent Irish racer. The fact that it was of a dark colour points to a considerable infusion of North African blood.

But already in the sixteenth century the Irish horses were regarded as superior, for Thomas Blnndeville in the work so often cited" thus describes them: "The Irish Hobbie is a prettie fine Horse, having a good head, and a bodie indifferentlie well proportioned, saving that manie of them be slender pin buttocked, they be tender mouthed, nimble, light, pleasant, and apt to be taught, and for the most part they be amblers, and therefore verie meete for the saddle, and to travell by the way; yea, and the Irish men, both with darts, and with light spears, do use to skirmish with them in the field. And manie of them do prove to that use verie well, by meanes they be so light and swift, notwithstanding I take them to be verie nesh and tender to keepe, and also to be somewhat skittish and fearful, partlie perhaps by nature, partlie for lacke of good breaking at the first."

John Major ${ }^{2}$ writing on Ireland in 1520 says: "The island produces a kind of horses which the natives call Haubini, whose pace is of the gentlest. They were called Asturcones (cf. p. 258) in old times, because they came from Asturia in Spain, and indeed the Spanish colonists brought those horses along with them. The French call these same horses English Haubini or Hobini, because they get them by way of England." Another medieval writer" says that in all Ireland "most excel-

1 The Risling and Breaking of Great Horses, ch. 2 (only in 2nd ed. 1580).

2 History of Great Britaine (transl. from the original Latin ed. (1522) by A. Constable (Edinburgh, 1892), pp. 53-4, with valuable notes). Littré explains Hobin as nom d'un race de chevaux d'Écosse; cf. Littré, s.v. Hobin.

3 See Carve, Lyra, ed. 1666, p. 43 (cited by Constable). 
lent horses of a very pure breed are produced termed Hobini by the English, which have a most gentle pace, and on that account are much sought by effeminate persons, and in France and Italy are given as presents to noble ladies"; and he states that he had seen "twelve pure white horses of this breed, housed with purple and with reins of silver, led in the Pope's procession, without any riders on their backs." It would thus appear that the best 'English' horses known on the ('ontinent in the 15 th century were really Irish (cf. p. 361).

The method of fighting described by Blundeville was that employed by the Irish at the time of the Norman invasion (A.I. 1172) of their country, for Giraldus Cambrensis ${ }^{1}$, Secretary

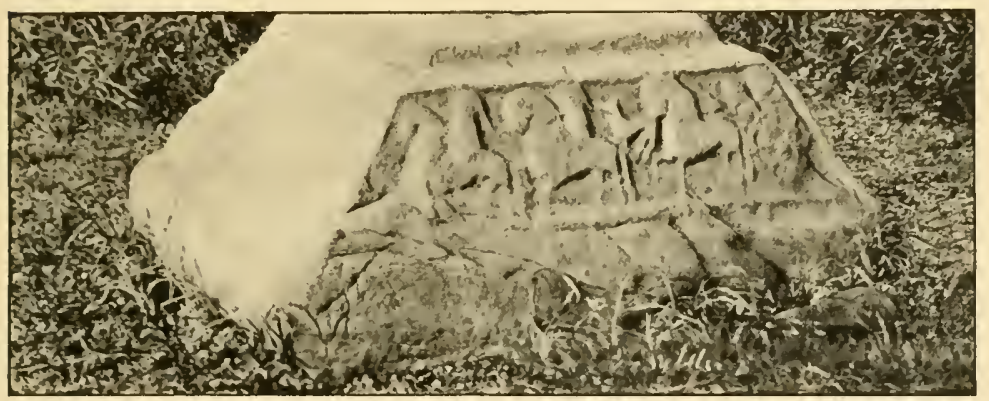

Fig. 109. Plinth of Cross, Kells, co. Meath.

and Chaplain to Henry II, says that they went to battle without armour which they despised, and with a short spear and two darts "like Basclenses (Basques)," whilst "in riding they neitlier use saddle nor boots nor spurs, but only carry a rod in their hand, having a crook at the upper end with which they both urge forward and guide their horses. They use halters which serve the purpose of a bridle and a bit and do not prevent the horses from feeding as they always live upon grass." On the other hand the Normans "with their complex armour and their deeply curred saddles found great difficulty in gretting on horseback and dismounting: still greater when uccasion demanded that they should march on foot." Though

1 Topogr. iri. 10. Conquest of Ireland, II. 36. 
unfortunately Giraldus gives no description of the Irish horses, they evidently had already that docility which stamped the Irish Hobbie of the sixteenth century, and which, as we have already seen, characterizes the horses of North Africa both in ancient as well as modern times, their descendants in Spain from before the Christian era, and their Eastern progeny, the Arabian. That these Irish horses were already known as Hobbies in the century when Giraldus wrote is proved by a Scotch document ${ }^{1}$ which gives the number of equi discooperti qui dicuntur hobelarii (i.e. Hobbies) among the Irish troops serving in Scotland in 1296. These Irish horses may well have been largely mixed with North African blood derived from Spain many centuries earlier than the Tudor period. The trade between the south and west of Ireland with Spain and southern France goes back into a very remote period, even one type of Irish Bronze Age axe differing from any found in Britain, but being similar to one in Spain.

Nor is this view unsupported by representations of the medieval Irish horse. On the contrary the beautiful remains of Irish art, unrivalled in their kind, furnish many representations of horses, both ridden and driven under chariots. Thus the famous North cross at Clonmacnoise, King's Co., bears on its phinth two panels, in the uppermost of which are three horsemen, in the lower two chariots and horses. The chariots (which contain men) have eight-spoked wheels. Another famous cross which, like that of Clommacnoise, may be assigned to the tenth century, still stands in the street of the town of Kells, co. Meath, and exhibits horsemen (Fig. 109)' in the panel on one side of the plinth, whilst the other panel shows a hunting scene.

The horses on both these monuments, although executed in a material not particularly well adapted for delicacy of delineation, are smart, well-bred animals, tallying completely

1 J. Stevenson, Documents illustrative of the history of Scotland (1870), Vol. 11. p. 125.

2 My illustration is from a photograph of the original by $\mathrm{Mr} \mathrm{R}$. Welsh of Belfast, well known for his photographs of Irish antiquities. Both the crosses are well figured in Henry O'Neill's Sculptured Crosses of Ancient Ireland (London, 1857), pp. 11, 22, and 33. O'Neill shows on the Kells cross four horsemen, two of whom carry round shields. 
with the descriptions of Blundeville and Giraldus Cambrensis. The horsemen on the Kells cross use bridles, but do not appear to have stirup or saddle, but the eross of Clonmacnoise has suffered too much from time and weather to sanction any dogmatic statement about these details.

In the matchless illuminations of the Book of Kells commonly assigned to the end of the seventh or the beginning of the eighth century, we meet representations of horsemen several centuries earlier than those from the cross of Kells, but as they are introduced for purely decorative reasons, we cannot rely on them for more than the costume of the riders and the trappings of the steeds. Thus the grotesque horseman on folio 89 wears a short green cloak with a broad band of bright red and a yellow border, green breeches, the feet being bare, whilst the horse has a yellow cover, all the portions which appear being depieted in green (Fig. 110)․ Neither has this horseman nor another on folio 255 stirup or saddle, though both have bridles. By the absence of defensive armour, stirrups and saddles, and the use of

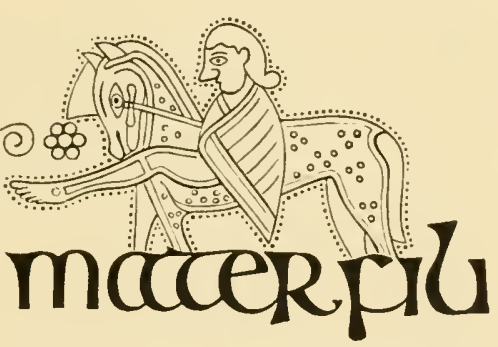

FIG. 110. Irish Horseman; Book of Kells. bridles or halters we may recognize in the horsemen of the Book of Kells the same equipment as that used by the Irish in the time of Giraldus some four centuries later.

It has now been proved that the typieal Irish horse as described by Thomas Blundeville in 1580 was no recent outcome of Spanish sires, as believed by the members of the Royal Commission, but was already in general use in Ireland by the tenth century, if not earlier. But this is not all; three horse-skulls lately discovered in a crannog (lake-dwelling) are of the highest importance in proving that not only were horses of the North African type used in Ireland as early as the tenth century, but possibly at a considerably earlier date.

1 Wilde's Cat. of the Antiq. of the Roy. Irish Academy, p. 300. 
These three skulls (now in the National Museum in Dublin) were found associated with various antiquities, the character of which has led Mr George Coffey, the keeper of the National Museum of Irish Antiquities, to date the deposit as not later than the tenth century and possibly as early as the sixth century A.D. Dr. Scharff, the head of the department of the Irish National Museum of Natural History, has pointed out to me that the skulls, which are beautifully preserved, have the distinctive features of the Arab, i.e. North African horse.

The various kinds of evidence here adduced put it beyond doubt that at a period long anterior to the supposed introduction of Spanish stallions into Ireland in Tudor times that country already possessed a breed of horses closely related to the North African.

The question now arises, Is the typical Irish horse an indigenous development from an Equus caballus celticus or from $E$. c. europeus typicus or from both, or is it the outcome of a very early and oft-repeated admixture of North African blood with that of the old European horses, whether an $E$. c. celticus or E.c.typicus, or with both?

Both Col. St Quentin and Sir Walter Gilbey hold that the superiority of the Irish horses over all others is due largely to the limestone formation of the great central plain of Ireland and the excellence of the pasturage, but probably neither of these writers would maintain that the present Irish horse could have been evolved either out of the typical Great Horse of the Continent and England in the lapse of some centuries, or from the ancient horses of Upper Europe without any blending of other blood. Indeed the very value attached to 'blood' by Col. St Quentin, when writing of the Irish horse, shows that he, like Mr Kenny, Dr Cox, and the members of the Royal Commission, believes that the Irish horses have in their veins a very large proportion of Arab, i.e. North African blood. It will therefore be hardly asserted by anyone that the Irish Hobbie of the time of Thomas Blundeville had been specialized merely under favourable conditions of soil and climate from the heavy-headed, thick-set horses of Europe and Asia, especially in view of the three skulls from a lake-dwelling just cited, which 
alone are sufficient to indicate that horses of the North African type or saturated with North African blood had reached Ireland at a very carly period. It is even possible to find some evidence of a fur earlier date which has a direct bearing on the origin of the horses whose skulls have been preserved in the peat-buried cramnog.

I have already pointed out (p. 98) that in the oldest Irish Epic cycle-that of Cuclulainn-the combatants never ride on horseback, but always fight from chariots, whereas the reverse is the case in the poems of the later or Ossianic cycle, as was apparently the established practice when the Book of Kells was written. Of course varions dates have been assigned by scholars to the Cuchulaim Saga, but thongh it may have been revised and augmented at a later period the main elements in the poems belong to pagan times. The events commemorated in these poems are supposed to have taken place in the first century before Christ, and even though it may not be admitted that they were first composed at so early a date it will be generally conceded that the main body of the poems was composed in pre-Christian times, for there is good evidence that some of them were already regarded as of great antiquity in the seventh century A.D.

In The Wooing of Emer (who lived at Lusk in co. Dublin) we are told that Cuchulainn went to Alba, i.e. Albion, to perfect himself in feats of arms, and that he learned there the use of the scythed chariot, and in such a chariot he set out to see Emer, after his return from Alba. When Caesar invaded Britain in 55 B.c. he found the Bclgic tribes still using chariots, although they also possessed cavalry, whilst for a considerable period later the tribes of the north of Britain continued to use chariots, as we have already seen (p. 95). But it seems most unlikely that they continued to do so for very long after the Roman Conquest. It is not very probable that the use of the chariot for war would have continued in Ireland very long after it had been replaced by men mounted on horseback in Britain.

Though this is not the place to deal in detail with the armature and dress described in the poems, it may however be pointed out that both dress and arms seem to belong to 
what is known as the La Tène, or 'late Celtic' period, so-called from the Ganlish settlement at La Tène, on Lake Neuchatel, where many remains typical of the Gallic culture of the centuries immediately preceding the Christian era were discovered.

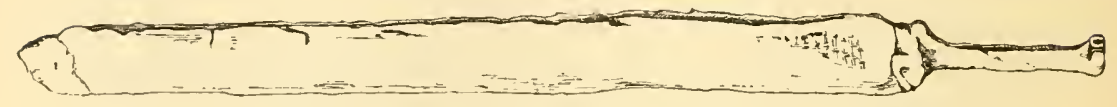

FIG. 111. Sword of La Tène type in its sheath; Connantre, Marne.

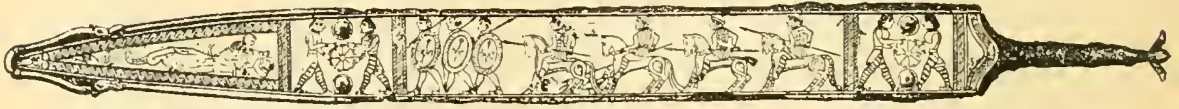

Fig. 112. Iron Sword (La Tène type) in bronze scabbard; Hallstatt 1 .

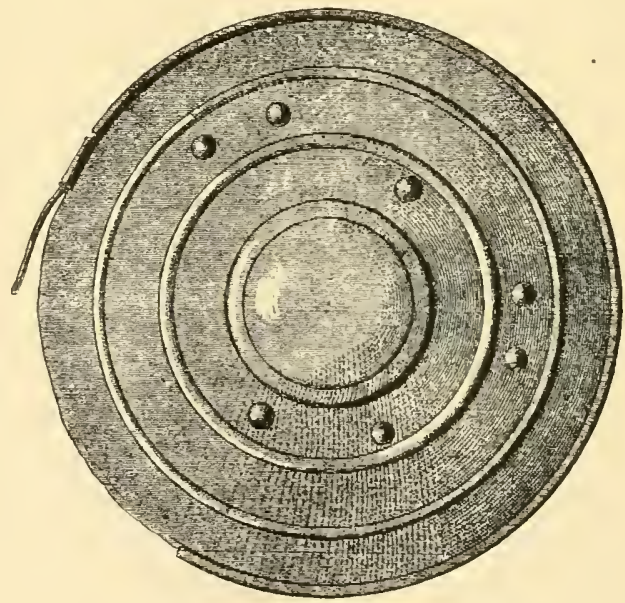

F1G. 113. Bronze Shield; Bingen?

The Gauls at that period used long iron swords of a welldefined type (Figs. 111, 112), carried oblong shields (Fig. 112) instead of the round shields (Fig. 113) of the previous period,

1 W. Ridgeway, The Early Age of Greece, Vol. I. p. 410.

Id., Vol. I. p. 478. 
and fastened their cloaks with a peculiar form of brooch (Fig. 114). Now relics of this La Tène culture are not wanting in

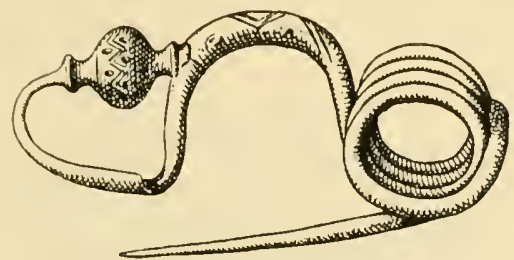

FIG. 114. Bronze Fibula; Marne .

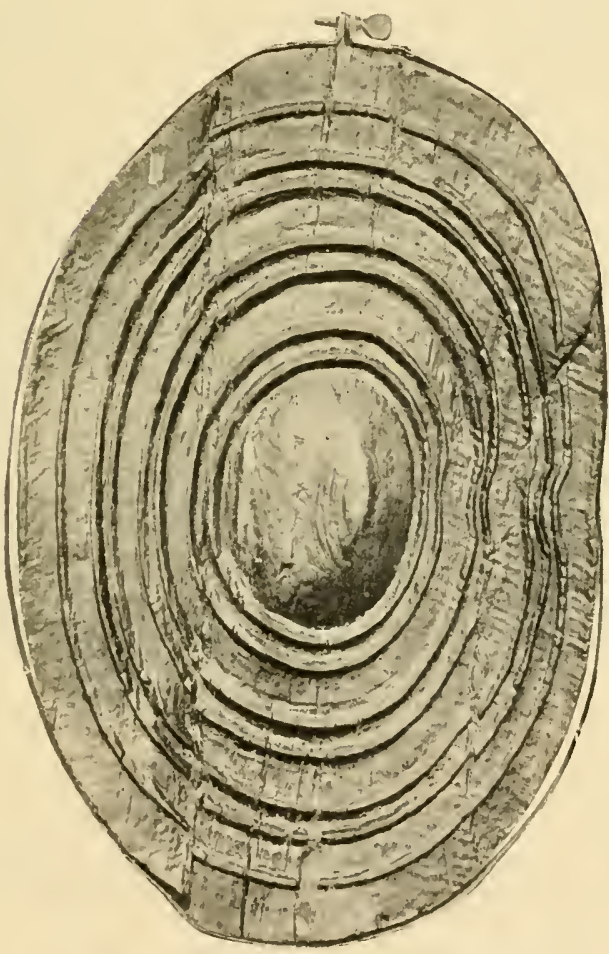

FIG. 115. Alderwood Shield; Ireland 2 .

Ireland, for there is a shield of the Gallic type in the Museum of the Royal Irish Acarlemy (Fig. 115) differing completely from
2 Ridgeway, op. cit. Vol. I. p. 456.
2 Id., Vol. I. p. 580. 
the earlier round shields used in Ireland (Fig. 118), and from the round shields used by the Irish at a later period, such as that still in the possession of the O'Donovan (Fig. 119). Similarly, brooches of undoubted La Tène or 'late Celtic' types have

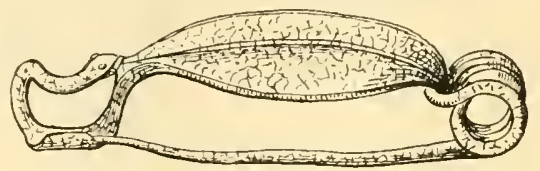

Fig. 116. Bronze Fibula; Ireland ${ }^{1}$.

occasionally been found in Ireland (Fig. 116), and this type of brooch is undoubtedly described in at least one passage of the Cuchulainn Saga, where Cuscraid son of Conchobar, the tall, yellow-haired, grey-eyed king of Ulster, is represented as wearing a dark-grey cloak fastened round him with "a leafshaped brooch (delg nduillech) of white metal

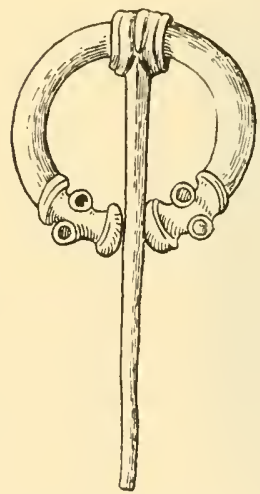

FIg, 117. Bronze Fibula; Ireland. over his breast ${ }^{2}$ " This epithet exactly fits such a brooch as that here figured from Navan Rath, co. Armagh (Fig. 116), but could not possibly be applied to the penanular (Fig. 117) brooches used in Ireland at a later period, and the genesis of which I have elsewhere traced ${ }^{3}$. As leaf-shaped brooches closely allied to the Irish brooch here shown, were in use by the Belgic tribes of East Anglia at the time of the Roman conquest of Britain ${ }^{4}$, there are good grounds for believing that the poems of the Cuchulainn cycle took shape in the period in which are laid the scenes described.

Iron swords of the La Tène type have been discovered in Ireland $^{5}$.

1 Ridgeway, op. cit. Vol. I. p. 464.

2 The Cattle Raill of Cualnge, translated by L. Winifred Faraday, M.A. (1904), p. 120 ; Lellow Book of Lecan, fol. 46 b, 28 .

3 The Early Age of Greece, Vol, 1. pp. 589 sqq., Figs. 146-152.

4 Ibid., p. 581, Fig. 131.

5 R. Mumro, The Lake-dwellings of Europe, pp. 382-4. 
Such relics seem to indicate that the Irish traditions of the invasion of fair-haired strangers from Gaul, in the centuries preceding the birth of Christ, are based on actual facts, and are not the mere outcome of a romancist's brain. In any case they demonstrate that there was constant intercourse and trade between the Continent and Ireland at that period.

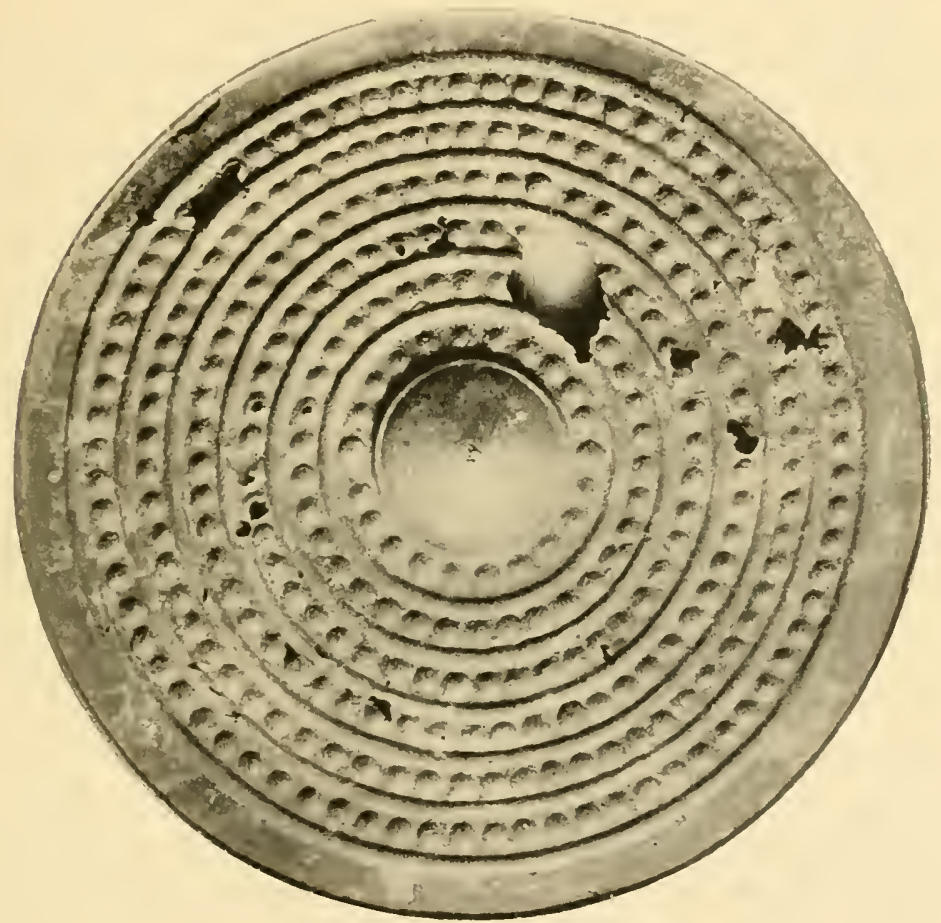

FIG. 118. Bronze Shield; co. Limerick ${ }^{I}$.

Fortunately, for our immediate purpose, a description of Cuchulainn's horses is given in The Wooing of Emer. They were "alike in size, beauty, fierceness and speed. Their manes were long and curly, and they had curling tails. The righthand horse was a grey horse, broad in the haunches, fierce, swift, and wild; the other horse jet-black; his head firmly knit,

1 The Early Age of Greece, Vol. 1. p. 479. 
his feet broad-hoofed and slender; long and curly are his mane and tail. Down his broad forehead hang heary curls of hair." "That was the one chariot which the host of the horses of the chariots of Ulster could not follow on account of the swiftness and speed of the chariot and of the chariot-chief who sat in it." The horses were guided by "two firm-plaited yellow reins," which shows that only a single rein was used for the pair.

From the results obtained in our previons investigations the reader will at once see that Cuchulainn's horses were well bred, the result of crossing the European-Asiatic horse with Libyan blood, as horses of grey and black have been proved to be, whether found among the Turcomans of Central Asia, in Asia Minor, Mesopotamia, Syria, Nubia, the Barbary States, Spain, or France. How came this breed into Ireland? When we remember that we traced the black horse of Ariège through Auvergne, Central France, along the Loire to Brittany, and when we remember that so great an authority as M. Sanson holds that there is a close kinship between the Breton pony and the ponies of Ireland and Great Britain, and when it is likewise borne in mind that all authorities are agreed in deriving the pedigree of the horses of Ariège, Auvergne, Morvan, and the Breton ponies from an 'Oriental,' i.e. Libyan, origin, there is at once a strong presumption that Cuchulainn's black steed was of Spanish or Gaulish blood. Again, when we remember that the little horses of Provence, which are grey in colour, are held by the best French authorities to be derived from Libyan blood at least a century before our era, and we also consider the fact that the Percheron, the most famous half-bred horse of France, is thought to have been already in the valley of the Seine from an early period, it seems equally probable that Cuchulainn's grey steed was also derived from either Northern Spain or Gaul. A recent discovery confirms this argument. In $1903 \mathrm{Mr}$ G. Coffe ${ }^{1}$ found in the centre of a small tumulus near Loughrea, co. Galway, a cremated burial "on the level of the old surface of the ground. It rested on a rude block of stone, and consisted of an almost plain urn

1 Proc. Roy. Irish Acad. Vol. xxv. sec. C, no. 2, p. 14. 
inverted over the burnt bones. Directly above the bones lay the skeleton of a woman with its head to the west, and beside it were the remains of a small horse, which lay on its left side with the head to the west," and which had been probably buried along with the human body. The woman was probably a slave killed to be the guardian of her master's grave. Dr. Scharff ${ }^{2}$, who examined the horse bones, states that they all belonged to one individual-a seven-year old stallion of small size. "To judge from the length of the humerus, radius, and metacarpal, the forelimb belonged to a small race of liorse or pony. The measurements of these bones are somewhat larger than those given by Dr. Marek of an Exmoor pony, but they

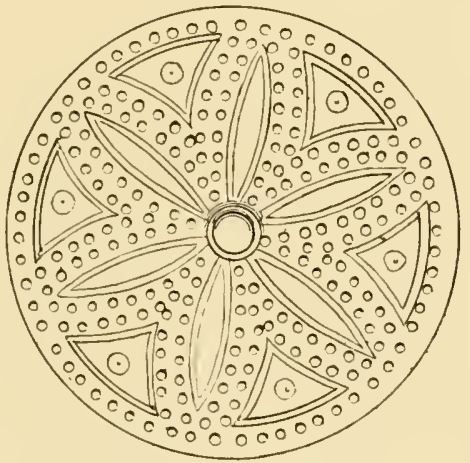

Fig. 119. The O'Donovan Shield; Skibbereen ${ }^{3}$.

are almost identical with those of the largest of the horses found at La Tène," which I have identified with the Ligurian gimni, the ancestors of the grey Camargue. As cremation only came late into Ireland and was never general, being chiefly used by the chieftain class, and as it was practised by the Gauls in Caesar's day and by the Belgic tribes of Kent', there is a high probability that it came into Ireland with the La Tène, or 'late Celtic' culture. It is certain that the Loughrea tumulus is pre-Christian and it probably belongs to the period when the La Tène culture came into Ireland. Accordingly

1 Ridgeway, Early Age of Greece, Vol. I. pp. 497, 505.

2 Proc. Roy. Irish Acad. loc. cit. $\quad 3$ Ridgeway, op. cit. Vol. I. p. 462.

$+I d$., Vol. I. pp. 503, 505. 
the horse found in the barrow whose measurements are identical with those of the Helveto-Gallic horses probably either sprung from imported ancestors or had been itself imported.

Nor is there any difficulty in proving that constant trade with France and the Peninsula was carried on in the days when the Cuchulainn Saga was composed. It is absolutely certain that already in the early centuries of the Christian era there existed a very considerable trade between Ireland and the Continent. According to the Confession of St Patrick, the apostle of Ireland sailed from that island to France in a ship whose cargo comprised those famous Celtic dogs ${ }^{1}$, which in the time of Augustus (29 B.C.-14 A.D.) also formed part of the exports of Britain ${ }^{2}$ to the Continent, where they were highly valued both for war (cf. p. 419) and the chase, more especially as the Greeks and other Mediterranean peoples possessed few dogs that conld run down a hare until they came to know the Celtic vertragus in the third century B.c. ${ }^{3} \quad$ Indeed Arrian-in what appears to be the oldest reference to the sport of coursing-calls special attention to the fact that some of the Celts who did not live by the chase, but hunted for sport, did not use nets (as did the Greeks), but gave the hare fair play. If dogs were exported from Ireland, there is no reason why the Irish should not have imported horses from France and Spain, for the Irish legends also point to early intercourse between the latter country and Ireland. Thus in The Wooing of Emer-the same poem which contains the description of Cuchulainn's steeds-we read how Emer's father, Forgall the Wily, "went to Emain Macha (the modern Navan Rath) in the garb of a foreigner, as it were an embassy from the king of the Gauls, that had corne to confer with Conchobar with an offering to him of golden treasures, and the wine of Gaul, and all sorts of good things besicles." This passage occurs in the older redaction of the poem, which is assigned to the eighth century by Prof. Kuno Meyer. From this it is perfeetly clear that when the poem was composed there was constant intercourse between Ireland and Gaul. Elsewhere in the sagas we hear of Irishmen going to the coast of Spain and Portugal.

1 Tripartite Life of St Patrick, ed. Whitley Stokes, pt. Ir. pp. 362-3.

2 Strabo, 166.

3 Arrian, Cynegeticus, 3. 
The very accurate knowledge of the geography of Ireland shown by Ptolemy (120 A.D.), puts it beyond doubt that traders from Britain and the Continent frequented the mouths of the Irish rivers in the first century after Christ. It is thus possible that before the beginning of our era the Irish had obtained some horses superior to those which they were then using, the latter being doubtless similar to those diminutive animals, still used, as we have seen, by the tribes of northern Britain to draw their war chariots at least two centuries after the Roman conquest.

There is no doubt that the trade between Gaul and Ireland and the British Isles in the first century B.C. was almost entirely in the hands of the Veneti, a tribe of Armorica (Brittany), who excelled in shipbuilding and seacraft, and whom Caesar had great difficulty in reducing to subjection ${ }^{1}$. They seem to have had the complete control of the Channel, and, as I have shown elsewhere", it was these people who were carrying on the tin trade between Cornwall, the Isle of Wight, and the mouth of the Loire when Pytheas of Marseilles made his memorable voyage into our northern seas about 350 B.C., and it was probably the same people who gave the Britons of Kent the news that Julins Caesar was preparing to invade their island home.

But, as it was probably to the mouth of the Loire that St Patrick sailed in company with the wolf-hounds, in the fifth century A.D., and as it was to the same haven that the tin of Cornwall was carried when Posidonius visited Britain about 90 B.C., it is exceedingly probable that it also was the port for the trade between Ireland and France at the time when the Cuchulainu Saga first took shape. But as, according to Sanson, the Breton pony, so similar to the ponies of Britain and Ireland, was already in Brittany before Roman times, and as we have proved the Libyan origin of that animal, it is highly probable that superior horses of Libyan blood, such as those of Cuchulainn, were imported into Ireland from Brittany. We have thus a satisfactory explanation of the origin

1 B. G., v. 8. 1.

2 Ridgeway, 'Greek Trade Routes to Britain,' Folklore Jour. Vol. I.

R. II. 
of the fine-headed horses of Libyan type, whose skulls have been discovered by Mr Coffey. From this it would follow that Sanson's E. c. hibernicus is not a separate species, or variety of horse, but only a derivative from the Libyan.

In the black Irish Hobbie that beat the best Barbs of the day, in the black Connemara ponies, in the black Hebridean ponies without hind callosities, and in the dark-coloured Highland ponies we seem to have lineal descendants from the black horses, like that of Cuchulainn, which were almost certainly sprung from the same stock as the black horses of Brittany, Auvergne, and Ariège. On the other hand, as there is good evidence of the presence of grey horses in Northern Spain at least two centuries B.c. (p. 256), and it has been made probable that the grey Camargues of Provence are descended from the ginni, which were identical with the horses of the Gauls of the La Tène period, and as there is also good reason to believe that the grey Percheron is of great antiquity in France, and that both it and the Camargue owe their excellence to Libyan blood (pp. 322, 325), we may reasonably conclude that Cuchulainn's grey steed was, like its black comrade, of Libyan ancestry derived through Gaul. These imported horses would be larger and stronger than the native Irish horses, whose own ancestors had been brought to Ireland at an earlier period.

As already stated, the Irish horses of the present day are the best in the world, and as it is in horses of the hunter type that Ireland especially excels, and as these are certainly not sprung from the unalloyed Irish Hobby, it is most desirable to trace the history of modern Irish horses. Without doubt the best representatives of the old Irish Hobbies at the present hour are those ponies of Connemara which have not been adulterated by the Clydesdale blood introduced by Scotch farmers during the second half of the last century, or by the Hackney stallions which, by a blunder begotten of historical ignorance, were introduced by the Congested Districts Board some years ago. As we have already seen, it has been generally held that the Irish Hobby was the outcome of Spanish blood (either derived from horses saved from the wrecked ships of the Armada) or directly through England (as believed by Sir W. Gilbey) or 
directly from Spain in Tudor times. Accordingly it has been the fashion to recognise an Andalusian type in the Connemara ponies, just as it is popularly supposed that a well-known type amongst the peasantry of the west and south of Ireland is due to Spanish blood derived from Spaniards escaped from the Armada, though history shows that, with very few exceptions, these unfortunates were despatched on the shore and left no time to perpetuate their race. In the chestnut colour, which

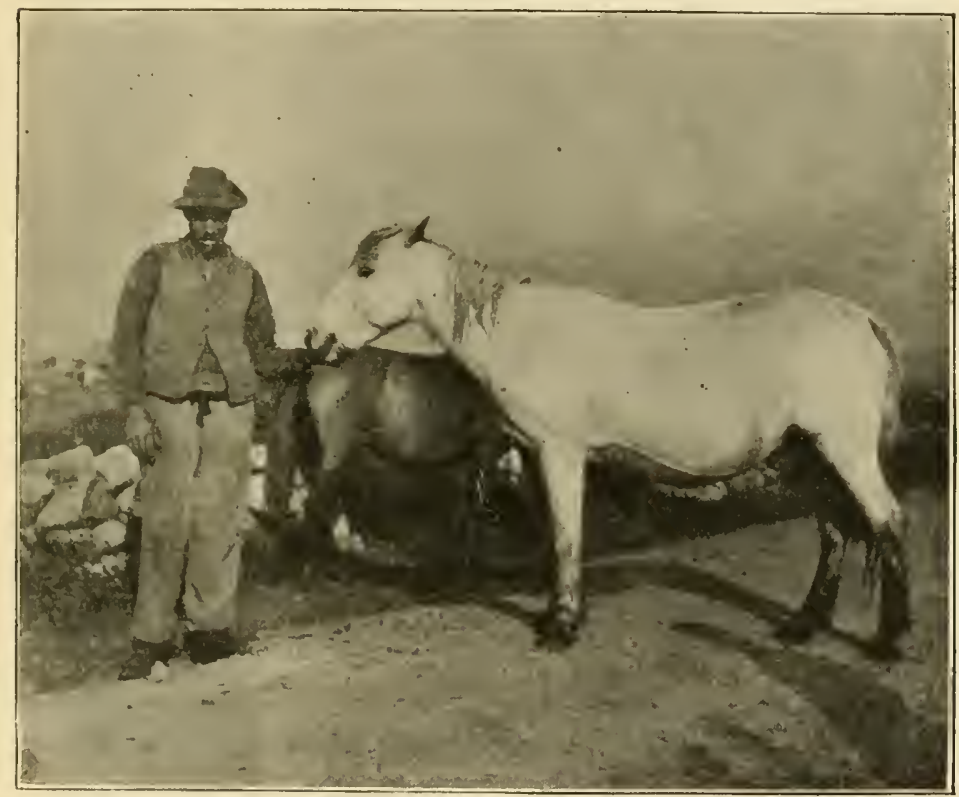

Fig. 120. Yellow-dun Connemara Pony (so-called 'Andalusian' type).

some have taken to be the most usual, writers have seen further proof of an Andalusian origin. But the Connemara ponies of to-day are dun, white, grey, black, chestnut, and bay, the most typical specimens of the so-called Andalusian type being yellow-dun (Figs. 120, 121)ㄹ, whilst the most common

I Ewart, Journal of the Department of Agriculture for Ireland, Nor. 1900, pp. 181 sqq. ; 'The Ponies of Connemara,' in Ireland, Industrial and Agricultural, 1902 , pp. 332 sqq. I am indebted to the Irish Department of Agriculture for 


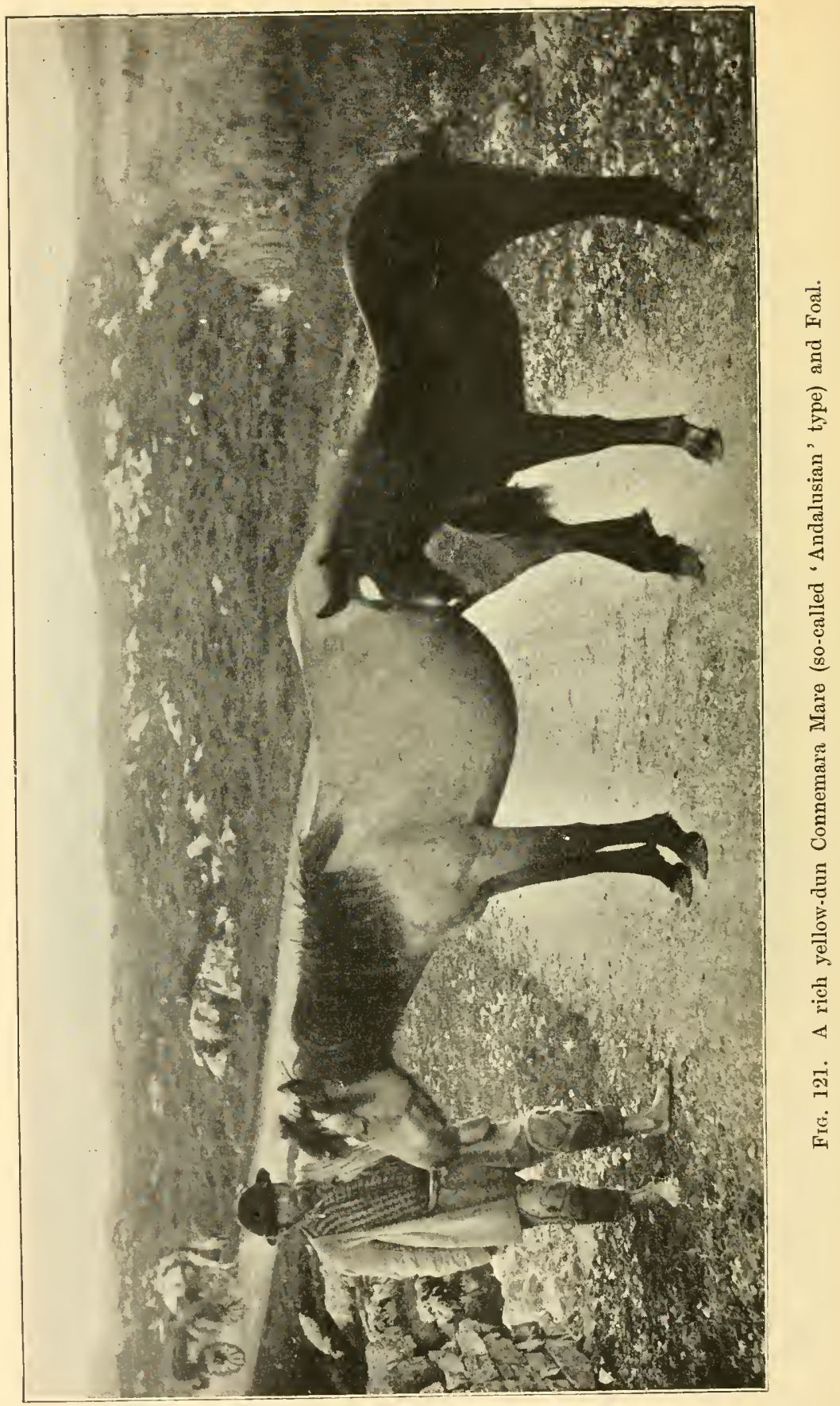


colour seems to be grey (Fig. 122). Though the old Connemara or 'Andalusian' type resembles in many respects ponies still to be seen in Andalusia, Prof. Ewart has pointed out that they bear a still more striking resemblance to some of the New Forest ponies (Fig. 123), which, as we have seen, are probably related to the Breton ponies and thus have in their veins Libyan blood derived through Spain and France (pp. 322-4),

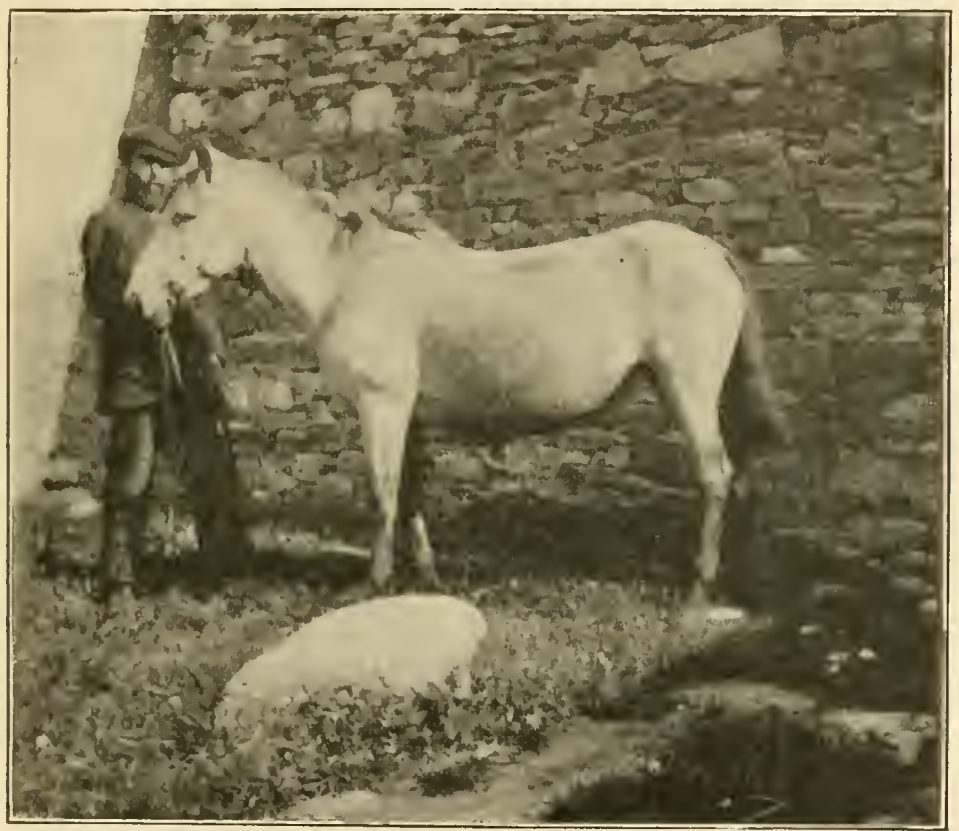

F1G. 122. Light-grey Connemara Pony (so-called 'Andalusian' type).

and possibly also that of the 'Celtic' pony. They vary from 13 to 13.2 hands: some are black, others grey or chestnut, but the most characteristic specimens are of a yellow-dun colour. Some of these are very fine in the bone with the long pasterns often seen in the New Forest ponies. The ears

the loan of all the blocks of the illustrations of Irish horses here shown (through the kindness of Mr T. P. Gill, Under-Secretary for Agriculture and Technical Education, Ireland). 
measure about five and a half inches; they have a tendency to be roach-backed, as is sometimes the case with Barbs; when compared with a Spanish jennet or with a Barb, these ponies are relatively shorter in the neck and legs, deeper in the ribs, shorter in the ears, and provided with more powerful jaws. "The Connemara is a slightly altered Barb on pony's legs"."

After having followed the pedigree of the Irish Hobby in the previous pages, the reader will not be surprised to find the

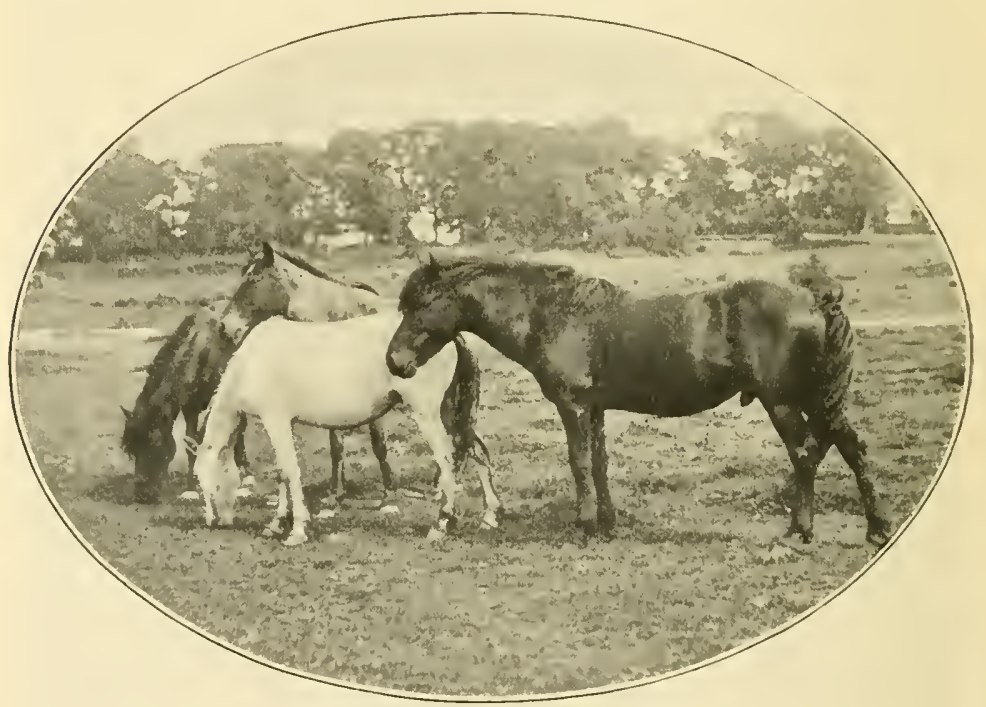

Fig. 123. New Forest Ponies 2.

resemblance and, at the same time, the difference between the Connemara pony and the North African horse. The prevalence of yellow ponies in the west of Ireland is dne to the fact that the ancient horses, whether 'Celtic ponies' or the heavy-built old European horses, were of a dun colour, and were sufficiently prepotent to transmit their colonr to a considerable proportion of their descendants, as has been done by the Asiatic element in the horses of Kattywar (p. 139) and by the ancient Spanish

${ }^{1}$ Ewart, loc. cit.

2 The illustration is from a photograph taken by Mr G. E. Low. 
horses to their descendants in the sierras of Spain. The yellowdun Connemara ponies are highly prized in some districts, not only because they are hardy and easily kept, but also because in staying power and vitality they are more like mules than purebred horses. Others of these ponies look more like Syrian

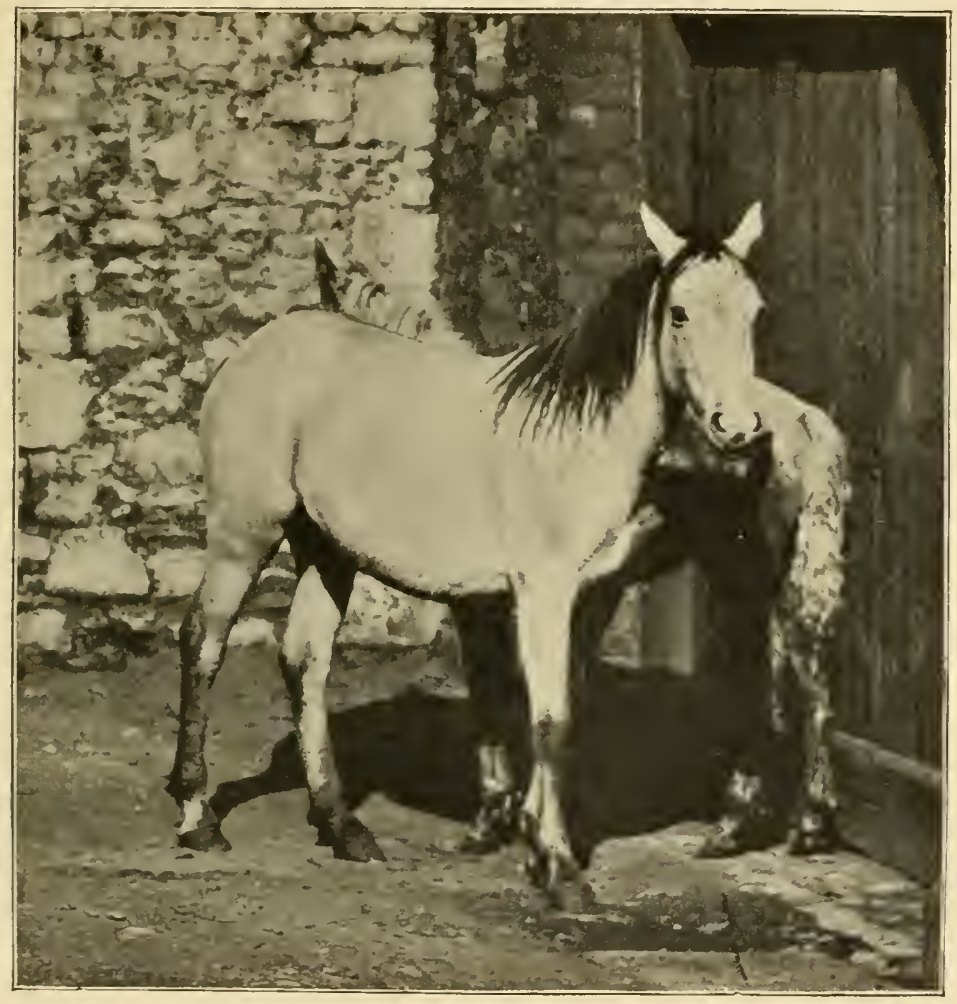

Fig. 124. Light-grey Connemara Filly (so-called 'Eastern' type).

Arabs than Audalusians, and they are frequently grey (Fig. 124). Intelligence, good-temper and courage seem to characterise the majority of the Connemara ponies. In the district of Clifden are bred ponies but little larger than the old Connemara, yet of very different build. The head is beautifully moulded and the face is very intelligent, the ribs are well arehed, the shoulders 
good, the loins and hind-quarters well developed, while the short legs stand an enormous amount of wear. A typical specimen of this strain measures $13 \cdot 2$ hands, has ears Arab-like in form measuring six and a half inches, and is of a grey colour (Fig. 125).

It is quite possible that in this type we have a blend between the old European horses of the Solutré type, the Libyan

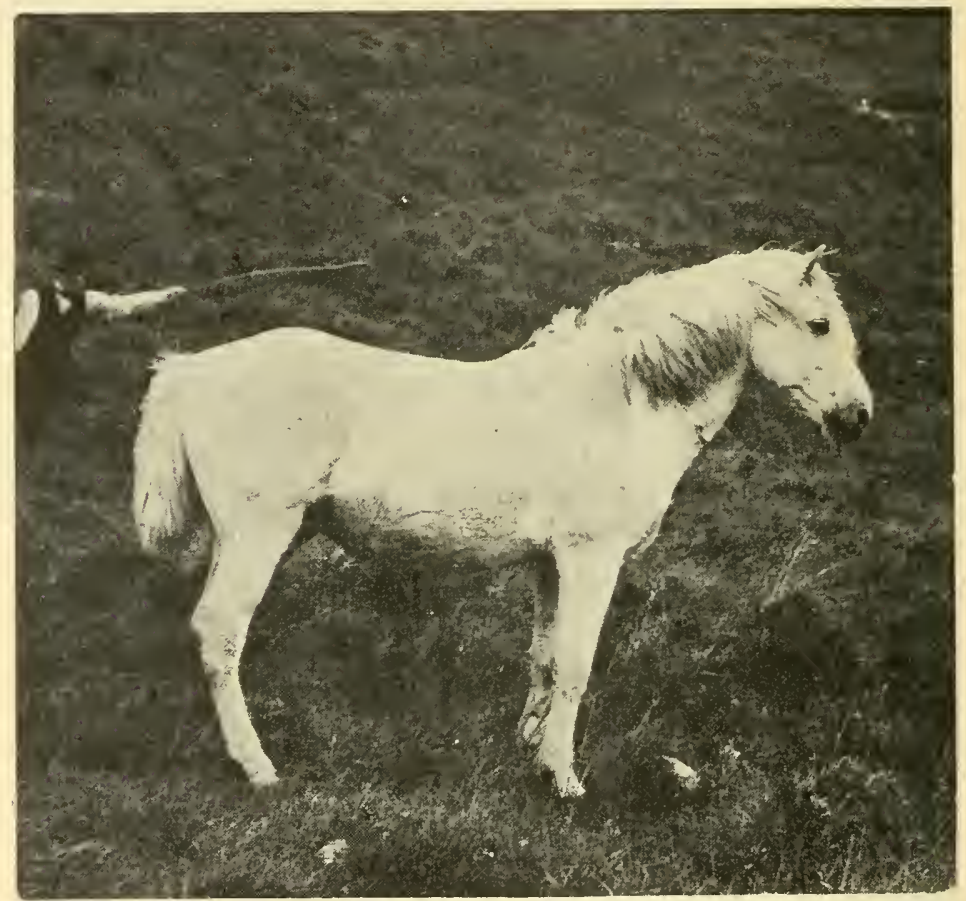

FIG, 125. Connemara Pony; Clifden district.

horse and 'Celtic' pony, the first mentioned giving it its characteristic strength of leg. There are also Connemara ponies which resemble more the Irish hunter type, and which probably have been crossed with large horses from Roscommon or from further east. Some of these make good hunters (Fig. 127). Finally there are ponies sprung from the crossing of the native mares with Clydesdale blood, which comes out in their hairy fetlocks, their small heads, and occasionally very bald faces. 
In the so-called 'Andalusian' and 'Eastern' types we may recognise the descendants of the old lrish Hobbies, which in their turn were descended from the black and grey horses imported from Gaul and which no doubt had blended very largely with the ponies previously introduced. We have seen that Connemara ponies not unfrequently lack hock callosities (p. 18), a fact which may point to their 'Celtic' ancestry, though, since many North African horses have a similar characteristic, the

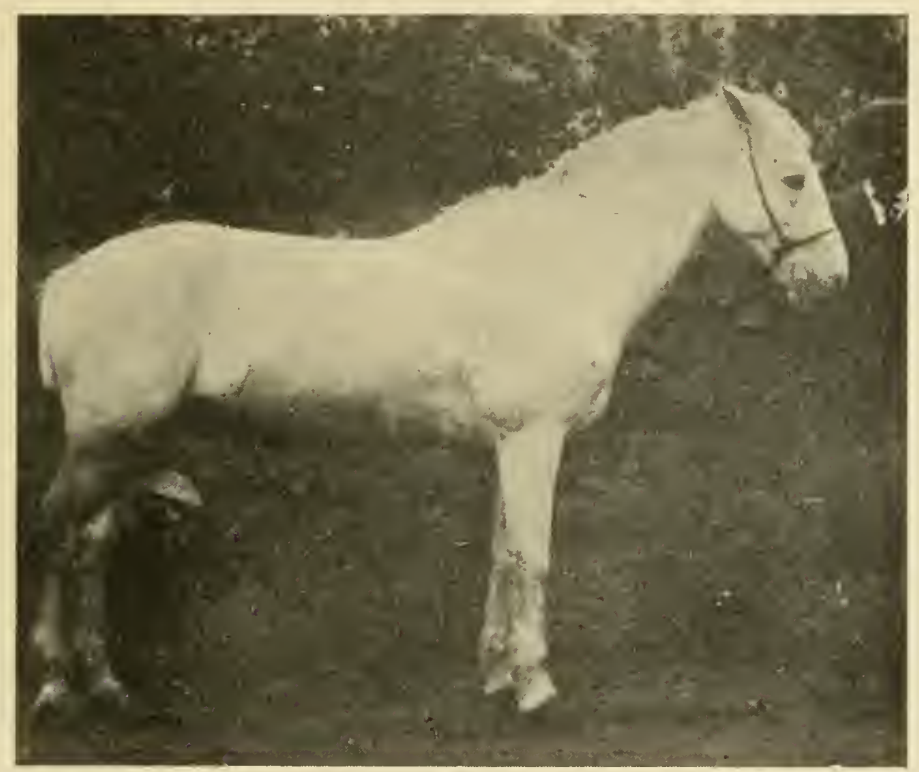

FIG, 126. Connemara Gelding of larger type; Cashel.

absence of the hind chestnuts in Connemara ponies may be due rather to the Libyan strain.

In the stout-legged ponies of the Clifden district we have animals which have probably in their veins more of the blood of the old thick-set European horses of the Solntré type, and we have found at least two other classes of Connemara ponies which are still more horse-like in their conformation : of these, one is due to the recent admixture of Clydesdale blood, whilst the others resemble the Irish hunter, and in fact some- 
times are used as hunters, and we saw that these probably result from blending the large horses of Roscommon or of the east of Ireland with the native ponies. This gradual infiltration of heavier strains shows us how the old Irish Hobby disappeared by degrees from all the eastern, north-eastern and southeastern parts of Ireland, finally surviving only in the extreme west, and even there hardly quite pure. In other words, in the

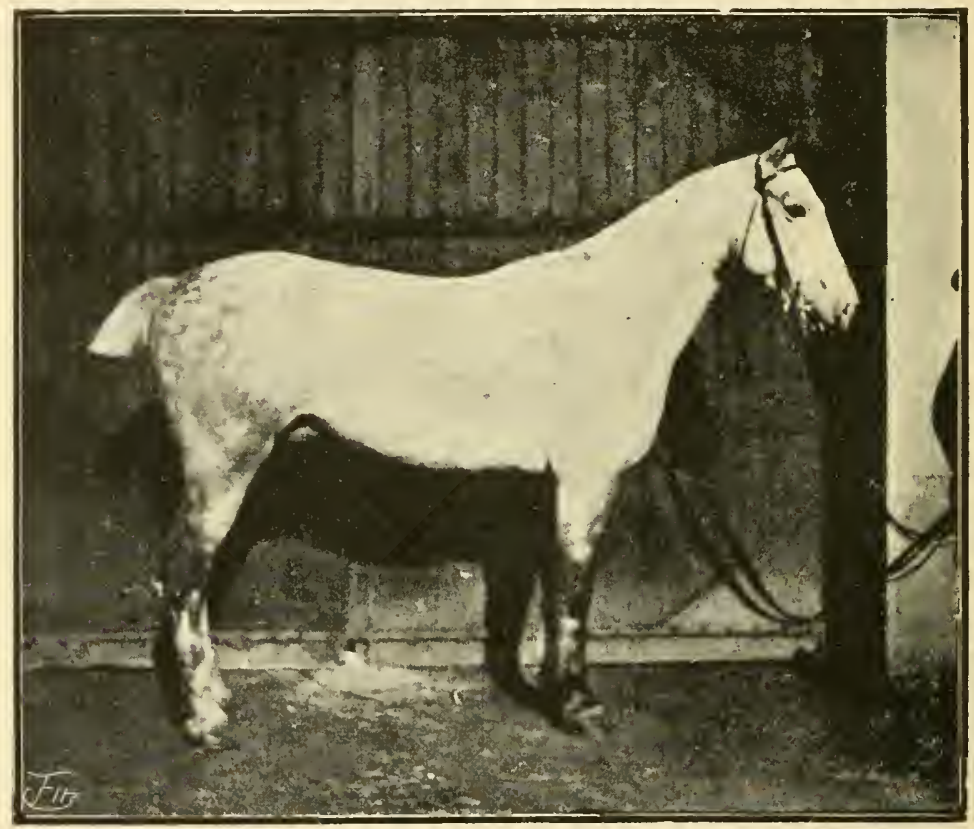

Fig. 127. Connemara Pony used as a hunter.

parts of Ireland which first passed under English influence the Hobby gave place to or was contaminated by horses of a larger type brought over from Great Britain. This is a fact of great importance, for it offers the true explanation of the origin of the Irish cart-horses (Fig. 128), the crossing of which with thoroughbred stallions since the eighteenth century has produced the Irish hunters. It is not improbable that there were practically no horses save those of the Hobby type in Ireland until after 


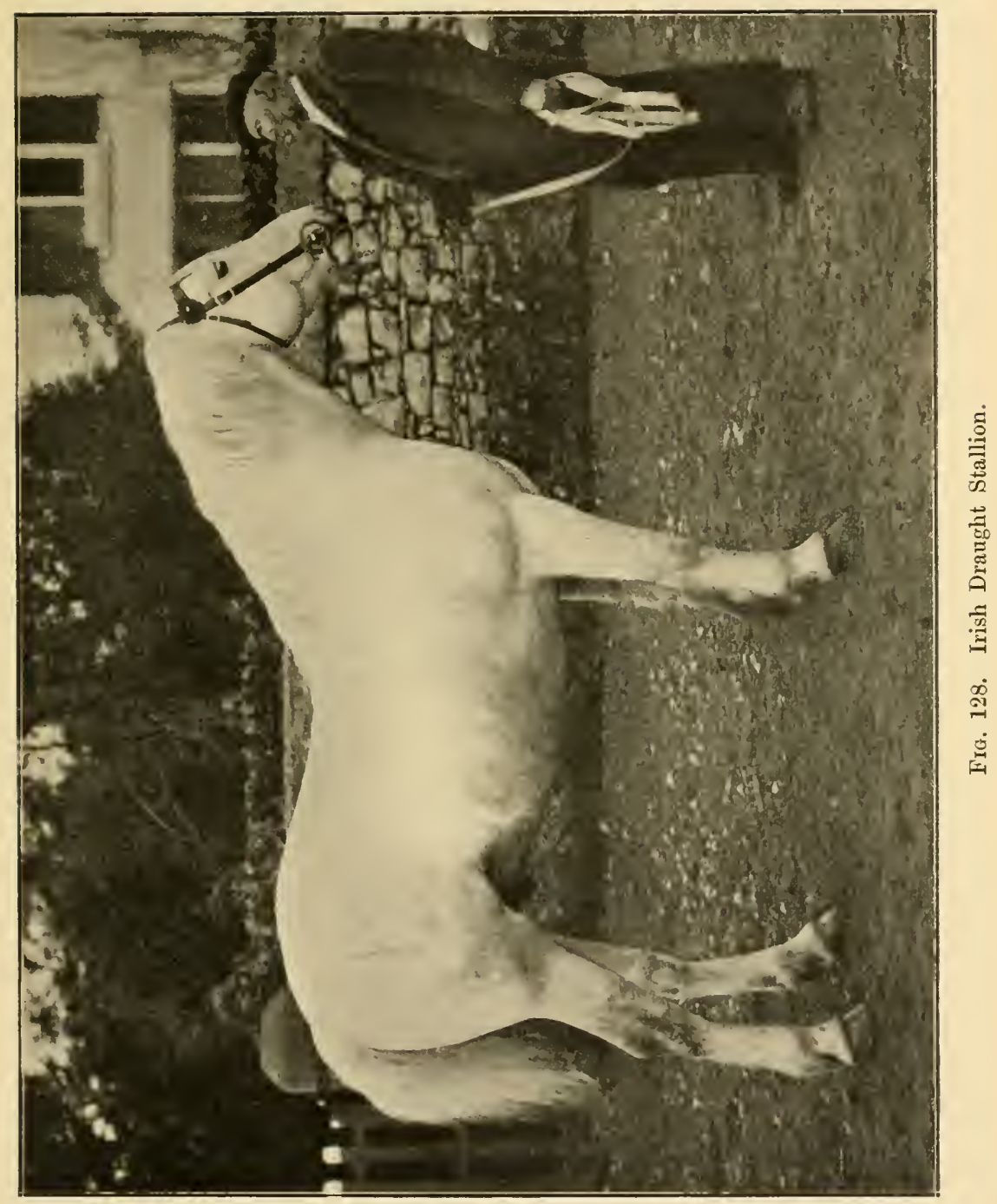


the Norman invasion in 1172 , but there can be no doubt that from that time onwards Ireland has never been without horses of a large size, at least in the English Pale. The passage cited above (p. 389) from Giraldus Cambrensis shows that the Normans brought with them to Ireland the same breed of large horses which their ancestors had carried into England, and on which they charged the Saxons at Hastings.

Nor can it be doubted that similar 'great horses' were from time to time imported as well as bred in Ireland, for the Normans, though in many respects becoming ipsis Hibernis Hiberniores, retained their own method of warfare, and consequently required horses of large size to mount their men-at-arms. Thus when the Pale was troubled by an irruption of the O'Byrnes and O'Moores in 1372, who burned the priory of Athy, John Colton ${ }^{1}$, the first Master of Gonville Hall (now Gonville and Caius College), and successively Dean of St Patrick's, Chancellor of Ireland, and Archbishop of Armagh, raised a force of 26 knights and a large body of men-at-arms, and fell upon the Irish and defeated them with great slaughter. Even within the then narrow limits of the Pale there must have been a considerable number of horses capable of carrying heavily-armed men. With the gradual extension of the area occupied by Norman, and later English settlers, the 'great horses' must have spread likewise and the native Hobbies must have constantly been crossed with the larger strain. The same process continued under the Tudors and the Stuarts. A single instance will suffice. Dr Winter, an Englishman, and a graduate of Emmanuel College, Cambridge, who became Provost of Trinity College, Dublin (1652-1660), was a great lover of liorses and had brought over horses of peculiar merit from England, some of 'which were stolen from him by the Irish army on one of his journeys with Cromwell's Commissioners? ${ }^{2}$ This loss was amply compensated by substantial grants of land in King's Co., and

1 J. Venn, History of Gonville and Cains College, Vol. IIr. p. 9. Bishop Reeves (Irish Arch. Soc. 1850) has published Colton's account of his Visitation of the Diocese of Derry, 1397, with a valuable introduction.

2 J. P. Mahaffy, An Epoch of Irish History: Trinity College, Dublin, Its Foundation and Early Fortunes (1903), p. 301. 
also at Agher, co. Meath, which his direct descendants still enjoy and where a rery large breed of horses said to be descended from the Provost's own animals is still maintained ${ }^{1}$. It is therefore probable that Dr. Winter's horses were the 'great' English horses of his own day (p. 366). This example suffices to show how in Meath and Westmeath the native Irish horses were gradually saturated with the blood of the large English horses, from which the Shires and Suffolk Punches are descended.

It is a well-known fact that horses whose ancestors have long been bred in Ireland are distinguished for their great development of bone, and for their clean, flat, hard legs, free from the spongy softness of bone so characteristic of British horses. As the infiltration of the blood of the English 'great horse' had thus gone on slowly for a very long period, the Irish horses of this mixed strain, owing to the extraordinary effects of the Irish soil and climate, did not inherit the softness and flabbiness found in the progeny of the Shires and Suffolk Punches introduced towards the end of the eighteenth century, and of the Clydesdales brought in about half a century later.

As the English draught-horses imported towards the end of the eighteenth century produced an unsatisfactory progeny, no further attempts were made to improve the breed in this way. The heavier class of native animals, the genesis of which I have just sketched, produced a better type of horse for the needs of Irish farmers. These animals made good roadsters and serviceable harness horses, and, though too coarse for hunting, they had a high spirit and a natural turn for jumping, inherited doubtless from their Hobby ancestors. It was the crossing of such mares with the thoronghbred (Fig. 129) that produced the Irish hunters. By the end of the seventeenth century horses of so-called 'Oriental' blood had reached Ireland, for example the Byerley 'Turk, brought to Ireland by his owner, Captain Byerley, who served in the army of William III, and

1 Mahaffy, loc. cit. My old friend Rev. T. T. Gray, Senior Fellow of Trinity College, Dnblin, of Carn Park, co. Westmeath, tells me that these animals, on which he himself has ridden, are of great size, and that the breed seems certainly derived from the Provost's horses. 
probably had that famous horse at the battle of the Boyne. The mixture of such horses with the native mares laid the foundation of the Irish thoroughbred strain, and fresh thoroughbred blood was continually being introduced, until by the middle of the eighteenth century there were in Ireland upwards of one hundred imported stallions. From that time onwards the history of the Irish thoroughbred is bound up with that of the English racing stock, but the Irish thoroughbred has continued to preserve traits derived doubtless from the Irish mares first mated with the imported sires of Libyan blood.

As the Irish hunters (Fig. 130) are the progeny of the Irish thoroughbred and the Irish cart-mares, on the number and quality of the latter must depend one of the most precious productions of Ireland. The hunters bred in Roscommon are especially noted for their size and great development of bone, though they are occasionally coarse, whilst, though the horses reared on the rich grass lands of Meath and Westmeath are not more fleshy and are scarcely equal in bone, they are, however, more shapely than those of Roscommon. The increase of tillage during the French war at the close of the eighteenth and the beginning of the nineteenth century gave a great impetus to the breeding of agricultural horses, as the bullock rapidly ceased to be the tiller of the soil, althongh in certain localities he has lingered on to our own day, both for the plough and the cart. The growth in the number of cart-mares naturally increased the production of weightcarrying hunters, but unfortunately since the repeal of the Corn Laws the shrinkage of Irish tillage has gone on steadily and there has been a corresponding diminution in the number and quality of Irish cart-mares. The larger farmers were the first to lay down their lands in permanent grass, and gradually the cart-mares only remained in the hands of smaller farmers who continued to till their ground, but, as was naturally to be expected, the mares kept by the latter were, as a rule, not of so good a quality as those formerly maintained by the wealthy farmers. The agricultural depression of the last quarter of a century has too often compelled the small farmers to sell their 


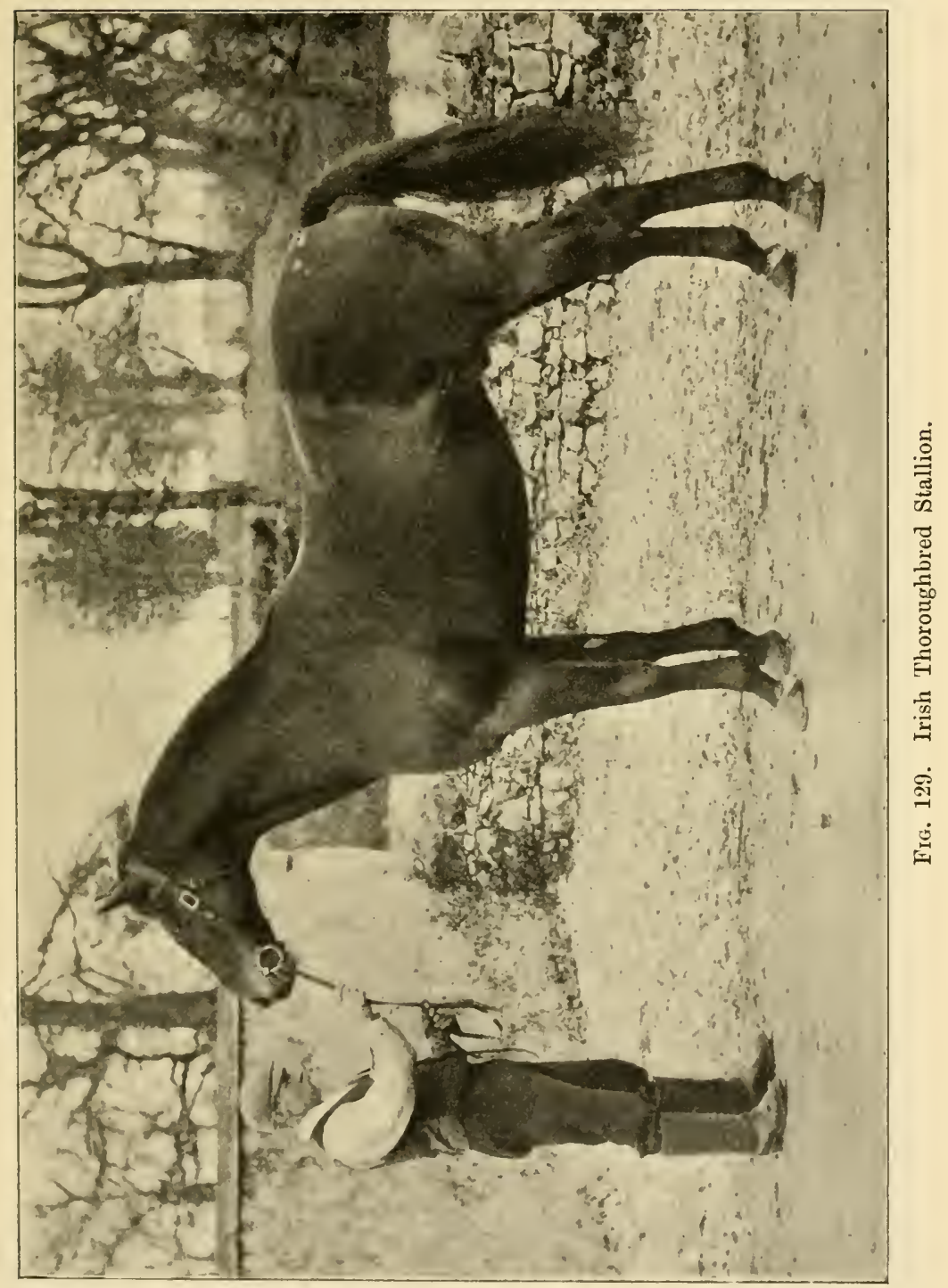


best fillies, and at the present moment Ireland possesses only some very old and degenerate specimeus of an invaluable breed ${ }^{1}$, the loss of which would be little short of a national disaster. Every year the demand for Irish hunters becomes greater and their value increases, and no matter what may be the fate of other classes of horses owing to the competition of motor-cars, the high-class Irish hunter is not likely to suffer through the rivalry of any mechanical contrivance. It is earnestly to be hoped that in view of the fatal damage done to the fine old breeds of France by the unwise admixture of foreign strains, and the like injury wrought to Irish horses by contamination with Shire, Suffolk Punch, Clydesdale, Cleveland Bay, and Hackney blood, no further rash experiments of this kind will be tried, but that steps will be taken to rebuild the old breed of Irish cart-horses by the careful selection for stud purposes of the best of those which still survive.

Let us now return to the horses of Scandinavia, the Faroes, and Iceland. We saw above (p. 18) that from the absence of hock callosities, the presence of short hair on the upper part of the tail, the shortness of the ears (in which they differ from Arabs), and the fineness of the head and limbs in certain ponies found in Connemara, the North of Ireland, the Outer Hebrides, Faroe Isles, and Iceland, Prof. Ewart was led to his doctrine that a separate variety of horse, which he names E. c. celticus, had survived from the Palaeolithic period in the north-west of Europe.

When and whence horses first reached Iceland we have ample eviclence. After Harold Fairhair had made himself sole king in Norway in 870 A.D., many of the turbulent Norwegian jarls preferred exile to submission. Among these were Ingolf and Leif, who set forth to Iceland in 871 A.D., and finally settled there in 874 A.D. 'Three years later Kettle Haeng led a further body of settlers to the same island. Gradually Harold Fairhair began to extend his authority and to root out the Vikings from the Western Isles, and after the fall of Thorstein the Red in Scotland there was a rush of settlers from the British Isles to Iceland (890-900).

1 Journ. Dept. of Agriculture (Ireland), Oct. 1904, pp. 25 sqq. 


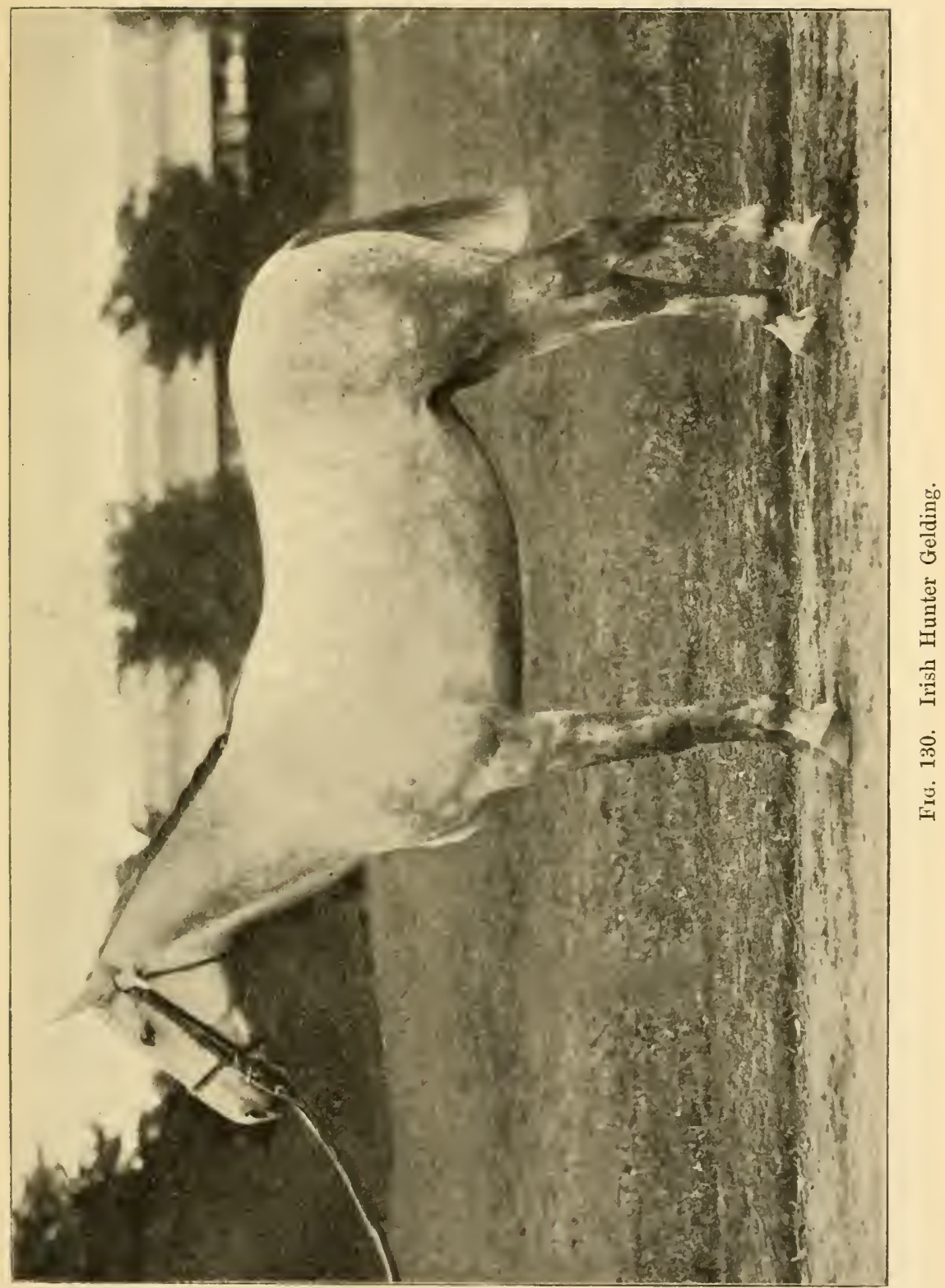

R. H. 
When Ingolf and his folk settled in Iceland that island had never known any human inhabitants save a few Irish anchorites, who cannot be deemed to have contributed anything towards the population, or to the domestic animals found there later on. If these ecclesiastics had brought horses with them -a thing in itself not very likely-these animals would have been Irish or Hebridean in origin. On the other hand the Norse settlers brought with them their families, household goods, and domestic animals, amongst which horses were almost certainly included. It is important to bear in mind that although all these colonists were Norsemen, more than half of them, as is definitely proved by the Landnamabocan ancient record of the names, ancestors, and holdings of the early settlers-had been living in the British Isles before they removed to Iceland, and that only a minority went direct from Scandinavia. It is therefore highly probable that the original stock of the ponies of Iceland and the Faroes came partly from Ireland, and partly from Norway, but as has been well pointed out the proportion that came from the former country was probably greater, inasmuch as some of the settlers from Scandinavia did not go directly to Iceland, but first went and sojourned for a while in the Western Isles. It is therefore not improbable that if these colonists brought ponies with them, the latter would be of the Hebridean or Irish breeds.

That the ponies of the Hebricles had been brought from Ireland by the Irish monks who settled at Ioua (Iona) is rendered almost certain by a famous passage in Adamnan's Life of St Columba ${ }^{1}$. In the erening of his life the old man, worn out with age, went about Iona in a cart to visit the brethren who were at work on the other side of the island. On the day he died, he and his attendant Diormit "went to bless the barn which was near at hand, and after having blessed two heaps of winnowed corn that lay therein, the saint left the barn, and in going back to the monastery rested half-way at a place where a cross, which was afterwards erected, and is standing to this day, fixed into a mill-stone, may be observed on the roadside. 
While the saint, bowed down with old age, sat there to rest a little, behold, there came up to him a white pack-horse, the same that used, as a willing servant, to carry the milk-vessels from the cow-shed to the monastery. It came up to the saint and, strange to say, laid its head on his bosom, inspired, I believe, by God to do so, as each animal is gifted with the knowledge of things according to the will of the Creator: and knowing that its master was soon about to leave it, and that it would see him no more, began to utter plaintive cries, and, like a human being, to shed copions tear's on the saint's bosom, frothing and greatly wailing. The attendant seeing this began to drive the weeping mourner away, but the saint forbade him, saying: 'Let it alone, as it is so fond of me-let it pour out its bitter grief into $m y$ bosom.' Then the saint blessed the work-horse, which turned away from him in sadness."

From what we have learned about the sanctity of white horses, it may not be rash to suggest that the prescience (p. 114) of St Columba's horse was not unconnected with its white colour in the mind of good Abbot Adamnan.

Moreover it is clear from the sagas that there was constant intercourse between Ireland and Iceland in the tenth and eleventh centuries, and that Irish slaves and Irish wolf-dogs were known in the latter island. Thus Otkell of Kirby had an Irish thrall named Malcolm ${ }^{1}$, whom his brother Hallbjorn the White had brought out to Iceland. Again, when Gunnar of Lithend, then in sore peril, was parting from his friend Olaf the Peacock, the latter said: "I will give thee three things of price, a gold ring, and a cloak, which Moorkjardtan the Erse king owned, and a hound that was given me in Ireland; he is big, and no worse follower than a sturdy man. Besides, it is part of his nature that he has man's wit, and he will bay at every man, whom he knows is thy foe, but never at thy friends; he can see too in any man's face, whether he means thee well or ill, and he will lay down his life to be true to thee." After that he said to the hound, "Now shalt thou follow Gumnar, and do him all the service thou canst." The hound went at once to

I The Saga of Burnt $\mathrm{Njal}$, xLvir. 
Gumnar, and laid himself down at his feet'. It will be remembered that Otkell of Kirby was the owner of the two dun horses with stripes on their backs - the two best in all the country. If slaves and dogs were brought from Ireland, it is not unreasonable to suppose that horses also would occasionally form part of the cargo of the homeward-bound Icelander. The reader will also remember that two other horses of exceptional merit are described in Burnt Njal-the chestnut stallion of Starkad and Gunnar's brown one. But our investigations have made it clear that the colours chestnut and brown in horses are a sure indication of a large proportion of Libyan blood. It is also to be noted that in Otkell's dun horses with dorsal stripes we may have an outcome of Libyan blood, similar to that so well exemplified in the horses of Kattywar-but with this feature we shall have to deal at greater length in the next chapter.

We have had good evidence for believing that there was a considerable element of Libyan blood, derived through Spain and France, in the best horses of Ireland, the country from which a large proportion of the original stock of Iceland was derived. It will also be remembered that, according to Sanson, some North African horses lack hock callosities, the absence of which often characterises Iceland and Faroe ponies. It cannot, therefore, be held that the fine heads and limbs, small joints and the absence of hock callosities in the ponies of Iceland and the Faroes, as well as those of the Outer Hebrides and some found in Ireland, are solely due to these animals being descended from a small horse which inhabited the north-west of Europe in late palaeolithic times. But as it is possible that the 'Celtic' pony in the north-west of Europe and the small Libyan horse of North Africa are both descended from the small horse of the Brighton 'elephant bed,' the Libyan blood which passed into Ireland through Spain and France may well have been there combined not only with the coarse European type, but also with a closer relative, and accordingly not a few of those (especially the bay, black, 
brown, and chestnut) 'Celtic' ponies which lack hock callositics may derive this feature from a double line of ancestry.

On the other hand, it is plain, as we have shown (p.:346), from the mention of black horses in the early literature that the best horses of Scandinavia were saturated with Libyan blood long before the colonisation of Iceland. This blood was probably derived through Germany, where the Frisians ahready possessed, in the fourth century, the famous breed of black horses still known by their name, and whose pedigree can be traced back to the horses owned by the Tencteri in the first century A.D., and still earlier to the horses imported by the Gauls from Mediterranean lands. It is therefore clear that in the best horses brought from Norway to Iceland and the Faroes there may hare been a fair proportion of Libyan blood. The presence of black, brown, chestnut, or striped dun animals in Iceland and also in the Faroes may therefore be due not only to the horses brought from Ireland, but also to those direct from Scandinavia. But Prof. Ewart informs me that, as far as he has seen, "Iceland and Faroe ponies in their ears, heads, manes, and tails are never like the large Barbs and Arabs, though Hebridean horses in which there is Spanish blood (introduced in the eighteenth century) frequently are like long-eared Arabs."

But it by no means follows that all the horses brought by the first colonists, or even those which came in later, were of a superior breed. On the contrary, the descriptions of the black and grey steeds of Cuchulainn, of Otkell's dun horses with dorsal stripes, and of the chestnut and brown horses of Starkad and Gunnar, all of which are commended for their peculiar excellence, show clearly that there were plenty of inferior animals, either of the old thick-set, heavy-limbed, large-jointed European-Asiatic horse, or possibly derived from an ancient horse of lighter build-Ewart's 'Celtic' pony itself, the descendant of the slender-built horse whose remains are found in the Brighton 'elephant bed.'

That ponies with large heads and of a heary build were familiar in Iceland in medieval times is proved by an old picture preserved in Iceland and reproduced by Brumn. But as 
it is clear that the chestnut and brown ponies of Iceland had certainly Libyan blood, and as, on the other band, the heavyheaded ponies of the picture seem almost certainly sprung from the old heavy type of European horse, it may be urged that it is difficult at first sight to show that any Icelandic or Faroe ponies owe their characteristics to the slender-built horse of palaeolithic times, though it is quite possible that in some Icelandic ponies the presence of short hair on the upper part of the tail, instead of the long hairs so characteristic of the Libyan stock, is a feature derived from this ancient light-built horse. But it seems difficult to derive the 'Celtic' 'tail-lock' (p. 18) from the Libyan infusion, whilst the fact that Icelandic and Faroe ponies more frequently lack hock callosities than is as yet proved to be the case with North African horses, indicates that this feature may not be wholly derived from Libyan ancestors, but may be due in some measure to an old 'Celtic' pony.

We have now passed in review all the chief breeds of horses of prehisturic and historical times, and the evidence has led us to the following conclusions: (1) that the horses of Upper Europe and Upper Asia were always dun or white, the vast majority of them being thick-set, slow animals, though in the north-west of Europe there was the 'Celtic' pony, an animal of much lighter build, more elegant shape, and probably greater speed; (2) that these coarse, thick-set horses of Upper Asia and Upper Europe have continually kept making their way into the regions lying south of the great mountain chains which cross the Asia-European Continent; (3) that these horses first made their appearance in Babylonia not long before 1.500 B.C., and about the same time in Palestine and Greece; (4) that the Arabs of the Peninsula did not become possessors of this or any other horse until after the Christian era; (5) that at some date not long prior to 1500 B.c. the kings of the xvilith Egyptian dynasty were already in possession of horses of a type completely different in shape, colour and manner of carrying their tails, from the Asiatic horses, though closely resembling in these particulars the best Arabian and Barbary horses of modem times; (6) that these horses are regularly depicted on Egyptian 
monuments as of a dark colour; (7) that by B.C. 1000, and we know not how much earlier, these horses were so highly esteemed by the horse-driving peoples of Western Asia that King Solomon imported them from Egypt at a great price, not only for himself but also for all the kings of Syria and for the kings of the Hittites; (S) that this bay breed was already in the Troad before B.c. 1000, and was there regarded as not only divine, but as quite different in origin from the dun and white horses of Greece and Thrace; (9) that it was even then distinguished by a star in its forehead, a feature which to this day is characteristic of the pure-bred Arab horses and their derivatives; (10) that already these horses were swifter than all others; (11) that the Greek legends regarded the horses bred near the Atlantic as the swiftest; (12) that Pegasus, the fabled winged steed, was said to have been born in Libya; (13) that the Libyan horses were the swiftest in the Roman Circus; (14) that these African horses have been continually sought for by the peoples of Asia and Europe for the purpose of improving the quality of their own indigenous horses, and that consequently their blood has influenced the horses of Asia as far as China and those of Europe as far as Ireland; (15) that it is to the blending of the bay horses of North Africa with the dun or white horses of Asia and Europe in varying degrees that are due not only all the improved breeds of the world, but also the various shades of grey, rufous-grey, roan, skewbalds, piebalds, chestnut, brown, and black; (16) that the white bracelets or stockings so frequent not only in bay, but also in black horses, are due to the Libyan strain, and that the white star or blaze on the forehead frequently found in domestic horses is due to the same cause; (17) that the peculiar blend of the two strains which results in black often produces great strength combined with fair speed; (1S) and that for this reason the black horse through the ages has been especially valued for war from Turkestan to England, and from Morocco to Sweden; (19) we have likewise seen that the horse has everywhere been driven under chariots before he was ridden, and that it was the Libyans in Africa and the Turko-Tartaric tribes in Asia who first began to ride habitually on horseback, 
and that the Greeks probably first learned this art from North Africa. Finally, we have learned a lesson that all the races which have in their turn held the mastery in Asia, Africa, and Europe, have owed the extension of their power, or the preservation of their liberty, to the possession of horses, whether they were Egyptians, Syrians, Libyans, Medes, Persians, Scythians, Macedonians, Carthaginians, Numidians; that the lack of horses till after the conquest of Gaul was the great weakness of Rome; that the acquisition of the horse by the Arabs was a main factor in the spreading of Islam; and that had not the Franks owned good horses by 732 A.D. Western Europe might have been enslaved by the Saracens; that the possession of horses enabled the Normans to conquer at Hastings, and the possession of great war-horses was the sure means of preserving one's own country or conquering that of others throughont the Middle Ages; even when armour was discarded the new cavalry mounted on light horses became an engine of war more formidable than any yet known; whilst Marlborough's great victories were largely due to his cavalry. With the improvement of fire-arms and the ability of infantry to resist cavalry it seemed as though the days of the horse-soldier were over, but the recent war in South Africa has shown that in the future struggles of the nations mounted infantry are likely to play an all-important part. Accordingly, though the place of the horse under the carriage, the ommibus, the waggon, and even the plough itself, may be taken by automobile engines, never in the history of the world was there greater need of horses to draw artillery and to carry infantry. It is therefore imperative that this country should not shut its eyes to the need of breeding horses suitable for war, and that careful steps should be taken to preserve our good breeds and not permit them to be contaminated and destroyed by rash experiments in breeding. 


\section{CHAPTER IV.}

\section{THE ORIGIN OF THE LIBTAN HORSE.}

The King, sir, bath wagered with him six Barbary horses.

Shakespeare, Hamlet, v. 2.

WE have now briefly surveyed the history of all the chiet breeds of horses-modern, medieval, and ancient-and we have been led steadily to the conclusion that the best horses are sprung wholly or in part from a North African stock, the lightly built horses excelling in speed being pure or almost pure derivatives, whilst the large heary cart-horse breed owes much to the same blood when blended with the coarse, large-headed, short-necked stock. Of the origin of the latter we have full knowledge, for we have seen that it is the indigenous horse of Upper Asia and Europe, and we have found a wild species of Equidae-Prejvalsky horse or the tarpan-existing down to our own time in Central Asia and Eastern Europe; it has been shown not unlikely that the ordinary Equus caballus of Europe and Asia and the Prejvalsky horse have sprung from a common immediate ancestor, or, what is less likely, that the former has developed out of the latter. But it is altogether different with the thoroughbred stock, inasmuch as Africa does not possess any wild horses such as the tarpan, although she is the mother of the Abyssinian ass, and at least three species of zebras (not including the recently lost quagga).

We have now to face the problem of the origin of this Libyan horse, which I shall provisionally term Equus caballus libycus. We have seen that it has been commonly held that all our domestic horses have come from a single stock, a view 
largely based on the fact that all interbreed with fertility. But, as I have already pointed out, this is no criterion, since animals which are regarded as distinct species, such as the dog, wolf, and jackal amongst carnivores, and the common ox, the zebu, and grunting yak amongst herbivores, also interbreed and produce fertile offspring ${ }^{1}$. As I have shown that M. Sanson's E. c. africanus, which he supposed to be a primeval stock of North-east Africa, has no historical basis, the Dongola breed, on which he principally based his argument, being merely a cross-bred animal of comparatively recent date, we must therefore look elsewhere for the source of the Libyan horse. As it is found among the Libyan tribes from the dawn of history, it is obvious that it was either developed from the ordinary horses of Asia and Europe, which they had obtained already domesticated, or else it was an indigenous species which had reached Africa either through Asia or through Asia and Europe, and had been there highly specialised by its peculiar environment, and domesticated by the Libyans themselves. The first alternative seems very improbable, since we have traced Libyans with chariots and horses up to a period almost contemporary with the first appearance of the horse on Egyptian monuments, and we have presented reasons for believing that the Egyptians, who admittedly borrowed the horse and the chariot from some other people or peoples, were using Libyan chariots about 1400 B.c., that they do not appear to have had the horse much before 1500 B.c., and that along with the light chariot with four-spoked wheels they had obtained the horse from the Libyans (p. 227).

We have seen that by Homeric days it was a general belief in Greece that the swiftest horses came from the Western Ocean, and that horses of a bay colour - the ever constant livery of the Libyan horse and its derivatives-were already known in Asia

1 Report by C. W. Campbell, H.M. Consul at Wuchow, On a Journey in Mongolia, Jan. 1904, p. 36: “The yak (Bos yrumniens), here (Mongolia) called sarlik, is kept in the place of cattle to a considerable extent throughout the mountainous parts of North Mongolia. Hybrids of the yak and ordinary cattle are common, and their milk is much esteemed." See also Blanford; Indian Mammalia, p. 491. 
Minor as far superior to the very best blood from the north, whilst by the tenth century B.c., although the Hittites and Syrians had plenty of horses, they were eager to purchase horses from Egypt at a great price, whilst in the post-Homeric myth Pegasus, the most famous of all steeds, is represented as born in the western Libyan desert. All these facts prove that before the end of the second millennium B.C. the Libyan possessed horses far superior in speed to those of Europe and Asia, and also that these horses were already distinguished by their bay colour with a star in the forehead, which characterises the Libyan stock and its posterity to this very hour. As the Egyptians did not obtain horses until the sixteenth century B.C., it is obviously impossible that the Libyans, supposing them to have obtained the horse for the first time from the Egyptians, could have developed by Homeric tinies a race of horse so absolutely distinct from all others bred since, even in times when men have expended much eare and skill in producing artificial varieties. But as it has been pointed out (p. 209) that the Arabs, who take such pride in their horses and their pedigrees, are ignorant of the very first principles of breeding, it is most unlikely that the nomad Libyans, who never kept any account of strains, such as Al-Khamseh, or practised castration, would have produced artificially in a comparatively short time the most wonderful breed of horses that the world has known, and with characteristics so indelibly fixed that they can permanently modify the form and colour of all other breeds.

If it be objected that there is no record of wild horses in Libya, either in ancient or medieval times, and that consequently there never was any indigenous horse for the Libyans to domesticate, I reply that remains of fossil horses have been found in North Africa, that though at present there is not any kind of ass either striped or unstriped in that same region, yet undoubted evidence has been given that there was in that area some kind of wild ass in the time of Herodotus, that manystriped asses existed in the Great Oasis down at least to the tenth century A.D., and we know not how much later, and finally that, according to Pigafetta (p.60), there were zebras 
in Barbary in the sixteenth century. That some parts of the region lying between Egypt and the Atlantic were admirably adapted for horses is proved by the accounts of Numidian and Cyrenean horse-breeding and by the fact that the liumrahs, the descendants of horses that have run wild, flourish in Northern Nigeria, where they are occasionally captured and broken in. How easy it is to exterminate the Equidae and other larger mammals has unhappily been too well demonstrated in our own time by the extinction of the quagga and all but complete destruction of the mountain zebra in South Africa, and the reduction of the vast herds of the North American bison to a few hundreds, which can only maintain a precarious existence under artificial protection. There are various reasons which lead especially to the destruction of the wild horse. In the first place it has been valued as food by many tribes, who have not domesticated it; secondly, when once a community has learned to tame and utilise the horse, the wild horse becomes a valuable prize when taken alive; thirdly, when the chief wealth of a community, such as those of the Tartars, the Gauchos, and the Pampas Indians, consists of horses, herds of wild horses are a constant nuisance and danger, as the domestic animals are often enticed away by their wild relations; fourthly, where pasture is often scarce, as in various parts of Africa, pastoral peoples, such as the Boers and Australian stock keepers, are always anxious to exterminate, or at least to lessen, the numbers of the large herbivores. If it be said that it is only by the use of fire-arms that such extermination takes place and that it could not be effected by men armed merely with spears, javelins, and lassoes, and that it is not at all likely that domestic horses handicapped by a rider's weight could overtake their unweighted wild brethren, these assertions can be at once disproved by modern instances.

How men on horses and without fire-arms are able to ride down wild horses and to kill or capture them is made clear by Azara $^{1}$, who relates that the Gauchos of the Pampas constantly 
persecute the wild droves and drive them away from their neighbourhood to prevent the domesticated horses from joining the wild ones. "Men on horseback drive the baguals before them until they are tired; when fresh men and fresh horses continue the chase, press upon and urge them on both sides, killing vast quantities of them with chuzos or spears, without ceasing to gallop or slackening their pace." The same observer ${ }^{1}$ points out that "all horses run swifter when mounted than when galloping loose, especially if ridden without a saddle." North America offers very valuable instances of a similar kind. Dr Richardson" states that "herds of wild horses, the offspring of those which have escaped from the Spanish possessions in Mexico, are not uncommon on the extensive prairies that lie to the west of the Mississippi. They were once numerons on the Kootannie Lands, near the northern sources of the Columbia, on the eastern side of the Rocky Mountain ridge, but of late years they have almost been eradicated in that quarter. They are not known to exist in a wild state to the northwarch of the fifty-second or fifty-third parallel of latitude. The young stallions live in separate herds, being driven away by the old ones, and are easily snared by using domestic mares as a decoy. The Kootannies are acquainted with the Spanish-American mode of taking them with the lasso."

Major Long ${ }^{3}$ says that the Osages hunted the wild horses, which are exceedingly fleet. "They go in large parties to the country of the Red Canadian River, where they are to be found in considerable numbers. When they discover a gang of the horses they distribute themselves into three parties, two of which take their stations at different and proper distances on the route, which by previous experience they know the horses will most probably take when endeavouring to eseape. 'This arrangement being completed, the first party commences the pursuit in the direction of their colleagues, at whose position they at length arrive. The second party then continues the

1 Azara, op. cit. p. 29.

2 Fauna Boreali-Americana: or the Zoology of the Northern Parts of British America (1829), pp. 231-2.

3 Fauna Boreali-tmericana, pp. 232-3. 
chase with fresh horses, and pursues the fugitives to the third party, which generally succeeds in so far running them down, as to noose and capture a considerable number of them. The domestic horse is an object of great value to the nomadic tribes of Indians that frequent the extensive plains of the Saskatchewan and Missouri, for they are not only useful in transporting their tents and families from place to place, but one of the highest objects of the ambition of a young Indian is to possess a good horse for the chase of the buffalo, an exercise of which they are passionately fond. To steal the horses of an adverse tribe is considered to be nearly as heroic an exploit as killing an enemy on the field of battle, and the distance to which they occasionally travel and the privations they undergo on their horse-stealing excursions are almost incredible. An Indian who owns a horse scarcely ever ventures to sleep at nightfall, but sits at his tent door with the halter in one hand and his gun in the other, the horse's fore-legs being at the same time tied together with thongs of leather. Notwithstanding all this care, however, it often happens that the hunter, suffering himself to be overpowered by sleep for only a few minutes, awakes from the noise made by the thief galloping off with the animal. The Spokans, who inhabit the country lying between the forks of the Columbia, as well as some other tribes of Indians, are fond of horse-flesh as an article of food; and the residents at some of the Hudson Bay Company's posts on that river, are under the necessity of making it their principal article of diet."

At the beginning of the eighteenth century there were many wild horses in Virginia ${ }^{1}$, and they became a great nuisance to outlying settlers, by enticing away their domestic horses. As the latter were English in origin, the wild horses were modified to some extent, though the Spanish traits still predominated. Similarly the feral horses of East Victoria in Australia became a constant source of annoyance and loss to the settlers in that region, until they were at length all captured.

For the following account of these animals I am indebted to my friend Dr A. W. Howitt, of Metung, Victoria, the famous 1 Wallace, The Horse of America, p. 204. 
Australian ethnologist" : Wild horses have been running in the mountainous country of East Gippsland, in which are the sources of the Buchan River, and through which the Snowy River and its tributary the Deddik River flow. To this I must add the dividing range from Omeo to Hount Kosciusko. These wild horses probably date back in places to a time antecedent to the discovery of Gippsland in 1842. On the Manero tableland which lies on the New South Wales side of the border, and extends up to Kosciusko and Kiandra, and Sunit, as also from the country to the heel of the dividing range, I have no doubt that horses escaped and became wild. Of course these have been of all kinds. On the high mountain plateau which lies between the upper 'Tambo River and the sources of the Buchan River I have seen horses which can be-best described as dwarfed cart-horses, and probably were the descendants of light draught stock used by prospectors and miners in the early times of gold discovery-after 1850. The country they lived in is very high and cold, being covered in winter with snow, and altogether ill adapted to feral horses. In the warmer but very hilly country which lies to the east of the Snowy River in Victoria, for instance at Gatemurra, Deddik, and Tubbut, the horses were of a much better stamp, in many cases showing good breeding, partly due to the excellent stamp of the New South Wales horses of about 50 years ago, but also to the fact that a Persian borse, imported by Benjamin Boyd, of Twoford Bay, escaped and lived for many years after in the Deddik, Gatemurra, and Tubbut country. The grey horses which occured there may be attributed to his influence.

"The horses of this district were in many cases very good, being especially sure-footed, but frequently were broken down by galloping when driven orer the mountainous and exceedingly rough country which they inhabited. I have often seen one of these 'mobs,' as they are called, coming down the mountain side when disturbed at a gallop. I remember one instance on the western side of the Snowy River, where a number were killed by running against trees, or by being crushed against them by others of the horses in their flight.

\footnotetext{
1 Dr Howitt's letter is dated September $14(1901)$.
} 
At one time about twenty years ago the horses became such a nuisance in the cattle stations in the district that steps were taken to get rid of them. This was most successfully done by building a yard of tree trunks on one of their main tracks, which led from one valley across a range to another. This was left open at each end for a time until the horses became accustomed to pass through it. Then a slip of white calico about 18 to 24 inches wide was fastened at each side of the entrance to the yard, continued from tree to tree for a considerable distance, liverging from the track on either hand. The wild horses being then driven from their feeding-grounds in the valley started to escape along the track across the range, and having entered between the two converging lines of calico were driven into the yard, the farther opening having been closed. The other entrance could be closed behind them. It was a usual practice to catch them and hobble them with plaited strips of green hide (salted and dried) before they were let out of the yard to prevent them escaping again and to admit of their being watched while grazing in the neighbourhood. Finally, they were driven to some market. I know of cases where they were driven to the coast, say at Bega, and sold at half-a-crown a head to people to repay themselves with the skin and hair, the flesh being boiled to feed pigs. I may add that so far as I remember it was not found to be possible to run in one of those 'mobs' to a yard, as they separated, the stronger ones outstripping the weaker. I remember another plan being tried. The 'mobs' on the western side of the country-near the Snowy River-were all started by a number of men on horseback, who drove them at full speed to the other side of the country, not themselves going all the way, but making as much noise by shouting and cracking whips as possible. The horses having gone even as much as eight miles, were turned back by other men; after a couple of days most of the horses had separated, and were scattered all over the country in twos and threes and even singly, many were lame, and some were then caught, but the expenditure of horseflesh in doing this was not compensated by the result. After this the method by a yard and calico 'wings' was 
adopted. Much of the country is now fenced and stocked with sheep. I imagine that the feral horses are not to be found excepting in the higher, more rugged, or scrubby country outside the fencing."

It is now clear that for various reasons herds of wild horses are almost certain to be exterminated in any region where the inhabitants are at all numerous and keep domestic horses.

Having rejected the view that the Libyan horse is a purely artificial breed developed by the Libyans out of the ordinary domestic horses of Asia and Europe, let us examine the evidence in favour of the second alternative-that the Libyan horses were descended from wild horses which passed into North Africa from Asia or from Europe or from both.

Colonel Hamilton Smith held that our domestic horses are descended from five original stirpes-the bay of Western Asia, i.e. Arab, the white, the black, the dum, and the pied-and he believed that dark stripes were a special characteristic of the dun stirps. Though Darwin rejected Hamilton Smith's doctrine of five original stocks, he found in the latter's dun-coloured stirps with a tendency to stripes the bases of his own hypothesis. From the facts that "horses in various parts of the world often have a dark stripe extending aloug the spine, from the mane to the tail," and that "oceasionally horses are transversely barred on the legs, chiefly on the under side," and "more rarely have a distinct stripe on the shoulder, like that on the shoulder of the ass, or a broad dark patch representing a stripe," and from a consideration of the general tendency of horses to revert to a yellow-dun hue, Darwin ${ }^{1}$ was led to the conclusion that "the seven or eight species of Equidae now existing are all descended from an ancestor of a dun colour more or less striped," and elsewhere ${ }^{2}$ he argued from the results of his experience in crossing pigeons and fowls that "the progenitor of the group was striped on the legs, shoulders, face, and probably over the whole body like a zebra." He thus assumed that the first horses domesticated by man (from which he held that all

1 Variation of Animals and Plants under Domesticution, Vol. I. pp. 58-9.

${ }^{2}$ Id., Vol. II. p. 17.

R. H. 
our domestic races, no matter what their form and colour, are descended) were of a dun colour.

But he himself points out that though "all English breeds however unlike in size and appearance, and several of those in India and the Malay Archipelago, present a similar range and diversity of colour, the English race-horse, however, is said never to be dun-coloured." He thought ${ }^{1}$ that this might be explained by the fact that "as dun and cream-coloured horses are considered by the Arabs worthless and fit only for Jews to ride, these tints may have been removed by long-continued selection." But as it has been demonstrated that the Arabs did not develope their famous horses by selection solely from the dun-coloured horses of ancient Persia or any other part of Asia, but, several centuries after Christ, obtained it from North Africa, where it was already of a dark colour at least a thousand years before the Arabs ever possessed a horse, it is obvious that Darwin's theory of the origin of the bay colour is based on a false assumption.

Again, as we have shown that whenever horses of a light colour are met with in Arabia, and in other parts of Western Asia, they are always kadishes, or in other words the coarse, thick-set, slow type of Upper Asia, the contempt of the Arabs for such horses is due to the fact that horses so coloured are always inferior, and not to any dislike of their livery, since they hold, as we do, that "a good horse is never of a bad colour," and we have also seen (p. 186) that the Arabs, like many other peoples, from religious motives have a preference for white and grey horses. It is then clear that Darwin's explanation of the dark colour of the English race-horse and his progenitors does not supply a vera causa.

If the bay colour of the Libyan horse has only been acquired by artificial breeding, and if, as Darwin held", "colour is a fleeting characteristic," the descendants of such horses when they become feral and return to a state of nature ought to revert to dun colour, or at least show a tendency to do so. Yet we have seen that although the Pampas horses descended from some

1 Variation, Vol. 1. p. 58.

2 Variation, Vol. I. p. 53. 
dozen Andalusian stallions and mares turned loose in 15:35, have been living under perfectly natural conditions for more than three centuries and a half, yet, as already noticed (p. 263), Azara" states that amongst the "numerous herds of wild horses that had passed under his observation, he had never seen any colour but bay, some inclining to brown, in others more or less to red, and whenever a piebald, black, or any other coloured horse is seen, it is immediately known to have been a domesticated individual, which had made its escape or had been carried off by the wild herds."

Elsewhere" he says that it is "unaccountable, the wild horses being, as I have observed, all bay, how so great a variety of colours is found amongst the tame, although black and dark-coloured are extremely scarce; I must also mention that white, bay, and greyish-coloured horses, and above all chestnut piebalds (sabinos), the ground colour of whose coat is white, with an infinity of obscure and cinnamon-coloured specks or spots, pass for the best swimmers."

I have pointed out already (p. 263) that the white, grey, and other light-coloured horses of South America are derived from the horses of Upper Spain, whilst the Pampas horses are sprung purely from those of Andalusia. But as the Andalusians are in great part of Libyan blood, and as their wild descendants of the Pampas obstinately refuse to revert to a dun colour, as they ought to do if their bay livery has simply been developed by artificial breeding, it is reasonable to infer that, whilst the Asiatic ancestors of the Libyan horses were dun-coloured, the bay colour of the Libyan horse was gradually acquired in North

1 Quadrupeds of Paraguay, p. 14 (English trans.). As I pointed out before, Col. Hamilton Smith, who seems to have worked direct from Azara's original Spanish, translates as 'bay' what the English translator renders 'chestnut,' but as Col. Smith had given great attention to the vast variety of names for different shades of colour used by Spanish writers on horses, and as the Pampas horses seem really to be what we term 'bay,' this rendering seems to be the true one. Mr Darwin (Variation, Vol. 1. p. 64), who cites Azara's French edition of his work, agrees with Col. Smitb, for he cites Azara (Les Quadrupeds: du Paraguay, Tom. II. p. 307) as stating that " 90 out of 100 horses were 'baichâtains,' the remainder were 'zains,' that is without any white; not more than 1 in 2000 being black."

2 Quadrupeds of Paraguay, p. 31 (Engl. trans.). 
Africa. We have seen that the quagga, whose habitat was bounded by the Vaal River on the north and extended as far as lat. $32^{\circ} \mathrm{S}$., had not only divested itself of its stripes to a still greater degree than the Burchell zebra, but had assumed a general bay colour except on its lower parts.

Mr Pocock ${ }^{1}$ has admirably traced the various gradations in coloration from Grant's zebra in North-east Africa to that of the Quaggas in the Cape Colony. The first of these is striped all over down to the very hoofs with black in strong contrast to its white ground colour, but even in British and German East Africa "the pale interspaces begin to be washed with brown and to be filled in with narrow intervening stripes, and such forms are difficult to distinguish from $E$. selousi of the Mashonaland plateau. From these may be traced a series of gradations represented by the local races named after Chapman, Wahlberg, and Burchell, in which the stripes gradually disappear and thin upwards from the fetlocks to the shoulders and haunches, while those on the body lose their connection with the mid-ventral band and becoming shorter leave the belly unstriped. Concomitantly the intervening 'shadow' stripes increase in number and definition as they extend forwards towards the neck, then the normal stripes themselves turn brown, and the ochre-stained brown colour deepens in hue. In Burchell's the shadow stripes reach the head, and the last of the complete stripes is the one that extends backwards from the stifles to the root of the tail, the hindquarters and the legs being practically, and the belly actually, stripeless. It is but a step from this to the extinct Grey's quagga, in wbich the stripes of the body were fused together and blended to a great extent with the brown of the intervening areas, those on the neck being exceedingly broad, and broken up by paler tracts of hair."

This process is almirably illustrated by the head and neck (Figs. 131-3) of a quagrga, hitherto unnoticed by the students of the Equidae, to which my attention was called by my friend Dr W. L. H. Duckworth2, M.A., Fellow of Jesus

1 'The Coloration of the Quaggas,' Nuture, 1903, pp. 356-7.

${ }^{2}$ Dr Duckworth (who has laid me under many obligations) on a hasty visit 
College, Cambridge, and which is here for the first time published. It is in the museum of the Elgin and Morayshire Society at Elgin, to which it was "presented in 1861 by John Maclean, Esq., of King Williamstown, British Kaffraria," according to a document hunted up for me by the most obliging curator, Mr Gordon Taylor, to whom I am indebted for the following description. "There are nine stripes on the face (Fig. 131), spreading out and meeting in a point on the forehead about three inches below the ears and meeting in the same way about four inches above the nose, with four or five rumning upward and inwards above each eye. The ears are smaller than those of the zebra. The ground colour of the head and face is a dark fawn, the neck (of which there are about 15 inches attached to the head) inclines to dull brown above, passing into a fawn colour below. On the portion of the neck attached to the head there are six dull white interspaces mixed with brown hairs measuring from half-an-inch up to an inch in width, the widest being nearest the body, the stripes themselves being very irregular and wavy and being completely fused on the throat. The hair of the almost erect mane is mostly reddish-brown tipped with a darker shade, having patches of white, the largest bunches being where the interspaces meet the mane. The stripes on the face are white, the spaces between them a dull brown, showing a decided contrast to the ground colour of the face. On the side of the face, running down across the jaw, are six or seven stripes of the same shade of brown, but no white." Of the described specimens of the quagga (pp. 70-7), Mr Pocock thinks that the Elgin specimen comes much nearest to $E$. greyi, but he thinks it may belong to a new type. The importance of an additional fragment of quagga is increased by the fact that it is the only one of the existing specimens the provenance of which is known.

The change in coloration from E. granti (pp. 63-9) to Daniell's quagga (p. 78) was probably due to "a change of habitat from bush to open plain. A new method of concealto the Elgin Museum last September noticed a specimen labelled 'Quagga' and at once called my attention to it. 
ment by means of shadow contraction was required and was gradually perfected by the toning down of the stripes on the upper side and the suppression of those on the hind-quarters and legs." Mr Pocock thinks that the ruddiness of Cape

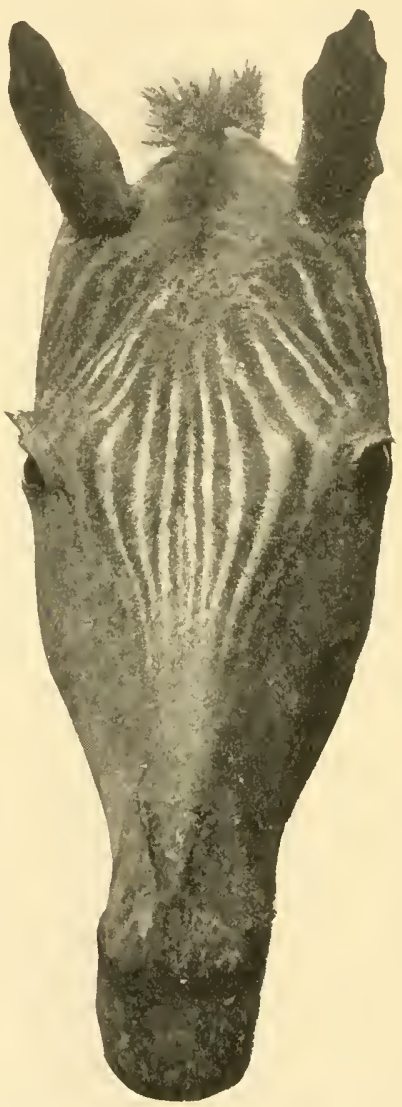

Frr. 131. The Elgin Quagga.

Colony quaggas was acquired by two different processes-"in the case of Daniell's quagga by a deepening of the red of the ground colour or interspaces and the reduction in the length

${ }^{1}$ Ann. Mag. Natural History, 1904, p. 328. 

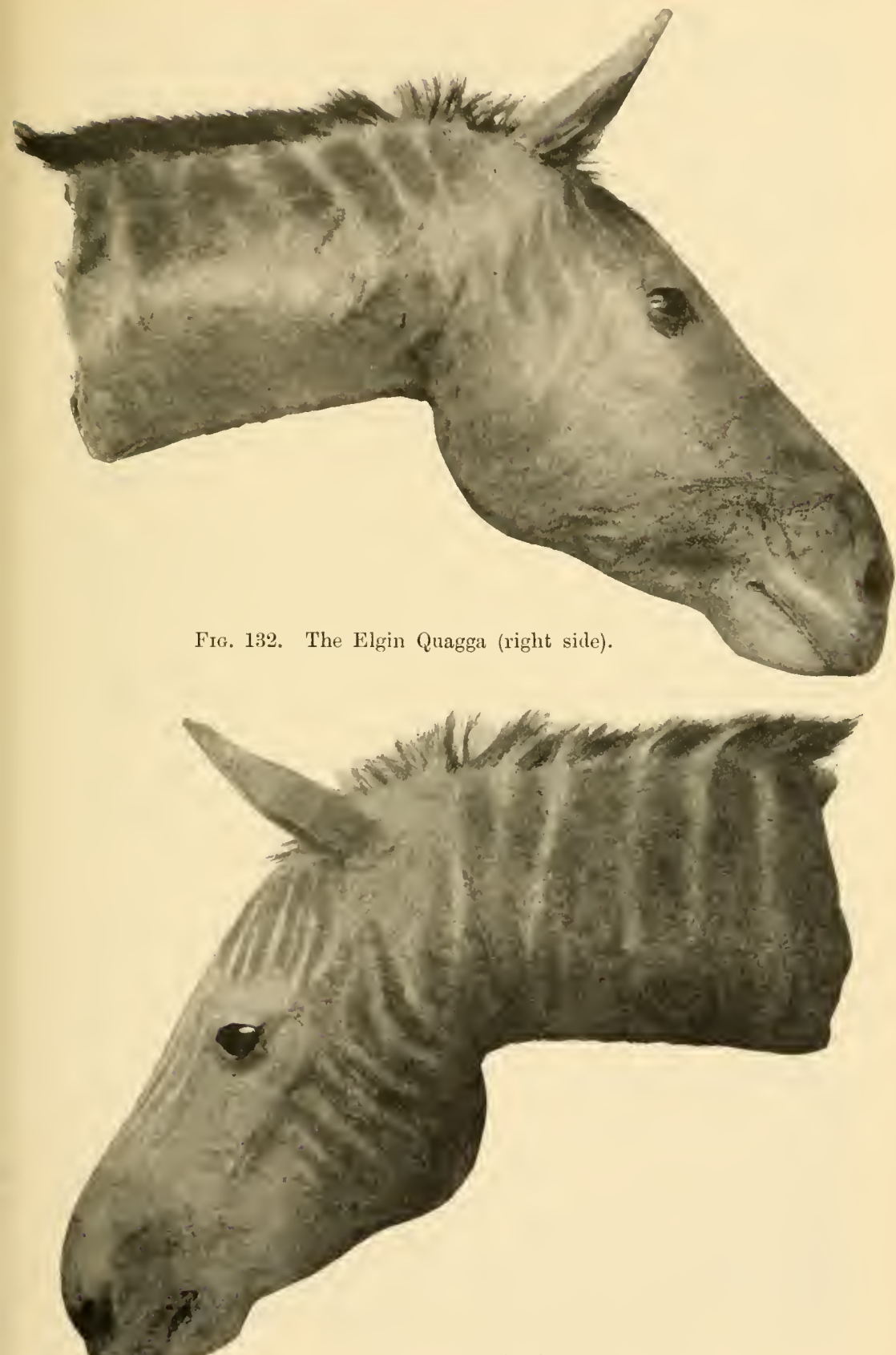

FIg. 133. The Elgin Quagga (left side). 
and the width of the black stripes on the neck and shoulder concomitantly with their suppression on the body, the result being a chestnut or bay-coloured animal with narrow black stripes on its fore-parts"; in the case of Grey's quagga (and the Elgin specimen) by an increase in the width and brownness of the stripes, followed by their fusion and loss of definition on the body, the result being a ruddy-brown animal marked with narrow pale bands (the interspaces) upon the head, neck, and shoulder, as in the Elgin specimen here figured.

Now as the Libyan horse makes its first appearance amongst the nomadic tribes of Libya whose territories were about lat. $32^{\circ} \mathrm{N}$. it is fair to suggest that similar conditions of climate and food and a like need of a protective colour suited for life in open plains had produced the bay colour in both the quagga and Libyan horse. It will also be remembered that the quagga closely resembled the horse in the character of its tail. It has likewise been shown that the feral horses of North America sprung from Spanish horses chiefly from Northern Spain after three centuries wore liveries of black, grey, roan, roan pied with dun, and dun frequently with dorsal stripes derived from their cross-bred ancestors, the dun with stripes not being a reversion to a primal ancestor, but simply the coat inherited from the dun-coloured striped horses of the sierras of Spain.

The swiftest horse known in Homeric days was a bay with a star in his forehead; in Greek classical times, the dark horses of Libya were the swiftest known and the same horses bore away the palm from all others in the Roman circus in the first century of our era; and the Saraceus, so soon as they got possession of these horses, became the swiftest riders in the world, and the best Anazah horses of the present day are bay with a star in the forehead and 'bracelets.' If then it could be shown that in a definite series of cases where very well bred, but not quite pure-bred, horses have been bred solely with a view to speed, the increase of speed in the stock has been steadily accompanied with the gradual disappearance of all other colours except bay (or chestmut), we should get a 
very substantial corroboration for our conclusion that the primeval colour of the Libyan horse was bay. The English race-horse supplies exactly the test case that we seek.

Major-General Tweedie $^{1}$, when discussing the colours of Arab horses, makes the following valuable observation on those of the English thoroughbred: "The production by man through methodical selection of breeds of horses of one colour, is as intelligible as the distribution by nature of troops of wild horses, every individual of which resembles the surface of the ground. But another fact here presents itself, which seems still to await explanation. Except in so far as statistics show that there have been more winners of one colour than of another colour, English breeders for the turf may safely be acquitted of all preference, or fancy, respecting colour. And yet, equally in our islands and at the Antipodes, the long course of scientific breeding, of which our racing stock is the product, has practically resulted in its becoming a family of bays and chestnutstwo colours essentially one. In olden times when England was full of fresh Eastern blood, greys were as often seen at the starting-post as they were down to a much later period in New South Wales and Victoria. In the thirty years preceding 1866 it was estimated ${ }^{2}$ that the Derby had been won by seven chestnuts, seven browns, and sixteen bays; the St Leger by five chestnuts, eight browns, and seventeen bays, and the Oaks in like proportion. The tendency of the highest breeding in latitudes far separated is to wipe out in horses all colours save bay and chestnut." Now, as it will be remembered that MajorGeneral Tweedie is a firm advocate of the theory that the Arab horse is a purely artificial product, his testimony is all the more valuable as it is that of a hostile witness.

An examination of the colours of the winners of the Derby, Oaks, and St Leger ${ }^{3}$ for the three decades from 1870 to 1899 inclusive proves that not merely has grey disappeared al together

1 The Arabian Horse, p. 267.

2 R. H. Copperthwaite, The Turf and the Race-horse, ed, 2 (1866), p. 144.

3 As the Racing Calendar does not attach colour marks to the lists of winners of the Derby, Oaks, and St Leger, I had to compile my table by going through the volumes of the Racing Calendar for the years tabulated. 
and that black has almost gone, but that chestnut (which Major-General Tweedie holds to be the same colour as bay) is also disappearing as well as brown.

TABLE I, of the colours of the winning horses in the Derby, Oaks, and St Leger from 1870 to 1899 :

$\begin{array}{cccccc}\text { Decade } & \text { Bay } & \text { Chestnut } & \text { Brown } & \text { Black or Brown } & \text { Black } \\ 1870-9 & 15 & 12 & 2 & 1 & 0 \\ 1880-9 & 16 & 8 & 5 & 0 & 1 \\ 1890-9 & 17 & 6 & 7 & 0 & 0\end{array}$

From the table it is clear that during the last third of the past century bay has been slowly gaining upon both brown and chestnut combined, and that brown has been gaining upon chestnut. Thus the dun element, which as we already believed from our previous investigations when mixed with bay gives chestnut, is steadily being eliminated and our racing stock is becoming a breed of bays and browns with a steady tendency to become eventually purely bay.

The same tendency is shown still more emphatically if we take the colours of the first three horses in each of the three great races just named.

TABLE $I^{1}$, showing the colours of the three first horses in the Derby, the Oaks, and the St Leger from 1870 to 1899 :

$\begin{array}{ccccccc}\text { Decade } & \text { Bay } & \text { Chestnut } & \text { Brown } & \begin{array}{c}\text { Brown } \\ \text { or Black }\end{array} & \text { Black } & \begin{array}{c}\text { Bay } \\ \text { or Brown }\end{array} \\ 1870-9 & 36 & 34 & 13 & 4 & 2 & 1 \\ 1880-9 & 42 & 28 & 16 & 0 & 2 & 1 \\ 1890-9 & 54 & 16 & 17 & 1 & 0 & 2\end{array}$

Out of 90 horses bay only had 36 in 1870-9, but rose to 54 in the last decade; whilst chestnut ${ }^{2}$, which was repre-

1 This table is not quite complete, for the colour was omitted in one instance in the Calendar, though those of the winners are given without fail.

2 With reference to the proportions of chestnut found in the two sexes the results are as follows: Totals for thirty years: colts 41 , fillies 36 . 1870-9: colts 20 , fillies $13 ; 1880-9$ : colts 9 , fillies $19 ; 1890-9$ : colts 12 , fllies 3 . The great decrease in chestuut in the last decade is therefore especially seen in the mares. 
sented by only 2 less than bay in the first decade, has sunk to 16 in the last; brown has gained slightly at the expense of chestnut, rising from 13 to 17 . There can be little doubt in view of these facts that the English racing stock is steadily becoming bay.

Table II shows that the intermediate steps between black and bay are (1) a hue which cannot be described as a really black or really brown, (2) true brown, (3) bay-brown, true bay being finally reached. Chestnut seems to pass into bay either directly or indirectly through brown. Thus dun and white (the characteristic colours of the old European-Asiatic horses), first disappeared, then grey went, black is almost gone, chestnut is following it slowly, and brown at a still slower rate.

I have shown in the course of our investigation that black, dull black, brown, various shades of grey, and probably chestnut, are due to the intermixture of Asiatic horses with Libyan in various proportions. But as the Asiatic horse of historical times is thick-set, coarse, and slow in pace, and inevitably injures the speed of the pure Libyan strain when erossed with it (as in the case of the 'Gulf Arabs,' p. 175) every attempt to improve the speed of such a mixed breed will inevitably tend to eliminate every Upper Asiatic element. But as the original Arabs, Barbs, and Turks which formed the basis of our thoroughbred stock ( $p .382$ ) were, with the single exception of the Darley Arabian, all more or less contaminated with European and Asiatic blood (e.g. the Yellow Turk, the White Turk, Hutton's Grey Barb, Grey Wilkes, etc.), the unceasing efforts of breeders to obtain greater lightness and speed are continually eliminating the Asiatic and European element, and accordingly dum and white have long disappeared from, aud grey, black, chestnut and brown horses are gradually ceasing to be found in, our blood stock. But as increase of speed is gradually rendering the English thoroughbred a purely bay stock, and as from the earliest times of which we have any record the Libyan horse has been not only the swiftest horse known, but also has been of a bay colour, we are justified in concluding that his bay colour is as fundamental a characteristic as his speed, and that it is due not to artificial selection, but to natural specialisation. 
Nor must Darwin's second conclusion-that the ancestor of all the Equidae was striped like a zebra-be accepted in its entirety. We have ahready seen (p. 78) that the tendency to stripes is least in the northern latitudes, where the genus first made its appearance in Asia, that this tendency gradually increases as we advance southwards, that it reaches its maximum in the tropical and sub-tropical regions of Africa, and that the stripes show a tendency to disappear in Burchell's zebra of the Transvaal and Orange River Colony, and to a still greater degree in the quagga, whose range seems always to have been south of the Vaal River. I showed that if the Equidae as a whole or in part are gradually divesting themselves of stripes, those of Africa have retained their stripes much more tenaciously than those of Asia, or if as a whole, or only in the case of certain species, they are gradually assuming stripes, those of Africa have far outstripped their congeners of the northern latitudes, and $I$ argued that the presence of manifold stripes all over the body in any member of the genus Equus is a strong indication that it has been long domiciled in Africa, where its progenitors for protection or recognition or for some other purpose, either retained and modified the coat of a common ancestor of all the Equidae, or else put on striping differing in different species and varieties according to the nature of their environment or for other reasons. These considerations suggest that the tendency to zebra stripes in certain domestic horses may be less due to reversion to the colour of a remote ancestor, than to their being descended from the Libyan horse.

It is therefore worth examining the evidence collected by Col. Hamilton Smith, Darwin, Ewart and others for the existence of such markings in horses. If it should turn out that all such animals are of undoubted North African origin, or at least very probably have some of that strain in them, our contention that the Libyan has been domiciled and highly specialised in North Africa from a very remote period, and that he is distinct from the Asiatic horses of recent epochs, will have received very substantial corroboration.

Let us now examine all the instances on which Darwin based his conclusion, supplementing them as we proceed with fresh examples:- 
1. Mr Edwards examined twenty-two foals of race-horses, and twelve had the spinal stripe more or less plain.

2 . A bay mare (belonging to $\mathrm{Mr}$. Darwin), descended from a dark brown Flemish mare by a light grey 'Turcoman horse, was put to Hercules, a thoroughbred dark bay, whose sire Kingston and dam were both bays; she had a colt which ultimately turned out brown, "but when only a fortnight old it was a dirty bay, shaded with mouse-grey, and in parts with a yellowish tint: it had not only a trace of the spinal stripe, with a few obscure transverse bars on the legs, but almost the whole body was marked with very narrow dark stripes, in most parts so obscure as to be visible only in certain lights, like the stripes which may be seen on black kittens. T'hese stripes were distinct on the hind-quarters, where they liverged from the spine and pointed a little forward: many of them as they diverged became a little branched, exactly in the same mamer as in some zebrine species.

The stripes were plainest on the forehead between the ears, where they formed a set of pointed arches, one under the other, decreasing in size downwards towards the muzzle; exactly similar marks may be seen on the forehead of the quagga and Burchell's zebra. When this foal was two or three months old all the stripes entirely disappeared ${ }^{1 .}$."

3. Prof. Ewart's ${ }^{2}$ high-caste Arab filly Fatima, bred by Mr Wilfrid Blunt, even when full-grown, shows as distinct stripes in the region of the knee and hock as are to be found in Norwegian dun-coloured ponies, and she has in addition to a dorsal band faint indications of markings across the withers.

4. Major Upton noticed very frequently among colt foals (though not in fillies) of the pure-bred Al-Khamseh horses of the Anazah tribes of Central Arabia "a line somewhat darker than the general colour of the animal running in continuation of the mane along the spine, and to be traced for some way even among the long hair of the tail. It is not obliterated with age; it can be traced in old horses and in those of a very dark colour ${ }^{3}$."

I Variation, Vol. I. pp. 60-1.

2 Ewart, Penycuik Experiments, p. lxx.

3 Op. cit. p. 339. 
5. Mr Edwards had seen a nearly thoroughbred chestnut horse which had the spinal stripe and distinct bars on the legs ${ }^{1}$.

6. Col. Hamilton Smith ${ }^{2}$ speaks of dun horses in the sierras of Spain which have a spinal stripe, and we have found the descendants of Spanish horses in Mexico and the Western States frequently of a dun colour marked with stripes (p. 265). But we have seen that all the horses of Spain from before the Christian era were more or less impregnated with Libyan blood (p. 256).

7. Out of 300 South American horses imported into Madras many had transverse stripes on the legs and short shoulder stripes $^{3}$. The most strongly marked individual was a mousedun with the shoulder stripe slightly forked.

We have shown that the Andalusian horses are almost wholly Libyan in blood, and that other Spanish horses are largely imbued with the same blood, and also that the South American Pampas horses are descended from some Andalusian horses introduced by the early Spanish settlers.

8. The Karadagh horses, which are the best native horses of Armenia to-day, were originally the dun horses of the southern slopes of the Caucasus. Many of them have been recently crossed with Russian blood (p. 193), which is of course largely Libyan, and probably have had much of the same strain through Arab and other channels. They are usually bay or chestnut with black manes and tails. They all have a dorsal stripe about an inch broad from the mane to the tail ${ }^{4}$.

9. In the north-western parts of India striped horses of more than one breed are very common. In Kattywar the native horses are usually of a rufous-grey or khaki colour. At one time Kattywar horses were not considered pure unless decorated with a dorsal band and bars across the legs. Sometimes in addition there were stripes on the neck, forehead and withers $^{5}$. The Kattywar horses are often fifteen or sixteen hands in height, and are well, but lightly built.

1 Darwin, Variation, Vol. I. p. 60.

2 The Horse, p. 275.

3 Darwin, Variation, Vol. I. p. 61.

+ Hayes, Points of the Horse, pp. 610-11.

5 Ewart, Exper. Contributions, p. 21. 
"There are sometimes stripes on the grey and bay Kattywars when first foaled, but they soon fade away"." But we have seen (p. 157) that the horses of all North-western India are a blend of the dun-coloured aboriginal horse of Upper Asia and Arab horses which have been imported in enormous quantities annually into India, and whose blood has saturated the 'Turcoman horses.

The fact that the Kattywar horses are dun, rufous-grey, and bay is sufficient proof in the light of our investigations that they are largely mixed with Arab blood, a conclusion strongly corroborated by their slender build, and the fact that "a horse is not considered pure unless he shows stripes" indicates that these stripes are a special characteristic of horses which have the greatest amount of good Arabian, i.e. North African, blood in their veins.

10. The horses of the Waziri are said to be not uncommonly decorated with stripes on the legs. But, as we have seen above, the horses of Afghanistan and Baluchistan (p. 159) are crossbreds between the Mongolian and the Arab, and there is some evidence for the existence of Arab blood in Afghanistan at least as early as the thirteenth century A.D. For Mareo Polo", speaking of Badakshan, says that "it produces numbers of excellent horses remarkable for their speed. They are not shod at all, although constantly used in a mountainous country and on very bad roads. They go at a great pace, even down steep descents, where other horses neither would nor could do the like." And Messer Marco was told that "not long ago they possessed in that province a breed of horses from the strain of Alexander's horse Bucephalus, all of which had from their birth a particular mark on the forehead. This breed was entirely in the hands of an uncle of the King's; and in consequence of his refusal to let the King have any of them the latter put him to death. The widow then in despite destroyed the whole breed, and it is now extinet." We have already repeatedly seen that a star in the forehead is especially' characteristic of the North African horse and its various 
derivatives. The statement that the best breed of Badakshan had a peculiar mark in the forehead curiously confirms the native belief that the strain had come from the westward.

11. We saw (p. 154) that the 'Tibetan ponies are the most richly decorated horses in Asia, and that they were mainly of Mongolian stock, but had probably been crossed with Libyan blood, like all the horses of western, north-western, and northern India. They are frequently piebald and skewbald, like the Sumatra ponies, sprung from the crossing of Arab horses with native ponies of a mixed Arab and Upper Asiatic stock, and as the Tibetan ponies also show dorsal and other stripes, like the ponies of Sumatra and Java just mentioned, and the horses of Kattywar, which are saturated with Arab blood, we may reasonably conclude that the colouring and striping of the Tibetan ponies are due to the blending of Arab blood with that of the Mongolian pony.

12. The Shan ${ }^{1}$ ponies have not unfrequently spinal, leg, and shoulder stripes; 13 the Burmese, and 14 Javanese ponies are frequently dun-coloured, and have three kinds of stripes "in the same degree as in England2".

15. Two bay Pegu ponies had leg stripes ${ }^{3}$, and 16 two Chinese ponies-one of the Amoy, the other of the Shanghai breed-in colour light-dun, had each the spinal stripe, the latter an indistiuct shoulder stripe 4

But I have already shown that all the horses of India, both Hither and Further, have been largely mixed with Arab blood, which has streamed for at least a thousand years into all parts of Hindustan, and thence into the lands beyond, and along with manifold other Arab influences into the great islands of the Malay Archipelago, which previously possessed no horses (pp. 142-6).

We have seen (p. 141) that the Shan (Burmese) or Pegu ponies, the Manipur ponies, and those of Sumatra and Java resemble each other. But as the Javanese and Sumatran ponies are largely impregnated with Arab blood, and as all the horses of India are saturated with the same strain, we need not

1 Darwin, Variation, Vol. I. p. 61.

2 Ibid.

3 Ibid.

4 Op. cit. Vol. I. p. 62 . 
hesitate to believe that the Shan and Manipur ponies liave been similarly crossed.

Nor need we be surprised to find in China ponies showing traces of stripes, when we recall the vigorous horse-trade between China and India in the days of Marco Polo, and when we bear in mind the repeated evidence of the steady determination of every tribe in Asia and Europe from the dawn of history to obtain for their mares the services of sires of the Libyan stock. Moreover we know from the Chinese documents that about B.c. 100 the emperor sent westwards to obtain horses of an improved breed from Turkestan ${ }^{1}$, whither it is highly probable horses of a mixed Libyan strain had found their way from Bactria. The fact that the two Pegu ponies cited by Darwin were of a bay colour in itself shows that they had a large infusion of Arab blood.

The occurrence in various parts of Eastern Asia of duncoloured horses with stripes can be completely accounted for by the historical fact that in the horses of all those regions there is a large substratum of Upper Asiatic blood, which has been more or less improved by the repeated introduction of Arab sires, as has been the case in Western Asia also (p. 183). And as in the latter region the predominant colour is that of the native Turcoman and Kurdish mares, which has been but slightly influenced by the dark colour of the Libyan sires, so too in Eastern Asia, whilst the structure and quality of the breed have been improved by the Arab sires, the latter have not been able to modify to any great extent the light colours of the native mares, though not unfrequently transmitting to their progeny their own zebra-like markings. Let us now return to Europe.

17. "On the Continent the offspring of black sires saturated with Arab blood are often more or less distinctly striped?".

18. The Cleveland Bays which resulted from crossing Yorkshire cart-mares with a Barb, had almost invariably a dorsal stripe (p. 386). This appears probably due to the Barb blood.

1 H. F. Osborn, Century Magazine, Nov., 1904, p. 16.

2 Ewart, Exp. Contributions, p. 21.

R. II. 
19. Two bay English carriage-horses had each a black spinal stripe; one of them had on each shoulder a light shoulder stripe, and the other had a broad, black, ill-defined stripe running obliquely half-way down each shoulder; neither had leg stripes'.

20. A bay Highland cob belonging to Prof. Ewart had a shoulder stripe nearly a foot in length, and a neck stripe that extended quite two-thirds across the neck, and six short stripes on the body behind the shoulder stripe?

21. The offspring of dark Highland pony sires not unfrequently show markings.

22. Darwin had seen marks on the forehead of a fully-grown fallow-dun, cob-like horse (which had also a conspicuous spinal stripe and its front legs well barred), marked similar to those on the forehead of his own foal.

23. A bright fallow-dun cob had its front legs transversely barred on the under side in the most conspicuous manner.

24. A bright fallow-dun colt, fully three parts thoroughbred, with very plain transverse stripes on the legs.

25. A small, purely-bred, light fallow-dun Welsh pony had a spinal stripe, a single transverse stripe on each leg, and three shoulder stripes; the posterior stripe corresponding with that on the shoulder of the ass was the longest, whilst the two anterior parallel stripes arising from the mane decreased in length in a reverse manner to that in the next instance.

26. A rather large, lightly-built, fallow-dun, Devonshire pon $y^{3}$, with a conspicuous stripe along the back, and with light transverse stripes on the under sides of its front legs, and with four parallel stripes on each shoulder. Of these four stripes the posterior one was very minute and faint: the anterior one, on the other hand, was long and broad, but interrupted in the middle and truncated at its lower extremity, with the anterior. angle produced into a long tapering point. "The shoulder stripe of the ass occasionally presents exactly the same appearance."

27. A dark leaden, mouse-coloured pony had leg stripes, but not very conspicuous.

1 Darwin, Variation, Vol. I. p. 60.

2 Op. cit. p. 105.

3 Variation, Vol. I. pp. 610-11. 
As no one will dispute the fact that our carriage-horses, riding horses and trappers are the result of a judicions blend of the coarse, thick-set Asio-European horse and the thoroughbred, and as it is also admitted that many of our native ponies, such as the Welsh and Exmoor, have been largely mixed with North African blood, the occurrence of stripes on such horses as those cited by Darwin can be readily accounted for on the hypothesis that the stripes are due to thoroughbred blood. In several of the instances given he himself states that the animal so marked was well bred, or else his description shows that such was the case, so there can be no doubt of the presence of Libyan blood in these animals. Our investigations have likewise shown that all shades of black and chestnut are due to a blending of the Libyan with the northern blood.

28. A pony said to be Welsh, in colour mouse-black or dark slate-grey, with a dorsal stripe, four stripes across the withers, and one or two indistinct ones on the $\mathrm{leg}^{1}$.

29. A chestnut-dun cart-horse had a conspicuous spinal stripe, with distinct traces of shoulder stripes but none on the legs.

30. A large, heavy Belgian cart-horse, of a fallow-dun colour, had a conspicuous spinal stripe and traces of leg stripes, and two parallel stripes on both shoulders.

31. Another rather light cart-horse of a dirty dark cream colour, with striped legs, and on one shoulder a large ill-defined dark cloudy patch, and on the opposite shoulder two parallel faint stripes.

But I have already shown that the large cart-horses of England have been imported from the Continent, and that these large breeds were evolved by infusing the blood of the Libyan horse into the little horses of Upper Europe. It has also been shown that dark sires saturated with Arabian blood constantly beget progeny marked with stripes. It is therefore not a matter for surprise if stripes occasionally appear on carthorses both in this country and on the Continent.

32. We have seen that the colour of the horses of the

1 This animal was examined by my friend Dr W. L. H. Duckworth, M.A., Fellow of Jesus College, Cambridge, at the Cambridge Midsummer Fair, 1904. 
North in early days was dun. In modern Norway the colour is dun, varying from cream colour to dark mouse-dun; and an animal is not considered purely bred unless it has the spinal and leg stripes. A large proportion (one-third) have striped legs, one pony having seven on the fore-legs and two on the hind-legs, but only a few exhibit shoulder stripes'.

33. A sand-coloured (yellow-dun) Norwegian pony, with black mane and tail, in the possession of Prof. Ewart, has stripes on the face, neck, body, and legs. "On the forehead there are two all but complete frontal arches and portions of five others. Being of a reddish-brown colour, these stripes are easily seen when the forelock is thrown back. The uppermost (orbital) arch ends in the frontal tuft, but instead of forming an actually pointed arch as in Matopo (his Burchell's zebra), it forms a somewhat rounded arch, as in the Amsterdam quagga" and in one of Prof. Ewart's zebra hybrids. Fragments of the other arches are most distinct in the middle of the forehead. "In having seven more or less complete frontal arches," says Prof. Ewart2, "this pony differs from my Burchell zebra, in which there are only three distinct arches in the corresponding position. When the incomplete arches are 'restored,' a pattern is formed which is almost intermediate between that of the Amsterdam quagga and the Somali zebra. From within the lowest arch several obscure lines, such as occur in zebra-ass hybrids, can be traced along the face. The stripes doubtless originally ended in or near a mealy-coloured muzzle, such as we find to-day in typical Exmoor ponies and some Somali zebras." In this Norwegian pony "there are only a few light hairs at the tip of the ears, but immediately below there is a broad black band, and an indistinct band near the base. Had the tip been lighter in colour, the ear of this pony would have not a little resembled in its decoration that of my Burchell zebra." Ewart has seen two other ponies, in colour light dun-

1 Darwin, Variation, Vol. I. p. 61. It is right to add that during the present summer (1904) my friend Dr Venn, F.R.S., and his son Mr J. A. Venn have examined for me a large number of Norwegian ponies at various coast towns in Norway, without having met a single instance of striping.

2 Penycuik Exp., pp. 102-3, fig. 36. 
one from Shetland, the other from Norway, "with the tips for quite half an inch almost white. In both cases a broad dark band extended across beneath the light tip ${ }^{1}$.'

Prof. Ewart adds that he has seen only two ponies with stripes on the face, and that he thinks that facial stripes are extremely rare. The same authority ${ }^{2}$ has "only seen faint indications of stripes on the side of the face, but from what he has seen he lıas no hesitation in saying that were a sketch male showing all the stripes of which fragments have been observed on the face of the horse during the present generation, the sketch would closely resemble the head of one of my (Ewart's) hybrids and less closely the Amsterdam quagga." We shall see very shortly that Ewart's hybrids show the decoration not of their sire Matopo, a Burchell zebra of the Chapman variety, but that of the Somali zebra.

Prof. Ewart's Norwegian pony has only a short shoulder stripe, and she has a number of ill-defined stripes in front of the shoulder stripe $^{3}$. She has three short stripes on the body behind the shoulder stripe, and an extremely well-developed dorsal band "as distinct and as broad as it crosses the croup as in my Burchell zebra." The edges of this band "give off short processes-rudiments of dereloping stripes, or vestiges of dwindling ones, such as are seen in some of the quaggas and in zebra-ass hybrids."

"In another light dun-colomred pony there are ten cervical stripes. As these ten stripes only extend about halfway along the neck, and as stripes are sometimes present immediately behind the ears, there may have been quite twenty stripes in the ancestors."

Prof. Ewart" remarks that "sometimes the shoulder stripes bifurcated some distance above the shoulder-joint," and thus suggests not so much the zebra as the quagga and zebrahybrids, and that "as a rule the neck stripes are short and indistinct, but that in some cases he had seen three or four cervical stripes nearly as well defined as in the zebras, whilst in one case he had observed several stripes extending into the mane."

\footnotetext{
${ }^{1}$ Ewart, op. cit. p. 104.

3 Op. cit. p. 105.

2 Op. cit.pp. 103-4.

4 op. cit. pp. 105-6.
} 
He adds that once only had he seen "as many as five distinct stripes extending from the dorsal band across the back."

First let us notice that stripes are in Norway, as in Kattywar, the marks of good breeding. But, as in the latter case, we know absolutely that the native horses have been saturated with Arab blood, the stripes in Norwegian ponies may be similarly explained. We have traced the improvement of the breeds of horses in Upper Europe from the second century B.C., when the Gauls began to import from the south a superior type of animal, and we saw that by Caesar's time Gaul was well supplied with southern horses. We also ascribed the superiority of the horses of the Tencteri, the only German tribe of the time of Tacitus which appears to have been wellmounted, to their close proximity to the Ganls. It is thus clear that by the second century A.D. a good deal of Libyan blood had made its way into Central and Upper Europe. It is not then surprising if by the tenth century excellent horses imbued with southern blood were found in Norway and Iceland. We have seen that the best horses mentioned in Burnt $\mathrm{Njal}$ are a chestnut, a brown, and two dun-coloured horses with black stripes down their backs, these last "were the best steeds to ride in all the comntry round." Here, again, the combination of black stripes with special excellence points to the same explanation as that given for the striped horses of Kattywar. If the stripes were but a characteristic feature of the dun stock of Northern Europe, why should horses of this description be superior to other duns, both in ancient and modern times? On the other hand, as soon as we recognize that the stripes are due to the presence of North African blood, the cause of the superiority of such animals is at once obvious. This is fully confirmed by Olaus Mlagnus, who says (p. 348) that the light dun is especially the livery of the wild horses of Europe, and that horses of this colour were always the worst (a view held by Virgil many centuries earlier), but that the best of them were those with a dorsal stripe. But since dun without stripes was the colour of the unimproved wild or feral horses of Europe, and the best duns whether in medieval Iceland and 
Europe or in modern India are commonly striped, and as we have shown that the striped horses of Kattywar owe their superiority to the infusion of Libyan blood, and since the striped dun horses of Spain are certainly a blend of the old dun European horses and the Libyan, we may conclude with high probability that stripes in all such cases are mainly dne to the infusion of Libyan blood.

An analysis of the instances of striped horses here adduced proves that the great majority were pure Arabians, English thoroughbreds, Spanish horses derived from North Africa, Pampas horses descended from Andalusian horses, three-quarter bred and half-bred horses, English carriage-horses and cobs, well-bred Welsh and Devonshire ponies, Kattywar, Burmese, and Javanese ponies largely infused with Arab blood, the progeny of dark sires saturated with Arab blood, and the offspring of dark Highland ponies. Prof. Ewart has lately informed me that he has seen three Mongolian ponies which show markings. They are particularly well defined in one in his own possession, but, as she is very fleet and shows clear indications of a good deal of Arab blood, we must not hastily ascribe the stripes to her Asiatic rather than to her Libyan blood. The account given on an earlier page (p. 138) of the Nongolian ponies shows that they are much mixed in blood, and as there is good reason to believe that the Chinese became acquainted with the fleet horses of the West at a comparatively early period, we need not be surprised if the Mongols, like the 'Turcomans, Kurds, and other horse-keeping tribes of Asia, were always anxious to infuse Arab blood into their own slow ponies.

Mongolian ponies have not come under the observation of scientific men to the same degree as the horses of other parts of Asia, and, consequently, the absence of more instances may be simply due to lack of information. Prof. Ewart has recently received from Mr Hagenbeck a Prejvalsky two-year old mare which has a distinct dorsal band, faint markings across the withers, and conspicuous bars in the vicinity of the knees and hocks. We have already seen that the Prejvalsky horses are thus marked, but unfortunately as the question of the purity of 
the specimens is very uncertain (p. 34), we cannot venture to say whether such markings are primitive in the stock or due to crossing with feral horses. On the other hand stripes are rare in cart-horses, which, as we know, are chiefly sprung from the old coarse, thick-set horses of Asia and Europe.

We must, therefore, conclude that such stripings are in a special degree characteristic of the Libyan horse and his derivatives, and are not equally common in all breeds of horses. But as manifold striping is especially characteristic of the Equidae of Africa, we may not unreasonably infer that the ancestors of the Libyan horse had long lived in Africa.

Prof. Ewart" has pointed out that in "highly bred foals with very fine coats there are often at birth across the sides and croup, and especially in the vicinity of the flank feather, narrow markings that might be mistaken for stripes. These markings are caused by the hair being arranged in well-marked tracks or ridges, separated by almost hairless spaces. In these tracks, which were very distinct at birth in a cinnamon-coloured foal I bred this year, out of a bay half-Arab mare-the sire was a chestnut thoroughbred horse-we have, it may be, a restoration for a time of an ancestral condition. Sometimes along with these hair-tracks or ridges there are faint stripes, seen only in certain lights, but evidently in part due to subtle colouring. Stripes of this nature I noticed plentifully scattered over a reddish-grey foal ont of my flea-bitten New Forest pony by the grey Arab Benazrek. More common and more evident are comparatively broad wavy bands often seen across the croup and on the brow of half-bred bay foals. These bands may occupy the position of ancestral stripes-stripes out of which the colour has been completely washed since they ceased to count in the struggle for existence." Ewart based his supposition on the fact that "they occupy the position of stripes in a yellow-dun Norwegian pony, and of the stripes over the croup of one of Lady Meux's [zebra] hybrids (p. 463), which may have been inherited either from the American trotting horse or from a remote common ancestor." 
The result then of our examination of the occurrence of stripes in horses has led us to the conclusion that such stripes are very often to be traced to North African blood. But as we have seen that it is in Africa the Fquidae show a special tendency to stripes, and that it is there alone they are found with stripes all over, as was the case with Darwin's colt, whose markings, as the reader will remember, resembled those of certain zebras, we are justified in inferring that the tendency to stripes which is so marked a feature of the North African horses and their derivatives is due to the circmustance that that strain is not a mere recent differentiation under domestication and artificial breeding of an Asiatic domestic breed, but is rather to be considered a species specialised during a long lapse of time in Libya under conditions somewhat similar to those which have produced the zebras.

It has been supposed that certain experiments conducted by Prof. Cossar Ewart in order to test the truth or falsity of the commonly received doctrine of Telegony, confirm Darwin's hypothesis that the common ancestor of the Equidae was a striped animal. The theory of Telegony gained much support from the famous letter of Lord Morton to Dr Wollaston, of Gonville and Caius College, Cambridge, then President of the Royal Society. In it Lord MIorton stated that he had mated his quagga stallion (Fig. 39) "with a young chestnut mare of seven-eighths Arabian blood, and which had never been bred from." The offspring was a filly, striped not only on the body but also on the legs, which were not so marked in her quagga sire. Lord Morton sold the chestnut mare to Sir Gore Ouseley, who bred from her by a very fine black Arabian horse a filly and a colt, which according to Lord Morton, in their colour and the hair of their mane had "a striking resemblance to the quagga." The filly and colt were in some respects more striped than either the quagga or quagga hybrid".

From this it was inferred that the quagga had so infected the mare that her union with him influenced the offspring of her subsequent matings. In order to test this, Prof. Ewart

1 Phil. Transactions, 1821, p. 21 ; Ewart, Penycuik Experiments, p. 59. 
crossed Matopo (Fig. 36), a stallion of the Chapman variety of the Burchell zebra, with mares of different kinds and colours as a preliminary, intending after they had foals to put them to ordinary horses. The results of these subsequent matings seem to put it beyond all doubt that there is no sound evidence for Telegony, at least as far as the Equidae are concerned. But the results of the mating of the mares with Matopo are in themselves of the highest interest apart from any question of Telegony. The hybrids, as was to be expected, were striped indeed like zebras, but instead of reproducing the broad characteristic markings of the Burchell species, to which their sire belongs, they showed numerous stripes not only narrow like those of the Somali zebra (Fig. 28), but showing the same arrangement, exhibiting on the forehead the round arches seen on the forehead of the Somali zebra instead of the pointed arches of Matopo, and bearing marks on the croup unknown on the Burchell zebra, but peculiar to the Somali and Mountain zebras. The oldest of the hybrids, Romulus ${ }^{1}$, was out of a thirteen hands, black, Island of Rum pony. "The well-bred, nearly black ponies of the Scottish Western Highlands and Islands, which have long been under observation, form a distinct breed, well adapted in many ways for crossing with zebras. Their resemblance to Eastern horses has been accounted for by saying that they have descended from sires which escaped from the ships of the Spanish Armada." But I have shown above (p. 400) that these dark-coloured ponies of the Western Isles and Highlands of Scotland are to be traced back to North Africa through France and Spain from before the Christian era, and their origin is no more to be ascribed to the horses from the Spanish Armada, than are the Connemara ponies to Spanish horses similarly obtained or imported during the Tudor period. "In the plan of his striping Romulus was utterly unlike his sire, and when a careful examination was made it became evident that in the number and arrangement of the markings he was not unlike a Somali zebra." "Instead of the four or five acutely pointed frontal arches of his sire, there are fourteen 
rounded arches, that remind one of the face of a Somali zebra. Instead of twelve cervical stripes as in Matopo, there are in Romulus twenty-four cervical stripes, all of which can be traced into the mane. In having so many cervical stripes he seems to be more primitive than even the Somali zebra (in which I have never seen more than fourteen cervical stripes), but closely agrees with one of my zebra mares, when the shadow stripes are included." Romulus likewise had at birth numerous spots arranged in nearly transverse rows over the loins and rump, which as he grew older united to form somewhat zigzag narrow bands, almost identical in their direction with the narrow stripes over the hind-quarters of the Somali zebras. "Counting from the shoulder stripe to the root of the tail, there are fortythree stripes in the hybrid-about the same number as in the Somali zebria."

Of all the hybrids Remus is most like a zebra. His mother was Biddy, an Irish mare, three-parts bred, in colour bay, with black points and black mane and tail. "Remus's ground colour is light bay, the stripes-numerous and distinct, except over the croup which has a mottled appcarance-are of a dark bay or brown tint. In his hoofs, mane, and tail, and in the bodyhair Remus is of all the hybrids most like a zebra."

Baron de Parana has made experiments by crossing a zebra stallion of the true Burchell type (Fig. 37), a white-legged variety with distinct shadow stripes, in build not far removed from the extinct quagga (Fig. 38), with South American mares. All the Brazil hybrids out of ordinary mares very closely resemble "Romulus in their markings - the legs being well striped, notwithstanding absence of markings on the legs of their sire-but they have rounder quarters and are apparently more cob-like in build ${ }^{2}$."

It has been cominonly held that these hybrids revert in their decoration to a remote common ancestor of the Equidae. But it is also possible, and I venture to think more probable

1 'Experimental Contributions to the theory of Heredity, Reversion, and Telegony in the Equidae,' Trans. Highland and Agricultural Soc. of Scotland, ser. 5, Vol. xiv. (1902), p. 41.

2 Ewart, Experimental Contrib., pp. 47-8. 
that the hybrids have not reverted to a remote ancestor, but rather to the immediate ancestor of the North African horses, with the blood of which Biddy, the three-quarters bred Irish mare, the well-bred Island of Rum pony, and the South American mares were saturated. We have just seen that beyond reasonable doubt there is a special tendency to exhibit zebra stripes in the Libyan horse and its descendants, whether they be in the Pampas of South America or in Kattywar, Tibet, or the Malay Archipelago. It is therefore not improbable that Prof. Ewart's hybricls show stripings closely resembling those of the zebra of North-eastern Africa instead of those of their sire because their mothers had in their veins more or less of the blood of the North African horse, which has retained or developed a tendency to stripes resembling closely in size and distribution those of the Somali zebra under conditions somewhat similar to those under which have arisen the stripes in the latter animal. 'The reader however will remember that it was shown (p. so) that although the plan of marking in the Somali zebra represents the oldest type amongst zebras, it by no means follows that the peculiar markings of the Somali zebra represent the original livery of the common ancestor of horses, asses and zebras.

A simple experiment seems to confirm this view. I mated a Muscovy drake 'Hans' (a gift from my friend Dr Gadow) with a common white Aylesbury duck. The Muscovy is, in spite of its name (which is a mere corruption for musk), a South American species, whilst, as is well known, the Aylesbury is derived from the Mallard or common wild duck. The progeny ${ }^{1}$, eight in number, resemble clearly in their colouring the Mallard, each showing the colouring of the corresponding sex in the wild ancestors (Fig. 134). But it will hardly be maintained that the colouring of the hybrids, which proved

1 My hybrids have proved absolutely sterile, though they paired off at an early age. The ducks did not lay a single egg, and a Pekin and an Aylesbury duck mated with one of the hybrid drakes did not produce a single fertile egg. One of the ducks was examined after death, and showed only vestigial ovaries, though a drake similarly examined had apparently the organs of reproduction fully developed. 
sterile (like Ewart's zebra hybrids), is a reversion to a remote common ancestor of both Muscovy and Mallard, and not rather to the Mallard, the immediate ancestor of the white Aylesbury duck.

But as the markings on the zebra hybrids resemble in character the narrow markings of the Somali zebra, we are led to conclude that this peculiar characteristic of the North African horse is not due to a comparatively recent differentiation under domestication of the domestic Asiatic horse in

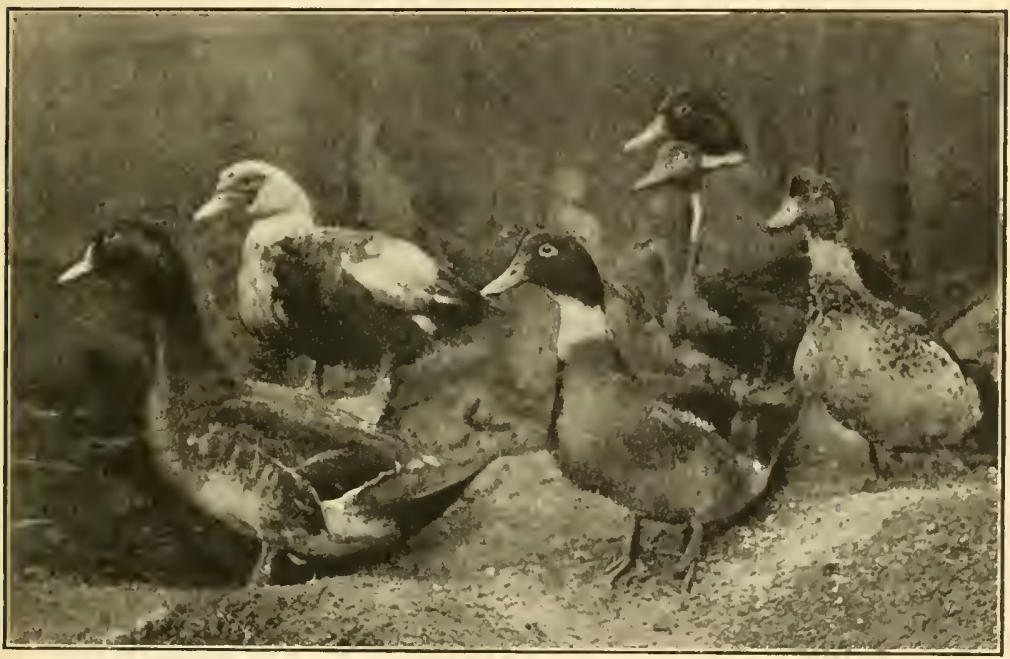

FIG. 134. The Muscory drake 'Hans' and his hybrids by a white Aylesbury duck.

Libya, but rather that living for a vast period under conditions similar to those which have produced the peculiar stripings of the Somali zebra, it has been so highly specialised as to constitute a separate species.

The circumstance that large functional tirst pre-molars are found in some of the horses of South-eastern Asia (as for instance in Javanese and Sulu ponies), which I have shown to be almost wholly of Libyan blood, and also in the Somali zebra and some members of the Burchell group (p. 142), points to a similar conclusion. 
All these considerations point to the conclusion that when the land-bridges were still unbroken between Europe and Africa, at least one variety of Equidae, probably Equus stenonis or some allied species (p. 10), had crossed over into the region lying between that occupied later on by Equus caballus in Europe on the one hand, and that by the Somali zebra on the other, had there been still more specialised, had differentiated its stripes and subsequently almost completely lost them, and pari passu had assumed a nearly uniform bay colour.

As Prof. Ewart's experiments have shown that it is most improbable that the stripes on the foals of Sir Gore Ouseley's chestnut mare, by the black Arabian, were due to infection from her former mate the quagga, the stripes in these foals are to be ascribed to the fact that the chestnut being seveneighths Arab had an inherent tendency to such markings, and as she is said to have come from India, the frequency of the occurrence of such stripes on well-bred Kattywar horses renders still more probable such a tendency in her. Furthermore, as we have seen that on the Continent black sires saturated with Arab blood frequently beget offspring with stripes, a fortiori, there must have been a very strong tendency to produce offspring with stripes in the black Arabian stallion as well as in the chestnut mare. The fact that the quagga hybrid was more striped than its quagga sire seems to indicate that the stripes on the hybrid, especially those on its legs, were due not merely to the quagga, but also to its dam; the further fact that her subsequent foals by the black Arabian were in some respects more striped than the hybrid suggest that the striping in their case may have been due to the dark black Arabian as well as to the dam.

The presence of stripes on the legs of the quagga hybrid, though such were absent in the quagga, is completely paralleled by the occurrence of stripes on the legs of hybrids bred by Baron de Parana from a true Burchell zebra (with white legs) and South American mares. As the latter are largely of Andalusian, and consequently of North African blood, and as South American horses constantly show stripes, the markings on the legs of the hybrids may in part be due to their dams, 
and need not be referred to a remote common ancestor of the Burchell zebra and the South American mares.

Further confirmation of my doctrine that the tendency to stripes is due to the presence of North African blood is afforded by Prof. Ewart's experiments, which point to the conclusion that the less Libyan blood there was in the mares mated with his zebra stallion, the less defined were the stripes in the offspring. Lady Douglas, a young fifteen-hands bay cart-mare by Matopo produced Brenda, who in make and disposition is quite unlike all the other hybrids: she is of a bay

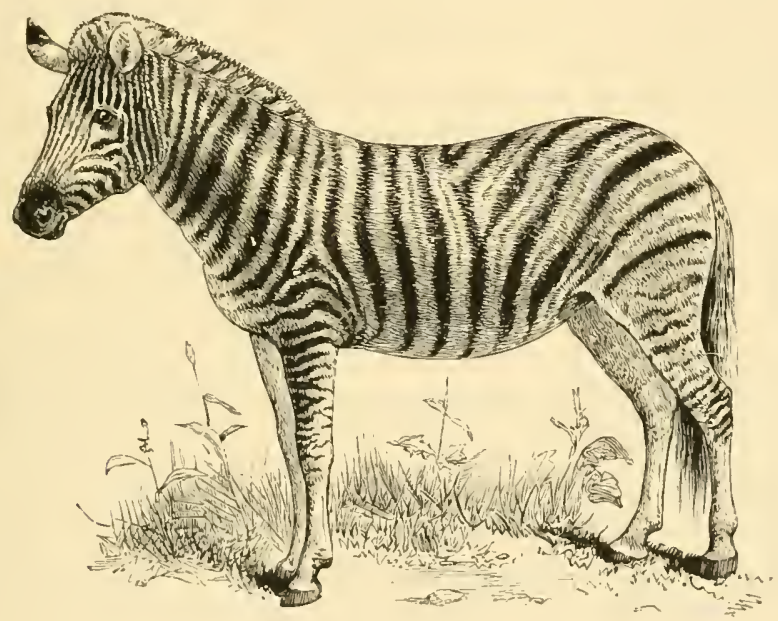

Fig. 135. Chapman's variety of the Burchell Zebra.

colour and not very distinctly striped. As a foal she was less intelligent than her hybrid half-brothers and sisters. Lady Douglas next by Matopo had Black Agnes, who "is almost black, so black that the stripes, though abundant, are hardly visible at a distance of a few yards. Black Agnes may have derived her colour from a recent maternal ancestor."

Contrast the description of the offspring of the cart-mare with that of Remus (p. 459), the son of the three-quarters bred Irish mare Biddy. Again, the hybrids bred at Theobalds by Sir H. Meux out of a Chapman zebra mare lend some support to this contention. The eldest, by an English pony, is a yellowish- 
brown, but faintly striped; the second, by an American trottinghorse, is brilliantly and richly decorated with brown stripes over a bright bay background; the third hybrid, by a Shetland or Highland pony, is only very faintly and partially striped ${ }^{1}$.

It is almost certain that the American trotting-horse was better bred, i.e. had more North African blood in him, for most of the blood in such trotting-horses is thoroughbred", than either of the other sires, a supposition rendered all the more likely by the fact that his progeny was bay, a sure index, as we have seen, of the presence of Libyan blood. This circumstance may well account (prepotency apart) for the fact that the hybrid by the American horse is much more richly striped than those by the other sires.

If then the hybrids of horses and zebras are the more striped, in proportion as the horse parent, whether it be sire or dam, is better bred, there is certainly a prima facie probability that stripes are more connected with North African than with Asiatic blood.

Darwin's view that the original ancestor of the Equidae was a dun-coloured animal striped all over was based, not merely on the occurrence of stripes in horses, which we have just discussed, but on his belief that such stripes were common in dun-coloured horses, and that there was a tendency in horses to revert to dun colour. But it must be confessed that the facts do not warrant his conclusion. In the first place, we have just seen that stripes are specially characteristic of the North African horse and its descendants. But, as we have shown on an earlier page, that the North African horse is invariably dark in colour unless there has been admixture from Europe or Asia, it follows that stripes, so far from being more closely connected with dun colour, are in reality as constant a feature of dark-coloured horses, such as the pure Arab of the Anazah breed, the English thoroughbred, and the South American pampas horses, the last mentioned being, as we saw above (p. 435), universally of a dark colour, bay largely predominating.

1 Ewart, Guide to Zebra Hybrids, pp. 33-4, figs. 28, 29 (Shetland pony sire).

2 Wallace, The Horse of America, pp. 456-7. 
In the four regions-Spain, Mexico, Kattywar and Norwaywhere stripes frequently occur in dun-coloured horses, we were able to make it highly probable that there was a large admixture of North African blood. From this it is clear that stripes are at least as often a concomitant of dark as of dun colour.

Horeover, if Darwin's hypothesis of a dun-coloured ancestor with stripes is sound, dark colours such as bay and brown must be of more recent origin, and accordingly there ought to be a great readiness on the part of the progeny of a light-coloured animal when mated with a dark to revert to the light. But Prof. Ewart's zebra stallion "has never been able to stamp his own peculiar pattern or his own colours on his hybrid offspring. The ground colour has been determined by the dams of the hybricls. The hybrids of the better bred mares are of a bay or chestnut hue-the prevailing colour of Arab foals; the hybrids of the Highland, Shetland, and Iceland mares are of a dun colour, and thus they probably take after the horses that in olden times inhabited the north temperate regions ${ }^{1}$."

There is a general belief that stars and blazes are found amongst all kiuds of horses. But we have now seen that (1) the bay horse has come from North Africa, (2) that it is specially prone to stripes on the head, legs, and back, and (3) that it and its derivatives are frequently characterized by having a star or blaze on the forehead and by white 'bracelets' or 'stockings.' These considerations suggest that the star in the forehead of the Libyan horse corresponds to the lightcoloured space included by the central arch in the forehead of the zebra, whilst the white 'stockings' are an extension of the light-coloured band which intervenes between the hoof and the first dark band on the leg of the Somali and Mountain zebras. But as this tendency to stars and 'stockings' corresponding to certain markings in the zebras is characteristic of the Libyan horse, it is another indication that that animal has been differentiated in the same region as the zebras. Of course others would explain the presence of 'stockings' and

\section{Ewart, Exper. Contr., p. 41.}

R. H. 
stars as due to in-breeding, and doubtless such markings may well arise from that cause. But there is no reason why they should not likewise occur under natural conditions, for the Quagga which turned bay in an environment similar to that in which the Libyan horses lived, had " a little white in the forehead" (p. 77), and the Elgin specimen also has white on the face. Prof. Ewart has a photograph of a Mountain zebra with a 'stocking,' whilst the white legs of the Burchell zebra and the Quagga are only more thoroughgoing examples of the same tendency. As the North African horse had a star in the forehead before 1000 B.c., and as the Libyans do not seem to have given any thought to artificial breeding down to the time of Christ, it is difficult to suppose that the stars and 'stockings' in Libyan horses were the result of in-breeding.

Nor is this all, for another argument of great weight is supplied by the colour of the skin. We have already shown that from the beginning of written history white horses are found all across Upper Europe and Upper Asia, and we found reasons for believing that wherever white horses make their appearance in Mediterranean lands, such as Greece, Italy, Sicily, Egypt, and North Africa, they are the result of importations from more northern regions, as was certainly the case with the famous white horses of Dionysius of Syracuse, the strain having been imported by that despot from the Veneti at the heal of the Adriatic, whilst the white and grey Arabs found in Egypt and North Africa in modern times are imported thither from Syria and other parts of Asia Minor.

It has also been shown that there is no tendency to revert to dun or white colour among the thousands of Pampas horses which are descended from the North African horse. Thus a light colour-dun, skewbald, or white-is an essential characteristic of Upper European and Upper Asiatic horses, whilst a dark bay or brown, with a constant tendency to stripes, is the stamp of the Barbary horse and the true Arab of Al-Khamseh. Moreover it has been clearly shown that the blue-black, antimony-like colour of the skin of Al-Khamseh horses is so marked a feature that it has furnished the generic name for the breed (Kohl) It will be remembered that the skin is of this 
dark colour, even on those parts of the body which are covered with white hair, as for instance in the star on the forehead. On the other hand, the skin of white horses is usually white, though in grey horses it is generally dark. But it has been shown that grey horses are especially common where the North African blood is mixed with the Asiatic, whilst the white horse is essentially the child of the regions lying north of the great central mountain ranges of Europe and Asia, where it has been specialised under conditions analogons to those which make the stoat and the ptarmigan turn white in winter, and have permanently clothed in white the Arctic hare and the Polar bear. Noreover, it is a fact well known in India that white horses have not the same power of enduring heat as bay and grey. But, as the latter have dark skins, while the former have a white skin, we may reasonably infer that the pigmentation of the skin helps to give the bay and grey horses their power of withstanding tropical heat. It follows that the dark skin of the African horse, like that of the negro, has been developed in a hot climate. But this specialisation cannot have been produced by the residence of the Asiatic horse in North Africa from the date of its importation already domesticated into Egypt about B.C. 1500 , for it might just as well be argued that a fair-haired, light-skinned people from Europe, if transported to Africa would in an equally short period develope the peculiar skin of the negro. It is of the highest importance to note that the zebras, which have admittedly been specialised in Africa, have dark skins like that of the Libyan horse. The skin of the Burchell zebra Matopo is described by Prof. Ewart ${ }^{1}$ "as dark throughout; under the white hair the skin is of an iron-grey colour, elsewhere it is nearly black, owing to the pigment in the hair roots." Thus the skin of the zebra is dark beneath his light as well as his dark parts, exactly as the skin of the Al-Khamseh horse is dark under its white markings as well as under the ground colour. We are therefore led inevitably to conclude that the dark skin of the Libyan horse is the result of its having been domiciled in North Africa for long ages before it was ever domesticated.

\footnotetext{
1 Penycuik Experiments, p. 75.
} 
We have seen that according to Sanson many North African horses and ponies frequently lack hock callosities, which have been generally regarded as one of the chief distinctions between Equus caballus and the asses and zebras, and Prof. Ewart has pointed ont the same peculiarity in the 'Celtic' ponies. But we have seen that the dark-coloured cross-bred 'Celtic' ponies are certainly closely related to the dark breeds of Brittany, Auvergne, and Ariège, which beyond doubt owe their form and colour to the mixture of Libyan blood with the indigenous horses of France. We have also seen that the Libyan horses have been crossed from several centuries before Christ with horses from Europe in order to give them greater strength, whilst it is absolutely certain that a vast proportion of the socalled Arabs, especially those of a grey colour and large size, such as the Gulf Arabs bred by the Montefic tribes of South Arabia, and the horses of Babylonia, have a very large proportion of Asiatic blood in their veins. But as the hock callosities are the special feature of both the clomestic Asiatic horses and also of Prejvalsky's horse, it would indeed be strange if Arab horses of a coarser type and many North African horses, which have much of the old European strain (derived through Spain) in their veins, should not have inherited hock callosities from their Asiatic and European ancestors.

Of course it is possible that, as in Upper Enrope there were two distinct types of horse-the slender and the coarse-so in North Africa there may have been a heavy type, corresponding to the old European horses of Solutré as well as the small slender horse, for it would indeed be rash to maintain (especially in view of Prof. Osborn's researches) that only one variety of horse had roamed the plains of Libya in remote epochs. But there is not a scrap of historical evidence to show that the Libyan tribes from the Nile to the Atlantic originally possessed any domestic horse except the small slender type, which I term E. c. libycus, whilst the presence of horses of a heavier type in those parts of North Africa which were in contact with Asia, Greece, Italy, and Spain, is fully explained by the abundant evidence of the introduction of the heavy horses of Asia and Europe into that region. 
Again, although ergots (fetlock callosities) are generally present in all domestic horses, Prof. Ewart has shown that they are frequently absent in Icelandic and occasionally in Hebridean and Connemara ponies, whilst Captain Hayes ${ }^{1}$ has "noticed their frequent absence in pure-bred Arab horses and in thoroughbreds." The same great authority observes that "the nearer a horse approaches the heavy draught type, the thicker is the growth of the callosities on his legs." In view of the complete absence of hock callosities and also of ergots in many horses of the same race, and the fact that such callosities seem universal in Prejvalsky's horse and the Mongolian pony, and that the more nearly a horse approaches the coarse type, the larger are such callosities, and the nearer he approaches the Libyan and Celtic types (in which they are sometimes completely absent), the smaller they become, the evidence indicates that E.c.libycus either had completely discarded or had a general tendency to get rid of both hock and fetlock callosities.

In the Libyan horse and its derivatives-the Arab, the Andalusian, and the English thoronghbred-the tail is different in structure, in its covering and in the manner in which it is carried (Figs. $58,68,7: 3,75$ ) from that of the Prejvalsky's horse and the Mongolian pony (Figs. 18, 53). Yet this is no more a mere outcome of artificial breeding since the Christian era than is the bay colour and the star in the forehead, for we have found the same feature in the horses driven by Seti I (p. 217), in those under Cypriote chariots on vases dating from 1000 B.c. (p. 2s8) and in those ridden by Libyans (p. 24:3) pourtrayed on the pottery found at Daphnae and dating from 600 B.c. Look at the well-bred Sicilian horse on the coins of Panormus (p. 25.5). The animal carries his tail in the characteristic fashion that we associate with Arabs, Barbs, and thoroughbreds.

We have already seen (p. 143) that since my paper appeared Mr Lydekker, in view of the facts that Hippurion had a deep pre-orbital pit for a gland, that $E$. sivalensis, an Indian fossil horse, had a rudimentary pre-orbital pit, and that he himself 
had found a similar depression in the skull of 'an Indian domesticated horse' and also in that of Bend Or, had suggested that the 'blood-horse,' unlike the 'cold-blooded' horse of Western Europe, may possibly have been the descendant of $E$. sivalensis. As these pages are passing through the press Mr Lydekker announces ${ }^{1}$ that he and Dr Ray Lankester have found that a like depression occurs not only in the skulls of the racers Bend Or and Stockwell, but also in those of Eclipse, Orlando, and Hermit, as well as in that of an Arab horse, and that "at present they fail to detect it in any of the ordinary English and Continental horses. It appears to be also lacking in horse-skulls from the drift and turbary of Europe. On the other hand it exists, in a less rudimentary condition, in the fossil horses of India," and Mr Lydekker repeats his suggestion that the 'blood-horse' is of Indian origin. But I have already shown (p. 143) that it is most unlikely that 'the Indian domesticated horse' on whose skull Mr Lydekker's argument depends was of pure Indian or Asiatic origin, since all Indian country-bred horses are saturated with so-called Arab blood, and accordingly this skull cannot be taken as a link between E. sivalensis and the Arab. On the other hand we have seen that Hipparion was common in Europe and Africa, that $E$. stenonis (a species closely related to $E$. sivalensis), which is found both in Europe and Northern Africa, had a deep pre-orbital depression, and that its later ally, E. quaggoides, had a similar feature, that Mr Lydekker himself (following Dr Forsyth Major) has pointed out the existence of this depression in the now extinct quagga, and also in the skull of an ass, and that $\mathrm{Mr}$ Pocock (p. 76) has shown a similar depression in the skull of a male Grant's zebra. Now as all the living Equidae which show this feature and whose origin is known - the quagga, Grant's zebra, and the ass (Nubian)-are A frican species or subspecies, the occurrence of such a characteristic in any of the living Equidae is a prima facie indication that it is African in origin. But as Mr Lydekker and Dr Ray Lankester have now shown that such a depression occurs in all

1 Times, 14 February, 1905. 
the skulls of Arabs and thoroughbred horses which they have examined, we have another clear indication that the ancestors of the Libyan horse had long lived on African soil.

But as E. stenonis of Sonthern Europe and Northem Africa and its later ally E'. queggoides had a pre-orbital depression as well as E. sivalensis, there is no need to go to India for the fossil ancestors of the Libyan horse, and the true explanation of the presence of such a depression in 'an Indian domesticated horse' is to be found in the historical facts that the Arabs got their 'blood-horse' from North Africa, and that for ages these so-called Arab horses have been pouring annually into India and are there crossed with the dun-coloured Asiatic horses.

If we could rely on the statement or rather on the reading of the text of Strabo in the passage where he declares that the Libyan horses have longer hoof's than those in any other region, it would further support the view that that animal has been specialised in Africa, where all the Equidae have hoofs of a longer conformation than the horses of Asia. It is certainly a fact of considerable interest that in some high caste Arabs the hoofs are longer than in the quagga ${ }^{2}$. It would seem therefore that Strabo's statement had a basis in fact.

Nor is it only in colour and other external respects that the Libyan differs from the Asiatic horse. As the cry of the quagga, from which that animal derived its name, was distinct from that of the zebra (p. $73 \mathrm{n}$.), so the voice of the Libyan horse differs from that of his vulgar Asiatic brother. This is rendered clear by the evidence of Major-General Twcedie already cited (p. 180), who, as before remarked, may be regarded as a hostile witness. In speaking of the Kuhailan horse he thus writes": "The stallion picketed beside the tent is as good as a sentinel. The first sound of an intruder brings him to attention. Generally he will stamp with one fore-foot and challenge; not braying like a liudish, but sounding one or two short and sharp notes, to intimate that he will make no terms."..."His gentle salutations of 
passing mares are widely different sounds from the bagpipelike squeals of the I'raki stallion." We have thus the unimpeachable testimony of a first-rate observer who has had exceptional opportmities over a long period of years for studying the Kuhailan and the kadishes (common Turkish horses) and the half-bred horses of the Euphrates region, and who, in spite of his preconceived notion that the Kuhailan has been produced by purely artificial breeding from the common horses of Asia, has nevertheless been forced to point out the remarkable difference in voice betwcen the pure-bred Arabian and the horses of undoubted Asiatic lineage.

Not only physical characteristics, but also temperament must be taken into consideration in discriminating between species and sub-species, as is clearly shown in the cases of the intractable Hountain zebra and the more docile Burchell species. The difference in disposition between the AsiaticEuropean horses and the Libyan and its derivatives has been noticed, as we passed in review the breeds of varions regions. The Libyan down to the Christian era and probably long after rode his horse without a bit, simply guiding it with a nose-band or a switch (p. 240), the Egyptians seem to have used the former contrivance for controlling their chariot-horses (p. 228), the ancient Andalusian horses were noted for their docility (p. 256), and their descendants the Pampas horses of South America, after having regained their liberty for three centuries and a half, are the most docile in South America; the ancient and medieval Irish rode their Hobbies with a mere halter unprovided with a bit, and the Arab to this hour employs only a nose-band to steer his foray stced; Col. Hamilton Smith has pointed out that frequent crossing of the Tureoman with Arab blood has rendered the well-bred 'lurkish horse almost as docile as his Arab ancestors, and the extraordinary tractability of the Prussian Trakehnen breed derived from English thoroughbreds and Arabians is a well known feature at the present moment. The ease with which Arabs and thoroughbred horses are broken in compared with cross-bred and inferior horses is a matter of common notoriety amongst horse-breakers, and we observed that horses of Libyan blood have been constantly taught to 
dance to music and to perform tricks. On the other hand Prejvalsky's horse is remarkable for its indonitable temper, and the Mongolian pony is famous for its bad manners; as the horses of Libya were proverbial for their gentleness before the Christian era, so on the contrary the horses of Northwestern India are specially mentioned by Aelian on account of their violent tempers and the difficulty of riding them, which necessitated the use not merely of bits but of muzzles to control them (p. 153), a fact in itself sufficient to disprove Mr Lyrlekker's theory of the Indian origin of the Arab horse; that the horses of Eastern Europe were of a similar temperament is rendered highly probable by the statement of Strabo that the Scythians and Sarmatians were the only peoples who habitnally castrated their horses, which they did to make them more easy to manage (p. 25), and we have seen that the term kadish applied to common Turcoman horses seems primarily to have meant a gelding. The legend of the flesheating mares of Diomede of 'Thrace points to a general belief in the savage nature of the ancient horses of that region, whilst in Roman times the horses of Dalmatia and Epirus, which were heavy horses fit for war, were noted for their bad tempers ${ }^{1}$, and the cross-bred horses of Persia descended from the Upper Asiatic stock were noted for their intractability? Finally we have seen that cantherius, the Roman term for a gelding, meant originally a pack-horse, and therefore an inferior animal of the Upper European type. We have seen the Libyans, Egyptians, medieval Irish and modern Arabs all riding and driving the Libyan horse without a bit, but on the other hand the Homeric Acheans were using bronze bits to control their dun-coloured horses before 1000 B.C., and bits of a primitive kind made not only of bronze or copper but also of horn and bone are found in the Lakedwellings of Switzerland and in the pre-historic graves of Russia and Central Asia, whilst the Massagetae in the fifth century B.c. rode their horses with copper bits (p. 130), and

1 Vegetius, Ars Veterin.,.Iv. 6. 6: postea Epirotas, Samaricos, ac Dalmatas, licet contumaces ad frena.

"Ibid., nisi labore subigetur assidıo, adversum equitem contumax. 
the peoples of North-western India used not merely bits but muzzles to control the Upper Asiatic horses. It seems therefore certain that the invention of the bit at so early a period by the peoples of Asia and Europe was due to the intractable nature of the indigenous horses, whereas the Libyan horse and his descendant the Arabian is ridden to this hour with nothing more than a nose-band. We have in this another specific difference between the two animals. If the Libyans had obtained the horse already in a state of domestication from Asia or Europe, they would probably have borrowed the bit, and it is inconceivable that they could in a short time have influenced the stubborn temper of the Asiatic horse to such a degree that not only their own horses, but all the descendants of these animals down to the present, even after they have been feral for centuries, are stamped with extraordinary docility and good temper. It is clear that the difference in temperament between the Libyan and Asiatic horse has not been acquired under domestication, but is fundamental, and this of itself is a sufficient indication that the Libyan horse is a naturally differentiated species or variety. It is significant that the 'Celtic' pony, which may be in part descended from a northern branch of the same variety as the Libyan horse, is also remarkable for its docility.

We have noted the well known belief that chestnut horses are frequently bad tempered, even when well bred, and reason has been given for thinking that chestnut colour in English thoroughbreds and even in Anazah horses is the outcome of a small strain of Asiatic blood. Now that we realise the fundamental difference in temper between the Asiatic and the Libyan horses, we at once understand why a cross temper should be a concomitant of chestnut colour.

Moreover if, as is commonly held, the 'Arab' horse is more prolific in Barbary than in other regions where it at present exists-from India to the British Isles-we may reasonably infer that as North Africa is best suited for its propagation, it was there that the stock was originally differentiated ${ }^{1}$.

1 Col. Hamilton Smith, "The Horse," Naturalist's Library, Vol. xil. p. 214. 
Finally, how comes it that no breed of Asiatic horse has ever been so improved by careful selection, or even by the admixture of African blood, as to be able to contend in speed with the latter, unless it be that the North African horse has been differentiated from the Asiatic horses during a very long lapse of time? It has been pointed out that the English thoroughbred only really arose when mares as well as horses of North African blood were imported by Charles II, and it is a well-known fact that no three-quarters bred horse has ever beaten a thoroughbred. The astonishing superiority in speed of North African horses over all others seems to indicate that that strain is the outcome of natural specialisation carried on through countless generations.

We have now examined the available data for tracing the history of the thoroughbred horse, and we found that the historical evidence put it beyond doubt that it originated in North Africa, from whence it has gradually kept spreading northward and eastward from at least 1000 B.C. The evidence of its characteristic bay colour, the not unfrequent occurrence of stripes on its head, borly and legs, its dark skin resembling that of the zebras, its special fecundity in North Africa, all point to its being no merely artificial breed formed under domestication by careful selection by man, but indicate clearly that it is a distinct variety developed during a long succession of time in Libya, under conditions similar to those which have produced some of the zebras with their finely-formed limbs, their dark skin, and striped bodies. The only other conceivable alternative is that domestic horses from Asia were crossed in North Africa with some variety of striped African Equidae. I mentioned this as a not wholly impossible alternative when writing in 1902, for the fecundity of zebra-horse hybrids had been held as not impossible by leading experts ${ }^{1}$, and as an animal deposited by the King in the Zoological Garden, Regent's Park², in that year was alleged by some to be the offspring of a horse and a zebra-hybrid. But as Prof. Ewart has now demonstrated the sterility of zebra-horse hybrids, and since the animal sent home

1 Ewart, Guide to the Zelra Hybrids (Edinburgh, 1900), p. 34.

2 Proc. Zool. Soc., 1902, Vol. Ir. p. 225. 
to England from South Africa by Lord Kitchener as the reputed offspring of a horse and a zebra-horse hybrid, has been proved to be only a zebra-horse hybrid (Fig. 136) $)^{1}$, this alternative must be summarily rejected.

All zoologists are agreed in regarding the African wild ass as a species distinct from the Asiatic group of asses on the grounds that it is grey instead of being rufous-brown, that it has a shoulder stripe, that its ears are a little longer, and that it has more frequently dark bars on its lower limbs. Mr Sclater holds that the Somali ass is a species separate from the Nubian because it is more grey in colour, has no shoulder stripe, has numerous black markings on the legs, smaller ears and a longer mane, and some make the Asiatic ass into three separate species, whilst those who do not, make them into three or more sub-species or varieties; and some have even made four valid species out of the Burchell group of zebras. Mr Lydekker holds that the Burchell zebra and the Quagga are specifically distinct on the grounds that (1) the pattern on the forehead of the Quagga forms a shorter and more regular diamond than in the Burchell zebra (Bonte quagga) and that in the former the centre of the diamond is a pale stripe with four or five dark stripes on either side of it, whereas in all Bonte quaggas or Burchell zebras the diamond is made up of from five to nine stripes, the middle line being black with from two to four stripes on each side, and (2) on the ground that quaggas may be distinguished from Burchell zebras by the presence on the skull in front of the orbit of a depression (p. 76); and the same authority regards as "subspecifically distinct from the kiang of Tibet" a wild ass from Mongolia which differs simply in colour from the kiang (pp. 44-5). Now as the Libyan horse differs from the Asiatic by being bay instead of yellow-rlun, by the shape of its head, by a pre-orbital depression in the skull, by the set of its ears, by frequent tendency to stripes on the back, legs, shoulders and face, by having typically white 'bracelets,' by having usually a white star or blaze on the forehead, by its dark skin, by the absence of hock callosities, by the absence

1 Proc. Zool. Soc., 1903, Vol. I. p. 2, fig. 1. The animal is the offispring of a male zebra and a common pony. 
or small size of the ergots, by the length of the hoof, by the covering and set-on of the tail, by its voice, by its disposition, and by its speed, I submit that if the African ass is a distinct

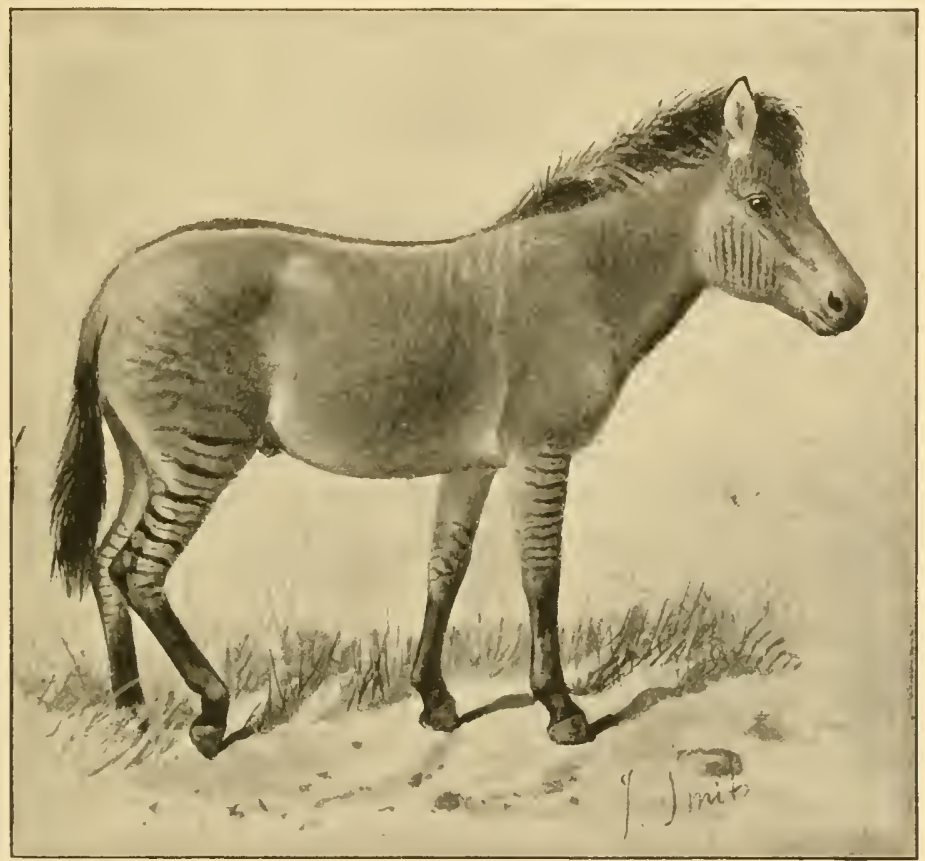

FIG. 136. Zebra-pony Hybrid.

species from the Asiatic, a fortiori, Equus caballus libycus must be considered a distinct species, or at least a distinct sub-species.

It is for others to decide on the cogency of my arguments. 


\section{CHAPTER V.}

\section{SUPPLEMENTARY.}

\section{THE DEVELOPMENT OF EQUITATION.}

The antique Persians taught three useful things, To draw the bow, to ride, and speak the truth.

Brrox, Don Juan.

Although the art of equitation does not fall strictly within the scope of the present work, yet, as it has been necessary in the course of our historical survey and in discriminating between the Asiatic and Libyan horses to mention the various methods of capturing, controlling and utilising the steed employed by the horse-owning peoples of the ancient world, it will not be out of place if we sketch briefly the chief steps in the evolution of equitation.

It is not improbable that amongst the Turko-Tartaric tribes the horse was first domesticated not for locomotion, but, like the ox amongst other races, for the sake of its milk and flesh, and just as at a later stage the cow-keeping peoples began to use the $o x$ to draw the plough and cart, so the Turko-Tartaric race began gradually to use their horses as a means of transport and locomotion. 'The deeply-rooted love of mares' milk which still characterises Kalmucks and other Tartars seems to indicate that it has formed a substantial part of the mutrition of their race through long ages.

The horse was ready to hand on all the vast plains of Upper Asia, where neither wild sheep, goats, nor cattle were to be had. On the other hand neither the Aryans of the Rig-veda nor the Libyans seem ever to have drunk mares' milk, probably because they had possessed cows, sheep and goats, and had been accus- 
tomed to drink the milk of these animals before they had mastered the horse.

The Lasso. The capture of the wild horse was of course the first step towards its domestication. This must have been accomplished either by the capture of foals or of animals not yet full-grown. This could hardly have been effected without employing a rope or cord of some kind, and as in modern times when man desires to domesticate either zebras or feral horses, he always resorts to the lasso, and as I have offered abundant proof of the use of the lasso amongst various peoples of the ancient world (pp. 49, 117, 130, 192), it seems certain that when man first essayed to tame the steed he used a rope with a running noose to ensnare his victim.

The Whip. From the inherent tendency in mankind, especially in the lower stages of civilization, to beat unmercifully domestic animals, we may without hesitation assume that the lassoed horse was well belaboured with stick and cudgel to cow and subdue him, and as all forms of the whip have grown out of the primitive stick or switch, we are justified in giving the whip precedency over the halter. This is rendered all the more probable by the fact that the Libyans frequently guided their docile horses solely by a switch (p. 240) and that the medieval Irish often controlled the descendants of the Libyan horse by a rod with a crook at one end (p. 389).

The Bridle. In each region where the horse was domesticated, it seems certain that the first device which can be properly termed a piece of harness was the halter or headstall. For it is most unlikely that man after capturing the horse with the lasso, would have ventured either to mount on the back of his new possession or to yoke him to any kind of wheeled car without some means of controlling him.

Thus thongh the Libyan horses were so docile that the rider could guide them with a switch, yet their masters regularly used halters (p. 240), as did also the medieval Irish. Indeed the straw halters still to be met in some remote parts of Ireland remind us of the rush halters of the Libyans and may be regarded as the most primitive representative still surviving of the earliest step in horse trappings. 
The Bit. It has been shown that the Libyan horse, whether driven under the chariots of Egyptian kings in the second millennium B.C., or ridden by the native Libyans in the centuries before Christ, or in the present day when ridden by Arabs or driven under the Neapolitan carrozzella, was and is controlled by a noseband without any bit, and the evidence is equally clear that from the earliest times the Asiatic-European horses have had to be controlled by a bit at first made of horn and bone and later of copper, bronze and iron, whilst in at least one case it was found necessary in ancient days to muzzle the horses of North-western India. The primitive bits found in Asia, Russia, and in the Swiss Lake-dwellings consist of two side pieces and a cross piece, a type which survived in the bits brought by the Huns into Europe. The earliest literary evidence for the use of bits is furnished by the Iliad, for in one passage the bronze bits are placed between the jaws of the horses. As regards the shape of those bits we have no means of judging, but as they were used to control the duncoloured horses of Upper Europe brought dlown by the Acheans into Greece, there is a prima facie probability that they were of the type found in Central Europe. Bits of this type were probably known to Xenophon ${ }^{1}$, for though he holds that it was necessary for a horseman to have two kinds of bits-one with smooth and moderate-sized links, the other with heavy links, with sharp points (in order that when the horse takes the latter into his mouth he may be offended with its roughness and consequently let it go), and after he has been trained with the rough bit, he may be ridden with the smooth, yet he emphatically urges "that whatever sorts of bits may be used, they should all be flexible, for wherever a horse seizes a rigid bit, he has the whole of it fast between his teeth, as a persou when he takes up a stick wherever he lays hold of it, raises up the whole. But the other solt of bit is similar to a chain, for of whatever part of it a person takes hold, that part alone remains unbent, but the rest hangs." The bits used in North-western Europe in the early Iron Age (pp. 96, 98) were more or less flexible, for in the middle they were either single jointed or double jointed (Fig. 45).

${ }^{1}$ De re equestri, 10. 6. 
The Chariot. We have already seen that in most regions men employed the horse for dranght before they habitually rode upon his back, not because they were afrail to mount him, but because he was either too small to be used effectively as a charger, or because where he was of sufficient size to carry a man easily, it took a long time before men were able to devise weapons and methods of warfare suitable for a man mounted on horseback. For example, peoples who carried large oblong shields, like the Egyptians, the Greeks of the Mycenean (Bronze) Age, or the Assyrians, would have to discard their national shiclds and adopt a new shape better adapted for a horseman. How unsuited the large oblong shield was for cavalry, is proved by the fact that although the Roman infantry carried the scutum, the cavalry carried the round shield, though even the latter was not the best possible shape for a horsesoldier. Accordingly the Teutonic peoples, such as the Normans, who had once used circular shields, when they began to fight on horseback, devised a shield large at the top and tapering towards the bottom somewhat like a boy's kite. Such are the shields carried by the Norman knights on the Bayeux tapestry, and from this type came the later medieval shield, which through its importance in heraldry has become the conventional idea of a shield in modern times. This shield tapering towards its lower end was admirably suited for horseback, its broad upper part protecting the bearer's body, whilst the tapering lower part fitted down along his thigh, thus obviating the inconvenience arising from a circular shield of any size, the lowest part of which, if it covered the wearer's body, would have had its bottom resting on the front of the saddle; if to obviate this it was worn to one side, it would leave a considerable portion of the body exposed.

Again, tribes whose chief weapon was the bow, like the Scythians and many other nations, would have to learn to shoot from horseback before they conld use their horses effectively in warfare. On the other hand the archer had little difficulty in shooting with precision from the chariot, as was the practice with the Egyptians (p. 217) and the Hittites (p. 215).

R. H. 
Where the bow was not the national weapon it was long before man was able to develop weapons adapted for horseback, the warrior simply used the chariot and horses as means of rapid locomotion to meet the foe, whom once reached, he dismounted in order to do battle with the arms long used before the advent of the horse.

Such seems to have been the case not only in Europe but also in Africa, whilst it seems equally true of the peoples of Asia Minor and of the Vedic Indians, though it is possible that the Turko-Tartarie tribes of Upper Asia may have ridden the horse from the outset. Yet as the Scythians down to the fifth century and later lived in waggons drawn by oxen, it is not improbable that they once lived in waggons drawn by horses, and that it was only when they got cattle at a later time they yoked the more patient and steady-going ox instead. Though indeed the Sarmatians, both men and women, rode on horseback it must not be assumed that they never had passed through a previous waggon-living stage like that of the Scythians, for although the Libyans, men and women alike, all rode on horseback in later times, yet it is certain that in the earlier period they habitually used chariots. The Sarmatians may therefore once have used the horse under the chariot, as did the Vedic Indians and the Libyans.

The Sledge. Hitherto it has been a generally received article of faith that wheeled vehicles and the modern spokedwheel have had an evolutionary history much as follows. First men fastened to poles their scanty household goorls and either themselves dragged them along (or more probably made their wives do so), when they shifted from one camp to another; in some cases they may have utilised their dogs for this purpose, as was perhaps the practice of certain North American Indians before they had tamed the feral horses of the prairies, an event which wrought a marvellous revolution in the social life of the Indians of the West, who from being feeble communities, dwelling along the banks of the great rivers, which yielded them abundance of fish, and who but rarely could kill a bison, were suddenly metamorphosed into powerful tribes of horsemen faring well on the flesh of the vast herds of bison, 
and who made their tents from, and clad themselves and their fumilies in, the warm robes of their noble quarry.

After these Indians had become possessed of horses it certainly became their practice on striking camp to pack up all their goods and chattels in the skin tents and tie the bundle on the pole, and trail the poles behind their horses, whilst the dogs were even employed to draw smaller loads on trailing stakes.

From such a rude begimning as that last mentioned it seems fairly certain that the Eskimo of the Far North developed thejr famous dog-sledges. There can be no doubt that the sledge is the first step in the evolution of the wheeled vehicle. The sledge or slide-car ${ }^{2}$ has played a considerable part in the life of the more remote districts of these Islands down to our days, for such were still in use in Strathglass, Kintail, and elsewhere in Scotland in the years 1863 and 1864 . It consisted of two shafts, the body being formed by two pieces of wood bent in a semicircle, the ends of which were fastened to the shafts, the one close behind the pony, and the other a little distance behind; the arches were steadied at the top by a piece of wood running from the one to the other. Thin slats of wood formed the bottom of this primitive contrivance. This vehicle is still in use in the glens of Antrim under the Gaelic name of carr sliunain.

The Wheel. It is assumed that the next step was to place beneath such a sledge or slide-car a roller formed out of the cylindrical trunk of a tree, but as 1)r Haddon well remarks, "there does not appear to be any positive evidence to render this view absolutely certain." Herr Stephan described a very primitive car that he saw in Portugal: a $\log$ is cut from a large tree, the central portion is hacked away so as to leave a solid disc at each end, joined together by an axle. The next step was to form the block wheels of two separate crosssections of a tree trunk, but fixed firmly on a separate axle-

1 For the following account of the slide-car and other primitive velicles, as well as block wheels, I am indebted to the admirable statement of the traditional view given by Dr Haddon in The Study of Man (London 1898), pp. $161-199$. 
tree, the wheels not yet revolving on the axle. Then to get greater lightness two or more holes were cut in the solid wheel, the solid portions left being the precursors (as is supposed) of the felloe and spokes made of separate pieces. Finally, the axletree no longer revolves, but is firmly fixed to the cart, and the wheels, now made of spokes, revolve upon it, being kept in their places by linch-pins inserted into a hole in each extremity of the axle.

At first sight nothing can be more plansible than this hypothesis, but when it is closely examined it must be confessed that there are but few facts to support it, and that those few are capable of other explanations.

In the preceding pages we have passed in review the earliest vehicles used by the horse-keeping peoples of the world, and in every case where we had any evidence-in Egypt under the xvinth dynasty, in India under the Vedic Aryans, amongst Hittites, Assyrians, Persians, Libyans, Mycenean Greeks (Bronze Age), Homeric Acheans (Iron Age), the Gauls of Northern Italy, as well as those of Gaul itself, ancient Britons and ancient Irish-everywhere the chariot wheel is formed of a felloe, a hub or nave, and of spokes ranging in number from four to ten or even twelve. It is therefore clear that the chariot is never found with solid wheels such as are supposed to have been the foremnners of the spoked wheel. Nor is this a matter for surprise. The horse, as we have seen, was throughout early and medieval times used almost solely for war. As speed and mobility were the grand requisite in the war-chariot, it is obvious that solid wheels, such as those used under Portuguese and Chinese ox-carts, would have rendered the vehicle useless for war. We may, therefore, safely conclude that from the first the war-chariot never had block wheels.

But it may be said that although the war-chariot from the first was fitted with spoked wheels, nevertheless the solid wheel had long preceded it, having been invented for purposes of agriculture, and that doubtless the ancient ox-cart, which was not built for lightness and speed like the chariot, was furnished with clog wheels. Yet if the reader will look at the picture of 
the Thracian ox-cart (p. 106), the oldest representation of any such vehicle that has reached us, his faith in this second hypothesis will be shaken on discovering that this ox-cart runs on four-spoked wheels. If it be said that this cart belongs to a comparatively advanced period, and that in earlier days, when agriculture was in its infancy, the carts used had solic wheels, I at once reply that amongst two at least of the great races which at the dawn of history had domestic horsesthe Libyans and the Turko-Tartaric peoples-agriculture was scarcely, if at all, practised, for both were essentially nomadic; whilst though the Scythians in later times at least used fourwheeled waggons to convey their families, the Libyans never used either ox-cart or ox-waggon for that purpose. It must also be clearly borne in mind that primeval agriculture had no need for the cart. Corn was not bound in sheaves as with us and carried home on carts or waggons. The ears of coru only were snipped off, gathered into baskets and carried to the threshing-floor or garner. Indeed, in the days when North Africa was one of the chief granaries of Rome, a basketful of corn-ears was placed as the symbol of Africa on a coin of Hadrian. Again, as there was no manuring in the common field system, there was no need of a cart for manure. The functions which in our minds are so inseparably associated with carts and waggons were in the earliest stages of society discharged by human beasts of burden, as they still are over a large part of Africa, and later on by pack-animals, as they were in medieval Europe and are in wide regions of the earth down to this very hour.

These facts sufficiently refute $\mathrm{Dr}_{1} \mathrm{Hahn}^{1} \mathrm{~s}^{1}$ theory that wheeled vehicles did not arise from the sledge fitted with a roller, for in that case (said he) wheeled vehicles would have arisen wherever rollers have been employed. He maintains that the waggon arose only in the district from which agriculture originally spread, which he assumes to be Greece. He believes that the waggon was primitively a holy implement, consecrated to Demeter, the great goddess of agriculture and fertility, and that it only subsequently became a secular

1 Demeter und Baubo (1896, Lübeck); Haddon, op. cit. pp. 170-1. 
farm implement. He avers that the waggon came into being because miniature wheels in the form of the common spindle whorls were already in general use. Dr Halın points out that he deals only with the four-wheeled ox-waggon, which was used for religions purposes. But, as it has just been shown, there is no evidence for the use of either the two-wheeled oxcart or the four-wheeled ox-waggon in primitive agricultural communities, whilst it seems certain that the Libyans, who never used ox-carts at all, had invented a very light form of spoked wheel at least by B.C. 1500. Dr Haddon ${ }^{1}$ has already pointed out that there is no reason to believe that agriculture was discovered only in some area of Eurasia, and that the art thence spread over the greater part of the habitable globe, and "it seems more in consonance with what we know of the history" of sacred institutions and implements that the waggon had an industrial origin and that it may well be that it arose in close comnection with agriculture." But though it may well have arisen in connection with agriculture, as Dr Haddon says, yet it may have come into use at a comparatively late period, and long after the invention of the war-chariot. The ox-cart or oxwaggon indeed was certainly in use in Greece in the seventh century B.C., for a certain Argive lady wished to go to the festival at the Argive Heraeum in a waggon and pair. When the oxen did not arrive in time from the pasture, her two sons, both distinguished athletes, yoked themselves to the waggon and drew their mother to the temple ${ }^{2}$. But if Dr Hahn's theory is sound, we ought to find the ox-waggon not merely in the early classical period, but in Homer. Yet neither the twowheeled ox-cart nor the four-wheeled ox-waggon appear in the poems, though the four-wheeled mule-waggon plays a conspicnous part. In such a vehicle Priam brought with him the rich gifts with which he set forth to the camp of the Acheans to ransom Hector's body from Achilles. "Thus having spoken fleet Iris departed from him and he bade his sons make ready the smooth-wheeled mule-waggon (amaxa) and bind the wicker carriage thereon ${ }^{3}$.

1 The Study of Man, pp. 170-2.

2 Herod. I. 30.

$3 \mathrm{Il}$. xxIv. 188-90. 
"Thus spake he and they fearing their father's roice brought forth the smooth-ruming car, fair and new, and bound the body thereof on the frame; and from its peg they took down the mule yoke, a boxwood yoke with knob and well fitted with guiding-rings; and they brought forth the yoke-strap, of nine cubits with the yoke. The yoke they set firmly on the polished pole on the rest at the end thereof, and slipped the ring over the upright pin, which with three tums of the strap they lashed to the knob, and then belayed it close round the pole, and turned the tongue theremder.

"Then they brought from the chamber and heaped on the polished ear (apene) the countless ransom of Hector's head and yoked strong-hoofed mules that work in harness, which on a time the Mysians gave to Priam, a splendid gift, but for Priam they yoked the horses that the old man kept for his use and tended carefully at the polished crib'."

'That Priam's mule-car had four wheels is shown by another prassage 2 . In the Odyssey ${ }^{3}$ we hear of "two-and-twenty excellent four-wheeled waggons (amaxai)," and apparently such too was the vehicle in which Nausicaa set out with her maidens to wash linen in the river". It was "a high waggon (apene) with good wheels and fitted with an upper frame." "Without the palace they made ready the smooth-running mule-wain (amaxa) and led the mules beneath the yoke and harnessed them under the car, whilst the maiden brought forth from her bower the shining raiment."

From these extracts it is clear (1) that the amaxa (waggon) is identical with the apene or car commonly drawn by mules also in the classical period. Thus in B.C. 500 a race for mulecars was established at Olympia (abolished in B.c. 444). Anaxilas, the despot of Rhegium, not many years after won the prize with his mule-car, and commemorated this event, as well as the fact that he was the first to introduce the hare into Sicily, by placing his victorious mule-car and the hare as types on his coins (Fig. 137). It will be seen that this mule-car has four-spoked wheels, and, as the epithet "easily rumning" is applied to the
1 Il. xxIv. $265-80$.
2 Ibid. 324.
3 Od. Ix. 242.
+ od. vi. 68 sqq. 
mule-car in the Homeric passages just cited, and we also learn that Nausicaa's mules trotted briskly off with the waggon, it is most unlikely that the Homeric waggon had block wheels.

Now, as the Homeric mule-car, the classical mule-car, and the Thracian ox-cart about B.c. 500 all have spoked wheels, there is therefore no evidence for the existence of the use of solid wheels under either mule-car or ox-cart in early times in the countries round the Aegean. If such did once exist there before the invention of the spoked wheel, it must have been at a time anterior to the appearance of the horse both on the monuments of Egypt and on the tombstones of Mycenae. But it has just been shown that the use of the ox-cart for agriculture at so early a period is extremely unlikely. Accordingly, so far from the ox-cart with solid wheels being the precursor of the chariot, it is most likely that the latter was the first to be invented for purposes of war, and that later a stronger and cheaper form of vehicle for oxen was modelled after the chariot for everyday use-a simple platform on which a wicker creel or crate like that of the Homeric mule-car could be placed.

Of course it will be said that block wheels survived in the British Isles down to our own time,-that in 1775 goods were conveyed about Dublin on carts furnished with solid wheels about 20 inches in diameter, that solid-wheeled carts may still be seen in the North of Ireland from Donegal to Down, and that two kinds of block-wheeled carts were in use in Inverness about 1730 , both of them being simply modifications of the slide-car still surviving in Antrim, with wheels about a foot and a half high, but which were soon worn very small. Yet it must not be assumed that such wheels were the first kinds known in all these localities. It is most improbable that any kind of wheeled cart was in use in Ireland in early times, yet there were war-chariots with spoked wheels in Ireland at the time of Christ. Again, it is on record that in Borrowdale wheeled vehicles did not make their appearance until about 1770 ; and when these novelties did reach the lakes they were clumsyand awkward in character. Clog-wheels were the first type used on farm carts, yet spoked wheels had long been in general use all over England, and had been known in the island from 
before the Christian era. It is most important that cheap substitutes be not taken for genuine survivals of a primitive type. To the former category we may assign not only the block-wheels of Borrowdale, Inverness, and Ireland, but also certain wheels seen on Greek vases consisting of a felloe and two parallel cross-pieces, crossed by another at right-angles (a variety in which some have recognised the first step towards a spoked wheel). 'T'o the same category I would likewise refer the Portuguese wheels made ont of a single piece of wood in which two elliptical holes are cut, the wheel itself being clamped with bands of iron. This wheel and others like it have been supposed to be a first step towards a spoked wheel, but they are rather to be regarded as cheap and clumsy substitutes, as are also the solid wheels built up of three piees of plank common
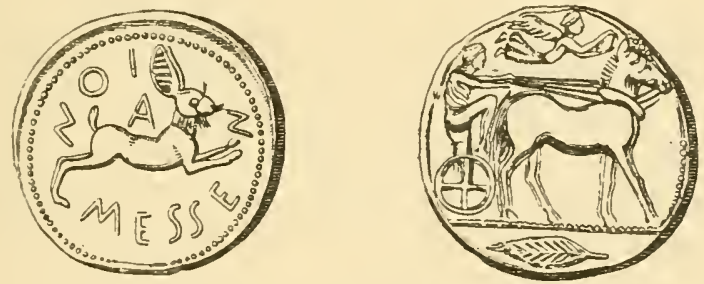

FIG, 137. Coin of Messana.

in Galicia, the Canaries and amongst the Zuñi Indians in Mexico, who have borrowed them from the Spaniards. These wheels are regularly clamped together by iron bands, although in Nexico they are said to be sometimes unshod.

In all cases of solid wheels the wheel is fixed on the axle, and does not revolve on it. Yet in the Florentine and Homeric chariot the wheels play freely on the axle. It can therefore hardly be maintained that we have genuine survivals of the first stage in the evolution of the wheel in the Portuguese and Spanish waggons with their revolving axles and wheels fixed to the axle, for it is clear that the principle of the wheel revolving on the axle has been known from an age far anterior to any evidence of the existence of an ox-cart with solid wheels.

But it is not in itself probable that solid wheels were evolved at a date when iron was not yet known, and copper was com- 
paratively scarce in most parts of the ancient world. The hewing of a section of a tree trunk two feet in diameter to serve as a solid wheel rather indicates a period when tools of a superior kind were available, or otherwise the task would have been so difficult that man would probably have resorted to some other method of shaping discs on which to set the frame of his car, though of course it is not utterly impossible that man by dint of hacking with a bronze, copper, or even a stone axe, conld have managed to rough-hew a pair of solid wheels connected by an axletree out of a tree-trunk. But as such wheels could never have been of practical use for war-chariots, and the Libyans, who had never any ox-cart, had devised for themselves long before they had metal in any quantity beautifully light chariots, in the structure of which no metal was employed, it is most unlikely that their spoked wheels were evolved from an antecedent block wheel. In the Florentine chariot the wheels are four-spoked and are 38 inches in diameter, both felloe and spokes being made of rods about one and a half inches in diameter. The spokes fit into a hollow hub formed of a wooden cylinder about nine inches long, with fairly thick walls through which the axle runs. The whole structure of this chariot is that of wicker and meshwork (p. 225). It is therefore far more probable that the spoked wheel was an adaptation from a circular piece of wicker-work, such as might be used for a shield or for some other purpose. The simplest form of such a circular frame consists of a rim strengthened and kept in shape by two other rods crossing each other at right-angles, thus forming four radii or spokes. 'The four-spoked wheel is found in the oldest representations of the chariot in Egypt, in Crete, Cyprus, and on the mainland of Greece. That it was consiclered by the Greeks the most ancient form of wheel is shown by the fact that in the myth of Ixion that miscreant is represented as bound to a four-spoked wheel. As the wheels of the Florentine chariot revolve on the axle, there is no reason to believe that such wheels ouly came into existence after a long period during which block wheels fixed to the axle had been in continuous use. We may reasonably conclude that the light war-chariot was invented long before the ox-cart or mule- 
cart, and that so far from the spoked wheel having been evolved from the block wheel, the converse is really the case.

In the tomb of the father and mother of queen Teic, the wife of Amon-hotep III and the mother of Amon-hotep IV, Mr. 'Theodore M. Davis has just found a pleasure chariot broad enough to hold two persons, richly painted and encrusted with gold. The leather work belonging to it is still as fresh as when it was first made. It is fitted with six-spoked wheels still covered with their wooden tires'.

This fresh discovery shows that the conjecture of Mr Carter and Mr Newberry that the wheels of the chariot of Thothmes IV had been fitted with metal tires is wrong. There is no reason now to doubt that it, like the newly discovered chariot and that at Florence, had no metal shoeing on its wheels.

We have seen that the mule-cart in Homer is fitted with wheels of lightness and elegance, and there is really nothing to distinguish them from those of the chariot. We have a full description of the Achean chariot in the Iliad, for we camnot doubt that the chariot of the goddess Hera is a faithful copy of those used by her worshippers, save that the car of the immortals is represented as being made of precious metals. "So Hera the goddess queen, daughter of great Cronos, went her way to harness the gold-frontleted steeds; and Hebe quickly put to the car (ochos) the curved wheels of bronze, eight-spoked, upon their axletree of iron. Golden is their felloe, imperishable, and tires of bronze are fitted thereover, a marvel to look upon; and the naves are of silver, to turn about on either side. And the body of the car (diphros) is plaited tight with gold and silver straps, and two rails (antux) run round abont it. And a silver pole stood out therefrom; upon the end she bound the fair golden yoke, and set thereon the fair breast-straps of gold, and Hera led beneath the yoke the horses, fleet of foot, and hungered for strife and the battle$\operatorname{cry}^{2}$."

This description when compared with actual specimens found in Egypt gives us a very clear view of the structure of the chariot, the plaiting with straps of gold and silver at once

1 Times, 10 March, 1905.

2 Il. v. $721 \mathrm{sqq}$. 
recalling the floor of the Egyptian chariots with their plaited leather meshwork (p. 22.5) in which we may recognise the first step towards leathern springs.

The Harness. The elaborate account of the harnessing of Priam's mules above cited when taken in conjunction with other passages in Homer, with the harness found in the tomb of Thothmes IV, and representations of Egyptian chariots (Fig. (i8), with the description of the Assyrian chariot-harness (pp. 195-196), with the Hittite (Fig. 67), with the Persian (Fig. 61), and with numerous representations of Greek chariots in classical times, enables us to form a clear idea of the nature of the harness used in early times and the method of attaching the horses to the car.

Whilst the harness seen on the monument of Seti I and found in the tomb of Thothmes IV belongs to a date anterior to Homer, that seen on the Assyrian monuments falls several centuries after that period. It is therefore but natural to find that whilst the Egyptian and Homeric horses are attached only by breast-straps, the Assyrian have also elaborate body bands which may be taken as the forerumners of the saddle or straddle of modern harness.

The Rein-rings. Attached to the yoke of the Florentine chariot (Fig. 69) are seen two Y-shaped objects, which must have hung down from the yoke or some other part of the harness or chariot. They are of wood, and the arms of each are pierced with holes near the extremity. The height of the whole is seven inches, the width from hole to hole not being more than four inches, and the tail ends in a large round bone stud, one and a half inches in diameter, which shows that the object was not meant to be inserted into a hole in any part of the yoke or chariot. They camnot have been collars (as commonly supposed) to rest on any part of the horses' necks, for they are obviously too small for that purpose, and are quite different from the actual collars found in the tomb of Thothmes IV figured in Mr Davis's publication (p. 227).

Associated with the pairs of bronze bits not unfrequently found in Ireland are usually pairs of spur-shaped bronze objects (Figs. 138, 139). 
Each of the specimens here shown (Figs. 1:38, 139) is one of a pair found along with the pairs of bronze bits, examples of which are given (p. 98, Fig. 45). These objects conld not have stood upright on the yoke or anything else, for the two arms are neatly rounded off (see Fig. 138 B, where an end is shown in detail): again, the tail could not have been inserted into a hole in the yoke or anything else, for in both the examples

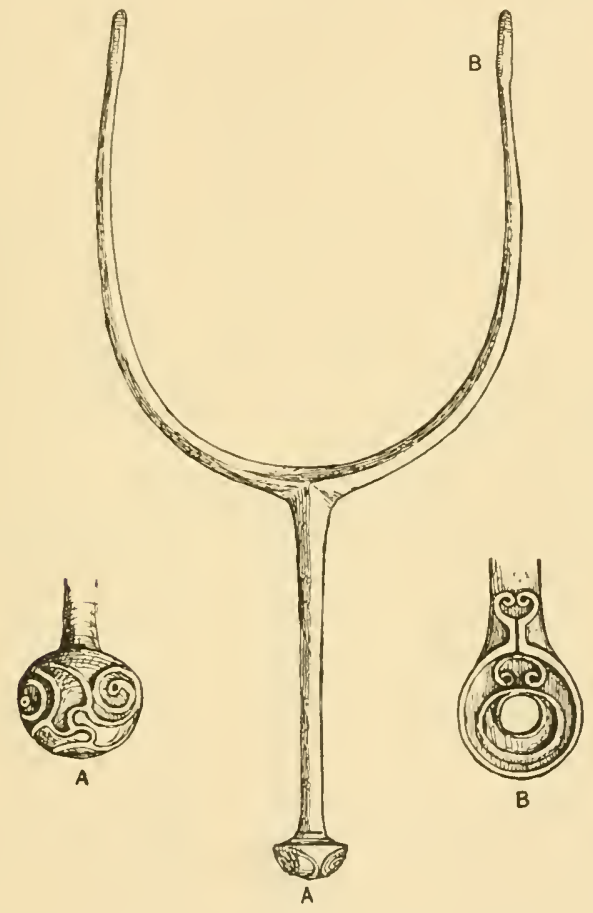

FIg. 138. Ancient Irish Rein-ring (all-dual)?

figured the end is ornamented, more especially in Fig. 138, where, as will be seen. (Fig. 138 A), it is beantifully ornamented in the 'late Celtic' style, as are also the ends of both arms, one of which, as already stated, is shown in detail (Fig. 138 13).

As this curious piece of metal work could not have stood up on either end. and as neither end was meant to be inserted into any other object, clearly these mysterious implements were suspended with the tail hanging free, as is demonstrated by the 
fact that the extremities of the two arms are always furnished with means of suspension. Some are perforated close to the extremity (Fig. 138 в), as if meant to be suspended. In most specimens, however (as in Fig. 139), there is a groove on the inside of the upper portion of each arm extending for some distance, and this groove is crossed a little below the end by a bronze loop (Fig. 139 B) which could be slipped on a hook, thus enabling the whole to be attached to the lower side of some object such as the yoke. In specimens of the second class where the loop has been accidentally broken off, its place has been supplied by a hole bored right through, which is plainly meant to admit the passage of a hook. When once the hooks fastened into the under side of the yoke were slipped through the loops or holes in the extremities of the spur-shaped objects they could not easily jump off. The analogy between these Irish bronzes and the primitive wooden pair found along with the Florentine chariot is very close, and they would both seem to have fulfilled a like function.

We may take it that the harness of the Homeric mule-car was practically identical with that of the Homeric chariot, for otherwise the harness of Priam's chariot would probably have been described. Now, we are told that the yoke was 'wellfitted' with oielies, literally 'steerers,' which are explained by the ancients themselves as "a kind of rings through which the reins were passec." This fact shows that from very early times it was found necessary to have some kind of rings attached to some part of the harness through which the reins might be passed, and thus kept them in place and free from entanglement with the horses' manes, and give more power to the charioteer. The reins in the Assyrian chariot seem to have passed through some such contrivance fastened to the under-side of the yoke (Fig. 62). In the Egyptian, Mycenean, Hittite, and Assyrian chariot the yoke, as was the case in Homer, was the only part to which such 'steering-rings' could be attached, though the reins might have been passed under a strap going round the horse's body, as is the case on the monument of Seti I (Fig. 68). As apparently no such rings were ever fitted into the yoke of the Florentine chariot, any such contrivance for guiding the 
reins must have been either suspended from the yoke or attached to it by strings. The two $\mathrm{Y}$-shaped objects were probably suspended from the yoke, much as they are at present (Fig. 69), and through them the reins were passed and kept in their place.

The more elaborate bronze objects found in Ireland probably served a like purpose, for as already argued they must certainly

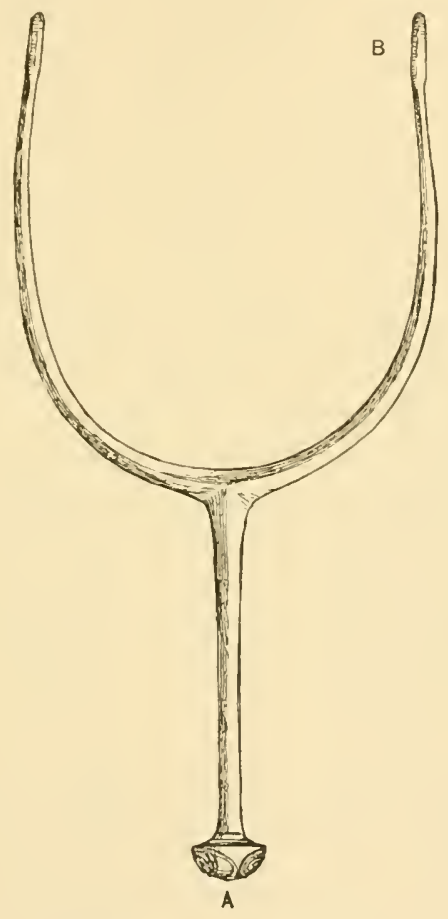

Fig. 139. Ancient Irish Rein-ring (all-dual)?

have hung down. This view can be supported from the oldest Irish texts-in these the name for reins is all: thus Laeghaire Buadach's chariot "had two pliable beautiful alls," and it had likewise "two rich yellow all-ducluch," literally, "two rich yellow rein-loops," or "rein-rings." Dr Sullivan thought that these rings were on a strarldle, but as it is very unlikely that the Irish chariot-horses wore straddles, it is far more 
probable that the all-dualach were attached in some way to the yoke, as was the case with the Homeric steerers. We may therefore conclude that the curious wooden objects on the Florentine yoke were really a primitive contrivance for keeping the reins in place, and that the Irish implements are simply more elaborate forms of the same type.

The Scythed Chariot. The addition of scythes probably prolonged the use of the chariot for war, as such "scythe-bearing chariots" became a formidable arm when driven against bodies of footmen. Thus, although owing to 'villainous saltpetre' the medieval knight with lance in rest has long departed, nevertheless lancer regiments still linger on in the armies of modern Europe, partly as a survival, and partly because they are found useful in certain conditions of modem warfare.

Certainly, whenever we hear of the employment of warchariots at a late period they are usually described as 'scythebearing.' The chariots used by the Persians at the battle of Cunaxà were so equipped, and chariots still more elaborately armed were employed in Syria at a much later date. Thus in the great battle between Eumenes of Pergamus and Antiochus of Syria, the latter placed in the front of his line four-horse chariots, furnished both with scythes and spears. Spears fastened round the pole projected like horns ten cubits in front of the yoke to transfix everything that came in the way; two scythes were attached to each end of the yoke, one fixed on a level with the latter, the other sloping towards the ground, the former being meant to cut away every obstacle from the side, the latter to strike foes already prostrate, or endeavouring to escape by passing under the more elevated blade, whilst from each axle two other scythes extended set at different angles like those attached to the yoke.

But Eumenes managed to stampede the chariot-horses of his adversary, which turned round and dashed into their own ranks, and Antiochus suddenly found his army panic-stricken and routed by the engines which he had devised for the destruction of his foes ${ }^{1}$.

Doubtless such occurrences as this were always liable to 1 Livy, xxxvir. 41. 
occur and accordingly we hear little of scythed-chariots in the armies of the civilised peoples of the Mediterranean from this time forth. The war-chariot only lingered on among the more barbarous peoples of the north-west of Europe, and amongst the remote Libyan Pharnsii, by the latter of whom also it was now fumished with scythes.

Riding. When men began to ride regularly on horseback at first they sat simply on the bare back of the steed, which in Asia and Europe, as we have seen, was from the first controlled by some form of bit, though the Libyan used at most but a noseband. The Greeks of the fifth century paid great attention to the shape of the bit, as is made clear by the elaborate directions respecting it given by Xenophon ${ }^{1}$.

The Horse-cloth. The first step towards a saddle was naturally some kind of cloth placed on the horse's back for the greater comfort of the rider. The Assyrians had already made this first advance by the eighth century B.C. (Fig. 64), and it was certainly known to the Greek settlers in Egypt by B.c. 600 (Fig. 72), whilst it had become a fully recognised part of the equipment of the Greek and Macedonian horse-soldier (Fig. 87) by the beginning of the fourth century B.c., if not earlier.

The earliest literary testimony is that of Antiphanes², the comic poet, who began to exhibit plays in 387 B.C., and his contemporary Xenophon ${ }^{3}$. The former speaks of "the coverlet for a horse."

But bare-backed riding was still regularly practised, as we know from the latter writer ${ }^{4}$, and apparently the jockeys in the races at the great festivals of Greece rode bare-backed (Fig. 86), as is the case in Mongolian horse-races held at temple feasts at the present hour (p. 139).

The cloth known as an ephippion (horse-cover) had come into universal use amongst the Romans by the time of Caesar (cf. p. 114), though the German tribes considered it disgraceful and a mark of laziness to use it, and were always ready, riding

\footnotetext{
1 De re equestri, 10,6 .

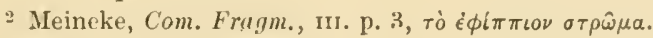

3 Eq. vir. 5, тd $\dot{\epsilon} \phi i \pi \pi\llcorner o \nu$.

4 loc. cit.
}

R. II. 
bare-backed, to attack any number of cavalry so equipped (ephippiati ${ }^{1}$ ).

The Saddle. It seems certain that attempts to make the horse-cloth more comfortable for the rider were made from time to time, and that it was gradually turned into a sort of pad. This is the stage in which the Arab who rides on a cotton pad and without stirrups still remains. Although there is a well-known representation of a Scythian saddle closely resembling the modern type, there is no evidence for the existence in the Roman empire of a saddle with a regular tree until the fourth century A.D., when on the column of Theodosius (A.D. 380) the true saddle with bow behind and before appears for the first time, and it is seen placed over the old horse-cloth from which it had been itself evolved. Henceforth it is known as the chair (Latin sella, whence French selle).

The Stirrup. Although objects which might be taken for stirrup-leathers are seen attached to the Scythian saddle mentioned above and to a Roman ephippium on a coin of Labienus, stirrups (staffae, stapides) are not mentioned in literature till about A.D. 600. It is significant that there is no native word in either Greek or Latin for the stirrup, and the names for it in French as well as in English are of Teutonic origin.

The English stirrup is simply a contracted form of Early English, stige-rap (from stigan = 'to mount,' and rap = 'rope'), i.e. 'mounting-rope.' Again, the French étrier is from the Old High German estrifa (modern Germ. streif = Engl. strip), a strap of leather. The original form was éstrivier, the $v$ of which survives in étrivière, the stirrup-leather. This evidence, taken in combination with that of the Scythian saddle and the coin of Labienus, makes it fairly clear that the first stage in the development of the stirrup was the attachment of a rope or a strap of leather to the riding-pad to assist the

1 Ephippium is glossed by Nonius as "tegimen equi ad mollem recturam paratum"; cf. Horace, Ep. I. 14, 43, "optat ephippia bos piger, optat arare caballus." In the Digest stragula is used for a horse-cloth (cf. Martial, xiv. 86: 'stragulum veredi '). 
rider to mount. The Germanic origin of the names for the stirrup and the known difficulty in mounting on horseback and retaining the seat when mounted experienced not by the Germans of the south and west, whom Caesar knew, but by those of the north-west such as the Angles and their immediate kindred (p. 35:3), clearly indicate that the stirrup wats the invention of the large-limbed heavy-built Teutonic tribes of the Lower Rhine and the contiguous region, from whence it gradually spread southwards and eastwards along with the con-

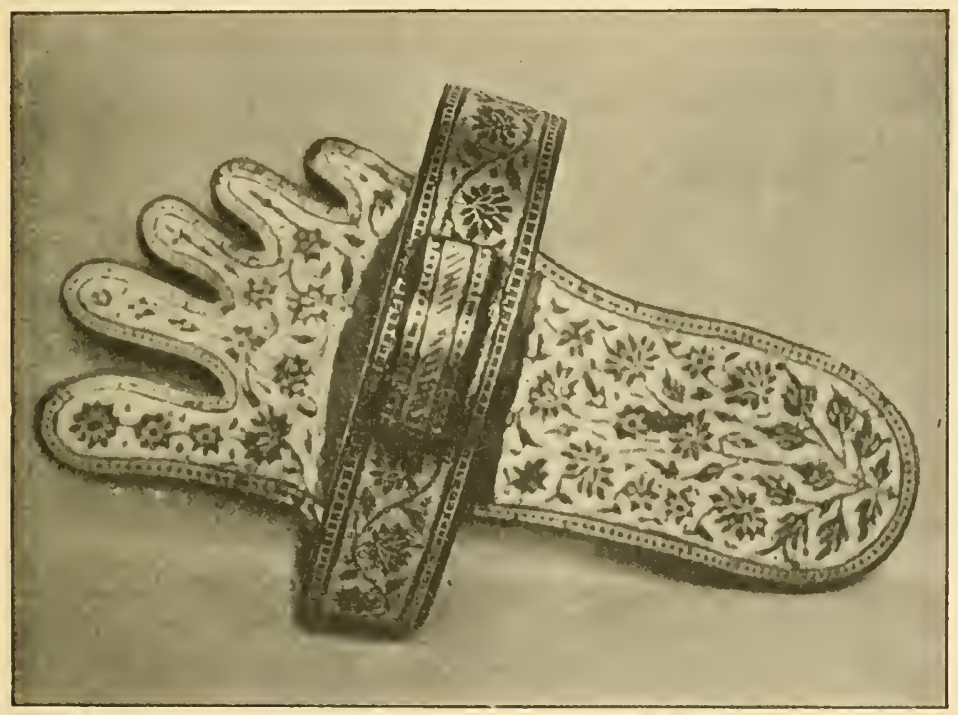

Frg. 140. Persian Stirrup (bronze inlaid with silver; 15th century).

quests of the Franks. The next stage was to attach to the strap or rope a piece of metal in which the foot might rest more comfortably and secmrely. This stage can be clearly seen at the present day in Abyssinia, where the stirup-leather and stirmp consist of a rope and a metal ring just large enough to receive the great toe. The next step would be to insert the whole of the bare foot in a larger ring. A reminiscence of this step can be seen in merlieval Persian stirups, which are formed of a circular piece of bronze with a plate for the foot shaped and ormamented to resemble a naked foot, as is 
the case in a pair dating from the fifteenth century from Gwalior in my owu possession (Fig. 140).

The Spur. The Greeks of classical times do not appear

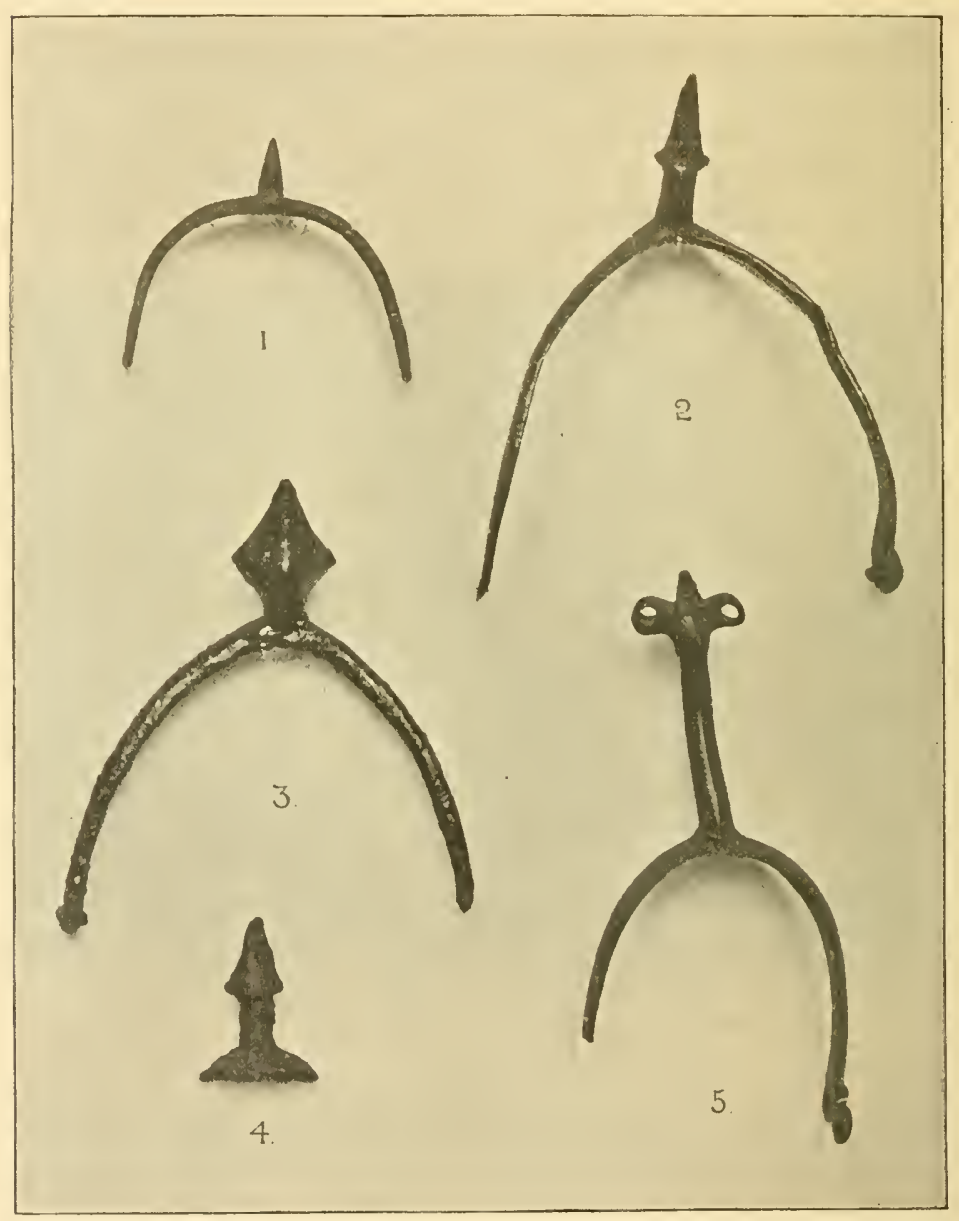

F1G. 141. Prick-spurs. 1. Ancient Roman. 2. Norman spur, Castle Jordan, Co. Westmeath. 3. Norman spur. 4. Tuddenham River, Suffolk. 5. Medieval English spur.

to have used the spur. Xenophon certainly does not mention it as part of the horseman's equipment, although he recomends the use of top-boots. But it seems to be indicated on the foot 
of an Amazon seen on a Greek vase dating from the century (4th B.c.) in which Xenophon lived. Bronze spurs have indeed been found at Dodona, but they probably belong to a comparatively late period.

The Romans used spurs from at least B.C. 2(10), and probably much earlier, for there are constant references to them in literature from Plantus (B.c. 200) downwards, and many specimens are cxtant (Fig. 141, no. 1). They are all prick-spurs, a form which continued in use everywhere in Europe down to at least the thirteenth century. Thus the Norman prick-spur from Castle Jordan, Co. Westmeath (Fig. 141, no. 2), must be later than

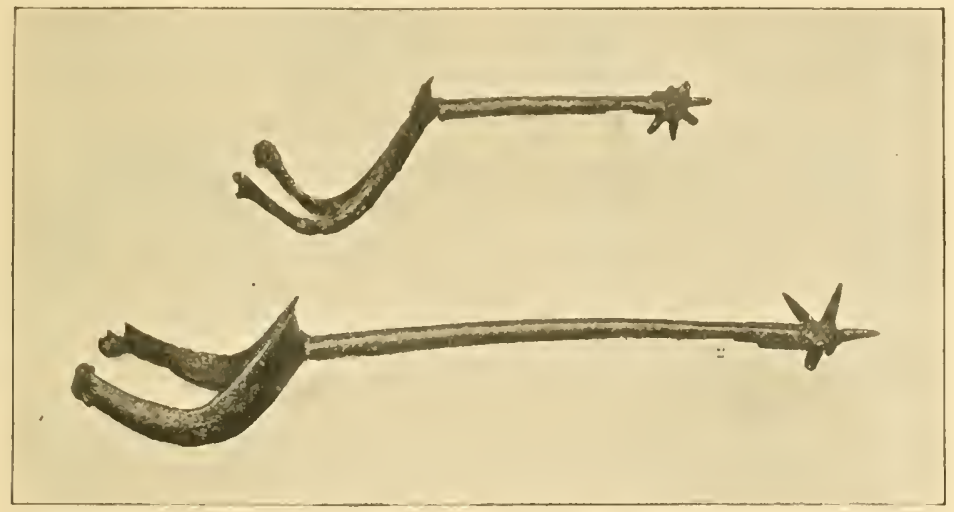

F16. 142. 1. Medieval Rowel-spur. 2. Fifteenth Century Rowel-spur.

the Norman conquest of Ireland (1172), as the native Irish rode in their bare feet.

I here figure various forms of the prick-spur, three of which are from the fine collection of $\mathrm{Mr} \mathrm{W}$. B. Redfern, one (no. 2) from the Murray Collection in the Cambridge Archaeological Musenm, whilst 110. 4 is a fragment (iron) found in Turddenham River, Suffolk, now in my own possession. It was gradually felt that the prick-spur was too severe, and Fig. 141, no. 5, shows the first step taken towards a less severe type, as the prick is now prevented by a sort of rosette from furrowing too deeply the horse's flank.

It was no great step from this form to the rowel-spur, which has continued in use ever since (Fig. 142)1. 'The great

${ }^{1}$ Both these specimens are in $\mathrm{Mr}$ W. B. Redfern's fine collection. 
development of horse-armour in the fifteenth century rendered it necessary to elongate to an extraordinary degree the heel of the spur (Fig. 142, no. 2), in order that the rider might be able to reach the unprotected lower part of the horse's body. But with the disappearance of horse-armour the heel soon shrank to the proportions which it has practically retained ever since.

The Horse-shoe. It was maintained in the sixteenth century by the famous Gesner that horse-shoes fixed on with iron nails were not employed down to the time of Vegetius (circa A.D. 380). There is indeed clear evidence that the Romans in the first century B.c. did place some kind of shoes on oxen and mules, for Columella speaks of hempen shoes (soleae sparteae) being used for oxen, while Catullus alludes to a mule losing its shoe (solea) in the mud. But it is almost certain that the shoe was a slipper made of hemp or leather tied on the animal's foot, just like the boots placed on horses employed to draw mowing machines on large lawns. In the first century after Christ Nero, who travelled with a train of one thousand carts, had his mules shod with silver soleae, whilst his wife, Poppaea, outdid him by having her mules fitted with shoes of gold. It is probable that the silver and golden shoes were simply leather slippers such as those just referred to, the upper portions of which were covered with plates of precious metal, but it is possible that soleae made altogether of metal may have been used, and that the golden and silver shoes just mentioned may have been all of metal, something like those shown in Fig. 143, nos. 5 and 6 . Such a type ought certainly to be the first step in advancing to metal from the hempen or leathern slipper. But as such a metal shoe would not give a secure foothold for the animal, the next step would be to cut a portion out of the middle of the sole, thus both saving metal and giving the horse a surer footing. Once such a step was made, less and less metal would be placed under the horse's foot, until finally the shoe was nothing more than a rim of metal which was not carried round the heel. The attachment to the foot would then be made by nails driven through the outer part of the hoof. The later steps in this supposed evolution, as I have given it, are of course only hypothetical. 
There is however no reason to doubt that iron shoes have been found in France associated with objects indicating that
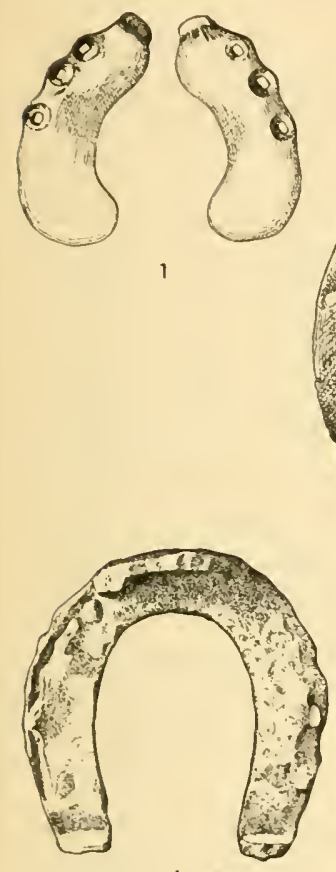

4

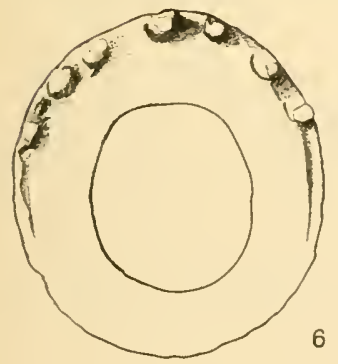

FIg. 143. Old English Horse-shoes.

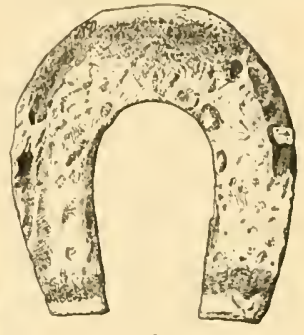

3
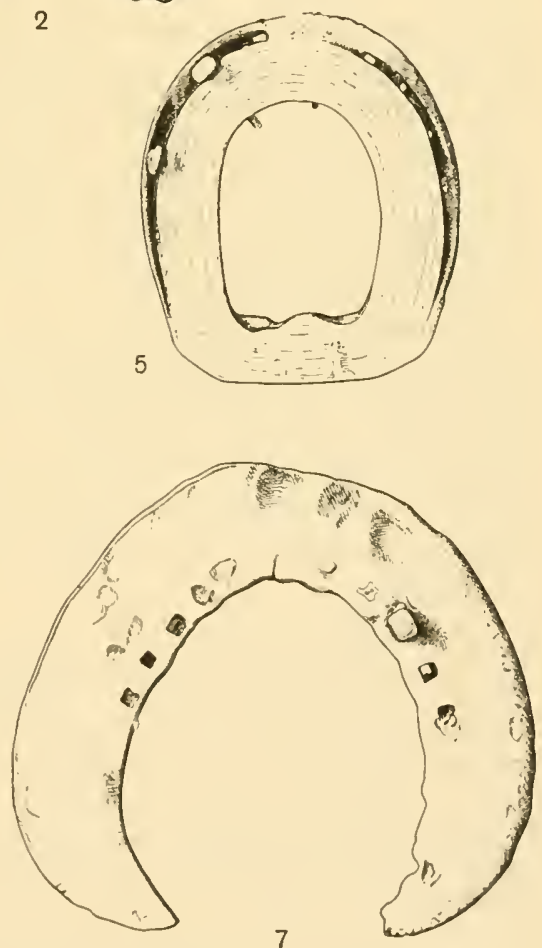

they were in use during the Roman period, and certain horseshoes remarkable for their small size, narrowness, and wavy 
outside margin (produced by the stamping of the nail-holes, in which process the iron bulged out along the edge) may be assigned to that age.

There are also small iron horse-shoes found at Silchester which certainly must have been used during the Roman occupation of this island. It is probable that the practice of employing some kind of protection for the feet of mules and horses in Italy and elsewhere in Roman times was due to the great paved roads which formed the highways of the Empire, and along which the public post-horses were constantly passing. But it must still remaiu an open question whether the iron horse-shoe was invented in Italy, or in some other southern land, or north of the Alps among the Celts in the regions where iron had probably first been systematically worked and used by that people. As the Angles had no horses when they came to Britain it is most unlikely that they brought any peculiar shape of horse-shoe, and Prof. McKenny Hughes is probably quite right in maintaining that many ancient horse-shoes found in England and commonly denominated Saxon, belong to a period posterior to the Norman Conquest ${ }^{1}$.

But it is probable that although the shoeing of horses has been continuously practised in this island from the Roman period downwards, the majority of horses in medieval England went barefooted, as was the case not only over most of the world in medieval times, but is still universal among Arabs, Tartars, Gauchos of the Pampas, and in the Western States of America.

Ornaments. As man attached to his own person certain objects for protection and decoration, so he not unnaturally treated his horse in the same fashion. We have seen tassels on the Assyrian horses, which of course may have been simply ornaments, but in the light of what we know of such appenclages to the harness of horses, asses, and camels in modern times, it is much more likely that they were some form of

1 "On Ancient Horse-shoes," Proc. of Cambridge Antiquarian Society, Vol. x. pp. 249-58 (with a plate of illustrations, for the use of which in this work I am indebted to my friend Prof. Hughes, and the Council of the Cambridge Antiquarian Society). 
ammlet. I have elsewhere tried to show that jewellery and all ornament originated not in aesthetic but in magic, and that probably holds true to a large degree of the ornaments on horse-harness.

The modern Italian attaches a piece of badger's hair or a tooth to his horse's bridle in order to avert evil. The ancient Italian used a piece of wolf-skin or a wolf's tooth for the like purpose. The modern Greek places an elaborate amulet to his horse's neck; the modern Kabyles of Kairwan hang round their asses' necks a thick woollen cord (purple and white), to which is attached two triangular amulets covered with purple velvet, embroidered with imitation Arabic writing in gold thread, and having a small round button between them; whilst the Arab regularly fortifies his camel against ill luck by an amulet attached to its neck. It is therefore not unlikely that the tassel attached to our modern cavalry bridle may be a survival of some such amulet, whilst, as has been already pointed out by others, the brass ornaments on the blinkers of our dray-horses may be survivals of similar protective charms. At the same time it must be borne in mind that our draught-horses are the descendants of the medieval war-horses, who not unfrequently had ornaments attached to their bridles consisting of their owners' arms on a small shield. The pieces of brass on the blinkers of modern draught-horses, with their conventional ornament, may in part at least be only debased imitations of medieval heraldic decorations. 


\section{ADDENDA ET CORRIGENDA.}

P. 58. I here add a summary of the facts about the Abyssinian zebra collected by Job Ludolphus to which attention was first called by Mr Edward Birlwell (Field and P.Z.S., 1901, II. 2), and which were printed very fully by $\mathrm{Mr} \mathrm{H}$. Scherren in the Field (March 4, $1905)$.

Job Ludolphus summarised the information collected by the Jesuits concerning the Abyssinian zebra in his Historia Aethiopica (1681). In his Commentarius (1691) he added much interesting matter, some of which he gleaned from Abyssinians, whom he met at Rome while collecting material for his Aethiopic Grammar and Lexicon, and perhaps from some of the Jesuit fathers. In his Commentarius he deplores the fact that on account of its large head and long ears this beautiful creature should be called an ass, by people ignorant of its proper name - that is as stated in the Historia (I. 10), zecora in Abyssinia, and on the Congo zebra. Then he quotes Philostorgius, an ecclesiastical writer (circ. 385-425), to the effect that the country produces very large wild asses, black and white, not spotted but zoned from the spine on to the sides and belly. Jacobus Gothofredus, who annotated Plilostorgius, thought these were onagroi, wild asses of the Westem Asiatic race, adding that no one else had so described their coloration. Ludolphus points out that Philostorgius does not use the ordinary Greek name onagroi, but onoi agrioi (and insists on their size). 'This animal,' he says, "was not unknown at Rome, whither all wonderful things were sent," thus anticipating $\mathrm{Mr}$ Lydekker's suggestion (Royal Natural History, II. 505), that the hippotigris of the Roman circus was an Abyssinian zebra. He also suggests that it was confused with the onager by those who had not seen that species or that it was called onager because people did not know its real name. Martial (xir. 101) is cited and due stress is laid on the epithet 'beautiful' 
applied by that author to the beast. Once more he deprecates its being called an ass and says that the ears by which it is disfigured might be cropped as is done in Germany with horses that have very long ears. "And it has a horse-like head somewhat too long, as I have seen here (quod hic vidi)."

Father Tellez in a report to the Superior at Rome speaks of the beauty of the animal, the equal width of the stripes, which seem to form curves on the flank "as the picture will show you better than any description could do." Ludolphus may have used this picture for the illustration in his Commentarius reproduced by Mr Scherren in the Field (March 4, 1905, p. 375).

Though the animal in Ludolphus' plate differs in many important respects from Grévy's zebra, there can, as $\mathbf{M r}$. Scherren maintains, be no doubt that it was intended for that species. Ludolphus lays stress on three characteristics-its great size, for in the IIistoria he says that it was as big as a mule, its equine head, and its long ears. The animal in the plate more nearly resembles a Grévy zebra than does that figured by Pigafetta resemble any variety of the Burchell zebra, for one of which it was undoubtedly meant.

These Abyssinian zebras even reached Japan, for Ludolphus learned from one Emmanuel Nawendorff, a native of Altenburg, resident in Batavia, that King As-saghedus sent some to the Governor of the Dutch East India Company at Batavia, who in his turn presented them to the Emperor of Japan. In return the emperor sent 10,000 silver taels and thirty Japanese dresses, so, as Nawendorff says, they were amply paid for. One specimen at least had reached Europe alive before the time when Ludolphus wrote, for a French writer had seen the animal alive at Constantinople. He said that among other gifts brought by the Abyssinian envoy to the Grand Seigneur was an ass with a very beautiful skin, if indeed it were natural. 'This however he declined to vouch for, not having examined the animal, but he noted the more than ass-like size, the large liead, long ears, and the regularity of the stripes "of the breadth of a finger," though he called the dark stripes chestnut-brown instead of black. Tellez also thought that he detected a reddish tinge in them. Ludolphus suggests that the discrepancy might be due to the differences of age or perhaps to geographical distribution (vel pro diversitate regionum diversos habeat colores). The Abyssinian envoy had started with three zebras as gifts for the Sultan, but two died on the way. 'These were flayed and the skins were presented 
with the survivor to the Grand Seigneur. Ludolphus was quite right in his suggesting that the difference in coloration was due to difference environment, for (as stated above, p. 58 n.) the Somali race of $E$. gréryi has the ground colour pale brown or ochre with chocolate stripes.

P. 64. Ward's Zebra. This sub-species, named after Mr Ward by Prof. Ewart, " is found in the vicinity of Lake Nakuro to the north of the Lombori Hills not far from Naivashi and the Uganda Railway. In its long ears, narrow hoofs, and gridiron it approaches the mountain zebra, and it is practically the mountain zebra of the Naivashi plateau." Prof. Ewart (who has kindly supplied me with this note) will shortly publish a full paper.

Equus Foai. Mr Pocock has kindly furnished me with the following very complete note on this most important sub-species.

\section{EQUUS FOAI.}

Prazík and Trouessart, Bull. Mlus. d'Ilist. Nat., Paris, v. pp. 350-354, 1899.

Ground colour ochre yellow; of belly white. Stripes black, narrow and numerous, those on the body meeting the mid-central line. Legs completely striped externally and internally to the fetlocks; pasterns black. Muzzle deep chestnut-brown, without yellowish tan colour above the nostrils. On the neck thirteen stripes cross the mane between the ear and the shoulder stripe. Behind the shoulder stripe there are from 8 to 10 complete vertical stripes, with their dorsal extremities at right angles to the spinal stripe, which is in contact with only the first and second of thase (1 to 9). The last body stripe with its dorsal end turned obliquely backward on to the croup and running parallel with the spinal stripe towards the root of the tail. The hind-quarters from the croup down to a point in a line with the belly, marked with about 9 obliquely longitudinal stripes. The upper two are united by 7 or 8 very short transverse stripes like the so-called gridiron of Crawshay's zebra. The anterior extremities of the upper 2 or 3 meet the last body stripe; but none extend for more than a few inches beyond the haunch on to the body. There are no "shadow stripes." The spinal stripe is narrow behind the withers but expands on the croup to 4 or $5 \mathrm{~cm}$. Except for a short distance behind the withers it is isolated from the body and croup stripes throughout its length. Tail striped, its tuft black. Ears with 
basal and subterminal black patch, the extreme tip white. Chestnuts small, somewhat as in E. gréryi.

Loc. Mountainous country opposite Tete on the north bank of the Lower Zambesi.

Differs from all the races of $E$. burchelli in the presence of a much greater number of principal stripes upon the body and hindquarters and in the fact that the dorsal extremities of all the body stripes with the exception of the last do not bend obliquely backwirds towards the croup but are approximately at right angles to the spinal stripe. In this particular it resembles both E. grévyi and $E$. zebra; but differs from both in that on the croup, the stripes adjacent to the spinal stripe are parallel with it, and point towards the root of the tail, as in Burchelli, instead of being at right angles to it. Hence there is no "gridiron," such as is found in $E$. zebra; and no trace of the circular or annuliform arrangement of the stripes round the root of the tail which is characteristic of $E$. grévyi. Also in the size and shape of the head and ears and in general build it approaches $1:$. burchelli much more nearly than $E$. zebra or E. grévyi.

\section{P. 76. The pre-orbital pit in the skulls of Quaggas.} Mr Pocock (Ann. and Mag. of Tatural Ilistory, Vol. x., series T, May, 1905, p. 516) now believes that Sir W. Flower was right in saying that no trace of the pre-orbital depression seen in the skull of IIipparion is to be found [in the adults] of any of the existing species of Equidae. The dissection of the skulls of horses slaughtered in the Garden has shown that the depression is sometimes present but more often absent: it exhibits indeed every gradation between a hollow perceptible to the eye and touch and a perfectly flat bony surface. From this hollow or from the corresponding area of the skull arises a long muscle which passes forwards to supply the upper lip and nose; and he "believes that its sole significance is to give an increase of surface for the attachment of muscular fibres." He therefore thinks that this pit never contained a gland, though the large depression in the skull of IIipparion was probably not for muscular attachment but for a gland as hitherto supposed. Onohippiclium has a pit even larger than that of Iipprerion and it lies higher on the face, in correlation with the extremely elevated fronto-nasal region of the skull, but in two casts of the skull of Onohippidium there may be noticed a little below and in front of the orbit an additional quite shallow depression, forcibly recalling 
both in position and development the pre-orbital muscular depression that exists in some skulls of recent Equidae. Mr Pocock points out that in the Museum of the Royal College of Surgeons there are skulls of two stallion quaggas and in neither of them is a trace of the depression perceptible.

P. 97. British Chariots. There are the remains of two chariots in the British Museum, and $\operatorname{Mr}$ R. A. Smith, of the Department of Prehistoric British and Medieval Antiquities and Ethnography, has kindly given me the following measurements of their tires.

1. Arras (Greenwell, British Barrows, p. 455). These are in diameter 2 feet 10 inches; in width $1 \frac{1}{2}$ inches.

2. Bererley (British Barrons, p. 456). The tires are in diameter 2 feet $8-9$ inches, and in width $1 \frac{1}{2}$ inches.

P. 100. Mr R. A. Smith has kindly given me the measurements of the tires of a Gaulish chariot from Somme Bionne now in the British Museum (Morel, La Champagne Souterraine, p. 29). The tires are 36 inches in diameter, and in width one and one-fifth inch. Canon Greenwell's measurements for the Arras specimen are not quite the same, but rust and distortion render any measurements merely approximate.

P. 218. No representations of Egyptians on horseback. Though no Egyptians are ever seen on horseback my friend Dr. Garstang has just called my attention to the fact that on the outer North Wall at Karnak, which has been lately cleaned by $\mathrm{Mr}$ Legrain for the Egyptian Government, in the picture of Seti I that monarch is seen in pursuit of the "vile Kheta" (Hittites). He himself is in his chariot (cf. p. 217), but some of his fleeing enemies are riding on horseback. It does not of course follow that because fugitives are seen on horseback they habitually rode, for in their flight they might well cut loose the horses from the chariots, and leap on their backs as did Odysseus and Diomede after the capture of the steeds of Rhesus (p. 109). It is quite possible, as I have said, that some of the Asiatic peoples who kept horses may have ridden on horseback from the first, but as the Hittites were using war-chariots several centuries later than the time of Seti I (cf. p. 215), it is not very probable that they habitually rode on horseback in the time of that king.

P. 236. With reference to my argument that the xvith and xvinth dynasties were Libyan in origin, my friend Mr F. W. Green 
points out that it gains support from the fact that the worship of Ammon, whose name appears in the names of various kings of the New Empire, rises into special prominence under those dynasties. For there was not only the great oracle of Ammon in the Oasis of Siwa (p. 239), but there was also a shrine of that god in the Great Oasis. Now, as the Libyans regarded the shrine in the Oasis of Siwa with special reneration, it is not at all likely that it was simply established there for the first time by an Egyptian king, and it is not more probable that the cult of Ammon was not native in the Great Oasis and had only been established by an Egyptian monarch at a later period. The fact that Ammon seems especially the god of horses under the New Enpire is not without significance. The Libyan god would naturally be the patron of the Libyan horse. Accordingly, just as the names of its lings are compounded with the name of Ammon, so too were those of the royal horses, e.y. "Ammon bestows strength," and "Ammon entrusts him with victory" (p. 218).

P. 239. For "()asis of Sûva" read "Oasis of Siwa."

Pp. 265 sqq. Prof. Ewart, who during the past winter and spring has been studying the horses of the West Indies and Mexico, on his return wrote to me as follows respecting the statement of Bernal Diaz which I have cited, and my conclusions respecting the horses of Spain and those brought by the Spaniards to the IVest Indies and Mexico:

"I have seen hundreds of horses, many most interesting. Towards the south of Mexico, especially in the Mitla region, a very considerable percentage of the horses are without ergots and hind chestnuts, or have them very small. In north Mexico, where American blood prevails, wartless ponies are extremely rare. In Mexico and Jamaica alike reversion seems to have been at work, producing a primeval beast suited to a warm dry climate in the one case, a warm moist climate in the other. Doubtless the reverts are a mixture of Spanish and Libyan types. I think all the evidence I have colleeted may be said to support your view about a Libyan variety (or species) - a variety which has been modified in various directions by the Arabs" (May 1, 1905). "The colours are very much what Diaz noted, but the nearer the Libyan type the less the evidence of striping, the nearer the cart type the commoner the vestiges of stripes. In the south of Mexico striping was less in evidence than further north. Prof. Osborn, who went specially 
in search of striped primeval forms, came across nothing worth photographing. In the 'Forest' variety still found in western Ross the striping is far more complete than in any horses seen in the West Indies or Mexico" (May 24, 1905).

Prof. Ewart's results will shortly be published, in Proceedings of the Royal Society of Edinburgh.

P. 402. Spanish blood in the Hebrides. Prof. Ewart has supplied me with the following note from Walker's History of the Hebrides, Vol. II. p. 160 (Edinburgh, 1808). Walker, who was Professor of Natural History in the University of Edinburgh, had visited the Highlands and Islands six times between 1760 and 1786 . The Spanish blood was introduced by Clanranald, who on returning from Spain a short time before he was killed in 1715 at the battle of Sheriffmuir "brought with him some Spanish horses, which he settled in his principal island of South Uist." These in a considerable degree altered and improved the horses in that and the adjacent islands. Even in the year 1764 not only the form but the cool, fearless temper of the Spanish horse could be discerned in the horses of that island. These at the time both in figure and disposition were the best horses observed in the Highlands, and though of low stature were judged more valuable than any other horses of the same size.

As the Spanish horses brought by Clanranald exercised such an important effect on the ponies of the Hebrides and Highlands, and as their descendants are recognized in modern Hebridean ponres of the 'Celtic' type (lacking hock callosities and having no ergots or very small ones), but which are black in colour', such as that figured on p. 22, and in view of the fact lately ascertained by Prof. Ewart (p. 511) that the horses of Libyan type brought to Southern Nexico by the Spaniards frequently lack hock chestnuts and ergots, we are still further justified in holding (1) that black ponies such as that driven by Cuchulainn, the black Irish Hobbies of medieval times, and the black Comnemara ponies of to-day are descended from Libyan blood derived through Spain and Gaul before the Christian era, and (2) that the absence of hock callosities in the ponies of the 'Celtic' type is certainly due in a large part to the presence of this African blood. 


\section{INDEX.}

Aahmes I, 215

Abdul Kadir, 167, 206

Abeyan strain, 169

Abraham, had no horses, 204

Abyssinia, ass of, 52

Acarnania, horses of, 302

Achaia, tombs in, 293

Achean horses, dun-coloured, 110

Acheans, 110, 251, 289; horses of, 285 ; nse bits, 473

Achen, Sultans of, 142; kept highclass horses, 142

Achilles, 218, 294; horses of, 110

Adamnan, abbot, 418

Aden, horses exported from, 147

Adhan (colour), black and brown, 178

Adhils, king of Sweden, his horses, 118

Adrastus, first of the Danaans to drive a chariot, 286; his horse Arion, 285

Adustion, 372

Aediles, 307

Aelian, account of horse, and elephant, 153; describes Indian horses, ib.; on Venetian horses, 104

Aelius Gallus, expedition into Arabia, 213

Acreas, horses of, 290

Aeschylus, 199

Aetua, city of, 296

Aetnacan steed, 296

Aetolia, horses of, 302

Afghanistan, horses of, 447

Africa, horses of. 184

African, blood, 373 ; horses, 312

Agamemnon, 112

Agasse, his drawing of Lord Morton's quagga, 77

Ageladas, the sculptor, 295

Agher, Co. Westmeath, 413

Agricultural Society, Royal, 386

Agriculture, Irish Department of, 405

Agrigentum, white horses at, 105

Almoar, bay, 177 ; denotes a European, 178

Alba, 3993

Albino horses, 142

Alby Hall, 384

R. II.
Aleppo, 176, 384; Darley Arabian obtained there, 188

Alexander the Great, 153, 253, 306; his political genius, 220

Alexandria, 220 ; its library, 220

Ali, his charger, Egyptian in origin, 212

Alix, 342

Al-Khamseh, 205, 381; names of, 166 ; origin of, 167 ; original stock, still in North Africa, 207; strains freely mixed, 170 ; sub-strains of, $i b$; colonrs of, $i b$; the strains of, 165 ; unknown in North Africa, 247

Almaine, the, 337; High, 377

Alsace, horses of, 325

Altai Mountains, 27, 135

Altamira, cave of, 87

Alvarado, 269; joins Cortes, 269

Alzada, of Pampas, 262

Amasis, 244

Amazon, 384

Ambacti, of Gauls, 317

Amblere, 359

Amblers, Celdones and Asturcones, 258

America, 4 ; fossil horses of, 8 ; North, feral horses of, 440 ; horses of, 265 ; South, horses of, 261, 271

American, thoronghbreds, 385 ; trotting horse, 464

Ammon, oasis of, 239, 511; shrine of, 222 ; temple of, 238

Anatolia, horses of, 188

Anazah, 169; hor'ses so called, in Syria, 182; stallions most prized, 183; tribes, 161; their migration, 161; occasionally have black horses, 177

Anchises, horses of, 290; mares of, 291

Anchitherium, 6

Anchorites, Irish, 418

Andalısia, horses of, 258, 259, 323, 387 ; colours of, $257-8$

Andalusian type, supposed in Connemara, 403

Angles, 334, 335; begin to ride, 330; not able to ride, 353 
Angli, 329, 335, 353

Anglo-Norman horses, 324

Angola, 59; zebra of, 55

Annandale, Mr N., 21

Antilles, horses from, 269

Antimachus, 286

Antimony, 165

Apis, 2:2

Apocalypse, horses of, 209

A pollo, 286

Apulia, horses of, 308

Aquitania, 332

Arab, blood, 142; merehants, 151; honesty in horse-dealiug, 177; lorse, 5; horses, 161, 344; in Irak, 161: of coarse type, have large hock callosities, 250 , probably cross-bred, ib. ; spoiled by crossing, 175 ; strains inferior, 173; three kinds of, 168; with large hock callosities, 38; witl large under-lip, 38

Arabia, 145; horses exported from, 148; its description, 200; no horses, 201; no mules, $i b$.: 110 swine, $i b$.; no wild hol'ses in, 165 ; three kinds of horses in, 161; Central, 161; lack of food in, ib.; Peninsula of, never had wild horses, 207; Turkish, horses of, 182; sent to India and Constantinople, 182

Arabian, 163, 381; Darley, 382 ; Markham, 364, 378; horse, 164; definition of, 161; described, 171, 180; differs from Iraki stallion, 180 ; lıorses, colours of, 177-9; height of, 173; inferior strains of, 173 ; in Irak, Syria, etc., 180

Arabs, Auazah tribes of, 161; conquests of, 213; do not contribute horses to Xerxes' host, 198; in Sumatra, 145 ; method of tracing pedigree, 187; predilection for white or grey horses from religious motives, 186; supply camel corps to Xerxes, 199; their conquests due to the acquisition of the horse, 213 ; truth of, 168 ; reluctant to sell mares, ib. ; tribes of interior deserts, 164

Araxes, river, 129

Arbela, battle of, 301

Arblast, 140

Arcadia, horses of, 301

Arcelin, M., 83

Arcesilas, 253

Archers, horse, 194, 196; Seythians, 482

Arches, on forehead, 445,452

Archipelago, Indian, horses in, 144; Islam in, 145 ; horses not indigenous in, 145
Aretas, Nabataean king, 202

Argolis, 285; horses of, 302

Ariège, horses of, 323,398

Arion, the horse of Adrastus, 285

Aristophanes, 296

Aristotle, 296, 300; describes wild mules, 49 ; on horses, 188

Arles, 321; races at, 330

Armada, 402

Armagh, brooches found near, 396

Armature, of Irish, 389

Armenia, 132; horses of, 18, 192, 446

Armenian horses, in modern times, 193

Armour, 336, 355, 389; discarded, 366 ; horse, 132 ; not worn by Irish, 388; Persian, 188

Arras, chariot burial at, 97, 510

Arrian, 190, 400

Arrow-shooting, 117

Arrows, poisoned, 140

Aryans, drive chariots, do not ride, 151; kept horses, ib.; sacrificed horses, $i b$.

Ashkar, chestnut, 178

Asia, hol'ses of, 306 ; Central, 164; Western, horses of, 160 sqq.; Vestern, origin of horses of, 188

Asia Minor, 132, 199

Asinus, 12

Ass, African, 52; differences from Asiatic, 53; Asiatic, 12; African, ib.; Somali, ib.; domestic, in Egypt, 218; hybrid, 37 ; hair of, ib.; hybrids, 35, 36, 39; in Homeric Greece, 112 ; shoulder stripe of, 450 ; Somali wild, 53-4; wild, 208,476 ; Asiatic, habits of, 50 ; capture of, in Assyria, 49; domesticated by Arabs, 52 ; in Scythia, 50; not so swift as hor'ses, 50; old stallion emasculates young ones, 50 ; west of Nile, 56 ; asses, $7,47,204$; Asiatic, division of, 43; Asiatic, two species of, 52; domesticated, in Western India, 47; draw Indian chariots, 192; of Job, 203 ; of Persia, 149; sacrificed to war-god, 150 ; used by Carmanians, 49 ; wild, 43 sqq., 202; wild, in Dzungaria, 43; wild, in Syria, 49; with horns, 56 ; without horns, 56; with six lumbar vertebrae, 42

Assouan, 238

Assur-bani-pal hunting, 49

Assyria, wild asses of, 49

Assyrian, empire, 230; horses, 194; horses, origin of, 198

Asturcones, 258, 38\%

Asturia, horses of, 258, 266

Atalualpa, the Inca ling, 271 
Atavism, $76^{\circ}$

Athlone, 83

Athy, priory of, burnt, 412

Atteschi, of Arabia, 161

Atymon, :8

Augeas, 251

Australia, feral horses of, 431; wild horses of, 18

Australian, race-horses, colours of, 441 ; thoronghbreds, 385

Austria, horses of, 345; ponies of, 345

Anvergne, horses of, 323 ; colour of, ib.

Avaris, capital of Hylssos, 230

Avebury, Lord, horse, late in Britain, 92

Avilius Teres, the charioteer, 312

Azara, 8, 9, 125, 152, 262, 428, 434

Azov, Sea of, 126; siege of, 30

Aztec empire, 270

Babylonia, horses of, 161,198

Babylonian monuments, hor'se on, 235

Bactrians, 157, 192; furnish horsemen but no chariots to Xerxes, 152; supply camels, 199

Badius, 291

Bagdad, 161, 162; horse, compared with Syrian, 186; horses of, 184; Pasha, horses of, 183

Baguals, 18, 429; Pampas horses, 262

Bai-chataine, 434

Baines, Mr, his journey, 66

Baio, 291

Balances, 210

Balas, 'bald,' 328

Balbon, 269; his death, 270

Bald-faced eharger, 328

Bald Galloway, 382

Balkan, horses in, 105

Baluchistan, horses of, 159,447

Balzano, 373

Barb, 323; crossed with Yorkshire cart-mares, 386 ; described, 249; Hutton's, 248-9, 3४1-2

Barbarian, 377

Barbary horses, 248, 376

Baroda, 158

Barra, ponies of, 18

Basclenses, 388

Bas-Medoc, horses of, 324

Basques, 388, 389

Basra, 167

Bas-reliefs, 194; Hittite, 215

Bateman, Mr, 02

Bath, Wife of, 359

Battak, ponies of, 141,156 ; colours of, 141,156 ; mouse-grey, 142 , with dorsal stripe, $i b$.
Battle, of Arbela, 304; of the Boyne, 413; of Crecy, 359; of Falkirk, 356-7; of Hastings, 354; of Lenctra, 300 ; of Poictiers, 333; of Toulouse, 332

Battus, king of Cyrene, 238

Bavaria, horses of, 344 ; their docility, ib.

Bay, 193, 258, 261, 262; chief colour of Kuhailan, 17t; Cleveland, 386; colonr, 156, 302; colour, origin of, 434 ; colour of the Markham Arabian, 378; horse, 359; horse, in Iliad, 289 ; horse, of Diomede, 291 ; horses, $173,211,357-8$; inherent in North African stock, 187; of Kuhailan breed, 173; offspring from bay stallion and chestnut mares, 374 ; origin of the various terms for, 291 ; stock, of Libya, 248; the best colour, 175 ; with black points, 170 ; bays, 38.5 ; numerous in Kuhailan, 169

Bay Malton, 381

Bayenx tapestry, 354

Beards, of Mauri, 240

Bechuanaland, 59

Beddard, Mr, 5, 200

Bede, 330, 354

Bedford, Duke of, 26, 44

Bedouins, 164

Beetewk, breed of, 351

Behring's Straits, 10

Belgic tribes of Britain, 351, 393

Belgium, horses of, 341

Belisarins, 327; his charger, 327-8

Bells, on horses, $19 \%$

Benat-el-Ahwaj strain, 207

Bend Or, 159; skull of, 11, 470

Beowulf, 120, 344

Berberah, 58

Berenger, Richard, 384 ; on Godolphin Barb, 384

Berkshire, White Horse of, 3553

Beruese Jura, 315

Bernie, shirt of mail, 331

Berwick, Duke of, 382

Bevan, Prof. A. A., 146

Beverley, chariot at, 510

Bhotan, 153, 156; ponies of, 134

Biddell, Mr Herman, 370

Bidder, $\mathrm{Mr}$ G. P., 283

Bidets, 324

Bidwell, Mr E., 506; on Abyssinian zebra, 58

Biedma, Hernandez de, 273

Bigourdan, horse, 322

Bison, 9, 428; in Paeonia, colour of, 300

Bit, Assyrian, 195; invention of, 474 ; not used by Arab, 176; not used by 
Libyans, 472 ; bits, horse, 129, 473; of horn, 93 ; of bone, of bronze, $i b$.; Mongolian, 139; not used by medieval Irish, 389; of bronze, 98 ; used by Acheans, 473; used by Assyrians, 196; used for Asiatic horses, 473, 480

Black, 258; colour of Ariège horses, 323 ; found in inferior Arab strains, 173; not original colour, 261; Hebridean ponies, 402 , 512; Highland ponies, 402, 512; horse, 346, 397; horse, syn. of Great Horse, 366; Irish ponies, 401; horses, 177, 210, $250,335,341,342,344,346,347$, $357-8,369,397$; as cavalry monuts, 368 ; come from West, 133; in France, 325; in Greece, 292; in Morocco, 248; Jelfon strain, 181; large, 335; not pure Al-Khamseh, 181; of Germany, Holland, Flanders, Friesland, Denmark, 331; result of mixture, 186

Black Agnes, 463

Blanford, Dr, 426

Blaze, 384 ; on face, 327 ; on forehead, 374,465

Bleeding Childers (or Bartlett's Childers), 381

Blood, 386; esteemed above all things by the Arabs, 176

Blow-fly, 9

Blundeville, Thomas, 318, 336, 371, 376 ; on colours of horse, $372-3$; on English horse-breeding, 363; on Flemish horses, 337; on Friesland horse, 340; on Spanish jennet, 259, 340 ; on Turk horse, 189

Blunt, Lady Anne, 161, 162, 208

Blunt, Mr WV. S., 162, 165, 166, 206, 445 ; doctrine of origin of Kohl breed, 207-8; ou Kadish horses, 163: on white horses, 186

Boats, 115

Bohemia, 345

Bombay, 149

Bone-caves, of Britain and Belgium, 89

Bones, burnt, in tumulus, 399; horse, in tumulus, 398; metacarpal and metatarsal, 152; of horse, 84, 85; of horse found with his master, 354 ; of reindeer, 84

Bonte quagga, 476

Book of Fiells, 390

Boots, Norman, 354

Bordealx, 333

Boreas, sire of horses, 290

Bos, gaurus, 4; grumniens, ib.

Bosnia, ponies of, 345

Botietle, river, 66
Boudissy, a Coptic king, 56

Boulonnais, 2

Bows, 240, 481

Boyne, battle of the, 414

Bracelets, on horses, 373

Breastplates, for horses, 130, 132

Breeding, not understood by Arabs, 176

Brenda, 463

Brennus, Celtic king, 316

Breton pony, 3

Breul, MI., 87

Bridegroom's gifts, 115

Bridle, 479 ; Assyrian, described, 195; bridles, 254 ; not used by Numidians, $i b$. ; made of rush, 240; Mongolian, 139 ; on Irish crosses, 390

Brigandines, 273, 27t

Brighton, 'Elephant-bed' at, 11

Britain, 393; Belgic tribes of, 351; no horses in, 353

British, charioteers, 98; horses, on the Continent, 361 ; Isles, horses of, 352

Britous, use chariots, 95

Brittany, horses of, 324

Broncho, 264

Bronze Age, axe of, 390 ; stations in Switzerland, 92

Brooch, from Navan Rath, 396; leafshaped, 396; penanular, used in Ireland, 396; brooches, Gallic, 394; gold, 248; La Tène, 396; penanular, 396

Brood mares, in Thrace, 306

Brown, found in inferior Arab strains, 173; not in Al-Khamseh, 383

Brumbies, 18

Brunchorst, Dr, of Bergen, 120

Brunn, Mr Daniel, 124; his book, 24

Bucephalus, bred in Thessaly, 301

Bucket, at Sesto Calende, 103

Buckingham, Earl of, 379

Buckley, Mr, on Chapman's zebra, 66

Buenos Ayres, 262

Buffalo, 140

Bullock, plough, cart, 413,414

Burchell zebra, 20, 59, 68, 445; deseribed, 66

Burckhardt, on Arab horses, 162

Burgundian horses, 318, 344

Burgundians, 327; conquered by Franks, 329-30

Burial customs, 128

Burial of horses with their masters, 128

Buriat, horseman, 135; women, 139

Burmese ponies, 141,448

Burnt Njal, saga of, 122; horse-fight, 122 
Bussorah, dealers of, 161

Byerley, Capt., owner of the Byerley Turk, 413

Byerley 'Turk, 378, 382, 413

Byzantine emperors, 306

Cabul, hor'ses of, 159

Caesar, 93, 334, 351, 393, 401

Cail, city of, 148

Caledonians, 352 ; horses of, 95

Caliphs, Arab, conquests of, 214

Callimachus, 253

Callosities, 12, 14; of Prejvalsky's horse, Clydesdales and Shires, 38; scarcely perceptible on hind legs of tangums, 154; absence of, 23,476 , 511 ; absent in the following:-Celtic pony, 18; Connemara ponies, ib.; Faroe ponies, ib.; Hebridean ponies, ib. ; Iceland ponies, 18, 420; Irish ponies, 409 ; Welsh pony, 18. Hock, 156; in hybrid, 39 ; on fetlocks, 12; absence of, 250; absent in Nortl African horses, 468 ; callosity, 7; hock, minute on Onager indicus, 37 (cf. Chestnut and Ergot)

Caltu, port of, 148

Calzeti, 374

Camargue, 399; grey, 402; of Provence, 321

Camarina, horses of, 276

Camel, Bactrian, 199; -breeding, 201 ; corps, Arab, 199 ; domestication of, 200; in Egypt, ib.; statuette of, ib.; camels, 199; used in war, 202; wild, $26,199,202$; in Lobnor, 200

Camerarius, 259, 319

Campbell, Mr C. W., 140, 426

Candace, queen of the Ethiopians, 238

Canfield, Dr, on colours of prairie horses, 265

Canoes, 273

Cantherius, meaning of, 311 ; its primary meaning, 473

Capitan, M., 87; on supposed domestication of horse in Palaeolithic times, 90

Car, sacred, of Zeus, 191

Caracalla, 55

Carajan, 140 ; horses of, $i b$.

Carian mercenaries, 243

Carmania, 47; asses of, 150

Carmanians, a warlike people, 49; sacrifice asses to war-god, $i b$.

Carni, 101

Carpus, 8

Cars, at Sentinum, 100 ; four-wheeled, 487

Carter, Ir Howard, finds a chariot, $2 \cdot 27$
Cartbage, 239, 253, 309

Cart, l'ortugnese, 483 ; see $\mathrm{Ox}$-cart

Cart-horse, 35.5; with stripes, 451; English origin of, 372

Cart-mare, Irish, 414; Lady Douglas, 463; Yorkshire, 385-6

Carvings, in bone, 86

Casperians, 192

Caspians, 192

Cassius, 101

Castor, 8

Castor and Pollux, on Roman coins, 308 ; ride white horses, 295

Castration, in England, 360; of horses, 12.5; of horses, practised by Gauchos and Pampas Indians, 125; practice of, $47: 3$

Catlin, 265

Cattle Raid of Cualnge, 396

Cancasus, 126

Cauchois horse, 2

Cavalarice, of G. Markham, 377

Cavalry, Assyrian, 196; Athenian, 298; English, 368; Macedonian, 303, 304 (described); Numidian, 310 ; of Celts, 316 ; of Goths, 329 ; of Macedon, 303; of Narvaez, 269; of Porus, 153; of Sybaris, Croton, and Tarentum, 279; of Thessaly, 303; rise of, in Greece, 292 ; Roman, 100, 309; Thessalian, 301, 481

Cave-dwellers, 240

Caves, Altamira, 87 ; Chabot, Cresswell Crags, S3 ; Kent, 11 ; Kesslerloch, 86; Kirkdale, 83; La Nouthe, Pair-non-Pair, 87 ; Combarelles, 86; Font-de-Gaune, 86; La Madelaine, 85 ; Laugerie, 85

Cecil, Lord Arthur, 35

Celdones, of Gallaecia, 258

Celebes, horses in, 144

Celle, horse-breeding of, 342

Celtiberian horses, 2.56, 260, 321

Celtic, cavalry, 316 ; dog, 398 ; pony, 18, 352 ; pony, differs from Arab and $13 a r b, 421$

Celts, did not tattoo, 105; of Italy, 100; of Noricum, 101; of Danube valley, 101; of Styria, 315, 316

Central Arabia, horses of, $\mathbf{1 6 2}$

Centuries of horse, 308

Cervus tarandus, 8.5

Chain-mail, 35.5

Chaldean type of horse, 16.1

Champagne, tumuli of, 99

Chandu, 134

Chapman, Mr J., his journey, 66

Chapman's zebra, 463; its distribution, 6.5 
Chariot, 305, 35.5; at Florence, 323; described, 223-4; burials, in Thrace, 106; fittings, 93; fittings, in Thrace, 107; four-liorse, 238, 251 ; fourhorse, invented by Lihyans, 247 ; made without metal, 226 ; of Sesto Calende, 103; of Thothmes IV, 227 ; price of, 214 ; -race, 295 ; -race, at Olympia, 276; racing, at Rome, 312 ; scythed, $247,393,496$; twohorse, 252, 285, 481 sqq.; chariots, 151, 152, 157, 351; Assyrian, 194; of Acheans, 289; with eight-spoked wheels, 289; of Britons, 95, 97, 510 ; of Britons not scythed, 98; in Champagne, 100; Egyptian, 2236; of Gauls, 95, 510; of Indians drawn by asses or horses, 192 ; Irish, 98, 397; Irish fight from chariots in Cuchulaiun Saga, 393; of Irish crosses, 390 ; of iron, 226 ; of Libyans, 192 ; on Iycenean gravestoues. 107; of Sigynni, 94; on vases, 352 ; remains of, 95 ; scythed, 240 ; Thracian, 109; used by Britons, 393 ; nsed by Romans, 306 ; Yorkshire, 95

Charioteer, a famous Roman, 312

Charles I, fond of horses, 366

Charles II, his stud, 380 sqq.; his Royal mares, 381 ; hor'ses and mares of, 188

Charles Martel, 332-3

Chartres, hor'ses of, 326

Chatti, 115; famous for their infantry, 115

Chaucer, 359

Chanci, 335

Chestnut, 8, 178, 193, 248, 300, 375 ; dark copper-coloured not coinmon in Kuhailan, 178; due to mixture, 187; fine bright, 374 ; found in strains outside Al-Khamseh, 174; horse, 122; horses, bad temper of, 474 ; horses, in Greece, 300; hunting geldiug for James I, 379; mare, 171, 184; Mongol mare, 35; origin of, 212 ; red, 376 ; now typical colour of best Suffolk Punch, 376; -roan, 141

Chestnuts, 13, 14, 37, 385; absence on fore-legs, 13; hind, absence of, 13; of ass hybrid, 37

Chigetai (Dzeggetai), 44; voice of, 52

China, borders of, 31; Great Wall, 140 ; ponies, 139,449

Chinese emperors, tombs of, 236

Chinghas Kaan, 134

Chivalry, Teutonic, 331

Choenix, 210

Christy, Mr H., 85
Chuzo, 429

Cilicians, pay tribute of white horses, 190

Cimarrona, of Pampas, 262

Cincibulus, a Gallic chief, 101

Circus, factions in, 312 ; rider, 252

Cirta, 239, 309

Clanranald, 512

Clarke, Sir Ernest, 364, 370, 377, 378, 386

Cleosthenes, the horse-breeder, 295

Cleveland Bays, 386, 449; origin of, 386

Cleves, duchy of, 338 ; the horse of, 338

Clifden, ponies of, 407

Cloak, dark grey, 396

Clonmacnoise, cross of, 389,390

Cloth, saddle, 197

Clovis, 329

Clydesdale, breed, 368, 409; horses, 402

Clydesdales, in Ireland, 413

Coach-horse, Yorkshire, origin of, 386

Coach, horses for, 379

Coaches, stage, 366

Coffey, Ir George, 392, 398, 402

Coin, of Potidaea, 301; with mare and foal, 306

Coins, Gaulish, 102; of Carthage, of Panormus, 253; of Sicilian cities, 276 ; Roman, 307

Co., King's, 389

Colonists, stupidity of, 77

Coloration, of zebras, of Libyan horse, 439-40

Colour, certain colours indicate mixed breed, 43; dark, 174; grey, 174; white, 174 ; bay, 174; of African ass, 53 ; of Asiatic, $i b . ;$ of Arab horses, 174; of Byzantine warhorses, 328; of Celtiberian horses, 256 , 257 ; of horses, 30 ; of Karadagh horses, 193; of Kattywar horses, 156 ; of kiang, 46 ; of onager, 46 ; of Kurdistan ponies, 160 ; of Nisaean horses, 194; of Norwegian pony, 452; of Onuger indicus, 47; of Parthian horses, 190 ; of Prejvalsliy's horse, 152; of Vedic horses, 15\%; received from sire, 178 ; terms for, used by Arabs, 177; of Turcoman horses, 133; white legs, 35 ; colours of Arabian horses, 175, 177-182; of Barbary horses, and Moorish horses, 248 ; of Libyan hor'ses, 248 ; of Connemara ponies, 403; of English race-horses, 385 ; of horses, 186 , $261,348,371,373,398$; of horses killed at Falkirk, 357; of horses 
of Mexico and Texas, 266; of modern Spanish horses, 258; of Pampas liorses, $26^{\circ}$; of prairie horses, 26.5; of Sluire horses, 368; of wild horses, 32 ; table of, 441-3; the best, 372

Colton, John, Archbislop, 412

Colt's head, symbol, 215

Columbus, 264

Conchobar, king of Ulster, 396, 400

Coneyskins, 382

Congested Districts Board, 402

Congo, 59; zebra of, 55,60

Comnemara, Celtic pony of, 18 ; pony, 40, 388; ponies, $40.2 \mathrm{sqq}$.; absence of hock callosities in, 409 ; colours of, 403 ; origin of, $405-6$; so-called 'Eastern' type, 408

Connemara-Welsh pony, 20

Conquests, Arab, due to acquisition of horse, 213; due to horses, 218

Constable, $\mathrm{Mr}$ A., 388

Constantinel1, 239

Constantinople, 161; horses sent to, 182

Consuls, allowed horses, 307

Contorniates, 329

Conway, Prof. R. S., 223

Copper, 130

Copperthwaite, Mr R. H., 441

Corax, a black horse, 295

Corn Laws, 414

Corsairs, plunder ships, 149

Corselets, linen, 117

Cortes, 266; his horses, 269; sets sail for Mexico, 269

Cossacks, 31

Cotton, pad of, used for riding, 177

Cow, flesh of, 222

Cox, Dr Nichael, 387, 392

Cradock, zebras near, 62

Crannog, horse skulls from Irish, 391

Crawfurd, Jolın, 144

Crawshay, Mr, 68

Crawshay's zebra, 61,68

Crecy, battle of, 359

Cremation, 398

Cresswell Crags, cave in, 83

Crete, 220

Crisp, Mr, his Suffolk stallion, 374

Croesus, horses of, 194

Cro-Mlagnon, rock shelter, 85.

Cromwell, Oliver, 366 ; buy's a black horse, 380; his Commissioners, 412

Cross-bred horses, 321 ; taller and stronger. 174 ; cross-breds, $160,248-$ 50 ; head longer in, 323

Cross, at Clonmacnoise, 389; Irish, 390

Cualnge, Cattle liaid of, 396
Cuba, 266, 269; conquered, 267; horses, wild oxen, and hogs, 271

Cuchulaimn, 98, 396; his horses described, 397 ; Sagn of, 393 sqq.

Curium, rase of, 289

Curule, oflices, 307; horses, ib.; chariots, at liome, ib.

Cutch, 158; asses of, 47

Cuvier, Prof., 8*2

Cuyer and Alix, 322,342 .

Cuzco, 271

Cyprus, vase-paintings, 289

Cyrene, 238, 251, 253; its horsebreeding, 238

Cyreneans, send war-horses to Alexander, 253, 306

Cyrus, 129, 191; crosses Gyndes, 191; horses sacrificed to, 190

Czerski, Dr, 43; on tarpan, 42

Dalmatia, horses of, 318,327 ; bad temper of, $i b$.

Dam, supposed to be the more important parent, 188

Danes' Graves, chariot burial, 97; chariot from, 95

Daniell's quagga, 75

Danish horse, 2; horses, 342,343

Daphnae, 242

Dappled-dum horses, Beowulf, 120

Dappled horses, 111

D'Arcy, lioyal mare, 382

D'Arcy 'Turk, 382

Darien, horses brought to, 269

Darius, 211; signet of, 192

Darley Arubian, 169, 382; his portrait and colour, 384

Darley, Mr, 384

Darwin, Charles, 3, 9, 151, 152, 157, 265, 433-4, 444 sqq.; cites striped ponies of Java, 1.2; on origin of Arab horse, 209, of English thoroughbred, ib.

Date colour, 177 (cf. Spadix)

Date-coloured horses, 348

Davis, Mr T. M., excavates a tomb, 227

Dawkins, Prof. Boyd, 83

Day, Mr A., has a horned horse, 152

Debae, use camels in war, 202

Decius Mus, 100

Defenneh, 242

Deli, 141

Delphi, 316

Denarius, Roman, 308

Denmark, 118

Depression, in horse skulls, 470 ; sec Fossa

Derby, winners of, $4 \pm 1$

Descent of a horse, 168; through males, 381 
Desert, Gobi, 32; Mongolian, ib. ; Palinyrene, 161 ; Syrian, $i b$.

Desmatippus, 6

Destriers, 147,355

Devonshire Childers, same as Flying Childers, 384

Dextrarii, 355

D'Hobsonville, 154

Diaz, Bernal, on horses, 267, 511

Digits, 13 ; lateral, 8; primal, 7 ; primal five, 6

Dio Cassius, 95; mentions zebra (hippotigris), 55

Diodorus, 99, 105

Diomede, captures horses of Aeneas, 290

Dionysius, of Syracuse, imports Ve. netian horses, 104; his white horses, 278

Dioscuri, 308

Dobrusky, M., 107

Docility, of Bavarian horses, 344; of Libyan liorse, 472 ; of Spanish jennet, 340

Docking, of horses, 140

Dog, 4; Celtic, 398; Gmmnar's Irish, 419; interbreeds with wolf and jackal, 426; dogs, Celtic, 400 ; Irish, 419 ; wolf, 401

Dolon, 108

Domestic horses, earliest, 4

Domesticated Indian horse, 159

Domestication, of horse, 128; of ox, 128

Don, river, 51, 126

Dongola, breed of, 2, 219; a cross, 250 ; horses, described, 249

Dordogne, caves of, 85 ; figures in, 84

Dorsal stripe, of hybrid ass, 37,386 , 445; in Cleveland Bay, 386

Draught-horses, 346

Drenthe, breed of hearse horses, 342

Dshigguetei, 44 (=Dzeggetai)

Dsjulfa, 170 ; strain of, 167

Dublin Co., 393, 488

Ducaila, Sultan of, 248

Duck, Aylesbury, 460; Muscovy, wild, ib.

Duckworth, Mr W. L. H., 436, 451

Ducrost, MI., 83

Duke of Newcastle, 378

Dukhova Moghila, barrow of, 106

Dun, 175; striped, 260; striped, in Mexico, 269 ; the worst horses, 260 ; Mongol pony, 39

Dun-coloured horses, 110, 296, 357, 465; of Acheans, 289; of Spain, 257 ; with dorsal stripe, 257,348 ; in Beowulf, 120; in Veda, 152; on vases, 294 ; with stripes, 274 ; with stripes, in North America, 265
Dupont, M., 89

Durr grass, 58

Dutch, stupidity of Dutch colonists, 77 ; horse, 368; horses, 341, 350

Dynasty, Egyptian, xvirth, xvinth, xixth, 236

Dzeggetai, 44, 52; of Mongolia, 44

Dzungaria, wild horses of, 26

Ears, projecting outwards, 38

Earth, mother of Arion, 286

Eastern, blood, so-called, 10; sires, 381

Eclipse, pedigree of, 382; his posterity, 384 ; skull of, 470

Edom, 202

Edward I, 356

Edward III, promotes horse-breeding, 358

Edwards, Mr, 445, 446; first described quagga, 72

Egypt, 161, 204; exports horses, 251; horse in, 215

Egyptian, conquests, due to horses, 218; horses, 215-6, 229; horses, dark colour of, 218; kings, tombs of, 236 ; terms for chariots, 215 , for charioteer, 216 ; xviIth dynasty Libyan in origin, 236

Egyptians, did not ride, 216, 510; who they are, 222

Eight-legged horse, its origin, 347

Eisir, 118

Elements, doctrine of the, 371

Elephant, 153 ; at Rome, 55; birth of, 148; skin of, nsed as shield, 240; elephants, 307 ; in India, 153 ; in Java, ased in war, 146

Elephant-bed, of Brighton, 82, 421

Elephantine, 222, 238, 243

Elis, 251 ; horses of, 285

Elizabeth, queen, on progress, 362

Elk, Irish, 85

El Masudi, on zebras, 56

Emain Macha, modern Navan Rath, 400

Emir, Wooing of, 393, 400

Emir, Fai-sal of Najd, his view of horses, 178

Emnanuel College, 412

Enactments to raise the standard of horses, 360

English Colonists, stupidity of, 77

English, great horses, 355-6 ; horses brought to Ireland by Dr Winter, $41^{\circ}$; race-horse, 212; thoroughbred, 323, 321; thoroughbred, crosses of, 324 ; thoroughbreds, 350 ; thoroughbreds, effect ou progeny, 323

Engravings on bone, 86 
Eocene, 6

\section{Eohippus, 6}

Epaminondas, 301

Epidaurus, horses of, 302

Epirote horses, 327

Epirus, horses of, 318

Equidae, ancestor of, 444 ; striping of, 79-90; the existing, 12 sqq.

Equitation, $478 s q q$.

Equus, ufricanus, 22 ; antiquorum, 61; uryanus, 3 ; asiaticus, 2 ; asinus, 52; belgicus, 2; Boehmi, 61 ; britannicus, 2 ; Burchelli, 59; c. germanicus, 312 ; c. hibernicus, 401; c. libycus, 469 ; c. mongolicus, of Pietrement, 209 ; caballus, 12, 16; caballus celticus, 12, 18 ; caballus libycus, 425 ; Chapmani, 61, 65 ; complicatus, 8, 263; Crawshayi, 68; excelsus, 264; foai, 64, 508; fraternus, 8; frisius, 2; germanicus, 2; hemionus, 43, 45; hibernicus, 2 ; kian!, 12, 43 ; mongolicus, 3; namadicus, 10 ; occidentalis, 8; onager, 43; pacificus, 264; pectinatus, 264; Przewalskii, 12; quagiga Danielli, 75; quaggoiales, 143,470 ; robustus, ligeris, 10 ; Selousi, 61 ; sequunius, 2 ; sivalensis, $10,11,142,470$; had pre-orbital pit, 469 ; somulicus, 12,53 ; stenonis, 10, 143,462, 470; tau, 8; Warli, 64 ; zebra, its description, 62 ; zebra Hartmanni, 62; zebra Penricei, 62 Eratosthenes, 51

Ergot, 13, 15; absence of, 13; ergots, absence of, 477 ; absence of, in Celtie pony and in Arabs, 19; frequently absent in Icelandic, Hebridean and Connemara ponies, in pure bred Arabs and thoroughbreds, 469; of ass hybrid, 38; see Cal. losities

Erichthonius, mares of, 290

Erlenbach, black breed, 345

Ermall, Prof., 216

Esau, 204

Escholtz Bay, 8

Esher, port of, 148

Esseda, Gallie, at Sentinum, 100

Essex, Pleistocene beds of, 11

Este, 103

Estremadura, horses of, 258

Ethiopians, 240 ; Troglolyte, 238

Etrusea11, horses, 314

Eudes, 332

Eunuch, Ethiopian, 238

Euphrates, 161; horses of, 199

Eurasia, 7

Ewart, Prof. J. C., 5, 7, 40, 55, 59, $61,64,66,68,79,152,403,421$,
$445,450,452,457,508,511-12$; his Celtic pony, 18; experiment with Asiatic ass, 35 ; experiment with chestuut Mongol pony, 40 ; his zebra hybrids, 163

Ewe-necked horses, 18:

Exaenetus, of Agrigentum, 105, 276

Exchequer Rolls, 35.5

Exmoor pony, 399 ; has good blood, 39 ; her hybrid, 35 ; ponies, 39

Export of horses, forbidden, 360

Eyzies, 85

Ezekiel, 193, 196

Fairs, horse, 193

Falkirk, battle of, 357

Fallow-dun cob, 450

Faraday, L. Winifred, 396

Faroe Islands, 22; origin of ponies of, 418

Faroe, ponies, 22, 352, 416 ; pony, 23,24 ; without callosities, 23

Fatima, Arab tilly, striped, 445

Feet, white, 181, 373-4; in Kuhailan, 173

Females, descent through, 381

Fenwick, Sir John, 381

Feral horses, 428 squ.; capture of, 432 ; extermination of, 133

Ferry, M., 83

Fertility, of breeds, 4 ; of Libyan horses in North Africa, 475

Fetlocks, hairy, 408

Fezzan, 238

Fibulae, La Tène, 100

Fillies, kept in tribe, 176

Finnish horses, 347

Fish, horses fed on, 148; used to feed horses and cows, 149

Fitzwilliams, $\mathrm{Mr}, 142$

Flamer, 307

Flanders, 356 ; horse, 377 ; horse of, deseribed by Blundeville, 337 ; stallion, 364

Flea-bitten grey, 301

Flemings, mares of, $337-8$

Flemish horse, 2

Flint implements, 83

Florida, Adelantado of, 271 ; hor'ses landed in, 271

Flower, Sir IV., 5, 13, 56; on Prejval. sky's horse, 35

Flying Childers, bay colour of, 384

Foal, 40; Arab, 37 ; Prejvilsky, 36; recldisli-grey fiom grey parents, 456 ; thoroughbred, 37 ; Arab, how reared, 176; highly bred, markings on, 456; of race-liorses, striped, 445 ; of Sir G. Ouseley's eliestnut mare, 462

Forehead of wild horse, 35 
Forster, the traveller, on wild horses, 30

Fossa, in skull of Quagga, 76; in skull of certain Equidae, 143, 509; pre-orbital, in Hipparion, in E.sivalensis, in E. stenonis, and E. quag. goides, in Quagga, in domesticated horse, in skull of Bend Or, 143; in 'blood' horses, 469-70; preorbital in young ass and in male Grant's zebra, 143

Four-horse, chariot, 251 ; chariot, on vases, 252 ; chariots, 238

France, horses of, $320 \mathrm{sqq}$.

Franks, 327, 329, 353; begin to employ cavalry, 330 ; conquer Thuringians and Burgundians, 329-30 ; method of fighting, 330 ; Ripuarian, 338-9

French horses, colour of, 325

Frenchmen, ride long, 140

Freyr, a Swedish god, 118

Friesland horse, 339, 340, 364, 377; described by Blundeville, 340 ; a good trotter, 340 ; origin of Pinzgaver breed, 346

Frisian horses, 318, 327, 421

Frisii, 335

Funeral horses, 342

Fur, trade in, 118 ; sables, $i b$.

Gadow, Dr Hans, 460

Gaetuli, 238

Galicia, 258; horses of, $i b$.

Gallic, brooches, 394; cavalry, 101 ; chieftains buried on their chariots, 100 ; shields, 394; spears, called saunia, 99

Games, funeral, 252

Ganymede, 290

Garamantes, 238

Garrison, at Elephantine, 238

Garstang, Dr, 510; on Hyksos, 233

Gascony, supplies horses to the English king, 359

Gauchos, 125, 428

Gaul, horses of, 312 ; ambacti of, 317

Gauls, have chariots in Italy, 100 ; horses of, 310; of Lower Danube, 315 ; serfs of, 316 ; used chariots, (). 5,99

Gavioe ponies, 141

Gazelle, 208

Gedrosia, 201

Gela, coins of, cavalry of, 277

Geldings, 163, 473; large grey for the king's coach, 379; price of, $i b$; used by Romans, 311

Genealogies, of Arab horses, 167
Gentleman, the medieval, 293

Georgi, Father, 154

Gerard, the brothers, 30

German, great horse, 336 ; modern horses, 341

Germanicus, E. c., 342

Germans, horses of, 113,332 ; utilize zebras in East Africa, 79 ; venerate white horses, 114

Germany, heavy horses of, 342 ; horsebreeding in, 342 ; liorses of, 314, $334-5$

Gestation, of horses, 16; of asses and zebras, $i b$.; period of, 36

Ghor-khur, 45,46

Ghour, 46

Ghur, 46

Ghuran, 46

Gilbey, Sir WV., 355, 363, 386, 392 ; on Irish horses, 386 ; on origin of Irish Hobbie, 402

Giles, Prof., 140

Gill, Mr T. P., 405

Ginni, of Liguria, 321

Giraldus Cambrensis, 354, 388, 389, 412

Gmelin, Dr, 42, 43; his notice of tarpan, 41

Gnoo, 73 ; accompanied quaggas, 74 ; brindled, accompanied Burchell's zebra, 74

Gobi desert, 28, 31

Godolphin Barb, 382, 384

Gods' horses, names of, 121

Gods, ride, 118

Goethe, on Selene's liorse, 297

Gog-MIagog, 384

Gold, 130 ; brooches, 248 ; ornaments, 240 ; trappings, bits, etc., 129

Gonville Hall, 412

Gothland, large war-horses of, 347

Goths, attack Rome, 327; cavalry of, 329

Grant's zebra, described, 70

Grave, shaft, at Mycenae, 285

Gravestone, at Mycenae, 28.5

Gray, Rev. T. 'T., 413

Great horses, 363, 361; scarcity of, 366

Greece, Bronze Age of, 251, 285; horses of, 285 sqq., 292, 300-2

Greek, chestnut horses, 300; horses not shod, 298; mercenaries in Egypt, 223; war-horse, 299-300

Greeks, 244; at Cirta, 239 ; descents upon Egypt, 220; did not use saddles, 299

Green, Mr F. W., 510

Greenwell, Canon, 92, 95, 97, 510

Grenada, horses of, 258 
Grèvy zebra, 11, 57-8, 59, 69; hoofs of, 5!) ; chestuuts of, 59,506

Grey, 258, 379; Celtiberian horses, 257 ; colour, 174; flea-bitten, 301 ; Now Forest ponies, 405 ; not original horse colour, 261; pommely, 359; ponies, 343 ; racing mare of James I, 379; usual colour in Turkish Arabia, 183; horses, 122, 346, 357-8, 397, $398,402,431$; Hamdani, 173; in Bagdad, 183; in France, 325 ; outcome of mixing North African with upper Asiatic and European blood, 186

Grey Hautboy, 382

Grey Wilkes, 382

Greyhound, 363

Grijimailo, the brothers, 26, 33, 43

Grunau, 117

Guillemark, Dr F. H. H., 149

Gumnar, his brown horse, 122; his dog, 419

Gutch, Mr Clement, 97

Gylfinnung, 121

Gyndes, river, 191

Hackney, English, 386; stallions, 402

Hadban, strain, 169, 170

Haddon, Dr, 483

Haflinger ponies, 345

Hagenbeck, Mr Carl, 26, 28, 33, 58

Halin, Dr, 484

Hair, mode of wearing, 239

Hakluyt, Richard, 271

Half-breds, 163

Halicarnassus, Mausoleum at, 306

Hall, Mr IV. H., 310

Hallstatt, swords from, 394

Halter, 479

Hamdan, 205

Hamdani, colour of, 169 ; shape of, 170 ; strain, 169,206

Hampshire sheriff, 356

Hannibal, 101; his cavalry, 254

Hanover, horses of, 342

Hanoverian, 341

Hans, Muscovy drake, 460

Harness, 492; of chariot, 228

Harquebushes, 259

Harold Fairhair, 416

Harold, king, at Hastings, 354

Harris, Capt. Cornwallis, 67; describes quagga, 73

Hart-draver, name of Friesland horse, 341

Hartwell, 60; translation of Pigafetta, 5)?

Harwood, Sir Edward, 366

Hasdrubal, 256
Hastings, battle of, 354

Hauberk, 331, 336, 355

Havanmah, 271

Hawes, Mr C. H., $135^{\circ}$

Hawk, mark of a gentleman, 293,363

Hawkewood, Sir John, 361

Hayes, Capt. M. H., 5, 13, 69, 141, $159,193,320,342,350,386$; breaks in a zebra, 78 ; on Indian horses, 116 ; on Mongolian pony, 134

Head, length of, characteristic of cross-bred horses, 298; longer in cross-breds, 323; of horse, on Attic tombstones, 294 ; size of, 323

Headstall, 479

Hearse horses, 342

Hebridean pony, black, 20 ; flat-nosed variety, 21

Hebrides, ponies of, 18, 418; Spanish blood in, 512

Height, of Arabian horses, 173

Heimdal, his horse, 121,346

Hejira, 165

Helios, horse of, 297

Helmets, conical, 315

Helvetian horses, 322

Helvetians, 93

Helveto-Gallic horse, 322, 399

Hemionus indicus (or Onager iudicus), 43

Hemionts, in Syria, 49

Hemippus, 12; in Syria, 49

Henga country, Crawshay's zebra of, 68

Hengist, 353

Hemry II, horses of, 355

Henry V11, forbids export of horses, 3.59

Henry VIII, his enactments to raise the standard of horses, 360 ; forbids export of horses, $i b$.

Hermit, skull of, 470

Herodotus, 94, 198; on wild asses, 56

Hervey, Lord Francis, 364

Hessian horses, 341

Hessleskewe, chariot-burial, 97

Hibernicus, E. c., 324, 401

High Almaine, stallion, 364

High-caste Arabs, 183

Highland ponies, 402,450

Hijaz, tlie, 164, 165, 213; horses of, 16.4

Hilprecht, Dr, 198, 214

Hindus, 151

Hindustan, Southern, had no indigenous horses, 150 ; ill adapted for the Equidae, iv.

IIipparion, 85, 470; antelopinum, 6; fossa in skull of, $142,143,469$ 
Hippemolgi, 127

Hippobosca, 9

Hippolytus, quadriga of, 294

Hippotigris, 55

Hittite inscriptions, 215

Hittites, 234; kings of, 214; no horses in Abraham's time, 235; regarded as Mongolian, 234; sup. posed to have introduced the horse to Western Asia, 234; who were they? 214

Hobbie, black, beat Barbary horses, 377,512 ; cause of its disappearance, 410 ; 'Englisb,' 361 ; Irish, 361,388 ; origin of, 392

Hobbies, Irish, 388-90 ; black, Irish, 402

Hobbini, i.e. Hobbies, 388 ; English, Irish Hobbies so termed in Frauce, ib.

Hobbles, on horses, 130, 190

Hobbye, Irish, 377

Hobelarii, i.e. Hobbies, 390

Hobley, Mr C. W., 79

Hock callosities, absence of, 23

Hocks, bent, 38

Hogged mane, 130

Hogs, in America, 273 ; price of, $i b$. wild, in Cnba, 271

Holinshed, Ralph, 360; on English horses, 352

Holman, Messr's, 216

Holofernes, 196

Holstein, liorses of, 341

Homer, 107; has not myth of Pegasus, 289

Homeric Age, 252, 289

Hommel, Prof., 216

Hoof, of Prejvalsky horse, 38; of Libyan horse, 470

Hoofed animals, 5

Horiad, tribe, 134

Horns, of reindeer, 84; on horses, 152

Horsa, 353

Horse, black, 210; bones, 92, 354; bones, in tumulus, 398 ; cloth, 497; domestic, late in Ireland, 98; driven in China, 140 ; figured on bone, 83; fossil, in Belgium and France, 83; fossil, of Essex, 11; head of, on Attic tombstones, 294; horned, 152 ; in Babylonia, 198; late in Egypt, 215 ; La Tène, size of, 93; Libyan, 5; Malay name for, 146; North African, 5 ; not indigenous in Sonthern Persia, 150 ; not native in Lydia, 194; of cave paintings of Dordogne, 19,85 ; on coins, 253 ; of Julius Caesar, 8 ; of Seius, 302 ; of Selene,
297 ; of Helios, $i b . ;$ price of, 214 ; red, 209 ; remains of, 399 ; ribs of, 151 ; ridden, 251, 252; sacrifice of, 129 ; small, of Pleistocene, 19; used as food, 84; with 34 ribs, 151-2 ; yellow, 210 ; horses, acquisition of, by Egyptians, 218; as a bridal gift, 115; Assyrian, 198; bnried in Gaulish graves, 100 ; captured by corsairs, 149; carriagehorses, 4; cart-horses, 4 ; dark, 244 ; destruction of American, 9 ; do not breed in South India, 148; domestic, 4 ; drawings of, in caves, 87; export of, forbidden, 359-60; fed on fish, 149 ; feral, $4,18,32$; five-toed, 7 ; one-toed, 7 ; fossil, in America, 8 ; fossil, in N. America, 264 ; fossil, two kinds in Essex Pleistocene, 82, in marl in Ireland, 82 ; hearse, $3 \pm 2$; Helvetian, 322 ; hunters, 4 ; imported into England, 356; Indian, bad tempered, 473 ; Indian, ridden with muzzles, 153; in Indian Arehipelago, 144; in Palaeolithic period, 89; in Zechariah, 211; killed at Falkirk, 357; 'kings of horses are dark,' 178; left behind in Texas, 273; lumbar vertebrae of, 42; Libyan, 240; Lydian horses eat snakes, 194; mentioned by Chancer, 359 ; mentioned in Koran, 213 ; not indigenons in Malay Peninsula, 146 ; none in Nabataea, 202 ; number of, used by Queen Elizabeth on her progresses, 362 ; Numidian, 241; objection of, to tread on dead, 109; of Acarnania, 302 ; of Acheans, 110 ; of Aeneas, 291; of Aetolia, 302; of Anchises, 291; of Antilles, 269; of the Apocalypse, 209; of Arcadia, 301; of Argolis, 112, 302; of Bigourdan, 322 ; of Cabnl, Baluchistan, and Trans-Indus, 159; of Cortes, 269; of Cuchulainn, 397; of Dalmatia, 318; of De Soto, 274; of Dongola, 249; of Elis, 112; of Epidaurus, 302; of Epirus, 318; of Germans, 113; of Greece, 292, 3003 ; of India, 146 sqq.; of large size, 246 ; of La Tène, 322 ; of Macedonia, 302; of Mexico, 266-7; of Navarre, 322; of Peloponnesus, 301; of Pyrenees, 322; of Sigymni, 94; of Solntré, clescribed, 84 ; of Syria, differ from those of Bagdad, and both inferior to Anazah, 184; of Tarbes, 322; of Texas, 266-7; of the Mausoleum, 306; of Thrace, 302 ; of Tros, 290 ; of Veneti, 104 ; 
price of, 147-8; ridden without bridle, 241 ; roadsters, 4; Roman, sent to Masinissa, 248; Russian, 30 ; sacrificel, $117,151,190$; saerificed, among Veneti, 105, by Illyrians to Cronus, 105 ; sacrificed at Rome, 307 ; scaree in Carmania, 49 ; slain at funeral, 128 ; slain by Tartars at funeral of a Khan, 136; sons of, 164; Spaniards, De Soto's followers kill their lhorses, except four or five, 273; trappers, 4; tribute of white, 190 ; two kinds in Palaeolithie time, 89; unknown in many islands of Indian Archipelago, 144; white, amongst the Veneti, 104 ; white, in Sicily, 105 ; wild, 16, 18,30 ; wild, extermination of, 433 ; wild, in Quaternary period, 83 ; wild, of North America, 265 ; with horns, 152; with stripes, 450 ; ornaments, 504

Horse-archers, 196

Horse-armour, 132

Horse-bits, 129 ; in Swiss Lake-dwellings, 93 ; of iron, 95 ; iron, at Sesto Calende, 103

Horse-breeding, 239, 355, 363; Arab ignorance of, 209; in Arabia, 205; in Armenia, 193; in England, 358 ; in Germany, 342; in Greece, 112; in Numidia, 310 ; in Sicily, 276 ; in Thrace, 306 ; Irish, $386^{\circ}$ sqq.; of Cyrene, 239; of Libyan tribes, 238; peoples, 192

Horse-fair, 140; outside London, 355

Horse-feeding Mead, 192

Horse-fighting, in Iceland, 122-3

Horse-flesh, 430 ; eating of, 122

Horse-hoofs, used for making corselets, 117

Horseman, on Gaulish coins, 102

Horse, Naster of the, 381

Horsemen, Assyrian, 194 ; Bactrian, 152 ; in Book of hells, 391; Spanish, 271

Horse-shoes, 352, 502 sqq.

Horse-sickness, 10, 77

Horse-trade, Indian, 183

Hound, mark of a gentleman, 293; on tomb, 293

Howitt, Dr A. IV., 431

Hrolf, the Ganger, 335

Hughes, Prof. MeKenny, 505

Hungarian horse, 319 , 377 ; stallion, 364

Hungerford, Sir Walter, 363

Huns, horses of, 318

Hunters, Irish, 408, 413

Hunting scene, 390
Hutehinson, Miss, translation of Pigafetta, 60

Hutton's, Bay Barb, 382 ; Grey Barb, ib.

Huxley, Prof., 143

Hyaena, in caves of Britain, 83

Hybrid, coat of, 37 ; zebra-horse, 476 ; luybrids, Brazilian, 459; duck, 460 ; Ewart's, 463, 468; zebra, 452; zebra-ass, 4.53; zebra, bred in British East Africa, 79 ; zebra, of Sir H. Meux, 463-4

Hyksos, 3, 215, 218, 229, 236 ; derivation of name, 234; identified with Hittites, 233; kings of, 230; expulsion of, 238

Hypanis, river, 125

Hypohippus, 7

Hyracotherium, 6

Iapodes, 101

Iazyges, 116

Iberian horse, 256

Iberians, warfare of, 256

Ibn Batuta, 145

Ice Age, 10

Iceland, colonisation of, 416,418 ; conversion of, 122 ; horse-fighting in, 122 ; yellow-dun pony of, 18

Ieeland ponies, $14,21,23,352,416$; colour of, 24 ; origin of, 418,420 ; without hock eallosities, 23

Idumea, 202

Iliad, bay horse in, 289

In-breeding, 466

Inca, capture of, 271

India, gets horses from Kalmucks of Khoten, 133 ; horses of, $146 \mathrm{sqq.;}$ ill adapted for horse-breeding, 153; North-western, 151 ; obtains horses from Turkish Arabia, 182 ; pied horses of, 349 ; IVestern, asses of, $\pm 7$

Indian Arehipelago, 144, 145

Indian horses, bad-tempered, 473 ; muzzles used for, $i b$. ; domesticated, skull of, 159 ; vicious, 153

Indians, 157, 199; chariots drawn by horses or wild asses, 152,192 ; drive wild asses, 47 ; employ ehariots, 152; hare horsemen, 15:; North American, 430 ; Pampas, 262 ; Querenia, 125

Indies, West, horses of, 511; see Cuba

Iudo-Seythia, 158

Iudus, 157

Infection theory, 462

Ingrolf, goes to Iceland, 416 ; settles in Iceland, 418 
Inscription, Latin, 312

Inscriptions, Hittite, 215

Inverarity, Dr, 54

Iona, 418

Ionian mercenaries, 243

Irak, horses of, 161

Ireland, La Tène period in, 394; Normans in, 354; North, ponies of, 18 ; trade with Spain, 389

Irish, native, wore no armour, 388; armature of, 389; fight from chariots, 393 ; method of fighting and riding, 388 ; representations of, $388-90$; anchorites, in Iceland, 418; bronze axes, 390 ; brooch, 396 ; cart-mares, 414 ; chariots, 98 ; crosses, 38990 ; dogs, 419; Epic, armature in, 393; Hobbies, 361, 377, 38890; Hobbies, exported to France and Italy, 388; horse, origin of, 391 ; horses, 352, 386 sqq. ; horses, bought for France, 387; horses, legs of, 151; horses, morlern, 402 $s q q . ;$ horses of a larger size, 412; horses, representations of, 389,390 ; horse-skulls, 391; hunter, 417; hunter, origin of, 410 ; hunters, 413 ; mare, 463 ; slaves, in Iceland, 419 ; thoroughbreds, 414; trade with Gaul and Spain, 400, 401

Iron, 129 ; bits, 95 ; chariots of, 226 ; tires of wheels, 95 ; horse-bits, at Sesto Calende, 103; late in Ireland, 98 ; not used by Sarmatians, 117

Iron Age, 103; in Greece, 112 ; in Italy, 103

Ironsides, 366

Isabella-coloured, 32,34 ; meaning of, 44

Ishmael, 206

Isidore, on dun horse, 260

Islam, in Indian Archipelago, 145

Istri, 101

Italy, horses of, $278-9,314$

Jabin, 226

Jackal, 4, 426

James I, 364

Jarls, Norwegian, 416

Java, horses of, 144, 349; ponies, 141 , 448 ; ponies with large functional pre-molars, 142 ; striped ponies of, 142 ; Sultan of, 145

Javanese, very bad riders, 144

Javelin, 240

Jelfon, strain, 167, 181; black horses, 187; colour of, 171; often black, 171 ; in Syria, 181

Jennet, of Spain, 259, 377; its docility praised by Blundeville, 340 ; of $\mathrm{Li}$ guria, 321

Jensen, Dr, 215, 234; origin of Hittites, 214, 234

Jilfan (=Jelfon) strain, sometimes included in Al-Kbamseh, 170

Job, 203

John, Don, of Austria, his horses, 188 ; the Stable of, 189

John, King, imports horses, 356

Johnston, Sir H. H., 262

Joruandez, 118

Joseph, 218

Josephus, 230

Jugurtha, 310

Juliacus, 338

Juliers, horse of, 338

Julins Caesar, 310

Jutes, 353

Jutland, horses of, 341, 342

Kaan, Knblai, 134; his white horses, ib.

Kiadischi, a mixed breed, 161

Kadish, 471; horses called, 164 ; its primary meaning, 473; voice of, 180,434

Kalmucks, horses of, 133, 351; their waggons, 127

Karabnlo, breed, 133

Karadagh, breed, 193; horses of Armenia, 446

Karakoum, 31

Kar-kuk, 161

Katerfelto, famous stallion, 39

Kathiawar, horses of, see Kattywar, 156

Kattywar, 158, 260; dun-coloured horses of, 465 ; horses of, 349,446 ; horses, described, 156; horses with stripes, 156

Keheilan (= Kuhailan), strain, usually bay, $16.5,169$; look more like thoroughbred, il.

Keheilet, 165

Keheilet Ajuz, 166

Keller, C., on Assyrian bas-relief, 49

Kells, Book of, 390, 391

Kells, cross of, 390

Keuny, Mr Natthew, 387, 392

Kent's Cave, 11; bones in, 83

Kerr, Prof. Grabam, 9

Kertch, 130

Kesslerloch cave, 86

Kettle Haeng, goes to Iceland, 416

Kherdecht, 47

Khorassan, best Turcoman horses, 132

Khoten, horses of, 133

Kiang, 20, 35, 45, 476; hybrid (socalled), 36 ; voice of, 46,52 
Kiảish, means a gelding, 163; not of Arab blood, 163

King, horses of, 355

King, of Gauls, 316; Scythian, his burial, 128

King's Co., 390, 412

Kings of horses, are dark, 178

Kings, Scleucid, 306

Kirghis, capture wild horses, 27 ; horses of, 351 ; hunt wild canels, 26

Kirkdale cave, bones in, 83

Kitcliener, Lord, 476

Kladrub breed, 345

Knight, Chaucer's, 359

Kuights, at Athens, 293

Kobdo, 27, 28

Kochlani, mentioned by Niebulır, 167 ; of Arabia, 161; where bred, 167

Kolıl, 16ว

Kohl breed, 165, 168; earliest reference to, 205 ; origin of, $166,206-9$; origin in North Africa, 246 ; strains of, 169 ; tail of, 229 ; theories of its origin, 207; myth of origin, 213

Koklani, in Persia, 167 ; cf. Kochlani

Kootannie lands, 429

Koppatias, colour of horses? '296

Koran, 145 ; passages about liorses, 213

Koulan, 41, 46

Koumiss, of Kalmucks, Nogais, and Seythians, 127

Kouyuujik, bas-reliefs of, 195

Kremer, Dr A. V., 216

Kublai, 134

Kuhailan, horse, 472 ; roice of, 180

Kuhl (=Kohl) breed, 165 ; origin of nane, $i b$.

Ku-mait, dark bay, 177

Kumrah, 18, 128

Kurdislı mares, 163, 449

Kurdistan, ponies of, 160 ; ponies, colours of, 160

Kurds, 132; anxious to obtain Arab stallious, 132 ; horses of, 161 ; sooty black horses of, 181

Kusneh, 31

Laban, 204

Laconian horses, 312

Ladak, kiang of, 44

Laderg, plateau of, 323

Isake Baringo, zebra from, 11

Lake-dwellings, Swiss, 92

I ampagie, 333

Land-bridges, 10

I andnamaboc, the, 418

Langobardi, 335
Lankester, Dr Ray, 470

La Plata, wild horses of, 262

Lartet, M. , 85

Lasso, 428, 429, 479 ; used by Sagartians, 1.12; used by Sarmatians, 117 ; used by Scythians, 130 ; used to capture wild ass, 49 ; used to eatch zebras, 78

La Tène, culture in Ireland, 394; horses of, 322, 398; period, 93, 100 ; period, in Ireland, 394 ; swords, 396

Laumont, breed of, 344

Lavenham, $36 \pm$

Layard, Sir A. H., 49, 197 ; description of Arab mare, 50 ; describes chestmut mare, 184

Layard, Mr, describes Chapman's zebra, 65

Leather, boiled, 140 ; morocco, 228

Leeds Arabian, 382

Leg, i.e. share, of mare, 168 ; legs, white, 374

Legion, Roman, 308

Leidy, Mr, 7

I,eif, goes to Iceland, 416

Leopards, 208

Leucippus, 292

Leuctra, 300

Library of Alexandria, 220

Libu, Libyans, 222

Libya, 5; asses in, 56

Libyan Egyptiaus, 238; llorse, hoofs of, 470 ; voice of, $i b$.; its docility, $472-3$; most fertile in North Africa, 474 ; origin of, 428 ; horses, 219 , 245 ; horses, described, 240 ; horse. breeding, 238; horsemen, described, 241 ; tribes, 219 , 238 sqq.; Libyans, at Marea, 222; chariots of, 192,247 ; dress and arms of, 240; had no metal, 226 ; invent four-horsechariot, 247

Libyphoenicians, 239

Life Guards, mounted on black horses, 369

Liguria, horses of, 321

Ligurians, 256

Limestone formation of central Ireland, 392

Limousin horse, 323

Lincolnshire trotting-horse, 374

Limmaeus, on wild horses, 30

Lion, does not breed, 148; hunt, 215

Lions, 77, 208, 240

Lippizaner llorses, 346

Lister Turk, 382

Lofoden Isles, extinct ponies of, 26 ; pony of, 121 
Loire, mouth of, 401

Lombards, 334, 335

Lombardy, horses of, 314

London, horse-fair outside, 354; its hearse horses, 342

Long, Major, 429

Lopez, Odoardo, his description of zebra, 61 ; his tame zebra, $i b$.

Lophiodontidae, 5

Lorraine, horses of, 325

Lortet, M., 83

Loughrea, tumulus near, 398

Low Countries, horses of, 337

Low, Mr G. E., 51, 406

Lucretius, 1

Ludolphus, 506 ; his account of Abyssinian zebras, 58

Lusitania, mares in, conceive from West Wind, 257

Lusk, Co. Dublin, 393

Lydekker, Mr R., 5, 13, 44, 67, 142, $159,469,470,476,506$; describes the wild ass, 44; divides quagga from Burchell zebra, 76 ; on depression in quagga skulls, $i b$; on wild asses, 52 ; on E. sinalensis, 142

Lydians, horses of, 194

Macedonia, horses of, 301, 303; Upper, 305

Macedonian, cavalry, 303; horses, 305

Maclean, Mr John, 437

Maeatae, horses of, 9.5, 352

Mahaffy, Dr J. P., 412

Mail, 331

Major, Dr Forsyth, 143, 470

Major, John, on Irish Hobbies, 388

Malay Peninsula, had no indigenous horses, 146

Mammoth period, 83

Man-at-arms, horse for, 363

Maneged horses, i.e. war-horses, 355

Maneghi sub-strain, 170

Mane, of mares, hogged, 130; yellow, 300

Manetho, 236; his account of the Hyksos, 229-30

Manipur pony, 141

Manni, 321

Mannus, 311

Maoli, tribe, 162

Marca, Celtic name for a horse, 317

Marea, 243; people of, Libyans, 222

Marek, Dr, 93, 322, 399

Nare, leg of, i.e. a share, 168; old Irish, 387; Sir Gore Ouseley's, 462 ; suckling foal, 306 ; mares, 364 ; allotted to each stallion, 198 ; Arab, given to Turcomans, 133;
Arab, hard to purchase, 188; herds of, 192; in Lusitania, conceive from West Wind, 257; Kurdish and Turcoman, 163; not sold by Arabs, 168; of Anchises, 291; of Erichthonius, 290; of Muhammad, 206; Royal, 382-3 ; the King's, 381

Mare-milkers, 127

Mareotis, Lake, 222

Markham Arabian, 378 ; bay in colour, $i b$. ; price of, 379

Markham, Gervase, 377

Markham, Mr John, 378

Marl, horse jaw in, 83

Marmidae, Libyan tribe, 238, 247

Marriage law, of Sarmatians, 126

Marseilles, captured by Franks, 330

Marsh, Mr, 7

Marshall, Mr F. H., 19

Marske, 383

Masaesylii, 239

Masai-land, 65

Maschineyer, Mr, 142

Mashonaland, 436

Masinissa, 239, 309; sent Romau horses, 248

Massagetae, 129

Master of the Horse, 381

Masuren, 117

Masylii, 239

Matopo, 70, 458

Matschie, Dr, 61

Mauri, 239, 242; description of their habits, their mode of fighting, their horses, 239

Mamritania, horses of, 312

Mausoleum, chariot-group of, 306

Mazurka, origin of name, 117

Meath, hunters, 414

Mecca, horses in, 164

Mecklenburg, horses of, 342, 343, 350

Medes, 192

Medhbb, queen, 98

Nedia, horses of, 18; Nisaean plain in, 191

Medineh, horses at, 164, 165

Megalopolis, 301

Megasthenes, horned horses, 152

Melanippus, 292

Memphis, 230, 244, 336

Menapians, 115

Mendoza, founds Buenos Ayres, 262

Menes, 229

Men, slain by Tartars at funeral of a Khan, 135

Mercenaries, Carian and Ionian, 243 ; Greek, 223

Merdin, 167

Merk, Mr Conrad, 86 
Merv, best Turcoman horses, 132

Mesohippus, 6

Mesopotamia, 132; horses from, 216 ; Shammar tribes of, 161

Messenger, 385

Metacarpal bones, 84

Metal, Libyans use no, 226

Metatarsal bones, 84

Metopes, from Selinus, 278

Metung, 431

Meurthe, horses of, 325

Menx, Sir Henry, his zebra hybrids, 463

Mexico, 8 ; horses of, 267,511 ; dun and striped horses of, 269 ; dun-coloured horses of, 465

Meyer, Prof. Kuno, 400

Micipsa, Numidian king, 239, 309

Milk, of mares, 127,478 ; mares, poured on the ground, 134

Minoya, 273

Miocene, 6

Miohippess, 6

Mississippi, 266, 272

Missouri, 430

Mithras, feast of, 193

Moerder, M., 350

Mograbins, horses of, 249

Mongolia, 45, 426; camels in, 200 ; ponies of, 134 ; wild ass of, 476

Mongolian, jockies, 139; mares, 27, 35 ; pony, 4, 136, 186; pony race, 138 ; pony, striped, 455 ; wild ass, 45

Mongols, 3 ; always ride, 136

Montefik, tribe, horses of, 175 ; have spoiled their breed by using Persian horses, 176

Montelius, Dr Oscar, 347

Mooreroft, 30, 154

Moore, Major J., 350

Moorish, horse, 242 ; horses, 248

Moroceo leather, Libyans famons for, 227

Mortimer, Mr, 95

Morton, Lord, his quagga, 77, 457

Morvan, horses of, 324

Moscoso, Luys de, 273, 274

Moselle, horses of, 325

Mosul, 161, 176

Motol-cars, 414

Mountain, affeets type, 323

Mountain zebra, 68 ; called wild pard, 62 ; description of, 63

Mouse-colour, 43

Muhammad, 332; his camels, 206; homilies of, 166 ; mares of, 165 ; successors of, $i b$.

Muhammad ben Ahmed, 56

Mnkden, tombs of Chinese emperors at, 236

R. II.
Mulberry-black, horse, 258

IIule, in Cuba, 271

Mule-breeding, in Greece, 302

Mule-car, 486 ; race with, 276, 487

Mules, 164; in Greece, 113; in Turcomania, 133; preferred for ploughing, 113; wild, in Homer, 50 ; wild, in Syria, 49

Multiple nature of horse evolution, 7

Munro, Dr Robert, 8, 83, 84, 89, 396

Murcia, horses of, 266, 270

Mustangs, 8, 18

Muzin, feral horses, 18, 31, 32

Muzzles, used on Indian horses, 153, 473

Mycenae, 252; tombstones of, 107

Mycenean Age, horses in, 285

Myrrh, 202

Nabataea, 51, 208; no horses in, 202

Nabuchodonosor, 196

Name, for horse, Malay, 146 ; of horse, 317; names, for horse, 128 ; of horses, 121, 122, 295 ; of horses, raven, sooty, golden-haired, silvertopped, gold-topped, 122

Narvaez, Pamphilo de, 272; brings hor'ses to Florida, 272

Nasamones, 238

Nasir-ed-Din, gives Arab mares to Turcomans, 133

Navarre, horses of, 322

Neapolitan, 377; horses, 344

Nebuchadnezzar, 19

Neckband, of Libyan horse, 240 ; of Arab horses, $i b$.

Negro, skin of, 467

Neigh, of horse, see Voice; of Prejvalsky horse, 39

Nejd, 162; Arabs migrate from, 161 ; dark bay in, 177

Nelson, Mr, on Indian horses, 146

Neohipparion, 7

Nepal, ponies of, 134, 153

Nestor, 109, 251

Neuchatel, 394; Lake, 93

Newberry, Mr Perey E., finds a chariot, 227; on Hyksos, 233

Newcastle, Duke of, 366, 378

New Forest, pony, 456 ; ponies, 19

Nicopol vase, 130

Niebuhr, Carsten, 167, 246; on Arab horse, 162

Nigretes, 240

Nike, 276

Nile, 52, 219 ; western mouth of, 220

Nineveh, monuments of, 195

Nisacan horses, 186,192 ; like Parthian, 190 ; sacred, 191

Noack, Dr, 53, 71 ; on quagga, 71 
Nogai Tartars, 127

Nomads, 202; of Morocco, 242

Nome, Sethroite, 230

Norfolk horse, 2

Noricum, Celts of, 101

Normandy, 334

Norman horses, in Ireland, 412 ; saddles, 354; war-horses, 355; shields, 481; Normans, in Ireland, 354, 389 ; introduce heavy horses into England, 354

Norsemen, 335, 354

Norse settlers in Iceland, 418

Northmen, 334

Norway, 416; dun-coloured horses of, 465 ; horses of, 119,347

Norwegian, ponies, 451-2 ; stallions, in Faroes, 22 ; stallions, in Iceland, 21

Nose-band, 196, 284

Nostrils, 185

Nubia, 2, 56, 219 ; ass of, 52

Numidia, 309

Numidian, horse-breeding, 239 ; horsemen, 254, 309; horsemen, described, 241 ; kings, 239

Numidians, Hannibal's, 101

Nyassaland, 68

Oaks, the, 441

Oasis, great, Ammon, Siwa, 511

Odin rides on Sleipnir, 118,348

O'Donovan, the, his shield, 396

Odysseus, in Egypt, 220

Oeland, ponies of, 348

Oestrus, 9

Olaf, the Peacock, his dog, 419

Olans Magnus, 347, 358, 373

Olbia, coins of, 131

Oldenburg, horses of, 342,343

Oligocene, 7

Olisipo, 257

Olive oil, 202

Olmutz, archbishop of, 345

Olympia, races at, 276

Olympic games, 251

Onager, $12,36,45,46$; in Scythia, 125 ; in Syria, 49

Onager, indicus, 43, 46; hemippus, 46

Oncean grove, 286

O'Neill, Henry, 390

Oppian, 259, 313

Orlando, skull of, 470

Orlov Trotters, 350

Ornaments, 504

Orohippus, 6

Osages, 429

Osborn, Prof. H. F., 7, 262, 264, 511

Osnabruck, 342 ; breed of hearse horses, $i b$.
Ossetes, 126

Othello, 376

Otkell, his Irish thrall, 419 ; his two dun ponies with stripes, 420

Ouseley, Sir Gore, 462 ; his mare, 457

Owen, Prof., 82; on horse in Egypt, 215

Ox, 4, 478

Ox-cart, 481, 486; in Rig-Veda, 151 ; Thracian, 105

Oxen, Scythian, have no horns, 127; wild, in Cuba, 271

Pachynolophus, 6

Pack-saddle, 199

Pad of cotton, used as saddle, 177

Paeonia, bison in, 300

Paget, Col. A., 58

Painting of a horse, 293

Palaeolithic period, horses in, 88

Palaeotheriidae, 5

Palestine, horses of, 211

Palgrave, Mr, on Arab horses, 162; sanctions illusion that best Arabs are grey, 177

Pallas, 30, 43, 127 ; description of wild horses, 30 ; on dzeggetai, 44

Palm-trees, 161

Palmyra, desert of, birthplace of Darley Arabian, 384

Palmyrene desert, 161

Pampas, 8, 428

Pampas horses, 262 sqq., 446; compared with horses of western prairies, 265

Pampas Indians, 428

Panama, 270

Panjab, people of, 153

Panormus, coins of, 253

Panthers, 240

Panticapaeum, 130

Paphlagonia, home of wild mules, 50

Paraguay, 10 ; cattle in, 9 ; no feral horses in, $i b$.

Parana, Baron de, 459; his zebra hybrids, 463

Paricanians, 192

Parliament, efforts of, to promote horse-breeding, 355

Paroas, a serpent, reddish-brown, 300

Parthenon, 297; horses of, $i b$; of Pheidias, ib.

Parthian horses, 18, 189, 194, 260; described by Strabo, 189; like Celtiberian horses, $i b$.

Pasterns, 374

Patagonia, 8

Patricians, Sabine in origin, 306

Pedigree, Arabs trace through dains, 187; pedigrees of Arab horses, 162 
Pedrarias, 269, 271

Pegasus, 252; earliest representation of, his birthplace, 245; myth of, 289

Pegu, pony, 141; ponies, 448

Pelasgians, 107

Pelopidas, his dream, 300

Peloponnesus, horses of, 301

Pelops, 251

Percheron horse, 2, 325 sq. ; grey, 402

Pericles, 295

Periplus, 158

Perissodactyles, 5

Perseus, 252

Persia, asses of, 149 ; good Turcoman horses, 132 ; horses of, 160 ; included Carmania, 4

Persian, 381; horse, 175, 431; horses, of Middle Ages, 188; kings, their horses, 190 ; stallions, 350

Persian Gulf, 149

Persians, 192; ancient, rodehabitually, 190 ; used scythed chariots, 247 ; venerate white horses, 115

Peru, horses of, 270

Peter the Great, 351

Petra, 202

Petrie, Prof., 215, 233

Phalanx, Macedonian, 303

Phalios, 'bald,' 328

Pharaoh, 204

Pharusians, 240

Pheidias, horses of, 297

Phenacodus, 6

Philip II of Macedon, 302 ; horses of, 303

Philippopolis, 106

Phillips, $\mathrm{Mr}$ Lort, shot Somali ass, 54

Phoenix, bay, 295

Phrygia, 49

Piebald chestuut, 435

Piebalds, 142, 154, 175

Pied horses, 348-50

Piètrement, M., 3, 30, 35, 89; his E. c. mongolicus, 229; on Aryan horse, 151

Pigafetta, description of zebra, 59

Pinzgauer breed, 346

Pirogues, 273

Pit, pre-orbital; see Fossa and Depression

Pizarro, 270, 271; his horses, 269

Platnauer, IIr, 97

Pleistocene, 7

Pliny, why mares' manes are hogged, 130

Pliocene, 6

Plotius, Aulus, 203

Plough-bullocks, 414
Ploughing, with mules, 113; with oxen, 113,351

Plumes on horses, 195

Plutarch, 300

Pocock, Mrr R. I., 66, 72, 75, 76, 436, $470,508-10$; on chestnuts of Grèvy zebra, 5.; on Grèvy zebra, $i b$; on pre-orbital fossa in male Grant's zebra, 143 ; on quaggas, 74 ; on reversal of hair on spine of mountain zebra, 63

Poictiers, battle of, 333

Pole, 221; covered with red leather, 228

Poliakoff, 26

Polidore Virgil, 359

Polo, Narco, 134, 447; notes Tartar horses, 134; on Indian horses, 146; praises Turcoman horses, 133

Polyphyletic law, 7

Pompey, 203

Ponies, 351; black Hebridean, black Highland, 403; Connemara, 402 sqq., 408; Exmoor, 399; Faroe, 352, 416; Iceland, 352, 416; Irish, of Solutré type, 409 ; Javanese, 11 ; Norwegian, 347; of Austria, 345; of Bosnia, 345; of Denmark, grey, 344 ; of Kurdistan, 160 ; of Oeland, 348 ; of Russia, 345; of Sulu, 11 ; pony, Connemara, 388; Mongolian, described, 138; race, Mongolian, ib.

Portuguese in Congo and Angola, 55

Porus, has both chariots and horsemen, 153

Poseidon, 301

Posidonius, 257, 401

Potidaea, coin of, 301

Pottery from Daphnae, 244

Powerscourt, Viscount, the late, 367

Praetors, 307

Prairie, horses, colours of, 265; western, horses of, $264 \mathrm{sqq}$.

Prejvalsky, his horse, 26; foal, woolly coat, 37 ; foals, described, 27 ; foals, their colours, 33; horse, 13, 38, 152,425 ; description of, 26,41 ; picture of, $i b$.; indomitable temper of, 473 ; considered a mule, 35 ; its relation to tarpan and to Equus caballus, 41 ; horses, young, resemble dwarf cart-horses, 36 ; not all genuine, 40

l're-molars, functional, in some Javanese and Sulu ponies, 142

Pre-orbital depression, in horse skulls, $159,469,470,476$

Prescott, W. H., 267, 270

Price, of chariot, 214; of hogs, 273 ; of horses, $150,214,218,273,296$, 
357; of horses bought for James I, 379; of Markham Arabian, $i b$.; of pony, 140 ; of slaves, 273

Pringle, Thomas, on cry of quagga, 73

Priory of Athy, 412

Prizes for races, 138

Procopius, 306; on Britain, 353

Progress, royal, 362

Protohippus, 6, 7

Provence, captured by Franks, 330; grey horses of, 325

Prussian, horses, 343 ; East, horses, 344

Prussians, East, 117; learn arrowshooting and acquire horses, $i b$.

Psammetichus I, 223, 238, 242

Psaumis, 276

Psylli, 238

Ptolemy, his accurate knowledge of Ireland, 401

Ptolemy Philadelphus, 200

Pungwe river, 66

Punic War, 309

Pyrenees, horses of, 322

Pyrrhus, 307

Pytheas, 401

Quagga (or Quacha), 12, 71 sqq., 428, 445; disappearance of stripes in, 79 ; babitat and colour of, 436 ; had white in the forehead, 466 ; its distribution and coloration, 71 ; its voice, 73 ; relationship to Burchell zebra, 76 ; Amsterdam, arch in forehead of, 452; Bonte, 67, 476; Elgin, 436-8; hybrid, 457, 462; Lord Morton's tame, 76,77

Quaggoides, E., 470

Queen Elizabeth, 362

Querandese Indians, 262

Race, pony, 137; with ridden horse, 291

Race-horse, at Olympia, 276; colours of, 440 ; origin of, 475 ; English, 212 ; English, origin of, 209; English, never dun-coloured, 433 ; race-horses, English, 377; English, now race of bays and chestuuts, 385; foals of, 444 ; monuments to, 276 ; of Romans, 312 ; origin of, 188

Races, prizes for, 139 ; length of, $i b$.; winners of, $i b$.

Racing, 254

Racing, among Mongols, 138; injured the breeding of great horses, 366 ; passion for, $i b$.

Racing mare, 379

Rameses II, 222
Ras-El-Fedowi, the name of the Darley Arabian, 384

Raven, as a horse's name, 122

Rawlinson, Sir H. C., 177; his bay Arabian, ib.

Redfern, Mr W. B., 501

Red-horse, 209; horses, in Veda, 152

Red-roan, 346

Red Sea, 164

Reeves, Bishop, 412, 418

Reinach, M. S., on cave drawings, 91

Reindeer horus, 84

Reindeer period, 83

Rein-rings, 492

Reins, 397

Remus, the hybrid, 459

Reyce, Robert, 364, 370

Reykjavik, 23

Rhacotis, 220

Rhesus, 107

Rhine, 327 ; crossed by Tencteri, 115 ; provinces, 341

Rhinoceros, at Rome, 55

Rhone, 254

Ribs of horse, normal number, 151

Richard II promotes horse-breeding, 358

Richardson, Charles, 381, 383

Richardson, Dr, 265, 429

Ridgeway, Prof., 7, 99, 223, 315, 399, 401

Rider, circus, 252

Riding, 252, 497; Arab method of, 177; in Rig-Veda, 151; Irish method of, 388; learned by Greeks from Libya, 292 ; not practised by Egyptians, 216 ; later than driving, 481

Rig-Veda, 151

Rivers, horses sacrificed to, 192

Rivière, M., 87

Roads, 366

Roadster, old English, 386

Roala tribe, 170

Roan horse, in Cuba, 271

Rodo, island of, its ponies, 26,120

Rolleston, Prof., 92

Roman, noses, 345 ; cavalry, 481; race-horses, 312

Romans, 353; inferior in cavalry, 306 ; race-horses of, 254 ; use chariots, 307

Rome, zebra at, 55 ; elephant at, $i b$.; rhinoceros at, $i b$. ; tiger at, $i b$.

Romero, John, 262

Romulus, 458

Roscoe, Rev. J., 67

Roscommon, horses of, 408 ; hunters, 414

Roses, Wars of, 359

Rouncy, a, 359 
Royal mares, 381

Russia, horses of, 350 ; ponies of, 345

liussian, horses, 132, 193; steppes, 164

Russians excavate at Dukhova Moghila, 106

Rutimeyer, 4 ; on the horse, 92

Rye, Mr, his edition of Hakluyt, 273

Sabeans, 201

Sabiuos, 435

Sables, 118 ; called Saphirinae pelles, il.

Sacae, 129

Sacrifice, of bulls, 190 ; of horses, 151 ; of horses at Rome, 307; of horses, by Persians, 190 ; of horses, to Cyrus, ii.; of white horses, 117; white horses preferred, 190; of ass, 150

Sacrificial animals, 222

Saddle, 498; not used by Assyrians, 197 ; pack-saddle, 199; pad used for, by Arabs, 176; saddles, not allowed by Mongols in racing, 139; not in Book of Kells, 391; not used by Greeks, 299; of Normans, 354

Sagartians use lasso, 192

Sagas, horses in, 122

Sahara, 207, 247

Salatis, king of Hyksos, 230

Salensky, Dr, 42; on Prejvalsky's horse, 10

Salsette, isle of, 149

Saluvii, 321 ; Ligurian tribe of, 310

Samnites, 100

Samphoras, term applied to horses, $296^{\circ}$

Sampson, 384

Sanctity of white horses, 187, 190, 210

San Domingo, 266; horses introduced, 267

San Lucar, 271

Sanson, MI., 2, 13, 30, 35, 219, 229, $250,325,401,420$; his eight species, 1 ; his two groups, 4

Santiago, 271

Saracens, 148, 322, 323 ; in Spain, 258 ; invade Spain and Gaul, 332

Sardinia, horses of, 274

Sardinian, 377

Sardis, 194

Sarissa, 304

Sarissophori, Macedonian, 304

Sarlik, Mongolian name of yak, 426

Sarmatae, 116

Sarmatian women, law of marriage, 126 ; rode on horseback, $i b$.

Sarmatians, 50; castrate horses, 125 ; horsemen only, 116; corselet, $i b$.; arms, $i b$.; use lasso, 117; their weapons, $i b$, do not use metal, $i b$; sacrifice horses, eat them, $i b$; their horses, 125,482

Saskatchewan, 430

Saturn, typical Suffolk Punch, 375

Sannia, Gallic spears, 99

Saxons, 334

Scandinavia, 118 ; horses of, 346,416

Scaurus, Aemilius, 202

Scedans, daughters of, 300

Scharff, Dr, $51,83,392,399$

Scherreu, Mr H., on Abyssinian zebra, 58

Schleswig-Holstein, horses of, 342

Schliemann, Dr, 285

Scipio, 308

Scipio Aemilianus, 309

Sclater, Mr P. W., 476; on Prejvalsky's horse, 35 ; description of Somali ass, 53

Scnlptured group of horses, 295

Scutum, 481

Scythed chariots, 247, 393

Scythia, Indian, 158

Scythian, funeral customs, 136 ; horses, in India, 158, 159; women, differ from Sarmatian, 126

Scythians, 50, 158, 192 ; castrate horses, 125; their horses, 125; Nomad, 126

Seal, Great, Charles I on, 366

Sebaa tribe, 162

Sedbury, Royal mare, 382

Seglawi strain, 169

Seine, 326

Seius, horse of, 302

Selene, horse of, 297

Seleucid kings, 306; use scythed chariots, 247

Selinus, archaic metope from, 277

Selous, Mr, zebra named after him, 66 ; zebra of, 436

Semites, 232; had no horses in time of Abraham, 235; obtain horse late, 203

Sentinum, 100

Sequanius, E. c., 326

Serfs of Gauls, 316

Serjeants of the king, 356

Serpent, 300 ; serpents eaten by horses, 194

Servius Tullius, constitution of, 308

Sesto Calende, 103; chariot of, $i b$.; bucket at, $i b$.

Sethroite, nome, 230

Seti I, horses of, 229

Seure, MI., 107

Shadingfield stock, 375

Shati'y, form of Islam, 145

Shakespeare, 294 
Shammar, sheikh, 50; tribes, 161; hor'ses of, $i b$.

Shan ponies, 141, 448

Shark, 385

Sheep, 129

Sliekels of silver, 214

Shepherd kings, 229-30

Sheriff, of Hampshire, 355, 356; of Viltshire, 356 ; sheriffs, 358

Shetland-TVelsh mare, 45

Shields, bronze, 394; Gallic, ib. ; Irish, 396 ; round, 315,481

Ships, built without metal nails, 148

Shire Horse Society, 369

Shire horse, typical, 368 ; colour of, 368 ; in Ireland, 413

Shirt of mail, 331

Shkorpil, the brothers, 106

Shoa, zebra of, 57

Shoes, hor'se, 298

Shoulder-stripe, in African ass, 53

Sicamber, 338

Sicambri, 338

Sicilian horses, 313

Sierras of Spain, horses of, 260

Signet of Darius, 192

Sigynnae, 94, 345

Silchester, 352

Silver, 130; talents of, 191

Simonoff, M. de, 360

Singapore, 141

Sinjar, ass of, 50

Sivalensis, E., 469

Siwa, oasis of, 239

Size of horses, 246

Skarphedinn, 123

Skeat, Mr IV. W., 146

Skeleton of woman, 398; skeletons, human, 107

Skewbalds, 142, 154

Skin, colour of, 466,476 ; of African horse, 467 ; of horses, 165 ; of uegro, 467 ; skins, 240

Skull of horse, 326; skulls, horse, from Irish craunog, 390,391 ; of horses, 143; of zebras and quaggas, 76

Slaves, Irish, in Iceland, 419; price of, 273

Sledge, 482-3

Sleipnir, Odin's eight-legged steed, 119,346 ; his origin, 121 ; grey colour of, 122

Slide-car, 483

Smetanka, 350

Smith, Col. Hamilton, 30, 42, 74, $177,433,416,472,474$; his five stirpes, 1

Smith, Mr A. J., 376

Smith, Mr R. A., 510
Smyrua, horses from, 188

Solomon, imports horses from Egypt, 214 ; mares of, $165,166,207$; stud of, 162,167

Solon, his class of knights, 293

Solutré, 83; horses of̀, $89,151,370$; horses of low stature, 84

Somaliland, 56; zebra of, 57

Somali wild ass, 54, 476; zebra, 58, 459 ; habitat, 58 ; striping of, 458

Somers, 362

Sons of horses, 163,164

Sooty, as a horse's name, 122

Sooty black horses of Kurds, 177

Sorrel, a bad colour, 372; coloured horse, Suffolk Punch, 368 ; horses, $357-8,371$

Soto, Ferdinando de, 271; dies by the Mississippi, 273

Spadix, derivation of, 291

Spain, cave remains in, 87 ; dun horses of, 265,465 ; horses of, 254,312 ; horses of sierras of, 260 ; Irish trade with, 387, 389

Spaniards, 8, 266

Spanish, breed, 345, 512 ; cavalry, 101 ; horsemen, 254; horses, 343, 387 ; horses, colours of, $25 \mathrm{~s}$; jennet, 259, 377

Spanker, 382

Spears, 99, 429

Spiletta, 383

Spiti, ponies of, 134,153

Spokans, 430

Spurs, 500; Norman, 354

Stade, Lorse-breeding of, 342

Stakes for a race, 138

Stallion, Irak, 472; Neapolitan, 364; stallions, 356, 360, 364; Anazah, prized, 183; Babylonian, each allotted twenty mares, 193; King Stephen sends round, 356 ; one hundred imported into England, 356 ; Persian, 350

Star, 187, 250, 261; in forehead, 173, $181,258,374,447-8,476$; stars, 465 ; correspoud to certain marks in zebras, 465 ; in forehead, 376

Starkad, 122

Starling-coloured horse, 296

Statius, 301

St Columba, 418

Stenonis, E., 462, 470

Stephanides, WVilliam, 345

Stephen sends round stallions, $\mathbf{3 5 6}$

Steppes, studs of, 351

Stevenson, Mr J., 390

Stillingfleet, Rev. E. W., 97

Stirrup, 498; not used by Arabs, 177 ; stirrups, Norman, 354; not in Book 
of Kells, 391; not on Kells cross, 391 ; not used by Irish, 390

St Leger, 441

Stocking, in mountain zebra, 466 ; white, on horse's leg, origin of, 465 ; stockings on horses, 373

Stockwell, skull of, 470

Stokes, Dr W., 400

Stot, 359

St Patrick, 400, 401

St Quentin, Col., 386, 392

Strabo, 190, 220, 471

Stradanus, 337, 338, 340 ; his drawings of horses, $188,242,260$

Striped, dun horses, 261; horses, of Tibet, 154; hor'ses, of TVaziris, 160 ; horses, Tibetan, 156 ; ponies, of Java, 142; Tibetan ponies, 155 ; stripe, dorsal, 372 , 386; dorsal, in Cleveland bay, 386; dorsal, in Battak ponies, 142 ; dorsal, of Karadagh horses, 193 ; stripes, cervical, 453-4, 450 ; concomitant of dark colour, 465; dorsal, on Arab colts, 182; facial, rarity of, 453 ; in dun horses, 465 ; in horses, $444 s q q ., 511$; in hybrids, 459; on dun horses, in Spanish sierras, 257; on dun horses of Mexico, 269; on horses, 373 ; on Kattywar horses, 157 ; on onager, 37

Striping of the Equidae, 79

Stroxton Tom, 368

Strymon, white horses sacrificed to, 192

Stud of 'Tsetsen Khan, 138

Stud-book, 381; Suffolk, 370

Stuttgard, stud of, 314

Styria, 346 ; horses of, 315

Suevi, 115, 116

Sutiolk, Breviary of, 364; Stud-book, 370

Suffolk Punch, 2, 316, 366; its history and origin, $370 s q q . ;$ later history of, 374 ; in Ireland, 413

Suiones, 118

Sultan, of Ducaila, 248; of Java, 145 ; of Sumatra, 145; Sultans of Achen, their horses, 142

Sumatra, pouies of, 141

Sumpter horses, $\mathbf{3 6 2}$

Sun, worshipped by Massagetae, 129; horses sacrificed, $i b$.

Surcingle, 177

Sutherland, Mr, 16

Swayne, Capt., 58

Sweden, horses of, I19, 349

Swedes, horses of, 118

Swimmers, horses as, 435

Switzerlaud, cave remaius in, 86 ; horse remains, lake-dwellings, 92 ; horses of, 344

Sword, La Tène, 99; swords, 100; of La Tène period, 394; La Tène, found in Ireland, 396; of Mauri, 240

Syene, 238

Syphax, 309

Syrdaria, 31

Syria, 161; export of horses from, 163; horses of, 167, 184

Syrian, desert, 161; horse, compared with Bagdad, 185

Syrians, 243

Tablets of 'Tel-el-Amarua, 214

Tacitus, 334

Tael, 140

'Tahpanhes, 242

Tail, as test of breeding, 304 ; docked, 140 ; of Arab, 174; of ass hybrid, 37 ; of horse, 8 ; of Kohl breed, 229 ; set high in Prejvalsky horse, and in desert Arabs, 38; setting of, 245, 254,477 ; structure, covering, and carriage of, 469

Tail-lock of Ieeland pony, 18

'Takja, 31

Tamerlane gives Arab mares to Turcomans, 133

Tanais, river, 125

Tangums, have very small hock callosities, 154; of Tibet, 350

Tangustan, 154

Tapestry, Bayeux, 354

Tapirs, 5, 6, 9

Tarbes, horses of, 322

Tarentum, horses of, 278

Tarpan, 1, 31, 34, 10, 41, 425; coat of, 33 ; description of, 32 ; its pecu. liar voice, 31 ; mouse-coloured, 41 ; skeletons of, 42 ; true, not larger than ordinary mules, 34 ; their colour, $i b$. ; voice of, 32 ; like mule, ib. ; tarpans, 35,125

Tartars, 30 ; their horses, 134; slay men and horses at funeral of a Khan, 135; use of camels, not early, 200

Tartary, 18

Tassels on lorses, 195, 504

'Tasso, 257

Taylor, Mr Gordon, 437

Teeth, Arab does not tell age by, 177 ; for age, 140; of Grévy and Baringo zebras, 146; of Javanese and Sulu ponies, 142 ; of zebras, $i b$. ; premolars, $142, \pm 61$

Tegetmeier, Mr, 16, 26, 28; on Somali zebra, 58 
Teheran, cab-horses of, 193

Telegony, 457

Tel-el-Amarna, tablets of, 214

Temper, 375 ; bad, of chestnuts, 474

Temple, Sir W., 387

Tencteri, 335, 338; cavalry of, 115 ; horses of, $115,326,331,339$

Tent-dwellers, Arab, 201

Terah, 204

Terms for colour, 177

Tertiary period, 4, 5

Teutonic chivalry, 331

Texas, horses of, 267, 271; Spaniards leave horses behind in, 273

Thana, town of, 149

Thangbrand, converts Iceland, 122; stops the eating of horse-flesh, $i b$.

Thebaid, kings of, 236

Thebans, white horses of, 295

Thebes, seat of New Empire, 236

Thera, 253

Thessalians, white horses of, 296

Thessaly, horses of, 285,301

Thor, does not ride, 118

Thoroughbred, American, 385 ; Australian, ib.; English, $380 \mathrm{sqq}$.; the Irish, 414; Melbourne strain, 38

Thorshaven, 23

Thorstein, the Red, $\mathbf{4 1 6}$

Thothmes IV, his tomb, 227; his chariot, 227-8

Thrace, horses of, 302 ; white horses of, 289

Thracian, horses, 306; war-chariots, 107

Thracians, 105; horses of, small, 107 ; tattoo, 105

Thrall, Irish, in Iceland, 419

Thuringian horses, 318

Thuringians, 327; conquered by Franks, $329-30$; laws of, 332

Tibet, horses of, 349 ; its piebald horses, 1; ponies of, 154; wild horses of, 18

Tibetan ponies, colours of, 156

Ticinus, 101, 255

Tiger at Rome, 55

Tigris, 161 ; horses of, 183

Timaeus, king of Egypt, 230

Tin trade of Britain, 401

Tiree, ponies of, 18

Togarmah, horses of, 193

Tom, river, 32

Tomaris, queen, 129

Tombs, in Achaia, 293; of Egyptian kings, 236 ; of Chinese emperors, $i b$.; Valley of, $i b$.

Toulonse, battle of, 332

Toussaint, M., 84, 89

Trade, with Gaul, 401
Trajan, 202

Trakehnen, horse, 472 ; stud of, 344

Trans-Indus horses, 153-4, 159

Trimarcisia of Celts, 317

Tripod, 251

Troglodytes, 238

Trojans, horses of, 290

Tros, 290

Trot, very hard, of German horse, 337

Trotter, Norfolk, 386; its origin, $i b$.

Trotting, desired in horses of service, 364

Trotting horse, American, 463; Lincolnshire, 374 ; mares, 364

Tsetse-fly, 10, 77

Tumulus, 398

Turcae, 129

Turcoman, black horses of, 187; horses, $156,176,181$; horses, colours of, bay, grey, black, white feet and a star in forehead, 133; mares, 163, 449 ; ponies, 163

Turcomania, 133; horses, $i b$.

Turcomans, get Arab mares, 133 ; horses of, 132 ; obtain Arab stallions, 132

Turk, Byerley, 382 ; Lister, $i b$. ; White, $i b$.; Yellow, $i b$.

Turk, horse, 160, 377; horses, in England, 189; the, 189, 378

Turkestan, horses of, 132 ; wild ass of, 47

Turkish Arabia, horses of, 182

Turkish, cavalry, how mounted, 163 ; horses, 344, 381, 472

Turko-Tartaric names for horse, 128

Turquans, 133

Tuscany, horses of, 314

Tusgul Sea, 26

Tweedie, Major-Gen., 157, 160, 162 , $165,441,471$; doctrine of origin of Kohl breed, 207; on kudush, 164; on colours of Arab horses, 177 ; on origin of Kohl breed, 209

Tyre, horses and mules at fairs of, 193

Ubii, 327

Ukraine, 1, 30; blood, 325

Ulster ehariots, 398

Umbrians use chariots, 103

Upton, Major, 162, 163, 164, 166, 180, 240, 445; notes stripes in Arab horses, 182; on colours of Arab horses, 180 ; views on horses of Syria and Bagdad, 184

Urga, the 'Derby' of Mongolia, 139

Urn, covering burnt bones, 398-9

Usipii, 115 
Val d'Arno, fossil horses of, 143

Vandals, 334, 335

Vandyck, his portrait of Cromwell, $366^{\circ}$

Vanir, 118

Varni (WVerini), not horsemen, 353

Vases, Greek, 293; show chmriots, 252

Vedic, horses, 151 ; Indians, 157

Vegetius, 319, 327, 344

Veneti, 101; of Amorica, 401 ; their horses, 104

Venn, Dr J., 120, 412, 452

Venn, Mr J. A., 121, 452

Vertebrae, lumbar, in tarpan, 42 ; in Prejvalsky horse, $i b$.

Vertragus, the Celtic dog, 398, 400

Vesuvius, battle of, 100

Vezère, cave of, 85

Victoria, feral horses of, 430

Viking period, 354

Vikings of Western Isles, 416

Virgil, Polidore, 359

Virginia, wild horses in, 430

Voice, of dzeggetai, 52; of kiang, 46, 52 ; of other asses, 52; of horse, 477 ; of Irak stallion, 472 ; of Kadish, 471; of Kuhailan different from Kadish, 180; of Libyan horse, 471; of onager, 46 ; of tarpan, 31

Waddell, Mr L. A., 156

Waggon, four-wheeled, Styria, 315 ; waggons, Scythian, drawn by oxen, 127,482

Wahlberg zebra, 436

Walers, 47

Wall, Great, of China, 140

Wallace, Mr J. H., 385, 430

WVall-eyed horses, 349

Walwich Bay, 65

War-chariots, 351 ; used against Pyrrhus, 307

Ward zebra, 64, 508

War-horse, 203; typical, of Byzantine period, 328; Cyrenian, 253; of Lower empire, 329

Warriors slain at funerals, 128

Waziris, horses of, 159, 447

Tiells, 161; dug, Arabia, 207

Werini (same as Varni), 329, 335, 35.1

Western Asia, horses of, 188

Westmeath, 413; hunters, 414

West Wind impregnates Lusitanian mares, 257

Wheel, 483 sqq.; four.spoked, sixspoked, eight-spoked, 225, 228; spoked, 484 ; origin of, 485 ; wheels, 223, 224; block, 483-4, 488 ; chariot, 95 ; eight-spoled, 315 ; eight-spoked, on Irish chariots, 390 ; eight-spoked, on Irish crosses, $i b$.; tires of, 95 ; evolution of, 482

Whip, 479

White, Arab, 169 ; Arab love of white horses, 178; elephant, sanctity of, 105 ; feet, $181,250,373$; feet, in Kuhailan, 173; horse, drowned in Gyndes, 191; horse, in Apocalypse, 210 ; liorse, of Berkshire, 353 ; horse, of St Columba, 419; legs, 374; star or blaze, 374 ; stars, 376 ; woru by Tartars on New Year's Day, 134; white horses, 120, 135, 174, 289, 294, $295,296,346$, 466; among Germans, 105, 114, 353; among Scandinavians, 105 ; at Agrigentum, 276 ; at Rome, 307; belong to upper Asia and Europe, 186; draw Zeus' chariot, 294 ; in Greece, 292 ; in Sicily, 105 , 278; in Thessaly, 301 ; in Thrace, 107 ; Julius Caesar drawn by, 307-8; of Kublai Kaan, 134 ; sacrificed, 294; sacrificed by Persians on march, 190 ; sanctity of, $105,186,187,294$, 419 ; tribute of, 190 ; wild, 125 ; used for divination by the Germans, 114

Why Not Royal mare, 382

Wife of Bath, 359

Wild ass, 50; in Scythia, 125

Wild horses, 16; extermination of, 433; of North America, 265; in Spain, 257, 260; not found in Arabia, 165,207 ; variation of colour, 27 ; why destroyed, 428

Wilde, Sir IV., 391

William III, charger of, 367

William, de Sancto Mauro, 355

Wiltshire sheriff, 356

Winchester, 356

Wind, 'Drinkers' of the, 249; West, impregnates Lusitanian mares, 257

Winter, Dr, his horses, 412

Wolf, 4, 208, 426; as a brand, 104

Wolf-dogs (see Dog), 401

Wollaston, Dr, 457

Woman, skeleton of, 398; nude, on horseback, 244

Women, ride on horseback, Libyan, 242

Woodbridge, 368

Wurtemburg, horses of, 344

\section{Xanthippus, 395}

Xenophon, 480 ; description of a good horse, 298

Xerxes, army of, 152; his car, 191; Indians in host of Xerxes, 47 ; roll of his army, 192; sacrifices white horses to rivers, $i b$. 
Xyston, 304

Yak, 4, 426

Yaman, horses of, 164

Yarkund, 134

Yellow, 175

Yellow horse, 210

Yemen, 164

Yoke, 224

Yorkshire, barrows, chariots in, 95; cart-mares, 385-6 ; coach-horse, 386

Youatt, Mr, 151, 161, 177

Young, Arthur, 368; description of Suffolk Punch, 370

Yucatan, 269

Yule, Col., 147, 150

Yunnan, horses of, 140

Zagan-norr, lake, 28, 40

Zain, 434

Zaizan, 26

Zama, 309

Zambesi, 66
Zebra, 7, 55 sqq.; Burchell, 59, 436, $445,472,476$; Burchell, domestication of, 78; Chapman's, 12 ; Craw. shay's, ib.; Grant's, ib.; Grévy's, 12 , 59; Grévy, Imperial or Somali, 58; hybrids, 36,452 ; hybrids, bred in East Africa, 79; hybrids, hock callosities, 39 ; large hybrids are out of well bred mares, $i b$. ; in Angola, 55 ; in Congo, $i b . ;$ known to Romans, $i b$; Mountain, $12,56,62,472$; pre-orbital depression in skull of, 143 ; Somali, striping of, 458 ; teeth of, 142; Wahlberg's, 436 ; Ward's, 64,508 ; zebras, coloration of, 436 ; now utilized in British East Africa, 79 ; west of Nile, 56 ; see also Equus Zebra-ass hybrid, 453 ; -horse hybrid, 476

Zebu, 4, 426

Zechariah, 211

Zegredoff steppe, tarpan of, 41

Zeus, car of, 191; drawn by white horses, 294 





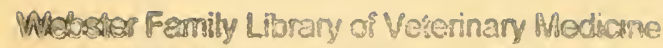
Gurmmolings School of " prinary Medicine at Tufts University 200 Westboro Road Nienth Gratinn RAt n. E: 

